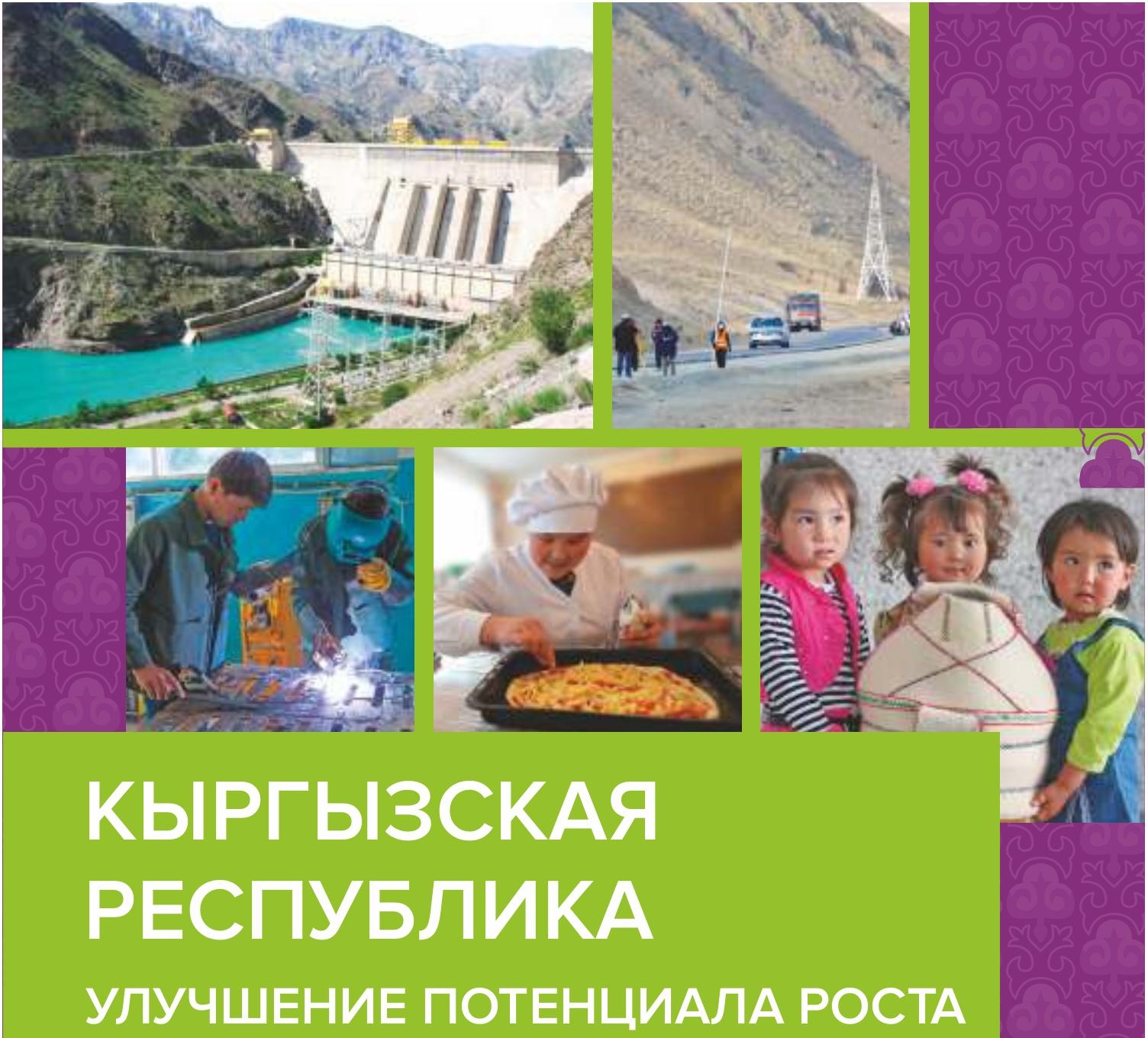

Такаши Ямано, Хэл Хилл,

Эдимон Гинтинг и Джиндра Самсон

Сентябрь 2019 года
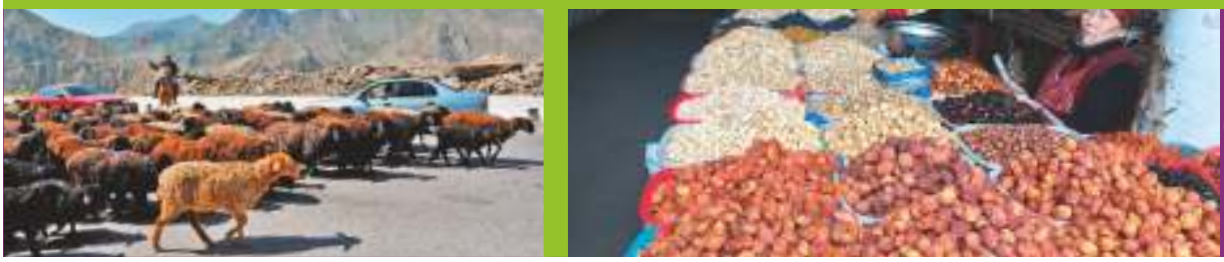



\section{КЫРГЫЗСКАЯ РЕСПУБЛИКА}

\section{УЛУЧШЕНИЕ ПОТЕНЦИАЛА РОСТА}

Сентябрь 2019 года

Такаши Ямано, Хэл Хилл, Эдимон Гинтинг и Джиндра Самсон 


\author{
(c) 2020 Asian Development Bank \\ 6 ADB Avenu \\ Tel +63 2632 4444; Fax +6326362444 \\ www.adb.orge, Mandaluyong City, 1550 Metro Manila, Philippines \\ Некоторые права защищены. Опубликовано в 2020 г. \\ ISBN 978-92-9262-074-5 (print), 978-92-9262-075-2 (electronic) \\ Номенклатурный номер публикации TCS190441-2 \\ DOl: http://dx.doi.org/10.22617/TCS190441-2
}

Взгляды, выраженные в данном документе, являются мнением авторов и необязательно отражают взгляды и политику Азиатского банка развития (АБР) или его Совета управляющих, или представляемых ими правительств.

АБР не гарантирует точности данных, включенных в данную публикацию, и не несет ответственности за последствия их использования. Упоминание конкретных компаний или продуктов определенных производителей не означает, что АБР одобряет или рекомендует их, отдавая им предпочтение перед другими компаниями или продуктам аналогичного характера, которые не были упомянуты.

Обозначения или ссылки на конкретную территорию или географический регион, а также использование термина "страна" в настоящем документе не являются выражением мнения АБР относительно правового или иного статуса какой-либо территории или какого-либо региона.

Доступ к данной работе предоставляется в соответствии с лицензией «Creative Commons Attribution 3.0 IGO» (CC BY 3.0 IGO) https://creativecommons.org/licenses/by/3.0/igo/. Используя содержание данной публикации, вы даете согласие соблюдать условия данной лицензии. Для ссылок, переводов, адаптаций и разрешений просим ознакомиться с положениями и условиями использования на https://www.adb.org/terms-use\#оpenaccess.

Данная лицензия СС не распространяется на содержащиеся в данной публикации материалы, не защищенные авторскими правами АБР. Если материал относится к другому источнику, просим связаться с владельцем авторских прав или издателем этого источника для получения разрешения на его воспроизведение. АБР не может привлекаться к ответственности в связи с каким-либо претензиями, вытекающими из использования вами таких материалов.

Если у вас имеются вопросы или комментарии в отношении содержания, либо если вы желаете получить разрешение владельца авторских прав на использование публикации в целях, не предусмотренных настоящими условиями, или разрешение на использование логотипа АБР, просим связаться с pubsmarketing@adb.org.

С исправленными опечатками в публикациях АБР можно ознакомиться по ссылке http://www.adb.org/publications/corrigenda.

Примечания:

В данной публикации символом “\$” обозначены доллары США.

АБР указывает “Кыргызстан”, имея в виду Кыргызскую Республику, “Китай” - Китайскую Народную Республику, и “Россия”, имея в виду Российскую Федерацию.

На обложке: вверху слева направо: Энергетика - Токтогульская ГЭС (Влад Ушаков); Дорога 3 - реконструкция дороги Бишкек-Нарын-Торугарт (Вячеслав Оселедько); Юноша в свароч-ной мастерской -профессиональный лицей в городе Ош (Канат Асанакунов); Проект профессионально-технического образования-2 - учащаяся на практических занятиях в лицее в Караколе (Вячеслав Оселедько); Проект развития детей младшего возраста - воспитанники детского сада в Гульче (Влад Ушаков). Внизу слева направо: Дорога 1 - Проект улучшения Коридора 3 ЦАРЭС (дорога Бишкек-Ош), Суусамырская долина (Вячеслав Оселедко); Сельскохозяйственный местный рынок в Оше (Такаши Ямано). Дизайн обложки -Джо Марк Ганабан.

Отпечатано на бумаге из вторичного сырья

Настоящий документ переведен с английского языка для охвата более широкой аудитории читателей. Английский язык является официальным языком Азиатского банка развития (АБР), и несмотря на предпринятые АБР усилия для проверки точности перевода, оригинал данного документа на английском языке - это его единственная официальная и юридически правомочная версия. При цитировании необходимо давать ссылку на оригинал. 


\section{Содержание}

Таблицы, рисунки и вставки ...............................................................1

Предисловие........................................................................................7

Вводная часть .................................................................................8 8

Выражение признательности.....................................................10

Краткая информация об авторах ............................................... 12

Сокращения...................................................................................18

1. Введение: Экономика Кыргызстана на распутье.........................21

1.1 Введение и общий обзор .....................................................................21

1.2 Общая характеристика ...............................................................................23

Историческое наследие - советский период и период независимости .. 24

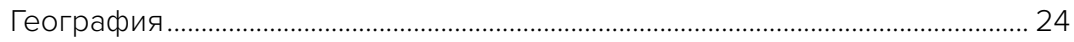

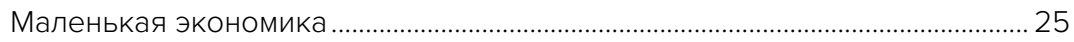

Экономика, построенная на денежных переводах............................................ 26

1.3 Экономическое развитие: общий обзор ................................................27

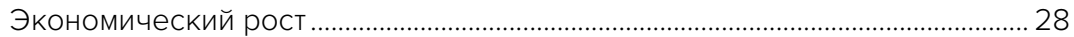

Отраслевые темпы роста и структурные изменения ........................................30

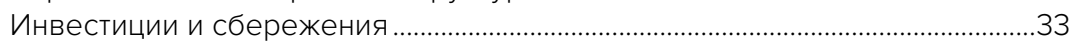

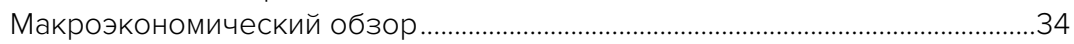

Подводя итоги: На горизонте макроэкономики скапливаются тучи?......... 40

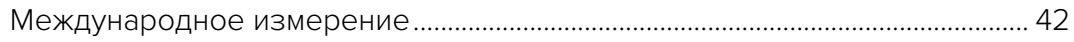

Кыргызская Республика и Евразийский экономический союз ..................... 46

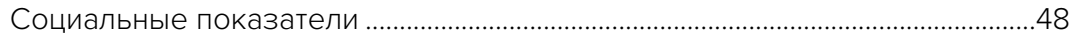

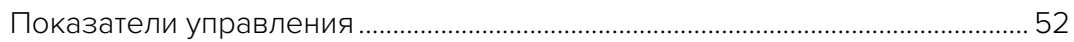

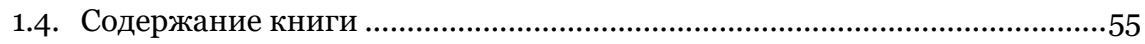

1.5. Итоги и стратегические выводы …...................................................58

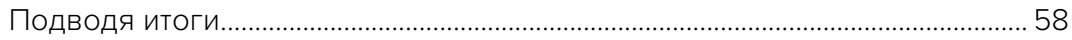

Практические выводы и рекомендации ............................................................. 59

2. Международные аспекты экономической трансформации: торговля, прямые иностранные инвестиции и трудовая миграция ........... 66

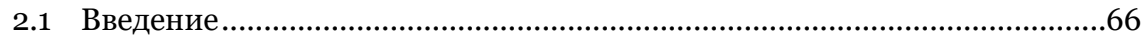

2.2. Реформы и структура стимулирующих мер............................................67

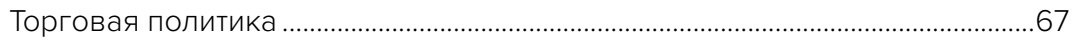

Политика прямых иностранных инвестиций....................................................... 71 
Макроэкономическая политика и международная конкурентоспособность .71

Торговые таможенные реформы ...........................................................................73

Инфраструктура, географические недостатки и торговые издержки........74

2.3. Позиция в отношении внешних платежей …….........................................75

2.4. Структура торговли..........................................................................78

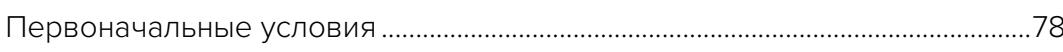

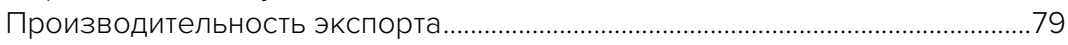

2.5. Тенденции и структура экспорта продуктов, не относящихся к золоту ... 81

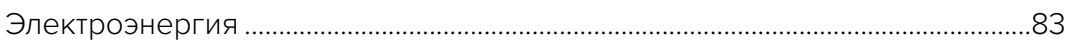

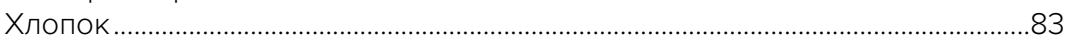

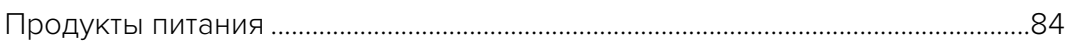

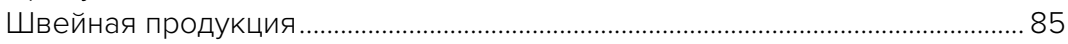

2.6. Прямые иностранные инвестиции ...................................................... 91

2.7. Трудовая миграция и денежные переводы.............................................95

2.8. Заключительные выводы................................................................... 98

3. Реформирование аграрного сектора .....................................104

3.1. Введение ...........................................................................................104

3.2. Сельское хозяйство Кыргызской Республики .........................................105

Исторический обзор сельскохозяйственной политики ...............................105

Сельское хозяйство в Центральной Азии ........................................................108

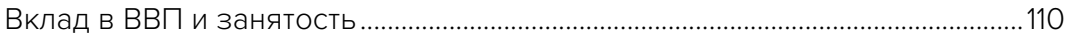

Сельскохозяйственные агроэкологические зоны в Кыргызской

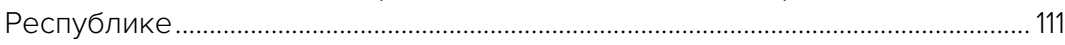

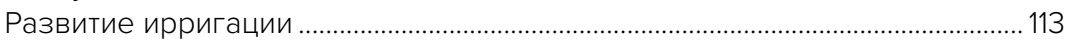

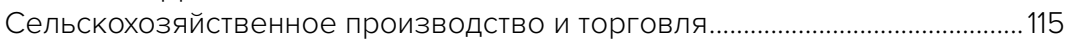

3.3 Развитие, ориентированное на экспорт: Два тематических

исследования .......................................................................................... 122

Фасоль обыкновенная ..............................................................................................122

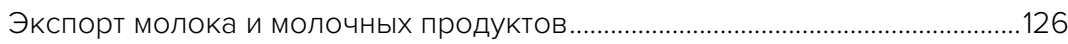

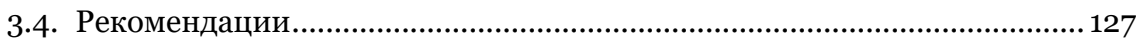

4. Эффективный рост сектора услуг в Кыргызской Республике..... 133

4.1. Введение .......................................................................................... 133

4.2. Текущее состояние сектора ..................................................................... 133

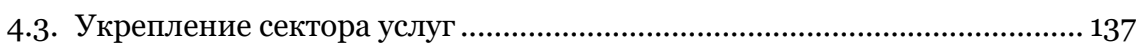

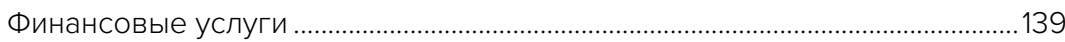

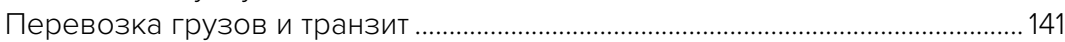

4.4. Туристический потенциал Кыргызской Республики ...............................143

Прямое, косвенное и индуцированное воздействие туризма ..................... 144

Специализированный (нишевый) туризм в Кыргызской Республике

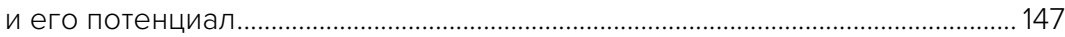

Факторы, препятствующие развитию туризма.................................................. 149 


\section{5. Цифровая трансформация и возможности}

в Кыргызской Республике

5.1. Введение 155

5.2. «Электронная готовность» Кыргызской Республики: обзор 156

Политические, правовые и рыночные аспекты.................................................... 157

Доступ к информационно-коммуникационным технологиям .........................158

Магистральная инфраструктура и связанность..

5.3. Достижения и препятствия на пути внедрения ИКТ в различных секторах 164

Ситуация с внедрением ИКТ по секторам 165

5.4. Национальная программа цифровой трансформации 171

5.5. Выводы и рекомендации в области политики 174

\section{6. Транспорт и логистика для обеспечения роста торговли} и инклюзивности .................................................................. 181

6.1. Введение и историческая справка..................................................... 181

6.2. Внутренние и международные сообщения..............................................185

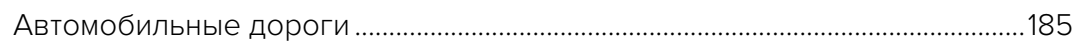

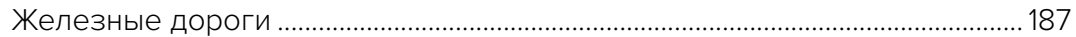

Воздушный транспорт .....................................................................................190

Физическая и нематериальная инфраструктура .............................................195

6.3. Издержки на ведение торговли Кыргызской Республики по сравнению с Центральной Азией.

6.4. Евразийский сухопутный мост посредством улучшенной железнодорожной системы ...............................................................201

6.5. Торговые инициативы и экспортный потенциал ................................ 203

6.6. Заключительные замечания и последствия для политики.................. 203

7. Реформирование сектора энергетики Кыргызской Республики..207

7.1. Структура сектора энергетики в Кыргызской Республике .....................207

Энергоресурсы, резервы, спрос и предложение............................................207

Правовая, институциональная и регуляторная структура сектора

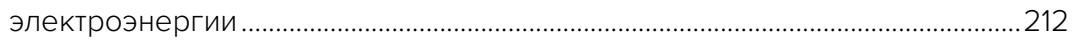

Технические показатели сектора электроэнергии ......................................... 214

7.2. Действующий механизм установления тарифов и субсидий .................2217

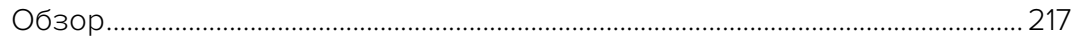

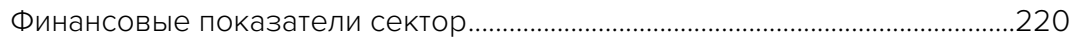

Среднесрочная тарифная политика на 2014-2017 годы...................................221

Прибыльность и задолженность энергокомпаний.........................................223

7.3. Воздействие действующих тарифов ......................................................224 


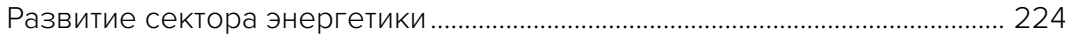

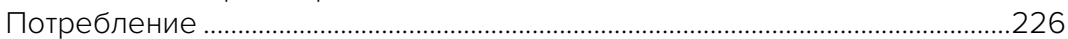

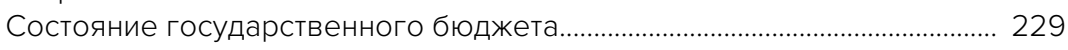

7.4. Международный опыт в реформировании энергосубсидий ................ 230

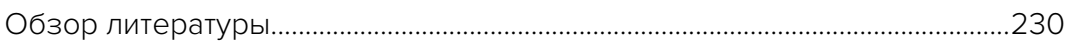

Практические примеры стран...........................................................................22

7.5. Возможные дальнейшие шаги для сектора энергетики

Кыргызской республики ...........................................................................2235

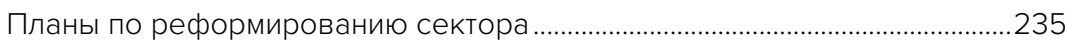

Важнейшие элементы реформирования сектора электроэнергии........... 237

8. Развитие человеческого потенциала для инклюзивного роста ...245

8.1. Введение .........................................................................................245

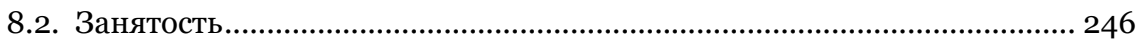

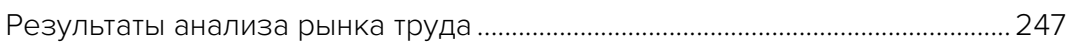

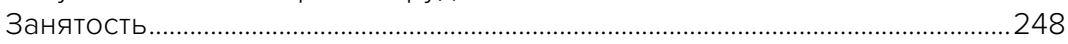

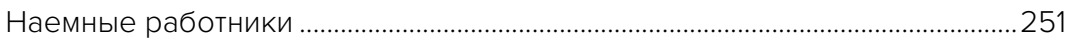

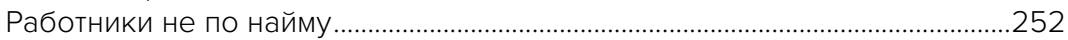

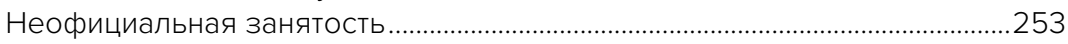

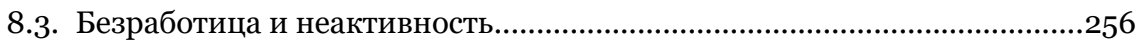

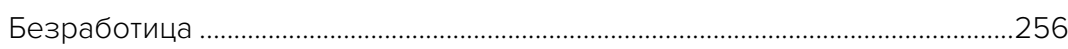

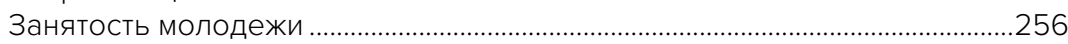

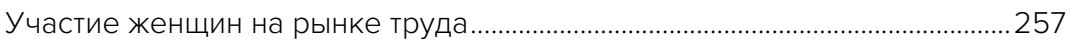

8.4. Работающие за рубежом ......................................................................258

Существующие тенденции трудовой миграции .............................................259

Социальные аспекты миграции .........................................................................263

8.5. Навыки, необходимые для повышения потенциала роста................... 264

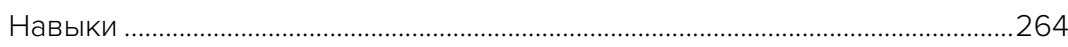

Информационно-коммуникационные технологии и навыки .........................226

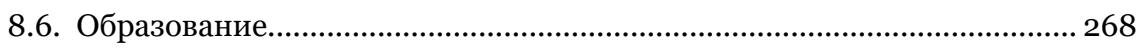

Последние достижения в секторе образования ……………..........................268

8.7. Демография и здравоохранение ...........................................................272

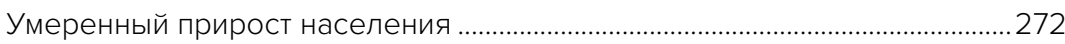

Ожидается рост городского населения ……………………………...............22 273

Продолжительность жизни увеличится и изменит структуру населения.. 273

Снизился уровень детской смертности, коэффициент фертильности

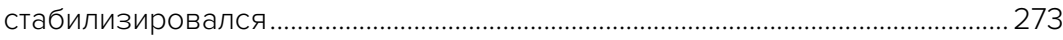

8.8. Заключительные замечания и практические выводы ..........................274

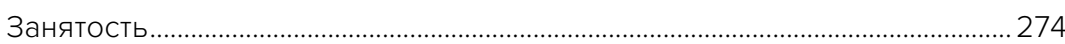

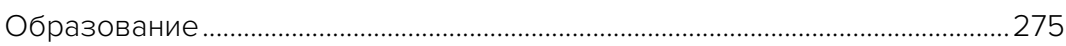

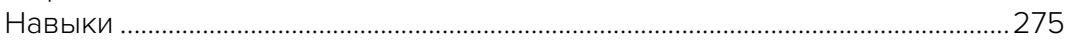

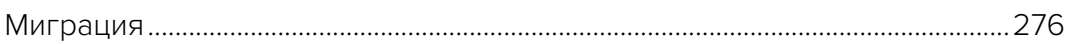

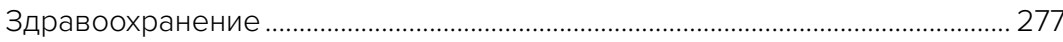




\section{Таблицы, рисунки и вставки}

\section{Таблицы}

1.1. Сравнительные показатели экономического роста...................................... 30

1.2. Краткий обзор состояния платежного баланса Кыргызской Республики...45

1.3. Сравнительные показатели на 1990 год.......................................................50

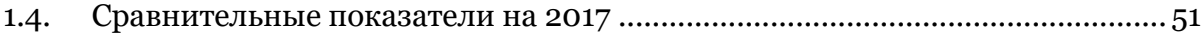

1.5. Сравнительные институциональные и бизнес показатели, 2018 ................53

1.6. Сравнительные показатели государственного управления, 2017 год ..........53

1.7. Сравнительные показатели в области государственного управления, 2000

2.1. Импортные пошлины, применяемые в рамках режима наибольшего

благоприятствования, Кыргызская Республика, 2017 год.

2.2. Показатели экономического переходного периода для стран Евразийского экономического союза, 1995, 2010 и 2014 гг...........................74

2. 3. Платежный баланс, Кыргызская Республика, 2000-2017 гг.........................77

2.4. Внешний долг и обслуживание долга, Кыргызская Республика, 2008-2017 гг.

2.5. Товарная структура экспорта, Кыргызская Республика, 1995-96, 2005-06 и 2015-16 гг.

2.6. Географическая структура экспорта товаров из Кыргызской Республики, 1993-2017 годы .................................................................. 88

2.7. Географическая структура импорта товаров.............................................. 89

2.8. ПИИ в странах Центральной Азии ..................................................................92

2.9. Региональное распределение прямых иностранных инвестиций в Кыргызской Республике, 2016-2017 гг.

2.10. Утвержденные прямые иностранные инвестиции по видам экономической деятельности, Кыргызская Республика, 2002-2017 гг

2.11. Источники прямых инвестиций в Кыргызской Республике

2.12. Денежные переводы трудящихся-мигрантов по способам денежного перевода, 2009-2016 гг. 
3.1. Аграрная реформы в Кыргызской Республике: политические документы, законодательные акты, этапы реализации

3.2. Сельскохозяйственное использование земель и добавленная стоимость по Центральной Азии, 2016

3.3. Характеристика агроэкологических зон в Кыргызской Республике, 2016

3.4. Распределение поголовья скота по агроэкологическим зонам, 2016

4.1. Добавленная стоимость секторов …......................................................... 135

4.2 Доля работающих по секторам и подсекторам ..........................................136

4.3. Доля вкладов всех компонентов в общий экономический вклад сектора туризма

4.4. Сравнительные показатели работы сектора путешествий и туризма в странах региона, 2018

5.1. Политика и стратегии в области информационных и

коммуникационных технологий в Кыргызской Республике

5.2. Использование информационно-коммуникационных технологий в фирмах Кыргызской Республики, 2013 г. 167

6.1. Аэропорты с регулярными коммерческими рейсами ..................................192

6.2. Легкость ведения бизнеса, 2014-2019 гг.

6.3. Среднее время прохождения некоторых пунктов пересечения границы, 2011-2016 гг.

6.4. Затрачиваемое время (часы) и издержки (долл. США) в некоторых пунктах пересечения границы, 2015 г.

6.5. Затрачиваемое время (часы) и издержки (долл. США) в некоторых пунктах пересечения границы в 2016 году

7.1. Энергетические ресурсы и запасы 208

7.2. Генерирующие мощности в секторе электроэнергии Кыргызстана

7.3. Фактические тарифы и тарифы, покрывающие себестоимость, на электричество и отопление

7.4. Тарифы за электроэнергию в некоторых странах

7.5. Пересмотры Среднесрочной тарифной политики на 2014-2017 гг. для отдельных групп потребителей.

7.6. Расходы, доходы и убытки энергокомпаний, 2016 г.

7.7. Текущие проекты, финансируемые партнерами по развитию 225

7.8. Социальное страхование и социальная помощь в Кыргызской

Республике, 2016 г. 230

8.1. Отдельные показатели по человеческому развитию, 2015 
8.2. Показатели рынка труда, 1991-2015

8.3. Характеристики формальной и неформальной работы, 2015 …................254

8.4. Участие женщин на рынке труда, 2015 …...................................................257

8. 5. Домохозяйства мигрантов, получающих денежные переводы по регионам, 2010-2015. 262

8.6. Использование информационных - коммуникационных технологий; наличие соответствующего оборудования

8.7. Показатели системы здравоохранения, 1980-2015

\section{Рисунки}

1.1. Динамика экономического роста, 1991-2018 ........................................... 28

1.2. Темпы роста по секторам .............................................................................. 31

1.3. Доля определенных секторов в ВВП ...........................................................32

1.4. Объем инвестиций и сбережений .................................................................33

1.5. Уровень инфляции и обменный курс.........................................................34

1.6. Сальдо бюджета и баланс по текущим счетам ….........................................35

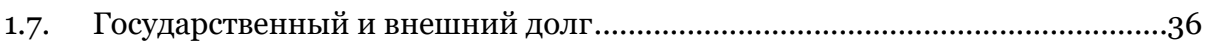

1.8. Состав экспорта товаров.........................................................................42

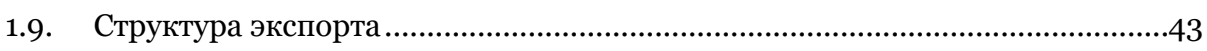

1.10. Денежные переводы, иностранные прямые инвестиции, официальная помощь в целях развития ...........................................................44

1.11. Уровень бедности и неравенства...................................................................49

2.1. Номинальный эффективный обменный курс (NEER), относительная цена, и реальный эффективный обменный курс (REER), Кыргызская Республика, 2000-2018 гг. ........................................................................72

2.2. Торговая открытость экономики Кыргызской Республики, 1995-2017 гг.....75

2.3. Сальдо торгового баланса и счета текущих операций, и денежные переводы работников (нетто) как доля ВВП, Кыргызская Республика, $1995-2017$ гг..........................................................................................76

2.4. Золото от общего объема экспорта товаров, 2000-2016 гг...........................79

2.5. Экспорт одежды из Кыргызской Республики, 2000-2016 гг........................87

2.6. Торговые отношения Кыргызстана с Евразийским экономическим союзом и Китайской Народной Республикой, 2000-2017 гг.

2.7. Прямые иностранные инвестиции в Кыргызской Республике, 1993-2016 гг.

2.8. Денежные переводы в Кыргызскую Республику по странам происхождения, 2016 г. 
3.1. Объем производства сельскохозяйственного сектора в странах Центральной Азии 108

3.2. Доля валового сельскохозяйственного производства в странах Центральной Азии, 2016 году

3.3. Доля сельского хозяйства в ВВП, уровне занятости; добавленная стоимость на работника .

3.4. Карта агроэкологических зон в Кыргызской Республике .112

3.5. Среднегодовой объем производства, 1992-1996 и 2012-2016 гг. .115

3.6. Распределение площадей под различные культуры по агроэкологическим зонам

3.7. Динамика роста поголовья овец и птицы в Кыргызстане, 1990-2016 гг..... 118

3.8. Динамика роста поголовья КРС, молочного скота, лошадей и свиней в период с 1990 по 2016 гг. 118

3.9. Объемы сельскохозяйственного импорта и экспорта, 2006-2016 гг. 120

3.10. Импорт и экспорт сельскохозяйственной продукции с определёнными соседними государствами, 2016

3.11. Сельскохозяйственный экспорт Кыргызской Республики: Объемы и страны - получатели, 2014 и 2016 гг

3.12. Динамика роста площадей, отведенных под выращивание бобовых по Кыргызстану и Таласской области, 1999-2017 гг.

3.13. Экспорт фасоли из Кыргызстана на основные рынки, 2009 - 2016 гг....... 123

3.14. Цепочка создания добавленной стоимости.

3.15. Структура экспорта молока и молочных продуктов из Кыргызстана, 2006 - 2017

4.1. Валовой объем продукции сектора в стоимостном выражении, 1990-2017.

4.2. Доли секторов в общем объеме ВВП …...................................................... 135

4.3. Количество трудоустроенных по секторам................................................. 137

4.4. Доля сектора услуг и торговли соседних стран в общем объеме

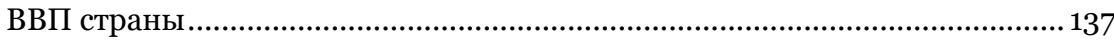

4.5. Индекс финансового развития стран-компараторов, 2016 .......................140

4.6. Общий индекс эффективности логистики …............................................142

4.7. Индекс эффективности логистики в секторе торговли и транспортных

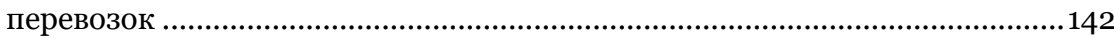

4.8. Добавленная стоимость туристического сектора.........................................143

4.9. Количество прибывших туристов ..............................................................144

4.10. Компоненты вклада туристического сектора: прямой, косвенный и индуцированный. 
4.11. Подробная разбивка затрат по сектору туризма и путешествий, 2011-2017 годы 146

4.12. Сегменты альтернативного туризма 148

5.1. Телекоммуникационные абоненты: Содружество Независимых Государств и мир. 158

5.2. Уровень пользования интернетом среди взрослых (2011-2017 гг.) и среди молодых женщин (2014 г.), Кыргызская Республика. 160

5.3. Оптическо-волоконная сеть Кыргызской Республики 161

5.4. Международная пропускная способность интернета, оптовая стоимость и пропускная способность на душу населения: выборочные страны .........163

5.5. Рейтинги Кыргызской Республики в области информационнокоммуникационных технологий, 2016 г.

5.6. Торговля компьютерными и информационными услугами, Кыргызская Республика

5.7. Индекс эффективности логистики, 2018 г., и онлайновые покупки, 2017 г. 168

5.8. Индекс уровня электронного правительства ООН 171

6.1. Доля видов транспорта в увеличении объемов грузовых и пассажирских перевозок 182

6.2. Грузооборот и пассажирооборот по видам транспорта 184

6.3. Железные дороги в Кыргызской Республике 188

6.4. Доля железнодорожных перевозок в общем объеме перевозок, 1990-2017 гг., и товарная структура железнодорожных грузовых перевозок, 2012-13 гг.

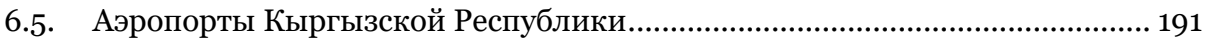

6.6. Торговые издержки и эффективность логистики....................................... 197

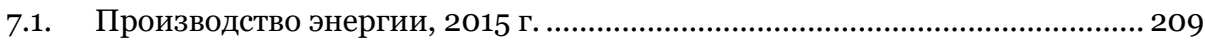

7.2. Общий объем предложения первичной энергии, 2015 г.......................... 209

7.3. Конечное потребление энергии по типу и по видам использования, 2015 г

7.4. Недостаток зимнего предложения

7.5. Институциональная структура сектора электроэнергии Кыргызской Республики

7.6. Срок службы генерирующих активов в Кыргызской Республике 216

7.7. Потери на этапах генерирования, передачи и распределения электроэнергии, 2012- 2016 гг.

7.8. Этапы методологии установления тарифов 218

7.9. Долгосрочные обязательства ЭС и НЭСК, 2012-2016 гг. .224 
7.10. Потребление электроэнергии на душу населения, 1990-2015 гг. 227

7.11. Среднемесячное потребление электроэнергии, 2015 г............................. 228

7.12. Энергоемкость валового внутреннего продукта ..................................... 228

7.13. Распределение энергосубсидий по децилям уровней доходов ...................229

8.1. Кол-во занятых в основных секторах, 1991-2015….................................... 249

8.2. Номинальное значение ВВП на работника, по секторам, 1993-2015 ........ 250

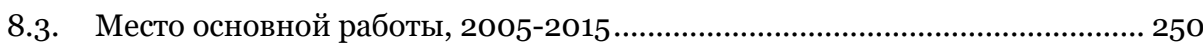

8.4. Типы трудового договора для наёмных работников ................................... 251

8.5. Среднее кол-во отработанных часов в сельской местности, 2005-2015.....253

8.6. Уровень неофициальной занятости, 2005 и 2015 …..................................253

8.7. Участие молодежи на рынке труда, 2005-2015 ….......................................257

8.8. Отношение к работе и образованию по полу ............................................258

8.9. Сравнение размеров заработной платы в Кыргызской Республике и Российской Федерации, 2013-2017 …....................................................261

8.10. Использование компьютеров разными возрастными группами................267

8.11. Количество детей в дошкольных учреждениях и принятых в 1-й класс

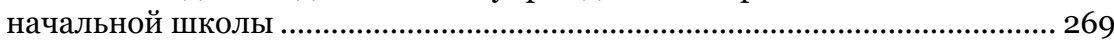

8.12. Поступление в учебные учреждения после окончания средней школы ... 271

8.13. Динамика роста населения, 1980-2050 ......................................................272

\section{Вставки}

2.1. Евразийский экономический союз ..........................................................70

2.2. Золотодобывающее предприятие «Кумтор» .............................................. 80

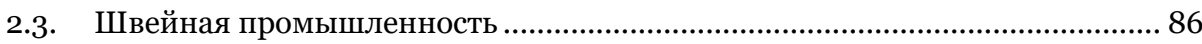

5.1. Проект «Цифровая Центральная и Южная Азия - Кыргызская

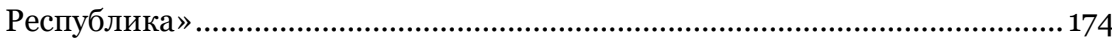

8.1. Источники данных по рынку рабочей силы в Кыргызской Республике .... 248

8.2. Качество работы в Кыргызской Республике ............................................. 251

8.3. Гендерные отношения и их восприятие ..................................................258

8.4. Какова численность мигрантов из Кыргызстана? .......................................259

8.5. Исследование 2013 года по развитию профессиональных навыков ......... 264 


\section{Предисловие}

трановое диагностическое исследование Кыргызской Республики, подготовленное Азиатским банком развития (АБР), содержит всесторонний анализ достижений в сфере развития и политических задач, стоящих перед Кыргызской Республикой.

В исследовании отмечается исторический контекст страны, особенно трудные первые годы после обретения независимости, а также географическая изоляция. Но в исследовании также отмечаются достижения страны, в том числе повышение уровня жизни на протяжении большей части этого столетия, и тот факт, что ее экономика и политика, возможно, являются наиболее открытыми среди стран Центральной Азии с переходной экономикой.

В исследовании признается, что Кыргызская Республика находится на пороге перехода от стран с низким уровнем дохода к странам с доходом ниже среднего. Также подчеркивается необходимость ускоренного экономического роста и роста занятости при сохранении и укреплении основ и достижений социальной политики страны.

В данном диагностическом исследовании представлен глубокий анализ и рекомендации, основанные на фактических данных, охватывающие несколько ключевых секторов, включая торговлю, сельское хозяйство, туризм и услуги, информационные и коммуникационные технологии (ИКТ), транспорт и логистику, энергетику, и человеческий капитал.

В исследовании также рассматриваются некоторые из основных текущих проблем развития страны, в том числе сильная зависимость от денежных переводов и доходов от горнодобывающих отраслей, адаптация к быстро меняющемуся положению в соседних странах, сохраняющаяся актуальность благоразумного макроэкономического управления и неравномерное региональное развитие. В исследовании делается вывод, что реформа может привести к более быстрому улучшению уровня жизни на широкой основе.

Мы приветствуем результаты исследования АБР, которое, как мы считаем, будет стимулировать диалог между основными заинтересованными сторонами страны в сфере развития по основным среднесрочным задачам страны. Исследование также послужит полезным справочным материалом для директивных органов, которые сталкиваются с некоторыми из важнейших современных проблем, стоящих перед Кыргызской Республикой.

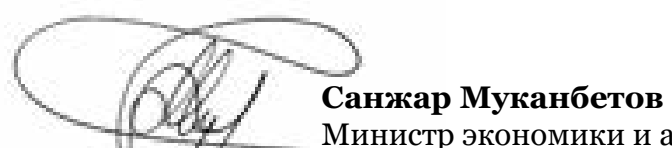

Министр экономики и альтернат управляющего в АБР от КР 


\section{Вводная часть}

населением чуть более 6 миллионов человек и экономикой, оцениваемой приблизительно в 7 миллиардов долларов США, Кыргызская Республика является одной из самых интегрированных экономик в Центральной Азии. После распада Советского Союза в 1991 году страна начала свое движение по сложному пути экономического перехода и становления независимого государства. В течение первой половины 1990-х годов уровень жизни в Кыргызской Республике резко снизился, наряду с географической изоляцией, будучи страной, «дважды не имеющей выхода к морю».

Несмотря на эти трудности, Кыргызская Республика имеет много значительных достижений. За последнюю четверть века уровень жизни возвратился к тем уровням, которые существовали в конце советского периода. Социальные показатели очень благоприятно выдерживают сравнение с теми из стран, которые находятся на аналогичных уровнях дохода на душу населения. Страна рассматривается как наиболее открытая экономика и общество среди бывших советских республик в Центральной Азии. Кыргызская Республика находится на пороге перехода в разряд экономики с доходами ниже среднего уровня.

Основная задача сегодня состоит в том, чтобы перевести все эти достижения и возможности ускоренный экономический рост и рост занятости. Выражаясь простым языком, экономика растет недостаточно быстро, чтобы удовлетворить потребности населения страны. Почти одна шестая часть населения вынуждена искать работу за границей. Это один из самых высоких показателей в мире.

Страновое диагностическое исследование Кыргызской Республики представляет глубокий анализ ключевых секторов, перспективный анализ достижений страны в области развития и политических задач. В докладе говорится, что, несмотря на географическую изоляцию страны, ключевые экономические реформы и реформы государственного управления могут привести к ускоренному экономическому росту, а также сохранить заметные социальные достижения страны.

Во-первых, диверсификация экспорта с точки зрения продуктов и рынков укрепит рост и минимизирует колебания, в условиях экономической открытости, ранее принятой страной. В свою очередь, это может оказать давление на столь необходимые реформы для бизнеса. Например, экспорт нишевой продукции в сельском хозяйстве (особенно фасоли) может расшириться с улучшением инфраструктуры сельского хозяйства. Усиленные меры безопасности пищевых продуктов необходимы для того, чтобы охватить огромный потенциал быстро растущего рынка Китайской Народной Республики. Экспорт текстильной одежды имеет потенциал роста, при условии оптимизации бизнес среды и нормативно-правовой базы. Экспорт услуг в сфере туризма также имеет потенциал с развитием инфраструктуры. 
Во-вторых, что касается инфраструктуры, с 1990-х годов в дорожной сети произошли значительные улучшения, но многое еще предстоит сделать, в том числе в области технического обслуживания дорог и безопасности дорожного движения. Ужесточение возможностей в отношении затрат и выгод и оценки проектов обеспечат более эффективное инвестирование ресурсов государственной и официальной помощи в целях развития. Существует также возможность для выгодных трансграничных соглашений для соединения с соседними странами и дальше. Услуги в области информационно-коммуникационных технологий (ИКТ) быстро совершенствуются параллельно росту охвата и качества обслуживания. Эти изменения способны преодолеть географическую изоляцию страны и внутренние барьеры на пути перемещения людей и товаров. Применение ИКТ также растет в сфере финансов, образования и управления.

B-третьих, реформы также необходимы в энергетическом секторе. Страна сильно зависит от работы нескольких гидроэлектростанций и двух ТЭЦ, на которых возможны аварии. Фактически, большая часть активов в генерирующей, передающей и распределительной сети устарела и нуждается в замене. Однако инвестиции в этот сектор не поощряются искусственно заниженными тарифами на электроэнергию и большими субсидиями, которые не могут быть оправданы экономическими, справедливыми и экологическими соображениями. Эти государственные субсидии можно было направить в столь необходимые экономический и социальный секторы. Например, в 2016 году субсидии в энергетический сектор почти вдвое превысили все затраты на социальную помощь.

B-четвертых, реформа сектора образования необходима как для сохранения исторически сложившихся сильных сторон в предоставлении всеобщего государственного образования, так и для того, чтобы система образования обеспечивала рынок труда более приспособленными к его условиям выпускниками, включая применение ИКТ в работе.

В-пятых, реформы в финансовом секторе необходимы для того, чтобы направить большие потоки денежных переводов в инвестиции в производственную экономику и социальное развитие. Расширение финансового посредничества позволило бы потенциально динамичному сектору МСБ более эффективно использовать кредиты официального сектора экономики.

Мы благодарны Правительству Кыргызской Республики за оказанную поддержку и сотрудничество в ходе подготовки данного исследования, которое, как мы надеемся, будет и впредь способствовать диалогу и внесет значимый вклад в будущие планы и стратегии страны. Мы в Азиатском банке развития надеемся на дальнейшее партнерство и сотрудничество.

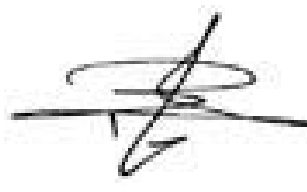

\section{Ясуюки Савада}

Главный экономист и генеральный директор

Департамент экономических исследований и регионального сотрудничества

Азиатский банк развития 


\section{Выражение признательности}

трановое диагностическое исследование для Кыргызской Республики было подготовлено Азиатским банком развития (АБР) в рамках проекта региональной технической помощи (RETA 9325) по подготовке страновых диагностических исследований в отдельных развивающихся странах-членах. Объектом изучения стали последние достижения страны, которые помогут вывести ее из списка стран, чье экономическое состояние и уровень дохода приравнивается к ниже среднему, а также проводится анализ того, каким образом эти достижения могут быть использованы для стимулирования значительного экономического роста страны в более широком формате. В исследовании приводятся предложения по проведению определенных политических и экономических реформ и реформ в управлении, столь необходимых для ключевых экономических секторов для достижения более широкого и всеобщего роста.

Изначально исследование было проведено Департаментом экономических исследований и регионального сотрудничества (ERCD) под руководством Эдимона Гинтинга, заместителя генерального директора ERCD, и было завершено под руководством Раны Хасан, директора отдела экономического анализа и операционной поддержки (EREA). Возглавил команду по подготовке исследования Такаши Ямано, старший экономист, при общей поддержке группы исследователей при техническом содействии со стороны Хиндры Нуеллы Сэмсон. Джи Энн Бурак, Аманда Мамон и Эйлин Гатсон оказали содействие по администрированию проекта.

Мы глубоко ценим поддержку, оказанную Постоянным представительством АБР в Кыргызской Республике (Постпредство АБР в КР), во главе с его директором Кэндис МакДэйган. Мы благодарны за эффективную координацию и поддержку по работе с правительственными органами, оказанную Стивеном Льюисом-Воркманом, Гулькаир Тентиевой, Саматом Алдеевым, Мирдином Ешеналиевым, Олесей Проценко, Динарой Рысалиевой, Айнурой Аскарбек кызы, Айнурой Бекболотовой и Алиман Темирбек.

Исследование является результатом широкого круга консультаций с ключевыми государственными министерствами в Кыргызской Республике, учреждениями по аналитической работе, агентствами и исследовательскими институтами, поддерживающими планирование развития и стратегии. Исследовательская группа хотела бы выразить особую благодарность Аппарату Правительства; Аппарату Президента; Министерству финансов; Министерству экономики; Министерству транспорта и дорог; Министерству культуры, информации и туризма; Министерству труда и социального развития; Министерству образования и науки; Министерству сельского хозяйства, пищевой промышленности и мелиорации; Государственному комитету энергетики, промышленности и недропользования; 
Государственному агентству по регулированию топливно-энергетического комплекса; Агентству по продвижению и защите инвестиций; Агентству начального профессионального образования; Национальному банку Кыргызской Республики; Центру социально-экономических исследований и Агентству развития города Бишкека, которые поделились и предоставили бесценную информацию и рекомендации для проведения исследования.

Углубленные отраслевые исследования были подготовлены следующим составом экспертов: Глава 1 (Экономика Кыргызстана на перепутье) Хэл Хилл, Такаши Ямано, Эдимон Гинтинг; Глава 2 (Торговля, прямые иностранные инвестиции и трудовая миграция) - Према-чандра Атукорала и Маниша Прадхананга; Глава 3 (Реформирование аграрного сектора) Такаши Ямано, Хиндра Нуэлла Сэмсон и Канат Тилекеев; Глава 4 (Эффективный рост сектора услуг в Кыргызской Республике) Джаяретанам Пиллаи, Киеши Танигучи; Глава 5 (Цифровая трансформация и возможности в Кыргызской Республике) - Соек Юн и Майкл Мингес; Глава 6 (Транспорт и логистика для обеспечения роста торговли и инклюзивности) - Ричард Помфрет и Айгуль Бердигулова; Глава 7 (Реформирование сектора энергетики Кыргызской Республики) Нил Мак-Каллох, Ки-Юн Нам и Лотис Цюяо; и Глава 8 (Развитие человеческого потенциала для инклюзивного роста) Дамир Эсеналиев и Киёси Танигучи.

Хэл Хилл обеспечил общий технический обзор и редактирование по экономическим вопросам, чтобы обеспечить согласованность и качество исследований всех глав, при поддержке редактора в лице Джилл Гейл де Вилья. Исследования и помощь со сбором данных были предоставлены Амадором Форондой, Дэриллом Навалом и Ренели Глорией. Перевод отчета на русский язык выполнили Гуля Кольбаева, Айгуль Джайчиева, Наргиза Кудайбердиева, Виктор Кульков и Светлана Чиркова при координации работ со стороны Олеси Проценко, ассистента по операциям в Постоянном представительстве АБР в Кыргызской Республике. Графический дизайн и верстка были выполнены Джо Марком Ганэбэном.

Мы также благодарим Департамент АБР по связям за заключительный обзор, печать, размещение в Интернете и публикацию отчета в СМИ.

Наконец, мы выражаем нашу благодарность нашим внешним заинтересованным сторонам и партнерам, включая гражданское общество, партнеров по развитию (Немецкое агентство по развитию (Deutsche Gesellschaft für Internationale Zusammenarbeit), Японское агентство международного сотрудничества и Агентство США по международному развитию), кооперативы, государственные предприятия и частный сектор (Торгово-промышленная палата, Международная ассоциация автомобилистов, Ассоциация банков), которые поделились опытом работы с проектами и экономическими перспективами, которые сыграли важную роль в исследовании. 


\section{Краткая информация об авторах}

\section{Према-чандра Атукорала}

Према-чандра Атукорала - профессор экономики экономического факультета Арндт-Кордена, Кроуфордской школы государственной политики Австралийского национального университета, и член Академии общественных наук Австралии. Его интересы распространяются, прежде всего, на области макроэкономики развития и международной торговли. В числе его публикаций 10 книг, 7 отредактированных томов, 120 статей в академических журналах, 82 главы в сборниках разных авторов, и многочисленные директивные документы, рецензии на книги и отчеты о проведенных консультациях. Он был, в разное время, консультантом Всемирного банка, Азиатского банка развития, Института Азиатского банка развития, Международной организации труда, Организации ООН по промышленному развитию, Всемирной торговой организации, Центра Международной торговли Организации Объединенных Наций и австралийского Агентства международного развития. Будучи консультантом, он работал в таких странах как Бангладеш, Камбоджа, Эфиопия, Грузия, Индия, Индонезия, Иордания, Кыргызская Республика, Лаос, Малайзия, Монголия, Непал, Пакистан, Шри-Ланка, Таиланд и Вьетнам.

\section{Айгуль Бердигулова}

Айгуль Бердигулова - аналитик Евразийского банка развития (ЕАБР), где она занимается экономическим и промышленным анализом государств-членов Евразийского банка развития. В сферу ее деятельности входит подготовка ежеквартальных прогнозов главных макроэкономических индикаторов Республики Казахстан, Кыргызской Республики и Республики Таджикистан, исследование промышленного сектора и развитие взаимной торговли. Ранее она работала в Национальном банке Кыргызской Республики в качестве руководителя исследовательской группы, которая участвовала в разработке проектов стратегических рекомендаций для комитета по монетарной политике. Она опубликовала ряд статей об экономическом развитии различных стран Центральной Азии. В разное время она состояла членом редакционной коллегии периодических изданий, издаваемых Национальным банком Кыргызской Республики.

\section{Дамир Эсеналиев}

Дамир Эсеналиев - старший научный сотрудник Международного центра по изучению международной безопасности и развития (ISDC), расположенного в Берлине, Германия. Его исследовательские интересы включают количественные микроэкономические исследования, связанные с социальной сплоченностью, рынками 
труда, неравенством, развитием сельского хозяйства и взаимоотношениями между различными поколениями общества. В последнее время он активно участвовал в исследованиях по оценке влияния миротворческих мероприятий в Кыргызстане, исследуя образование в сфере социальной сплоченности и мира. Дамир Эсеналиев является академическим координатором исследования «Жизнь в Кыргызстане». Ранее он работал в Стокгольмском международном институте по исследованию проблем мира, Германском институте экономических исследований (DIW, Берлин), в офисе Всемирного банка в Кыргызской Республике и Национальном банке Кыргызской Республики. Его работы публиковались в «Журнале сравнительной экономики», «Экономика переходного периода», «Исследования социальных показателей» и Международного журнала психологии. Кроме того, он является автором многих рабочих документов и отчетов, опубликованных Германским институтом экономических исследований (DIW), Институтом изучения трудовых отношений (IZA), Университетом Центральной Азии и Всемирном банком.

\section{Эдимон Гинтинг}

Доктор Эдимон Гинтинг - заместитель генерального директора департамента экономических исследований и регионального сотрудничества Азиатского банка развития (ADB). Перед этим назначением доктор Гинтинг был директором отдела экономического анализа и операционной поддержки, где он курировал обзор экономической целесообразности всех проектов АБР и проводил подготовку диагностических исследований для развивающихся государств-членов АБР (РСЧ). Эдимон Гинтинг перешел на работу в АБР в 2007 году и впоследствии возглавлял несколько крупных и стратегических операций АБР по поддержке экономических реформ, включая кредиты для поддержки РСЧ АБР в условиях мирового финансового кризиса. До перехода в АБР доктор Гинтинг работал экономистом в Международном валютном фонде; советником в Парламенте Индонезии; экономистом-исследователем в Комиссии по вопросам производительности труда в Австралии; исследователем и лектором в Университете Индонезии; научным сотрудником с учёной степенью в Университете Монаш; и экономистом-исследователем в Университете Гэдджи Мады. В Университете Монаш он получил степень доктора философии по экономике.

\section{Хэл Хилл}

Хэл Хилл - почетный профессор (H.W. Arndt) по экономике стран Юго-Восточной Азии в Австралийском национальном университете. Его главными исследовательскими интересами являются экономические системы АCEAН, включая тематические исследования стран и тематическую, сравнительную работу; индустриализацию и иностранные инвестиции в страны Восточной Азии; региональное (субнациональное) развитие; экономика стран переходного периода и политическая экономия развития. Он - автор или редактор 20 книг, и подготовил около 160 научных статей и книжных глав. Хэл Хилл является не только автором множества публикаций в австралийских и азиатских газетах, журналах и веб-сайтах, но также и комментатором на радио и ТВ. Он работал консультантом для правительств Австралии и Индонезии, Азиатского банка развития, Всемирного банка и некоторых агентств Организации Объединенных Наций. Он читает лекции в университетах и институтах в 10 странах, является членом редакционных коллегий 14 академиче- 
ских журналов, член Академии общественных наук Австралии. В настоящее время Хэл Хилл является президентом Восточноазиатской экономической ассоциации.

\section{Нил Мак-Каллох}

Нил Мак-Каллох - директор Группы стратегической практики. Главная область его интересов - политическая экономия реформ в энергетическом секторе. Сюда входит работа над реформой энергетического сектора в Кыргызской Республике и Пакистане; доступ к энергии в Индии; помощь в реформировании энергетического сектора в Африке; реформа топливной субсидии в Индонезии и Нигерии; и реформа рынка электроэнергии в Гвинее, Мали и Того. Ранее доктор Мак-Каллох был директором Программы экономической политики в Оксфордском стратегическом управлении, а до этого, - ведущим экономистом Австралийской программы помощи в Индонезии. Он также возглавляет Группу изучения проблем глобализации в Институте изучения развития в Великобритании, и был старшим экономистом Всемирного банка в Индонезии.

\section{Майкл Мингес}

Майкл Мингес - консультант по тенденциям и влиянию цифровых технологий. Ранее он возглавлял отдел анализа рынка в Международном союзе телекоммуникаций, специализированном учреждении Организации Объединенных Наций. Он имеет большой опыт работы в области политики и стратегий по информационным и коммуникационным технологиям на развивающихся рынках. Недавние его работы включают консультирование правительства Оман в разработке стратегии электронной коммерции, моделирование цифровой экономики в Египте и изучение влияния разрушительных цифровых технологий в развивающихся странах. Он имеет степень магистра делового администрирования в Университете Джорджа Вашингтона.

\section{Ки Ён Нам}

Ки Ён Нам - главный экономист по энергетике в группе энергетического сектора кластера сектора консультативных служб департамента устойчивого развития и изменения климата (SDCC) в АБР. У него более чем 30-летний профессиональный опыт работы в энергетическом секторе. До прихода в департамента устойчивого развития и изменения климата, Ки Ён Нам был главным экономистом отдела экономического анализа и операционной поддержки (EREA), где он внес значительный вклад в аналитические исследования и техническое консультирование операционных отделов ERCD по различным дисциплинам, включая развитие энергетического сектора и реформы, возобновляемую энергию, субсидии ископаемого топлива, транспорт, оценку воздействия, диагностические исследования страны, и проблемы, связанные с экономическим анализом инвестиционных проектов, особенно в секторах энергетики, инфраструктуры и окружающей среды. До прихода в АБР он работал в Международном агентстве по атомной энергии (МАГАТЭ), Международном институте прикладного системного анализа и в Организации Объединенных Наций по промышленному развитию. Ки Ён Нам получил степень доктора философии (Ph.D.) по экономике в Венском университете, Австрия. 


\section{Маниша Прадхананга}

Маниша Прадхананга - экономист департамента экономических исследований и регионального сотрудничества АБР. До прихода в АБР Маниша была доцентом экономики в колледже Нокс, США, где она преподавала курсы по макроэкономике, международной торговле и экономическому развитию. До этого она работала в Институте Азиатского банка развития, Токио, Япония. Маниша получила степень $\mathrm{PhD}$ по экономике в Массачусетском университете в Амхерсте и степень бакалавра в Колледже Маунт-Холиок, США.

\section{Джаяретанам Синния Пиллаи}

Джаяретанам Синния Пиллаи - начальник отдела бизнеса и декан школы предпринимательства и управления бизнесом, и Адъюнкт-профессор экономики и государственной политики в Американском университете в Центральной Азии (АУЦА). Он также является профессором экономики в Академии Организации по безопасности и сотрудничеству в Европе (Академия ОБСЕ). Недавно он был награжден Премией Мэтью Нимица (2018) за выдающийся интеллектуальный вклад в продвижение исследований в Американском университете в Центральной Азии. Джая имеет множество публикаций по политической экономии Юго-Восточного и Центральноазиатского экономического развития. Он исследует и анализирует роль государства в содействии экономическому развитию. Он на экспертном уровне исследует важность технологического развития и возникновения кластерного экономического прогресса в странах с формирующейся экономикой. Развитие совместных научно-исследовательских разработок и формирования политики в центральноазиатских странах - это именно та ключевая область, которой он сейчас отдает свои силы.

\section{Ричард Помсрет}

Ричард Помфрет возглавляет программу Jean Monnet по экономике европейской интеграции в Институте международной торговли и с 1992 года является профессором экономики в Университете Аделаиды. С 1979 по 1991 годы он являлся профессором экономики в Школе специальных международных исследований при Университете Джонса Хопкинса. Он работал консультантом в Организации Объединенных Наций, Всемирном банке, ОЭСР, МВФ и АБР. Он опубликовал более ста статей и двадцать книг, включая такие книги, как «Экономика региональных торговых соглашений» (Oxford UP, 2001 г.), «Центрально-Азиатские экономики после обретения независимости» (Princeton UP, 2006 г.), «Регионализм в Восточной Азии: Почему он процветает, начиная с 2000 года, и как далеко он зайдет?» (World Scientific, 2011 г.), «Век равенства: Двадцатый век в экономической перспективе» (Harvard UP, 2011 г.), «Международная торговля: Теория, действительность и политика (World Scientific, 2016 г.) и «Экономики Центральной Азии в двадцать первом веке: Прокладывая новый великий шелковый путь (Princeton UP, 2019 г.).

\section{Лотис Цюйяо}

Лотис Цюйяо является специалистом по экономике в департаментах EREA-ERCD, AБР. Она принимала участие в работе отдела в области энергетики в течение по- 
следних семи лет, в частности по экономическому анализу энергетических проектов, подготавливая оценку энергетического сектора во время проведения АБР диагностических исследований и оказывая помощь в других публикациях. До прихода в АБР она работала консультантом во Всемирном банке. Она имеет степень магистра в области экономики развивающихся стран от Филиппинского университета.

\section{Хиндра Нуэлла Сэмсон}

Хиндра Нуэлла Сэмсон - старший специалист по национальным экономикам департамента экономических исследований и регионального сотрудничества Азиатского банка развития (АБР). Она работает в АБР больше 10 лет, участвуя в разных региональных проектах технической помощи и в различных исследовательских работах в областях сельского хозяйства и природных ресурсов, сельского развития, экономики в условиях изменения климата, занимается экономическим анализом, оценкой воздействия и диагностическими исследованиями страны. Она оказывает поддержку отделу в обеспечении качественного отбора данных и поддержки экономического анализа для инвестиционных проектов АБР. До перехода в АБР она была младшим научным сотрудником Международного центра тропического земледелия (CIAT) при Международном научно-исследовательском институте риса в Лос-Баносе, где она занималась развитием сельского хозяйства и полевыми исследованиями. Кроме того, она ранее работала в различных неправительственных организациях, осуществляющих оценки воздействия на окружающую среду на Филиппинах. Она закончила Филиппинский университета со степенью магистра в области наук об окружающей среде и степенью бакалавра в области экономики.

\section{Киеши Танигучи}

Киеши Танигучи - главный экономист в ERCD, AБР. В этой должности он руководил подготовкой диагностических исследований во многих РСЧ АБР. Он также руководит исследовательскими группами по проведении оценки воздействия. В АБР он занимал несколько экономических должностей, включая должности в департаменте операций частного сектора, Постоянном представительстве АБР в Узбекистане, и департаменте по Тихоокеанскому региону. Перед назначением на текущую должность Киеши Танигучи был экономистом в Сети сокращения бедности и управления экономикой Всемирного банка. Он начинал свою карьеру в качестве экономиста в Продовольственной и сельскохозяйственной организации ООН (ФАО) в Риме, Италии. Он занимал разные должности в области исследований и обучения в Международном университете Японии, Международном Вестминстерском университете в Ташкенте и в Филиппинском университете. Он имеет степень доктора философии (PhD) и степень магистра в области экономики от Университета штата Огайо, бакалавра наук в области экономики с отличием от Университета штата Орегон, и бакалавра юридических наук от Университета Чиба в Японии.

\section{Канат Тилекеев}

C 2012 года Канат Тилекеев является старшим научным сотрудником Института государственного управления и политики Университета Центральной Азии. Он 
работает в научно-исследовательских проектах Всемирного банка, АБР, ЮСАИД, ФАО, Международного исследовательского центра развития (IDRC) и других донорских и исследовательских организаций в сферах продовольственной политики, измерения бедности, анализа стоимостной цепочки, развития сельской общины, бизнес-среды и стратегической оценки воздействия. Ранее он работал в проектах развития и частном секторе в областях финансовой реформы, развития сельского хозяйства, транспорта и проблем транзита, в консультировании бизнеca, и в пищевой промышленности. Он получил степень доктора философии (PhD) в экономике от Университета Гиссена, Германия в 2012 г. Его диссертация была на тему зависимости сельской бедности от экономической эффективности домашних хозяйств в отдаленных сельских районах Кыргызстана. Его в сферу его исследовательских интересов входят экономика сельского хозяйства, государственная политика, экономика бедности, экономика развивающихся стран, развитие бизнеса, региональная торговля и развитие сельской общины.

\section{Такаши Ямано}

Такаши Ямано - старший экономист отдела экономических исследований и регионального сотрудничества АБР. Его текущие обязанности включают проведение оценки воздействия, проведение экономического анализа проектных предложений, а также проведение диагностических исследований стран и секторов. Он пришел в АБР в 2017 году. До этого, в 2011-2017 годах, он работал специалистом по оценке воздействия в Международном научно-исследовательском институте риса. В 2002-2011 годах он преподавал на курсах подготовки аспирантов в Национальном институте политических исследований (GRIPS) в Токио, Япония. Кроме того он работал консультантом во Всемирном банке в 2000-2002 годах. Он получил степень доктора философии (PhD) в экономике и сельскохозяйственной экономике в Университете штата Мичиган в 2000 г.

\section{Соук Ён Юн}

Соук Ён Юн в настоящее время работает в АБР в качестве главного специалиста по государственному управлению (электронное управление) в отделе цифровых технологий для развития, SDCC. Он является координатором в области цифровых технологий (DT) в операциях АБР. Он возглавляет ряд проектов DT в качестве сотрудника по проектам и организует различные внутренние и региональные информационные мероприятия для лучшего использования DT в различных секторных операциях АБР. Как координатор по DT и электронному управлению в SDCC, он координирует партнерские программы с международными организациями развития, частным сектором и гражданским обществом. Также он играет активную роль во внедрении DT в секторные операции АБР посредством технической помощи и деятельности секторных/тематических групп. 


\section{Сокращения}

$\begin{array}{ll}\text { АБР } & \text { Азиатский банк развития } \\ \text { АО } & \text { акционерное общество } \\ \text { АВП } & \text { ассоциции водопользователей } \\ \text { ВВП } & \text { валовый внутренний продукт } \\ \text { ВТО } & \text { Всемирная торговая организация } \\ \text { ВЦДС } & \text { всемирная цепочка добавленной стоимости } \\ \text { WТТС } & \text { Всемирный совет по туризму и путешествиям } \\ \text { ВЭФ } & \text { Всемирный экономический форум } \\ \text { ГЭС } & \text { гидроэлектростанция } \\ \text { ГКИТиС } & \text { Государственный комитет по информационным технологиям } \\ & \text { и связи } \\ \text { ДЭСВ ООН } & \text { Департамент ООН по экономическим и социальным } \\ & \text { вопросам } \\ \text { ДЭИиРС } & \text { Департамент экономических исследований и регионального } \\ \text { ЮНИСЕФ } & \text { сотрудничества } \\ \text { ЕАЭС } & \text { Детский фонд Организации Объединенных Наций } \\ \text { ЕЭК ООН } & \text { Евразийский экономический союз } \\ \text { ЕБРР } & \text { Европейская экономическая комиссия ООН } \\ \text { ЕС } & \text { Европейский банк реконструкции и развития } \\ \text { ЗСТ } & \text { Европейский Союз } \\ \text { ИМЭК } & \text { зона свободной торговли } \\ \text { ИЭЛ } & \text { измерение и мониторинг эффективности коридоров } \\ \text { ИПП } & \text { индекс эффективности логистики } \\ \text { ИОДвК } & \text { инициатива «Один пояс - один путь» } \\ \text { ИКТ } & \text { интегрированное обследование домохозяйств в Кыргызстане } \\ \text { ЖвК } & \text { информационные и коммуникационные технологии } \\ \text { КНР } & \text { исследование «Жизнь в Кыргызстане» } \\ \text { ЮНКТАД } & \text { Китайская Народная Республика } \\ \text { Лаос } & \text { Конференция ООН по торговле и развитию } \\ \text { МВФ } & \text { Лаосская Народно-Демократическая Республика } \\ \text { МСЭ } & \text { Международный валютный фонд } \\ \text { НСУР } & \text { Международный союз электросвязи } \\ \text { НЭСК } & \text { Национальная стратегия устойчивого развития } \\ \text { НБКР } & \text { Национальный банк Кыргызской Республики } \\ & \end{array}$


Нацстатком

НЭОК

OPC

Великобритания

ОАЭ

$\mathrm{OOH}$

ОЭСР

ОЭАиОО

$\mathrm{OAO}$

ОПЦР

ПРООН

$\Phi A O$

ПИИ

ППГ

PCY

POK

РЭОК

СЭ3

$\mathrm{CH \Gamma}$

СШ

CCCP

СТП

СMTК

ТЭЦ

ЮНФПА

ЦАиЮА

ЦТ

ЭСКАТО

ЭС
Национальный статистический комитет Кыргызской Республики

номинальный эффективный обменный курс

обследование рабочей силы

Соединенное Королевство Великобритании и Ирландии

Объединенные Арабские Эмираты

Организация Объединенных Наций

Организация экономического сотрудничества и развития

отдел экономического анализа и операционного обеспечения

открытое акционерное общество

официальная помощь в целях развития

Программа развития $\mathrm{OOH}$

Продовольственная и сельскохозяйственная организация прямые иностранные инвестиции

пункт пересечения границы

развивающиеся страны-члены

реальный обменный курс

реальный эффективный обменный курс

свободные экономические зоны

Содружество Независимых Государств

Соединенные Штаты

Союз Советских Социалистических Республик

среднесрочная тарифная политика

стандартная международная торговая классификация

теплоэлектроцентраль

Фонд народонаселения ООН

Центральная Азия и Южная Азия

цифровая технология

Экономическая и социальная комиссия ООН для Азии и Тихого океана

электростанция

\section{Единицы измерения}

га

ГВтсч

$\mathrm{M}^{2}$

кбит/с

$\kappa В Т \bullet ч$

Кг

KM

Мбит/с

$\mathrm{MBT}$

M

THT гектар

гигаватт час

квадратный метр

килобит в секунду

киловатт-час

килограмм

километр

мегабит в секунду

мегаватт

метр

тысячи тонн нефтяного эквивалента 


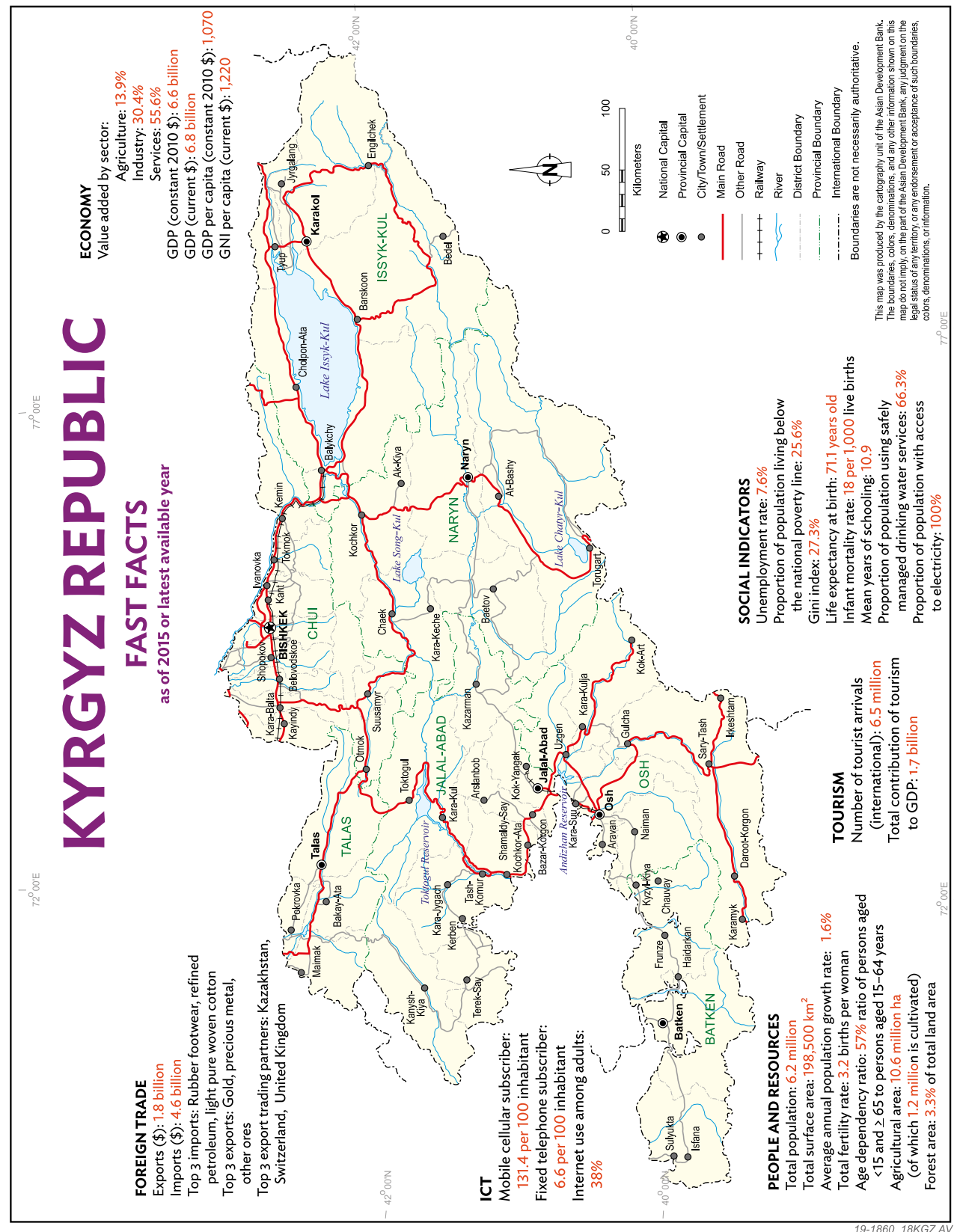




\title{
Глава 1
}

\section{Введение: Экономика Kыргызctaнa нa pacnyтьe}

\author{
Хэл Хилл, Такаши ямано и эдимон Гинтинг
}

\section{1. Введение и общий обзор}

ереход от централизованной плановой к рыночной экономике - это сложный процесс, гораздо сложнее, чем многие думают. Необходимы новые институты, ранее не существовавшие, когда страна переходит от командной системы к рыночной. Руководители должны научиться работать с этими институтами по-новому. И это требует времени», - заметил Перкинс, авторитетный автор работ по переходной экономике (2018).

Это замечание очень актуально для оценки сложившейся ситуации в экономике Кыргызской Республики. Кыргызская Республика ${ }^{1}$ прошла путь от республики Советского Союза до независимого государства. После обретения независимости Кыргызская Республика не только выжила, сохранив территориальную целостность, она также создала парламентскую систему с полным комплексом национальных институтов. Действительно, по большинству сравнительных показателей Кыргызская Республика считается наиболее открытой, обладающей открытой экономикой страной среди бывших Центрально-Азиатских республик Советского Союза. Кыргызская Республика установила рабочие взаимоотношения с четырьмя странами, с которыми у страны есть общая граница.

В течение первой половины 1990-х годов, экономика Кыргызской Республики испытала катастрофический спад, ВВП снизился практически наполовину, и это было одним из самых резких сокращений как в Центральной Азии, так и среди других бывших советских республик. Через четверть века доход на душу населения и условия жизни вернулись к показателям, существовавшим в советское время. Социальные показатели Кыргызстана очень выгодно отличаются от показателей стран с аналогичным уровнем экономического развития. Республика находится на пороге перехода в разряд стран, имеющих доход ниже среднего.

После получения независимости страна называлась Республика Кыргызстан, с мая 1993 года официальным названием страны стало «Кыргызская Республика». В данной главе будет использоваться термин «Кыргызская Республика» и «Кыргызстан» для обозначения страны после получения независимости, а «Киргизия» - до получения независимости. 
Несмотря на эти достижения, Кыргызская Республика сталкивается со сложными проблемами в области развития. По сути, она «потеряла» четверть века экономического и социального развития. За этот период доходы на душу населения во многих азиатских развивающихся странах, по крайней мере, удвоились, а в некоторых случаях - выросли еще значительнее. В соответствии с исследованием Помфрета (2019), показатели развития экономики Кыргызской Республики были ниже, чем ожидалось. Для страны с низкими доходами экономика развивается недостаточно быстро. ${ }^{2}$ Экономический рост около $4 \%$ в год приводит к ежегодному росту на душу населения в $2 \%$. Это подразумевает удвоение дохода на душу населения только каждые 35 лет, что слишком медленно для страны с ВВП на душу населения чуть более 1000 долларов США. Хотя уровень бедности в Кыргызской Республике значительно снизился в этом столетии, большая часть населения живет чуть выше черты бедности (угрожающе низкий уровень). Основным источником создания рабочих мест является выезд из страны в Российскую Федерацию и другие страны. Это свидетельствует о том, что рынок труда - путь к социально-экономическому прогрессу для подавляющего большинства населения - функционирует неэффективно, что, в свою очередь, находит отражение в вялом экономическом росте. Хотя занятость за рубежом является эффективной краткосрочной стратегией сокращения масштабов нищеты, она не обеспечивает основу для устойчивого развития в долгосрочной перспективе. Со временем наиболее мобильные и творческие граждане страны все больше будут ориентироваться на «зарубежные» варианты. Некоторые из них могут никогда не вернуться в страну, тем более что урегулированы возможности работать и жить в Российской Федерации. Более того, очень высок уровень денежных поступлений относительно размера экономики, в некоторые годы этот показатель был самым высокими в мире. Это ведет к снижению прибыльности сектора товаров, пользующихся спросом, что, в свою очередь, еще больше ограничивает возможности трудоустройства на родине.

Кроме того, на горизонте появились макроэкономические проблемы, которые могут подорвать достигнутый на сегодняшний день рост. В отсутствие реформ правительство имеет очень ограниченные бюджетные возможности и, следовательно, существует малая вероятность увеличения производительности и привлечения инвестиций в инфраструктуру, развитие сельских районов, образование и здравоохранение. Более того, поскольку страна меняет статус страны с низкими доходами, уменьшается возможность финансирования крупных бюджетных дефицитов за счет официальной помощи в целях развития (ОПР), полученной на высокольготных условиях. Доходы от золоторудного предприятия Кумтор, по прогнозам, сократятся в течение ближайшего десятилетия. Кроме того, налоговая база Кыргызстана уменьшилась, поскольку значительная часть экономически активного населения ищет работу за рубежом. Существует также сильное политическое сопротивление более целенаправленному использованию крупных социальных трансфертов и субсидий на электроэнергию.

Хотя Кыргызская Республика сталкивается со значительными трудностями географического характера, включая изоляцию от крупных центров торговли и

2 Всемирный банк провел классификацию экономик всех стран по уровню доходов и условно поделил их на четыре группы. Данная классификация базируется на измерении уровня дохода на душу населения. Уровень рассчитывается с использованием метода Атлас (Всемирный банк, апрель 2019г.). По результатам расчетов Кыргызская Республика перешла в разряд стран со средним и ниже среднего доходом. Тем не менее, Международный валютный фонд считает Кыргызстан страной с низким доходом, и поэтому страна получает помощь на льготных условиях. Отметим, что кредиты от Китайской Народной Республики правительству также выдаются по этим льготным протоколам 
чрезвычайно пересеченную местность, более быстрый экономический рост может быть достигнут с помощью реформ - и это является ключевым посылом этой книги. Реформы, предложенные ниже, в этой и последующих главах, могут и должны иметь нейтральный характер и основываться на историческом опыте и достигнутом социальном прогрессе.

По сути, Кыргызской Республике при проведении второго раунда реформ для перехода от советской экономики к динамичной, глобально ориентированной рыночной экономике необходимо создать новую модель развития, ориентированную на рост и развитие страны. Необходимо активизировать производственный сектор с тем, чтобы избежать сильной зависимости от денежных переводов. Несмотря на то, что экономика в целом открыта, необходимы срочные реформы для создания более благоприятной среды для ведения бизнеса, для создания условий, чтобы преодолеть текущую проблему, когда малые фирмы не хотят расти . Институциональная и регулятивная реформа является ключом к улучшению бизнес-климата.

Данная глава построена следующим образом. В разделе 2 рассматриваются вопросы исторического наследия, необычной географии, малых размеров страны и даются специфические экономические характеристики. В разделе 3 дается описание социо-экономического развития и, где это возможно, в сравнительном международном контексте. В разделе 4 даются основные выводы по основополагающим вопросам, рассмотренным в последующих главах: международное измерение, транспорт, логистика, энергетика, сельское хозяйство, человеческие ресурсы, сфера услуг, моделируются логические выводы. Заключительный раздел представляет собой перечень ключевых аргументов и стратегических рекомендаций на будущее.

\section{2. Общая характеристика}

История экономического развития напоминает нам, что страны и их развитие не обязательно «зависят от предшествующего развития». То есть страны, которые пережили длительные периоды экономической стагнации или упадка, могут прервать этот вектор движения «вниз» проведением всеобъемлющей политической реформы. Три развивающихся азиатских гиганта иллюстрируют это утверждение: правительства КНР (1978), Индии (1991) и Индонезии (1966) инициировали смелые программы реформ, которые привели к крупным поворотным моментам в их истории, и, как следствие, значительно улучшили экономический рост и подняли уровень жизни.

Тем не менее, история, география и другие особенности страны представляют собой важные факторы, которые формируют траекторию развития страны, определяют приоритеты и предлагают варианты политических решений. Несмотря на свою древнюю историю, Кыргызская Республика - это молодое национальное государство, функционирующее как независимое политическое образование немногим более четверти века. Важно рассматривать историю и географию страны в качестве ключевых параметров как при оценке траектории ее развития, так и при принятии политических решений. Этот раздел представляет собой обзор текущего положения страны; авторы в деталях анализируют некоторые из упомянутых факторов. 


\section{Историческое наследие - советский период и период независимости}

Три четверти 20 века (с 1917 по 1991 год) Кыргызская Республика находилась под руководством Москвы, как удаленная часть Советского Союза, а начиная с 19 века в сфере влияния России. Разделение труда, сложившееся в рамках модели командной экономики, усилило ресурсную обеспеченность экономики, так как Киргизия служила, прежде всего, поставщиком сырья для всей советской экономики. В Киргизии проводилась насильственная коллективизация сельского хозяйства, хотя и не в таких масштабах, как в других республиках Союза Советских Социалистических республик (СССР), позже - некоторая индустриализация страны. Экономика бывших советских республик была ориентирована, в первую очередь, на нужды Москвы, нежели на приоритеты развития республик. Вследствие этого региональная интеграция протекала медленно, осложненная произвольным географическим и административным делением, которое продолжает создавать трудности в современную эпоху. Международные обязательства Киргизии определялись обязательствами СССР, который не поддерживал отношения с Западом, а после китайско-советского конфликта, то есть после 1960 года, разорвал отношения с КНР. Эти факторы означают, что Киргизия в значительной степени оставалась не связанной с растущими азиатскими экономиками почти всю вторую половину 20-го века.

Безусловно, это историческое наследие имело свои положительные стороны. Кыргызская Республика по доходу на душу населения по-прежнему поддерживает хороший уровень всеобего образования, сохраняет базовые рамки социальной политики, которые, в значительной степени, являются результатом эгалитарной советской модели. Привлекательность столицы, города Бишкек, частично уходит корнями в советскую эпоху. Страна до сих пор пользуется крупными объектами энергетической и транспортной инфраструктуры, построенными в советский период.

Внезапный распад СССР в конце 1991 года создал огромные экономические, политические и социальные сложности, о которых речь пойдет ниже. Тем не менее, Российская Федерация остается важной для экономики Кыргызской Республики (Льюис, 2015). Российская Федерация является основным торговым партнером ${ }^{3}$ и основным источником денежных поступлений в виде переводов от трудовых мигрантов. Несмотря на значительный отток русского населения в 1990-е годы, они по-прежнему составляют около 6\% населения страны. Русский язык по-прежнему широко используется в государственном управлении, образовании и торговле. В Российской Федерации существует многочисленная кыргызская диаспора, тем самым обеспечивая доступ к русскоязычному миру.

\section{География}

Кыргызская Республика - одна из самых изолированных стран мира со сложным географическим положением. Она вдалеке от основных мировых торговых центров. Страна, являясь «дважды закрытой», то есть страной не имеющей выхода к морю, граничащей с тремя странами, которые тоже не имеют выхода к морю. Помимо своей международной изолированности, внутренняя экономическая интеграция сдерживается чрезвычайно пересеченной горной местностью. Почти 90\%

Фактически, главным торговым партнером является Швейцария ( экспорта), так как именно в Швейцарию направляется почти все экспортируемое золото. Тем не менее, в главе 1 и 2 этот вопрос исключается из обсуждения международных торговых партнеров Кыргызской Республики. 
территории находится на высоте более 1500 метров над уровнем моря. Некоторые регионы настолько изолированы и удалены, что до них невозможно добраться наземным транспортом, особенно в суровый и длительный зимний период. В некотором смысле в Кыргызстане существует две экономики: более развитая - на севере страны, с центром в Бишкеке, более тесно связанная с Казахстаном и Российской Федерацией, и на юге страны, граничащая, но не обязательно открытая для трех соседних стран. Завершение строительства асфальтированной дороги из Бишкека в Ош постепенному укрепило внутреннюю экономическую интеграцию, хотя нахождение в пути достаточно сложное, а в зимний период дорогу могут закрывать в период экстремальных метеоусловий. Другие виды сообщений нивелируют, до некоторой степени, изолированность юга от севера. Правительство приняло политику «открытого неба» для гражданской авиации, и как указано в главе 5, внедрение цифровых технологий создает новые возможности для электронной торговли и других форм телекоммуникаций.

В международной литературе по экономике стран, не имеющих выхода к морю, обращается внимание на обусловленные этим фактором высокие транспортные и логистические издержки (данный вопрос подробно исследуется в главе 6). Качество инфраструктуры и политическое сотрудничество с соседними странами определяет, насколько серьезной проблемой становится фактор «изолированности». В этом отношении Кыргызская Республика добилась определенного прогресса, но есть значительные существующие трудности.

Среди необычных географических факторов можно назвать, по меньшей мере, четыре, которые играют важную роль в развитии Кыргызской Республики. Во-первых, страна всегда будет сталкиваться с инфраструктурным дефицитом, и ей нужно будет выделять относительно высокую долю своего бюджета на инфраструктуру. Во-вторых, транзитные договоренности с соседями всегда будут играть важнейшую роль. В-третьих, воздушный транспорт является жизненно важным, и Кыргызская Республика разумно приняла политику «открытого неба» для гражданской авиации и превратила крупные города Бишкек и Ош в узловые аэропорты. Возможность прямых рейсов в Европу по-прежнему ограничена, поскольку авиакомпании Кыргызской Республики не соответствуют европейским требованиям и стандартам безопасности. В-четвертых, развитие телекоммуникаций всегда будет одним из самых приоритетных направлений развития страны. Эти вопросы являются взаимосвязанными и рассматриваются в различных главах этой книги.

\section{Маленькая экономика}

Экономика Кыргызской Республики - крошечная, самая маленькая и в Центральной Азии. ВВП страны составляет около 7 миллиардов долларов США . В сравнительном выражении это эквивалентно по размеру экономике небольшого города в богатой развитой стране. Помимо географической изолированности Кыргызской Республики, на экономическую политику и вопросы в сфере развития влияют ее размеры, то есть ее небольшая территория.

Важно заметить, что размер территории не является абсолютным препятствием для развития страны. В докладе об экономическом росте за 2008 год были определены 13 наиболее быстро растущих экономик за предыдущее столетие: пять из них - Ботсвана, Гонконг, Мальта, Оман и Сингапур - имеют очень маленькие территории с населением меньше, чем в Кыргызской Республике (Комиссия по экономическому росту и развитию, 2008). Различные факторы определяют вы- 
сокие темпы экономического развития этих стран, но опыт, как и существующая литература, указывают на причинно-следственные связи.

К примеру, малые экономики с большей вероятностью будут открытыми, просто по необходимости, а более открытые экономики, как правило, развиваются более быстрыми темпами, поскольку их экономическая структура определяется сравнительными преимуществами, а дисциплина открытости не допускает принятия ошибочных политических решений. У таких стран меньше соблазна прибегать к дорогостоящим и длительным стратегиям импортозамещения. Существующая литература согласуется и с опытом Кыргызстана, как первой из пяти «-стан» стран по либерализации своей экономики. ${ }^{4}$ Тем не менее, стране предстоит продемонстрировать еще одну гипотетическую связь между открытостью и результативностью: для открытой экономики необходимы эффективные, международно-ориентированные институты.

Еще одно гипотетическое утверждение заключается в том, что очень маленькие страны могут иметь ограниченную автономию кредитно-денежной политики из-за широкого использования различных иностранных валют в национальной экономике. Это, по сути, то, что происходит в Кыргызстане (речь об этом пойдет ниже). В целом, потеря мощного экономического рычага влечет за собой негативные последствия, хотя есть и позитивные моменты, при условии, что используемая иностранная валюта является валютой хорошо управляемой макроэкономики с низкой инфляцией; в этом случае долларизацию можно рассматривать в качестве «якоря» для кредитно-денежной политики. Финансово-бюджетная политика остается рациональной, а рынки факторов производства - гибкими. Этот вопрос также обсуждается ниже.

\section{Экономика, построенная на денежных переводах}

Кыргызская Республика и Таджикистан являются наиболее зависимыми странами во всем мире от переводов денежных средств трудовыми мигрантами. Почти треть всех работоспособных жителей Кыргызстана трудоустроена за рубежом, а денежные переводы являются одним из самых больших источников поступления иностранной валюты. Объемы денежных переводов быстро росли в первом десятилетии 21-го века, когда российская экономика процветала, а рабочая сила Российской Федерации - быстро старела. Причины такой чрезвычайно высокой зависимости от денежных переводов очевидны: низкая заработная плата и анемичный рост занятости в родной стране. Миграцию облегчало относительно хорошее общее образование населения и выполнимые условия миграции, знание культуры и языка. Основные страны, где трудоустроены кыргызские граждане - Российская Федерация и, в меньшей степени, Казахстан. Членство в Евразийском экономическом союзе (ЕАЭС) с 2015 года облегчает процедуру трудовой миграции.

Обсуждение вопроса высокой зависимости от денежных переводов ведется по всему миру. Есть очевидная краткосрочная выгода. Доходы домохозяйств увеличиваются и уровень бедности сокращается. Потоки денежных переводов имеют тенденцию быть стабильными и даже контр-циклическими, особенно по сравнению с некоторыми другими потоками капитала, такими как, например, портфельные инвестиции. Занятость в других странах может позитивно влиять на

4 Фактически, соотношение торговли к ВВП в Кыргызстане - приблизительно 80\% к 100\%, аналогично соотношению некоторых малых открытых экономик Восточной Азии. 
развитие коммерческих возможностей, включая приобретение навыков и знаний о международных рынках. Опыт некоторых азиатских стран, ставших не столь давно промышленно развитыми, таких как Республика Корея и Тайбэй, Китай, иллюстрирует эти преимущества.

Но в долгосрочной перспективе есть и серьезные негативные последствия. По сути, денежные переводы в таких масштабах характерны для слабой экономики и свидетельствуют о неспособности обеспечить широкую занятость жителей внутри страны, особенно в секторе конкурентоспособных товаров. Если эту проблему не решать, она может привести к «культуре денежных переводов», при которой лучшие и самые яркие представители каждого нового поколения сосредоточатся на возможностях трудоустройства за рубежом. Это может привести к «утечке мозгов», постоянной потере талантов. В то время как денежные переводы действительно сокращают бедность, они также могут усугублять неравенство, где более образованные члены домохозяйств будут получать непропорционально большие выгоды. Могут возникнуть последствия политико-экономического характера, в частности, занятость за рубежом может уменьшить давление на правительство проводить реформы, направленные на стимулирование динамичного роста рынка труда.

Кроме того, ключевым среднесрочным вопросом является развитие финансовых инструментов и финансового посредничества в целом, что позволяет превращать денежные потоки в продуктивные внутренние инвестиционные возможности. До сих пор очень малая часть денежных переводов от кыргызских мигрантов проходит через официальную банковскую систему страны, которая демонстрирует разрыв между депозитными и кредитными ставками, что действует как дестимулятор или сдерживающий фактор для производительных инвестиций. Существует вероятность, что большая часть денежных переводов направляется в бурно развивающийся строительный сектор в Бишкеке и других крупных городах. Несомненно, эта строительная деятельность ведет к улучшению жилищных условий в стране, способствует росту городского среднего класса. Но это является и симптомом того, что в стране ограничено финансовое посредничество.

\section{3. Экономическое развитие: общий обзор}

В данном разделе дается анализ социального, экономического и институционального развития республики в период независимости. Анализ базируется, в основном, на данных, опубликованных Национальным статистическим комитетом Кыргызской Республики (НСК) и Национальным банком Кыргызской Республики (НБКР), дополнительно использовались отдельные сравнительные статистические данные, приводимые международными институтами. Кыргызская статистика считается достаточно надежной по меркам Центральной Азии. Тем не менее, она ограничена возможностями системы документооборота страны и наличием большого неформального сектора, по которому отчетность, в лучшем случае, приблизительная 5 . Анализ статистики ограничивается еще и несовпадением принципов ведения статистики на данный момент и в советское время.

\footnotetext{
5 Кроме того, широко используемая проверка - так называемые «зеркальные данные» по международной торговле - невозможна, поскольку некоторые из основных торговых партнеров Кыргызстана не предоставляют достоверную отчетность в систему Comtrade OOH (глава 2).
} 


\section{Экономический рост}

Сразу после официального распада СССР 25 декабря 1991 года, произошел резкий спад экономики Кыргызстана. Отрицательный рост зафиксирован в каждый из первых 5 лет независимости, ситуация усугублялась особо тяжелыми экономическими спадами 1993 и 1994 годов (Рисунок 1.1) ${ }^{6}$ К 1995 году худшее, казалось, было позади. Начался положительный рост экономики. Исключением были 4 года: 2002, 2005, 2010 и 2012 годы, когда экономика испытала незначительный или отрицательный рост ВВП, хотя ВВП на душу населения неуклонно рос в течение 23 лет. По мнению Помфрета (Помфрет, 2019, Таблица 2.3), реальный объем ВВП в период с 1991 по 1995 годы сократился примерно на 45\%, а объем ВВП в 1999 году составил около 63\% значения ВВП 1989 года. По сравнительной шкале, по его мнению, экономический спад в Кыргызстане был значительнее, чем в Узбекистане, а в целом схож с казахстанским кризисом, хотя последний случился до нефтяного бума 21-го века. Снижение уровня экономических показателей в Кыргызской Республике было меньшим, чем в других «- стан» странах, в частности, в Таджикистане, в связи с его затяжной гражданской войной.

\section{Рисунок 1.1: Динамика экономического роста, 1991-2018}

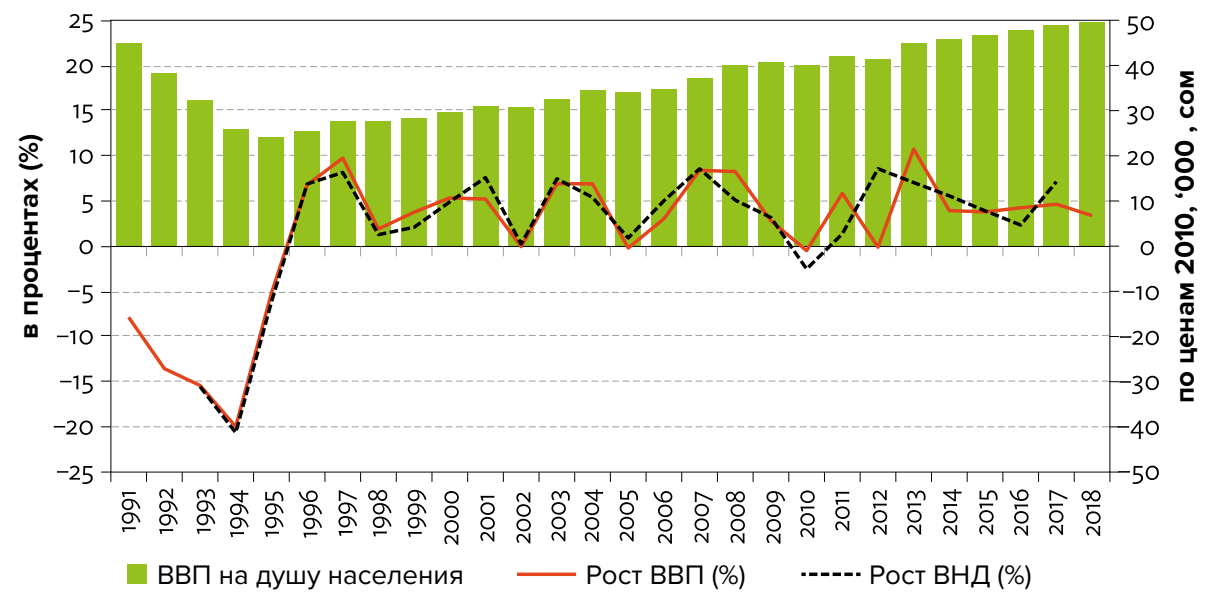

ВВП - Валовой внутренний продукт; ВНД - Валовой национальный доход. Источник: АБР, Ключевые индикаторы 2007 и 2018, Всемирный банк, ИМР, https://databank.worldbank.org/data/reports.aspx?source=world-development-indicators (по состоянию на апрель 2019); Национальный статистический комитет Кыргызской Республики, http://www.stat.kg/en/statistics/nacionalnye-schema (по состоянию на апрель 2019 года)

Тем не менее, рост был неустойчивым, что отражало последствия экзогенных шоков в небольшой и открытой экономике, и последствия внутренних событий. Например, падение темпов роста в 1998-1999 годах объясняется банковским кризисом. Золоторудное предприятие Кумтор начало свою работу в 1997 году, это повлекло за собой немедленный рост экономики. В 1997-2009 годах предприятие производило от 7\% до 10\% ВВП страны. Временное закрытие Кумтора в 2002 году является основной причиной низких темпов экономического роста в тот год. Политические кризисы 2005 и 2010 годов негативно повлияли на темпы роста эконо-

«Современный Бишкек - благополучный, процветающий город с культурной жизнью» (Рашид 2014). 
мики, значительно их снизив. Сырьевой бум в Российской Федерации в течение 10 лет, вплоть до 2014 года, и последующая рецессия оказали сначала позитивное, а затем негативное влияние на экономику Кыргызской Республики и повлияли через экспортный спрос, количество денежных переводов, туризм и другие аспекты.

Как пояснил Помфрет (2019), необходимо подходить с осторожностью к интерпретации национальных счетов, особенно если это касается 1990-х годов. В 1990-х годах (1) снизился потенциал государственного сектора, (2) произошел переход от статистических концепций советской эпохи с их перекосом в ценах и неполной оценкой продукции сферы услуг к ныне существующим, современным принципам. Кроме того, оценка достоверности статистики национальных счетов в течение этого периода осложнена четырьмя дополнительными факторами: крупным неформальным сектором; значительным незаконным оборотом наркотиков (главным образом в регионе Ферганской долины и транзитом через нее); нелегальным транзитом товаров через государственные границы; неучтенными денежными переводами. Тем не менее, общая картина резкого первоначального снижения экономики и постепенного восстановления считается достаточно точным показателем существовавших тенденций. Из-за неустойчивости роста экономики нелегко определить «нормальный» уровень роста для страны, относительно того, что можно было бы разумно ожидать в отсутствии резких положительных или отрицательных колебаний. С учетом того, что самое резкое снижение роста экономики 1990-х годов минуло, самым вероятным «нормальным» уровнем роста можно назвать темпы около 4\%. Как отмечается, из-за медленного и неустойчивого восстановления экономики с конца 1990-х годов, ВВП на душу населения в Кыргызстане только сейчас возвращается к уровню, преобладавшему в позднесоветскую эпоху. По сути, из-за длительного периода восстановления, страна «потеряла» почти три десятилетия развития в процессе национальной реконструкции.

Приведенные выше статистические данные относятся к ВВП. Но для страны с очень большим количеством денежных переводов более точным показателем экономического благосостояния является валовой национальный продукт (ВНП). ВВП измеряет стоимость конечной продукции товаров и услуг, произведенных в стране, а ВНП измеряет стоимость товаров и услуг, произведенных факторами производства, принадлежащими данной стране. Благодаря очень большим суммам денежных переводов, значение ВНП Кыргызской Республики будет выше значения ВВП. Как показано ниже, объем денежных переводов значительно превысил объем прямых иностранных инвестиций (ПИИ). Надежные данные о ВНП (и ВВП по паритету покупательной способности [ППС]) пока отсутствуют, и поэтому точная количественная оценка величин требует подготовки более полного набора статистических данных по национальным счетам.

Возможно ли сравнить экономический рост Кыргызстана с ростом экономики других стран, находящихся на такой же ступени развития и обладающими подобными географическими особенностями? Принимая во внимание необычную географию и историю Кыргызстана, найти абсолютно идентичную страну невозможно. Но для сравнения, в иллюстративных целях, можно отобрать 5 стран: четыре «-стан» страны, то есть Казахстан, Таджикистан, Туркменистан, Узбекистан, а также Лаос (Лаосская Народно-Демократическая Республика - ЛНДР). Эти пять стран сравнительно небольшие, ни одна из них не имеет выхода к морю. Четыре «-стан» страны - бывшие республики Советского Союза, Лаос вошел в коммунистический блок в 1975 году и руководящая Народно- Революционная партия Лаоса является единственной политической партией в стране. 
Таблица 1.1 показывает сравнительную динамику роста экономики шести стран. ВВП на душу населения составляет лишь половину значения ВВП Лаоса, а Лаос - одна из беднейших стран Ассоциации государств Юго-Восточной Азии (АСЕАН). Значение ВВП Кыргызстана составляет менее одной пятой от значения ВВП двух основных экспортеров углеводородов Центральной Азии, то есть Казахстана и Туркменистана. Экономический рост Кыргызской Республики, начиная с 1990 года, также был практически самым медленным; ВВП на душу населения в 2017 году чуть превысило значение ВВП советского времени, хотя, как показано ниже, социальные показатели выглядят лучше. Кроме того, Кыргызская Республика, по сравнению с остальными пятью странами, работала недостаточно эффективно во все периоды, показывая самый медленный рост за период 2000-2017 гг. и такой же медленный рост с 2010 года.

Контраст с ЛНДР особенно разителен, по крайней мере, в отношении экономических показателей. К 1990 году ЛНДР только начала процесс либерализации экономики, после войны и изоляции на протяжении более четверти века. Разница между двумя странами отражает, как минимум, два момента: достаточно легкий экономический переход от централизованного планирования к реформам в Лаосе, который был абсолютно аграрной страной до начала реформ, и динамичный эффект соседства в регионе Меконга.

\section{Таблица 1.1: Сравнительные показатели экономического роста}

\begin{tabular}{|c|c|c|c|c|c|c|}
\hline Индикаторы & 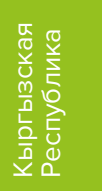 & 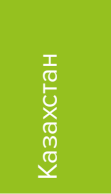 & 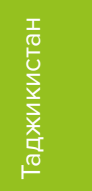 & 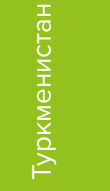 & 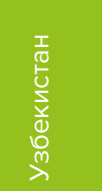 & $\begin{array}{l}\frac{n}{\mathrm{I}} \\
\frac{1}{5}\end{array}$ \\
\hline $\begin{array}{l}\text { ВВП на душу населения } \\
\text { (2017, текущие цены в \$) }\end{array}$ & 1219,82 & 9030,38 & 801,10 & 6586,63 & 1533,85 & 2457,38 \\
\hline $\begin{array}{l}\text { ВВП на душу населения } \\
(2017, \text { в ценах } 2010, \$)\end{array}$ & 1070,32 & 10867,82 & 1020,14 & 7317,55 & 2031,05 & 1730,40 \\
\hline \multicolumn{7}{|l|}{$\begin{array}{l}\text { ВВП на душу населения } \\
(2017, \text { в ценах } 2010, \$) \\
\text { В соотношении к }\end{array}$} \\
\hline $\begin{array}{l}\text { ВВП на душу населения } \\
(2010, \text { в ценах 2010, \$) }\end{array}$ & 1,22 & 1,20 & 1,38 & 1,65 & 1,47 & 1,52 \\
\hline $\begin{array}{l}\text { ВВП на душу населения } \\
(2000, \text { в ценах } 2010, \$)\end{array}$ & 1,64 & 2,42 & 2,46 & 3,07 & 2,50 & 2,57 \\
\hline $\begin{array}{l}\text { ВВП на душу населения } \\
(1990, \text { в ценах } 2010, \$)\end{array}$ & 0,98 & 1,85 & 0,79 & 1,97 & 2,04 & 3,75 \\
\hline
\end{tabular}

ЛНДР - Лаосская Народно-Демократическая Республика; \$- доллар США

Источник: Всемирный банк, Индикаторы мирового развития,

https://databank.worldbank.org/data/reports.aspx?source=world-development-indicators

(по состоянию на апрель 2019).

\section{Отраслевые темпы роста и структурные изменения}

Анализ отраслевых темпов роста приводит к пониманию траектории развития Кыргызской Республики и причин волатильности роста экономики. В первой половине 1990-х годов экономика на основе интеграции и кооперации Советского Союза рухнула, особенно пострадал производственный сектор, поскольку предприятия, как часть централизованной плановой экономики, утратили свои пре- 
ференциальные доступы к рынкам и ресурсам. Учитывая, что этот сегмент экономики значительно ослаб, основной стратегией выживания было возвращение к сельскому хозяйству, поскольку этот сектор пострадал меньше, чем промышленность и сектор услуг. Увеличилось количество занятых в сельском хозяйстве и доля этого сектора в экономике страны начала расти (Рисунки 1.2 и 1.3).

\section{Рисунок 1.2: Темпы роста по секторам (\%)}

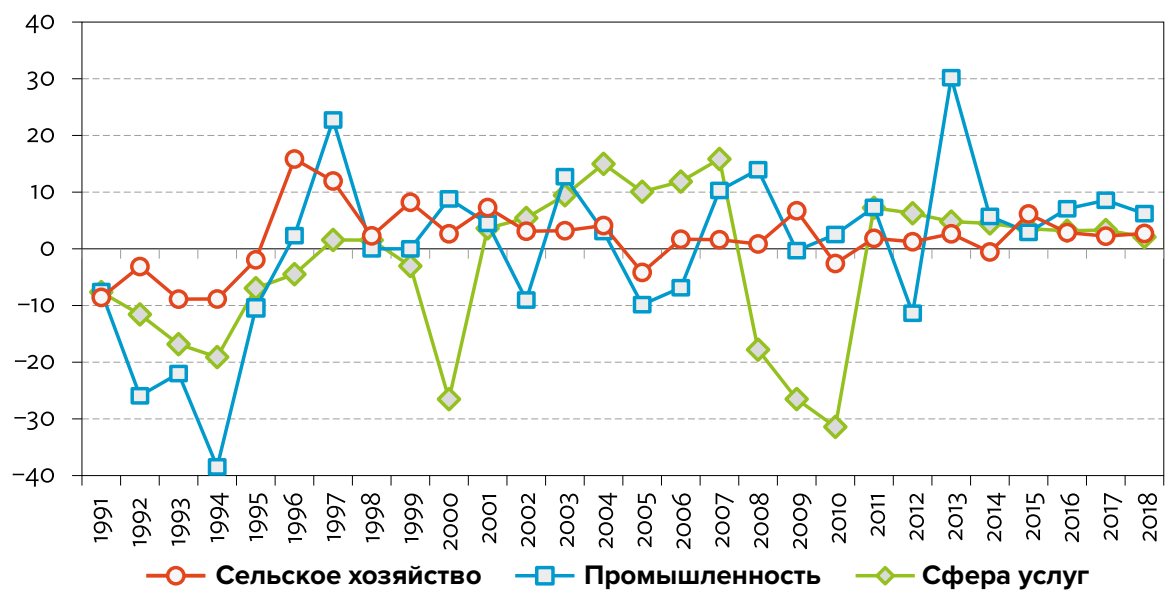

ВВП - Валовой внутренний продукт.

Источник: АБР, Ключевые индикаторы 2010 и 2018 (данные 1991-2009 гг);

Национальный статистический комитет КР (данные 2010-2018гг),

http://www.stat.kg/en/statistics/nacionalnye-scheta/ (по состоянию на апрель 2019 года).

Сектор услуг, хоть и пострадал, но не столь сильно, как промышленный сектор. Появились неформальные торговые связи, начала осуществляться трансграничная торговля, то есть политика открытости Кыргызской Республики начала приносить свои дивиденды. К середине 1990-х годов промышленный сектор начал возрождаться, благодаря, в основном, золотодобывающему предприятию Кумтор. В большой степени последующая волатильность промышленного производства объясняется колебаниями в положении этого предприятия. Со временем начало восстанавливаться мелкомасштабное производство, в основном, производство товаров для дома и швейное производство, которое превратилось в динамичный экспортный сектор; швейные изделия отправлялись, в основном, на рынки Российской Федерации. Фирмы, расположенные в свободных экономических зонах, начали получать финансовые преференции. Стал интенсивно расти строительный сектор, во многом благодаря увеличению числа объектов строительства жилья в крупных городах, финансируемых за счет денежных переводов.

Как это обычно бывает, рост сельскохозяйственного сектора был медленным, но стабильным. В главе 3 дается анализ развития данного сектора, обращается внимание на основную отрасль сельского хозяйства в Кыргызстане - животноводство, и выращивание определенных товарных культур; рассматривается история успеха фасоли в Таласе, которая быстро стала экспортной культурой. Рост сектора услуг был относительно стабильным, об этом говорится в главах 4 и 5 . Основу всего сектора составляют торговля и предоставление государственных услуг. Относительно высокая доля торговли частично является результатом экономической открытости страны: рынок Дордой в Бишкеке в течение определенного 
периода считался крупнейшим рынком в Центральной Азии. В лучшие годы на Дордое работало около 50 ооо человек. Он привлекал торговцев со всего региона; популярнее всего были дешевые товары из КНР7. Туризм развивается достаточно быстро и имеет значительный потенциал, развитие туризма оказало воздействие на развитие ремесел и сферы питания. Существует также ряд меньших сфер деятельности, таких как информационно-коммуникационные технологии (ИКТ), образование и здравоохранение ${ }^{8}$.

\section{Рисунок 1.3: Доля определенных секторов в ВВП (\%)}

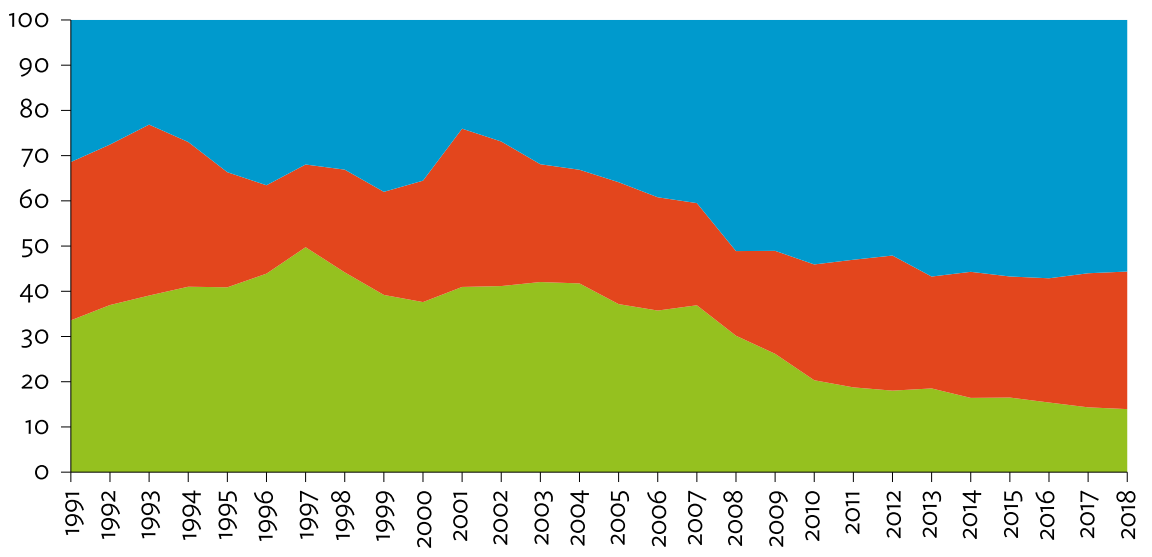

Сельское хозяйство Промышленность

Сфера услуг

Замечание: Доли рассчитаны по значению ВВП по текущим ценам; ВВП - Валовой внутренний продукт.

Источник: АБР, Ключевые индикаторы 2010 и 2018 (данные с 1991 по 2009 год); Национальный статистический комитет Кыргызской Республики (данные с 2010 по 2018 год), http://www.stat.kg/en/statistics/nacionalnye-scheta / (по состоянию на апрель 2019).

До некоторой степени структурные изменения, представленные на рисунке 1.3, напоминают экономику страны с доходом выше среднего. Доля сельского хозяйства в ВВП с середины 1990-х годов сократилась более чем вдвое и составила менее 15\% ВВП в 2018 году. Напротив, доля сектора услуг выросла почти вдвое и составила 55\% ВВП в 2018 году. Однако, если исключить Кумтор, который повышает долю промышленного сектора, основным фактором, объясняющим необычно высокую долю сектора услуг в ВВП, является «экономика денежных переводов». Большой дефицит торгового баланса Кыргызской Республики показывает недостаток конкурентоспособности сектора товаров, пользующихся спро-

7 См работы Камински и Рабаленда (2009) по реэкспортной торговле, которая распространилась и в Оше, и других южных городах. Значимость Дордоя на данный момент падает в результате высоких торговых барьеров со стороны КНР в ответ на решение Кыргызстана присоединиться $\mathrm{k}$ ЕАЭС, и открытия рынка беспошлинной торговли на границе КНР и Казахстана в Хоргосе.

8 Кыргызская Республика стала региональным образовательным хабом для Центральной Азии. Этому послужила и открытость страны, наследие Советского образования, конкурентоспособные цены и невысокий прожиточный минимум. Несколько университетов предлагают курсы на английском языке, ориентируясь на региональные рынки в Центральной и Южной Азии. Среди этих университетов - Американский университет в Центральной Азии (АУЦА), который поддерживается фондом Сороса, Университет Центральной Азии, который поддерживается фондом Ага Хана. Также можно назвать Кыргызско-Турецкий университет Манас, поддерживаемый правительством Турции. Студенты из разных стран обучаются и на медицинских факультетах университетов, расположенных в Бишкеке. В целом, количество зарубежных студентов невелико, но, вероятно, это количество будет увеличиваться, поскольку репутация страны уже сложилась и потребность в высшем образовании растет 
сом, осложняемый тем фактом, что денежные переводы направляются, в основном, в строительство, недвижимость и торговлю. Более того, близость к высоко конкурентным производителям КНР делает производство в Кыргызстане неконкурентным, за исключением специализированных ниш - производство для внутреннего потребления и экспорта в Российскую Федерацию.

\section{Инвестиции и сбережения}

Как и следовало ожидать, количество инвестиций и сбережений резко упали в начале 1990-х годов (Рисунок 1.4). Весьма незначительные сбережения, а иногда и отсутствие каких-либо сбережений - это была стратегия выживания в годы экономического спада и разрухи. Правительство старалось выполнить свои обычные обязательства, и объем государственных инвестиций сократился. Частные инвестиции сдерживались из-за экономического спада и неопределенности инвестиционного климата. Однако процесс инвестирования восстановился на удивление быстро, так как политическая ситуация нормализовалась, заработало золоторудное предприятие Кумтор. В последние годы инвестиции составляют 35\% ВВП, что указывает, с учетом умеренно медленного роста, на необычно высокий коэффициент капиталоотдачи. Высокий приростной коэффициент капиталоотдачи указывает, с большой вероятностью, на неэффективное использование капитала, хотя на коэффициент могут повлиять и крупные инфраструктурные проекты с низкой экономической отдачей. Отрицательный уровень сбережений на протяжении большей части 21 века вызывает недоумение. Рассчитанный как остаток на национальных счетах, он может отражать ограничение данных при наличии очень высокого уровня денежных переводов. В любом случае, очень большой разрыв между сбережениями и инвестициями является оборотной стороной значительного дефицита счета текущих операций. По сути, Кыргызская Республика смогла поддерживать текущий уровень потребления благодаря большому притоку капитала в виде денежных переводов, официальной помощи в целях развития (ОПР) и прямых иностранных инвестиций (ПИИ).

\section{Рисунок 1.4: Объем инвестиций и сбережений (\% к ВВП)}

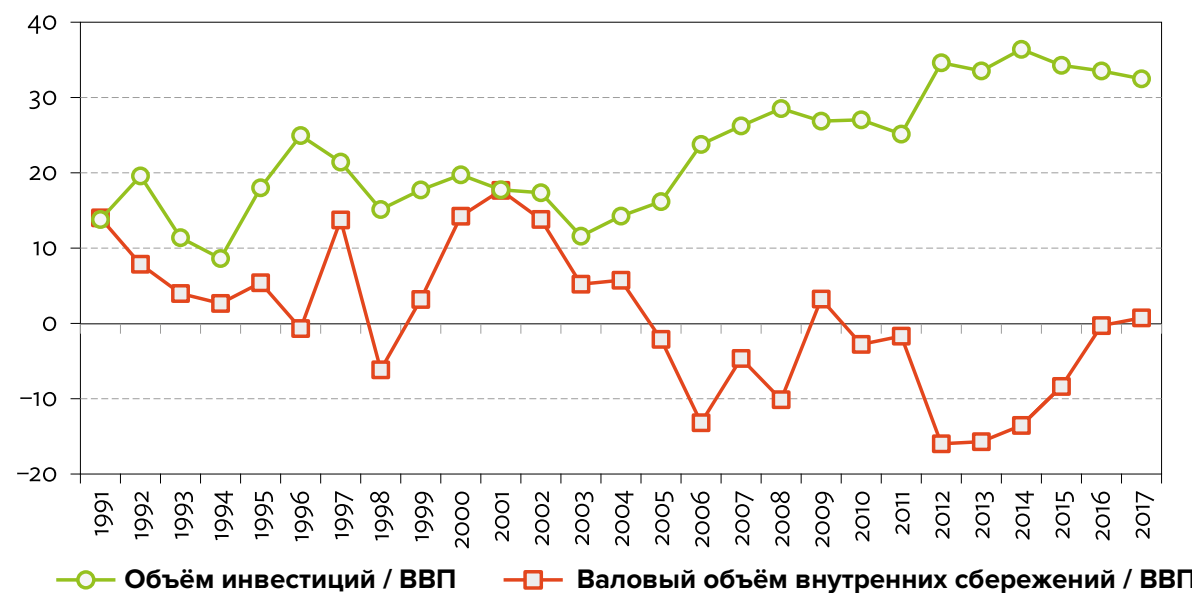

ВВП - Валовой внутренний продукт.

Источник: Национальный статистический комитет Кыргызской Республики, http://www.stat.kg/en/statistics/nacionalnye-scheta (по состоянию на апрель 2019). 


\section{Макроэкономический обзор}

Макроэкономическая стабилизация являлась одной из основных задач экономической политики, стоящей перед новым правительством. После развала Советского Союза Российская Федерация либерализовала цены и бывшие республики СССР были вынуждены последовать этому примеру. Без жестких бюджетных ограничений и надежных центральных банков во всех пяти Центрально-Азиатских странах наблюдалась гиперинфляция. (Помфрет 2019, глава 2). Как и в ситуации с политической системой, Кыргызская Республика была первой, которая в мае 1993 году ввела в оборот «сом» - национальную валюту, первой смогла взять гиперинфляцию под контроль, и первой установила связи с Международным валютным фондом (МВФ) в мае 1992 года. Кыргызская Республика постепенно, в 1990-е годы, перестроила свою финансовую систему, но за счет очень крупных зарубежных заимствований. Новая независимая республика не имела государственного долга, поскольку Российская Федерация взяла на себя весь долг бывшего Советского Союза. Но к концу 1990-х годов, величина государственного долга сравнялась с ВВП (100\% ВВП) и правительство неуклонно шло к долговому кризису.

На рисунках 1.5 - 1.7 представлены макроэкономические показатели страны с середины 1990-х годов. Как показано на рисунке 1.5, инфляция контролировалась практически в течение всего периода, с периодическими пиками, например, в 1999 и 2008 годах, что объясняется более свободными фискальными правилами или инфляцией, возникшей из-за импорта. Обменный курс сома к доллару США неуклонно снижался, главным образом в 1990-е годы и в последние 5 лет. Однако, обменный курс сома к доллару не дает полную картину системы валютных курсов: продолжающееся номинальное обесценивание было необходимо для восстановления международной конкурентоспособности, и в любом случае ключевым обменным курсом является курс сома к российскому рублю, поскольку рубль это валюта основного торгового партнера и страны, откуда идет основной поток денежных переводов. Продолжение обсуждения этого вопроса последует ниже.

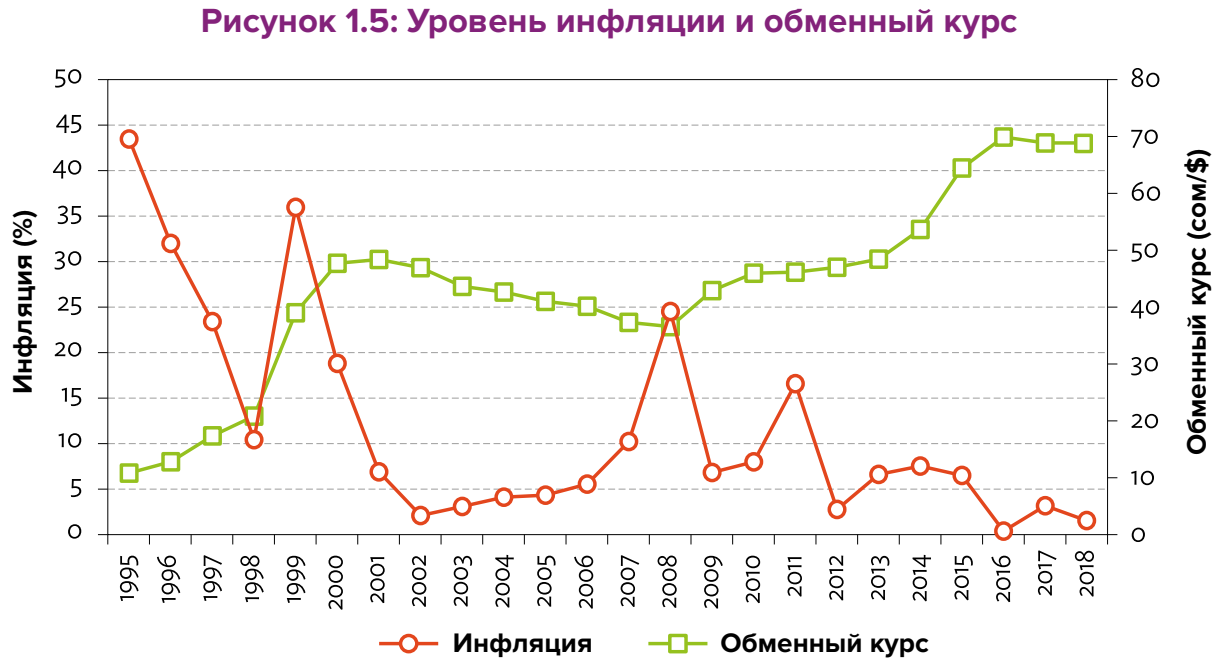

Замечание: Обменный курс сома к доллару США; \$ - доллар США

Источник: АБР, Ключевые индикаторы 2007 и 2018; НСК Кыргызской Республики, http://www.stat.kg/en/statistics/nacionalnye-scheta, по состоянию на апрель 2019 года. 
У Кыргызской Республики на протяжении всего периода независимости сохранялся такой же дефицит, как и раньше, в советское время, когда были чистые трансферты из центра. Как показано на рисунке 1.6, дефицит по счета текущих операций был очень большим, зачастую превышал 10\% ВВП. Дефициты покрывались, главным образом, за счет ОПР, ПИИ и других источников притока долгосрочного капитала. В свою очередь, дефицит торгового баланса был еще выше, большая его часть финансировалась за счет денежных переводов. Сводные данные платежного баланса представлены в таблице 1.2. В главе 2 детально рассматриваются различные составляющие платежного баланса и факторы, влияющие на состояние баланса.

Вся ОПР (официальная помощь в целях развития) и значительная доля долгосрочных потоков капитала использовались для финансирования крупных бюджетных дефицитов. Оба дефицита - дефицит счета текущих операций и дефицит бюджета, в основном, являются стабильными в связи с долгосрочной природой потоков капитала и очень льготным характером ОПР. Российская Федерация и западные партнеры периодически списывали долги. В результате, на протяжении большей части этого столетия, государственный долг не превышал 6о\% ВВП и оставался в допустимых пределах Маастрихтских руководящих принципов, частично принятых поочередно сменявшим друг друга руководством страны.

\section{Рисунок 1.6: Сальдо бюджета и баланс счета текущих операций (\% к ВВП)}

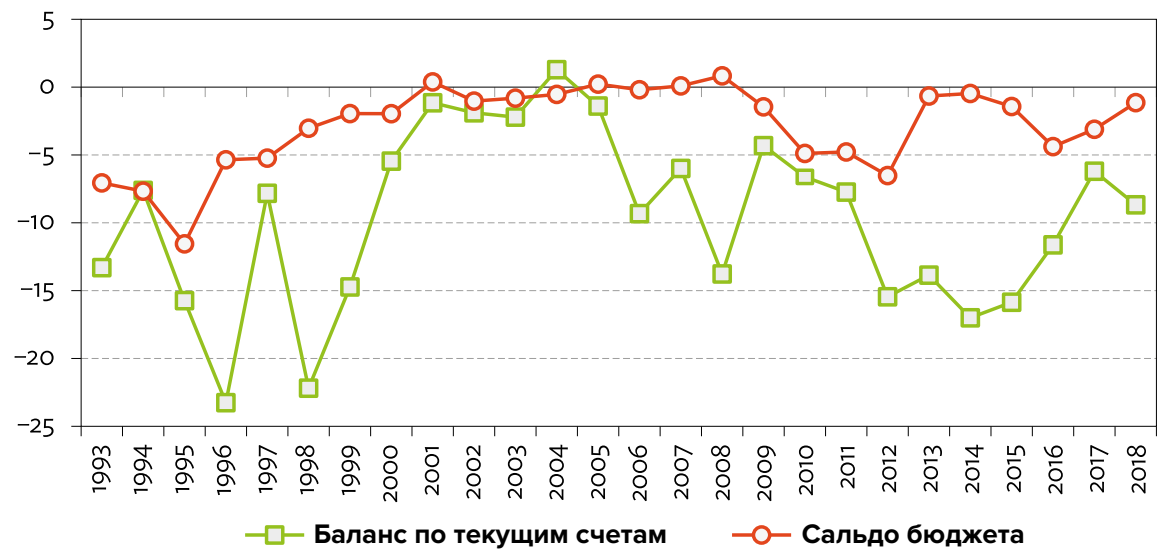

Источник: АБР, Ключевые индикаторы 2007 и 2018; Национальный статистический комитет Кыргызской Республики, http://www.stat.kg/en/statistics/nacionalnye-scheta/ (по состоянию на апрель 2019 года).

Практически весь государственный долг является внешним и долг деноминирован в иностранной валюте. Растет также внешний долг частных компаний, который оценивается в 40\% - 50\% ВВП. Как показано на рисунке 1.7 , совокупный внешний долг страны, как государственный, так и долг частных компаний, в настоящее время превышает 100\% ВВП. Эта задолженность росла в течение последнего десятилетия, хотя она остается ниже уровня 1998-20оо годов, когда разразился долговой кризис. 


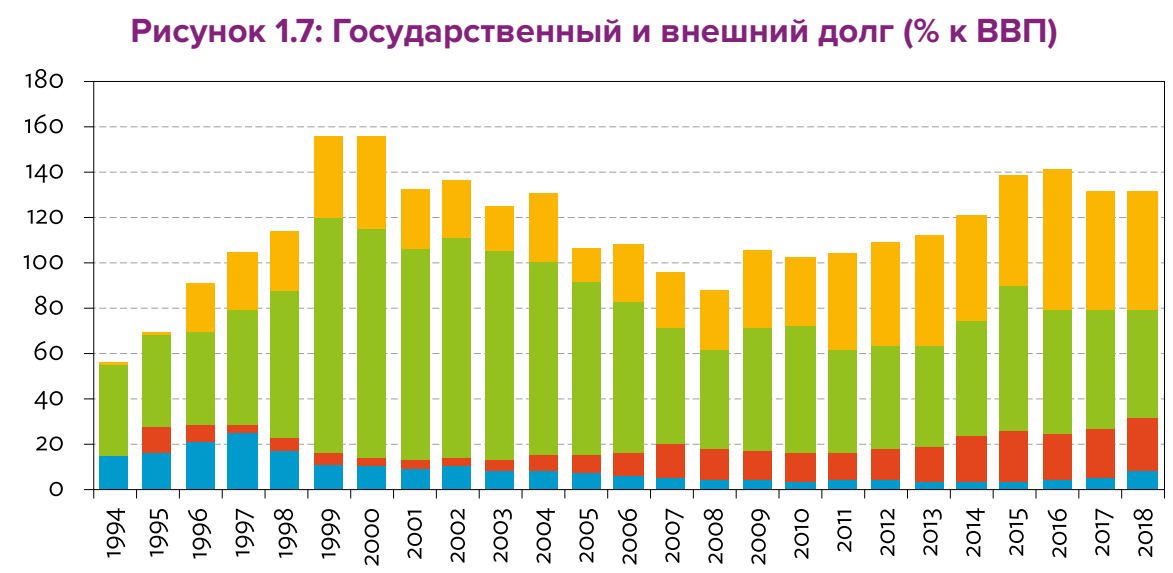

Внутренний государственный долг Внешний государственный долг

Внутренний долг частных компаний Внешний долг частных компаний

Источник: АБР, Ключевые индикаторы 2007 и 2018, Национальный Банк Кыргызской Республики, https://www.nbkr.kg/index.jsp?lang=ENG (по состоянию на апрель 2019);

Всемирный банк, ежеквартальная статистика внешней задолженности, http://datatopics.worldbank.org/debt/qeds (по состоянию на апрель 2019 года. и учета.

Сейчас мы рассматриваем аспекты режима макроэкономической политики

Налогово-бюджетная политика. Макроэкономическая ситуация Кыргызской Республики, в среднем, хорошая. Правительственные затраты, по стандартам стран с низким доходом, высоки, они составляют около 35\% ВВП. Государственный долг составляет 56\% ВВП, ниже максимального уровня, который составляет $60 \%{ }^{9}$, в то же время правительство поддерживает высокий уровень дефицита бюджета, обычно в пределах 7\%-9\% ВВП. Как отмечается, в ближайшем будущем дефицит бюджета и долг будут управляемыми, поскольку значительная часть дефицита финансируется за счет безвозмездной помощи (грантов) и высокольготных займов. В результате долг имеет длительный срок погашения, поэтому не предвидится внезапного оттока капитала. В настоящее время около 35\% всей суммы ОПР - это грантовый компонент. Средняя процентная ставка по государственному долгу невысокая - в пределах 1\% - 2\%. Со временем грантовый компонент будет уменьшаться, поскольку страна выходит из категории «страны с низким уровнем доходов».

Однако, бюджетные возможности правительства весьма ограничены. Дефициты неуклонно растут, особенно в предвыборные годы и периоды политической нестабильности. Что касается доходной части, маловероятно, что налоги будут увеличиваться, учитывая их достаточно высокий уровень. Прогнозируется, что доходы от золоторудного предприятия Кумтор, составляющие на данный момент около 20\% государственных доходов, будут снижаться в ближайшем десятилетии. Кроме того, 24\% - 40\% экономики находится в теневом секторе (МВФ, 2016) и, следовательно, налоговые поступления от теневого сектора невысоки. Таким образом, доходы правительства, составляющие приблизительно 30\% ВВП, взимаются с двух третей экономики, несущих тяжелое бремя налогов. Более того, налоговая база является ограниченной и нестабильной. Администрирование налогов и вы-

\footnotetext{
9 Ожидается, что максимальное значение поднимется до 70\%.
} 
полнение налоговых обязательств считается слабым. Налог на добавленную стоимость (НДС) взимается в размере 12 \%, но существует масса исключений и лазеек, в то же время регистрационный порог в восемь (8) миллионов сомов считается очень высоким. Некоторые компании поддерживают оборот ниже этого уровня, разделяя деятельность между филиалами, хотя на самом деле они являются одним и тем же предприятием. Фактически, различные налоговые послабления, выдаваемые компаниям, особенно работающим в свободных экономических зонах, и которые не имеют конечных сроков действия, разрушают налоговую базу. Экономическое обоснование для выдачи налоговых послаблений не было досконально разработано ${ }^{10}$.

Кроме того, существуют тяжелые обязательства. Во многом это наследие советской системы социального обеспечения: пенсионные счета, составляющие около 7,5\% ВВП, образование - около 6\% ВВП, система здравоохранения - около 4\%. Эти три статьи социальных расходов поглощают около половины государственного бюджета. Они играют важную роль в содействии социальной сплочённости общества и недопущения повсеместной нищеты, как в других странах с аналогичным уровнем дохода (например, в Южной Азии). Но главная сложность, относящаяся к их фискальной устойчивости - эффективность расходов и их обезличенная направленность (индифферентное таргетирование). Фактически, большинство социальных расходов не обусловлены проверкой нуждаемости и поэтому не обеспечена точная направленность расходов.

Вопросы устойчивости касаются, в частности, и крупной национальной пенсионной системы и связанных с ней социальных выплат, которые поглощают более 20\% бюджета (ОЭСР, 2018). Пенсия состоит из двух компонентов: накопительного и обязательного. Все граждане имеют право на последний компонент ежемесячную пенсию в размере 1,5 тысяч сомов для всех женщин в возрасте 58 лет и старше, и всех мужчин в возрасте 63 лет и старше, даже если они провели большую часть своей трудовой жизни за рубежом. Последнее является важным элементом, учитывая, что каждый шестой гражданин в настоящее время работает за рубежом, это примерно четверть населения трудоспособного возраста. Все работники официального сектора должны платить 17\% от своей заработной платы в пенсионный фонд, в то время как работодатели вносят 10\%. Тем не менее, Организация экономического сотрудничества и развития (ОЭСР) в своем докладе отмечает, что увеличение числа получателей пенсий по-прежнему опережает рост базы плательщиков взносов. Молодые работники, в частности, не ожидают, что они смогут получать пенсию в полном объеме по достижению пенсионного возраста. В результате, пенсионные выплаты являются, де-факто, подоходным налогом и неким стимулом искать работу за рубежом.

Кыргызская Республика вышла из программ МВФ и теперь правительство может иметь свободный доступ к международным рынкам капитала ${ }^{11}$. Учитывая дефицит инфраструктуры страны, это представляет собой серьезную проблему для фискальной политики. В принципе, брать долгосрочные кредиты для выполнения жизнеспособных проектов капитального строительства имеет экономический смысл. Однако, на практике многое зависит от деталей: проводился ли независимый анализ затрат и выгод для каждого проекта (особенно в стране с та-

10 См. Агентство по продвижению и защите инвестиций Кыргызской Республики. Свободные экономические зоны. http://invest.gov.kg/en/why-kyrgyzstan/free-economic-zones / (на июнь 2019).

11 В декабре 2015 года Кыргызской Республике впервые присвоен кредитный рейтинг В2 (бросовый кредитный рейтинг) агентством Moody's Investors Service и Standard \& Poor's. 
кими сложными географическими условиями); каковы условия международного кредита (процентные ставки, срок погашения, валюта); и следует принимать во внимание, что стандарты управления правительства гораздо ниже, чем существующие в международной практике. Последний вопрос будет обсуждаться далее.

Кредитно-денежная политика. Кыргызская Республика постепенно переходит к принятию современной международной практики инфляционного таргетирования и плавающему обменному курсу в контексте открытого учета международного капитала. Кыргызстан в значительной степени успешно справился с переходом от закрытой советской экономики к очень маленькой, но открытой экономике, подверженной частым внешнеэкономическим и политическим потрясениям. В частности, на нее оказывали влияние и мировой финансовый кризис 20082009 годов и периодические кризисы в Российской Федерации, начиная с 2014 года, и некоторые изменения в правительстве и кабинете министров Кыргызстана ${ }^{12}$.

Целью Национального банка Кыргызской Республики (НБКР) является поддержание официального курса инфляции в пределах 5\% - 7\% (по современным меркам является относительно высоким уровнем), в основном, за счет корректировок процентной ставки. Представляется, что перед НБКР, неофициально, стоит цель - сохранять стабильным обменный курс сома к доллару США. Так, например, в ответ на снижение мировых цен на нефть и ухудшение отношений между Российской Федерацией и Европейским Союзом (EC) и Соединенными Штатами Америки (США), российский рубль (и казахстанский тенге) существенно подешевел по отношению к доллару США за последние годы. Сом также несколько обесценился по отношению к доллару США, но в меньшей степени, это привело к значительному укреплению валюты по отношению к рублю, хотя рост был несколько смягчен в реальном выражении высокой инфляцией в России. Существует значительная волатильность валютных обменных операций из-за переменных потоков денежных переводов (которые, в свою очередь, зависят от ожиданий будущего обменного курса) и цен на сырьевые товары, особенно на золото и нефть. ${ }^{13}$ НБКР осуществляет операции, «сглаживающие» колебания резервов иностранной валюты. А также Нацбанк имеет возможность, нечасто используемую, стерилизовать потоки крупных поступлений (например, всплеск денежных переводов) через продажу облигаций внутри страны.

Проведение политики «сильного сома» имеет два очевидных преимущества. Первое - она способствует понижению инфляции путем уменьшения относительных цен на товары, пользующиеся спросом, и второе - она облегчает обязательства правительства по обслуживанию долга, поскольку внешний долг деноминирован в иностранных валютах (в основном, в долларах США). Однако, основным недостатком является то, что это снижает конкурентоспособность сектора товаров, пользующихся спросом, в частности, сельского хозяйства и производства. Оба эти сектора, в последние годы, развивались медленно. Более того, аргумент о контроле инфляции не особенно актуален в сегодняшней среде с низкой инфляцией, как внутри страны, так и в мире. Более детально этот вопрос обсуждается в главе $2 .{ }^{14}$

12 В Кыргызской Республике сменилось пять президентов и более 20 премьер-министров за период независимости. В соответствии с пересмотренной Конституцией 2010 года, президент может избираться единожды сроком на 6 лет.

13 См работу Бердигуловой, она доказала существование корреляции между уровнем денежных переводов и повышением цены на нефть. Цены на нефть, в свою очередь, влияют на экономический рост и уровень занятости в Российской Федерации (и в Казахстане).

14 Закончился срок действий правительственного трехлетнего соглашения с МВФ и расширенного кредитного механизма МВФ 8 апреля 2018 года. 
Три дополнительных фактора описывают денежно-кредитное регулирование и регулирование обменного курса НБКР.

Во-первых, денежно-кредитная политика обусловлена консервативным финансовым сектором. Финансовый сектор Кыргызской Республики остается слаборазвитым: он невелик, дуалистичен, разрыв между процентными ставками по кредитованию и депозитам очень большой. Малые и семейные предприятия редко обращаются в крупные банки, вместо этого они полагаются на микро-кредиты, процентные ставки по которым вполне управляемы в краткосрочной перспективе, в целях рабочего капитала, но для долгосрочных инвестиционных проектов слишком высоки. Тем не менее, банковские кризисы в Кыргызской Республике, в отличие от соседей, случались редко. Финансовый надзор, который также осуществляется НБКР, рассматривается как тщательный, компетентный и независимый.

Во-вторых, хотя правительство испытывает дефицит бюджета, на НБКР не оказывается давление, чтобы монетизировать дефицит бюджета путем увеличения денежной массы. Как отмечалось, дефицит финансируется главным образом за счет субсидий ОПР и льготных ссуд. Существует небольшой внутренний рынок облигаций, состоящий из облигаций правительства и НБКР. Первые из вышеуказанных являются наиболее важными и, как правило, у них среднесрочные и долгосрочные сроки погашения. Последние из двух имеют короткий срок погашения, как правило, до 3 месяцев, и экономно используются НБКР в целях стерилизации финансовых поступлений и для стабилизации обменного курса. В сумме эти облигации составляют 5\% - 10\% ВВП. Они продаются коммерческим банкам, в действительности, эти банки вынуждены покупать облигации. В принципе, они доступны и для продажи населению и корпорациям, но на практике этот вторичный рынок очень мал.

В третьих - долларизация. Как и все очень малые переходные экономики с открытыми счетами капитала и крупными, относительно размера экономики, международными операциями, Кыргызская Республика должна была решить вопрос о том, разрешить ли использовать иностранные валюты в качестве финансовых инструментов для совершения транзакций и хранения сбережений на счетах (как средство сохранения стоимости). Существует много международных публикаций, в которых изучаются плюсы и минусы экстенсивной долларизации. ${ }^{15}$ На самом общем уровне долларизация подразумевает утрату ключевого инструмента денежно-кредитной политики и политики курса обмена валют. Но, с практической точки зрения, долларизацию можно рассматривать как приемлемый вариант для маленьких экономик, имеющих нестабильную денежно-кредитную историю, и стран с низким уровнем доверия финансовым органам. Эти механизмы варьируются от неофициального принятия долларизации до введения целенаправленного механизма валютного управления и механизма жёсткой привязки валютного курса, как в Гонконге, Китае и в Тиморе-Лешти.

Опыт Кыргызской Республики иллюстрирует неопределенность правительства по этому вопросу. Сразу после получения независимости, страна предпочла пойти по пути открытого учета международного капитала. Существует рынок валютных операций и на данный момент он работает без ограничений. Денежные средства могут переводиться из страны в страну без ограничений, следует только задекларировать суммы, превышающие три тысячи долларов США. В периоды денежной турбулентности правительство стремилось ограничить валютные опе-

15 См, например, работы Менон (2008) по Камбодже. 
рации, как например, во время российского кризиса 2015-2016 годов оно ввело ограничение в 500 долларов США на каждую сделку. Эти условия были в значительной степени проигнорированы. Подобно этому, НБКР разработал правила, запрещающие использование иностранной валюты для совершения крупных сделок, таких как покупка недвижимости, автомобиля и других потребительских товаров длительного пользования. Но на практике эти правила слабо применяются. По официальным оценкам долларизация находится в диапазоне от $35 \%$ до 40\% от объема денежной массы, что является мерой, эквивалентной М2, то есть денежная наличность и депозиты поступают в банки, и сомовые, и валютные. Неофициально, учитывая сделки с недвижимостью и потребительские долгосрочные сделки, долларизация считается не менее $50 \%$.

Поскольку граждане Кыргызстана и иностранные резиденты могут иметь счета как в сомах, так и в другой иностранной валюте, разница в процентных ставках внутри одного и того же банка указывает на ожидаемое снижение обменного курса. Например, если в апреле 2018 года на депозитные счета в долларах США начислялось около 2\%, то на сомовые счета начислялось $10 \%-12 \%$.

Текущая ситуация, по всей вероятности, не изменится. Возможно, правительство временами будет ограничивать хождение иностранных валют ${ }^{16}$. Но до тех пор, пока существуют открытый учет международного капитала, и суммы денежных переводов остаются большими по отношению к ВВП, варианты выбора политики у правительства ограничены. По сути, у правительства ограничены возможности в сфере денежно-кредитной политики. Следовательно, налогово-бюджетная политика и создание благоприятного инвестиционного климата являются ключевыми вопросами ускорения экономического развития.

\section{Подводя итоги: На горизонте макроэкономики скапливаются тучи?}

Было показано, что краткосрочные макроэкономические перспективы, как представляется, достаточно спокойны и комфортны: рост умеренный, государственный долг умеренно высокий (приближается к 60\% ВВП), но, в основном, финансируется за счет долгосрочных, льготных заимствований; уровень инфляции низкий; несбалансированности валютных курсов не предвидится; и имеющий хорошую репутацию НБКР постепенно внедряет инфляционное таргетирование и плавающий обменный курс. Но этот позитивный прогноз скрывает ряд потенциально серьезных макроэкономических вызовов. Приведут ли вызовы к какому-либо экономическому кризису - а такие события трудно прогнозировать - или просто к замедлению экономического роста, покажет время.

Во-первых, в то время как государственный долг (и коэффициент обслуживания долга) на данный момент является управляемым, в ближайшей и среднесрочной перспективе финансирование, скорее всего, будет затруднено. Кыргызская Республика, вероятно, в ближайшее время выйдет из группы стран с низким уровнем доходов, и следовательно, стране не будет предоставляться финансирование на очень льготных условиях. Вместо этого для финансирования бюджетного дефицита (с некоторыми оговорками - неприемлемо высокого) республика будет брать кредиты под более высокие проценты и с небольшим льготным периодом или без него.

16 Например, НБКР ввел правило, запрещающее брать кредиты в иностранной валюте, если только заемщик не докажет валютный доход или наличие активов. 
Во-вторых, ряд дополнительных факторов может усугубить финансовую ситуацию. К таким факторам можно отнести:

- возможный рост мировых процентных ставок;

- возможность укрепления доллара США относительно сома (большая часть долга деноминирована именно в этой валюте);

- увеличение бремени погашения задолженности по прошлым кредитам (некоторые, возможно, с низкой отдачей, например, крупные инфраструктурные проекты), для которых наступает срок погашения; и

- снижение роялти от добычи золота, поскольку добыча золота на Кумторе будет снижаться в ближайшее десятилетие.

В-третьих, существует значительный внешний долг частного сектора, он точно не измерен, но оценивается примерно в 40\% ВВП. Внешний долг, в основном, получен не на льготных условиях и на короткий срок. В принципе, может применяться аргумент «по обоюдному согласию»: то есть, если возникают проблемы с платежами, вопросы будут решаться непосредственно самими кредиторами с использованием определенных механизмов урегулирования задолженностей. Будет ли это применимо - предположить сложно. Во всем мире правительство оказывает финансовую помощь должникам частного сектора, особенно если заемщики имеют политическое влияние и/или работают в «стратегических отраслях». Кыргызская Республика вряд ли станет исключением из этого правила. Таким образом, значительные условные обязательства могут увеличить объем государственного долга страны.

В-четвертых, бюджетные возможности правительства ограничены рядом других факторов:

- крупные и слабо целевые субсидии (например, в электроэнергетике, подробно описанные в главе 6), которые, очевидно, трудно реформировать;

- значительное бремя выплачиваемых пенсий по возрасту, особенно с учетом того, что многие налогоплательщики работают за рубежом, но по-прежнему имеют право, по меньшей мере, на обязательную часть пенсии;

- уровень государственных доходов на уровне 25\% -28\% ВВП уже довольно высок для страны с низким уровнем дохода.

В-пятых, в целом реальный обменный курс (РОК) достаточно стабилен, что говорит об отсутствии больших изменений в конкурентоспособности сектора товаров, пользующихся спросом. Однако, как показано в главе 2, это камуфлирует различные тенденции в реальном обменном курсе для двух основных торговых групп: членов Евразийского экономического союза (ЕАЭС) и остального мира. Следуя недавнему обесценению рубля, РОК Кыргызской Республики повышается относительно ЕАЭС: степень повышения номинального эффективного курса (обмена) намного больше, чем относительно низкий уровень инфляции в Кыргызстане по сравнению со странами ЕАЭС. Это негативно сказывается на конкурентоспособности товаров, экспортируемых Кыргызстаном на его основной рынок. Для остальных мировых рынков, РОК значительно не изменился, но коммерческие связи, логистика и знания рынка являются ограничивающими факторами, особенно для важнейшего экспортного рынка КНР.

В-шестых, в любом случае Кыргызская Республика значительно долларизирована - официально около 40\% по М2, неофициально до 60\% и, таким образом, 
эффективность этого политического инструмента для «выравнивания» ситуации, несколько снижена. Периодически предпринимались попытки снизить уровень долларизации, но высокие уровни денежных переводов делают эти попытки бесполезными. Следовательно, для правительства варианты денежно-кредитной и валютной политики ограничены.

Заключительный момент - структура рынков факторов производства уменьшает зону действий правительства. Готовность к трудоустройству за рубежом, на самом деле, устанавливает минимальную границу реальной заработной платы, тем самым лимитируя гибкость рынка труда (в сочетании с ограниченной гибкостью обменного курса). На рынке замечен высокий уровень концентрации капитала в формальном банковском секторе, в результате чего образуется разрыв между депозитными и кредитными ставками. Таким образом, изменение основной процентной ставки НБКР может иметь ограниченную эффективность.

Отсюда вытекает, что без проведения реформы, возможности правительства финансировать развитие серьезно ограничены, и в будущем они, вероятно, станут еще более ограниченными.

\section{Международное измерение}

В главе 2 дается анализ международной ситуации, с акцентом на относительную экономическую открытость страны, ее необычную структуру экспорта и последствия её географической изоляции. Ниже, в краткой форме, приводятся несколько ключевых моментов.

Во-первых, товарный экспорт Кыргызской Республики состоит, в основном, из сельскохозяйственной продукции и полезных ископаемых, этот факт коррелируется с исторической ролью экспорта в бывшем Советском Союзе и показывает его сравнительное преимущество (Рисунок 1.8).

\section{Рисунок 1.8: Состав экспорта товаров (\%)}

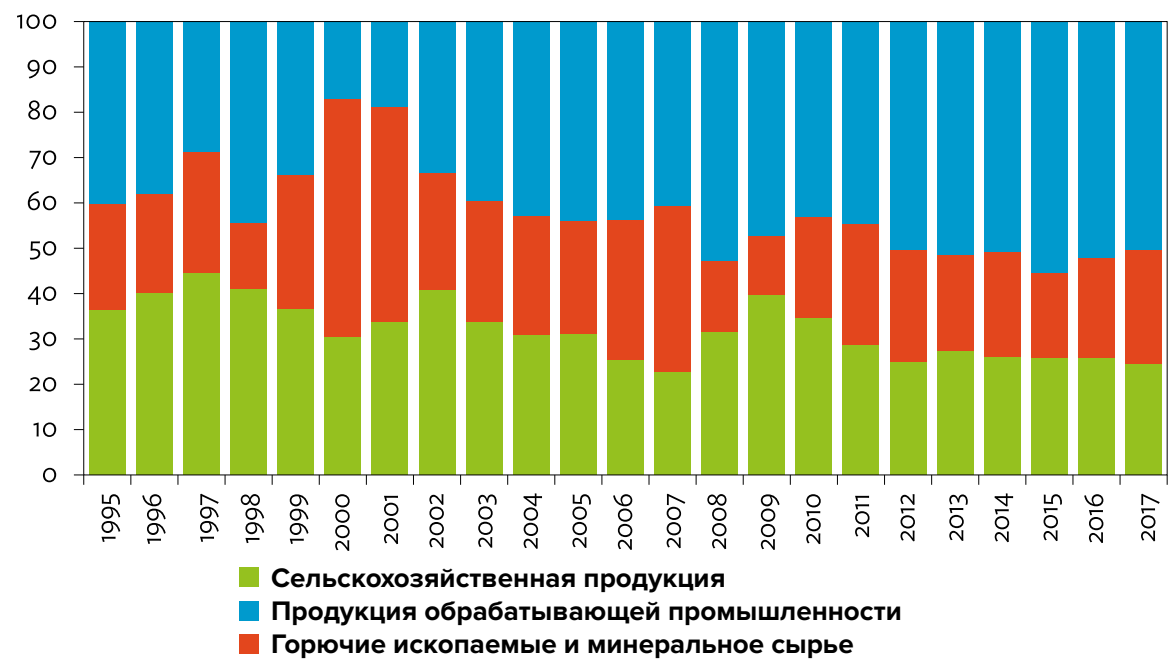

Источник: Всемирная торговая организация (ВТО),

https://www.wto.org/english/res_e/statis_e/merch_trade_stat_e.htm (по состоянию на апрель 2019). 
В отличие от структуры экономики всей страны, доля экспорта оставалась относительно стабильной с конца 1990 годов, несмотря на колебания цен на сырьевые товары. Как было замечено, основной продукт экспорта - это золото, в основном, с месторождения Кумтор. Он составляет около 30\% всего экспорта страны. Как показано в главе 3, страна экспортирует, в небольших количествах, сельскохозяйственную продукцию, в частности, хлопок, фасоль, мясо и молочные продукты, фрукты и овощи. У этой продукции высокий потенциал. Данные на рисунке 1.8 показывают, что Кыргызская Республика - значительный экспортер промышленных товаров. На экспорт, в основном в Россию, идут швейные изделия, но объем экспорта невелик (Тилекеев 2014), промышленные товары показаны в торговой статистике как реэкспорт, то есть импорт из КНР, следующий в южные соседние страны.

Включение услуг существенно меняет картину. Услуги, в основном, денежные переводы - доминанта в экспорте страны (Рисунок 1.9). В первые годы независимости они составляли около 10\% от общего объема, но со временем эта цифра увеличивалась. Интенсивный рост приходится на нынешнее столетие (Рисунок 1.10). За последнее десятилетие уровень денежных переводов составил около половины от общего объема всего экспорта, поэтому не будет преувеличением назвать экономику Кыргызской Республики экономикой «денежных переводов».

\section{Рисунок 1.9: Структура экспорта (\%)}

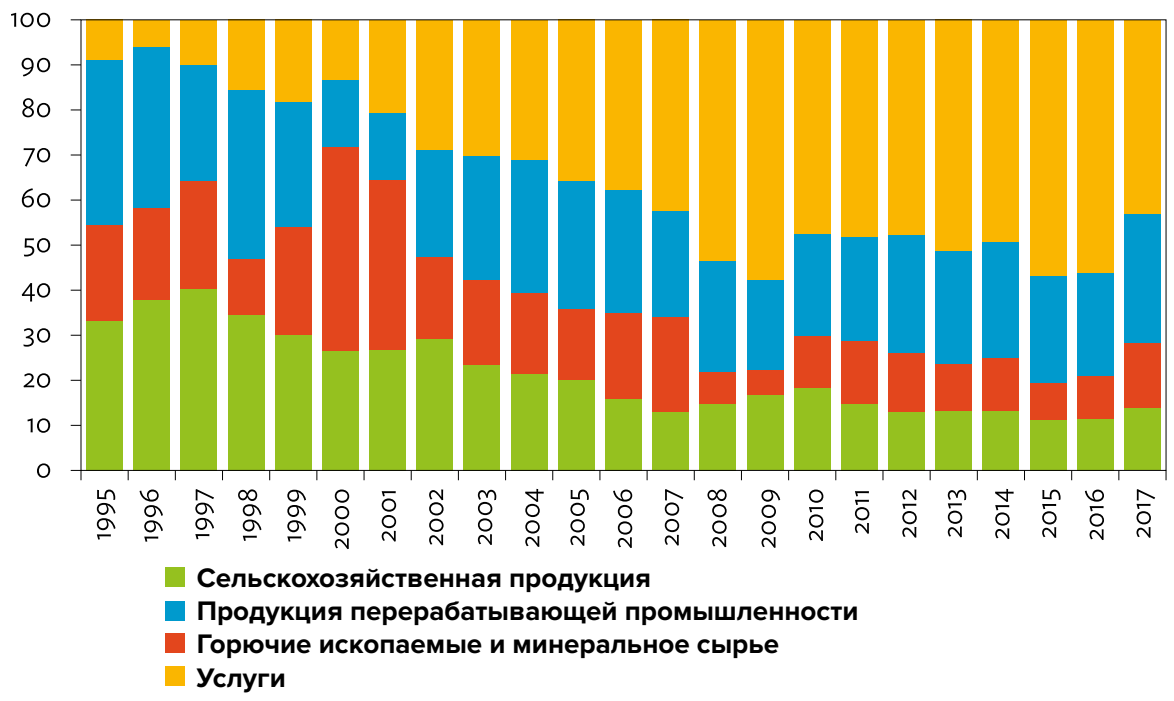

Источник: Всемирная торговая организация (ВТО), статистика товарооборота,

https://www.wto.org/english/res_e/statis_e/merch_trade_stat_e.htm (по состоянию на апрель 2019).

Статистика по экспорту должна интерпретироваться с осторожностью. Во-первых, вопрос реэкспорта. Во-вторых, можно предположить, что в стране, не имеющей выхода к морю, где не отрегулирована работа таможенных служб, и соседствующей со странами, чья экономика относительна закрыта, существует огромный оборот нелегальной торговли, технической и физической. 


\section{Рисунок 1.10: Денежные переводы, иностранные прямые инвестиции,} официальная помощь в целях развития (млн. долларов США)

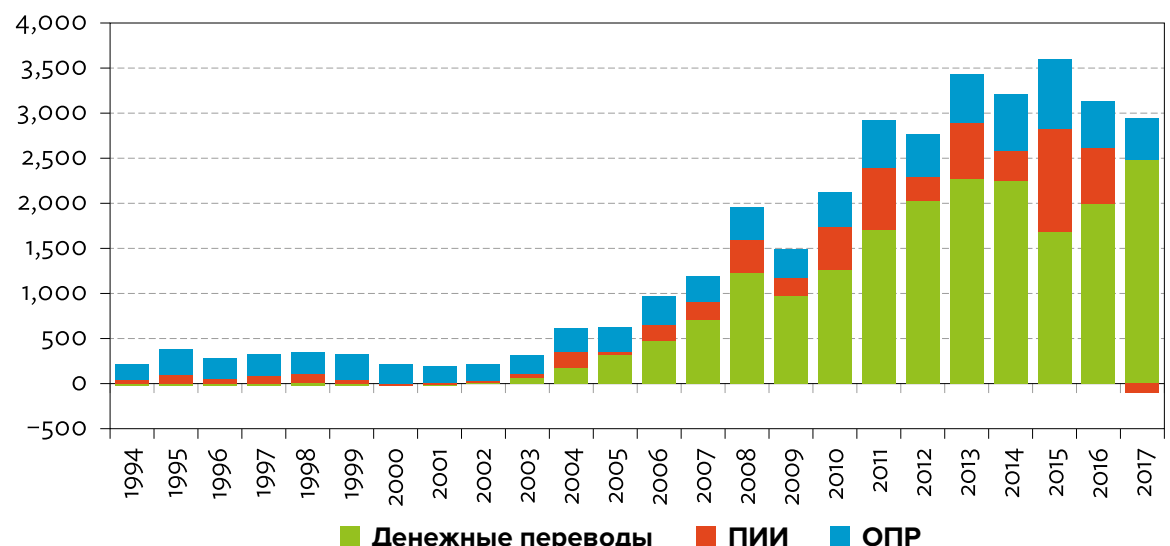

ПИИ - прямые иностранные инвестиции; ОПР - официальная помощь в целях развития; \$ -доллар США. Источник: Всемирный банк - Показатели мирового развития (ПМР): данные по объемам ПИИ и денежных переводов https://databank.worldbank.org/data/reports.aspx?source=world-development-indicators; Организация экономического сотрудничества и развития (ОЭСР): данные по ОПР https://stats.oecd.org/Index.aspx?DataSetCode=Table2A (по состоянию на апрель 2019).

Достоверных данных по оборотам нелегальной торговли и ее составу - нет. Данных по статистике торговли, полученных методом «зеркальной статистики» тоже нет. В-третьих, относительно торговли услугами, только небольшая часть денежных переводов проходит по официальным каналам, через банковский сектор, соответственно, размеры этих сумм подсчитываются приблизительно. ${ }^{17}$

В самом начале периода независимости, главным источником притока капитала была официальная помощь в целях развития (ОПР), размеры ПИИ (за исключением Кумтора) и денежных переводов были незначительными. За последние 20 лет денежные переводы стали основным источником притока капитала, в некоторые года достигая 50\% всего объема притока капитала (рис 1.10). В последние годы уровень денежных переводов был стабилен, но в 2015 году наблюдался спад, как отклик экономического кризиса в России, снизился приток рублевой массы и произошел спад обменного курса рубля к доллару США. Ожидается, что уровень ОПР будет более стабилен, нежели ПИИ. Со временем ожидается, что значение ПИИ для республики возрастет.

В таблице 1.2 дан краткий обзор состояния платежного баланса Кыргызской Республики с 5-летними интервалами, начиная с 1995 года. ${ }^{18}$ Страна испытывала дефицит торгового баланса и дефицит текущих статей. Объем экспорта в течение 2016-2018 годов был меньше половины объема импорта товаров, в результате чего образовался дефицит торгового баланса в пределах 30\% - 40\% ВВП. Значение экспорта, исключая золото, варьировалось от одной трети до половины значения импорта. Баланс экспорта услуг - отрицательный, но значение невелико. Быстрый рост уровня денежных переводов вкупе с развивающимся туризмом

17 Существует мнение, что большая часть денежных переводов проходит по неофициальным каналам или привозится домой самими трудовыми мигрантами.

18 Данные взяты из информационного бюллетеня НБКР «Платежный баланс Кыргызской Республики». 
привел к увеличению уровня экспорта услуг почти до значения импорта услуг. В результате, чистое значение вторичного дохода, в основном, денежных переводов, покрывает почти полностью дефицит торгового баланса. Дефицит текущих статей платежного баланса покрывается профицитом счёта операций с капиталом, большую часть капитала составляют ПИИ и ОПР.

\section{Таблица 1.2: Краткий обзор состояния платежного баланса Кыргызской Республики}

\begin{tabular}{|c|c|c|c|c|c|c|c|}
\hline & 1995 & 2000 & 2005 & 2010 & 2016 & 2017 & 2018 \\
\hline Баланс по текущим счетам & $-234,7$ & $-76,1$ & $-37,4$ & $-343,7$ & $-792,0$ & $-477,4$ & $-701,8$ \\
\hline Торговый баланс & $-122,0$ & 4,7 & $-418,7$ & $-1202,2$ & $-2136,5$ & $-2383,3$ & $-2779,2$ \\
\hline Экспорт & 408,9 & 510,9 & 686,8 & 1778,7 & 1607,9 & 1813,9 & 1815,2 \\
\hline В том числе: золото (не денежный) & 0,1 & 195,3 & 230,7 & 668,3 & 701,6 & 700,4 & 664,2 \\
\hline Импорт & 531,0 & 506,2 & 1105,5 & 2980,9 & 3744,4 & 4197,2 & 4594,4 \\
\hline Баланс - торговля услугами & $-156,0$ & $-86,1$ & $-30,8$ & $-201,2$ & $-203,5$ & $-92,0$ & $-135,5$ \\
\hline Экспорт & 39,2 & 62,0 & 259,4 & 600,1 & 841,0 & 823,8 & 833,7 \\
\hline Импорт & 195,1 & 148,2 & 290,3 & 801,3 & 1044,5 & 915,8 & 969,2 \\
\hline Чистый первичный доход & $-35,4$ & $-82,0$ & $-88,2$ & $-331,6$ & $-355,6$ & $-371,6$ & $-208,1$ \\
\hline Чистый вторичный доход & 78,7 & 87,4 & 500,3 & 1391,3 & 1903,6 & 2369,5 & 2420,9 \\
\hline $\begin{array}{l}\text { В том числе: денежные переводы, } \\
\text { чистые поступления }\end{array}$ & 0,8 & 1,4 & 280,4 & 1130,7 & 1634,3 & 2030,5 & 2143,0 \\
\hline Счет капитала, чистый & 2,2 & 16,2 & 42,9 & $-11,1$ & 112,6 & 133,8 & 339,4 \\
\hline Финансовый счет, чистый & 340,6 & 90,8 & 72,9 & 509,9 & 604,5 & 347,2 & 218,3 \\
\hline ПИИ, чистые поступления & 96,1 & $-6,9$ & 42,6 & 455,2 & 579,0 & $-78,1$ & 48,3 \\
\hline ОПР & 284,7 & 214,7 & 267,5 & 383,9 & 516,0 & 460,8 & --- \\
\hline $\begin{array}{l}\text { Гранты по линии технического } \\
\text { сотрудничества }\end{array}$ & 28,5 & 37,5 & 91,2 & 62,1 & 60,8 & 0,7 & --- \\
\hline Ошибки и пропуски, чистые & $-78,3$ & 0,9 & 62,4 & $-48,3$ & 413,4 & 143,6 & 139,2 \\
\hline Баланс итого & 29,8 & 31,9 & 140,7 & 106,8 & 338,5 & 147,2 & $-4,8$ \\
\hline
\end{tabular}

«-» - нет данных, ОПР- официальная помощь в целях развития, ПИИ - прямые иностранные инвестиции.

Источник: Международный валютный фонд (данные с 1995 по 2010 гг.),

http://data.imf.org/?sk=7A51304B-6426-40C0-83DD-CA473CA1FD52;

НБКР (данные с 2016 по 2018 гг.), https://www.nbkr.kg/index.jsp?lang=ENG ;

Организация по экономическому сотрудничеству и развитию (данные по ОПР):

https://stats.oecd.org/Index.aspx?DataSetCode=Table2A;

Всемирный банк, Индексы мирового развития (данные по грантам в рамках ТП), https://databank.worldbank.org/data/reports.aspx?source=world-development-indicators (по состоянию на апрель 2019)

Как объясняется в главе 3, в стране существует значительный потенциал для расширения экспорта сельскохозяйственной продукции. Несмотря на гористую местность, коэффициент «рабочая сила - количество земли» в Кыргызской Республике благоприятный, по сравнению с другими странами Восточной Азии.

Торговля со странами Запада и Севера уже достаточно хорошо развита, о чем свидетельствует задокументированная история успеха экспорта фасоли в Турцию и другие страны. Членство в ЕАЭС даст некоторые дополнительные преимущества республике на Российском рынке. Но экспорт сельхозпродукции в КНР и другие динамично развивающиеся страны Восточной Азии, с которыми Кыргызская Республика имеет значительный потенциал взаимодополняемости, остается незначительным. 
Для дальнейшего развития необходимо разработать стратегические инициативы по установлению более тесных торговых отношений с Китайской Народной Республикой, акцентируя внимание на вопросах поставок. Как показано в главе 7, транспортные и логистические расходы остаются высокими, хотя и снижаются, по крайней мере, на китайской стороне границы, поскольку Китай продолжает свои массовые инвестиции во все виды транспорта. Предлагаемый крупный железнодорожный коридор через Кыргызскую Республику, соединяющий КНР с Востоком и Узбекистан с Западом, мог бы облегчить доступ продукции Кыргызстана на рынок КНР.

Что касается вопросов поставок, для экспорта сельскохозяйственной продукции Кыргызской Республики существуют ограничения по безопасности пищевых продуктов и существующим стандартам (см. главу 3). Эти вопросы, ограничивающие экспортный потенциал, должны быть разрешены до момента выхода продукции Кыргызстана на рынки за пределы ЕАЭС. Например, существуют барьеры для экспорта мясных и молочных продуктов, как сообщалось, из-за болезней животных и вопросов гигиены. Для экспорта продуктов растениеводства необходимо разработать санитарные и фитосанитарные стандарты. Такие технические вопросы могут быть разрешены при технической поддержке международных организаций и совместно с инвесторами из стран, на рынки которых направляется экспорт. Для работы с мелкими производителями, живущими и работающими в труднодоступных районах, требуется служба сельскохозяйственных консультаций и расширение гибкой торговой сети.

Правительство разрабатывает меры реагирования на эти вызовы, в частности, в 2017 году были приняты Закон о продовольственной безопасности и Программа развития молочной промышленности. Создаются механизмы отслеживания, проводятся инспекционные проверки в соответствии с Законом 2017 года, предусматривающим сокращение проверяющих агентств с 22 до 17. Для ценных скоропортящихся продуктов дорогостоящие воздушные грузовые перевозки остаются проблемой, прямых рейсов в Европу из Кыргызстана пока нет.

\section{Кыргызская Республика и Евразийский экономический союз.}

Как отмечается, Кыргызская Республика либерализовала свою экономику и открыла границы быстрее, чем любая другая экономика Центральной Азии (см. главу 2, главы 7 и 10, работу Помфрета (2019). Это была первая бывшая советская республика, присоединившаяся ко Всемирной торговой организации (ВТО) в июле 1998 года. Кроме ВТО, Кыргызская Республика приняла на себя международные коммерческие обязательства как член ЕАЭС. Евразийский экономический союз, куда входят также Армения, Беларусь, Казахстан и Российская Федерация, являет собой работающий в полную меру союз с таможенными правилами, которые соответствуют требованиям ВТО. В целом ЕАЭС является аналогом Европейского Союза. ЕАЭС предусматривает свободную торговлю товарами и услугами, а также неограниченную мобильность капитала и рабочей силы в рамках единой таможенной зоны. Однако, страны - члены ЕАЭС сохраняют независимые денежно-кредитные и валютные режимы, и нет перспективы образования единого валютного союза.

В данной публикации мы не будем обсуждать в деталях издержки и выгоды членства Кыргызской Республики в ЕАЭС. Обычно называют преимущества, получаемые от установления торговых отношений в противопоставление нарушениям торговых связей, наряду с более важными геостратегическими соображени- 
ями как, например, установление дипломатических отношений с сопредельными государствами. Относительно торговли, экономическая теория и эмпирический анализ ясно показывают, что односторонняя, недискриминационная либерализация является наиболее выгодной стратегией для любой страны, за исключением особых случаев, которые применимы к очень крупным экономикам, чьи размеры дают возможность участвовать в торговых переговорах на основе принципа взаимности (хотя потенциально это разрушает глобальную, основанную на правилах либеральной торговли, систему). В соответствии с теорией «второго лучшего», соотношение выгод и издержек таможенного союза будет тем лучше, чем больше число стран-членов союза и чем лучше была их существовавшая ранее структура торговли.

В этом контексте, и как обсуждалось в главе 2, существует ряд наблюдений, которые можно соотнести с членством Кыргызской Республики в ЕАЭС. Первое как самая открытая экономика из пяти государств-членов ЕАЭС, членство в ЕАЭС влечет за собой увеличение торговых барьеров с остальным миром, в том числе с тремя из четырех сопредельных государств Кыргызской Республики - КНР, Таджикистаном и Узбекистаном. Это связано с тем, что торговые барьеры Кыргызской Республики ниже, чем в Российской Федерации, доминирующей в ЕАЭС стране. Это понятная «цена» членства, тем более, что пять крупнейших экономик стран мира - США, КНР, Япония, ЕС и Индия-не включены в ЕАЭС.

Второе - Кыргызская Республика, конечно, имеет тесные отношения с другими четырьмя странами-членами ЕАЭС, но наиболее тесные - с Российской Федерацией и Казахстаном. На долю этих двух стран приходится около 45\% экспорта (исключая золото) и 40\% импорта Кыргызской Республики. Русский язык является языком образования, в частности во многих ВУЗах, и членство в ЕАЭС расширяет доступ на российский рынок труда. Рабочие из Кыргызстана могли трудоустраиваться на российском рынке труда и до вступления Кыргызской Республики в ЕАЭС, а новые согласования и принятые механизмы снимают остававшиеся ограничения и обеспечивают большее официальное признание квалификаций и навыков кыргызстанских рабочих. Следовательно, со временем, вероятно, кыргызстанские работники смогут получать работу, требующую более широкой и высокой квалификации. Фактически, уровень денежных переводов в 2017 и 2018 годах вырос в ответ на рост цен на нефть и восстановление экономики Российской Федерации

Третье - общее членство в ЕАЭС не разрешило временных противоречий во взаимоотношениях с Казахстаном. Казахстан - это спасательный круг для всех транзитных перевозок в Российскую Федерацию, в страны Ближнего Востока и Европы. Например, основные сухопутные пути для грузовых перевозок в страны Европы проходят через Грузию (глава 6). В принципе, нет больших препятствий для транзитной торговли, но в реальности политическая напряженность между двумя государствами периодически приводит к проблемам на границе. ${ }^{19}$

Четвертое - основные издержки от перенаправляемой торговли связаны с КНР; и если последствия будут носить постоянный характер, то это будет иметь отрицательные последствия для экономики Кыргызстана. В статистике уже отразилось сокращение доли импорта из КНР, вероятно, этот импорт перешел в неформальные торговые потоки. Например, с введение более высоких торговых барье-

19 Например, осенью 2017 года Казахстан ограничил движение на почве несоблюдения кыргызской стороной правил продуктовой безопасности. 
ров на импорт КНР, рынок Дордой, как сообщается, теряет свою региональную роль и вместо этого становится рынком для кыргызских потребителей. ${ }^{20}$ Объёмы прямой торговли между КНР и другими членами ЕАЭС увеличиваются, поскольку некоторые члены ЕАЭС снижают торговые барьеры. ${ }^{21}$ Например, через Хоргос, не столь давно открывшийся рынок беспошлинной торговли на границе КНР и Казахстана, проходят основные потоки неформальной торговли.

В противовес этому, не исключено, что издержки с точки зрения переориентации торговых потоков могут быть не столь велики, как изначально опасались (Могилевский 2012). Во-первых, в соответствии с обязательствами перед ВТО Казахстан и Российская Федерация постепенно снижают торговые барьеры, а значит, автоматически барьеры снижаются и другими странами ЕАЭС. Во-вторых, улучшенная дорожная сеть, соединяющая КНР и Кыргызскую Республику, позволяет снизить торговые затраты, как за счет улучшенной транспортировки, так и за счет привлечения большего количества трейдеров на рынок. Это важно для региона, где исторически ценовые различия часто были связаны с высоким уровнем издержек транспортного и логистического характера и с преодолением торговых барьеров формального характера. В-третьих, хотя таможенные договоренности вступили в силу, все еще существует, в значительной степени, неформальная торговля. ${ }^{22}$

\section{Социальные показатели}

Позитивным наследием советской эпохи является стремление Кыргызской Республики сохранить всеобщее государственное образование и систему здравоохранения и, по минимуму, систему социального обеспечения, хотя и слабо адресную, включая выплату пенсии по старости (Могилевский 2011). Развал Советского Союза означал, что система социального обеспечения оказалась под большим финансовым стрессом. Помфрет (2019), например, посчитал, что в первые годы монетарного кризиса и гиперинфляции реальная стоимость государственных трансфертных платежей резко упала, на 90\%. Тем не менее, основные рамки социальной политики сохранены, и социальные показатели Кыргызстана выгодно отличаются от показателей стран с аналогичным доходом на душу населения. Например, продолжительность жизни в Кыргызстане приближается к продолжительности жизни в стране с доходом выше среднего. Гендерные различия сравнительно незначительны, хотя существует профессиональная сегрегация по признаку пола и в исследованиях отмечается неравенство мужчин и женщин. В стране - всеобщее начальное образование и практически повсеместно среднее образование. Хотя, как отмечается, уровень качества образования снизился, а социально-экономическое расслоение увеличилось, особенно с распространением практики частных школ с более качественным образованием.

20 Дополнительным фактором является то, что Кыргызская Республика после вступления в ЕАЭС поменяла таможенные правила и расчёты, основанные ранее на весе товара, теперь производятся на основании стоимости товара. Это уменьшило нелегальный оборот товара в форме занижения сумм в счетах-фактурах.

21 Хотя Узбекистан, самая густонаселенная страна Центральной Азии, не является членом ЕАЭС, после того, как в 2016 году президентом страны стал Шавкат Мирзиёев, произошли позитивные сдвиги между соседями и ушла экономическая и политическая напряженность. В 2017 году прошла первая с 2000 года встреча руководителей Узбекистана и Кыргызстана. Произошла либерализация трансграничной торговли и послабление правил пересечения границы. В результате увеличилось количество жителей, пересекающих границу, улучшилась торговля сельхозпродукцией. Узбекский сум (национальная валюта) теперь свободно конвертируем. См. The Economist (2017).

22 Авторы наблюдали интенсивную микроторговлю, происходившую на границе между Кыргызстаном и Узбекистаном, недалеко от города Ош. 
Надежные данные обследований домашних хозяйств, по которым рассчитывается уровень бедности и неравенства, доступны только за этот век. Разрозненные и фрагментарные данные для 1990-х годов показывают, что уровень бедности значительно увеличился с резким экономическим спадом. В течение 2000 - 2018 годов уровень жизни, в целом, был восстановлен, по крайней мере, до уровня, существовавшего в позднесоветскую эпоху. Подсчет доли бедного населения показал, что нижний уровень бедности, то есть нищеты, который исчисляется по меркам Всемирного банка в 1,90 долларов США в день, упал с более чем 40\% в начале века до незначительного уровня. А количество населения, проживающего на 3,20 доллара США в день, снизилось с почти 80\% до приблизительно 20\% (Рисунок 1.11). Сокращение масштабов нищеты происходит гораздо быстрее, чем можно было бы предположить, судя по скромным темпам роста ВВП, что указывает на то, что большая часть домашних хозяйств, вероятно, временно скатились за черту бедности. Самое значимое сокращение масштаба нищеты пришлось на первое десятилетие этого столетия, что свидетельствует о том, что вопросами глубоко укоренившейся нищеты следует заниматься надлежащим образом, поскольку этот вопрос еще полностью не решен. И это несмотря на довольно щедрые расходы бюджета на социальные нужды, что, в свою очередь, говорит о необходимости более эффективного обеспечения адресности получателей. ${ }^{23}$ Между тем, коэффициент Джини был в целом стабилен в течение этого периода и сохранялся на относительно низком уровне 0,3 .

\section{Рисунок 1.11: Уровень бедности и неравенства (\%)}

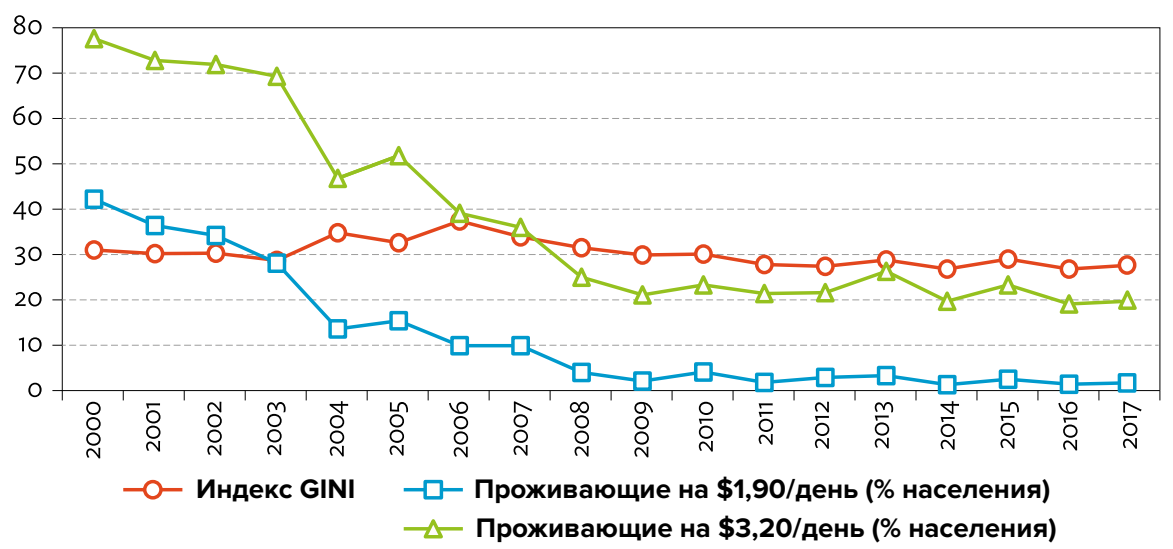

\$- доллар США

Замечание: Индекс численности бедных на 2011 год, рассчитан по ППС (паритет покупательной способности), в долларах.

Источник: Всемирный банк, ПМР, https://databank.worldbank.org/data/reports.aspx?source=worlddevelopment-indicators (по состоянию на апрель 2019).

В таблицах 1.3 и 1.4 сравниваются социально-экономические показатели Кыргызской Республики с показателями пяти стран, выбранных для сравнения.

23 Помфет (2019), проанализировав фрагментарную литературу по вопросам бедности в Кыргызской Республике, пришел к выводу, что проживание в городе и уровень образования являются ключевыми переменными, позволяющими жить выше уровня бедности. В 1990-х уровень жизни в регионах, где превалировала моно-индустрия, и которая была зависима от советской централизованной плановой экономики, стал гораздо ниже, чем в других регионах. 
Сравниваются данные конца советской эпохи и самые последние данные. ${ }^{24}$ Также приводятся данные за 1990 год, но к ним следует относиться с осторожностью, поскольку они достаточно приблизительны. Наследие советской эпохи и относительно низкий уровень неравенства в Кыргызской Республике ярко проявились в 1990 году. Показатель продолжительности школьного обучения более типичен для стран с доходом выше среднего, в то время как ожидаемая продолжительность жизни и даже младенческая смертность находятся на уровне стран со средним доходом. Гендерные различия также довольно умеренны. Кыргызская Республика выгодно отличается от своих соседей и значительно опережает Лаосскую Народно-Демократическую Республику (ЛНДР). Индекс человеческого развития приближается к показателю ВВП на душу населения на то время, когда начался резкий экономический спад.

\section{Таблица 1.3: Сравнительные показатели на 1990 год (до получения независимости)}

\begin{tabular}{|c|c|c|c|c|c|c|}
\hline Индикаторы & 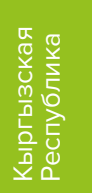 & 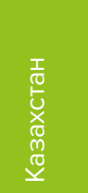 & 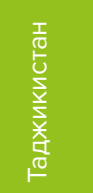 & 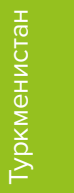 & 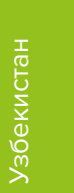 & $\begin{array}{l}\text { 号 } \\
\text { 甹 }\end{array}$ \\
\hline ВВП на душу населения (в ценах 2010, \$) & 1096 & 5890 & 1278 & 3713 & 997 & 462 \\
\hline ВВП (в ценах 2010, \$, миллиард) & 4,8 & 96,3 & 6,8 & 13,7 & 20,5 & 2,0 \\
\hline Население (млн. человек) & 4,4 & 16,3 & 5,3 & 3,7 & 20,5 & 4,3 \\
\hline Торговля/ВВП (\% к ВВП) & 78,8 & 149,3 & 63,0 & 66,1 & 76,6 & 35,9 \\
\hline \multicolumn{7}{|l|}{ Средняя продолжительность школьного обучения } \\
\hline Женщины & 8,1 & 7,6 & 8,7 & --- & --- & 1,9 \\
\hline Мужчины & 9,1 & 8,6 & 10,6 & --- & --- & 4,3 \\
\hline Всего & 8,6 & 8,1 & 9,6 & --- & --- & 3,1 \\
\hline \multicolumn{7}{|l|}{ Ожидаемая продолжительность жизни (годы) } \\
\hline Женщины & 70,2 & 71,5 & 66,6 & 66,5 & 69,4 & 54,9 \\
\hline Мужчины & 62,3 & 61,8 & 59,8 & 59,1 & 63,4 & 52,3 \\
\hline Всего & 66,3 & 66,8 & 63,1 & 62,8 & 66,5 & 53,6 \\
\hline $\begin{array}{l}\text { Младенческая смертность } \\
\text { (детей до года на } 1000 \text { живорождённых) }\end{array}$ & 54,3 & 44,4 & 84,1 & 69,5 & 59,4 & 110,7 \\
\hline Чистый экспорт (\% к ВВП) & $-31,4$ & 8,1 & $-25,2$ & $-8,6$ & $-8,9$ & $-7,1$ \\
\hline Денежные переводы (\% к ВВП) & 32,9 & 0,2 & 31,3 & 0,0 & -- & 1,5 \\
\hline ИЧР $(X / Y)$ & $76 / 142$ & $53 / 142$ & $72 / 142$ & --- & --- & $118 / 142$ \\
\hline Рейтинг ВВП на душу населения - рейтинг ИЧР & 23 & -10 & 24 & --- & --- & 0 \\
\hline
\end{tabular}

ВВП - Валовой внутренний продукт, ИЧР - индекс человеческого развития, ЛНДР - Лаосская Народно- Демократическая Республика, «-» - нет данных; X - страна в заголовке столбца, Y - все страны, среди которых проведено ранжирование; \$ доллар США

Замечание: Средняя продолжительность школьного обучения - среднее количество лет, проведенных в школе или период получения образования людьми в возрасте 25 лет и старше, исходя из уровня образования при использовании официальной продолжительности каждого уровня.

Соотношение «торговля/ВВП» для Туркменистана взято за 1991 год, а для Казахстана - за 1992 год; соотношение «чистый экспорт к ВВП» для Туркменистана - за 1991 год, для Казахстана - за 1992 год; соотношение «денежные переводы к ВВП» для Туркменистана - за 1996 год.

24 Хотя существует ограничения во всех сравнительных анализах, статистика Кыргызстана по социо-экономическому направлению считается лучшей в регионе, возможно потому, что Кыргызстан - наиболее открытая страна. См. также Помфрет (2019, Таблицы 2.1, 2.2 и 2.8) об анализе сравнительных социо-экономических данных. 
Источник: Всемирный банк, ИМР (ВВП, количество населения, торговля, чистый экспорт, денежные переводы); ПРООН, Отчет по человеческому развитию за 2018 год (рейтинг ИЧР и рейтинг ВВП на душу населения минус рейтинг ИЧР (по состоянию на апрель 2019).

Несмотря на безликие экономические показатели 1990-х годов, социальные показатели Кыргызской Республики остаются относительно хорошими (Таблица 1.4). Продолжительность школьного обучения является характерным для стран с доходом выше среднего. Гендерный разрыв практически исчез. Показатели Кыргызстана сопоставимы с показателями более богатых соседей и значительно лучше показателей Лаоса. Продолжительность жизни увеличилась незначительно, как и в соседних странах. Младенческая смертность в настоящее время составляет около одной трети от показателя начала 1990-х годов, что является вторым самым низким показателем среди шести стран и отражает сравнительно высокие стандарты здравоохранения в стране. ${ }^{25}$ Существует большой разрыв при ранжировании по соотношению ВНД (валовой национальный доход) страны и ИЧР (индекс человеческого развития).

\section{Таблица 1.4: Сравнительные показатели на 2017 год}

\begin{tabular}{|c|c|c|c|c|c|c|}
\hline Показатели & 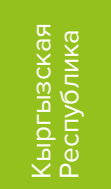 & $\begin{array}{l}I \\
\sqrt{0} \\
\frac{1}{U} \\
x \\
0 \\
0 \\
0 \\
0 \\
x\end{array}$ & 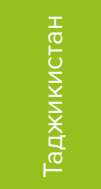 & 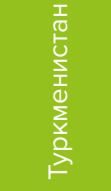 & 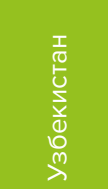 & $\frac{\text { 든 }}{\frac{1}{5}}$ \\
\hline ВВП на душу населения (в ценах 2010, \$) & 1071 & 10868 & 1020 & 7318 & 2031 & 1730 \\
\hline ВВП (в ценах 2010, \$, миллиард) & 6,6 & 196,0 & 9,1 & 42,1 & 65,8 & 11,9 \\
\hline Население (млн. человек) & 6,2 & 18,0 & 8,9 & 5,8 & 32,4 & 6,9 \\
\hline Торговля/ВВП (\% к ВВП) & 102,2 & 60,6 & 56,7 & 53,6 & 68,5 & 75,8 \\
\hline \multicolumn{7}{|l|}{ Средняя продолжительность школьного обучения } \\
\hline Женщины & 10,9 & 11,8 & 10,7 & -- & 11,2 & 4,6 \\
\hline Мужчины & 10,8 & 11,7 & 10,2 & -- & 11,8 & 5,7 \\
\hline Всего & 10,9 & 11,8 & 10,4 & 9,8 & 11,5 & 5,2 \\
\hline \multicolumn{7}{|l|}{ Ожидаемая продолжительность жизни (годы) } \\
\hline Женщины & 75,1 & 74,8 & 74,4 & 71,4 & 74,2 & 68,6 \\
\hline Мужчины & 67,1 & 65,3 & 68,4 & 64,5 & 68,6 & 65,4 \\
\hline Всего & 71,1 & 70 & 71,2 & 68 & 71,4 & 67 \\
\hline $\begin{array}{l}\text { Младенческая смертность } \\
\text { (детей до года на } 1000 \text { живорождённых) }\end{array}$ & 18,8 & 10,1 & 37,1 & 43,4 & 21,4 & 48,9 \\
\hline Чистый экспорт (\% к ВВП) & $-31,4$ & 8,1 & $-25,2$ & $-8,6$ & $-8,9$ & $-7,1$ \\
\hline Денежные переводы (\% к ВВП)* & 32,9 & 0,2 & 31,3 & 0,0 & 3,7 & 1,5 \\
\hline Рейтинг по ИЧР & $122 / 189$ & $58 / 189$ & $127 / 129$ & $108 / 189$ & $105 / 189$ & $139 / 189$ \\
\hline Рейтинг ВВП на душу населения - рейтинг ИЧР & 26 & -4 & 28 & -35 & 20 & -15 \\
\hline
\end{tabular}

ВВП - Валовой внутренний продукт; ИЧР - индекс человеческого развития; ЛНДР - Лаосская Народно-Демократическая Республика; «-» - данные отсутствуют.

* уровень денежных переводов по Узбекистану за 2016 год.

Примечание: Среднее количество лет в школе - среднее количество лет, проведенных в школе или период получения образования людьми в возрасте 25 лет и старше, исходя из уровня образования при использовании официальной продолжительности каждого уровня.

25 Кыргызская Республика привлекает иностранных студентов в медицинские университеты, это является индикатором качества обучения и приемлемой платы за обучение. 
Источник: Всемирный банк, Индикаторы мирового развития: ВВП, население, торговля, экспорт, денежные переводы трудовых мигрантов; ПРООН, Отчет по человеческому развитию (2019) - данные по уровню ИЧР и ВВП на душу населения минус ИЧР (по состоянию на апрель 2019).

\section{Показатели управления}

Кыргызская Республика - молодое государство, бедное ресурсами, которое должно было быстро развивать институты и органы национального правительства в период серьезных экономических спадов. Страна находится в очень неспокойном регионе, она вынуждена справляться с последствиями отъезда сотен тысяч, в основном квалифицированных и знающих граждан - этнических русских. Поэтому неудивительно, что большая часть литературы по Кыргызской Республике описывает плохое качество управления. Фактически, несмотря на свои небольшие размеры, Кыргызская Республика привлекла огромное внимание исследователей. Непропорционально много работ среди существующей академической литературы по Центральной Азии посвящены Кыргызстану. Но это не говорит о том, что эти проблемы в Кыргызстане более серьезны, чем у соседей. Напротив, это говорит о сравнительной открытости страны. Эта открытость взрастила самые активные и свободные средства массовой информации, которые, предположительно, внесут свой вклад в улучшение качества институционального управления.

Ниже идет краткое описание исследований, проведенных международными агентствами в различных районах страны. Приводимые расчетные данные крайне субъективны, поэтому они, в лучшем случае, наводят на размышления, позволяют что-либо предположить, тем более, что сравнение нужно проводить с глубоким пониманием уникальности страны. ${ }^{26}$

В таблице 1.5 рассматривается ряд стандартных бизнес показателей. Данные говорят о том, что некоторые экономические рейтинги и рейтинги Всемирного банка «Ведение бизнеса» приблизительно равны рейтингам Узбекистана и значительно выше рейтинга Казахстана, Таджикистана и Лаоса. Объем ПИИ республики (относительно ВВП) также занимает «серединное положение», значительно опережая Лаос с его крупным сектором государственных предприятий (ГП). При интерпретации показателей необходимо учитывать относительную долю интенсивной деятельности, относящуюся к ПИИ, в случае с Казахстаном это нефть и её производные. Показатели восприятия коррупции в Кыргызской Республике несколько улучшились (132 против 135 в 2017 году); тем не менее, это второй показатель, следующий за показателем Казахстана по Центральной Азии. Индекс эффективности функционирования логистической цепочки хуже, чем у Казахстана, Лаоса и Узбекистана. Тем не менее, авторы главы 6 утверждают, что индекс эффективности функционирования логистической цепочки может вводить в заблуждение.

26 В главе 6 авторы убеждены, что некоторые логистические показатели, используемые в исследованиях «Ведение бизнеса» неприменимы к Кыргызской Республике в силу ее географической «изолированности». 


\section{Таблица 1.5: Сравнительные институциональные и бизнес показатели, 2018}

\begin{tabular}{|c|c|c|c|c|c|c|}
\hline Показатели & 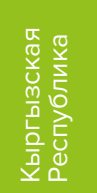 & 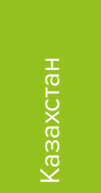 & 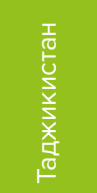 & 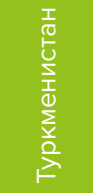 & 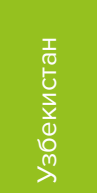 & $\begin{array}{l}\text { 읃 } \\
\text { 돋 }\end{array}$ \\
\hline Лёгкость ведения бизнеса, рейтинг (2018) & $70 / 190$ & $228 / 190$ & $126 / 190$ & - & $76 / 190$ & $154 / 190$ \\
\hline Объем ПИИ/ВВП (2017, \% ВВП) & 77.2 & 90.5 & 35.1 & 90.8 & 19.0 & 39.2 \\
\hline Индекс восприятия коррупции, рейтинг, (2018) & $132 / 180$ & $124 / 180$ & $152 / 180$ & $161 / 180$ & $158 / 180$ & $132 / 180$ \\
\hline Индекс восприятия логистики, рейтинг (2018) & $108 / 160$ & $71 / 160$ & $134 / 160$ & $126 / 160$ & $99 / 160$ & $82 / 160$ \\
\hline
\end{tabular}

«-»- нет данных, ВВП- внутренний валовой продукт; ПИИ- прямые иностранные инвестиции.

Источник: Всемирный банк, ИМР (данные по показателю лёгкости ведения бизнеса):

https://data.worldbank.org/indicator/ic.bus.ease.xq;

Конференции ООН по торговле и развитию (ЮНКТАД) (объемы ПИИ и ВВП):

https://unctadstat.unctad.org/wds/TableViewer/tableView.aspx?Reportld=96740;

Международная прозрачность (индекс восприятия коррупции):

https://www.transparency.org/cpi2018;

ВБ (2018) (Индекс восприятия логистики); (все данные по состоянию на февраль 2019).

В таблице 1.6, сравниваются широко используемые показатели государственного управления. Они представлены в виде процентильного рейтинга. В 2017 году Кыргызская Республика заняла 25 место (т. е. 28-й процентиль), что является вторым значением по величине в Центральной Азии. Среди шести стран, показатели которых отражены в таблице, Кыргызская Республика занимает самое высокое место по праву быть услышанным и уровню подотчетности, второе место по качеству регулирования. Среди пяти стран Центральной Азии Кыргызстан занимает второе место по качеству регулирования, верховенству права, контролю за коррупцией, эффективности работы правительства. Таким образом, более открытая политическая система (о чем свидетельствует право быть услышанным и уровень подотчетности) не привела к повышению эффективности работы правительства и политической стабильности.

Таблица 1.6: Сравнительные показатели государственного управления, 2017 год (процентильный рейтинг)

\begin{tabular}{|c|c|c|c|c|c|c|}
\hline Показатели & 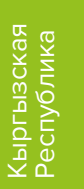 & 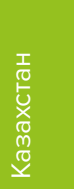 & 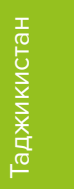 & 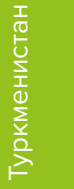 & 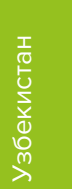 & 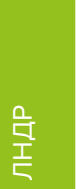 \\
\hline $\begin{array}{l}\text { Право быть услышанным и уровень } \\
\text { подотчетности }\end{array}$ & 33,0 & 13,8 & 4,9 & 1,0 & 3,4 & 4,4 \\
\hline $\begin{array}{l}\text { Политическая стабильность и отсутствие } \\
\text { насилия / терроризма }\end{array}$ & 30,0 & 45,2 & 21,9 & 40,0 & 34,8 & 63,3 \\
\hline Эффективность работы правительства & 23,1 & 53,8 & 13,0 & 10,1 & 32,7 & 38,5 \\
\hline Качество регламентирующих актов & 38,5 & 61,1 & 12,0 & 1,9 & 8,7 & 25,5 \\
\hline Главенство закона & 17,3 & 38,5 & 8,2 & 6,3 & 11,1 & 18,3 \\
\hline Контроль за коррупцией & 13,0 & 19,7 & 7,7 & 4,3 & 12,0 & 15,9 \\
\hline Среднее значение & 25,8 & 38,7 & 11,3 & 10,6 & 17,1 & 27,7 \\
\hline
\end{tabular}


ЛНДР- Лаосская Народно-Демократическая Республика.

Источник: Всемирный банк, Мировые показатели государственного управления, https://info.worldbank.org/governance/wgi/\#home (по состоянию на апрель 2019)

Более того, если мы доверяем цифрам, то рейтинг Кыргызской Республики со временем ухудшился, и относительно показателей пяти отобранных стран, и относительно мировых показателей. В 2000 году рейтинг Кыргызской Республики по показателям государственного управления был самым высоким среди 6 стран (Таблица 1.7). Данные достоверно показывают, что политическая система стала более открытой и конкурентной. Но по другим показателям, рейтинг снизился, в отдельных случаях (верховенство права) - очень значительно.

Все же результаты нужно интерпретировать с большой осторожностью, поскольку они порой основаны на неподтвержденной информации. Самое элементарное - государственная служба, по сути, плохо оплачиваемая, перегруженная по количеству работников, руководит сложной и непрозрачной системой регулирования, в регламент которой постоянно вносятся изменения со стороны министерств или премьер-министра. Во многих исследованиях по состоянию бизнеса в стране отмечено, что процедуры закупок особенно уязвимы перед проблемой коррупции. Коррупция неискоренима и пронизала судебную систему и правоохранительные органы. Эти факторы рассматриваются как одна из причин того, что структура предпринимательского сектора имеет дуалистический характер: с одной стороны - крупные предприятия, связанные с политическими структурами, с другой - малые и семейные предприятия, которые сознательно остаются ниже «экрана радара» правительственных структур и, соответственно, не подвергаются поборам.

\section{Таблица 1.7: Сравнительные показатели в области государственного управления, 2000 (процентильный рейтинг)}

\begin{tabular}{|c|c|c|c|c|c|c|}
\hline Показатели & 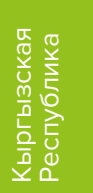 & 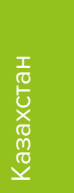 & 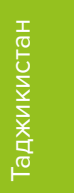 & 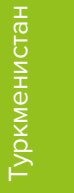 & $\begin{array}{l}\frac{T}{0} \\
\frac{0}{U} \\
\frac{5}{2} \\
\frac{1}{10} \\
0 \\
m \\
\end{array}$ & $\begin{array}{l}\text { 음 } \\
\text { 돋 }\end{array}$ \\
\hline $\begin{array}{l}\text { Право быть услышанным и уровень } \\
\text { подотчетности }\end{array}$ & 15,4 & 20,4 & 10,5 & 4,0 & 2,0 & 11,0 \\
\hline $\begin{array}{l}\text { Политическая стабильность и отсутствие } \\
\text { жестокости / терроризма }\end{array}$ & 39,7 & 49,2 & 7,4 & 44,4 & 12,8 & 28,0 \\
\hline Эффективность управления & 36,4 & 26,7 & 7,7 & 6,2 & 13,9 & 22,1 \\
\hline Качество регламентирующих актов & 50,8 & 26,2 & 13,3 & 3,6 & 2,1 & 8,2 \\
\hline Главенство закона & 25,3 & 14,9 & 5,6 & 8,4 & 10,9 & 20,3 \\
\hline Контроль за коррупцией & 19,8 & 9,6 & 5,6 & 9,1 & 13,2 & 21,3 \\
\hline Среднее значение & 31,2 & 24,5 & 8,3 & 12,6 & 9,0 & 18,5 \\
\hline
\end{tabular}

Источник: ВБ, ИМР https://info.worldbank.org/governance/wgi/\#home (по состоянию на май 2019)

На фоне этих прогнозов население в Кыргызской Республике остается грамотным, понимающим, активным в социальных сетях; и существуют некоторые независимые средства информации (СМИ). Страна продемонстрировала способность поддерживать жизнестойкость демократии и демократические изменения. Как утверждается в заключительном разделе, ряд институциональных реформ может опираться на социальную активность населения. 


\section{4. Содержание книги}

Этот раздел содержит краткое содержание семи последующих глав.

В главе 2 Према-чандра Аукорала и Маниша Прадхананга анализируют международное измерение процесса экономической трансформации Кыргызской Республики, обращая особое внимание на роль торговли, прямых иностранных инвестиций (ПИИ) и трудовой миграции. Благодаря рыночным реформам, проведенным с начала 1990-х годов, Кыргызская Республика стала одной из наиболее глобально интегрированных экономик на постсоветском пространстве и центром транзитной торговли в Центральной Азии. Однако модели глобальной экономической интеграции Кыргызской экономики до сих пор были довольно тенденциозными. Хотя в структуре экспорта произошли некоторые заметные изменения, как и в сравнительных преимуществах страны, быстрое проникновение импорта в экономику не сопровождалось структурными изменениями на экспортном фронте. Это привело к усилению зависимости экономики от денежных переводов трудовых мигрантов и внешнего финансирования. Предполагается, что ПИИ будут играть важнейшую роль в структурных изменениях экономики и производстве экспортно ориентированной продукции, но до сих пор ПИИ рассматриваются как малая часть притока капитала. Структура внешнего финансирования начала смещаться от грантов и льготных кредитов к кредитам по коммерческим ставкам, что потенциально подвергает экономику дополнительному внешнему экономическому шоку. Одной из основных задач современной политики, стоящих перед страной, является расширение экспортной базы. Это требует быстрой реализации широкого спектра реформ для поддержки открытости для внешней торговли и инвестиций. Отсутствие «рыночной дисциплины» приграничного рынка (внутри страны) ограничивает возможности и предполагаемую выгоду, получаемую от значительных торговых и политических реформ, инициированных частным сектором.

В главе 3 Такаши Ямоно, Джиндра Н. Самсон, Канат Тилекеев описали изменения, происходящие в сельскохозяйственном секторе Кыргызской Республики, в связи с переходом от централизованного планирования к продовольственной безопасности и ориентированности на рынок. В валовом сельскохозяйственном производстве доля овощей и фруктов увеличилась с 11\% (1992-1996 годы) до 24\% (2010-2014 годы), а доля технических культур в Кыргызской Республике снизилась с 11\% до 5\%. Производство сельскохозяйственных культур остается на низком уровне, возможно, из-за разрушения ирригационной системы и устаревших сельскохозяйственных технологий. Сельское хозяйство Кыргызской Республики, учитывая небольшие его объемы, для повышения своей производительности должно полагаться на внешние технологические знания и ресурсы извне. Став звеном глобальной цепочки добавленной стоимости, Кыргызстан мог бы экспортировать сельхозпродукцию не только в соседние страны. Во второй половине главы авторы рассказывают о производстве фасоли в Таласской области и рассматривают этот пример как хорошую практику. Фасоль является основным экспортным сельскохозяйственным продуктом, общая стоимость которого ежегодно составляет около 50 миллионов долларов США. Практически половина общего объема экспорта фасоли направляется в Турцию. Производство фасоли было инициировано и поддерживается турецкими импортерами с конца 1990х. Экспорт молока и молочных продуктов из северных регионов страны в Казахстан и Российскую Федерацию - еще один пример, рассмотренный в этой главе. 
В главе 4 Жаяресанам Пилай и Киеши Танагучи анализируют сектор услуг, уделяя особое внимание развитию индустрии туризма. Сектор услуг, на данный момент, является самым крупным и быстрорастущим сектором в Кыргызской Республике. Сектор услуг, начиная с 2002 года, имеет самую крупную долю добавленной стоимости, а с 2004 года в этом секторе занято около половины всего количества работников. Доля сектора услуг составляет 57\% ВВП. Авторы анализируют работу сектора и трудности финансового и транспортного характера, препятствующие развитию всего сектора услуг. Определены возможности для развития сектора в стране, в частности, требуется продуманная политика, направленная на модернизацию государственной инфраструктуры, развитие человеческого капитала, обеспечение доступа к финансированию и предоставление доступных кредитов и улучшения, в целом, бизнес-среды.

Во второй половине главы анализируется состояние туристической отрасли, которая может развиваться путем установления прямой и обратной связи с другими отраслями. Несмотря на существование таких туристических объектов как Иссык- Куль (в переводе с кыргызского - теплое озеро), ледник Иныльчек, древний Шелковый путь, развивается отрасль достаточно медленно. Среди факторов, препятствующих развитию туризма, можно назвать следующие: сезонность, недостаток квалифицированных кадров в секторе туризма, недостаток качественной инфраструктуры. Для стимулирования будущего роста отрасли и преодоления упомянутых факторов Кыргызской Республике требуется продуманная маркетинговая стратегия, направленная на продвижение природных красот Кыргызстана и гостеприимства его жителей.

В главе 5, Соек Юн и Майкл Мингес оценивают возможности цифрового развития Кыргызской Республики. Авторы говорят, что цифровые технологии могут способствовать установлению прозрачности, уменьшению уровня коррупции, увеличению эффективности оказываемых услуг, путем сокращения прямых контактов между гражданами и чиновниками, представителями бизнеса и государственного сектора. Правительственные стратегии национального развития указывают на важность информационно-коммуникационных технологий (ИКТ), рассматривают вопрос развития ИКТ как один из приоритетов в стране, как и указано в концепции «Цифровой Кыргызстан». В этой главе анализируется нормативно-правовое и законодательное регулирование использования информационно-коммуникационных технологий, наличие, качество и потребности в инфраструктуре ИКТ. Авторы отмечают, что Кыргызская Республика - готова к цифровой трансформации, уступая лишь Казахстану среди всех стран Центральной Азии. Несмотря на отсутствие выхода к морю, его географическое расположение между КНР и Европой дает возможность стать цифровым хабом (центром) вдоль Шелкового пути. В данной главе анализируется применение цифровых технологий в различных секторах экономики (образовании, торговли, бизнесе, здравоохранении, финансовом и государственном секторах). Реализация концепции «Цифровой Кыргызстан» поможет провести революцию в сфере оказания государственных услуг и поднять к 2040 году доход на душу населения выше среднемирового.

В главе 6, Ричард Помфрет и Айгуль Бердигулова анализируют состояние транспортного сектора и логистики в целях продвижения торговли и инклюзивности. Они соглашаются, что Кыргызстан столкнулся с двоякой проблемой, с одной стороны - плохое транспортное сообщение и с другой - недостаточная рыночная интеграция, как внутри страны, так и в международном масштабе. С получением независимости страна унаследовала хорошее международное сообщение 
с Российской Федерацией, а местная транспортная система была в плохом состоянии. Северная часть страны лучше связана с Алматы (Казахстан), чем с городом Ош, главным городом на юге Кыргызстана, а Ош - лучше связан с Узбекистаном, нежели с Бишкеком, столицей, расположенной в северной части. Приоритетным вопросом в 1990-х годах было строительство национальной системы дорог, ремонт и модернизация дороги Бишкек - Ош. С начала века система дорог внутри страны значительно улучшилась, хотя вопрос безопасности на дорогах и их поддержание в хорошем состоянии стоит достаточно остро. Очень малые изменения произошли в системе железнодорожного сообщения внутри страны, оно практически не существует, несмотря на амбициозные планы в 1990х годах установить железнодорожное сообщение между севером и югом. Воздушное сообщение, особенно международное, ограничено. Развитие Евразийской сети железнодорожного сообщения, следуя примеру успешного строительства сухопутного трансконтинентального сообщения из Китая в Европу, несет в себе большой потенциал. Усовершенствование автомобильных и железных дорог и воздушного сообщения, как внутри страны, так и в мировом масштабе, потребует финансирования, что, очевидно, является серьезным вопросом для страны. Авторы акцентируют наше внимание на необходимости улучшить социальную инфраструктуру, которая связана с транспортной, и на важности инвестиций.

В главе 7, Нейл МакКулох и Ки-Юнг Нам анализируют энергетический сектор Кыргызской Республики. Сектор является не только надежным поставщиком электричества, что жизненно важно для производственного сектора, но и источником теплоснабжения и средством отопления, столь необходимого в холодные кыргызские зимы. Тем не менее, несмотря на огромный гидроэнергетический потенциал страны, потенциал производства солнечной и ветровой энергии, запасов угля, в секторе ощущается нехватка электроэнергии из-за растущего спроса. Одной из причин этого являются трудности, с которыми сталкиваются правительства, сменяющие друг друга, при инвестировании в этот сектор. В стране устаревшие генерирующие активы, устаревшие линии передач и распределительные сети, которые подвержены частым поломкам, что приводит к высоким, хотя и уменьшающимся, потерям.

Основная причина отсутствия инвестиций связана с проблемами, с которыми сталкивается правительство в связи с изменениями тарифов, предложенными регулятором. Низкие тарифы для населения создают значительную финансовую нагрузку для всех ключевых участников энергетического сектора и значительно ограничивают возможности для инвестиций, как со стороны государственного, так и частного секторов. Низкие тарифы также снижают энергоэффективность удельная энергоёмкость в Кыргызской Республике одна из самых высоких в Центральной Азии. Скрытые субсидии на электроэнергию и отопление носят регрессивный характер; выигрывают, в большей степени, обеспеченные домохозяйства и городские домохозяйства, нежели сельские и бедные. Субсидии при этом обходятся в два раза дороже, чем весь бюджет социальной помощи. Опыт других стран показывает, что энергетические субсидии могут быть реформированы, и с этой целью в главе приводятся примеры Армении, Доминиканской Республики и Мексики. Реформа тарифов возможна при наличии четкой политической воли и эффективной коммуникации и последовательной реализации. Кыргызская Республика имеет смелые планы по улучшению сектора. Успех планов, вероятно, будет зависеть от способности правительства провести серьезную реформу тарифов в рамках привлечения широкого пакета инвестиций в сектор. 
В главе 8, Дамир Эсеналиев и Киоши Танагучи говорят о том, что происходит структурный сдвиг на рынке труда - перемещение рабочей силы из низко-производительного сектора сельского хозяйства в сферу услуг. Качество занятости и обеспеченность рабочими местами снижается в силу существования неформального сектора. Уровень безработицы достаточно высок, хотя количество работников с неполной занятостью уменьшилось. Участие женщин на рынке труда становится менее активным. Увеличилось количество трудовых мигрантов. На современном этапе развития трудовая миграция - факт современной истории страны; миграция оказывает значительное влияние на благосостояние и социальную сферу как на макроэкономическом уровне, так и на уровне домохозяйств. Трудовая миграция стала еще более жизнеспособной альтернативой трудоустройству на внутреннем рынке благодаря членству Кыргызской Республики в ЕАЭС с 2015 года, что обусловлено более высокими доходами в странах, где работают мигранты, в основном, в Российской Федерации. Хотя кыргызские трудовые мигранты трудоустраиваются, но трудоустраиваются, в основном, на низкооплачиваемую работу. Также значительно изменились приоритеты в получении образования, на рынок труда выходят все более молодые люди, профессионально техническое образование стало более популярным, нежели в начале 2000-х годов, снизилось количество желающих получить высшее образование. Существуют свидетельства о том, что уровень образования снизился. В целом, система образования отстает от требований инновационной экономики и в предоставлении требуемых на рынке труда навыков. В программы школьного образования следует включить так называемые «жизненные навыки» и расширить спектр получаемых ИТ навыков.

\section{5. Итоги и стратегические выводы}

\section{Подводя итоги}

Несмотря на сложные проблемы переходного периода, географическую изоляцию и чрезвычайно пересеченную местность, Кыргызская Республика сумела многого достичь как независимое национальное государство за период чуть больше четверти века. Страна пережила чрезвычайно трудный период после внезапного распада Советского Союза, переход от плановой к рыночной экономике, от авторитарного правления к демократии. Она сохранила свою территориальную целостность в сложном регионе. Крупные инфраструктурные проекты постепенно объединяют страну и географически, и экономически. Она сохранила некоторые из своих прежних преимуществ в экономической и государственной политике. В октябре 2017 года Кыргызская Республика достигла заметного успеха - впервые в Центральной Азии президент был избран мирным путем на национальных выборах. Сохраняются и улучшаются социальные показатели - хорошее наследие Coветского Союза. Бедность, в значительной степени, ликвидирована. Открываются новые возможности в сельском хозяйстве, туризме и, возможно, в обрабатывающей и горнодобывающей промышленности.

Главная задача состоит в том, чтобы использовать эти достижения и возможности в целях мощного широкомасштабного экономического роста. Экономика растет недостаточно быстро для удовлетворения потребностей населения. Почти шестая часть населения вынуждена искать работу за рубежом; этот показатель является одним из самых высоких в мире. Хотя занятость за рубежом и денежные переводы в таких масштабах способствуют в краткосрочной перспективе 
сокращению масштабов бедности, они не обеспечивают основу для долгосрочного экономического развития. Необходимо ускорить экономический рост и создание рабочих мест, особенно в секторах конкурентоспособных товаров. В свою очередь, это требует фундаментальной экономической и управленческой реформы, как указано в этой книге. Правительство должно создать благоприятные условия для ведения бизнеса, что стимулировало бы рост и процветание предприятий. Необходимо провести нормативно-правовую реформу, бороться с глубоко проникшей коррупцией. Нужна большая конкуренция существующим бизнес-структурам в современном секторе экономики.

Проведение фискальной реформы является приоритетным вопросом; положительные результаты реформ помогут обеспечить эффективное использование инвестиций в инфраструктуру и более целенаправленное расходование средств на социальные нужды. У страны большой государственный долг, без реформы он может возрасти; поскольку поступления доходов не гарантированы. Рост процентных ставок, как в глобальном масштабе, так и конкретно для Кыргызской Республики из-за уменьшения возможности получения ОПР на льготных условиях, вероятно, приведет к фискальным затруднениям. Денежно-кредитная политика сама по себе не может справиться с фискальными трудностями, в любом случае эффективность денежно-кредитной политики ограничена и без того обширной долларизацией.

Для открытого общества со сравнительно хорошим уровнем базового образования и языковыми навыками, в частности, знанием русского языка (и среди молодого поколения еще и английского языка), с учетом того, что более чем одна четверть трудоспособного населения работает за рубежом, выезд из страны является легкодоступным вариантом для большей части населения. Большое количество выпускников 50 университетов страны не могут найти работу, соответствующую полученной специальности. Это может отражать несоответствие между сектором образования и требованиями рынка труда, но это также может говорить об анемичном состоянии рынка труда. Образование и международный опыт трудоустройства - обоюдоострый меч, это и сила, и слабость страны. В благоприятных бизнес- и политических условиях образование и опыт могут работать на пользу развития, ориентированного на международный уровень. Но если возобладает вялый рост из прошлого, из страны уедут таланты и просто хорошо образованные люди, а это негативно повлияет на перспективы развития. Таким образом, Кыргызская Республика на данный момент находится на перепутье и выбор внутренней политики является ключевым фактором, определяющим, по какому пути пойдет страна.

\section{Практические выводы и рекомендации}

Нижеследующие рекомендации вытекают из каждой главы книги, в которых рассматриваются ключевые для развития страны и взаимосвязанные между собой вопросы о необходимости ускоренного экономического роста, макроэкономической осмотрительности, проведении бюджетной реформы, о снижении зависимости от денежных переводов, о создании более благоприятной среды для ведения бизнеса, об институциональных инновациях и целевых социальных расходах. Эти рекомендации в целом поддерживают и согласуются с долгосрочной Национальной стратегией устойчивого развития страны на 2018-2040 годы. 
Во-первых, что касается международной торговой политики, то следует поддерживать и поощрять экспорт продовольствия с учетом продолжающегося перехода от традиционного экспорта пищевых продуктов к экспорту продукции пищевой перерабатывающей промышленности с высокой стоимостью. Экспорт переработанных продуктов питания может сыграть важную роль в сокращении увеличивающегося торгового дисбаланса с КНР. Важной предпосылкой экспорта переработанных пищевых продуктов является следование международным стандартам безопасности (санитарным и фитосанитарным), что потребует создания определенных институциональных механизмов, помогающих как производителям, так и экспортерам. В этой связи международные учреждения, занимающиеся вопросами развития, могут играть важную роль в рамках новой инициативы «помощь в интересах торговли». Помощь иностранных инвесторов, построенная на принципе вертикальной интеграции, тоже может сыграть свою роль.

Во-вторых, правительство могло бы изучить возможности, чтобы помочь своей швейной промышленности выйти на глобальный уровень на основе той ниши, которую она уже заняла на рынках со средним уровнем дохода в Казахстане и Российской Федерации. Правительству следует снять административные и финансовые ограничения, которые препятствуют появлению крупных предприятий, перенаправить ПИИ в промышленность и ввести схему возврата импортных пошлин для экспортеров. Швейная промышленность может быть достаточно привлекательной для турецких компаний - производителей одежды, которые начали переводить свое производство в страны с низкой оплатой труда из-за повышения уровня заработной платы в Турции. Для привлечения ПИИ правительство могло бы рассмотреть вопрос о возмещении импортной пошлины экспортерам одежды; такое нововведение могло бы выровнять уровень прибыльности, которая может снизиться из-за увеличения затрат на закупку импортных материалов после вступления Кыргызской Республики в ЕАЭС.

В-третьих, правительство могло бы провести реформы финансового сектора, направленные на переадресацию денежных переводов трудовых мигрантов и использовать их как социально и экономически необходимые инвестиции. Для этого необходимо разработать соответствующую политику и провести институциональные реформы для поощрения финансового посредничества как механизма производственного инвестирования денежных переводов.

Сектор услуг, обеспечивающий жизнеспособность частного сектора является ключом к поддержанию устойчивого экономического роста и созданию новых рабочих мест в Кыргызской Республике. Это, в свою очередь, потребует разработки политики по обеспечению доступных и дешевых в обслуживании кредитов, модернизации государственной инфраструктуры, развития человеческого капитала, улучшения бизнес среды. Поддержка роста финансового сектора важна и для роста и развития частного сектора. Доступные и дешевые кредиты позволят вновь открывающимся и уже существующим предприятиям улучшить их конкурентоспособность, и, таким образом, расширить ассортимент товаров и увеличивать их ценность, а так же стоимость предоставляемых услуг. Обеспечение внедрения и исполнение строгих правил финансового регулирования также может способствовать снижению стоимости капитала за счет привлечения большего объема частных инвестиций. Развитие транспортной системы страны и улучшение логистики важны для роста экономического потенциала страны. Потребуются упрощенные прозрачные процедуры прохождения пограничного контроля, что позволит уменьшить количество задержек и снизить транзакционные затраты. Туристиче- 
ская отрасль страны, которая имеет сильные «обратные и прямые» связи, является перспективным источником роста занятости; туризм значительно выиграет, если будет разработана всеобъемлющая, инклюзивная стратегия устойчивого развития туризма. Для развития туристической отрасли потребуется подготовка и повышение квалификации работников сферы туризма, развитие транспортной и информационно-коммуникационной инфраструктуры, создание благоприятной среды для ведения и развития бизнеса. Поддержка «туристического коридора» на Иссык-Куль, одну из главных достопримечательностей Кыргызской Республики, предоставляет множество потенциальных возможностей для развития туризма и роста сектора услуг. Проведение туристических мероприятий и продвижение достопримечательностей Кыргызстана позволит привлечь туристов в зимний сезон, когда спрос низок, при сохранении традиционного летнего рынка. Страна может стать важным региональным образовательным центром для высшего образования, на базе уже достигнутых успехов. В этом отношении Кыргызстан может извлечь уроки из опыта Малайзии, поскольку эта страна стала одним из самых динамично развивающихся хабов высшего образования в Восточной Азии.

Что касается ИКТ, то успех новой программы цифровой трансформации будет зависеть от того, насколько эффективно Кыргызская Республика сможет мобилизовать человеческие и финансовые ресурсы для такой амбициозной инициативы. Также будет крайне важно следовать курсу и обеспечить, чтобы институциональные механизмы для реализации программы могли адаптироваться к сложной политической обстановке в стране. Институциональные механизмы для новой программы должны иметь достаточно возможностей, полномочий и прав для осуществления надзора за реализацией такой стратегической инициативы высокого уровня по всей стране и для мониторинга и координации деятельности на разных уровнях государственного управления.

Для успешного выполнения новой программы крайне важно сформулировать стратегию реализации, предусматривающую последовательность действий. На определенном этапе стране необходимо будет перейти к общему протоколу и системам структуры электронного правительства. Этот шаг повлечет за собой значительные усилия по преобразованию существующих систем и, следовательно, должна быть определена последовательность. Расчет затрат по реализации всей инициативы или определение отдельных проектов должны быть четко обозначенными, чтобы частный сектор и другие партнеры по развитию могли определить проекты или сферы, в которых инвестиции или поддержка в области развития наиболее необходимы.

Для энергетического сектора первая рекомендация заключается в обеспечении долгосрочной финансовой устойчивости путем строгого соблюдения нового среднесрочного тарифного плана как части комплексного пакета реформ сектора. Во-вторых, сектор должен инвестировать в повышение качества услуг для того, чтобы клиенты осознали получаемые от повышения тарифов преимущества. В-третьих, необходимо обеспечить защиту домашних хозяйств с низкими доходами, но не ограждая их от повышения тарифов, а за счет существенного увеличения объема ресурсов, выделяемых на социальную помощь и услуги, которыми активно пользуются малоимущие слои населения. В то же время важно, чтобы домохозяйства, имеющие средний доход, тоже получали выгоду от предоставления дополнительных ресурсов на социальные программы, направленные на улучшение уровня жизни всего населения, например, на программу улучшения системы здравоохранения. В-четвертых, должна вестись борьба с коррупцией внутри 
сектора за счет увеличения прозрачности и путем привлечения представителей гражданского общества к надзору за работой энергетического сектора. Нынешний кризис в секторе может быть использован для объяснения и проведения смелых реформ, полезных в долгосрочной перспективе; для поддержки идеи реформ необходимо создать коалицию из представителей различных политических кругов. И наконец, сектор должен: (1) разработать эффективную коммуникационную стратегию, одобренную и публично поддержанную на высшем уровне государственного управления; (2) объяснить необходимость изменений; (3) проводить консультации с гражданами; и (4) учитывать мнения граждан в ходе проведения реформ.

Авторы разработали четыре рекомендации, направленные на развитие транспорта и логистики. Во-первых, правительству необходимо не только строить новые дороги, но и обеспечить ремонт существующих и безопасность движения на дорогах. Следует таким образом управлять транспортными активами, чтобы поддерживать требуемое техническое состояние активов и максимально снизить затраты на ремонт дорог на протяжении всего их жизненного цикла и для направления инвестиций в строительство новых подъездных автомобильных дорог. Во - вторых, предпринять все возможное для снятия ограничений ЕС, запрещающих полеты кыргызских авиакомпаний в Европу по соображениям безопасности. Частично, это можно решить с помощью привлеченных в этот сектор ПИИ. Используя ПИИ, можно улучшить стандарты безопасности местных перевозчиков. В-третьих, транспортному сектору следует уделить пристальное внимание маршруту и финансированию предлагаемого железнодорожного сообщения Каши-Андижан через юг Кыргызской Республики. И последнее, за счет улучшения работы пограничных служб сократить расходы на международную торговлю.

Для повышения навыков и профессиональной подготовки специалистов авторы предлагают несколько рекомендаций стратегического характера. Во-первых, необходимо упростить регулирующие документы, касающиеся малых и средних предприятий, с тем, чтобы стимулировать их переход из неформального сектора в официальный. Один из возможных вариантов - уравнять налогообложение для малых и крупных компаний, снизить налоги на заработную плату и уменьшить регулятивное и коррупционное давление на крупные фирмы. Во-вторых, необходимы дополнительные инвестиции в качественное обучение для расширения профессиональных и карьерных возможностей преподавателей, улучшения культуры сотрудничества, системы наставничества, оценки эффективности и социальных льгот. В-третьих, в программы школьного образования следует включить так называемые «жизненные навыки» и расширить спектр получаемых ИКТ навыков. Жизненные навыки, такие как эффективная коммуникация, умение делать презентацию, тайм-менеджмент, управление капиталом и здоровый образ жизни, в настоящее время являются незначительной частью школьной программы, но эти навыки доказали свою важность для профессиональной жизни. Необходимо внедрить стандарты преподавания ИКТ и осуществлять более целенаправленное обучение программированию и навыкам работы с компьютером.

B-четвертых, следует усилить секторальные инициативы по разработке квалификационных стандартов и стандартов сертификации. Некоторые отраслевые ассоциации (например, текстильная промышленность и гостиничный бизнес) разрабатывают набор квалификационных стандартов для проведения аттестации независимым органом. Это позволит работникам, которые проходят подготовку на местах, пройти аттестацию и подтвердить свои навыки. Важно продолжать по- 
могать мигрантам получать навыки и информацию, необходимую для легального трудоустройства в Казахстане и Российской Федерации. Обладание навыками и информацией позволит трудовым мигрантам получить лучшую работу; это скажется положительно на повышении благосостояния, как на уровне домашних хозяйств, так и на макроэкономическом уровне.

В дополнение к этим конкретным рекомендациям по отдельным секторам, можно внести следующие релевантные предложения.

Во-первых, в качестве одной из приоритетных задач необходимо создать качественный потенциал «на расстоянии вытянутой руки» для проведения анализа затрат и выгод крупных инфраструктурных проектов. На это существуют три причины: сложная география страны; многообразие внешних источников финансирования, каждый из которых имеет свои особые требования и определенные способы работы; и уже высокий уровень государственного долга.

Во-вторых, реформа социальной политики должна стать приоритетной задачей. Достоин похвалы высокий уровень расходов правительства на социальные нужды, это способствовало тому, что Кыргызстан стал страной с относительно высокими социальными показателями. Однако, для того, чтобы преодолеть надвигающиеся трудности финансового характера в стране, создать некоторые бюджетные возможности и изыскать столь необходимые фонды для инвестирования в инфраструктуру, для содействия другим приоритетным направлениям, например, в сфере налогообложения, ценообразования на электроэнергию, необходимы более эффективные целевые показатели и цели, основанные на результатах.

B-третьих, движение вперед страны как демократического государства должно сопровождаться более эффективным государственным управлением. Система регулирования и лицензирования создала двойную экономику, в которой относительно небольшой формальный сектор сосуществует с крупным неформальным сектором. Рост малых и семейных предприятий ограничивается большими сложностями, коррупцией, бизнес средой с высокими налогами. Без значительных изменений, упрощения регулятивных документов и правил, занятость за рубежом (и, возможно, постоянная миграция) останется устремлением большей части населения страны.

В-четвертых, демократическая сущность страны может быть эффективно использована для искоренения широко распространившейся коррупции. Необходим мощный, надежный и независимый орган, обладающий необходимыми ресурсами и прокурорскими полномочиями, пользующийся широкой поддержкой сообщества. Успешно работающее антикоррупционное агентство Индонезии может стать образцом для подражания. 


\section{Библиография}

Азиатский банк развития (АБР). 2007. Ключевые индикаторы АБР за 2007. https://www.adb.org/publications/key-indicators-asia-and-pacific-2007 . 2010. Ключевые индикаторы АБР 2010. https://www.adb.org/publications/ key-indicators-asia-and-pacific-2010 . 2018. Ключевые индикаторы АБР 2018. https://www.adb.org/publications/ key-indicators-asia-and-pacific-2018

. Кыргызская Республика и АБР. https://www.adb.org/countries/kyrgyzrepublic/main

Бердигулова, А. 2018. Что движет денежными переводами: случай Кыргызской Республики? Евроазиатский научный журнал. Евразийский банк развития. 16 ноября. С. $124-130$.

Всемирный банк. 2018. Показатель эффективности логистики 2018. https:// www.worldbank.org/en/news/infographic/2018/07/24/logistics-performanceindex-2018 (по состоянию на февраль 2019).

. Показатель легкости ведения бизнеса. https://data.worldbank.org/ indicator/ic.bus.ease.xq (по состоянию на февраль и апрель 2019).

. Объединенный центр сбора данных о внешней задолженности. QEDS: Поквартальная статистика. http://datatopics.worldbank.org/debt/qeds (по состоянию на апрель 2019).

. Всемирный банк в КР. https://www.worldbank.org/en/country/ kyrgyzrepublic (по состоянию на июнь 2019).

. Показатели мирового развития (ПМР). https://databank.worldbank.org/ data/reports.aspx?source=world-development-indicators (по состоянию на апрель 2019).

. Мировые показатели управления Всемирного банка за 2018. https://info. worldbank.org/governance/wgi/\#home (по состоянию на февраль и май 2019).

Всемирная торговая организация (ВТО). 2006. Впечатляющий успех, но оставшиеся реформы - важны. Пресс релиз: Обзор Торговой Политики: Кыргызская Республика. https://www.wto.org/english/tratop_e/tpr_e/tp271_e.htm (по состоянию на февраль 2018.

. Обзор Торговой Политики: Кыргызская Республика. https://www.wto.org/ english/tratop_e/tpr_e/tp388_e.htm (по состоянию на февраль 2018).

. Статистика по товарообороту. https://www.wto.org/english/res_e/statis_e/ merch_trade_stat_e.htm (по состоянию на апрель 2019).

Государственное агентство по продвижению инвестиций и экспорта при Министерстве экономики Кыргызской Республики. Свободная экономическая зона. http://invest.gov.kg/en/why-kyrgyzstan/free-economic-zones/ (по состоянию на июнь 2019).

Конференция ООН по торговле и развитию. Прямые иностранные инвестиции. https://unctadstat.unctad.org/wds/TableViewer/tableView.aspx?ReportId= 96740 (по состоянию на февраль 2019). 
Международный валютный фонд. 2016. Определенные вопросы по Кыргызской Республике. Отчет по стране No. 16/56. Вашингтон, О.К. https://www.imf. org/external/pubs/ft/scr/2016/cr1656.pdf

. 2017. Выводы Исполнительного совета МВФ, Консультации с Кыргызской Республикой по статье IV. 25 октября. https://www.imf.org/en/News/ Articles/2017/10/25/pr17409-imf-executive-board-concludes-2017-article-ivconsultation-with-the-kyrgyz-republic

. Платёжный баланс, статистика. http://data.imf.org/?sk=7A51304B-642640Co-83DD-CA473CA1FD52 (по состоянию на апрель 2019).

. Офис МВФ в Кыргызской Республике. https://www.imf.org/en/Countries/ ResRep/KGZ

Transparency International. Индекс восприятия коррупции. - 2018. URL: https:// www.transparency.org/cpi2018 (по состоянию на февраль 2019).

Национальный банк Кыргызской Республики (НБКР). Статистика. https://www. nbkr.kg/index.jsp?lang=ENG (по состоянию на апрель 2019).

Национальный статистический комитет (НСК) Кыргызской Республики. http:// www.stat.kg/en/statistics/nacionalnye-scheta/ (по состоянию на апрель 2019).

Новости Кыргызстана 24. https://24.kg/english.

Организация экономического сотрудничества и развития (ОЭСР). 2018. Анализ Системы социальной защиты Кыргызстана. ОЭСР. Пути развития. Париж: ОЭСР. https://doi.org/10.1787/9789264302273-en

. Распределение помощи между странами и регионами [DAC2a]. https:// stats.oecd.org/Index.aspx?DataSetCode=Table2A (по состоянию на апрель 2019).

Программа развития Организации Объединенных Наций (ПРООН). 2019. Отчет по человеческому развитию 2018. http://hdr.undp.org/en/2018-update

Экономист. 2017. Узбекистан: С низким исходным уровнем. 16 декабря 2017. https://www.economist.com/printedition/2017-12-16 


\section{Глава2 2}

\section{Международные аспекты әкономической трансформации: торговля, прямые иностранные инвестиции и труовая Миграция}

\section{Према-чандра Атукорала и Маниша Прадхананга}

\section{1. Введение}

вляясь одним из пятнадцати независимых государств, возникших в результате распада бывшего Советского Союза, Кыргызская Республика в относительном выражении осуществила хорошие шаги в процессе перехода от централизованной плановой экономики к рыночной. Большая часть первого десятилетия независимости страны запомнилась ярким примером реформ в Центральной Азии. Реформы способствовали созданию одной из наиболее интегрированных в глобальном масштабе экономик на постсоветском пространстве и центра реэкспортной торговли в Центральной Азии. После 1990-х годов экономика росла в среднем на 4,5\% в год, при этом бедность на уровне стандартного контрольного показателя, равного «менее двух долларов в день», фактически была искоренена. Тем не менее, рост был неустойчивым и не соответствовал предполагаемому потенциалу страны. Экономика сталкивается с нарастающими проблемами, связанными с расширением дефицита торгового баланса и постоянной зависимостью от денежных переводов и накоплением внешнего долга. Главная задача современной политики страны - это рост экспортной базы посредством диверсификации на основе рыночных принципов и внедрение широкого спектра экономических, институциональных и политических реформ.

Задача данной главы - изучить процесс экономической трансформации в Кыргызской Республике, уделяя особое внимание роли торговли, прямых иностранных инвестиций (ПИИ) и трудовой миграции. Внимание уделяется достигнутому до сегодняшнего дня прогрессу и вариантам политики для дальнейшей интеграции в мировую экономику через торговлю и ПИИ. С самого начала важно заранее предупредить, что точные величины соответствующих переменных ненадежны, учитывая то, что национальная система представления данных в стране все еще развивается. Охват данных, касающихся внешней торговли и денежных переводов мигрантов, неравномерен в разные периоды из-за корректировки торговли и денежных переводов, осуществляемых по неофициальным каналам. Данные о ПИИ основаны на утвержденных объемах инвестиций, а не на фактических (реализованных) инвестициях. Еще более важно то, что для межвременного ана- 
лиза нельзя предположить, что величина ошибок отчетности остается постоянной по двум причинам. Во-первых, доля неформальной торговли и денежных переводов, а также темпы фактической реализации утвержденных инвестиционных проектов варьируются с течением времени. Во-вторых, процедуры, которых придерживались органы по учету и составлению данных для работы с неформальной торговлей и денежными переводами, по-видимому, периодически менялись. По последней причине в некоторых случаях требуется несколько лет (а не 1-2 года, как в случае со странами с развитыми системами отчетности), чтобы установились определенные ряды данных.

Глава начинается с изучения процесса реформ и политики по укреплению рынка, а также структуры стимулирующих мер с акцентом внимания на незавершенности реформ. В следующем разделе представлен обзор ситуации с внешними платежами в стране с целью обеспечения контекста для последующего анализа. Затем следуют три основных раздела, каждый из которых касается результатов реформ и дальнейших императивов, связанных с реформами в области торговли, ПИИ и трудовой миграции. В заключение главы приводится резюме основных выводов и последствий с точки зрения политики.

\section{2 Реформы и структура стимулирующих мер}

\section{Торговая политика}

Кыргызская Республика выделяется среди советских республик, которые приобрели свою независимость после распада Советского Союза 25 декабря 1991 года, тем, что она вступила на путь либерализации и глобальной экономической интеграции на ранней стадии переходного процесса. В 1993 году она подписала двустороннее соглашение о сотрудничестве с Соединенными Штатами Америки, что послужило основой для обширной международной помощи. Процесс реформ получил сильную поддержку со стороны международных институтов, таких как Азиатский банк развития, Международный валютный фонд, Всемирный банк и другие международные организации развития и крупные двусторонние доноры.

В течение первых пяти лет были ликвидированы государственные монополии на внешнюю торговлю, отменены требования о лицензировании импорта, а также начаты тарифные реформы. В дополнение к открытию торговли практически все меры ценового контроля на внутреннем рынке были ликвидированы, кроме сектора общественного транспорта, электроэнергии и коммунальных услуг. В июле 1998 года она стала первой среди государств-преемников СССР, присоединившихся к Всемирной торговой организации (ВТО)ํ. В 1999 году либерализация торговли и конвертируемость валюты дали стране право на получение статуса «Статьи IV» Международного валютного фонда. К тому времени конвертируемость валюты фактически была осуществлена для операций с капиталом, требовалось лишь раскрытие информации.

Кыргызская Республика устранила количественные ограничения на импорт в рамках обязательств по вступлению в ВТО. В 2017 году простые средние и средневзвешенные торговые тарифы составили 6,9\% и 7,7\% соответственно (Таблица 2.1).

Российская Федерация стала членом ВТО в 2012 году. Среди стран Центральной Азии Казахстан и Таджикистан вступили в ВТО в 2013 и 2015 годах соответственно. Туркменистан и Узбекистан до сих пор не являются членами ВТО. 
Большинство применяемых ставок пошлины в 2016 году на двухзначном уровне товарных кодов Гармонизированной системы были значительно ниже максимальных предельных ставок. Как правило, постоянные пошлины на экспорт отсутствуют, за исключением некоторых временных пошлин, периодически налагаемых на некоторые сельскохозяйственные продукты, в первую очередь для стабилизации внутреннего предложения в период временного дефицита предложения.

В 2015 году Кыргызская Республика стала членом Евразийского экономического союза (ЕАЭС) (Вставка 2.1). В настоящее время Кыргызская Республика находится в процессе согласования своих тарифов на импорт из стран, не входящих в ЕАЭС, с едиными тарифами Таможенного союза. Согласно расчетам, сделанным ВТО, 30\% кыргызстанских пошлин уже согласованы с едиными тарифами Таможенного союза, а 21\% могут быть повторно согласованы без нарушения обязательств перед ВТО (поскольку единые тарифы ниже тарифных ставок ВТО, установленных в Кыргызской Республике), но согласование остальных тарифов требует переговоров и выплаты компенсации членам ВТО. Существуют значительные тарифные различия для мяса и мясных продуктов, алкогольных напитков, некоторых химических продуктов, дерева и бумаги, железа и стали, алюминия и мебели. Средние тарифные ставки Таможенного союза на эту продукцию превышают средние тарифы Кыргызской Республики на 10\% или более (ВТО, 2014 г.). Органы власти Кыргызской Республики уже начали переговоры.

По сравнению с действующими тарифами, применяемыми в Кыргызской Республике в рамках режима наибольшего благоприятствования, единые тарифы Таможенного союза обычно выше на сельскохозяйственную продукцию и ниже на несельскохозяйственные продукты. ${ }^{2}$ Однако в обоих случаях разница пошлинных ставок невелика и в среднем составляет примерно 2 процентных пункта. Таким образом, если сфокусировать внимание исключительно на различиях в тарифах, влияние торговой политики на кыргызскую экономику от вступления в ЕАЭС вряд ли будет столь значительным, как считается, особенно с учетом «естественных» торговых издержек, связанных с отсутствием выхода к морю и расстоянием до рынков, и огромных конкурентных преимуществ Китайской Народной Республики (КНР) перед странами-членами ЕАЭС в мировой торговле продуктами перерабатывающей промышленности. Однако, в политических кругах Кыргызской Республики есть опасения, что применение общего пограничного режима, санкционированного членством в ЕАЭС, может значительно снизить роль Кыргызской Республики как центра реэкспортной торговли в регионе.

Данные по российским тарифам взяты у ВТО. 2018. www.wto.org/statistics (по состоянию на 8 мая 2018 г.). 


\section{Таблица 2.1: Импортные пошлины, применяемые в рамках режима наибольшего благоприятствования, Кыргызская Республика, 2017 год (\%)}

\begin{tabular}{|c|c|c|c|c|c|c|}
\hline \multirow[b]{2}{*}{ Группа продукции } & \multicolumn{3}{|c|}{ Итоговые тарифы } & \multicolumn{3}{|c|}{ Применяемые тарифы } \\
\hline & Средний & $\begin{array}{l}\text { Беспош- } \\
\text { линный }\end{array}$ & $\begin{array}{l}\text { Макси- } \\
\text { мальный }\end{array}$ & Средний & $\begin{array}{l}\text { Беспош- } \\
\text { линный }\end{array}$ & $\begin{array}{l}\text { Макси- } \\
\text { мальный }\end{array}$ \\
\hline $\begin{array}{l}\text { Продукты животного } \\
\text { происхождения }\end{array}$ & 17.1 & 8.7 & 95 & 15.0 & 19.0 & 55 \\
\hline Молочные продукты & 14.4 & 0 & 15 & 14.9 & 0 & 18 \\
\hline Фрукты, овощи, растения & 8.1 & 0.2 & 13 & 8.2 & 4.8 & 20 \\
\hline Kофе, чай & 5.4 & 4.2 & 20 & 5.4 & 20.8 & 3 \\
\hline Зерновые и продукция из них & 9.6 & 1.9 & 15 & 9.4 & 4.0 & 20 \\
\hline $\begin{array}{l}\text { Масличные семена, жиры и } \\
\text { масла }\end{array}$ & 5.6 & 32.0 & 60 & 6.6 & 19.1 & 15 \\
\hline Сахар и кондитерские изделия & 10.2 & 0 & 233 & 11.1 & 0 & 54 \\
\hline Напитки и табачные изделия & 20.5 & 2.1 & 0 & 21.7 & 4.4 & 233 \\
\hline Хлопок & 0.0 & 100.0 & 10 & 0.0 & 100.0 & 0 \\
\hline $\begin{array}{l}\text { Другие сельскохозяйственные } \\
\text { продукты }\end{array}$ & 5.3 & 0.8 & 14 & 4.8 & 7.4 & 10 \\
\hline Рыба и рыбные продукты & 0.8 & 88.6 & 15 & 7.2 & 4.5 & 30 \\
\hline $\begin{array}{l}\text { Полезные ископаемые и } \\
\text { металлы }\end{array}$ & 7.0 & 0.4 & 5 & 7.6 & 6.8 & 17 \\
\hline Несть & 5.0 & 0 & 12 & 4.4 & 12.7 & 5 \\
\hline Химикаты & 4.7 & 9.1 & 15 & 5.0 & 8.7 & 13 \\
\hline Древесина, бумага и т. д. & 5.0 & 37.6 & 15 & 8.2 & 6.4 & 16 \\
\hline Текстиль & 7.4 & 0.2 & 24 & 8.0 & 0.6 & 20 \\
\hline Одежда & 8.9 & 0 & 15 & 9.1 & 0 & 24 \\
\hline Кожа, обувь и т. д. & 6.0 & 4.2 & 15 & 6.2 & 9.9 & 20 \\
\hline Неэлектрические машины & 6.4 & 31.1 & 15 & 2.6 & 67.3 & 15 \\
\hline Электрические машины & 4.8 & 41.1 & 15 & 4.5 & 45.1 & 20 \\
\hline Транспортное оборудование & 7.5 & 11.6 & 15 & 8.1 & 16.8 & 23 \\
\hline Другие производители & 7.0 & 22.5 & 15 & 8.0 & 21.0 & 20 \\
\hline \multicolumn{7}{|l|}{ Резюме } \\
\hline \multicolumn{7}{|l|}{ Общий импорт } \\
\hline Простой средний & 7.5 & & & 6.9 & & \\
\hline $\begin{array}{l}\text { Средневзвешенный } \\
\text { уровень пошлины }\end{array}$ & & & & 7.7 & & \\
\hline \multicolumn{7}{|c|}{ Сельскохозяйственная продукция } \\
\hline Простой средний & 12.7 & & & 9.2 & & \\
\hline $\begin{array}{l}\text { Средневзвешенный } \\
\text { уровень пошлины }\end{array}$ & & & & 17.9 & & \\
\hline \multicolumn{7}{|c|}{ Несельскохозяйственная продукция } \\
\hline Простой средний & 6.7 & & & 6.5 & & \\
\hline Средневзвешенный уровень & ршлины & & & 6.0 & & \\
\hline
\end{tabular}

а Продукты, обозначенные на уровне двухзначного кода Гармонизированной системы (ГС).

Источник: ВТО. 2018. www.wto.org/statistics (по состоянию на 8 мая 2018 г.) 


\section{Вставка 2.1: Евразийский экономический союз}

В 2010 году Беларусь, Казахстан и Российская Федерация создали таможенный союз. Его заменил Евразийский экономический союз (ЕАЭС) в 2015 году. Армения присоединилась к ЕАЭС 2 января 2015 года, а затем Кыргызская Республика 6 августа 2015 года. Пять стран-членов ЕАЭС имеют интегрированный единый рынок, насчитывающий 183 миллиона человек с ВВП более 4 триллионов долларов США (по паритету покупательной способности).

Чтобы оценить влияние ЕАЭС на структуру торговли стран-членов, важно понимать различие между зоной свободной торговли (ЗСТ), таможенным союзом и экономическим союзом. ЗСт - это объединение двух или более стран, в котором отменяются все импортные тарифы и квоты, а также экспортные субсидии и другие аналогичные государственные меры, оказывающие влияние на торговлю, в то время как каждая страна продолжает сохранять свои собственные международные торговые меры в отношении стран, не являющихся частью этого объединения. Нет необходимости в использовании правил происхождения, то есть конкретных критериев оценки приемлемости каждой страны для получения права на согласованные торговые концессии, что является неотъемлемой частью соглашения. Они необходимы для предотвращения того, чтобы третьи страны не получали выгод от доступа на рынки в зоне свободной торговли через страну-члена с самыми низкими тарифами («отклонение торговли»). Фактическая степень либерализации торговли, достигнутая в рамках соглашения о свободной торговле, зависит от характера правил происхождения и жесткости, с которой они применяются. Таможенный союз является эквивалентом ЗСТ плюс общие внешние тарифы для торговли с государствами, не являющимися членами. В данном случае необходимость в правилах происхождения отпадает, поскольку единые тарифы исключают отклонение торговли. Экономический союз эквивалентен таможенному союзу плюс дополнительная характеристика, заключающаяся в согласовании дополнительной политики: денежно-кредитной, налогово-бюджетной, социальной помощи, а также предоставлении свободы перемещения факторов производства между странами-членами. Чтобы достичь статуса «экономического союза», ЕАЭС должен пройти длительный путь для реализации предложенной программы ресрорм. ЕАЭС даже не вписывается полностью в определение таможенного союза: по-прежнему существуют значительные нетарифные барьеры для торговли между странами-членами. Кроме того, соглашение ЕАЭС не охватывает санитарные и фитосанитарные меры, касающиеся торговли пищевыми продуктами между странамичленами. Страны-члены могут решать санитарные и фитосанитарные вопросы только посредством неофициальных двусторонних переговоров и/или путем применения процедуры урегулирования споров Всемирной торговой организации.

Помимо беспошлинного доступа на рынки стран-членов, Кыргызская Республика выиграет от регулирования статуса трудящихся мигрантов, решения вопросов, связанных с пенсионными правами работников, а также доступа к улучшенным транспортным коридорам Север-Юг в рамках ЕАЭС. Соглашение ЕАЭС о трудовой миграции предусматривает упрощение административных требований для въезда трудящихся мигрантов, увеличение периода непрерывного пребывания в данной стране, предоставление социальных прав семьям мигрантов (особенно в сфере образования) и упрощения доступа к информации для трудящихся мигрантов.

30 мая 2015 года ЕАЭС подписал соглашение о свободной торговле с Вьетнамом. ЕАЭС также нацелен на обсуждение комплексных договоров с крупнейшими торговыми и экономическими партнерами - Европейским союзом и Китайской Народной Республикой (КНР). ЕАЭС и КНР уже начали диалог по Соглашению о торгово-экономическом сотрудничестве. Обсуждаются также вопросы участия ЕАЭС в экономическом поясе Шелкового пути под руководством КНР.

Источники: ЕАБР (2017 г.), Помфрет (2018 г.), Тарр (2016 г.), Винокуров (2017 г.). 
В течение последних двух десятилетий торговля, которая перемещает товары КНР через базары в Бишкеке и Оше на рынки в Казахстане и Российской Федерации, стала значительным источником экономического динамизма в Кыргызской Республике. Торговцы-челноки извлекли особую выгоду от единой системы взимания пошлин на основе веса продукции в Кыргызской Республике, которая должна быть заменена на единые импортные тарифы ЕАЭС, основанные на стоимости (адвалорем).

Учитывая, что импорт, предназначенный для любой страны-члена, может поступать в Таможенный союз через любую другую страну-член, договоренность о расщеплении таможенных пошлин является неотъемлемой частью таможенного союза. Согласно соглашению о распределении доходов ЕАЭС, Кыргызская Республика должна будет получить долю на уровне 1,9 процента от расщепления всех собранных таможенных пошлин ЕАЭС.

\section{Политика прямых иностранных инвестиций}

Открытие страны для ПИИ является неотъемлемой частью реформ по либерализации в Кыргызской Республике, и с середины 1990-х годов она остается одной из самых открытых стран для ПИИ в Центральной Азии и Восточной Европе. Помимо внутреннего и международного авиатранспортного сектора, в котором иностранная доля ограничена 49\%, все остальные сектора полностью открыты для участия иностранного капитала (за исключением того, что иностранцы не имеют право собственности на землю). Кыргызское законодательство предусматривает равное отношение к отечественным и иностранным инвесторам в отношении собственности местных компаний. Предприятия с иностранными инвестициями могут открывать и вести банковские счета в иностранной валюте. Отсутствуют минимальные требования к капиталу. Разрешается бесплатная репатриация капитала и прибыли.

Пять свободных экономических зон (СЭЗ) были созданы в качестве координационных центров для привлечения иностранных инвесторов: в Бишкеке, Караколе, Лейлеке, Маймаке и Нарыне. Стимулы, предлагаемые предприятиям СЭ3, включают освобождение от всех налогов, пошлин и других сборов на весь период работы в СЭЗ, а также упрощенные и ускоренные регистрацию предприятия и таможенные процедуры. Предприятиям СЭЗ разрешается продавать до 30\% от общего объема производства на внутреннем рынке без налога. Продажи свыше данного лимита подлежат налогообложению в соответствии с налоговым законодательством страны.

\section{Макроэкономическая политика и международная конкурентоспособность}

Первые три года становления государства стали периодом гиперинфляции в Кыргызской Республике. Введение национальной валюты в 1993 году сыграло важную роль в создании функционирующей рыночной экономики, необходимой для сдерживания инфляции. Это (в сочетании с (1) режимом управляемого плавающего обменного курса, поддерживаемым притоком льготного капитала, а также (2) открытым режимом торговли, который смог удовлетворить скрытый внутренний спрос за счет импорта), способствовало снижению ежегодных темпов роста инфляции ниже 50\% к середине 1990-х годов и до 4\%-6\% в последующие годы. 
В период с начала 2000 года по 2015 год реальный эффективный обменный курс (REER) в основном соответствовал движению номинального эффективного обменного курса (NEER), поскольку темпы внутренней инфляции были в значительной степени схожи с темпами стран-торговых партнеров (Рисунок 2.1). Однако, с тех пор REER для торговли со странами-членами ЕАЭС и остальным миром демонстрирует расходящиеся модели.

NEER укрепился для стран ЕАЭС в течение этого периода с учетом массивного обесценивания рубля по отношению к доллару CША после завершения ресурсного бума. Однако, REER продолжает обесцениваться, в основном благодаря относительно низкой инфляции в Кыргызстане по сравнению с другими странам ЕАЭС.

Реальный эффективный обменный курс (REER) продолжал расти за этот период по сравнению с ситуацией в странах, не входящих в ЕАЭС, обусловленный повышением номинального обменного курса по отношению к валютам этих стран. Дезагрегированные данные (не отражены здесь для краткости) показывают, что с начала 2016 года сом укрепился по отношению к евро, китайскому юаню, казахскому тенге, турецкой лире и доллару США, в то время как наблюдалась некоторая девальвация по отношению к российскому рублю. Учитывая контрастные модели изменения NEER по отношению к ЕАЭС и другим странам, совокупный REER продемонстрировал умеренный уровень роста (примерно на 10\%) в период между 2015 и 2016 годом (рисунок 2.1).

Рисунок 2.1: Номинальный эффективный обменный курс (NEER), относительная цена, и реальный эффективный обменный курс (REER),

Кыргызская Республика. 2000 - 2018 гг. (2010 = 100)

а. Во всем мире

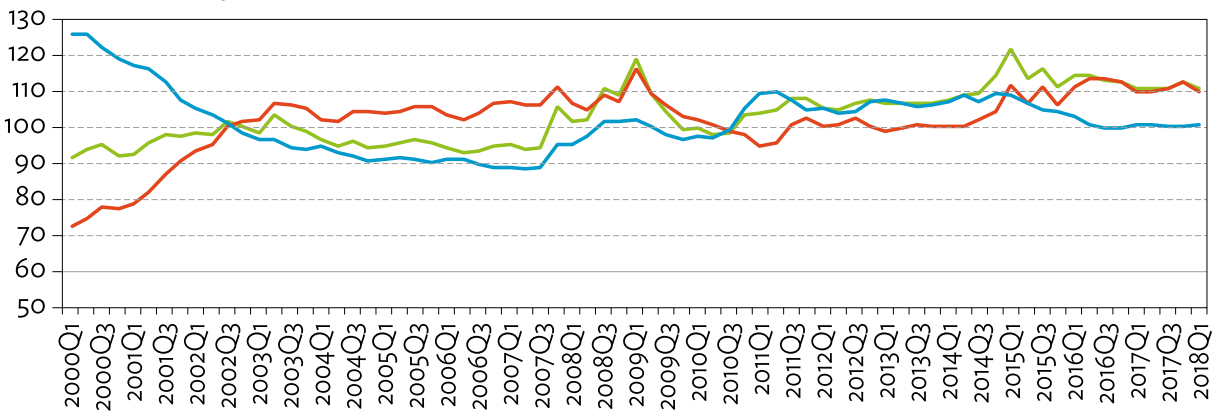

b. Страны Евразийского экономического союза ${ }^{b}$

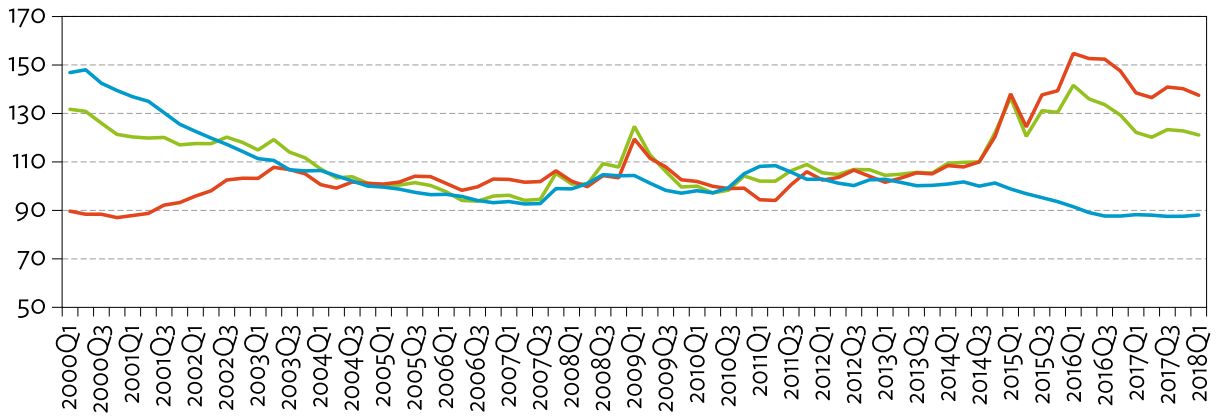




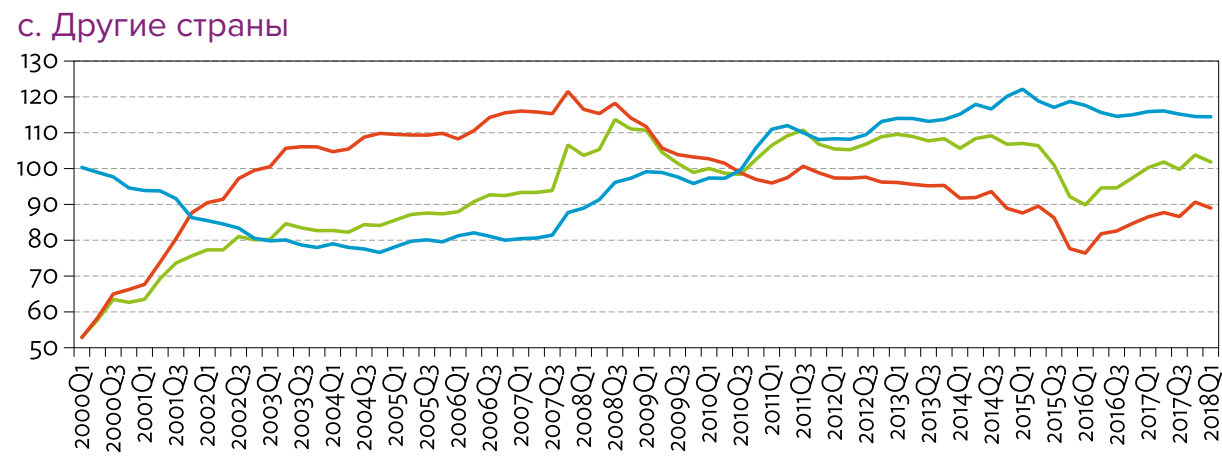

\section{REER NEER RP}

NEER = Номинальный эффективный обменный курс; RP = уровень цен в Кыргызской Республике относительно стран-торговых партнеров; REER = NEER $\times$ RP = реальный эффективный обменный курс. Увеличение REER указывает на реальный рост: (снижение международной конкурентоспособности экономики Кыргызстана) и наоборот.

а Охватывает общую торговлю Кыргызской Республики (импорт и экспорт) с семнадцатью крупнейшими торговыми партнерами-странами.

ь Поразительно схожи с тремя сериями данных для Содружества Независимых Государств (СНГ), учитывая доминирование Казахстана и Российской Федерации в обеих группах стран.

Источник: Составлено на основе данных НБКР, Ежемесячные статистические бюллетени, 20002018 гг. http://www.nbkr.kg/DOC/07122017/000000000048812.xls (по состоянию на 6 мая 2018 года).

Поведение номинального обменного курса в основном было обусловлено денежными переводами трудящихся мигрантов и другими притоками капитала. Сравнение изменений валютных резервов и обменного курса сома по отношению к доллару США свидетельствует о том, что центральный банк (Национальный банк Кыргызской Республики) осуществлял интервенции на валютном рынке только во избежание чрезмерной волатильности: нет доказательств того, что Национальный банк «шел против ветра».

\section{Торговые таможенные реформы}

Несмотря на значительные торговые таможенные реформы и макроэкономическую стабилизацию, в проведении более сложных институциональных и правовых реформ, необходимых для создания «среды, в которой рыночные силы могли бы производить социально желаемые результаты» (Помфрет, 2018 г., с. 180) достигнутый прогресс был ограниченным. Показатели экономического переходного периода, рассчитываемые Европейским банком реконструкции и развития, кратко обобщены для стран-членов ЕАЭС в Таблице 2.2. Показатели оценивают политику по шкале от 1 (без реформы) до 4 (соответствует стандартам рыночных экономик с высоким уровнем доходов).

Кыргызская Республика достигла уровня рыночных экономик с высоким уровнем доходов в контексте мелкомасштабной приватизации, стабилизации цен и либерализации торговых и валютных систем. Однако, согласно другим показателям, ее рейтинг не сильно отличается от рейтингов других стран ЕАЭС.

Кыргызская Республика также имеет низкий рейтинг в области управления, реструктуризации предпринимательства, а также политики в области конкуренции в соответствии с различными глобальными обследованиями и рейтингами. 
Кыргызская бизнес-среда не способствует привлечению иностранных инвестиций и, как правило, диверсификации экономики от зависимости от сырьевых товаров посредством инициатив частного сектора. Отсутствие рыночной дисциплины внутри страны препятствует благотворному влиянию существенных реформ в области торговой и инвестиционной политики.

Таблица 2.2: Показатели экономического переходного периода для стран Евразийского экономического союза, 1995, 2010 и 2014 гг.

\begin{tabular}{|c|c|c|c|c|c|c|c|}
\hline Страна & Год & $\begin{array}{c}\text { Масштабн. } \\
\text { приватиз. }\end{array}$ & $\begin{array}{c}\text { Мелко- } \\
\text { масштабн. } \\
\text { приватиз. }\end{array}$ & $\begin{array}{c}\text { Управление } \\
\text { и реструк- } \\
\text { туризация } \\
\text { предприятий }\end{array}$ & $\begin{array}{c}\text { Либерал. } \\
\text { цен }\end{array}$ & $\begin{array}{c}\text { Система } \\
\text { торговли и } \\
\text { Forex }\end{array}$ & $\begin{array}{c}\text { Конкурент. } \\
\text { политика }\end{array}$ \\
\hline \multirow[t]{3}{*}{ Казахстан } & 1995 & 2 & 3 & 1 & 4 & 3 & 2 \\
\hline & 2010 & 3 & 4 & 2 & 4 & 3.7 & 2 \\
\hline & 2014 & 3 & 4 & 2 & 3.7 & 3.7 & 2 \\
\hline \multirow{3}{*}{$\begin{array}{l}\text { Кыргызская } \\
\text { Республика }\end{array}$} & 1995 & 3 & 4 & 2 & 4.3 & 4 & 2 \\
\hline & 2010 & 3.7 & 4 & 2 & 4.3 & 4.3 & 2 \\
\hline & 2014 & 3.7 & 4 & 2 & 4.3 & 4.3 & 2 \\
\hline \multirow[t]{3}{*}{ Таджикистан } & 1995 & 2 & 2 & 1 & 3.3 & 2 & 2 \\
\hline & 2010 & 2.3 & 4 & 2 & 4 & 3.3 & 1.7 \\
\hline & 2014 & 2.3 & 4 & 2 & 4 & 3.7 & 1.7 \\
\hline \multirow[t]{3}{*}{ Туркменистан } & 1995 & 1 & 1.7 & 1 & 2.7 & 1 & 1 \\
\hline & 2010 & 1 & 2.3 & 1 & 2.7 & 2 & 1 \\
\hline & 2014 & 1 & 2.3 & 1 & 3 & 2.3 & 1 \\
\hline \multirow[t]{3}{*}{ Узбекистан } & 1995 & 2.7 & 3 & 2 & 3.7 & 2 & 2 \\
\hline & 2010 & 2.7 & 3.3 & 1.7 & 2.7 & 2 & 1.7 \\
\hline & 2014 & 2.7 & 3.3 & 1.7 & 2.7 & 1.7 & 1.7 \\
\hline \multirow[t]{3}{*}{ Армения } & 1995 & 2 & 2.7 & 2 & 3.7 & 3 & 1 \\
\hline & 2010 & 3.7 & 4 & 2.3 & 4.3 & 4.3 & 2.3 \\
\hline & 2014 & 3.7 & 4 & 2.3 & 4 & 4.3 & 2.3 \\
\hline \multirow[t]{3}{*}{ Беларусь } & 1995 & 1.7 & 2 & 1.7 & 3.7 & 2 & 2 \\
\hline & 2010 & 1.7 & 2.3 & 1.7 & 3.3 & 2.3 & 2 \\
\hline & 2014 & 1.7 & 2.3 & 1.7 & 3 & 2.3 & 2 \\
\hline \multirow{3}{*}{$\begin{array}{l}\text { Российская } \\
\text { Федерация }\end{array}$} & 1995 & 3 & 4 & 2 & 3.7 & 3 & 2 \\
\hline & 2010 & 3 & 4 & 2.3 & 4 & 3.3 & 2.3 \\
\hline & 2014 & 3 & 4 & 2.3 & 4 & 3.7 & 2.7 \\
\hline
\end{tabular}

Источник: ЕБРР. http://www.ebrd.com/what-we-do/economic-research-and-data/data/forecastsmacrodata-transition-indicators.html (по состоянию на 27 мая 2018 года).

\section{Инфраструктура, невыгодное географическое положение и торговые издержки}

Отсутствие связанности с внешним миром остается серьезным препятствием в Кыргызской Республике для глобальной экономической интеграции. Старые торговые маршруты, ведущие в Азию через Таджикистан и Афганистан, оставались фактически закрытыми в течение многих лет из-за гражданской войны в Афганистане. В настоящее время основной наземный транспортный маршрут, связывающий Кыргызскую Республику с мировыми рынками, проходит через Казахстан, Российскую Федерацию и Грузию в Турцию, а оттуда - в другие европейские 
пункты назначения. Чтобы добраться до Турции, стандартному грузовому автотранспортному средству (22 тонны) требуется 7-8 дней, и 10 дней, чтобы добраться до других стран Европейского Союза, а стоимость грузоперевозки колеблется от 4000 до 5000 долларов США за один грузовик. Транспортировка в Российскую Федерацию занимает от 3 до 4 дней, а стоимость доставки посредством стандартного грузового автотранспортного средства составляет от 2000 до 2400 долларов США (Тилекеев и др., 2018 г.).

Восточная граница с КНР, которая оставалась закрытой на протяжении более тридцати лет в советское время, была вновь открыта после распада бывшего Советского Союза. Автодорожные сети страны, ведущие к границе КНР, также были улучшены при поддержке международных финансовых институтов и двусторонних доноров. Новая автодорога из Бишкека в Нарын и далее в Торугарт на границе с КНР (двухполосная круглогодичная автомагистраль, финансирование большей частью АБР) содействует перевозкам из Бишкека до границы КНР без транзита через Казахстан. Власти в КНР также стремятся увеличить экономическое развитие Синьцзян-Уйгурского автономного района путем расширения торговли с Кыргызской Республикой и другими странами Центральной Азии.

\section{3. Позиция в отношении внешних платежей}

Степень торговой ориентации экономики Кыргызской Республики, измеряемая стандартным соотношением торговли к валовому внутреннему продукту (ВВП), непрерывно повышалась в течение нескольких лет экономической корректировки с начала 1990-х годов до примерно 2013 года. С тех пор произошло заметное изменение тенденции (Рисунок 2.2). Как увеличение торговой ориентации, так и последующее снижение, в значительной степени определялись поведением соотношения импорта к ВВП (импортная ориентация экономики). Соотношение экспорта к ВВП варьировалось в диапазоне от 30 до 40\% в период с 2000-2013 гг., а затем сократилось примерно до 25\% в промежутке с 2016-2017 гг. ${ }^{3}$

\section{Рисунок 2.2: Торговая открытость экономики Кыргызской Республики, 1995-2017 гг. (\%)}

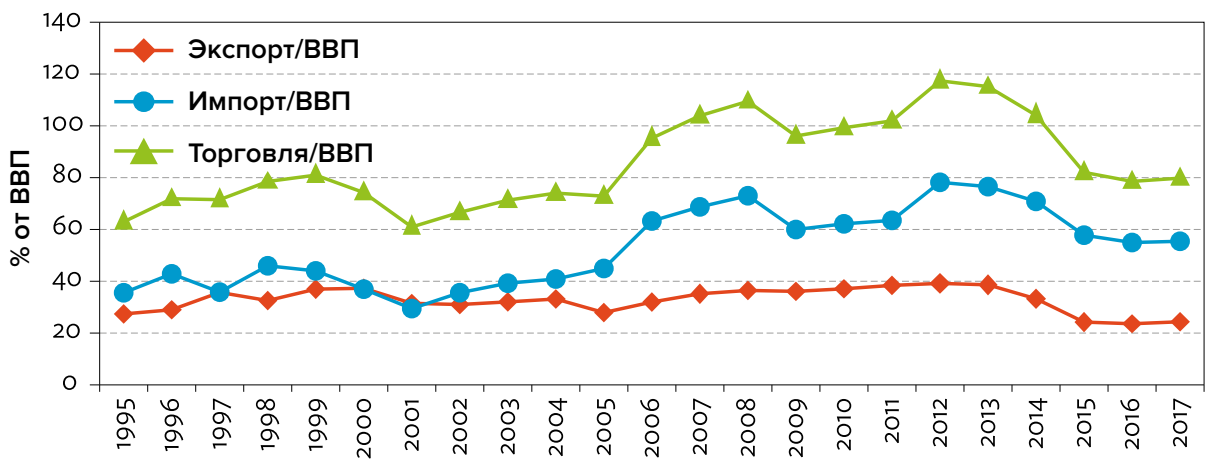

ВВП = валовой внутренний продукт.

Источник: Составлено на основе данных НБКР, Ежемесячные статистические бюллетени, 19952017 гг. (http://www.nbkr.kg/DOC/07122017/000000000048812.xls, (по состоянию на 28 мая 2018 г.).

3 В межвременных сопоставлениях в этой главе используются средние значения за два года, чтобы свести к минимуму возможные случайные шоки и погрешности измерения. 
Растущий разрыв между коэффициентами импорт-ВВП и экспорт-ВВП, который показывает дефицит торгового баланса по отношению к ВВП, увеличился примерно с 5\% в 2003 году до более 27\% в 2017 году. Как видно из Рисунка 2.3, более двух третей растущего торгового дефицита были заполнены за счет денежных переводов мигрантов за данный промежуток времени. Следовательно, дефицит текущего счета оставался на контролируемых уровнях: около 3,5\% от ВВП. Но данная совокупная цифра не является хорошим показателем устойчивости позиции внешних расчетов. Важнее всего то, за счет чего финансируется дефицит. В 1990-х годах и в начале первого десятилетия этого столетия гранты и льготное институциональное кредитование (льготные кредиты) помогли Кыргызской Республике сгладить потребительский шоки в результате распада Советского Союза и снизить давление, чтобы привести текущие доходы в соответствие с расходами. Однако за последнее десятилетие или около того произошел сдвиг в структуре притоков капитала от льготных кредитов в сторону кредитов по коммерческим ставкам. Учитывая открытый режим операций с капиталом в сочетании с высокой стоимостью кредитных ресурсов на внутреннем банковском рынке (более 10\% годовых), притоки иностранного капитала в виде коммерческих кредитов частному сектору значительно увеличились. ПИИ, представляющие собой наиболее желательную форму притоков капитала, которая имеет потенциал для укрепления внешней позиции путем расширения товарного производства в экономике, не заявили о себе как о существенном источнике притоков капитала (Таблица 2.3).

\section{Рисунок 2.3: Сальдо торгового баланса и счета текущих операций, и денежные переводы работников (нетто) как доля ВВП, Кыргызская Республика, 1995-2017 гг. (\%)}

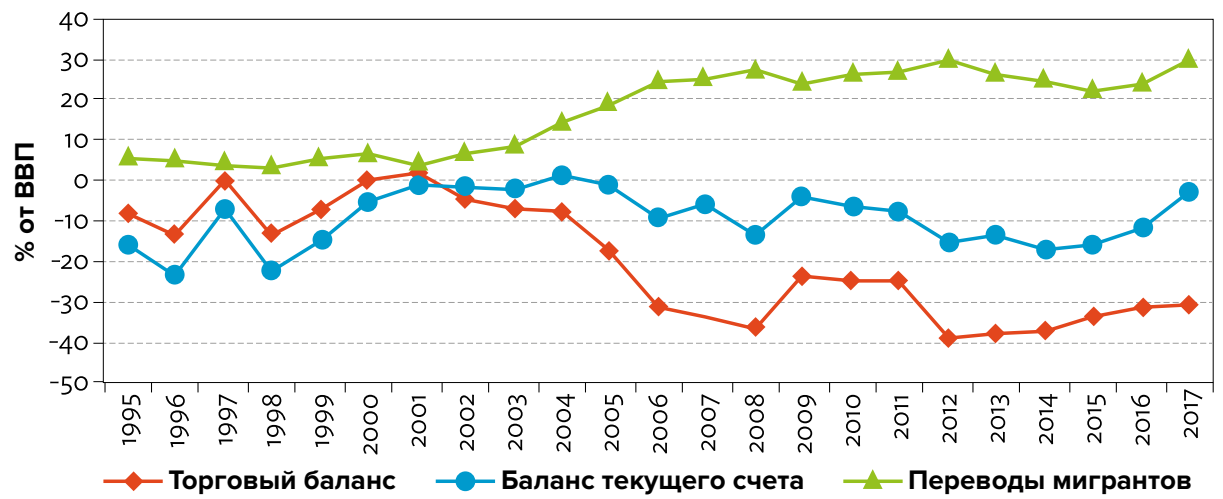

ВВП = валовой внутренний продукт.

Источник: Составлен на основе данных НБКР, Ежемесячные статистические бюллетени, 1995-2017 гг. (http://www.nbkr.kg/DOC/07122017/000000000048812.xls, (по состоянию на 28 мая 2018 г.)

В период с 2008 по 2016 год объем государственного долга увеличился на 80\% (с 2,084 млрд. долл. США до 3,740 млрд. долл. США), а доля частного сектора удвоилась (с 3,423 млрд. долл. США до 6,830 млрд. долл. США). Следовательно, соотношение долга к ВВП в 2016 году составило 103\% (самый высокий показатель в Центральной Азии), по сравнению с 67\% десятью годами ранее. Коэффициент обслуживания долга (погашение основной суммы и выплата процентов как процентное соотношение экспорта товаров и услуг), который составляет около $30 \%$, еще не достиг критической линии (Таблица 3.4). Это связано с тем, что коэффи- 
циент обслуживания государственного долга по-прежнему считается низким, с учетом того, что в структуре долга преобладает долгосрочный долг. Тем не менее, коэффициент обслуживания долга будет возрастать по мере того, как накопленный долг будет достигать срока выплаты, и, что более важно, потому что большая часть заемных средств до сих пор тратилась на долгосрочные проекты, с низким потенциалом генерировать доходы в иностранной валюте в краткосрочной и среднесрочной перспективе.

\section{Таблица 2.3: Платежный баланс, Кыргызская Республика, 2000-2017 гг. (млн. долл. США)}

\begin{tabular}{|c|c|c|c|c|c|c|c|c|}
\hline Статья & $\begin{array}{c}2005- \\
06^{a}\end{array}$ & $\begin{array}{c}2010- \\
11^{\mathrm{b}}\end{array}$ & 2012 & 2013 & 2014 & 2015 & 2016 & $2017^{2}$ \\
\hline Торговый баланс & -653 & $-1,379$ & $-2,577$ & $-2,780$ & $-2,808$ & $-2,241$ & $-2,137$ & $-2,347$ \\
\hline Экспорт (ФОБ) & 796 & 2,080 & 2,588 & 2,833 & 2,483 & 1,619 & 1,608 & 1,840 \\
\hline Импорт (ФОБ) & 1,449 & 3,458 & 5,165 & 5,614 & 5,290 & 3,860 & 3,744 & 4,187 \\
\hline Баланс услуг & -57 & -152 & -336 & -51 & -331 & -188 & -204 & -28 \\
\hline Текущие переводы & 628 & 1,615 & 2,061 & 2,238 & 2,176 & 1,628 & 1,904 & 2,366 \\
\hline Баланс текущего счета & -149 & -398 & $-1,020$ & $-1,016$ & $-1,269$ & $-1,059$ & -792 & -232 \\
\hline Остаток на счете капитала & 145 & 758 & 872 & 1,013 & 618 & 805 & 717 & 155 \\
\hline Прямые иностранные инвестиции (нетто) & -86 & 687 & 240 & 608 & -565 & 359 & 135 & -280 \\
\hline Кредиты правительству (нетто) & 38 & 173 & 285 & 178 & 443 & 261 & 257 & 229 \\
\hline Кредиты частному сектору (нетто) & 8 & 65 & 68 & 14 & 257 & -28 & -145 & -19 \\
\hline Другие обязательства & 75 & 75 & -53 & 110 & 71 & 1 & 57 & 1 \\
\hline Ошибки и упущения & 111 & -242 & 333 & 104 & 414 & 212 & 413 & 224 \\
\hline Общий баланс & 107 & 118 & 184 & 101 & -238 & -41 & 339 & 147 \\
\hline Финансирование & -107 & -118 & -184 & -101 & 238 & 41 & -339 & -147 \\
\hline Резервы НБКР ("-" рост) & -125 & -108 & -166 & -91 & 257 & 56 & -326 & -141 \\
\hline Кредиты МВФ & -18 & -24 & -21 & -17 & -20 & -15 & -13 & -13 \\
\hline Исключительное финансирование & 37 & 14 & 3 & 7 & 2 & 0 & 0 & 6 \\
\hline Другое & -1 & -25 & -21 & -17 & -20 & 0 & 0 & 0 \\
\hline \multicolumn{9}{|l|}{ Для справки } \\
\hline Валютные резервы (млн. долл. США) & 715 & 1,777 & 2,067 & 2,238 & 1,958 & 1,778 & 1,969 & 2,176 \\
\hline $\begin{array}{l}\text { Импорт-месячная эквивалентность } \\
\text { резервов }\end{array}$ & 8 & 4 & 4 & 4 & 4 & 4 & 4 & $4^{*}$ \\
\hline Обменный курс (средний годовой) (\$/сом) & 40.6 & 46.1 & 47.0 & 48.4 & 53.7 & 64.5 & 69.9 & 68.9 \\
\hline
\end{tabular}

ФОБ = франко борт, МВФ = Международный валютный фонд, НБКР = Национальный банк Кыргызской Республики.

а Среднее за два года.

ь Условно.

Источник: Составлено на основе данных НБКР, Ежемесячные статистические бюллетени, 20082017 гг., http://www.nbkr.kg/index1.jsp?item=137\&lang=ENG (по состоянию на 17 мая 2018 г.)

Стандартная мера адекватности резервов - эквивалент резервов на конец года в месяцах импорта - оставалась выше «критического» уровня в 3 месяца за последние пять лет. В эпоху Бреттон-Вудского соглашения, учитывая сочетание фиксированного обменного курса и обязательного контроля потоков капитала, худшая ситуация, которая может возникнуть в отношении управления платежным балансом, заключалась в том, что страна может потерять доступ к торговому 
кредиту (погашение которого обычно наступает через три месяца). Однако данная мера адекватности резервов на основе импорта не является надлежащим критерием для измерения адекватности резервов страны с фактически открытым счетом операций с капиталом и риском со стороны внешнего долга, который значительно возрос за последние годы. (Атукорала и Варр, 2002 г.).

\section{Таблица 2.4: Внешний долг и обслуживание долга, Кыргызская Республика, 2008-2017 гг.}

\begin{tabular}{|c|c|c|c|c|c|c|c|c|c|c|}
\hline & 2008 & 2009 & 2010 & 2011 & 2012 & 2013 & 2014 & 2015 & 2016 & $2017^{b}$ \\
\hline $\begin{array}{l}\text { Общий внешний долг } \\
\text { (млн. долл. США) }\end{array}$ & 3,423 & 3,947 & $4,209.4$ & 4,731 & 5,229 & 5,930 & 6,371 & 6,670 & 6,830 & 7,026 \\
\hline В процентах от ВВП & 66.6 & 84.6 & 90.0 & 80.5 & 81.0 & 83.4 & 94.4 & 119.5 & 103.2 & 92.8 \\
\hline $\begin{array}{l}\text { Коэффиициент об- } \\
\text { служивания долга }\end{array}$ & 25.8 & 44.1 & 24.5 & 10.7 & 16.8 & 20.3 & 26.9 & 42.2 & 32.1 & 34.0 \\
\hline $\begin{array}{l}\text { Общий государствен- } \\
\text { ный внешний долг }\end{array}$ & 2,084 & 2,503 & 2,616 & 2,803 & 3,032 & 3,159 & 3,437 & 3,601 & 3,743 & 4,081 \\
\hline В процентах от ВВП & 40.6 & 53.7 & 55.9 & 47.7 & 47.0 & 44.4 & 50.9 & 64.5 & 56.6 & 53.9 \\
\hline $\begin{array}{l}\text { Коэффиициент об- } \\
\text { служивания долга }\end{array}$ & 2.8 & 3.6 & 3.8 & 3.0 & 2.7 & 2.4 & 3.4 & 5.3 & 5.9 & 5.4 \\
\hline $\begin{array}{l}\text { Доля государствен- } \\
\text { ного долга от общего } \\
\text { внешнего долга (\%) }\end{array}$ & 60.9 & 63.4 & 62.1 & 59.2 & 58.0 & 53.3 & 54.0 & 54.0 & 54.8 & 58.1 \\
\hline
\end{tabular}

ВВП - валовой внутренний продукт

а Выплата долга и процентные платежи в процентах от экспорта товаров и услуг

ь Условно.

Источник: Составлено на основе данных НБКР. http://www.nbkr.kg/index1.jsp?item=137\&lang=ENG (по состоянию на 17 мая 2018 года)

\section{4. Структура торговли}

\section{Первоначальные условия}

В Советский период Кыргызская Республика была в основном поставщиком сырьевых товаров, в основном хлопка и некоторых стратегических полезных ископаемых (урана и ртути). Тяжелая промышленность республики в основном ограничивалась производством сельскохозяйственной техники, предназначенной для пересеченной местности Киргизии и соседних республик, а также некоторой военной техники и запасных и комплектующих частей к ней. В пищевой промышленности насчитывалось несколько крупных сахарных заводов, а также мясоперерабатывающие и консервные предприятия. Особое внимание уделялось первичной переработке хлопка и других волокон. Прочее производство включало текстиль и одежду, а также изделия из кожи. Торговля осуществлялась по искусственно устанавливаемым ценам, с существенным занижением стоимости электроэнергии и других сырьевых товаров по сравнению с промышленными товарами. Поэтому Киргизия часто сталкивалась с хроническим дефицитом торгового баланса по сравнению с остальными республиками Советского Союза, который покрывался за счет трансфертов из центрального бюджета. Прямых связей с мировой экономикой не было, поскольку вся международная торговля проходила через центральные торговые офисы в Москве (Кауффман и Хардт, 1993 г., Румер, 1989 г.). 


\section{Производительность экспорта}

Яркой особенностью структуры экспорта Кыргызской Республики за последние два десятилетия является роль немонетарного золота как единственного наиболее важного экспортного продукта (Рисунок 2.4). Доля золота от общего объема экспорта товаров в среднем составляла около 30\% в период между 2000-2017 годами, с резкими колебаниями в виду волатильности мировых цен и нарушением внутреннего производства. На долю золота, производимого золотодобывающим предприятием «Кумтор», приходится почти 98 процентов общего объема экспорта золота, Кумтор, несомненно, является единственным самым важным предприятием в стране, чей вклад в ВВП составляет около 10\%, а доля в государственных доходах составляет 20\% (Вставка 2.2).

Рисунок 2.4: Золото от общего объема экспорта товаров, 2000-2016 гг. ${ }^{\text {a }}$ (млн. долл. США и \%)

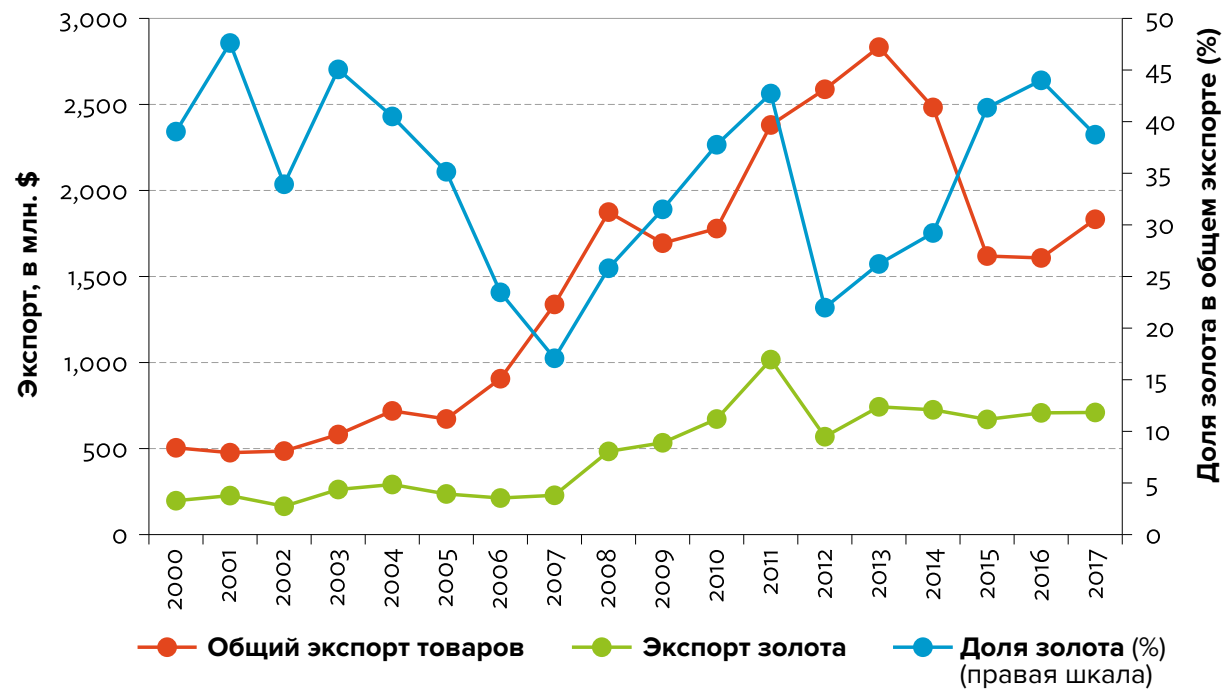

Примечание: Данные за 2017 год - предварительные.

Источник: Составлено на основе данных НБКР.

(http://www.nbkr.kg/DOC/07122017/000000000048812.xls, (по состоянию на 28 мая 2018 г)

Почти всё добытое золото в стране перевозится воздушным транспортом. Горная промышленность Кыргызской Республики также добывает цветные металлы (сурьма, ртуть и редкоземельные металлы) в небольших объемах. Страна имеет неиспользованные месторождения золота, олова, вольфрама, угля и, возможно, нефти. При переходе к использованию этих ресурсов основное внимание в политике должно уделяться тому, насколько легко продукты могут транспортироваться на международные рынки по конкурентоспособным мировым ценам. 


\section{Вставка 2.2: Золотодобывающее предприятие «Кумтор»}

Золотодобывающее предприятие «Кумтор» расположено в горах Тянь-Шаня в Иссык-Кульской области, примерно в 350 км к юго-востоку от Бишкека и примерно в 60 км к северу от международной границы с Китайской Народной Республикой и является одним из крупнейших в мире золотодобывающих предприятий. В 1978 году золоторудные месторождения были обнаружены в Кумторе геологической экспедицией Кыргызского Государственного управления геологии, но разработка месторождения не была экономически оправданной из-за низкого уровня содержания золота в твердых породах. Правительство Кыргызстана стало искать иностранных разработчиков, а в декабре 1992 года канадская уранодобывающая компания «Саmeсо» представила технико-экономическое обоснование, основанное на технологии цианидного кучного выщелачивания, которое может выгодно перерабатывать руду, содержащую всего лишь 0,01 тройских унций на тонну; расчетные издержки производства на «Кумторе» составляли около 200 долл. США за унцию.

В 1992 году «Кыргызалтын» (государственная компания по разведке полезных ископаемых) и «Сатесо» создали совместное предприятие «Kumtor Gold Inc» (далее «Кумтор») для проведения разведки и добычи золота. «Кыргызалтыну» принадлежало две третьих «Кумтора», а остальное принадлежало и «Сатесо Canada». Компания начала коммерческое производство в 1997 году. В 2004 году совместное предприятие было передано вновь созданной компании «Centerra», прошедшей листинг на бирже в Торонто. К концу 2014 года собственность «Centerra» была следующей: «Сameco» 54\%; «Кыргызалтын» - 16\%; Европейский банк реконструкции и развития -4\%; и другие акционеры - 26\%.

В период 2016-2017 годов «Centerra» и кыргызское правительство участвовали В длительных переговорах по соглашению о разделении прибыли «Кумтора». Переговоры закончились в сентябре 2017 года с соглашением об урегулировании на 60 млн. долл. США, которое должно быть выполнено «Сатесо» к концу мая 2018 года. По соглашению «Сатесо» было разрешено вывезти замороженные средства из страны.

1 мая 2018 года лондонский «Chaarat Gold Holdings» выкупил Кумтор. Сделка включала выплату в размере 400 миллионов долларов наличными и обмен на сумму 400 миллионов долларов акциями Центерра, принадлежащих «Кыргызалтыну» за 50\% прямого предпочтительного экономического интереса в горнодобывающем предприятии. «Chaarat» станет владельцем всего собственного капитала «Кумтора» и возьмет под контроль управление и работу предприятия. Правительство, в свою очередь, будет владеть всеми привилегированными акциями «Кумтора» и иметь право на получение 50\% прибыли. Кроме того, «Chaarat» согласился инвестировать до 600 миллионов долларов в горнодобывающую промышленность страны в течение следующих пяти-семи лет. С 2017 года «Chaarat» участвует в разведке золота в долине реки Сандалаш на северо-западе Кыргызской Республики. Этот район является частью золотого пояса Тянь-Шаня, который содержит несколько крупных месторождений золота мирового класса, включая месторождение Мурунтау и месторождение Кумтор.

С 1996 года, когда «Кумтор» начал коммерческую деятельность, до 2014 года предприятие произвело 308 тонн золота. По состоянию на 31 декабря 2014 года оставшиеся оценочные запасы золотой руды составили 68,5млн. тонн, содержащих 6,1 млн. унций золота. Исходя из этих запасов полезных ископаемых, ожидается, что добыча будет продолжаться до 2023 года, после чего вскрышные работы завершатся в 2026 году. Общая чистая прибыль «Centerra» от «Кумтора» в период между 20092013 годами составила 767 миллионов долларов США. Из этой суммы 480 миллионов долларов США поступили в бюджет правительства Кыргызстана в виде налога на прибыль. Кроме того, значительную часть общей стоимости составляют заработная плата, выплаты местным подрядчикам и другие внутренние расходы. 
По состоянию на январь 2014 года «Кумтор» обеспечил 2617 рабочих мест для местных специалистов и 103 рабочих места для иностранных специалистов. В дополнение, для работы на объектах были привлечены 470 местных подрядчиков. Средняя заработная плата местных работников в 11 раз превышала среднюю заработную плату по стране. Недавно проведенные расчеты по исчислению модели общего равновесия показали, что вклад горнодобывающего предприятия в экономику страны составил 23\% от ВВП (Могилевский и др., 2015 г.). Существуют и другие нематериальные выгоды, такие как передача навыков, обеспечение доступа к рынкам капитала, способствующие формированию международного имиджа страны, которые помогают привлекать инвесторов. Конечно, существуют также негативные внешние эффекты, такие как разливы опасных материалов и загрязнение рек, и даже неблагоприятное воздействие на качество институционального развития за счет процветания кумовства и нецелевого использования средств (Тьянен и другие, 2014 г.; Кроненберг, 2014 г.).

Источники: Chaarat. Chaarat Gold Holdings. https://www.chaarat.com/project (по состоянию на 8 июня 2018 года), Кроненберг (2014 г.), Могилевский и др. (2015 г.), Помфрет (2018 г.), Тьянен и др. (2014 г.)

\section{5 Тенденции и структура экспорта продуктов, не относящихся к золоту}

Учитывая известные особенности золота как продукта, котируемого на международном рынке (высокая ценовая волатильность и локальная специфичность, определяемая ресурсным обеспечением данной страны), необходимо выделить другие продукты («помимо золота») для проведения значимого анализа эффективности экспорта. Это разделение особенно важно для понимания того, в какой степени изменился состав производства, унаследованный от советской эпохи, за период после обретения независимости.

При анализе тенденций и структуры экспорта товаров, не относящихся к золоту, важно обратить внимание на роль страны как центра реэкспортной торговли в Центральной Азии (Камински и Рабалланд, 2009 г., Каминский и Митра, 2012 г., Помфрет, 2018 г.). В 2000-х годах реэкспортная (челночная) торговля, при которой идет перемещение товаров из КНР через базары в городах Бишкек и Ош на рынки других стран региона, была важным источником расширения торговли и экономического динамизма в Кыргызской Республике. Официальные (отчетные) данные о торговле включают как внутреннюю торговлю, так и реэкспорт. Для данного анализа внутренний экспорт был приближенно отделен от отчетных данных посредством использования имеющихся косвенных данных, касающихся товарной структуры рыночной торговли. ${ }^{4}$ В Таблице 2.5 для сравнения приведены обобщенные данные суммарного экспорта и внутреннего экспорта (суммарный экспорт минус челночный экспорт). Дальнейшее обсуждение акцентирует внимание на последнем.

4 Используемая здесь дезагрегация товаров рассматривает рыночную торговлю преимущественно (если не полностью) сконцентрированную в следующих семи двузначных категориях Международной стандартной торговой классификации (SITC): офисная техника и автоматические машины для обработки данных (SITC 75); телекоммуникационные и звукозаписывающие и воспроизводящие аппараты и оборудование (SITC 76); электрические машины и приборы (SITC 77); автодорожные транспортные средства (SITC 78); другое транспортное оборудование (SITC 79); профессиональное, научное и контрольное оборудование (SITC87); фотографическая и оптическая продукция (SITC88) 
Заметные изменения в структуре экспорта за последние два десятилетия включают снижение доли экспорта электроэнергии и хлопка и увеличение доли продуктов питания и промышленных товаров. Среди продуктов питания доля сахара, который был ключевой статьей экспорта в советское время, резко снизилась 5 с заметным смещением в сторону молочных продуктов, фруктов и овощей. Среди плодоовощных фасоль стала самым динамичным экспортным продуктом. Рост производства товаров в основном обусловлен заметным расширением экспорта одежды. Сократилась доля промышленных товаров, производимых на базе ресурсов, которые доминировали в структуре экспорта в советское время.

\section{Таблица 2.5: Товарная структура экспорта, Кыргызская Республика, 1995-96, 2005-06 и 2015-16 гг. ${ }^{\text {( }}$ \%)}

\begin{tabular}{|c|c|c|c|c|}
\hline \multirow{2}{*}{ Коды SITC } & \multicolumn{2}{|c|}{ Общий экспорт } & \multicolumn{2}{|c|}{ Внутренний экспорт } \\
\hline & $1995-96^{\mathrm{a}}$ & $2015-16^{a}$ & $1995-96^{\mathrm{a}}$ & $2015-16^{a}$ \\
\hline Продукты питания, напитки и табачные изделия & 25,3 & 30,6 & 30,5 & 31,6 \\
\hline O Продукты питания и живой скот & 18,8 & 15,5 & 22,6 & 26,1 \\
\hline 1 Мясо и мясные продукты & 0,6 & 0,2 & 0,7 & 0,3 \\
\hline 2 Молочные продукты & 0,5 & 3 & 0,6 & 5 \\
\hline 4 Зерновые и злаковые продукты & 1,7 & 0,3 & 2,1 & 0,5 \\
\hline 5 Овощи и фрукты & 5,7 & 10,3 & 6,8 & 17,3 \\
\hline 5423 Фасоль & 0 & 6,6 & 0 & 11,1 \\
\hline 6 Сахар и продукты из сахара & 8,5 & 0,3 & 10,3 & 0,4 \\
\hline 1 Напитки и табачная продукция & 6,5 & 3,3 & 7,8 & 5,5 \\
\hline 111 Минеральная вода & 0 & 0,2 & 0,1 & 0,3 \\
\hline 12 Табак & 4,6 & 2,9 & 5,5 & 5 \\
\hline Первичный материал & 29 & 12,8 & 35 & 21,5 \\
\hline 2 Сырой материал кроме топлива & 15,6 & 11,6 & 18,8 & 19,6 \\
\hline 263 Хлопок & 6,5 & 2,4 & 7,8 & 4 \\
\hline $3 \begin{array}{l}\text { Минеральное топливо, смазочные материалы и } \\
\text { сопутствующие материалы }\end{array}$ & 13,3 & 1,1 & 16 & 1,9 \\
\hline 35 Электроэнергия & 12,5 & 0 & 15 & 15 \\
\hline 4 Животные и растительные масла, жиры и воск & 0,1 & 0 & 0,1 & 0 \\
\hline Переработанная продукция & 40,1 & 47,2 & 34,5 & 46,8 \\
\hline 5 Химикаты и сопутствующие товары & 13 & 3,5 & 15,7 & 5,9 \\
\hline 68 Цветные металлы & 5,4 & 0,9 & 6,5 & 1,5 \\
\hline 6 Продукты, классифицированные по материалус & 13,2 & 8,9 & 9,6 & 13,4 \\
\hline $65 \begin{array}{l}\text { Текстильная пряжа, ткани и сопутствующие } \\
\text { товары }\end{array}$ & 5,2 & 1 & 6,3 & 1,6 \\
\hline 7 Машинное и транспортное оборудование & 9,6 & 22,7 & 4,2 & 9,3 \\
\hline 71 Энергетическое оборудование & 0,5 & 2,7 & 0,7 & 4,5 \\
\hline 72 Сельскохозяйственная техника & 1,1 & 1,3 & 1,3 & 2,2 \\
\hline 73 Специальное промышленное оборудование & 0,4 & 0 & 0,5 & 0 \\
\hline 74 Общее промышленное оборудование & 1,5 & 1,5 & 1,8 & 2,6 \\
\hline $\begin{array}{l}75 \text { Офисная техника и машины по обработке } \\
\text { данных }\end{array}$ & 0 & 0,3 & & \\
\hline
\end{tabular}

5 Этого следовало ожидать, поскольку Кыргызская Республика не имеет сравнительного преимущества в производстве сахара. 


\begin{tabular}{|c|c|c|c|c|c|}
\hline 76 & $\begin{array}{l}\text { Телекоммуникационное и звукозаписывающее } \\
\text { оборудование }\end{array}$ & 0,4 & 0,1 & & \\
\hline 77 & Электрооборудование & 4 & 2,8 & & \\
\hline 78 & Дорожный транспорт & 1,5 & 7,8 & & \\
\hline 79 & Прочее транспортное оборудование & 0,1 & 6,2 & & \\
\hline 8 & Различные промышленные товары & 4,3 & 12,1 & 5 & 18,2 \\
\hline 84 & Одежда и аксессуары для одежды & 1,8 & 7,3 & 2,1 & 12,4 \\
\hline 87 & Профессиональные и научные инструменты & 0,1 & 1,3 & & \\
\hline 88 & Фотоаппараты и часы & 0,1 & 0,1 & & \\
\hline Всего & & 100 & 100 & 100 & 100 \\
\hline \$ мил & лион ${ }^{d}$ & 459,5 & 748,8 & 405,4 & 451,5 \\
\hline
\end{tabular}

Примечания:

а Среднее за два года.

b В основном обработанные полезные ископаемые (за исключением золота) и основные продукты из металла.

с За исключением цветных металлов (SITC 68).

d За исключением немонетарного золота и других «специальных» статей экспорта (SITC 9).

Источник: Составлено на основе базы данных ОOH «Comtrade» (Редакция 3 SITC).

http://comtrade.un.org (по состоянию на май 2018 г.).

\section{Электроэнергия}

Имея высокогорные ледниковые реки, Кыргызская Республика обладает значительным потенциалом для расширения производства гидроэлектроэнергии: производственные мощности оцениваются в 150 ооо гигаватт-часов (ГВт/ч). Однако экспорт электроэнергии в стране резко сократился. Несмотря на то, что 90\% внутреннего спроса на электроэнергию удовлетворяется за счет гидроэлектроэнергии, страна в настоящее время использует менее 10\% своего гидроэнергетического потенциала. В течение последнего десятилетия экспорт сократился с примерно с 8 ооо ГВт/ч в 1990 году до 2000 ГВт/ч к 2012 году (АБР, 2014 г., рисунок 45). Расширение производства электроэнергии ограничивается ежегодными межправительственными соглашениями с соседними странами, расположенными вниз по течению, в отношении контроля над водными ресурсами реки Нарын, в частности, сброса воды из Токтогульского водохранилища. Производство электроэнергии также значительно колеблется от сезона к сезону и из года в год в зависимости от погодных условий.

Производство электроэнергии также обременено устаревающей инфраструктурой, которая уже изжила свой срок службы. Средний продуктивный возраст электроэнергетической инфраструктуры оценивается в 34 года. Только три из гидроэлектростанций, на которые приходится 11\% генерирующих мощностей, находятся в эксплуатации менее 20 лет, более половины передающих подстанций старше 30 лет, и около одной пятой линий электропередачи находятся в эксплуатации на протяжении более 45 лет (АБР, 2013 г.). Обветшавшая инфраструктура и годы недостаточного технического содержания приводят к частым отключениям и потерям электричества при передаче.

\section{Хлопок}

Среди коммерческих культур, развитых в советское время, хлопок - это, пожалуй, основная сельскохозяйственная продукция, по которой Кыргызская Республика 
имеет сравнительное преимущество на международных рынках. Тюкованный хлопок (после очистки) имеет гораздо меньшую стоимость транспортировки по сравнению с большей частью сельскохозяйственной продукции. Хлопок также является регионально важной коммерческой культурой для южных районов страны, где почвенно-климатические условия схожи с таковыми в Узбекистане, основной стране, производящей хлопок в регионе.

Доля хлопка в экспорте Кыргызской Республики снизилась с 7,8\% в 20052006 годах до 4,2\% в 2015-2016 годах, когда цена на хлопок в мире была нестабильной, а объем экспорта хлопка из соседнего Узбекистана продолжал расти. Основными причинами низкой эффективности экспорта, по-видимому, являются (1) конкуренция за обрабатываемые земли под другие коммерческие культуры (в основном фрукты и овощи); и (2) невозможность модернизации обветшавших фабрик по переработке хлопка, что приводит к значительному снижению качества в процессе переработки (Могилевский и др., 2017 г.).

\section{Продукты питания}

Экспорт молочных продуктов, овощей и фруктов показал впечатляющий рост за последние два десятилетия. Доля молочных продуктов в общем экспорте увеличилась с о,6\% в 1995-1996 годах до 5,2\% в 2015-16 годах. Увеличение доли овощей и фруктов было еще более впечатляющим - с 6,3\% до 18,1\%. В рамках данной группы продуктов наиболее динамичной статьей экспорта оказались высушенные бобы (фасоль).

Возникающие тенденции в экспорте продовольствия из Кыргызской Республики соответствуют возникающим тенденциям в глобальной торговле. За последние три десятилетия наблюдался заметный сдвиг в структуре мировой торговли продуктами питания. Относительная важность «классических» пищевых продуктов (кофе, чай, сахар, какао и т. д.) резко подорвана в результате быстрого расширения торговли такими продуктами, как свежие фрукты и овощи, птица, рыба и молочные продукты, которые экспортируются как переработанные продукты питания после технологически сложной переработки ${ }^{6}$ (Атукорала и Жайасурия, 2013 г., Джонгванич и Магтибай-Рамос, 2009 г.)

Мощные силы, как со стороны спроса, так и со стороны предложения, содействовали данному структурному сдвигу. По-видимому, ключевую роль играет «интернационализация пищевых привычек» со стороны спроса: повышенная значимость импортируемых обработанных продуктов в структуре потребления в развитых странах, а также среди широких слоев населения во многих развивающихся странах. Данному явлению способствовали такие факторы, как международная миграция, революция в области коммуникаций и международный туризм. Кыргызская Республика имеет все возможности воспользоваться данным структурным сдвигом в мировой торговле продуктами питания с учетом богатой сельскохозяйственной ресурсной базы и широкой доступности рабочей силы в сельской экономике.

\footnotetext{
6 Термин «переработанные продукты питания» относится к пищевым продуктам, которые подвергаются существенной переработке в стране происхождения до экспорта и, как правило, имеют высокую стоимость и подвергаются все более жестким стандартам безопасности пищевых продуктов. Широко используемые альтернативные термины - «готовые к употреблению продукты» и «продукты с высокой стоимостью».
} 
По ряду причин, возможности экспорта переработанной пищевой продукции заслуживают особого внимания в политике развития экспорта стран, богатых сельскохозяйственными ресурсами. Во-первых, эластичность доходов и цен со стороны спроса на переработанные пищевые продукты намного выше по сравнению с большинством традиционных первичных сельскохозяйственных продуктов. Поэтому диверсификация экспортного ассортимента в данную категорию товаров может привести к более быстрому росту экспорта и принести значительные выгоды с точки зрения торговли.

Во-вторых, конечные этапы переработки пищевых продуктов являются трудоемкими, в отличие от производственных процессов других ресурсных продуктов, таких как полезные ископаемые и сельскохозяйственное сырье. Это означает, что расширение сектора перерабатываемых пищевых продуктов может оказать сильное положительное влияние на создание рабочих мест. В-третьих, с точки зрения потенциального влияния на чистый платежный баланс (чистые экспортные поступления) и увеличение национального дохода, переработанная продукция превосходит «обычные» экспортные промышленные товары. Большинство обычных промышленных товаров, экспортируемых из развивающихся стран, основаны на простой внутренней переработке импортируемых материалов. Переработанные пищевые продукты, как правило, имеют более высокое содержание внутренних производственных ресурсов, и, следовательно, большую внутреннюю добавленную стоимость. Наконец, расширение данного экспорта является мощным инструментом для обеспечения положительной связанности сельской экономики с текущим процессом экономической глобализации.

\section{Швейная продукция}

В советское время текстильная и швейная промышленность была ключевым направлением промышленного производства в Киргизии. К моменту распада СССР на текстиль и одежду приходилось 65\% легкой промышленности страны, обеспечивающей занятость для более 100 ооо человек на 14 крупных государственных предприятиях по всей стране (Ботоева и Спектор, 2013 г.).

Текстильное и швейное производство рухнуло из-за разрыва централизованно планируемых цепочек поставок после распада Советского Союза. Текстильная промышленность так и не смогла восстановиться в процессе перехода к рыночной экономике просто потому, что это капиталоемкая отрасль, которая не подходит под ресурсную базу экономики Кыргызской Республики. Но швейная промышленность, являющаяся квинтэссенцией стартовой экспортно-ориентированной индустриализации в стране с низкой заработной платой, возродилась в 2000-х годах в либерализованной экономике в качестве крупного экспортера данной продукции в стране. Доля швейной продукции в общем объеме экспортных товаров увеличилась с 2,0\% в 1995-1996 годах до 11,7\% в 2015-2016 годах (Вставка 2.3).

Экспорт одежды из Кыргызской Республики почти полностью предназначен для Казахстана и Российской Федерации. Ключевыми факторами успешного проникновения кыргызстанской одежды на эти рынки являются относительно низкая стоимость рабочей силы, способность производить изделия более высокого качества для удовлетворения предпочтений клиентов на рынках среднего уровня по сравнению с продуктами из КНР и Турции, и легкий доступ к импортированной ткани (в основном из КНР, а также из Турции) через торговые сети базары (Вставка 2.3). 
Характерной особенностью структуры экспорта кыргызской одежды является сильная концентрация в женской одежде (Рисунок 2.5). В течение 200о2016 годов на женскую одежду приходилось более 90\% от общего объема экспорта одежды, в то время как эта доля в общем экспорте одежды из развивающихся стран за тот же период (рассчитанная на основе базы данных «Comtrade» $\mathrm{OOH}$ ) составляла лишь $68 \%$.

\section{Вставка 2.3: Швейная промышленность}

Производство одежды было самым быстрорастущим сегментом промышленности в Кыргызской Республике за последние два десятилетия. Промышленность сосредоточена в Бишкеке (более 95\% от общего объема производства) и Оше. По состоянию на 2013 год насчитывалось 740 официально зарегистрированных предприятий, но согласно неофициальным источникам существует более 3000 малых и средних незарегистрированных предприятий. Крупнейшая фабрика насчитывает примерно 300 швейных машин, а средняя компания использует около 15 машин. Согласно официальным данным, общая занятость составляла 120000 человек, но по другим оценкам эта цифрра составила около 300000 человек, или 12\% общего объема рабочей силы страны (Биркман и др., 2014 г.). Ежемесячная заработная плата среднего работника швейного производства составляла от 240 до 300 долларов, а более опытного - от 340 до 500 долларов. В основном владельцами швейного бизнеса являются женщины (около 70-85\%).

Большинство фабрик берут на себя простую задачу шить одежду на основе лекал, разработанных их покупателями. Покупатели в основном выбирают популярные фасоны из КНР и Турции. Некоторые крупные фирмы берут на себя все этапы цепи производства одежды: от дизайна до производства и продажи, а некоторые из них перешли на компьютерный дизайн (Жениш, 2014 г.).

Основным конкурентом Кыргызской Республики на рынках одежды среднего класса в Казахстане и Российской Федерации является Беларусь. Самое большое преимущество, которое имеют производители одежды из Беларуси, по сравнению со своими коллегами из Кыргызстана, - это сильное внутреннее производство тканей, унаследованное с советского времени. Беларусь является четвертым по величине производителем льна в мире (Жениш, 2014 г). Пока что кыргызским производителям удается конкурировать, в основном, благодаря легкому доступу к тканям из КНР по низким ценам, благодаря либеральному торговому режиму и весовой тарифной системе для импорта через рыночную торговлю, а также способности кыргызских компаний производить одежду в соответствии с вкусовыми предпочтениями клиента. Наличие крупной кыргызской диаспоры в Казахстане и Российской Федерации также способствовало расширению рынка для одежды, производимой в Кыргызской Республике. Стоимость рабочей силы в Кыргызской Республике также значительно ниже (около 0,50 долл. США в час), по сравнению с Беларусью (1,20 долл. США), КНР (1,50 долл. США) и Турцией (2,10 долл. США).

После появления экспортно-ориентированного производства одежды как спонтанного ответа на реформы в области либерализации, правительство внедрило многоуровневую систему налогообложения. В стране существует упрощенная система налогообложения для индивидуальных предпринимателей, с количеством рабочих мест менее 30 человек. Когда количество рабочих мест превышает данный предел, компания сталкивается с более высокими налогами, более громоздкими регулирующими процедурами и издержками для дачи взяток, связанными с регулярными проверками со стороны налоговых органов (Биркман, 2014 г., Жениш, 2014 г.). Высокие затраты, связанные с соблюдением административных процедур и положений, приводят к уходу в теневой бизнес и препятствуют росту компаний. 
Базары являются очень важным узлом в сетях по производству одежды. Большинство производителей покупают текстиль и другие материалы, а также оборудование на базаре, который специализируется на факторах производства из КНР. Более 90\% продукции экспортируется через логистических посредников, занимающихся торговлей внутри региона, через базары в Бишкеке и Оше, а остаток продается «челночным» торговцам, работающим на этих базарах (Камински и Митра, 2012 г., Спектор 2018 г.). В бизнес-сообществе существует опасения, что присоединение Кыргызской Республики к Евразийскому экономическому сообществу (ЕАЭС) может существенно повысить стоимость производства одежды. Единый тариф ЕАЭС, который представляет собой налог на основе стоимости (ад валорем), будет выше, чем текущий налог по весу, применяемый к импорту товаров для реализации на базарах. Основным преимуществом налога по весу для импортера является то, что фактическая налоговая ставка отрицательно связана с качеством продукта. Более того, единая адвалорная пошлина, скорее всего, будет более систематически применяться в рамках процедуры пограничного контроля Таможенного союза.

Источники: Биркман (2012 г.), Жениш (2014 г.), Каминский и Митра (2012 г.), Спектор (2018 г.).

Рисунок 2.5: Экспорт одежды из Кыргызской Республики, 2000-2016 гг. (млн. долл. США)

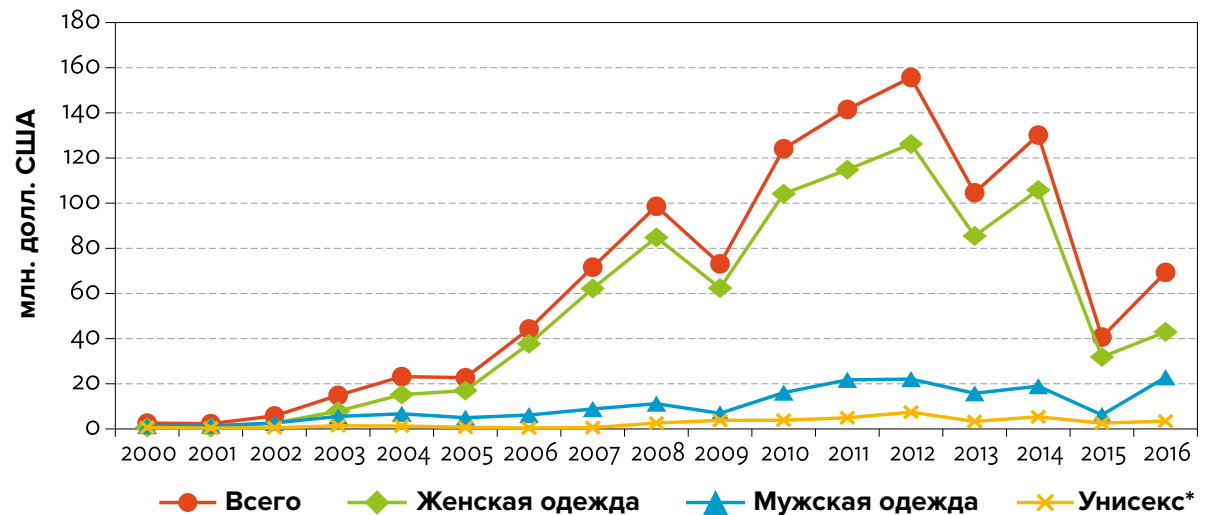

Примечание: *Детская одежда, футболки, нижнее белье, головные уборы и т. д.

Источник: Данные составлены на основе «Comtrade» $\mathrm{OOH}$.

http://comtrade.n.org (по состоянию на 8 мая 2018 года).

\section{Направление торговли}

С 1997 года, с момента начала коммерческого производства на золоторудном предприятии «Кумтор», Швейцария являлась самой далекой точкой назначения для общего экспорта кыргызских товаров. Доля Швейцарии в общем экспорте товаров варьировалась в диапазоне от 30\% до 33\% в этот период. Единственным продуктом, экспортируемым из Кыргызской Республики в Швейцарию, является золото, а на Швейцарию приходится 97\% общего объема экспорта золота из страны. Таким образом, данные, исключающие экспорт в Швейцарию, представляют собой географический профиль экспорта товаров, помимо золота, из Кыргызской Республики. Это является фокусом внимания в ходе последующего обсуждения в данном разделе. 
Казахстан и Российская Федерация в указанном порядке являются двумя самыми крупными экспортными рынками. В 2016-1917 годах на эти две страны приходилось более 45\% экспорта из Кыргызской Республики.7 Между Кыргызской Республикой и двумя другими странами-членами ЕАЭС (Беларусь и Армения) нет заметных торговых связей. Доля экспорта в страны СНГ снизилась с 9о\% в начале 1990-х годов до примерно 60\% в начале 2000-х годов и оставалась примерно на том же уровне в последующие годы (Таблица 2.6 и Рисунок 2.6). Этот сдвиг в структуре экспорта от стран СНГ согласуется со схемами поведения REER, изображенными на Рисунке 2.1. За последние пять лет REER Кыргызской Республики, по сравнению со странами СНГ, по-прежнему оставался существенно высоким в сравнении с предыдущими десятью годами или около того.

Таблица 2.6: Географическая структура экспорта товаров из Кыргызской Республики, 1993-2017 годы (выборочные годы) (\%)а

\begin{tabular}{|c|c|c|c|c|}
\hline Страна & 1993-1994 & 2000-2001 & 2010-2011 & 2016-2017 \\
\hline Страны СНГ & 88.6 & 59.6 & 65.9 & 60.6 \\
\hline Беларусь & 1.3 & 0.7 & 0.5 & 0.5 \\
\hline Казахстан & 25.9 & 27.6 & 32.5 & 24.8 \\
\hline Российская Федерация & 25.4 & 13.7 & 22.9 & 20.1 \\
\hline Таджикистан & 1.3 & 1.5 & 1.9 & 2.1 \\
\hline Туркменистан & 2.4 & 0.5 & 0.5 & 0.5 \\
\hline Украина & 3.5 & 0.4 & 0.4 & 0.3 \\
\hline Узбекистан & 10.1 & 14.5 & 6.3 & 12.2 \\
\hline Другие & 18.6 & 0.8 & 0.9 & 0.1 \\
\hline Другие страны (не входящие в СНГ) & 11.4 & 40.4 & 34.1 & 39.4 \\
\hline Афганистан & 0.1 & 1.1 & 1.2 & 0.5 \\
\hline Канада & 0.5 & 2.2 & 0.6 & 0.1 \\
\hline KHP & 0 & 0.2 & 2.6 & 8 \\
\hline Германия & 0.2 & 0.6 & 0.6 & 0.5 \\
\hline Иран & 7.2 & 6.7 & 0.6 & 0.9 \\
\hline Турция & 0 & 1.6 & 3.4 & 10 \\
\hline OAЭ & 0.1 & 16.7 & 16.5 & 3.1 \\
\hline США & 0.6 & 0.1 & 3.3 & 0.1 \\
\hline Другие & 2.7 & 10.1 & 9.3 & 15.1 \\
\hline Общая доля & 100 & 100 & 100 & 100 \\
\hline Сумма (\$ миллионов) & 315 & 474 & 1,368 & 1,110 \\
\hline
\end{tabular}

КНР = Китайская Народная Республика, СНГ = Содружество Независимых Государств, ОАЭ = Объединенные Арабские Эмираты, США = Соединенные Штаты Америки.

Источник: НБКР, http://www.nbkr.kg/index1.jsp?item=138\&lang=ENG (по состоянию на 18 мая 2018г.)

\footnotetext{
Часть экспорта в Казахстан может быть перевалкой на более крупный российский рынок.
} 


\section{Рисунок 2.6. Торговые отношения Кыргызстана с Евразийским экономическим союзом и Китайской Народной Республикой, 2000-2017 гг. (млн. долл. США)}

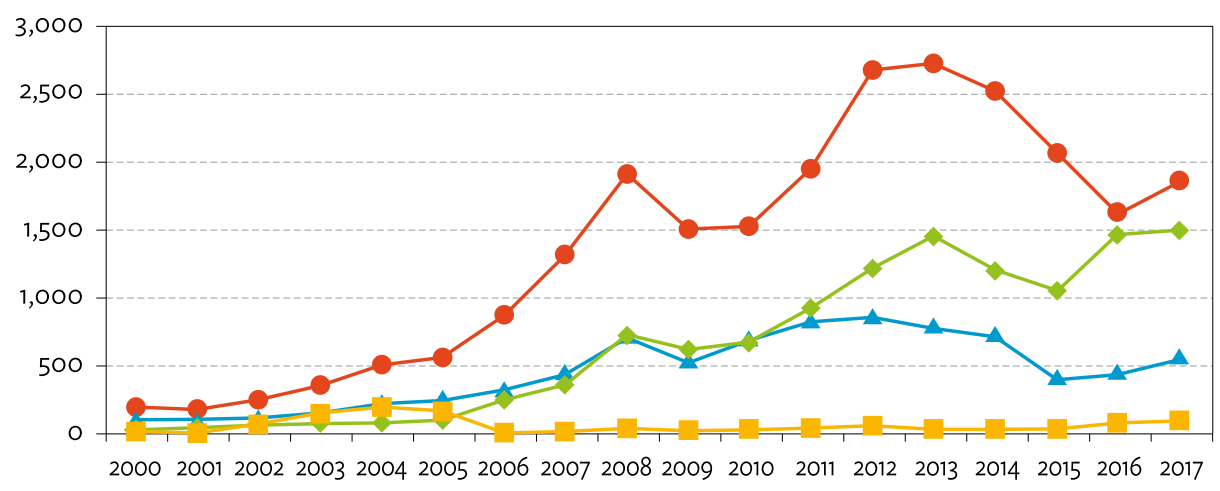

- - Импорт из ЕАЭС - - Экспорт в ЕАЭС - Импорт из КНР - Экспорт в КНР

ЕАЭС = Евразийский экономический союз, КНР = Китайская Народная Республика.

Источник: Составлено на основе данных НБКР

http://www.nbkr.kg/DOC/07122017/000000000048812.xls (по состоянию на 28 мая 2018 года).

Доля импорта из стран СНГ сокращалась более быстрыми темпами: с 93\% в 1993-94 годах до 45,1\% в 2016-17 годах (Таблица 2.7). К 2017 году КНР стала крупнейшей страной-источником импорта (35\%), превзойдя бывшего торгового партнера - Российскую Федерацию (26,3\%). На долю КНР в настоящее время приходится почти две трети импорта Кыргызстана за пределами региона. В последние годы экспорт в КНР также увеличился, но по-прежнему составляет лишь $10 \%$ от общего объема экспорта. Турция является единственной страной, не входящей в СНГ, с которой кыргызские торговые связи увеличились в середине 1990 годов. В 2016-2017 годах на Турцию приходилось 10\% и 4,9\% от кыргызского экспорта и импорта, соответственно.

Важным изменением в структуре торговли Кыргызской Республики с 2005 года является увеличение дефицита торгового баланса с КНР, превысившее дефицит со странами ЕАЭС. В 2005-2006 годах дефицит Кыргызской Республики с ЕАЭС был примерно в пять раз выше дефицита с КНР (431 и 84 млн. долларов США соответственно). К 2016-2017 гг. картина изменилась с дефицитом в 2,8 млрд. долл. США с КНР по сравнению с дефицитом в 2,5 млрд. долл. США со странами ЕАЭС.

Таблица 2.7: Географическая структура импорта товаров

\begin{tabular}{lccc} 
Страна & $1993-2004$ & $2010-2011$ & $2016-2017$ \\
\hline Страны СНГ & 93,0 & 52,0 & $\mathbf{4 5 , 1}$ \\
\hline $\begin{array}{l}\text { Беларусь } \\
\text { Казахстан }\end{array}$ & 0,8 & 2,2 & 1,5 \\
\hline Российская Федерация & 20,7 & 10,6 & 13,2 \\
\hline Украина & 30,3 & 33,6 & 26,3 \\
\hline Узбекистан & 1,4 & 2,8 & 0,9 \\
\hline
\end{tabular}




\begin{tabular}{lccc} 
Страна & $1993-2004$ & $2010-2011$ & $2016-2017$ \\
\hline Другие страны СНГ & 17,2 & 2,4 & 2,7 \\
\hline Другие страны (не входящие в СНГ) & 7,0 & 48,0 & 54,9 \\
\hline Канада & 0,2 & 0,6 & 0,2 \\
\hline КНР & 0,8 & 21,2 & 35,0 \\
\hline Германия & 0,8 & 3,1 & 1,5 \\
\hline Иран & 0,9 & 0,2 & 0,2 \\
\hline Япония & 0,4 & 3,4 & 0,6 \\
\hline Корейская республика & 0,5 & 1,5 & 0,9 \\
\hline Нидерланды & 0,1 & 0,9 & 0,3 \\
\hline Швейцария & 0,1 & 0,4 & 0,4 \\
\hline Турция & 1,5 & 2,7 & 4,9 \\
\hline ОАЭ & 0,0 & 0,2 & 0,1 \\
\hline Великобритания & 0,1 & 0,5 & 0,3 \\
\hline США & 0,1 & 5,4 & 3,6 \\
\hline Другие страны, не входящие в СНГ & 1,6 & 8,0 & 6,3 \\
\hline Общая доля & 100 & 100 & 100 \\
\hline Сумма (\$ миллионов) & 358 & 3742 & 42 \\
\hline
\end{tabular}

КНР = Китайская Народная Республика, СНГ = Содружество Независимых Государств, НБКР = Национальный банк Кыргызской Республики, ОАЭ = Объединенные Арабские Эмираты, США = Соединенные Штаты Америки.

Источник: НБКР.

http://www.nbkr.kg/index1.jsp?item=138\&lang=ENG (по состоянию на 18 мая 2018 года).

Каким будет влияние от вступления страны в ЕАЭС для кыргызско-китайских торговых отношений? Это вопрос требует дальнейшего изучения, но авторы считают, что незначительное увеличение пограничного тарифа, связанное с переходом к единым адвалорным тарифам, в сочетании с предполагаемым более строгим пограничным контролем, вряд ли окажет серьезное влияние. Это связано с тем, что взаимодополняемость торговых отношений страны, которая преимущественно производит сырьевые товары, намного сильнее с КНР, которая сейчас является мировым производственным центром, чем с Казахстаном и Российской Федерацией. Кроме того, Кыргызская Республика имеет потенциал для расширения экспорта переработанных пищевых продуктов и различных сырьевых материалов, на которые в КНР существует большой спрос. Это в значительной степени зависит от реформ со стороны поставок, чтобы использовать скрытое сравнительное преимущество страны в линейках продуктов и в свете улучшенных торговых отношений с КНР.

Данные по направлениям торговли по товарным группам, имеющиеся в последних выпусках «Платежного баланса» Национального банка Кыргызской Республики, помогают понять влияние «тирании дистанции» (торговые издержки, связанные с расстоянием) на модели торговли. Согласно этим данным (не приведены здесь из-за экономии места), два наиболее важных продукта, экспортируемые на отдаленные рынки, помимо золота, - это хлопок и фасоль, а Турция является основным рынком для сбыта хлопка, не входящим в состав СНГ. Они являются продуктами с «высокой стоимостью за единицу веса», которые также 
не портятся в течение длительного времени транспортировки. Напротив, почти весь экспорт кыргызского продовольствия приходится на региональные рынки, преимущественно в Казахстан и Российскую Федерацию. Некоторые из этих продуктов могут соответствовать критериям «высокой стоимости за единицу веса», но они быстрее портятся и сталкиваются с отсутствием надежной наземной транспортной инфраструктуры с современным охлаждающим оборудованием и/или воздушного транспорта для доставки этих продуктов на отдаленные рынки.

\section{6 Прямые иностранные инвестиции}

В течение первого десятилетия независимости ежегодные ПИИ в Кыргызской Республике имели тенденцию роста: с 10 млн. долл. США в 1993 году до 109 млн. долл. США в 1999 году (Рисунок 2.7 и Таблица 2.8). Эта тенденция была серьезно нарушена политической нестабильностью в начале 200о-х годов: среднегодовой уровень ПИИ упал до всего лишь 5 млн. долл. США в период 2000-2002 годов. Последующие годы показывают значительный рост, хотя и с высокими колебаниями на протяжении года. Общий объем ПИИ в 2010-2016 годах составил 558 млн. долл. США, по сравнению с 174 млн. долл. США за предыдущие семь лет. Доля ПИИ в общем валовом внутреннем капитале увеличилась с 25\% до 28\% в течение этих двух периодов. Объем притоков ПИИ в Кыргызскую Республику был намного меньше по сравнению с соседними богатыми ресурсами странами Центральной Азии - Казахстаном и Туркменистаном, но в целом сопоставим с Таджикистаном и Узбекистаном (Таблица 2.8).

\section{Рисунок 2.7: Прямые иностранные инвестиции в Кыргызской Республике, 1993-2016 гг.}

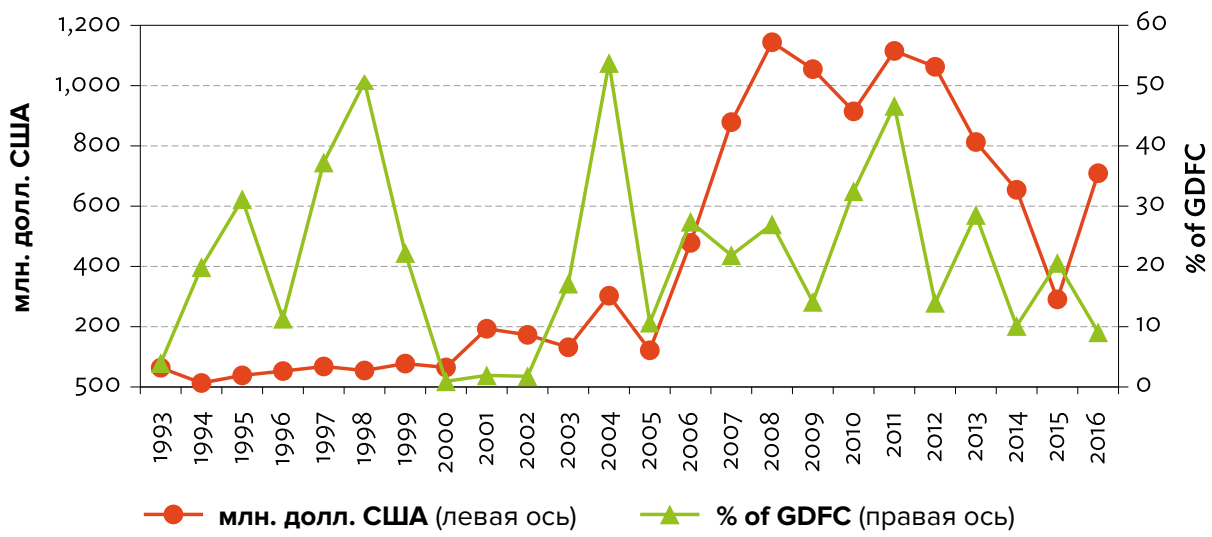

ПИИ = Прямые иностранные инвестиции, GDFC = валовое внутреннее накопление основного капитала а2000 год опущен. В этом году ПИИ составили -2,4 млн. долл. США, а коэффициент ПИИ-GDFC -0,94.

Источник: UNCTAD, база данных Доклада о мировых инвестициях (http://www.unctad.ord, (по состоянию на 15 марта 2018 г.) 
Таблица 2.8: ПИИ в странах Центральной Азии, (млн. долл. США)

\begin{tabular}{|cccccc} 
Годы & Казахстан & $\begin{array}{c}\text { Кыргызская } \\
\text { Республика }\end{array}$ & \multicolumn{2}{c}{$\begin{array}{c}\text { Таджикистан } \\
\text { Туркменистан }\end{array}$} & Узбекистан \\
\hline $1993-99$ & 1,136 & 61 & 15 & 117 & 88 \\
\hline $2000-04$ & 2,591 & 46 & 75 & 231 & 97 \\
\hline $2005-09$ & 9,387 & 200 & 310 & 1,567 & 525 \\
\hline 2010 & 11,551 & 438 & 155 & 3,632 & 1,636 \\
\hline 2011 & 13,973 & 694 & 227 & 3,391 & 1,635 \\
\hline 2012 & 13,337 & 293 & 262 & 3,130 & 563 \\
\hline 2013 & 10,321 & 626 & 168 & 3,528 & 629 \\
\hline 2014 & 8,406 & 248 & 408 & 3,830 & 632 \\
\hline 2015 & 4,012 & 1,142 & 545 & 4,398 & 65 \\
\hline 2016 & 9,069 & 467 & 434 & 4,522 & 67 \\
\hline
\end{tabular}

Источник: UNCTAD, база данных Доклада о мировых инвестициях (http://www.unctad.ord, по состоянию на 15 марта 2018 г.)

ПИИ в Кыргызской Республике демонстрируют сильную региональную концентрацию. В 2016 и 2017 годах 84,4\% от общего объема ПИИ приходилось на северные регионы. На Бишкек как столицу и Чуйскую область взятые вместе приходилось 67,5\% от общего объема ПИИ. Из доли южного региона (15,6\%), 13,2\% приходилось на Джалал-Абадскую область, при этом на южную столицу (г. Ош) приходилось всего о,4\% (Таблица 2.9).

\section{Таблица 2.9: Региональное распределение прямых иностранных инвестиций в Кыргызской Республике, 2016-2017 гг.}

\begin{tabular}{cc} 
Область/город & Доля (\%) \\
\hline Баткенская область & 1.0 \\
\hline Джалал-Абадская область & 13.2 \\
\hline Иссык-Кульская область & 16.8 \\
\hline Нарынская область & 0.1 \\
\hline Ошская область & 0.4 \\
\hline Таласская область & 0.9 \\
\hline Чуйская область & 26.6 \\
\hline Бишкекская область & 40.9 \\
\hline Всего & 100.0 \\
\hline Сумма (млн. долл. США) & 1404.1 \\
\hline
\end{tabular}

Источник: данные, предоставленные отделом иностранных инвестиций, Министерство экономики, Кыргызская Республика.

ПИИ в значительной степени сконцентрированы в производственном секторе (включая переработку полезных ископаемых), а также в финансовом секторе и секторе страхования (Таблица 2.10). Невозможно систематически оценить рыночную ориентацию ПИИ в производственном секторе, хотя они вносят вклад как в расширение экспорта, так и в удовлетворение внутреннего спроса. Из пяти СЭЗ 
Кыргызстана до настоящего времени только СЭЗ «Бишкек» успешно привлекала ПИИ. СЭЗ «Бишкек» была открыта для инвесторов в июле 1995 года. Она расположена в Чуйской области на нескольких участках общей площадью 346,09 гектаров (га): в Национальном выставочном центре в Бишкеке (43 га), поселке Ак-Чий в Аламудунском районе Чуйской области в 10 км к северу от Бишкека (204,09 га) и городе Кара-Балте Жайылского района Чуйской области (100 га). В настоящее время в трех местах действуют 120 компаний, в которых работают около 3000 человек. Большинство фирм в СЭЗ, за исключением фабрики среднего размера по производству одежды и фирмы, перерабатывающей полезные ископаемые для экспорта в КНР, занимаются производством потребительских товаров длительного пользования, безалкогольных напитков, кондитерских изделий и строительных материалов для внутреннего рынка. Органы власти Кыргызстана ожидают, что присоединение к ЕАЭС поможет привлечь инвесторов для развития производства специально для экспорта в другие страны-члены ЕАЭС.

\section{Таблица 2.10: Утвержденные прямые иностранные инвестиции по видам экономической деятельности, Кыргызская Республика, 2002-2017 гг. (\%)}

\begin{tabular}{|c|c|c|c|c|c|c|c|}
\hline Сектор & $\begin{array}{l}2004- \\
2005\end{array}$ & $\begin{array}{l}2010- \\
2011\end{array}$ & 2012 & 2013 & 2014 & 2015 & 2016 \\
\hline $\begin{array}{l}\text { Сельское хозяйство, лесное } \\
\text { хозяйство и рыболовство }\end{array}$ & -1.1 & 0.0 & 0.6 & 0.0 & 0.0 & 0.0 & 0.0 \\
\hline Добыча & 34.6 & 2.3 & 8.6 & 1.6 & -0.4 & 1.2 & 4.3 \\
\hline Производство а & 13.8 & 60.6 & 16.6 & 33.2 & 21.2 & 41.9 & 27.4 \\
\hline Электричество, газ и вода & 1.6 & 0.0 & 0.0 & 2.1 & 0.0 & 11.1 & 19.6 \\
\hline Строительство & 0.9 & -0.9 & 0.6 & -1.2 & 0.9 & 5.2 & 3.6 \\
\hline $\begin{array}{l}\text { Торговля и ремонт транспортных } \\
\text { средств }\end{array}$ & -10.5 & 4.2 & 4.1 & 2.3 & 4.1 & 2.8 & -2.8 \\
\hline Транспорт и связь & 4.2 & 0.9 & 0.4 & 0.4 & -0.4 & -0.2 & 0.0 \\
\hline Гостиницы и рестораны & 2.3 & -0.1 & 0.5 & 0.1 & 0.9 & 0.4 & 0.1 \\
\hline Финансы и страхование & 38.9 & 5.7 & 14.1 & 9.9 & 35.5 & 25.2 & 28.1 \\
\hline Операции с недвижимостью & 9.1 & 27.2 & 54.3 & 51.0 & 0.7 & 0.2 & 0.0 \\
\hline $\begin{array}{l}\text { Образование и профессиональ- } \\
\text { ная деятельность }\end{array}$ & 1.1 & 0.0 & 0.0 & 0.7 & 25.9 & 12.2 & 19.5 \\
\hline Всего & 100 & 100 & 100 & 100 & 100 & 100 & 100 \\
\hline Сумма (млн. долл. США & 46 & 566 & 293 & 758 & 348 & 1142 & 616 \\
\hline
\end{tabular}

а Включая переработку золота и других полезных ископаемых.

Источник: Составлено на основе данных НБКР.

(http://www.nbkr.kg/DOC/07122017/000000000048812.xls, (по состоянию на 28 мая 2018 г.).

В 1990-х годах и в первом десятилетии 2000-х годов более 90\% от общего объема ПИИ в Кыргызской Республике поступало из стран дальнего зарубежья (Таблица 2.11). С тех пор эта доля снизилась с увеличением инвестиций со стороны стран СНГ, что обусловлено преимущественно увеличением инвестиций российских компаний. В течение 2012 и 2015 годов доля стран СНГ увеличилась с 10,9\% до 44,9\%, при этом на долю Российской Федерации приходится 98\% прироста. Среди стран дальнего зарубежья, в качестве основных стран-источников выделяются Канада, КНР и Великобритания. ПИИ КНР работают как в горнодо- 
бывающей, так и в обрабатывающей промышленности. Инвестиции из Канады и Великобритании поступают исключительно в золотодобывающую отрасль. Как обсуждалось ранее, совместное предприятие «Сатесо» с участием государственной горнодобывающей компанией «Кыргызалтын» до недавнего времени было крупнейшим иностранным инвестором в стране. За последние два года британская золотодобывающая компания «Chaarat» участвовала в разведке золота в золотом поясе Тянь-Шаня. В 2018 году, после покупки золотодобывающего предприятия «Кумтор» у «Сатесо», она стала крупнейшим иностранным инвестором в Кыргызской Республике (Вставка 2.2).

Таблица 2.11: Источники прямых инвестиций в Кыргызской Республике

\begin{tabular}{|c|c|c|c|c|c|c|c|c|}
\hline Страна & $\begin{array}{c}1996- \\
97\end{array}$ & $\begin{array}{c}2000- \\
01\end{array}$ & $\begin{array}{c}2010- \\
11\end{array}$ & 2012 & 2013 & 2014 & 2015 & 2016 \\
\hline Страны СНГ & 3.1 & 41.7 & 6.7 & 10.9 & 10.7 & 42.6 & 44.9 & 45.4 \\
\hline Беларусь & 0.0 & 0.0 & 0.0 & -0.2 & 0.3 & -0.5 & 1.5 & -2.9 \\
\hline Казахстан & 1.3 & 7.2 & 1.9 & 4.9 & -0.3 & 3.5 & 0.5 & 2.6 \\
\hline Российская Федерация & 1.5 & 30.3 & 4.8 & 6.2 & 10.7 & 39.6 & 42.9 & 45.6 \\
\hline Страны дальнего зарубежья & 96.9 & 58.3 & 93.3 & 89.1 & 89.3 & 57.4 & 55.1 & 54.6 \\
\hline Австралия & 0.0 & 79.0 & 2.4 & 2.7 & 0.5 & -0.9 & 0.1 & 0.6 \\
\hline Канада & 37.7 & 19.6 & 57.2 & 3.4 & 0.8 & 34.7 & 11.4 & 16.7 \\
\hline KHP & 0.5 & 25.9 & 14.9 & 23.3 & 60.3 & 13.2 & 31.6 & 28.4 \\
\hline Кипр & 0.4 & 1.8 & 0.1 & 0.3 & 4.1 & 4.1 & 2.3 & 2.0 \\
\hline Германия & 3.8 & -18.4 & -0.3 & 4.5 & 0.0 & -0.1 & 0.4 & -0.1 \\
\hline Япония & 0.5 & 0.0 & 0.0 & 0.0 & 0.0 & 0.0 & 0.0 & 0.0 \\
\hline Республика Корея & 0.2 & 13.2 & 1.5 & -0.3 & 2.1 & 0.0 & 0.0 & 0.0 \\
\hline Нидерланды & 0.3 & 1.6 & 0.0 & 3.8 & 1.5 & 1.9 & 1.2 & 1.5 \\
\hline Пакистан & 0.0 & -5.0 & 1.0 & 1.5 & 0.9 & 1.1 & 0.1 & 0.4 \\
\hline Швейцария & 3.9 & -1.8 & 2.4 & 7.1 & 1.8 & -12.1 & 0.4 & 0.4 \\
\hline Турция & 20.2 & 43.3 & -0.9 & 3.0 & -0.2 & 3.2 & 6.3 & 4.2 \\
\hline ОАЭ & 0.0 & -6.6 & 0.5 & 0.6 & 0.4 & 0.1 & -0.1 & 0.3 \\
\hline Великобритания & 8.1 & -7.4 & 7.1 & 23.2 & 12.9 & 15.3 & 0.8 & 0.0 \\
\hline США & 7.8 & -6.6 & 0.7 & 1.7 & 0.4 & 1.6 & 0.8 & 0.4 \\
\hline Всего & 100 & 100 & 100 & 100 & 100 & 100 & 100 & 100 \\
\hline
\end{tabular}

КНР = Китайская Народная Республика, СНГ = Содружество Независимых Государств, ОАЭ = Объединенные Арабские Эмираты, США = Соединенные Штаты Америки

Источник: Составлено на основе данных НБКР,

(http://www.nbkr.kg/DOC/07122017/000000000048812.xls, (по состоянию на 28 мая 2018 г.)

После выхода Российской Федерации из кыргызского гидроэнергетического сектора, похоже, что роль главного инвестора будет играть Государственная энергетическая инвестиционная корпорация КНР. В 2013 году Бишкек согласился стать частью линии D газопровода Центральная Азия - КНР, проходящего через Кыргызстан, Таджикистан и Узбекистан. Ожидается, что в страну будут поступать ежегодные транзитные пошлины в размере 40 миллионов долларов США. Китайские фирмы также участвуют в производстве потребительских товаров для внутреннего кыргызского рынка и в разведке золотых месторождений. Есть ран- 
ние признаки создания производственных баз КНР в Кыргызской Республике для производства на рынки ЕАЭС, но официальные данные о ПИИ в сектор сельского хозяйства и переработку сельскохозяйственной продукции пока отсутствуют. ${ }^{8}$

\section{7. Трудовая миграция и денежные переводы}

Международная миграция оказывала ключевое влияние на кыргызскую экономику со времени обретения независимости. Первая эмиграция приняла форму постоянного оттока этнических русских и других групп европейского происхождения. Это сопровождалось увеличением трудовой миграции. Последняя включает в себя все большее число этнических кыргызов и узбеков - двух групп, которые в советское время имели очень низкие темпы миграции (Агаджанян и Корина, 2018 г., Шмидт и Сагынбекова, 2008 г.). Число кыргызских работников, мигрирующих на заработки, быстро возрастало, поскольку нефтяной бум подпитывал спрос на рабочую силу в Российской Федерации и, в меньшей степени, в Казахстане. Два других направления - это Турция и Объединенные Арабские Эмираты в указанном порядке.

Количество рабочих-мигрантов из Кыргызстана в 2013 году составило 738 300 человек, из которых 572678 выехали в Российскую Федерацию (Всемирный банк, 2016 г.). По некоторым оценкам это число еще выше, более одного миллиона (АБР, 2014 г.; Брук и др., 2018 г.). Все эти цифры необходимо принимать с осторожностью, поскольку сложность заключается в определении «трудящегося-мигранта»: многие работники приезжают домой по несколько раз за время работы за границей, что приводит к двойному учету количества мигрантов, и многие работают нелегально в принимающих странах. Тем не менее, даже если брать во внимание самые низкие расчеты, цифры поразительно велики для страны с населением в 5,8 млн. где внутренняя рабочая сила составляет 2,7 млн. человек.

Структура занятости трудящихся-мигрантов за рубежом в целом схожа со структурой занятости мигрантов в других частях мира: большинство из них занимаются неквалифицированным трудом, причем даже профессионально подготовленные работники часто выполняют неквалифицированный труд (Атукорала, 2006 г., Лукас, 2005 г.). Вместе с тем существует важное различие между кыргызстанскими трудящимися-мигрантами и их коллегами в других частях мира, в частности, в Азии. Большинство азиатских трудящихся-мигрантов в основном являются «контрактными мигрантами», которые работают за рубежом определенный период, а затем возвращаются домой навсегда; они работают с целью накопления определенных средств, чтобы в будущем жить на родине. Большинство кыргызстанских рабочих, напротив, работают в странах назначения более длительный период, время от времени посещая свои семьи на родине, чему способствует более короткое расстояние от страны, где они работают, до их родной страны, и отсутствие строгих ограничений на продолжительность занятости. Таким образом, многие мигранты видят работу за рубежом как путь к постоянному переселению, особенно в Российскую Федерацию, и «постоянная» обратная миграция не является четко идентифицируемым аспектом трудовой миграции в Кыргызстане. Это отражается на схемах расходов и сбережений трудящихся-мигрантов и семей, получающих денежные переводы.

Видимо турецкие инвестиции в производство фасоли в Таласской области (Тилекеев и др., 2018 г.) прошли по неофициальным каналам. 
Согласно данным платежного баланса, денежные переводы трудящихся-мигрантов в Кыргызскую Республику увеличились со среднего уровня примерно 80 млн. долл. США за год в период 2000-2005 годов почти до 1,8 млрд. долл. США в 2014 году. После значительного сокращения в 2015 году (до 1,5 млрд. долл. США) в результате экономического спада в Российской Федерации, приток денежных переводов резко вырос до исторического максимума в 2,2 млрд. долл. США в 2017 году (Рисунок 2.8). Похоже, что этот всплеск отражает благоприятное отношение Российской Федерации к кыргызстанским рабочим после вступления страны в ЕАЭС, по сравнению к мигрантам из Таджикистана или Узбекистана. Примерно с 2000 года денежные переводы в процентах от ВВП варьировались в пределах от $24,0 \%$ до 29,5\%, составляя от $60 \%$ до $80 \%$ от общего объема экспорта товаров, и охватывали более двух третей годового дефицита счета текущих операций страны. По этим показателям Кыргызская Республика является второй по величине страной, зависящей от денежных переводов в мире после соседнего Таджикистана.

Около 88\% денежных переводов поступает из Российской Федерации (77\%) и Германии (11\%). Украина является крупнейшей страной-источником денежных переводов вне региона, на долю которой приходилось около $3 \%$ от общего объема денежных переводов в 2016 году. Действительно, угроза Москвы ограничить поток трудящихся-мигрантов в Российскую Федерацию из стран, не входящих в ЕАЭС, может стать решающим фактором для вступления Таджикистана в ЕАЭС (Куин-Джадж и Стрински, 2016 г.).

\section{Рисунок 2.8: Денежные переводы в Кыргызскую Республику по странам происхождения, 2016 г. (\%)}

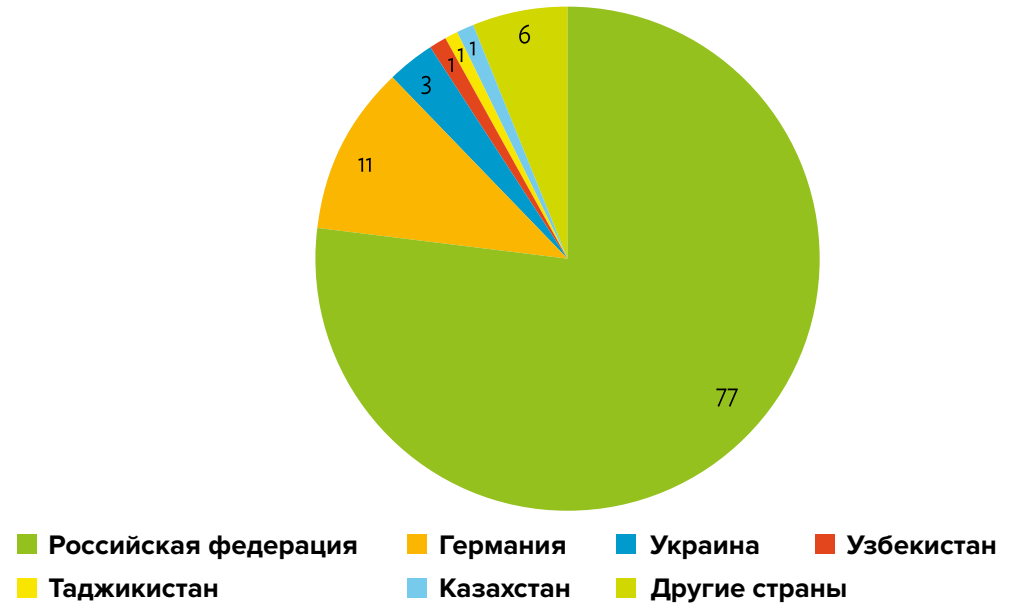

Источник: Всемирный банк. Данные по миграции и денежным переводам.

http://www.worldbank.org/en/topic/migrationremittancesdiasporaissues/brief/migration-remittance-data (по состоянию на 12 марта 2018 г.).

Частные системы денежных переводов остаются основным способом перевода денег, используемым трудящимися-мигрантами (Таблица 2.12). Лишь небольшая часть денежных переводов проходит через официальную банковскую систему или государственную почтовую службу. Популярность систем денежных переводов обусловлена их доступностью, безопасностью и низкой стоимостью (Кызы и др., 2015 г.). Операторы денежных переводов имеют офисы по всей стра- 
не, и перевод денег может занять менее нескольких часов. Средняя стоимость отправки денег в Кыргызскую Республику намного ниже средней мировой стоимости в 7,13\% от суммы перевода. Например, в 2018 году отправка денег из Российской Федерации стоила менее 1,5\% от суммы перевода. Система денежных переводов рассматривается Национальным банком Кыргызской Республики как «официальный» институт, но система фактически является «квази-официальной», потому что денежные переводы, проходящие через систему, не включаются в официальный процесс финансового посредничества через банковскую систему страны. Домохозяйства мигрантов получают денежные переводы в виде наличных денег через операторов денежных переводов. Деньги используются для удовлетворения нужд домохозяйства, а большая часть оставшихся средств поступает в систему микрофинансирования, которая быстро росла, начиная примерно с 2000 года, увеличив объем кредитования в четыре раза, а число клиентов в три раза (АБР, 2014 г.). Учитывая жесткие требования к залоговому обеспечению и другие трудности, связанные с получением банковских кредитов, свыше одной трети кредитов в экономике приходится на микрофинансовые институты при высоких процентных ставках, от 20\% до 69\% годовых.

Таблица 2.12: Денежные переводы трудящихся-мигрантов по способам денежного перевода, 2009-2016 гг. (млн. долл. США)

\begin{tabular}{lccccccccc} 
Способ перевода & 2009 & 2010 & 2011 & 2012 & 2013 & 2014 & 2015 & 2016 \\
$\begin{array}{l}\text { Поступления через системы } \\
\text { денежных переводов }\end{array}$ & 967.0 & 1252.6 & 1695.4 & 2017.9 & 2268.2 & 2235.9 & 1683.6 & 1991.3 \\
\hline $\begin{array}{l}\text { Поступления через } \\
\text { коммерческие банки }\end{array}$ & 11.0 & 9.2 & 9 & 9.7 & 6.5 & 4.8 & 2.9 & 2.4 \\
\hdashline Почтовая служба & 4.3 & 4.4 & 4.2 & 3.8 & 3.4 & 2.2 & 1.2 & 0.9 \\
\hline Лично & 90 & 113.1 & 152 & 177.4 & 0 & 0 & 134.4 & 0 \\
\hline Всего & 1072.0 & 1379.3 & 1859.7 & $\mathbf{2 2 0 8 . 8}$ & $\mathbf{2 2 7 8}$ & $\mathbf{2 2 4 2 . 8}$ & $\mathbf{1 8 2 2 . 1}$ & 1994.6 \\
\hline
\end{tabular}

anelik, Baziko, Contract, Migom, MoneyGram, Western Union, Unistream, Золотая корона, Лидер, Быстрая почта, Fast Post, Allure и многие другие.

'Денежные переводы свыше 3000 долларов США не охвачены.

сОценка Национального банка Кыргызской Республики денежных переводов, которые трудящиеся-мигранты привозят наличными.

Источник: НБКР, http://www.nbkr.kg/index1.jsp?item=138\&lang=ENG (по состоянию на 18 мая 2018 г.)

Трудовая миграция действует в качестве «предохранительного клапана» в условиях давления на внутреннем рынке труда и помогает домохозяйствам, получающим денежные переводы, преодолеть черту бедности. В то время как денежные переводы являются жизненно важным источником иностранной валюты для страны, чистое воздействие трудовой миграции на социально-экономическое развитие страны остается спорным вопросом. По данным опросов домохозяйств в Кыргызстане, данные денежные переводы в основном используются на потребительские цели, а не для инвестиций или в качестве дополнения к национальным сбережениям. Имеются также отдельные свидетельства нехватки рабочей силы среди разнорабочих и рабочих среднего звена в экономике из-за массовой эмиграции рабочих из данных категорий. Более того, члены домохозяйств, получающих денежные переводы, с меньшей вероятностью пополнят рынок труда, тем самым создавая дополнительное давление на внутреннее предложение рабочей силы. 
Перспективные участники рынка труда предпочитают получить квалификацию, а привлечение профессионально подготовленных трудящихся-мигрантов к неквалифицированному труду отрицательно сказывается на развитии человеческого капитала в отправляющей стране. Наконец, широко обсуждаемые социальные издержки включают неблагоприятные психологические последствия для членов семьи и негативные последствия для образования детей (АБР, 2014 г., ПРООН, 2015 г.).

Важным вопросом, касающимся воздействия трудовой миграции на экономику страны-отправителя, является вопрос о том, стимулирует ли трудовая миграция внутреннее предпринимательство, используют ли рабочие-мигранты свои сбережения и опыт, приобретенный за рубежом, для открытия бизнеса на родине. Недавно проведенное исследование о выборе профессии среди вернувшихся мигрантов в Кыргызской Республике привело к двум интересным выводам, касающихся данной проблемы (Брук и др., 2018 г.). Во-первых, возвращающиеся мигранты, которые были самозанятыми до миграции, реже предпочитают становиться самозанятыми по возвращении. Во-вторых, варианты выбора профессии среди вернувшихся мигрантов менее устойчив, чем у не мигрантов: те, кто ищет возможности для самозанятости, часто считают это временным вариантом, прежде всего потому, что повторная миграция остается в качестве альтернативного выбора. Оба вывода ставят под сомнение любой потенциальный долгосрочный вклад вернувшихся мигрантов в экономическое развитие Кыргызской Республики посредством предпринимательства.

\section{8 Заключительные выводы}

За прошедшую четверть века Кыргызская Республика добилась значительных успехов в процессе экономического перехода к глобальной экономической интеграции. Однако модели глобальной экономической интеграции до сих пор были довольно однобокими: быстрое проникновение импорта в экономику не соответствовало структурным изменениям на экспортном фронте. Были отмечены заметные изменения в структуре экспорта в соответствии с сравнительными преимуществами страны. Но в последние годы экспортные доходы были достаточными для покрытия лишь половины общей стоимости импорта товаров. Это привело к увеличению зависимости экономики от денежных переводов и внешнего финансирования. За последние пятнадцать лет денежные переводы покрывали более двух третей торгового дефицита.

Структура внешнего финансирования стала смещаться от грантов и льготных кредитов к кредитам по коммерческим ставкам, что потенциально подвергает экономику дополнительным внешним экономическим потрясениям. Обязательства страны по обслуживанию долга по-прежнему остаются в рамках управляемых пределов, но неизбежно будут расти с учетом изменения в структуре внешнего финансирования. ПИИ, которые, как ожидается, будут играть ключевую роль в экспортно-ориентированном производстве и структурной перестройке в либерализованной экономике, в дополнение к их прямому вкладу в укрепление позиции внешних платежей, до сих пор составляли лишь небольшую долю притоков капитала. 
Учитывая богатые запасы полезных ископаемых страны и торговые издержки, связанные с расстояниями, как страны, не имеющей выхода к морю, Кыргызская Республика имеет сравнительные преимущества в добыче золота и других полезных ископаемых, имеющих высокую стоимость за единицу веса. Как было видно на примере затянувшегося спора по распределению прибыли золотодобывающего предприятия «Кумтор», разработка более эффективного механизма аренды минеральных ресурсов и налогообложения ресурсов остается одной из основных политических задач. Это жизненно важно для извлечения максимальной национальной выгоды от добычи ресурсов и повышения привлекательности страны для мировых высококачественных инвесторов. Идея рентного налога на полезные ископаемые заключается в том, чтобы получить высокую часть стоимости сверх уровня, необходимого для привлечения инвестиций, без сдерживания маргинальных инвестиций. Решение проблем инвесторов может потребовать некоторого послабления местного контроля. Этот компромисс будет политически приемлемым только в том случае, если правительство систематически будет воплощать политику в области горнодобывающего сектора в рамках хорошо продуманной национальной стратегии развития (Гарнаут и Клунис-Росс, 1975 г. и 1983 г.).

Важным событием, связанным с экспортом продукции, не относящейся к золоту, которое заслуживает фокуса внимания политики, является появление пищевых продуктов (молочных продуктов, фруктов и овощей) и швейной продукции в качестве динамичных экспортных линий. Расширение экспорта продуктов питания соответствует текущему смещению в структуре глобальной торговли продуктами питания от обычных первичных пищевых продуктов к высокоценным переработанным пищевым продуктам. С улучшением торговых отношений с КНР и транспортных сетей, экспорт продовольствия может сыграть важную роль в сокращении торгового дефицита с КНР. Переработанные продукты питания стали одними из наиболее динамичных статей китайского импорта, поскольку изменения внутреннего спроса происходит в соответствии с увеличением уровня доходов домашних хозяйств. Необходимым условием для продвижения переработанных продуктов питания является создание институционального механизма, призванного помочь производителям и экспортерам соответствовать международным стандартам безопасности пищевых продуктов (таким, как санитарные и фитосанитарные стандарты). Это та область, в которой международные агентства развития могут сыграть важную роль как часть нового акцента внимания на инициативах «Помощь в интересах торговли».

За последние два десятилетия швейная промышленность Кыргызской Республики завоевала нишу на рынках со средним уровнем доходов в Казахстане и Российской Федерации. Важно искать способы, чтобы помочь отрасли «выйти на мировой уровень», отталкиваясь от этих впечатляющих результатов. Устранение административных ограничений, которые препятствуют появлению крупных фирм, продвижение ПИИ в отрасль и внедрение схемы импортных пошлин, возможно, являются аспектами политики, заслуживающими приоритетного рассмотрения.

Турция, крупный торговый партнер Кыргызской Республики вне региона, стала вторым по величине экспортером одежды (наряду с КНР) в мире после отмены Соглашения по текстилю (MFA) в 2015 году. Возможно, Кыргызстан будет привлекательной страной для турецких производителей одежды, так как они уже начали перемещение производства в страны с низкой заработной платой в связи с ростом внутренней заработной платы. 
До вступления в ЕАЭС ключевым определяющим фактором рентабельности/ конкурентоспособности одежды из Кыргызской Республики было наличие импортных тканей, облагаемых специальными (на основе веса) пошлинами, через торговые сети, центрами которых служили базары. Стоимость производства должна возрасти после введения импортных тарифов на основе стоимости в рамках таможенного администрирования ЕАЭС. В данном контексте важно ввести схему возврата импортных пошлин для экспортеров одежды, предназначенной для экспорта, с целью поддержания нормы прибыли против увеличения затрат на закупку импортных факторов производства. Роль хорошо функционирующей схемы возврата пошлин заключается в том, чтобы предоставить производителям доступ к импортированным факторам производства по ценам мирового рынка. Это жизненно важно для поддержания конкурентоспособности на экспортном рынке, особенно для производителей в такой стране, как Кыргызская Республика, где отсутствует сильная отечественная текстильная база.

Какие имеются у страны варианты политики для направления денежных переводов мигрантов в социально и экономически желательные инвестиции? В более ранней литературе и рекомендациях в области политики приводился аргумент в пользу реализации схем развития предпринимательства (Бохнинг, 1984 г.). Основная стратегия заключалась в том, чтобы направлять работников (или их семьи, получающие денежные переводы) к созданию предприятий на индивидуальной или коллективной основе в соответствии с приоритетами национального развития. Однако многие попытки внедрить эту стратегию в разных странах-экспортерах рабочей силы потерпели неудачу. Причина заключалась в том, что мигранты-работники, не имеющие навыков ведения бизнеса, не были способны определить, разработать и/или управлять бизнес проектом. Более того, даже мигранты-работники, относящиеся к категориям рабочей силы высокого уровня, не имели адекватных сбережений, либо не желали инвестировать в бизнес из-за соображений риска.

Это соображение подкрепляет теперь общепринятое мнение о том, что вместо сосредоточения внимания на «инвестиционных программах, связанных с мигрантами» страны-экспортеры рабочей силы должны попытаться использовать процесс финансового посредничества в качестве инструмента для направления денежных переводов в продуктивные инвестиции. Вместо того, чтобы пытаться превратить трудящихся-мигрантов в инвесторов, правительства могли бы разрабатывать политику для передачи денежных переводов через финансовое посредничество предпринимателям, которые являются способными бизнесменами, а также могут брать на себя бизнес-риски. Сберегательные схемы и инвестиционные инструменты, специально разработанные с учетом моделей доходов работников, могут играть определенную роль, но ключ к успеху таких инициатив в очень большой степени зависит от более широкой политики в области финансового сектора с целью продвижения роли официальной банковской системы. Таким образом, в конечном итоге, политика, необходимая для максимизации доходов от денежных переводов мигрантов, не отличается от той политики, которая необходима для эффективной мобилизации внутренних сбережений для экономического развития. 


\section{Библиограсрия}

Агаджанян В. и Горина Е. 2018. Экономические колебания, политическая нестабильность и миграция в Кыргызстане. Европейский журнал народонаселения. 1-20. https://doi. org/10.1007/s10680-018-9482-4

Муктарбек кызы, Ч. Сеитов и Н. Жениш. 2015. Влияние денежных переводов на структуру расходов домохозяйств в Кыргызской Республике. Рабочий документ Центра экономических исследований 2015-о2, Бишкек: Центр экономических исследований Национального банка Кыргызской Республики.

Азиатский банк развития (АБР). 2013. Оценка энергетического сектора: Кыргызская Республика. Манила.

Азиатский банк развития (АБР). 2014. Кыргызская Республика: Стратегическая оценка экономики. Манила.

Атукорала П. 2006. Международная трудовая миграция в Восточной Азии: тенденции, модели и вопросы политики. Азиатско-тихоокеанская экономическая литература, 20(1). с. 18-39.

Атукорала П. и Варр П. 2002. Уязвимость к валютному кризису: уроки азиатского опыта. Мировая экономика, 25(1). с. 33-57.

Атукорала П. и Джаясурия С. 2003. Вопросы безопасности пищевых продуктов, торговля и правила ВТО: перспектива развивающихся стран. Мировая экономика, 26(9). с. 613-637.

Биркман Л., Калошника М., Хан М., Шавуров У. и Смолхаус С. 2012. Текстильная и швейная отрасль в Кыргызстане, Гарвардская школа Кеннеди и Гарвардская школа бизнеса, Кембридж М.А.

Бонинг В. 1984. Исследования в международной трудовой миграции, Лондон: Macmillan.

Ботоева А. и Спектор Р. 2013. Шитье для души: ремесленное предпринимательство в современном Кыргызстане. Исследование в Центральной Азии, 32(4), стр. 487-500.

Брук Т., Мейе К. и Науде В. 2018. Возвращение мигрантов и самозанятость: данные из Кыргызстана. Документ для обсуждения IZA № 11332, Бонн: Институт экономики труда IZA. ftp://repec.iza.org/RePEc/Discussionpaper/ dp11332.pdf .

Винокуров Е. 2017. Евразийский экономический союз: текущее состояние и предварительные результаты. Российский журнал экономики. 3(1). сс. 54-70.

Всемирный банк. 2014. Записка о политике в энергетическом секторе для Кыргызской Республики, Вашингтон, О.К. : Всемирный банк.

Всемирный банк. 2016. Обзор экономической ситуации в Кыргызской Республике, зима 2016: Устойчивая экономика на траектории медленного роста. Вашингтон, О.К,.: Всемирный банк. https://openknowledge.worldbank.org/handle/10986/25973 Лицензия: CC BY 3.oIGO. (по состоянию на 8 июня 2018 года). 
Всемирная торговая организация (ВТО). 2014. Обзор торговой политики: Отчет Секретариата, Кыргызская Республика. Женева: ВТО. 2018. Статистическая онлайновая база данных ВТО, Тарифные профили.

http://stat.wto.org/Home/ WSDBHome.aspx?Language $=\mathrm{E}$ (по состоянию на май 2018 г.).

Гарнау Р. и Клюнис-Росс Э. 1975. Неопределенность, неприятие риска и налогообложение проектов в области природных ресурсов. Экономический журнал 85(338): с. 272-287. 1983. Налогообложение аренды минеральных ресурсов. Оксфорд: Clarendon Press.

Евразийский банк развития (ЕАБР). 2017. Евразийская экономическая интеграция 2017. Центр интеграционных исследований ЕАБР. Санкт-Петербург: ЕАБР.

http://greatereurope.org/wp-content/uploads/2017/o6/edb-centre_2017_ report-43_eng.pdf (по состоянию на июнь 2018 года).

Европейский банк реконструкции и развития (ЕБРР). Прогнозы, макроданные, онлайновые наборы данных индикаторов переходного периода. https://www.ebrd.com/what-we-do/economic-research-and-data/data/ forecasts-macro-datatransition-indicators.html (по состоянию на май 2018 года).

Жениш Н. 2014. Экспорто-ориентированное развитие МСБ в Кыргызстане: швейная промышленность. Институт государственного управления и политики. Доклад № 26, Бишкек: Университет Центральной Азии.

Йонванич Дж. и Магтибай-Рамос Н. 2009. Детерминанты структурных изменений в экспорте продовольствия из развивающихся стран. Азиатско-тихоокеанская экономическая литература, 23 (2). с. 94-114.

Каминский Б. и Митра С. 2012. Безграничные базары и региональная интеграция в Центральной Азии: новые модели торговли и трансграничного сотрудничества, Вашингтон, округ Колумбия: Всемирный банк.

Каминский Б. и Рабалланд. 2009. Челночная торговля Китайскими товарами потребления в Центральной Азии: загадка реэкспорта через кыргызские базары. Евразийская география и экономика. 50 (5). С. 581-90.

Квинн-Джадж К. и Стронски П. 2016. Кыргызстан через двадцать пять лет: «подступающая вода». Фонд Карнеги за международный мир. https://carnegieendowment.org/2016/o7/21/kyrgyzstan-at-twenty-fivetreading-water-pub-64152

Лукас Р. 2005. Международная миграция и экономическое развитие: уроки из стран с низким уровнем доходов, Cheltenham: Edward Elgar Publishing.

Министерство экономики, Правительство Кыргызской Республики. Без даты. Данные по региональному распределению прямых иностранных инвестиций Кыргызской Республики.

Могилевский Р., Абдразакова Н. и Чалбасова С. 2015. Влияние золотодобывающего предприятия «Кумтор» на экономическое и социальное развитие Кыргызской Республики, Рабочий документ № 32, Институт государственного управления и политики, Бишкек: Университет Центральной Азии. 
Могилевский Р., Абдразакова Н., Чалбасова С., Джумаева Ш. и Тилекеев К. 2017. Результаты 25-летней сельскохозяйственной реформы в Кыргызстане. № 162. Халле: Документ для обсуждения 162, Институт сельскохозяйственного развития Лейбница в странах с переходной экономикой. https://www. econstor.eu/bitstream/ 10419/155774/1/882056298.pdf

Организация Объединенных Наций. База данных Организации Объединенных Наций по торговле сырьевыми товарами (ОOH Comtrade). https://comtrade. un.org (по состоянию на май 2018 года).

Организация Объединенных Наций. Конференция по торговле и развитию (ЮНКTAД). UNCTADSTAT, онлайновая база данных о мировых инвестициях. https://unctad.org/en/Pages/DIAE/FDI\%20Statistics/FDI-Statistics.aspx (по состоянию на март 2018 г.).

Помфрет Р. 2018. Центрально-азиатские экономики в XXI веке: строительство нового Шелкового пути, новый рай, Нью-Джерси: Princeton University Press.

Программа развития Организации Объединенных Наций (ПРООН). 2015. Трудовая миграция, денежные переводы и человеческое развитие в Центральной Азии. Серия «Развитие человеческого потенциала в Центральной Азии». Нью-Йорк: Региональное бюро ПРООН для Европы и Содружества Независимых Государств.

Румер Б. 1989. Советская Центральная Азия: трагический эксперимент, Бостон: Unwin Hymman.

Спектор Р. 2018. Региональная производственная сеть в хищническом государстве: экспортно-ориентированное производство в пределах закона. Обзор международной политической экономики, 25(2). с. 169-189.

Тарр, Д. 2016. Евразийский экономический союз России, Беларуси, Казахстана, Армении и Кыргызской Республики: может ли он преуспеть там, где потерпел неудачу его предшественник? Восточноевропейская экономика. 54 (1). C. 1-22.

Тилекеев К., Могилевский Р., Абдразакова Н. и Джумабаева Ш. 2018. Производство и экспорт фасоли в Кыргызской Республике: анализ цепочки стоимости, Институт государственного управления и политики. Рабочий документ 43, Бишкек: Университет Центральной Азии.

Тьянен Х., Сайринен Р. и Новиков В. 2014. Добыча в Чаткальской долине в Кыргызстане - вызов социальной устойчивости. Политика ресурсов 39 (2014): c. $80-87$.

Цены на денежные переводы в мире. https://remittanceprices.worldbank.org/ en (по состоянию на май 2018 года).

Чаарат. Проект «Чаарат». https://www.chaarat.com/project (по состоянию на июнь 2018 г.).

Шмидт М. и Сагынбекова Л. 2008. Прошлое и настоящее миграции: изменение моделей в Кыргызстане. Обследование в Центральной Азии. 27.2. с. 111-127. 


\section{Глава 3}

\section{Реформирование аграрного cekTopa}

\section{T. Ямано, Х.H. Сэмсон, К. Тйекеев}

\section{1. Введение}

асштабы и глубина сельскохозяйственных реформ в странах бывшего Советского Союза существенно различаются. В начале переходного периода во всех странах бывшего Советского Союза наблюдалось снижение уровня производительности сельского хозяйства (Свиннен и Вранкер, 2010). Кыргызская Республика была одной из первых стран в Центральной Азии, которая после получения независимости начала проводить сельскохозяйственную реформу (Чаки, 2000). Реформа заключалась в либерализации торговли, приватизации земель, приватизации государственного рынка, либерализации рынков ресурсов и продукции, отмене обязательных заказов на производство товаров. После значительного уменьшения уровня производства в 1990-1995 годах сельскохозяйственное производство в Кыргызстане восстановилось, превысив дореформенный уровень (до 2000 года).

Киргизия была частью Советского Союза, где проводилось крупномасштабное сельскохозяйственное планирование. Овцеводство (разведение, в основном, тонкорунных пород для производства шерсти) и выращивание хлопка было сельскохозяйственной специализацией Киргизии, в то же время республика зависела от импорта пшеницы и других продовольственных товаров. Потеря государственной поддержки после 1990 года, вкупе с низкими ценами на шерсть, привела к сокращению поголовья овец с десяти (10) миллионов в 1991 году до четырех (4) миллионов в 2003 году (Акрамов и Омуралиев, 2009), впоследствии поголовье выросло до 6 миллионов. Фермеры в районах, благоприятных для выращивания продовольственных культур, перешли от выращивания хлопка и других промышленных культур к выращиванию продовольственных и высокотоварных культур, поскольку встал вопрос продовольственной безопасности и максимизации доходов. В последнее время появились цепочки создания добавленной стоимости, которые связывают кыргызских фермеров с международными рынками; тем не менее, в сельском хозяйстве существуют серьезные проблемы.

Сельское хозяйство Кыргызской Республики находится на этапе модернизации производственных систем и присоединения к глобальным цепочкам добав- 
ленной стоимости. Сельское хозяйство страны, учитывая небольшие его размеры, для повышения своей производительности должно полагаться на технологические знания и ресурсы извне. Став звеном глобальной цепочки добавленной стоимости, Кыргызстан мог бы расширить экспортные направления и экспортировать сельхозпродукцию не только в соседние страны. А при содействии международных организаций, группы фермеров и кооперативы могли бы получать новые знания, материалы и ресурсы, как от государственного сектора, так и от частного. Правительство Кыргызстана также может сыграть важную роль в содействии интеграции сельского хозяйства в глобальную цепочку добавления стоимости (мирохозяйственные связи). Кроме того, государственные инвестиции в инфраструктуру, например, в ирригационные и логистические объекты, могут значительно нивелировать трудности, стоящие перед фермерами и торговыми предприятиями, однако, такие инвестиции должны основываться на спросе. В этой главе мы охарактеризуем сельскохозяйственный сектор Кыргызстана и обсудим его экспортный потенциал. Чтобы проиллюстрировать возможности сектора, мы рассмотрим несколько успешных примеров и опишем полученные уроки. Рекомендации по дальнейшему развитию экспортного потенциала сельскохозяйственного сектора приведены в конце этой главы.

\section{2 Сельское хозяйство Кыргызской Республики.}

\section{Исторический обзор сельскохозяйственной политики}

Различные этапы аграрной реформы в стране привели к кардинальным преобразованиям в сельскохозяйственном секторе (Таблица 3.1). На первом этапе реформы, в 1991-1994 годах, в центре внимания сельскохозяйственной политики находился вопрос о передаче сельскохозяйственных земель в частное пользование, то есть в руки фермеров. Колхозы были реорганизованы в акционерные общества, сельскохозяйственные кооперативы и крестьянско-фермерские объединения, хотя большинство этих объединений своей деятельностью по-прежнему напоминали старый социалистический уклад хозяйствования (Могилевский и др., 2017). Несмотря на крах государственного бюджета, многие фермеры по-прежнему зависели от государственных субсидий. В 1994 году около 12\% земель в Кыргызстане было распределено среди фермеров, невзирая на то, что ясности относительно прав собственности на землю не было. Хотя земельные паи и активы уже были распределены, по крайней мере, на бумаге, многие работники коллективных хозяйств могли претендовать на земельные паи в определенных местностях и создавать индивидуальные крестьянские хозяйства (Себатес-Вилер и Чилдресс 2004). В этот период де-регулирование цен на сельскохозяйственную продукцию, в сочетании с процессом перераспределения земель, привело к медленному упадку сельскохозяйственного производства.

В ходе второго этапа реформ, начавшегося в 1994 году, был издан новый указ президента о мерах по углублению земельной и аграрной реформы в Кыргызской Республике, нацеленный на разработку новых шагов и мер по выполнению программы реформирования аграрного сектора. В рамках программы было успешно реорганизовано около 262 совхозов и 190 колхозов (Акрамов и Омуралиев 2009). В этот период около $75 \%$ пахотных земель и $68 \%$ совхозного скота были распределены между индивидуальными фермерами (Блох и др., 1996), 16\% тракторов и зданий попали в частные фермерские хозяйства. Согласно исследованию 
Акрамова и Омуралиева (2009), также началась децентрализация ирригационной системы, что вовлекло фермеров в управление внутрихозяйственными системами полива. Принятые юридические документы предоставили возможность создавать Ассоциации водопользователей (АВП) и владеть внутрихозяйственными ирригационными системами, однако, межхозяйственная ирригационная система осталась в государственной собственности. Было перераспределено и передано около 920 тысяч гектаров (га) пахотных земель под крестьянские хозяйства и приусадебные участки, а крупным сельскохозяйственным предприятиям и другим пользователям было оставлено для возделывания менее 400 тысяч га сельскохозяйственных угодий. Средний размер фермерских хозяйств сократился с 15 гектаров в 1994-1996 годах до 3 гектаров в 2002 году. В соответствии с новым законом о водной реформе 2002 года АВП получили статус юридического лица (некоммерческой организации), что позволяло им управлять и содержать ирригационную систему в сельских районах, собирать плату за воду, распределять воду в пределах своей зоны ответственности и отвечать за эксплуатацию и техническое обслуживание ирригационных систем, используя для этого собранную оплату. Тем не менее, управление АВП остается слабым; АВП сталкиваются со значительными трудностями в сборе платы за воду, что дает некоторым более обеспеченным пользователям облегченный доступ к воде.

\section{Таблица 3.1. Аграрная реформа в Кыргызской Республике: мероприятия по осуществлению аграрной реформы, этапы реализации реформы.}

\begin{tabular}{|c|c|c|}
\hline $\begin{array}{l}\text { Этапы } \\
\text { реформирования } \\
\text { сектора }\end{array}$ & Дата & $\begin{array}{l}\text { Мероприятия по осуществлению ресрормы, политика и } \\
\text { стратегии }\end{array}$ \\
\hline \multirow[t]{2}{*}{$\begin{array}{l}\text { Постсоветский этап } \\
\text { (первый этап) }\end{array}$} & 1991 & $\begin{array}{l}\text { Закон о крестьянском (фермерском) хозяйстве, Закон о предприятиях } \\
\text { в Республике Кыргызстан, Закон о земельной реформе, Земельный } \\
\text { Кодекс }\end{array}$ \\
\hline & 1993 & Новая Конституция \\
\hline \multirow[t]{4}{*}{ Второй этап } & 1994 & $\begin{array}{l}\text { Постановление Правительства о мерах по углублению земельной и } \\
\text { аграрной реформы в Кыргызской Республике, } \\
\text { Создание Национального земельного фонда (переименован в Фонд } \\
\text { перераспределения сельхозугодий) }\end{array}$ \\
\hline & 1998 & $\begin{array}{l}\text { Референдум о введении частной собственности на землю для граждан } \\
\text { Кыргызстана, } \\
\text { Указ Президента Кыргызской Республики о регулировании и } \\
\text { введении частной собственности на землю, } \\
\text { Закон о государственной регистрации прав на недвижимое имущество } \\
\text { и сделок с ним }\end{array}$ \\
\hline & 1999 & $\begin{array}{l}\text { Земельный Кодекс, Закон Кыргызской Республики о крестьянском } \\
\text { (фермерском) хозяйстве }\end{array}$ \\
\hline & 2001 & $\begin{array}{l}\text { Об управлении землями сельскохозяйственного назначения (отмена } \\
\text { моратория на продажу земли в КР) }\end{array}$ \\
\hline \multirow[t]{4}{*}{ Третий этап } & 2004 & $\begin{array}{l}\text { Указ Президента Кыргызской Республики О новых направлениях и } \\
\text { мерах земельной и аграрной реформы, Закон о кооперативах }\end{array}$ \\
\hline & 2008 & Налоговый Кодекс о налогообложении на землю \\
\hline & 2009 & Закон о пастбищах \\
\hline & 2013 & Национальная стратегия устойчивого развития \\
\hline
\end{tabular}




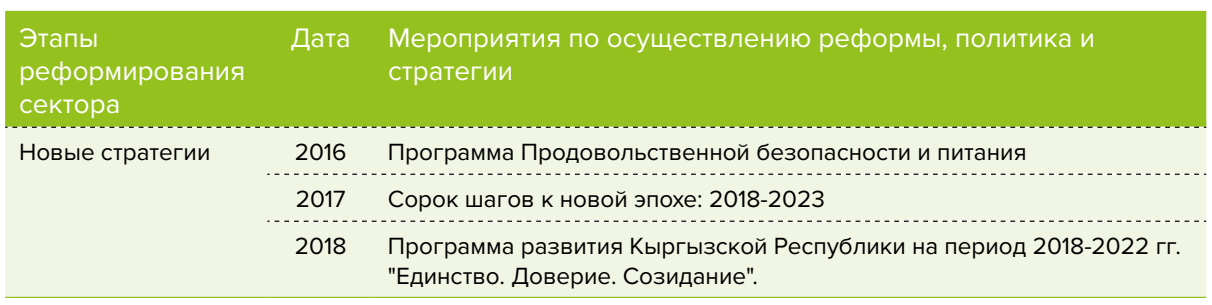

Источник: Лерман и Седик (2009), Могилевский и др. (2017)

На третьем этапе аграрной реформы, начиная с 2004 года, основное внимание было уделено усилению работы службы по оказанию консультационных услуг и вопросу увеличения инвестиций в инфраструктуру (Лерман и Седик 2009). Развитие кооперативов, крестьянско-фермерских хозяйств и агропредприятий, сохранение и улучшение водных и пастбищных хозяйств, а также социальное развитие села являлись приоритетами работы правительства. Консультативная служба в сельских районах (КСС) была создана для оказания консультационных услуг фермерам и фермерским хозяйствам; служба КСС получила существенную поддержку со стороны донорских организаций. Уровень государственных инвестиций, полученных от различных донорских институтов, вызывают серьезную озабоченность в вопросе институциональной устойчивости. При низком уровне бюджетной поддержки со стороны правительства обслуживание инвестиций и реализация программ вряд ли будут устойчивыми.

В 2013 году Указом Президента Кыргызской Республики № 11 утверждена Национальная стратегия устойчивого развития Кыргызской Республики (НСУР) на 2013-2017 годы, в которой предусмотрены среднесрочные государственные стратегии, определяющие развитие агропромышленного комплекса в качестве одного из приоритетных направлений. Целевые показатели для этого сектора включают: (1) обеспечение продовольственной безопасности за счет роста производства и производительности труда; (2) повышение эффективности и конкурентоспособности агропромышленного комплекса и сельского хозяйства в целом; (3) повышение эффективности использования ресурсов государственного бюджета; и (4) решение социальных проблем крестьян. ${ }^{1}$

Политические заявления, отраженные в НСУР (Национальной стратегии устойчивого развития), были слишком амбициозными. В работе Могилевского (Могилевский и др., 2017 г.) указано, что единственные реальные сельскохозяйственные меры политики, включенные в НСУР КР, и которые были полностью реализованы, включали следующее: (1) поддержку в предоставлении критически важных для сельского хозяйства общественных товаров и услуг (ветеринарные услуги, создание семенного фонда и т.д.), (2) восстановление инфраструктуры (например, ирригационные системы, дороги) за счет финансирования доноров, (3) улучшение доступа к рынкам внутри Евразийского экономического союза (ЕАЭС), что облегчило доступ кыргызских фермеров на рынки России, Казахстана и других стран ЕАЭС, (4) предоставление более дешевых кредитов фермерам и агропредприятиям в рамках государственных программ субсидирования и кредитов коммерческих банков производителям и переработчикам, (5) введение льготных налоговых ставок и налоговых исключений для предприятий агропромышленного комплекса и индивидуальных фермеров.

В Приложении 1 опубликован перечень мер, указанных в НСУР, для решения указанных проблем в рамках целевых показателей. 
В 2017 году правительство Кыргызстана объявило о новой пятилетней программе под названием «Сорок шагов к новой эпохе: 2018-2023 годы». Этот документ включал девять программ реформирования и девять программ развития. В качестве ключевых инвестиционных проектов, определенных на неоднократных встречах с официальными лицами государства, были выделены следующие: (1) Таза Коом (что означает «Чистое общество» и являет собой политическое видение, направленное на создание цифровой экономики, включая электронное правительство), (2) обеспечение населения чистой питьевой водой, особенно сельских и отдаленных районов, и (3) ирригация для улучшения сельскохозяйственного производства. В «Сорок шагов» также было включено развитие агропромышленного сектора и системы кооперативов. Эти вопросы будут рассмотрены в следующих разделах.

\section{Сельское хозяйство в Центральной Азии}

Распад СССР в 1991 году негативно отразился на сельскохозяйственном производстве. Сельское хозяйство находилось в упадке в течение нескольких лет, начиная с 1992 года. Подобная ситуация была во всех странах Центральной Азии, за исключением Узбекистана (Рисунок 3.1). Сектор сельского хозяйства Казахстана пострадал больше всего. Производство сократилось на 5О\% в период 1992-1998 годов. Восстановление сельскохозяйственного производства до уровня 1992 года заняло около 15 лет. Сельское хозяйство в Кыргызстане восстановилось достаточно быстро, быстрее, чем в других странах Центральной Азии. К 1997 году добавленная стоимость сельского хозяйства и производство превысило уровень 1992 года и в 2003 году достигло уровня в 150\% (относительно уровня 1992 года). Среди всех Центрально - Азиатских стран Кыргызская Республика была первой, которая достигла такого уровня, хотя с 2004 года рост производства сельского хозяйства в Кыргызстане замедлился, а Узбекистан и Таджикистан достигли уровня в 200\% (относительно 1992 года). Сельское хозяйство Узбекистана неуклонно растет за последние два десятилетия и утроило добавленную стоимость по сравнению с 1992 годом.

\section{Рисунок 3.1. Объем производства сельскохозяйственного сектора в странах Центральной Азии}

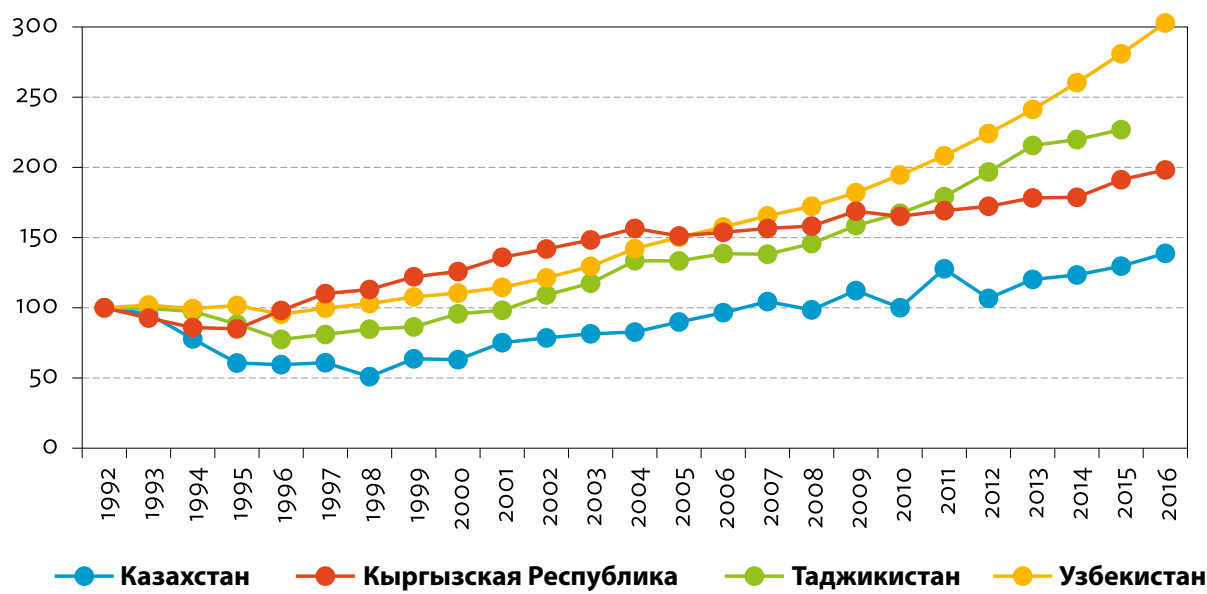

Данные за 1992 год берутся за 100\%

Источник: Статистика ФАО. http://fao.org/faostat/en/\#data (по состоянию на марта 2018 года) 
В минувшую советскую эпоху сельскохозяйственное производство и потребление продовольствия контролировалось централизованно, независимо от региона; эти два аспекта (производство и потребление) были взаимозависимы. Например, значительная доля пшеницы в Центрально-Азиатском регионе выращивалась на севере Казахстана («пшеничный пояс») и экспортировалась в южные регионы, в Таджикистан и Кыргызстан (Помфрет, 2016). На орошаемых землях южных регионов выращивался хлопчатник, в основном, в Узбекистане, Туркменистане и Таджикистане. Следует заметить, что относительно высокие цены на хлопок в 1992-1995 годах облегчили переходный период к рыночной экономике в этих странах.

Уменьшение или отсутствие государственной поддержки выращивания хлопчатника и других промышленных культур вынудило фермеров прекратить или резко снизить объемы выращивания этих культур. В результате валовая стоимость производства промышленных культур снизилась в трех из четырех стран Центральной Азии (Рисунок 3.2). В Кыргызской Республике, например, доля валовой стоимости производства промышленных культур сократилась с более чем 10 (десяти) до менее 5 (пяти) процентов; в Таджикистане и Узбекистан она снизилась с примерно 30\% до 10\%. Только в Казахстане производство технических культур осталось примерно на прежнем уровне. ${ }^{2}$

\section{Рисунок 3.2. Доля валового сельскохозяйственного производства в странах Центральной Азии, 2016 году (\%\%)}

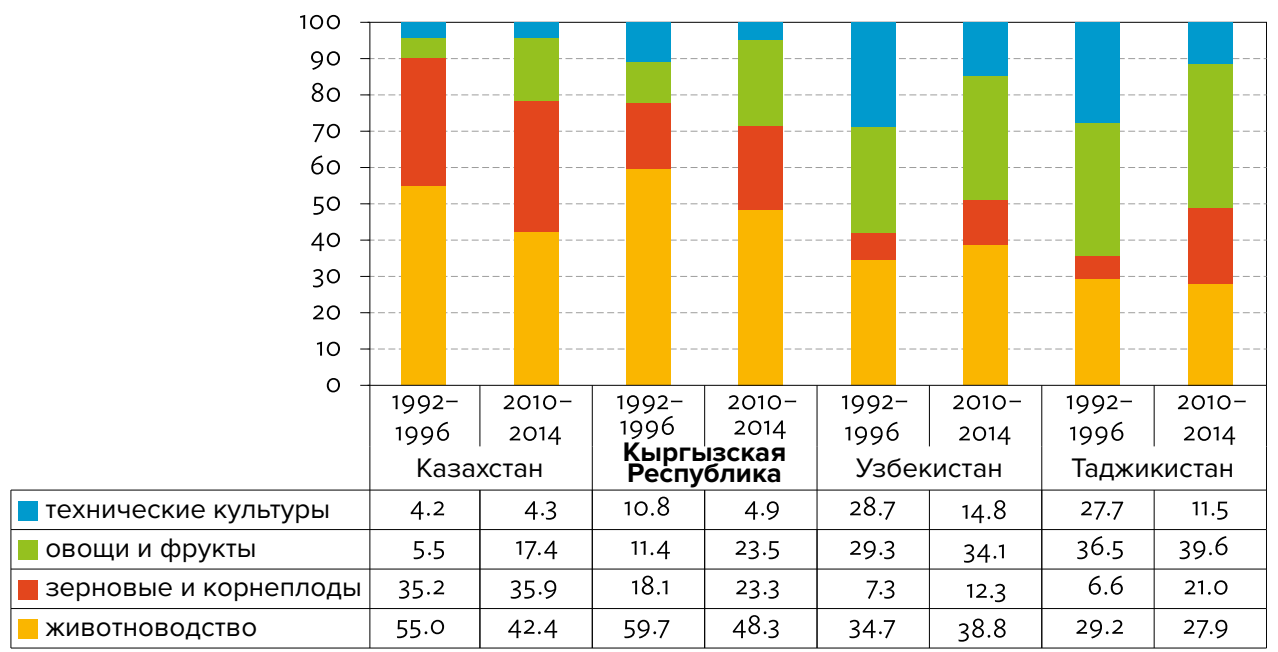

Источник: ФАО http://fao.org/faostat/en/\#data (по состоянию на март 2018г)

Индивидуальные фермеры, получившие землю в результате проведения аграрной реформы, стали принимать самостоятельные решения в отношении сельскохозяйственного производства; поскольку встал вопрос о продовольственной безопасности, они стали выращивать, в основном, продовольственные культуры. В южных республиках Центральной Азии производство зерновых и корнеплодов значительно возросло, эти республики перестали полагаться на импорт

2 Использование детского труда при выращивании и сборе хлопка, отсутствие мотивации, необходимое огромное количество воды для выращивания хлопка, все это привело к снижению уровня выращивания хлопчатника - см. Помфрет (2016). 
из Казахстана и других стран бывшего Советского Союза. В валовом сельскохозяйственном производстве доля зерновых и корнеплодов в Кыргызской Республике увеличилась с 18\% до 23\%, а доля овощей и фруктов увеличилась с 11 до 24\%. В Узбекистане и Таджикистане доля этих культур тоже увеличилась.

Таблица 3.2 демонстрирует состояние сельскохозяйственного производства в Центральной Азии на 2016 год. Страны Центральной Азии постепенно, в несколько этапов, после распада Советского Союза, приватизировали земли, причем страны пошли разными путями. Во всех странах, кроме Казахстана, приватизация земли, в основном, завершена. Примечательно, что в двух странах: в Кыргызстане и в Узбекистане более 9о\% сельскохозяйственных земель принадлежит фермерам. В Казахстане приватизация земли не закончена: только 39\% земли принадлежит индивидуальным фермерам. Кроме того, Казахстан обладает обширными сельскохозяйственными угодьями, но имеет самую низкую продуктивность земли и самую высокую производительность труда среди четырех стран. В Узбекистане объём производства сельского хозяйства в денежном выражении составляет более 10 миллиардов долларов США; высока в этой стране продуктивность и земли, и труда.

По сравнению с Узбекистаном и Таджикистаном, продуктивность земли в Кыргызской Республике значительно ниже. Добавленная стоимость в Кыргызской Республике составляет всего 90,8 долларов США на гектар (га), по сравнению с Узбекистаном и Таджикистаном, где добавленная стоимость на землю составляет более 300 долларов США на 1 га. Основной причиной высокой продуктивности земель в Узбекистане и Таджикистане является выращивание овощей и фруктов; доля овощей и фруктов в валовом объеме продукции составляет около 40\% в Узбекистане и $34 \%$ в Таджикистане.

\section{Таблица 3.2. Сельскохозяйственное использование земель и добавленная стоимость по Центральной Азии, 2016}

\begin{tabular}{|c|c|c|c|c|c|}
\hline & $\begin{array}{c}\text { Использова- } \\
\text { ние земель } \\
\text { (млн. га) }\end{array}$ & $\begin{array}{c}\text { Земля в инди- } \\
\text { вид. пользо- } \\
\text { вании (\%) }\end{array}$ & $\begin{array}{l}\text { Добавленная } \\
\text { стоимость с/х } \\
(2010, \$, м л н .)\end{array}$ & $\begin{array}{c}\text { Добавленная } \\
\text { стоимость на } \\
\text { га }(2010, \$)\end{array}$ & $\begin{array}{l}\text { Добавленная } \\
\text { с/х стоимость } \\
\text { на работника } \\
(2010, \$)\end{array}$ \\
\hline Казахстан & 217,0 & 39 & 8574 & 39,5 & 7766 \\
\hline Узбекистан & 26,8 & 98 & 10493 & 391,5 & 4072 \\
\hline Кыргызстан & 10,6 & 95 & 963 & 90,8 & 1968 \\
\hline Таджикистан & 4,9 & 83 & 1528 & 311,8 & 1936 \\
\hline
\end{tabular}

\$ - доллар США, га- гектар, с/х - сельское хозяйство

Примечание: В колонке «Добавленная стоимость с/х» для всех стран (Казахстана, Кыргызстана и Таджикистана) используются данные за 2016, за исключением Туркменистана - данные за 2010 год.

Источник: Индикаторы мирового развития, 2017

http://datacatalog.worldbank.org/dataset/world-development-indicators

\section{Вклад в ВВП и занятость}

Сразу после распада Советского Союза рабочие вернулись в родные села в поисках временной работы в сельскохозяйственном секторе. По этой причине доля занятых в сельском хозяйстве возросла с 33\% в 1990 году до 52\% в 2001 году (Рисунок 3.3). Доля сельского хозяйства в ВВП увеличивалась до 1996 года, поскольку доля сектора услуг и доля промышленности в ВВП значительно сократились. Увеличение 
доли сельского хозяйства в ВВП и уровне занятости явилось пассивной реакцией на экономические потрясения, которые проявляются в снижении средней производительности труда, измеряемой добавленной стоимостью на одного работника в сельскохозяйственном секторе (1995 год). Аналогичный спад произошел во всех странах бывшего Советского Союза (Свиннен и Вранкен, 2010). С оздоровлением экономики Кыргызстана работники стали трудоустраиваться, помимо сектора сельского хозяйства, в других секторах. Соответственно, доля занятых в сельском хозяйстве к 2016 году снизилась до 30\%. С оттоком работников из сельскохозяйственного сектора, средняя производительность труда увеличилась вдвое (1992 по сравнению с 2016 годом). Производительность труда в сельскохозяйственном секторе все еще остается невысокой, по сравнению с Узбекистаном и Казахстаном.

\section{Рисунок 3.3. Доля сельского хозяйства в ВВП, уровне занятости; добавленная стоимость на работника}

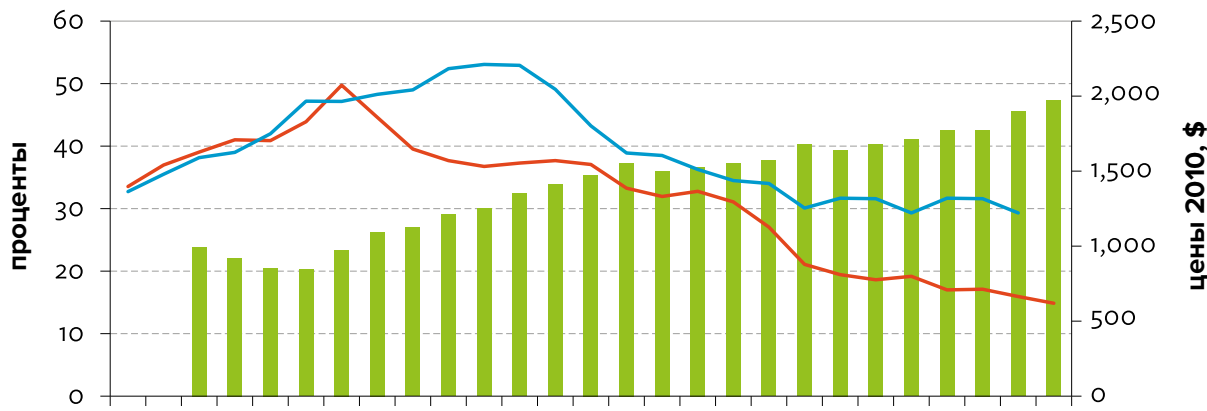

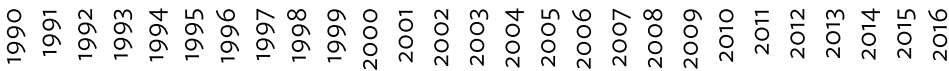

Добавленная стоимость на работника

\section{- Доля к ВВП (\%)}

— Доля занятости (\%)

\$ - доллар США

Источник: Индикаторы Развития 2017,

(https://data.worldbank.org/data-catalog/world-development-indicators), октябрь 2017

\section{Агроэкологические зоны в Кыргызстане}

Территория Кыргызской Республики - горная, большая часть территории (198 $500 \mathrm{~km} 2$ ) расположена выше 1000 метров над уровнем моря, средняя высота над уровнем моря - 2750 метров. Хотя 55\% земли, а это 11 миллионов гектаров, классифицируются как сельскохозяйственные угодья, только 7 процентов сельскохозяйственных угодий, около 1,2 миллиона га, обрабатываются. Обрабатываемые участки расположены вдоль речных долин, около 60\% площадей орошаются (НСК, 2016). Остальная часть сельскохозяйственных угодий используется в качестве пастбищ. Сельскохозяйственные земли могут быть поделены на четыре агроэкологические зоны (Рисунок 3.4).

Северная зона: Эта зона включает в себя долины реки Чуй, окрестностей озера Иссык-Куль; около 66\% обрабатываемых площадей в этой зоне - орошаемые земли (Таблица 3.3). В этой зоне расположена столица страны, Бишкек, самый густонаселенный город (около 1 миллиона человек). Благодаря наличию ирригационных систем и легкому доступу к основным городским рынкам, в этой зоне выращиваются ценные сельскохозяйственные культуры. Сельскохозяйственные животные 


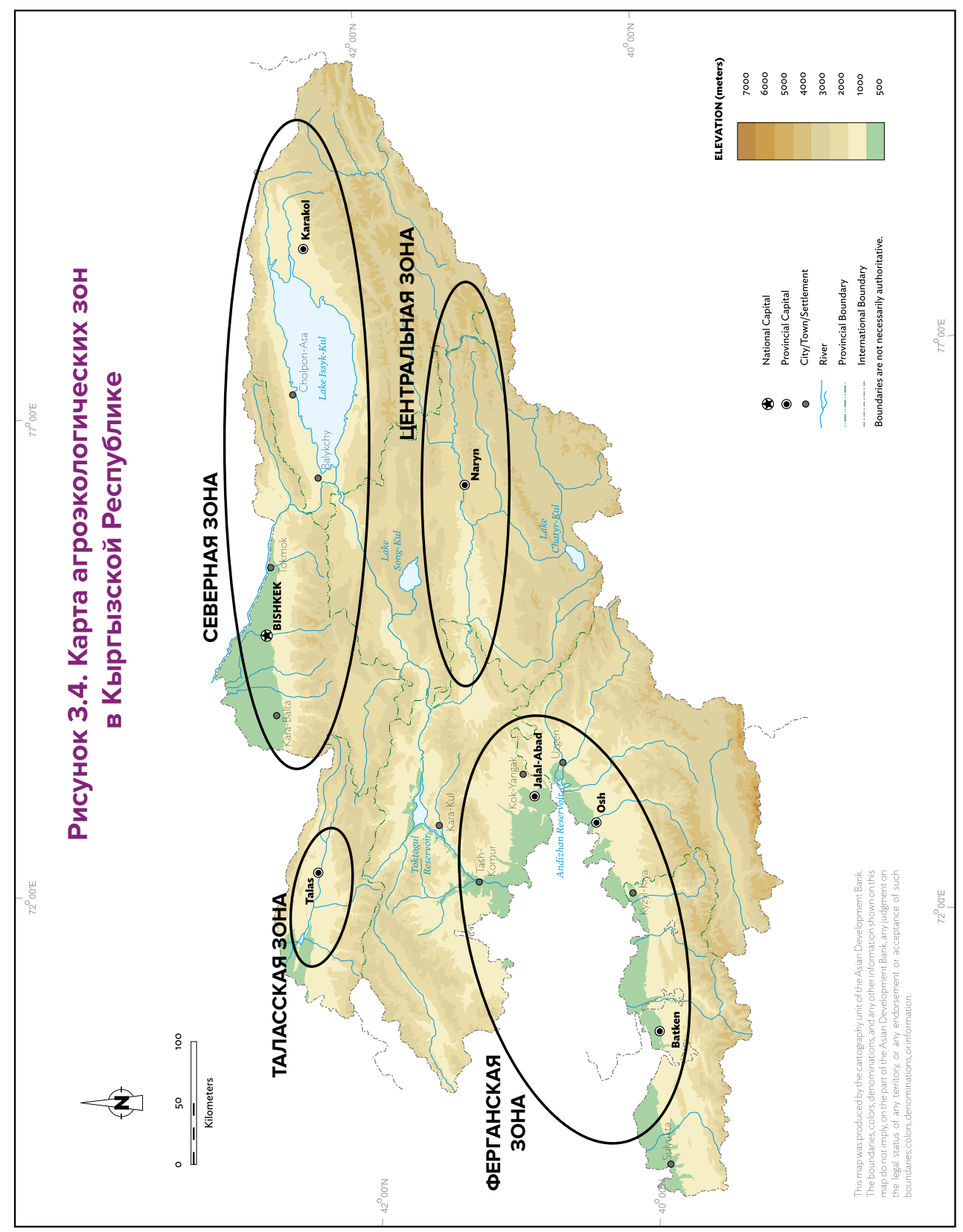

182922A 18KGZ ABV 
содержатся в гористой местности, где производится молоко для городских районов. Доля продукции животноводства в общем объеме сельскохозяйственной продукции составляет около 47\%. Продукция молочного производства используется как для внутреннего потребления, так и для экспорта. Численность сельского населения составляет 1,1 миллиона человек. Всего сельскохозяйственной продукции в 2016 году было произведено на сумму 1 миллиард 603 миллиона долларов США, что составляет 978 долларов США на одного сельского жителя. Большая часть продукции, отправляемой на экспорт, а это, в основном, Казахстан и Россия, второй и третий по значимости рынки, выращивается и перерабатывается в этой зоне.

Зона Ферганской долины (Южная зона): Три страны делят Ферганскую долину (22 ооо км², население составляет 14 миллионов). Узбекистан занимает большую часть долины, Кыргызская Республика и Таджикистан занимают ее окраинные части. Две реки, берущие начало в Кыргызстане, Нарын и КараДарья, в Ферганской долине сливаются и образуют Сырдарью, протекающую через Узбекистан. Доля поливных земель низка, составляет всего 42\%; в долине располагаются густонаселенные кыргызские (например, Ош и Жалал-Абад) и узбекские города. На территории долины, принадлежащей Кыргызстану, проживает 2,5 миллиона человек, хотя объем сельскохозяйственной продукции этой зоны выше только на 23\% объема продукции, производимой в северной зоне, и около половины общего объема сельскохозяйственного производства приходится на животноводство.

Центральная зона (Нарынская). Эта зона расположена вдоль реки Нарын, окруженной крутыми горами. Река вытекает из озера Каракол, собирая ледниковую воду с окружающих гор. Неожиданные наводнения могут причинить серьезный ущерб, существует озабоченность, усугубляемая изменениями климата, по поводу возможного ущерба от наводнений. Общая численность сельского населения составляет около 242 тысяч человек, а общий объем сельскохозяйственного производства составляет 203 миллиона долларов США. Более трех четвертей валового объема сельскохозяйственной продукции приходится на животноводство; в этой зоне поголовье овец составляет более одного миллиона.

Таласская зона: Расположенная вдоль долины реки Талас в северо-западной части Кыргызской Республики, эта зона является изолированной и удаленной от крупных городов страны. Общая площадь пахотных земель составляет около 90 тысяч га, а общий объем сельскохозяйственной продукции составляет около 17,8 миллиарда сомов (около 255 миллионов долларов США). Только 30\% от общего объема сельскохозяйственного производства приходится на животноводство. Эта зона имеет самую высокую продуктивность земель (производство сельскохозяйственных культур), что, в основном, обусловлено выращиванием фасоли на экспорт.

\section{Развитие ирригации}

До обретения независимости общая площадь орошаемых земель, по оценкам, занимала более 80\% пахотных угодий страны и составляла 1,1 миллиона га. Поврежденные или неработающие ирригационные системы привели к сокращению орошаемых площадей, и часть орошаемых угодий стала относится к категории богарных земель (ФАО, 2012). Обслуживание старых советских систем в то время представлялось сложным из-за высокой цены на электроэнергию и отсутствия запасных частей для ирригационного оборудования. Как показано в таблице 3.3 , 
в 2016 году орошалось лишь часть пахотных земель, 61\%, то есть общая площадь орошаемых земель составила 634455 га. Этот вывод очень близок к тому, о чем сообщал АБР (2013). Используя данные Ассоциаций водопользователей (АВП) за 2011 год, АБР (2013) сообщил, что общая площадь орошаемых сельскохозяйственных угодий, числящихся за АВП, составила 636400 га.

\section{Таблица 3.3. Характеристика агроэкологических зон в Кыргызской Республике, 2016}

\begin{tabular}{|c|c|c|c|c|c|c|}
\hline & $\begin{array}{c}\text { Пахотные } \\
\text { земли } \\
\text { 'ооо га }\end{array}$ & $\begin{array}{c}\text { Поливные } \\
\text { земли } \\
\%\end{array}$ & $\begin{array}{c}\text { Население } \\
\text { в сельских } \\
\text { районах } \\
\text { 'ооо }\end{array}$ & $\begin{array}{c}\text { Валовое } \\
\text { с/х произ- } \\
\text { водство, } \\
2016 \\
\text { млн. \$ }\end{array}$ & $\begin{array}{c}\text { Доля } \\
\text { животно- } \\
\text { водства в } \\
\text { ВСП, } 2016 \\
\%\end{array}$ & $\begin{array}{c}\text { Доля } \\
\text { растение- } \\
\text { водства в } \\
\text { ВСП, } 2016 \\
\text { млн. \$ /га }\end{array}$ \\
\hline Северная зона & 479,5 & 65,7 & 1087 & 1063 & 46,7 & 1,2 \\
\hline Ферганская зона & 373,7 & 42,6 & 2517 & 1303 & 50,9 & 1,7 \\
\hline Центральная зона & 92,4 & 94,3 & 242 & 203 & 75,5 & 0,5 \\
\hline Таласская зона & 89,6 & 81,8 & 219 & 255 & 30,1 & 1,9 \\
\hline Всего & 1035 & 61,3 & 4066 & 2824 & 49,2 & 1,4 \\
\hline
\end{tabular}

ВСП - валовой сельскохозяйственный продукт

Источник: НСК. Сельское хозяйство.

http://stat.kg/en/statistics/selskoe-hozyajstvo/ (по состоянию на февраля 2018 года)

Факторы, непосредственно влияющие на водоснабжение, такие как сезонная доступность воды и другие социальные факторы (ограниченный доступ к кредитам, семенам или удобрениям), не позволяют орошать 100\% земель в определенных областях. Например, в Чуйской области площади сельскохозяйственных земель сократились из-за засоления и заболачивания. Считается, что 283700 га орошаемых земель обслуживаются не АВП. Фактических данных по количеству земли, обрабатываемой не АВП, нет. Информация о состоянии и эффективности основных ирригационных систем остается ограниченной и не обновляется. Согласно данным АБР, многие ирригационные системы начали разрушаться в 1990х годах из-за: (1) существенного сокращения инвестиций и бюджетов на эксплуатацию и техническое обслуживание ирригационных систем и (2) ограниченного финансирования для поддержки и укрепления институционального потенциала ведомства, ответственного за надзор и управление системами.

В настоящее время по-прежнему требуется восстановление и улучшение ирригационных систем, однако, необходима тщательная оценка потребностей в системах и определение, какие системы более приемлемы для различных экологических и экономических условий, что позволит определить приоритеты при распределении инвестиций. Например, в Нарынской области необходимы ирригационные системы, смягчающие такие экстремальные погодные риски, как засуха и наводнения, поскольку регион уязвим именно к такого рода рискам. Далее, экономическая отдача от инвестиций в ирригацию, скорее всего, не будет высокой, так как область находится в отдаленном регионе и плотность население невысока. Ирригационные системы для северной и Ферганской зон могут быть спроектированы для выращивания ценных сельскохозяйственных культур. Инвестиции из частных источников могут возместить свои расходы. 


\section{Сельскохозяйственное производство и торговля}

Растениеводство. Пшеница и хлопок считались наиболее важными экономическими культурами, выращиваемыми в советское время, вплоть до первых лет независимости. Растениеводством в советское время занимались колхозы, где производство постоянно контролировалось и субсидировалось государством. Производство пшеницы служило основой продовольственной безопасности и в сознании многих фермеров оставалось приоритетным в трудный период переходной экономики. В 1992-1996 годах производство пшеницы составляло более 30\% от общего объема растениеводства страны, за ним следовали картофель (16\%), ячмень (14\%) и овощи (13\%). В этот же период времени доля промышленных культур, таких как хлопок и табак, снизилась до двух (2) и одного (1) процента соответственно, из-за значительного сокращения посевных площадей (Рисунок 3.5). Сокращение посевов технических культур явилось результатом перераспределения земель, то есть передачи прав собственности на землю индивидуальным хозяйствам.

С 1998 года по настоящее время, доли выращиваемых культур изменились, то есть система сместилась в сторону товарного производства. С 2012-2016 гг. среднее производство картофеля, овощей, кукурузы, сахара, бобовых (в основном, фасоли) и фруктов выросло, так же увеличилось количество посевных площадей, усилилась рыночная ориентация фермеров. Этому способствовали реформы, связанные с приватизацией земель, улучшением доступа к рынкам, увеличением размеров инвестиций в систему ирригации и улучшением сельскохозяйственных знаний о современных технологиях производства (например, о посадочном материале, удобрениях, расширении ирригационных систем и т. д.).

\section{Рисунок 3.5. Среднегодовой объем производства, 1992-1996 и 2012-2016 гг. (тыс. тонн)}

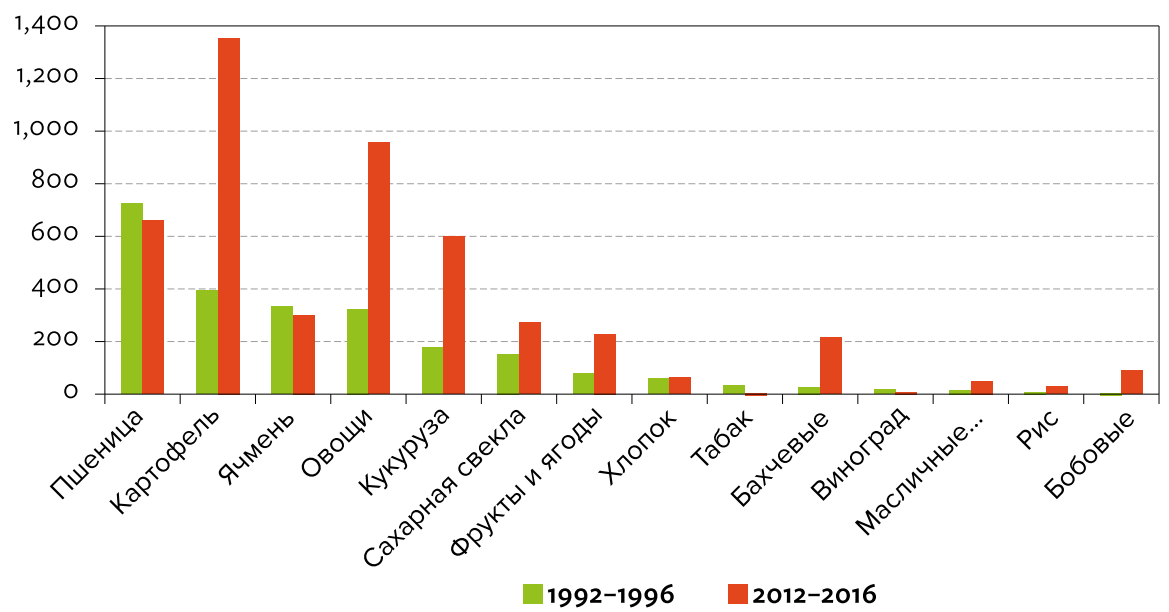

Источник: Национальный статистический комитет. http://stat.kg/en/statistics/selskoe-hozyajstvo/ (по состоянию на февраль 2018 года)

За период между 1992-1996 годами и 2012-2016 годами общий объем сельскохозяйственного производства в стране удвоился. Между обозначенными двумя периодами среднегодовое производство картофеля, овощей и кукурузы увеличилось примерно в три раза. Картофель не только является основной культурой, 
но и продуктом экспорта, наряду с овощами и фруктами. Картофель считается второй по важности продовольственной культурой в стране после пшеницы с точки зрения продовольственной безопасности. Средняя урожайность картофеля составляет менее 16 тонн на гектар, на урожайность влияют определенные факторы, такие как относительно короткий вегетационный период и высокие температуры весной и летом (Абдулхамидов и др., 2015). Семенной картофель импортируется из Европы, в частности, из Нидерландов. Было также отмечено, что производство бобовых (особенно фасоли) выросло многократно, что обусловлено высоким экспортным спросом со стороны Турции. Ниже, в разделе 3.3 в качестве примера, рассматривается вопрос выращивания фасоли.

Изменения в соотношении выращиваемых культур в разных регионах. Соотношения площадей, отведенных под выращивание той или иной культуры, различны; они зависят от агроэкологической зоны страны. Во всех агроэкологических зонах страны, за исключением Нарына, общая площадь обрабатываемых земель увеличилась с периода 1992-1996 до 2012-2016 гг. (Рисунок 3.6). В северной зоне общая площадь обрабатываемых земель увеличилась с 425 тысяч га до 480 тысяч га. Площадь, занятая под пшеницу, увеличилась в северной зоне более чем на 30\%, хотя в других зонах площадь, отведенная под посевы пшеницы, уменьшилась. В северной зоне увеличились посевы высокотоварных культур, таких как картофель, овощи и фрукты, благодаря лучшему доступу на рынки Бишкека и других густонаселенных городов. Единственной группой, потерявшей значительные площади в северной зоне, были промышленные культуры. За последние два десятилетия площади под промышленными культурами сократились с 50 тысяч га до 18 тысяч га.

В Ферганской зоне, известной плодородной долине в Центральной Азии, за последние два десятилетия общая площадь пахотных земель увеличилась на 30\%. Хотя площадь посевов пшеницы значительно сократилась, с 132 тысяч га до 93 тысяч га, площади под посевы овощей и фруктов увеличились в два раза, с 46 тысяч га до 86 тысяч га. Площадь посевов кукурузы увеличилась в три раза, с 21 тысячи га до 68 тысяч га, поскольку спрос на кукурузу, как и другие качественные корма, увеличился; корма необходимы для растущего поголовья скота в стране. Хлопок по-прежнему выращивается в этой зоне. Площадь, засеянная хлопчатником в этом регионе, составляла около 22 тысяч га в период с 2012 по 2016 год, и Ферганская зона единственная, где выращивают хлопок.

В Таласской зоне площади, занятые под бобовые, значительно увеличились с очень незначительного уровня в 1992-1996 гг. до 41300 га в 2012-2016 гг. В этой зоне за последние два десятилетия увеличились площади, отведенные под посевы картофеля, овощей и фруктов. Выращивание бобовых в Таласе началось примерно в 1995 году фермерами, связанными с покупателями из Турции (см. раздел 3.3). Только в Нарынской зоне за последние два десятилетия произошло общее сокращение посевных площадей. Уменьшились площади, отведенные под выращивание пшеницы и ячменя, а животноводство стало основным видом сельскохозяйственной деятельности.

Животноводство. Доля валовой продукции животноводства, по отношению к валовому объему сельскохозяйственного производства, увеличилась с $42 \%$ в 2005 году до $48 \%$ in 2015 году. Овцеводство, ${ }^{3}$ разведение крупного рогатого скота (КРС), разведение лошадей и птицеводство представляют собой четыре основные

\footnotetext{
3 В категорию «овцы» входят козы - 14,6\% в 2015 году.
} 
направления животноводства в Кыргызской Республике. КРС и птица в основном содержатся в домохозяйствах, в сараях на прилегающем к дому подворье. Лошади и овцы содержатся в крестьянских хозяйствах, использующих пастбища. Стада овец и табуны лошадей выпасают на отдаленных летних пастбищах, а затем перегоняют на зимние пастбища, расположенные вблизи сел. Тем не менее, некоторые животные остаются на зимних пастбищах в летний период. В результате зимние пастбища перегружены, а летние (отдаленные) пастбища остаются недоиспользуемыми. Поголовье овец и коз в 1991 году составляло около 10 миллионов голов (в основном, тонкорунные породы овец), в конце 1990-х и начале 2000-х годов поголовье резко сократилось до менее 4 миллионов голов (Акрамов и Омуралиев, 2009); однако, с тех пор оно увеличилось и достигло 5,9 миллионов голов в 2015 году (Рисунок 3.7).

\section{Рисунок 3.6. Распределение площадей под различные культуры по агроэкологическим зонам}

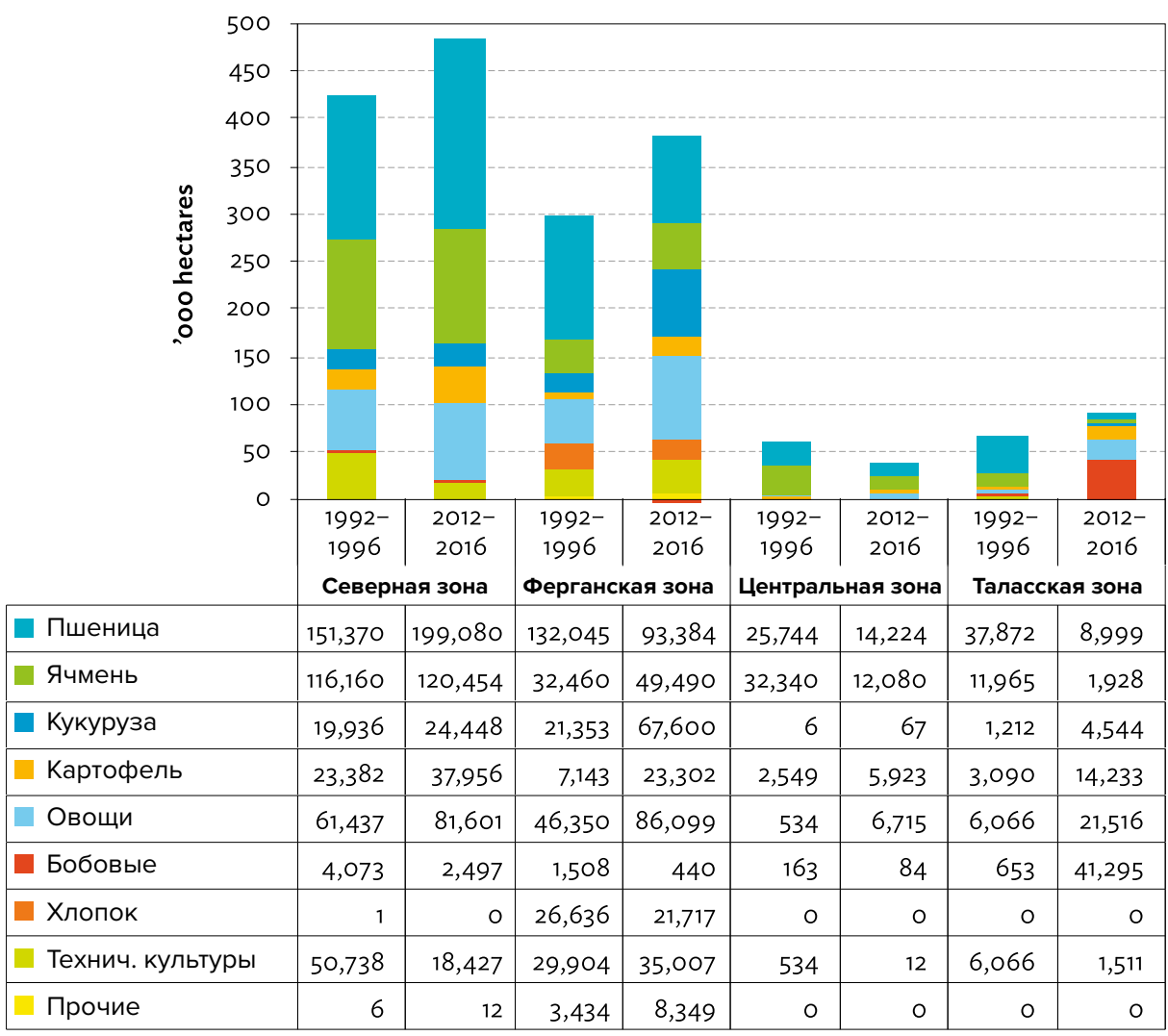

Источник: Национальный Статистический Комитет.

http://stat.kg/en/statistics/selskoe-hozyajstvo/ (по состоянию на февраль 2018 года)

Поголовье скота (КРС) и лошадей увеличилось, хотя с 1990 года наблюдалось уменьшение поголовья в течение нескольких лет, а поголовье свиней уменьшилось (в 1990 году насчитывалось 400 тысяч голов) и уже не восстановилось (Рисунок 3.8). Увеличение поголовья травоядных животных усугубило плохое состояние зимних пастбищ из-за чрезмерного выпаса. Необходимы серьезные 
инвестиции в соответствующие геоботанические исследования для всей страны (ФAО, 2018).

\section{Рисунок 3.7. Динамика роста поголовья овец и птицы в Кыргызстане, 1990 - 2016 гг.}

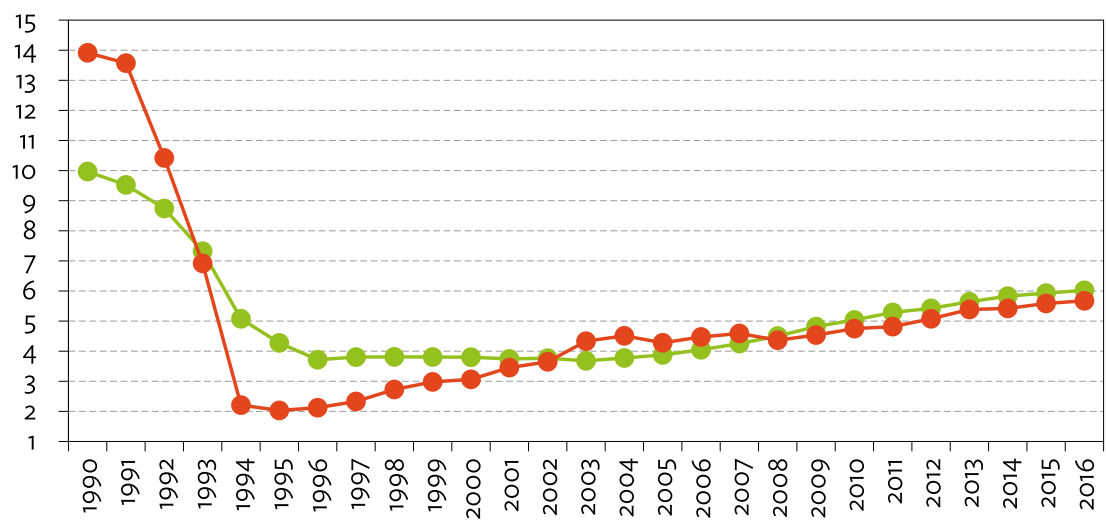

- Овцы и козы - - Птица

Источник: НСК (2016) Национальный статистический комитет.

http://stat.kg/en/statistics/selskoe-hozyajstvo/ (по состоянию на февраль 2018 года)

Рисунок 3.8. Динамика роста поголовья КРС, молочного скота, лошадей и свиней в период с 1990 по 2016 гг.

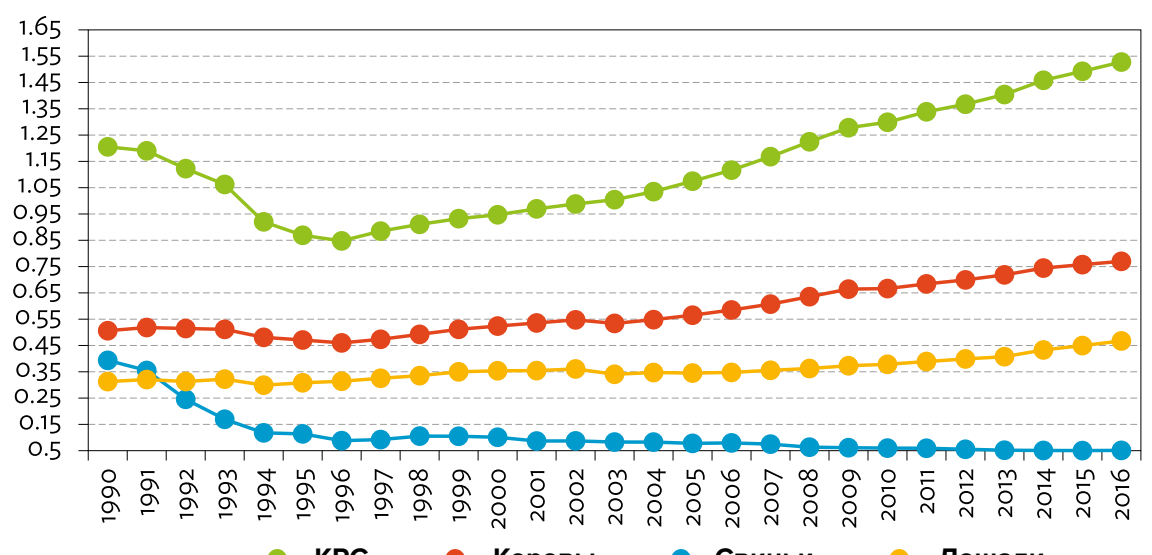

- КРС - - Коровы - Свиньи - Лошади

Источник: Национальный статистический комитет.

http://stat.kg/en/statistics/selskoe-hozyajstvo/ (по состоянию на февраль 2018 года)

Распределение поголовья скота по регионам. Таблица 3.4 показывает распределение поголовья скота по агроэкологическим зонам. Северная и Ферганская зоны благоприятны для разведения и содержания КРС. Чуйская и Ошская области густо заселены, там расположено множество домохозяйств. В отличие от этих областей, горные районы Жалал-Абадской и Нарынской областей малонаселенны; и, ведя кочевой образ жизни, фермеры летом перегоняют животных на горные пастбища. Основными районами овцеводства являются Нарынская (цен- 
тральная) и северная зоны. В этих зонах в 2015 году было зарегистрировано около $72 \%$ всех овец. Темпы роста поголовья овец варьируются от региона к региону, и самый низкий рост приходится на Баткенскую область, где поголовье овец в период с 2006 по 2015 год увеличилось только на 16\%. В то же время количество овец в Жалал-Абадской области почти удвоилось за последнее десятилетие; темпы роста составляют 98\%. Поголовье овец в Жалал-Абадской области увеличилось с $16 \%$ от всего количества овец в 2005 году, до 21\% в 2015 году. Концентрация овец в регионе, в основном, зависит от наличия пастбищ.

\section{Таблица 3.4. Распределение поголовья скота по агроэкологическим зонам, 2016}

\begin{tabular}{|c|c|c|c|c|c|}
\hline Зона & $\mathrm{KPC}$ & $\begin{array}{l}\text { Молочный } \\
\text { скот }\end{array}$ & $\begin{array}{c}\text { Овцы и } \\
\text { козы }\end{array}$ & Лошади & $\begin{array}{c}\text { Среднегодовой } \\
\text { надой/ корову }\end{array}$ \\
\hline & КоЛ-во голов & кол-во голов & кол-во голов & кол-во голов & $\mathrm{K} \Gamma$ \\
\hline Северная зона & 496254 & 244918 & 1550925 & 164353 & 2507 \\
\hline Ферганская зона & 810242 & 417302 & 2910563 & 168592 & 1740 \\
\hline Нарынская зона & 153570 & 74291 & 1023147 & 108889 & 1471 \\
\hline Таласская зона & 66991 & 33250 & 537555 & 25311 & 2253 \\
\hline Всего & 1527057 & 769761 & 6022190 & 467145 & 1980 \\
\hline
\end{tabular}

Источник: HCK. http://stat.kg/en/statistics/selskoe-hozyajstvo/ (по состоянию на февраль 2018 года)

В Ошской, Жалал-Абадской, Нарынской и Иссык-Кульской областях содержится 80\% лошадей от общего количества по стране, а в Баткенской области только 2\% всех лошадей по Кыргызстану. Поголовье лошадей увеличилось на 25\% в Жалал-Абадской области и на 67\% - в Чуйской. В период с 2005 по 2015 гг. поголовье лошадей в Чуйской области увеличилось с 10\% до 13\% от общего количества по стране. В Иссык-Кульской области за тоже десятилетие поголовье лошадей увеличилось с 18\% до 21\%. Нарынская и Жалал-Абадская области вновь показывают, что основными заводчиками лошадей являются крестьяне-фермеры.

Региональное распределение птицеводства также выявляет некоторые интересные факты. Данные по Чуйской, Ошской и Жалал-Алабадской областям указывают на то, что мелкие землевладельцы (включая кочевые и крестьянские хозяйства) держат значительное поголовье птиц-30\%, 20\% и 22\% соответственно -а доля поголовья птиц в остальных областях незначительна. В Нарынской области произошло уменьшение поголовья птицы в 2015 году на шесть (6) процентов по сравнению с 2005 годом. В Таласской области наблюдается умеренный рост поголовья птицы на уровне шести (6) процентов. Наиболее значительный рост произошел в Жалал-Абадской области, на 57\%, соответственно, доля Жалал-Абадской области (относительно общего количества птицы в стране) увеличилась с 19\% в 2005 году до 22\% в 2015 году. За тот же период доля Ошской области в разведении птицы также выросла с 18\% до 20\%.

Сельскохозяйственная торговля. Кыргызская Республика является чистым импортером сельскохозяйственной продукции (Рисунок 3.9), с общей стоимостью импорта, возросшей к 2013 году до 600 миллионов долларов США (цены 2010 года, доллары США), но затем, к 2016 году, импорт сократился до 200 миллионов долларов. Экспорт сельскохозяйственной продукции достиг своего пика в 2013 году на уровне 200 миллионов долларов США и снизился в 2016 году до 80 миллионов долларов США. Импорт сельскохозяйственной продукции в 2016 
году составил около 16\% от общего объема импорта, а доля экспорта сельскохозяйственной продукции в 2016 году составила около 14\%.

\section{Рисунок 3.9. Объемы сельскохозяйственного импорта и экспорта, 2006-2016 гг.}

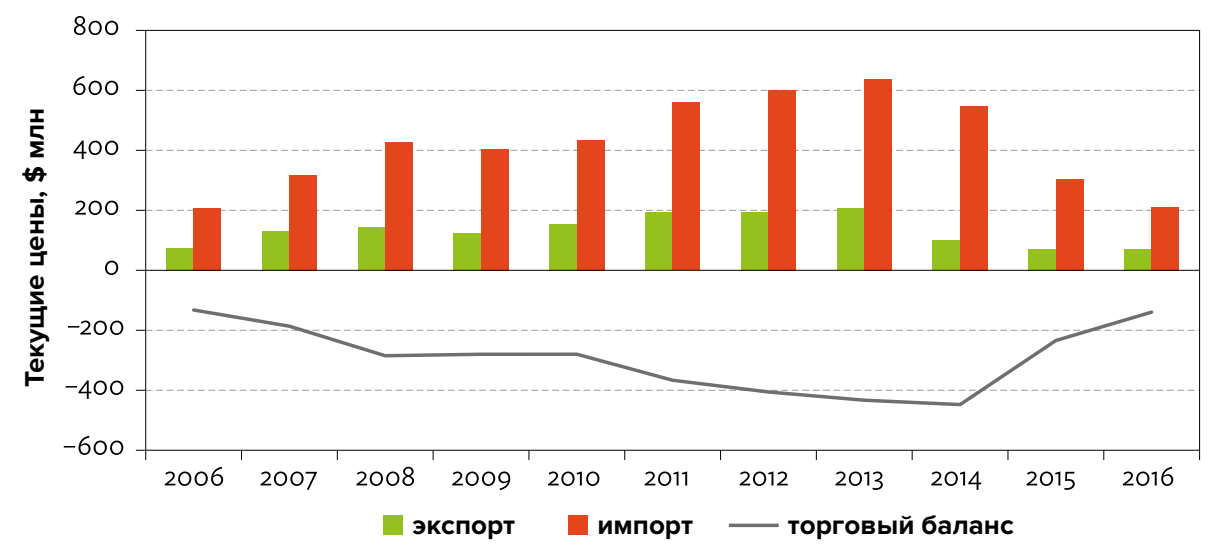

Источник: Статистика международной торговли товарами ООН, 2017.

https://comtrade.un.org/db/default.aspx , (по состоянию на октябрь 2017г.)

Крупнейшим экспортером сельскохозяйственной продукции в Кыргызскую Республику в 2016 году был Казахстан (Рисунок 3.10), а общая стоимость экспорта сельскохозяйственной продукции составила 159 миллионов долларов США. Вторым по величине экспортером стала Российская Федерация с объемом экспорта в денежном выражении 146 миллионов долларов США. Большая часть импорта сельскохозяйственной продукции из Российской Федерации поступает через Казахстан автомобильным транспортом; таким образом, импорт сельскохозяйственной продукции поступает через таможню на кыргызско-казахской границе. В свою очередь, Кыргызская Республика экспортирует сельскохозяйственные товары в Казахстан и Российскую Федерацию в объеме 34 и 40 миллионов долларов США, соответственно, что значительно ниже, чем импорт из этих стран.

Турция является самым крупным импортером сельскохозяйственной продукции из Кыргызстана. Четвертым импортером (по объему продукции) является Китайская Народная Республика. Общий объем экспорта сельскохозяйственной продукции в Турцию составил в 2016 году 42,6 миллиона долларов США. Фасоль обычная - главный экспортный товар для Турции. Турция является единственным чистым импортером Кыргызской сельскохозяйственной продукции среди пяти самых крупных торговых партнеров, как показано на Рисунке 3.10.

Среди пяти крупнейших торговых партнеров по импорту-экспорту сельскохозяйственной продукции, Узбекистан занимает саму маленькую долю, что немного удивительно, поскольку Кыргызская Республика и Республика Узбекистан имеют общую протяженную границу в Ферганской долине В 2017 году страны согласились начать торговый обмен. Торговля между двумя странами повлечет за собой увеличение объема торговли сельскохозяйственной продукцией, поскольку обе страны делят территорию Ферганской долины, знаменитой своими благоприятными сельскохозяйственными условиями. Предполагается увеличение производства и объемов переработки и торговли хлопком, овощами и фруктами между двумя странами в ближайшие годы. 


\section{Рисунок 3.10. Импорт и экспорт сельскохозяйственной продукции с} определёнными соседними государствами, 2016 (млн, доллары США)

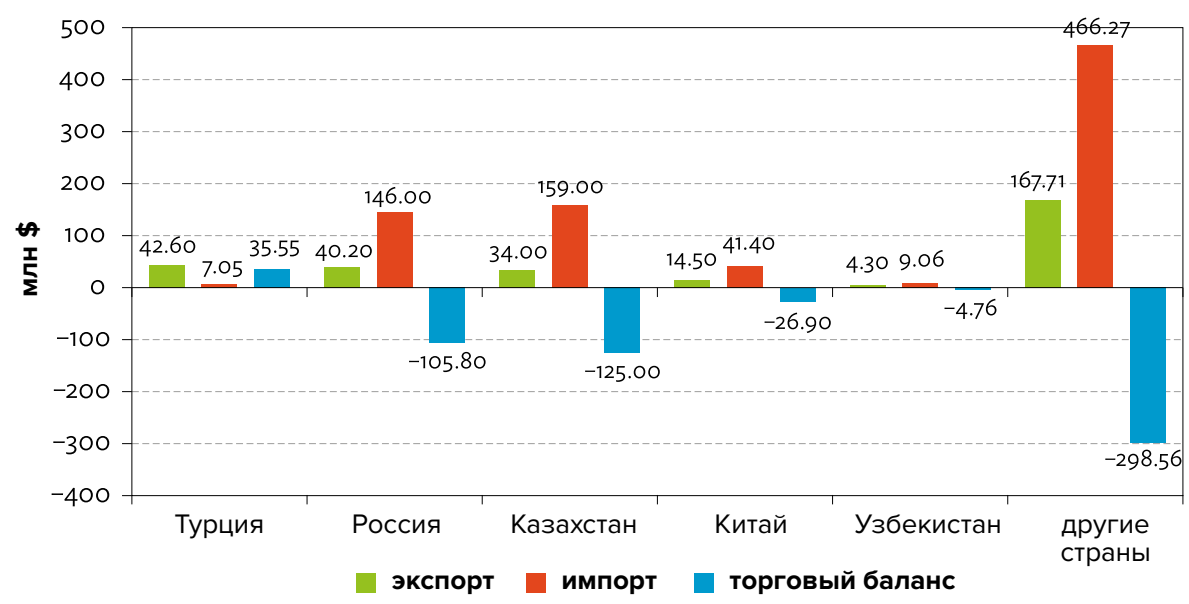

Источник: расчеты авторов на основе статистики международной торговли товарами ООН, 2017. https://comtrade.un.org/db/default.aspx, (по состоянию на октябрь 2017 года)

Сельскохозяйственный импорт и экспорт. Общая стоимость экспорта фасоли составляет около 50 миллионов долларов США, она является основным экспортным сельскохозяйственным продуктом (Рисунок 3.11). Фасоль в Кыргызстане, в основном, выращивается в Таласской области. Около половины всего экспорта фасоли идет в Турцию, частично экспортируется в Российскую Федерацию и в другие страны.

\section{Рисунок 3.11. Сельскохозяйственный экспорт Кыргызской Республики:} Объемы и страны-получатели, 2014 и 2016 гг.

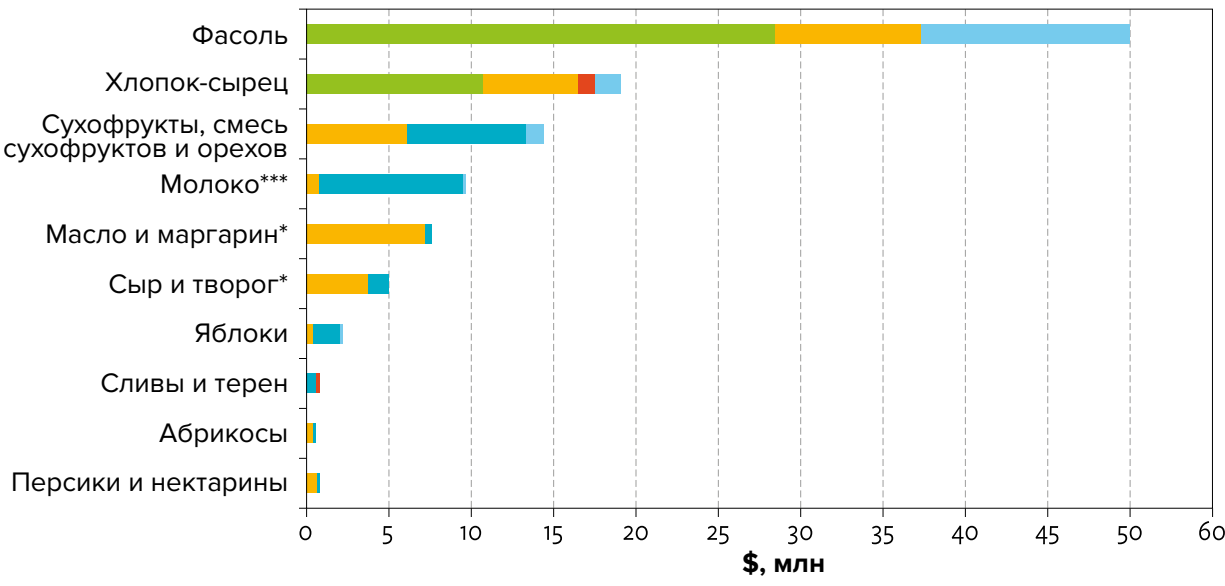

Турция Россия Казахстан Узбекистан Китай др. странь

Источник: статистика международной торговли товарами ООН за 2016. https://comtrade.un.org/db/default.aspx, (по состоянию на март 2018 года);

*Данные за 2014 г по производству сливочного масла. ФАО, http://fao.org/faostat/en/\#data (по состоянию на март 2018 года); 
**Данные за 2014 г по производству сыра из коровьего молока. ФАО, http://fao.org/faostat/en/\#data (по состоянию на март 2018 года);

*** Данные НСК за 2016. http://stat.kg/en/statistics/selskoe-hozyajstvo/ (по состоянию на март 2018);

Все остальные данные относятся к 2016 году. UN Comtrade. https: //comtrade.un.org/db/default.aspx (по состоянию на март 2018 г.)

Несмотря на снижение объемов производства хлопка-сырца, он остается важным экспортным продуктом. Турция является важнейшим рынком, импортирующим более 50\% хлопка-сырца из Кыргызстана. Турция также импортирует сухофрукты и орехи. Российская Федерация импортирует фасоль, хлопок-сырец, сухофрукты и орехи, а также масло и другие молочные продукты из Кыргызской Республики. Часть импортируемого из Кыргызской Республики молока может быть переработана в Казахстане для дальнейшего экспорта в Россию. Северная зона наладила рыночные каналы экспорта молочной продукции в Казахстан и Российскую Федерацию. В свою очередь, Кыргызская Республика импортирует из Казахстана пшеницу, а из России - растительное масло и сахар. Основным сельскохозяйственным экспортным продуктом Кыргызстана в Китайскую Народную Республику является куриное мясо.

\section{3. Развитие, ориентированное на экспорт: Два тематических исследования}

\section{Фасоль обыкновенная}

Развития сектора фасоли. Фасоль стала экспортной культурой благодаря усилиям курдских фермеров, которые имели доступ к турецким фирмам-импортерам бобовых ${ }^{4}$. Вначале фасоль выращивали в Кара-Бууринском районе, где компактно проживают курды ${ }^{5}$. Курды составляют этническое меньшинство проживающих в Кара-Бууринском и Манасском районе (2,5\% населения региона). До появления турецких компаний курды выращивали фасоль в небольших количествах для собственных нужд. В связи с устойчивым спросом на фасоль и ростом закупочных цен после появления конкурентоспособных фирм, кыргызские фермеры также начали выращивать фасоль, со временем увеличивая площади. Устойчивый спрос на фасоль со стороны турецких фирм-экспортеров сыграл ключевую роль в продвижении фасоли как основной культуры региона. Выращивание фасоли в коммерческих целях началось в конце 1990-х, но широко начали ее выращивать после 2005 года. На рисунке (3.12) показана общая площадь по Кыргызстану и по Таласской области, отведенная под выращивание бобовых. Доминантным продуктов в группе бобовых является фасоль. Как видно из рисунка 3.12, вне Таласской области, площади, отведенные под выращивание бобовых, незначительны. Общая площадь под бобовыми составляла в 2017 году 55 тысяч га, для сравнения - в 1999 году площадь была равна 5 тысячам гектаров. Экспортируется фасоль в Турцию, Восточную Европу (Болгарию, Черногорию и Сербию) и другие страны.

За период с 2009 по 2016 год, в среднем, Кыргызстан отправлял на экспорт от 60 до 70 тысяч тонн фасоли в год. Стоимость экспортируемой фасоли варьируется от года к году из-за колебаний цены на фасоль на международных рынках.

4 Фермеры-курды начали выращивать фасоль на экспорт в 1995 году на 230 гектарах благодаря связям с турецкой фирмой Робин (Болотова, 2010)

5 Курдов в 1930 х годах интернировали с Кавказа а Среднюю Азию. Это было во время Сталинской эпохи (Минахан, 2004). 
Рисунок 3.12. Динамика роста площадей, отведенных под выращивание бобовых по Кыргызстану и Таласской области, 1999-2017 гг., (тысячи га)

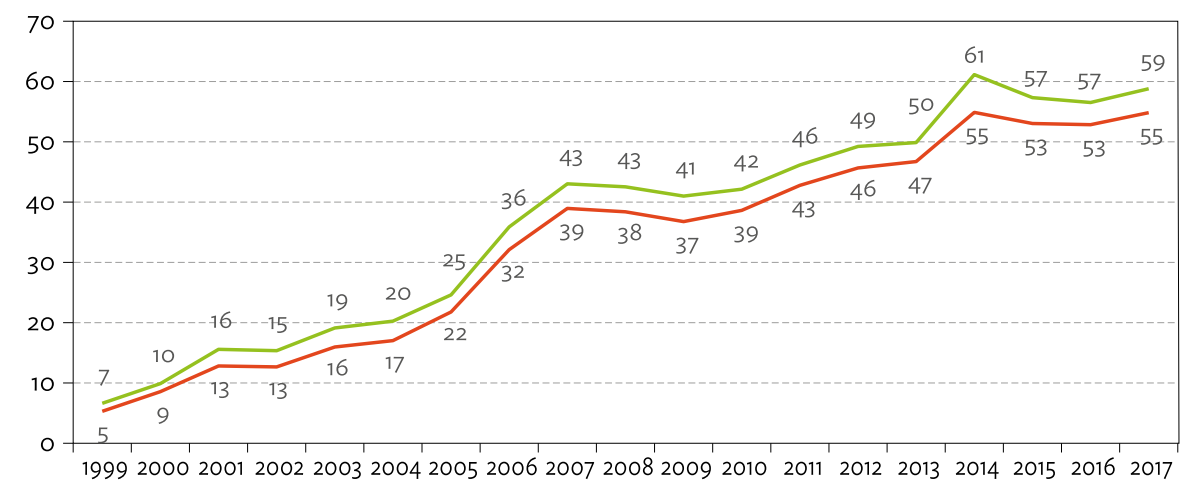

— Площади, отведенные под бобовые по Кыргызстану
— Площади, отведенные под бобовые по Таласской области

Источник: Национальный статистический комитет Кыргызской Республики.

http://stat.kg/en/statistics/selskoe-hozyajstvo (по состоянию на март 2018 года).

Ежегодный доход от экспорта фасоли в указанный период составлял в среднем 45-50 миллионов долларов США. Экспорт фасоли в общем объеме экспорта из Таласской области составляет 92-96\% (НСК, 2015). В 2016 году доля основных импортеров (Турции и стран Восточной Европы) достигла 73\% (Рисунок 3.13).

\section{Рисунок 3.13. Экспорт фасоли из Кыргызстана на основные рынки, 2009 - 2016 гг., (тысячи тонн)}

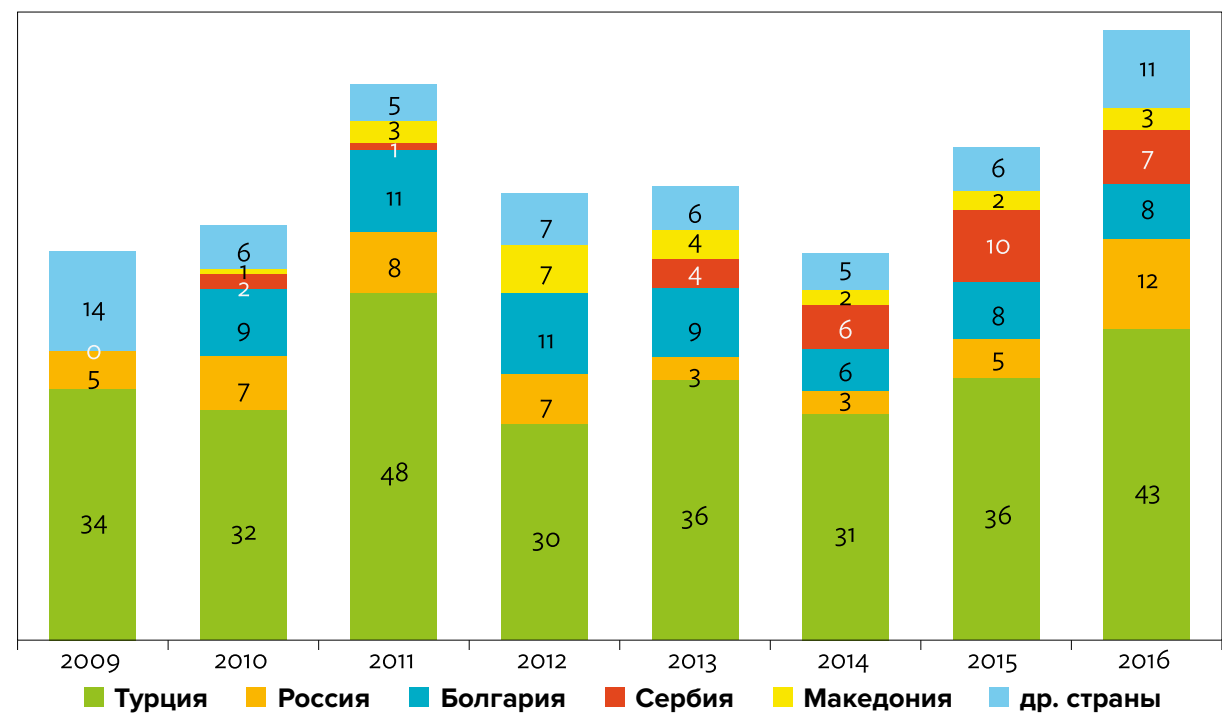

Источник: Статистика международной торговли товарами ООН, Правительство Кыргызской Республики

В 2013 году закупочная цена поднималась до 100-120 сом/кг (что эквивалентно приблизительно 2,06-2,48 доллара США), это была самая высокая цена. 
Резкое поднятие цены произошло из-за недостатка поставок фасоли на мировые рынки ключевыми экспортерами. Взимание таможенной пошлины в размере 19,3\% на импортируемые в Турцию бобы в 2014 году спровоцировало снижение закупочной цены на кыргызскую фасоль. Снижение закупочных цен на фасоль повлекло за собой определенное снижение посевных площадей, как в стране, так и в области, в период с 2015 по 2016 годы.

Развитие цепочки добавленной стоимости фасоли. В цепочку добавленной стоимости для фасоли (Рисунок 3.14) входят: фермер - производитель, фермер - поставщик, занимающийся выращиванием, закупкой и продажей фасоли, коммерческий дилер, экспортер из Кыргызстана в другие страны, а так же цеха по очистке фасоли и транспортные компании. Описание каждого участника этой цепочки дано ниже. Данные были собраны во время поездок на места в период с ноября 2016 по февраль 2017 года (Тилекеев и др. 2018).

\section{Рисунок 3.14. Цепочка создания добавленной стоимости}
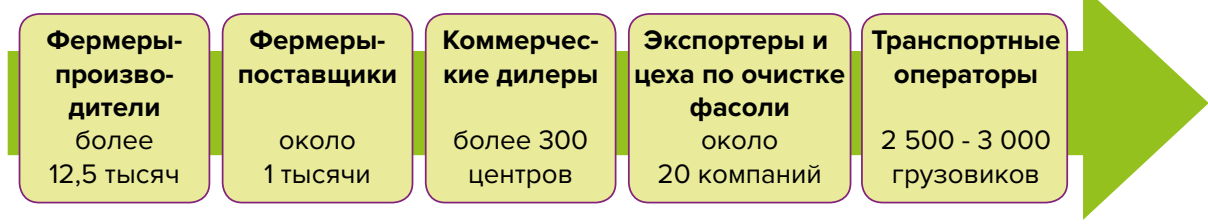

Источник: Оценка автора.

Фермеры-производители и фермеры-поставщики. Рассмотрим две группы фермеров: (1) фермеры-производители, производящие бобы и другую сельскохозяйственную продукцию, и (2) фермеры-поставщики, то есть те, кто не только производит, но и закупают бобы у соседних фермеров и перепродают их рыночным агентам. Обе группы производят фасоль на своих участках (площадь участка составляет около 2 гектаров орошаемых земель) и некоторые фермеры берут в аренду дополнительные участки для расширения своей деятельности. Фермеры в районах Бакай-Ата и Кара-Буура засаживают около 70\% своей земли фасолью. Бобовые приносят 93\% всех доходов от растениеводства в этих двух районах. Наиболее популярный сорт фасоли среди фермеров - белая фасоль; не менее 70\% всех бобовых, выращиваемых в регионе, - именно белая фасоль. Фермеры понимают, что основными факторами, влияющими на урожайность, являются: хорошие семена, удобрения (минеральные и органические), а также регулярность полива. Многие фермеры осознают необходимость соблюдения севооборота для поддержания хороших урожаев, однако, они не следуют этой практике, поскольку боятся упустить прибыль, теряя благоприятное время. В среднем фермер-поставщик успевает закупить и перепродать до 200-250 тонн фасоли за сезон.

Коммерческие дилеры - оптовики. Основным активом для оптовиков является складские помещения, площадь которых варьируется от 50 до 1500 м². Крупные склады, площадью 1 ооо м² и более, обычно оснащены оборудованием для очистки и сортировки фасоли. Ежегодный объем закупок фасоли на одного оптовика колеблется от 1 ооо до 10 ооо тонн. Послеуборочная обработка бобовых постепенно становится более механизированной. Цеха по очистке бобов зарегистрированы как хозяйствующие субъекты (общества с ограниченной ответственностью или индивидуальные предприниматели) и имеют штат от 5 до 30 человек в зависимости от сезона. 
Экспортеры. Завершающим этапом цепочки добавленной стоимости фасоли является коммерческая фирма-экспортер. Более 60 компаний в Кыргызстане продают фасоль на экспорт, однако, большинство компаний принадлежит 10-15 крупным игрокам на рынке, т. е. четыре - пять различных компаний принадлежат одному учредителю (фирме или лицу). Основная организационная форма фирм-экспортеров - общество с ограниченной ответственностью, а иногда индивидуальный предприниматель. Многие компании имеют партнерские отношения с торговыми фирмами из Турции. Средний уровень поставок одной компании составляет 8500 тонн груза в год.

Транспортные компании. Автомобильный транспорт является основным средством транспортировки грузов. ${ }^{6}$ В Таласской области имеется несколько мест, в Кара-Бууринском и Бакай-Атинском районах, где водители ожидают получения заказов на грузоперевозки. Заказы на перевозку согласовываются и оформляются в режиме онлайн, при этом транспортные компании, в основном, являются зарубежными. Казахстанские грузоперевозчики, базирующиеся в Шымкенте или Таразе, работают на рынках ЕАЭС. Стоимость доставки колеблется от 2000 до 2400 долларов США за 1 грузовик грузоподъёмностью в 22 тонны. Маршрут проходит через Тараз, Шымкент, Атырау и Астрахань (Российская Федерация). Пункт назначения - Южный федеральный округ (Ростов-на-Дону, Краснодарский край). Казахстанские водители используют действующую в Российской Федерации систему взимания платы «Платон» (Платон 2019), что затрудняет и делает проезд иностранных перевозчиков по России более дорогостоящим. Срок доставки в Российскую Федерацию составляет от трех до четырех дней; европейские маршруты, в основном, обслуживаются турецкими грузоперевозчиками. Стоимость доставки одного грузовика в Европу составляет 4000 - 5000 долларов США.

Основные проблемы и перспективы выращивания фасоли. За последние два десятилетия выращивание бобовых в Таласской области превратилось в основной источник дохода. Масштабы и скорость распространения новой культуры являются беспрецедентными для сельского хозяйства Кыргызстана. Очевидно, возможность экспорта и доступ к международным рынкам являлись решающими факторами успеха. Еще одним важным фактором производства фасоли является высокий уровень конкуренции на всех этапах цепочки добавленной стоимости. Конкуренция и сопутствующая ей малая концентрация «добавленной стоимости» на каком-либо участке цепочки способствуют разделению выгоды от экспорта среди всех участников производственного процесса и поддержанию разумной рентабельности производства. Практически полное отсутствие государственного регулирования позволило сформировать отрасль как саморегулирующийся кластер с относительно низкими транзакционными издержками. Природные и климатические условия, благоприятные для выращивания фасоли, географическая концентрация производства, удобное расположение рядом с международными автомобильными и железнодорожными магистралями также сыграли свою роль в развитии данного сектора.

Несмотря на достигнутые успехи, упомянутый сектор сталкивается с рядом производственных и институциональных препятствий и ограничений. Эти препятствия и ограничения следующие:

Альтернативой автомобильному транспорту может служить железнодорожный транспорт от станции Маймак, расположенной рядом с Казахской границей. В начале 2000-х годов транспортировка проводилась через Маймак, но проблемы с инфраструктурой и местными жителями не позволили развивать эту возможность. На данный момент только 10\% всех перевозок осуществляются железнодорожным транспортом. 
- В Таласской области не осталось больше «свободных» земель для выращивания фасоли, ставшей монокультурой. Севооборот не соблюдается, а это ухудшает состояние почвы; дальнейшее возделывание фасоли принесет вред земле и экологической ситуации в регионе и, безусловно, приведет к уменьшению урожайности.

- Знания мелких фермеров о сельскохозяйственных технологиях ограничены. Недостаточное использование удобрений и химикатов снижает плодородие почвы и способствует росту болезней растений и распространению вредителей.

- Уровень механизации недостаточен; применяемый ручной труд не позволяет увеличить производительность труда и затрудняет развитие сектора.

- Государственная поддержка экономически выгодных поставок семян и средств защиты растений - неэффективна. Требуется большая поддержка фермеров в вопросах приобретения знаний агрономического и маркетингового характера.

- Нет спроса на фасоль внутри Кыргызстана.

Ситуация с фасолью в Таласской области представляет собой успешный пример регионального развития и отличным материалом для дальнейшего изучения и распространения в разных уголках Кыргызстана со схожими климатическими и почвенными характеристиками. Важно мелким фермерам оказывать надлежащую поддержку, консультативную и техническую, в целях уменьшения их уязвимости и для преодоления возникающих барьеров.

\section{Молоко и молочные продукты}

В соответствии с данными НСК, около 70\% продуктов молочного производства идет на продажу, причем большая часть - это свежее молоко. В среднем производится около 1,5 миллиона тонн молока в год, но перерабатывается только малая доля. В то же время производство сливочного масла уменьшилось с 12 до 4 тысяч тонн. В стране работают всего несколько компаний по переработке молока. Большинство мощностей по переработке сконцентрировано в Бишкеке или Чуйской долине, где и перерабатывается около 60-70\% общего объёма. В Таласе начинают работу еще несколько компаний по переработке молока. В Иссык-Кульской области производится одна треть всего производимого в Кыргызстане сыра. В остальной части страны молоко потребляется в чистом виде в домохозяйствах или продается без переработки.

Среди молочных продуктов, идущих на экспорт из Кыргызстана, можно назвать такие продукты как сыр, сливочное масло, творог, пахта, йогурт и мороженое. За последнее десятилетние объемы экспорта варьировались (Рисунок 3.15). В 2017 году общий объем экспорта молочных продуктов превысил 40 млн долларов США, невзирая на некоторое недопонимание, возникшее между Кыргызстаном и Казахстаном. Казахстан указывал на то, что на перерабатывающих предприятиях в Кыргызстане не хватает лабораторий для сертификации товаров, отправляемых на экспорт. Вступление в ЕАЭС требует открытия биолабораторий, сертифицирующих продукцию на соответствие стандартам ЕАЭС. Недопонимание разрешилось и торговля вернулась в свое русло. Для поддержания и увеличения экспортного товарооборота с Российской Федерацией и Казахстаном следует впредь избегать подобных ситуаций. 
Институциональные механизмы играют важную роль в оказании технической помощи, ветеринарных услуг (таких, как искусственное осеменение и вакцинация), а также в сборе и переработке молока. Хотя молочные кооперативы предоставляют такие услуги в некоторых странах, фермеры пытаются продавать свое молоко частным торговцам, но по более высокой цене в сезон низких надоев, это подрывает принципы работы кооперативов и не позволяет кооперативам оказывать технические и ветеринарные услуги. Без надлежащего регулирования сбыта молока некоторые члены кооператива, продавая молоко «на сторону», будут наносить вред работе молочных кооперативов.

\section{Рисунок 3.15. Структура экспорта молока и молочных продуктов из Кыргызстана, 2006 - 2017 гг., (млн долларов США)}

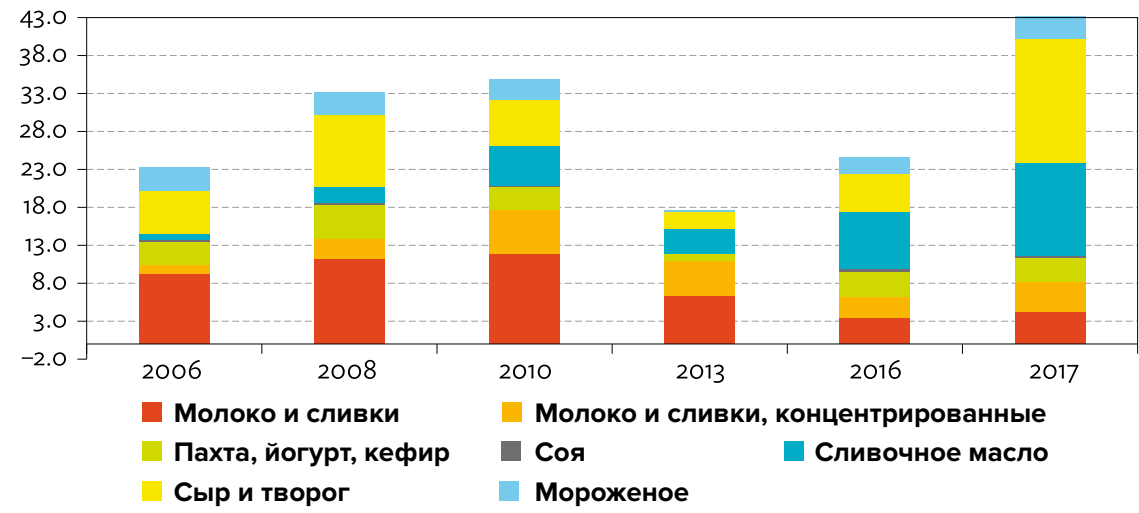

SITC - MCTK - Международная стандартная торговая классификация

Примечание: Молочные продукты - это молоко и сливки, неконцентрированные или без добавления сахара (Код СМТК - 0401); молоко и сливки, концентрированные, с добавлением сахара (СМТК 0402); пахта, йогурт, кефир (СМТК 0403); соя (СМТК 0404); сливочное масло (СМТК 0405); сыр и творог (СМTK 0406); и мороженое (СМTK 2105).

Источник: Расчеты авторов на основе данных ООН Comtrade http://comtrade.un.org/data/bulk (данные по состоянию на 4 марта 2018 года)

\section{4 Рекомендации}

С момента обретения независимости Кыргызская Республика достигла значительных успехов в развитии сельского хозяйства. Правительство, в основном, завершило земельную реформу и разработало законодательную базу для ассоциаций водопользователей, комитетов по управлению пастбищами и сельских консультативных служб. Фермеры постепенно перешли на сельскохозяйственные системы, ориентированные на рынок. Производство фасоли и развитие этого сектора в Таласской области находится в руках частного сектора. Правительство могло бы продолжать оказывать помощь развитию сельскохозяйственного сектора, как это предусмотрено в новой пятилетней программе «Единство. Доверие. Созидание», и быть готовым принимать и управлять сельскохозяйственными рисками. Региональное развитие является еще одним важным аспектом государственной политики; и, как было указано выше, сельскохозяйственная политика оказывает значительное влияние на региональное развитие. 
Успешный пример экспорта фасоли из Таласской области демонстрирует важность международных знаний и доступа к рынкам. Существует ряд вопросов, вызывающих озабоченность: (1) в Таласской области практически не осталось «свободных» земель для увеличения посевов фасоли (2) эффект выращивания монокультуры, (3) ограниченный экспорт (в Турцию и Россию) делает сектор уязвимым к внешним шокам. Поскольку сельскохозяйственный сектор региона в значительной степени зависит от фасоли, устойчивость производства фасоли имеет решающее значение для Таласской области.

Молочная промышленность является основной отраслью промышленности в северной зоне. Молоко и молочные продукты являются важной экспортной продукцией и экспортируются в Казахстан и Россию. Конфликтные ситуации на границе между странами представляют собой экономические риски, и правительству необходимо работать, дабы избежать подобных рисков. Безопасность пищевых продуктов, снижение транзакционных издержек, связанных с прохождением таможни, улучшение бизнес среды в молочной промышленности - важные вопросы, которым следует уделить особое внимание.

Поскольку Центральная зона зависит от животноводства, она подвержена рискам, связанным со здоровьем животных. Программы вакцинации в стране слабы и требуют особого внимания, фермеры имеют недостаточно знаний о профилактике заболеваний и борьбе с ними, а это ведет к опасениям за безопасность получаемой продукции. Очевидно, что именно в этом вопросе необходимо вмешательство правительства.

Открытие торговых отношений между Кыргызской Республикой и Узбекистаном на основе Соглашения двух стран, подписанного в 2017 году, как ожидается, приведет к увеличению объемов торговли сельскохозяйственной продукцией. Сельскохозяйственный сектор в Ферганской долине ${ }^{7}$ может значительно выиграть от увеличения объемов торговли между двумя странами. Но, предварительно, фермерам, перерабатывающим фирмам и трейдерам необходимо пересмотреть свою деятельность и привести ее в соответствие с новыми условиями торговли. Правительству, возможно, придется содействовать развитию торговли сельскохозяйственной продукцией. Расширение торговли на юге будет способствовать сбалансированности торговли внутри страны

7 Исследование Азиатского банка развития по «Выявлению ограничений развития стоимостной цепочки в секторе садоводства в Ферганской долине» направлено на анализ бизнес возможностей и определение сфер для поддержания их инвестициями и поддержки, необходимых для развития стоимостной цепочки в секторе садоводства в этой долине. Продолжающееся исследование планируется выполнить к 2020 году. 


\section{Приложение: \\ СТРАТЕГИЯ УСТОЙЧИВОГО РАЗВИТИЯ КЫРГЫЗСКОЙ РЕСПУБЛИКИ}

Цели для сельскохозяйственного сектора

- Увеличить производство сельскохозяйственной продукции, улучшить качество продукции и обеспечить продовольственную безопасности страны во всех аспектах.

* Улучшить эффективность производства сельскохозяйственного сектора и конкурентоспособность продукции всего сельскохозяйственного комплекса.

* П Повысить финансовую отдачу от аграрного комплекса.

* Решить социальные вопросы крестьян.

Задачи и стратегии выполнения:

(1) Улучшить систему управления сельскохозяйственного сектора, увеличить эффективность и действенность регулирования.

- Оказать институциональную поддержку развитию кооперативов и продвигать кластерный подход внутри Министерства сельского хозяйства и подчиненных агентств.

- Создать ценностную цепочку для сельскохозяйственной продукции.

- Остановить перевод сельскохозяйственных угодий, особенно пахотных земель, в другую категорию земель, предназначенных не для сельскохозяйственного использования.

- Защищать права собственности.

- Убрать ограничения на использование земли в качестве залога в кредитных институтах.

- Способствовать преобразованию мелких частных хозяйств в кооперативы.

- Улучшить прозрачность и создать эффективную систему стабилизации рынка и цен.

- Внедрять современные технологии в процесс управления пастбищами и практику мониторинга.

- Продвигать сельскохозяйственную продукцию на внешний рынок и расширить географический охват экспорта.

- Создать и расширять семенной фонд и животноводческие фермы; продвигать внедрение лучших практик.

(2) Улучшить качество услуг в сельскохозяйственном секторе, создать предпосылки для технической и технологической модернизации сельскохозяйственного производства. 
- Обеспечить технологическое развитие и восстановление ирригационных систем, проведение мелиоративных работ, содействовать повышению плодородия почв.

- Развивать ветеринарию и улучшить систему защиты растений через поддержку частных ветеринаров и упорядочение регулирования частной практики, совершенствовать оказание ветеринарных и фитосанитарных услуг, соответствующих нормативным требованиям Таможенного союза.

- Повысить доступность сельскохозяйственной техники за счет расширения сети и повышения качества услуг крупных поставщиков сельскохозяйственной техники, созданных на принципах государственно-частного партнерства для последующей передачи доли государства частному сектору.

- Обновить и пополнить семенной и племенной фонды путем создания экономических стимулов, как для производителей семян, так и для животноводов и сельхозпроизводителей.

- Повысить доступность финансовых ресурсов для производителей и расширить спектр финансовых услуг для сельских районов (например, развитие финансовых институтов в сельской местности, кредитование, лизинг, страхование и др.)

- Продолжить подготовку и переподготовку местных производителей по вопросам современных с/х технологий через организацию регулярных курсов и программ.

- Построить инфраструктуру в сельских районах (например, дороги) обеспечить сельские районы электричеством, улучшить водоснабжение домохозяйств, обеспечить наличие воды для полива.

Источник: OOH. UN Comtrade.

http://comtrade.un.org/db/default.aspx (по состоянию на март 2018 года) 


\section{Библиография}

Абдулхамидов Д., Абдурахманов Т., Моневе Р. Картофель в Кыргызстане: второй хлеб// Сельскохозяйственные науки и науки о жизни. - 2015. - № 5 (1). - С. $54-63$.

Азиатский банк развития. Разрабатывая стратегии сектора водных ресурсов: Кыргызская Республика. Отчет консультанта в рамках ТП-8015. Манила

Акрамов К. и Омуралиев Н. Институциональные изменения, сельские услуги и сельскохозяйственная деятельность в Кыргызстане. Международный исследовательский институт продовольственной политики (МИИПроП). - 2009. - No 904, рабочий документ. URL: http://cdm15738.contentdm.oclc. org/utils/getfile/collection/ p15738coll2/id/24616/filename/24617.pdf

Блоч Р.С., Делеханты Дж.М. и Рос М.Дж. Земельная и аграрная реформа в Кыргызской Республике. Центр земледелия. Висконсинский университет в Мэдисоне. - 1996. -С.134.

Болотова М. А. Развитие аграрного сектора экономики в рыночных условиях (на примере Таласской области: диссертация на звание кандидата наук по экономике. (КГНУ)- Б, 2010.

Чаки С. Сельскохозяйственная реформа в Центральной и Восточной Европе и странах бывшего Советского Союза: состояние и перспективы// Сельскохозяйственная Экономика. - 2000. -№ 23. - С 37-54.

Всемирный банк. Кыргызская Республика: Оценка рисков в сельскохозяйственном секторе. Документ по глобальным практикам ТП. - Вашингтон DC: ВБ, 2016.

Всемирный банк. Индикаторы мирового развития http://data.worldbank.org/ data-catalog/world-развитие-indicators (по состоянию на февраль 2018)

Всемирный банк. Индикаторы мирового развития http://data.worldbank.org/ data-catalog/world-развитие-indicators (по состоянию на октябрь 2017)

Лерман 3. и Седик Д. Восстановление сельского хозяйства и индивидуальное землепользование: уроки ЦА. Будапешт: ФАО, Региональный офис ФАО по Европе и Центральной Азии, 2009. No.2009-3. http://www.fao.org/ docrep/o17/aq335e/aq335e.pdf.

Минахан Дж. 2004. Разнообразие народов бывшего Советского Союза: справочник. Санта Барбара: ABC-Clio, 2004.

Могилевский Р., Абдразакова Н., Болотбекова А. и др. Результаты 25 лет аграрной реформы в Кыргызстане. Рабочий документ 162. Лейпциг. Институт сельскохозяйственного развития в переходной экономике (IAMO). Халле, Германия, 2017.

Национальный совет по устойчивому развитию Кыргызской Республики. www. president.kg/files/docs/NSSD-final-version-eng-Feb4. doc (март 2018).

Национальный статистический комитет Кыргызской Республики. Перепись населения и жилищного фонда Кыргызской Республики 2009 года.

- Бишкек, 2010. 
Национальный статистический комитет Кыргызской Республики. Международная торговля 2010-2014. - Бишкек, 2015.

Национальный статистический комитет Кыргызской Республики. Б, 2016. http://stat.kg/en/.

Национальный статистический комитет Кыргызской Республики. Сельское хозяйство. http://stat.kg/en/statistics/selskoe-hozyajstvo/ (по состоянию на февраль 2018)

$\mathrm{OOH,} \mathrm{База} \mathrm{статистических} \mathrm{данных} \mathrm{ООН} \mathrm{по} \mathrm{торговле} \mathrm{товарами} \mathrm{(«Комтрейд}$ ООН»), по состоянию на октябрь 2017 и март 2018)

Платон.2019. http://platon.ru/ru/about/procedure-and-conditions/

Продовольственная и сельскохозяйственная программа (ФАО). 2012. Аквастат. URL: http://www.fao.org/nr/water/aquastat/countries_regions/KGZ/ (по состоянию на 7 февраля 2018).

Продовольственная и сельскохозяйственная программа (ФАО). Аналитический отчет по внедрению добровольных руководящих принципов ответственного регулирования вопросов владения и пользования земельными, водными и лесными ресурсами в Кыргызской Республике. Проект.

Продовольственная и сельскохозяйственная программа (ФАО). FAOSTAT. http://www.fao.org/faostat/en/\#data (по состоянию на март 2018).

Помфрет Р. Модернизируя сельское хозяйство в ЦА // Глобальный журнал появляющихся рыночных экономик. -2016. - 8 (2). - С. 104-125.

Сабатес-Виллер Р., Чилдресс М.Д. Объединение активов в неопределенное время: последствия фермерства для реструктуризации сельского хозяйства в Кыргызской Республике. Серия рабочих документов. № 239. - Брайтон: IDS, 2010

Свиннен Дж., Вранкен Л. Реформы и сельскохозяйственная продуктивность в Центральной и Восточной Европе и странах бывшего Советского Союза: 1989-2005. //J. Prod. Analysis. - 2010. № 33 -C 241-258.

Тилекеев К., Могилевский Р., Болотбекова А., и Джумаева 3. 2016. Цепочки добавленной стоимости производства баранины в Кыргызской Республике и потенциал ее экспорта в страны ЕАЭС. Университет Центральной Азии. Институт государственного управления и политики (ИГУП). Обсуждаемый документ No. 36, - Бишкек, V.R.S. Company, 2016. URL: https://www. researchgate.net/publication/313497288_Sheep_Meat_Production_Value_ Chains_in_the_Kyrgyz_Republic_and_Export_Capacity_to_the_EAEU_ Member_States 


\title{
Глава 4 \\ Эффрективньй рост сектора услуг в KHPrbl3ckoй Pecnyбликe
}

\author{
Джайяратенем Пиплай, Киёси Танитучи
}

\section{1 Введение}

момента приобретения независимости Кыргызская Республика зависела от сельского хозяйства, торговли, добычи золота, денежных переводов трудовых мигрантов и помощи, оказываемой международными институтами. Тем не менее, устойчивый рост экономики и, соответственно, рост количества рабочих мест требовали более высокого уровня продуктивности и разработки многоплановой модели экономического роста. Устойчивое и более интенсивное развитие экономики требует от секторов, которые обладают хорошим потенциалом в производстве услуг и продуктов, обладающих высокой добавленной стоимостью, способных занять свою нишу на новых рынках и привлечь инвестиции от частного сектора, одновременно создавая большое количество рабочих мест.

В данной главе сектор услуг рассматривается как «двигатель» устойчивого и инклюзивного экономического роста Кыргызской Республики. Сектор услуг, на данный момент, является важным источником роста объемов производства и главным создателем рабочих мест. Тем не менее, информации о качестве работы сектора, о его положительном влиянии на процесс сокращения бедности, недостаточно. Развитие сектора услуг - это грандиозная и сложная задача. Создание конкурентоспособных услуг требует проведения эффективных политических реформ, направленных на преодоление широкого спектра внутренних и внешних искажений рыночных механизмов, которые затрудняют развитие рынка и мешают росту производительности сектора. Помимо реформ, для роста сектора услуг необходимы дополнительные инвестиции в физическую инфраструктуру и в развитие человеческого капитала.

\section{2. Текущее состояние сектора}

В Кыргызстане происходит переориентация экономики от промышленного и сельскохозяйственного секторов в сторону сектора услуг, который, на данный момент, является самым крупным и быстрорастущим сектором в Кыргызской 
Республике. Сектор услуг, начиная с 2002 года, имеет самую крупную долю добавленной стоимости, а с 2004 года в этом секторе занято наибольшее число работников. Вступление Кыргызской Республики во Всемирную торговую организацию (ВТО) в 1998 году способствовало развитию международной торговли и логистических услуг, особенно реэкспорта. Однако, несмотря на расширение сферы услуг, стране необходимо сделать её более продуктивной. Кыргызской Республике необходимо найти способы и возможности увеличить производительность и повысить уровень занятости в данном секторе.

Сдвиг экономики республики в сторону сектора услуг и увеличения его производительности коррелируется с международным опытом. Политические реформы, проведенные для облегчения перехода страны от плановой экономики к рыночной, способствовали этому. В течение десяти лет сектор показывал отрицательный рост, а в период с 2000 по 2017 год сектор услуг утроил свои размеры и превысил показатели секторов сельского хозяйства и промышленности (Рисунок 4.1).

\section{Рисунок 4.1 Валовой объем продукции сектора в стоимостном выражении, 1990-2017 гг. (в ценах 2010 г.)}

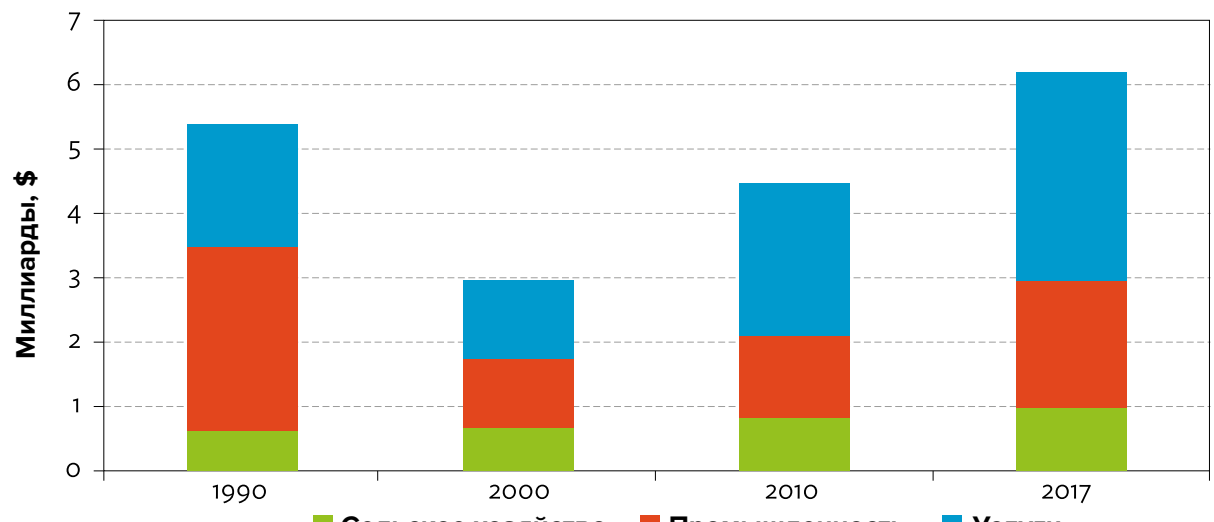

\$ - доллар США

Источник: Всемирный Банк

https://datacatalog.worldbank.org/dataset/world-development-indicators (по состоянию на 5 декабря 2018).

В период с 1990 по 2000 год доля сектора услуг составляла менее одной трети ВВП, а в 2017 году составила около 57\% (Рисунок 4.2). В 2017 году на сектор услуг приходилось почти половина всех существующих рабочих мест в стране (Рисунок 4.3), при этом большую их часть занимали женщины (57\% рабочих мест в секторе услуг были заняты женщинами). То есть с быстрым ростом сектора увеличились возможности трудоустройства женщин. 


\section{Рисунок 4.2. Доли секторов в общем объеме ВВП (\%)}

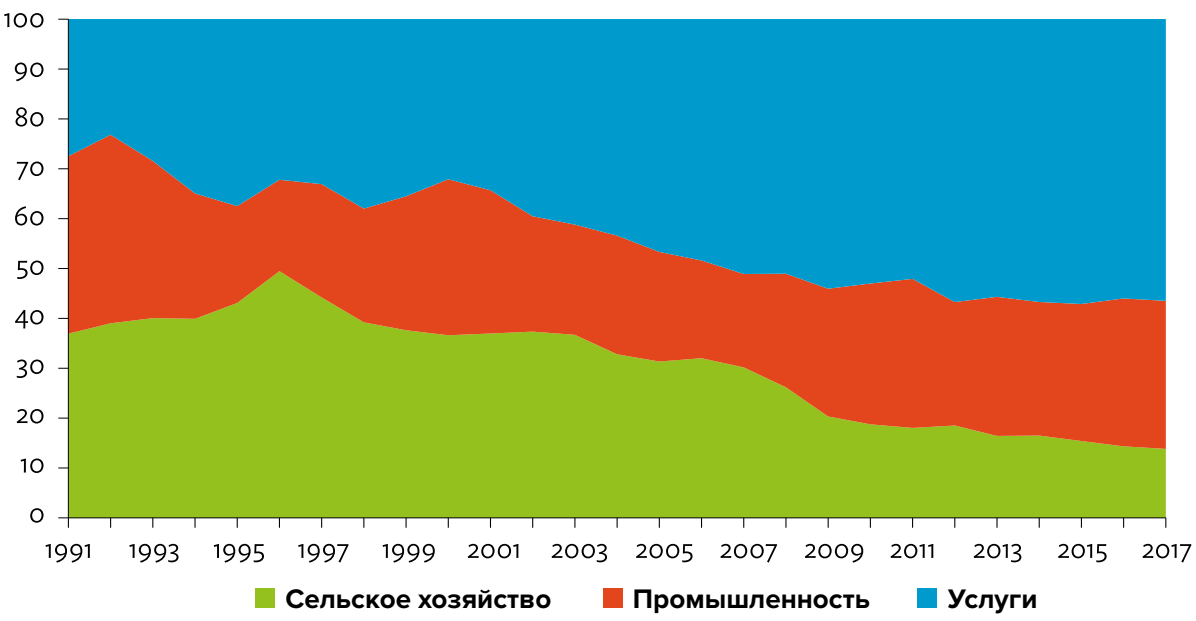

Примечание: Доли рассчитаны на основании данных о ВВП по текущим ценам.

Источник: АБР, Ключевые индикаторы 2010 и 2017, данные за 1991-2009 гг.); Национальный статистический Комитет КР, данные за период с 2010 по 2017 (по состоянию на апрель 2018.

В секторе услуг доминирует подсектор оптовой и розничной торговли, на которые в 2016 году приходилось 20,3\% ВВП и 15,5\% от общей занятости по стране (Таблицы 4.1 и 4.2).

Таблица 4.1 Добавленная стоимость секторов (\% от объема ВВП)

\begin{tabular}{llllllllll} 
& 2007 & 2008 & 2009 & 2010 & 2011 & 2012 & 2013 & 2014 & 2015 \\
\hline
\end{tabular}


а) имеются в виду все виды деятельности (за исключением аренды и производства), связанные с автотранспортом, включая грузовики и самосвалы, оптовая и розничная торговля новыми и подержанными авто, запасными частями, аксессуарами, ремонт автомобилей. Также включена деятельность агентов, занятых в оптовой и розничной торговле, мойке, полировке машин и пр. Но исключена розничная продажа топлива, смазочных материалов, аренда авто.

Источник: ADB, 2018.

Затем следует подсектор транспорта, складов и коммуникаций, на который приходится 8,5\% ВВП и 8,2\% занятости, и подсектор образования, составляющий 6,7\% ВВП. Помимо большого количества мелких розничных торговцев, несколько автоперевозчиков и транспортно-экспедиторских компаний в стране предоставляют услуги по сопровождению товаров и грузов для торговли товарами в регионе.

\section{Таблица 4.2 Доля работающих по секторам и подсекторам} (\% от общего количества занятых)

\begin{tabular}{|c|c|c|c|c|c|c|c|c|c|}
\hline & 2007 & 2008 & 2009 & 2010 & 2011 & 2012 & 2013 & 2014 & 2015 \\
\hline Сельское хозяйство & 34,5 & 34 & 32,4 & 31,2 & 30,8 & 30,1 & 31,7 & 31,6 & 29,3 \\
\hline Промышленность & 20,3 & 20,5 & 21,2 & 21,1 & 21 & 21,7 & 20,2 & 20,4 & 20,9 \\
\hline Обрабатывающая промышленность & 8,3 & 8 & 7,8 & 7,8 & 7,6 & 7,6 & 6,9 & 7,0 & 7,4 \\
\hline Услуги & 45,2 & 45,5 & 46,4 & 47,7 & 48,3 & 48,2 & 48,1 & 48,0 & 49,8 \\
\hline Оптовая и розничная торговля & 14,7 & 14,4 & 14,3 & 15,0 & 15,2 & 15,1 & 15,9 & 15,1 & 15,5 \\
\hline Размещение и питание & 2,7 & 3,3 & 3,7 & 3,7 & 3,8 & 3,7 & 3,5 & 3,7 & 4,2 \\
\hline Транспорт, склады и коммуникации & 6,2 & 6,0 & 6,5 & 6,6 & 6,5 & 6 & 6,3 & 6,3 & 6,9 \\
\hline Финансы и страховка & $\ldots$ & $\ldots$ & $\ldots$ & $\ldots$ & $\ldots$ & 1,2 & 1,1 & 1,2 & 1,3 \\
\hline Недвижимость & 2,1 & 2,3 & 2,5 & 2,6 & 2,5 & 0,2 & 0,3 & 0,4 & 0,4 \\
\hline Прочие & 19,0 & 18,8 & 18,6 & 19,0 & 19,6 & 20,9 & 19,9 & 20,2 & 20,3 \\
\hline
\end{tabular}

... - нет данных

Источник: АБР, 2018

Рынок Дордой - один из самых крупных азиатских рынков - служит в качестве хаба трансграничной торговли между Кыргызстаном и Казахстаном, Российской Федерацией и Узбекистаном (АБР, 2013). В условиях более либеральной торговой политики, базары в Кыргызстане служат платформой для экспорта продукции отечественного производства, а также реэкспорта китайской продукции (например, тканей, обуви и прочих видов продукции) в другие страны региона. Подсекторы оптовой и розничной торговли страны также включают продажу новых и подержанных автомобилей и прочих транспортных средств, запчастей к ним, а также ремонт и техническое обслуживание автомобилей и мотоциклов.

За последние два десятилетия в Казахстане и Таджикистане также наблюдалась тенденция к увеличению объема продукции сектора услуг (Рисунок 4.4). Но в отличие от Казахстана и Таджикистана, в Кыргызстане наметился вектор увеличения объемов торговли (экспорт плюс импорт). В период с 1995 по 2017 годы доля торговли в ВВП более чем удвоилась. Произошло увеличение с 14\% в 1995 году до 29,2\% в 2010 году, а к 2017 году - доля снизилась до 23,0\%. Вступление в ВТО в 1998 году и реформирование частного сектора помогло расширить сферу экспорта и импорта, включая услуги, связанные с торговлей, например, логистикой и оказанием финансовых услуг. Тем не менее, Кыргызская Республика остается «чистым» импортером товаров и услуг. 


\section{Рисунок 4.3. Количество трудоустроенных по секторам (\%)}

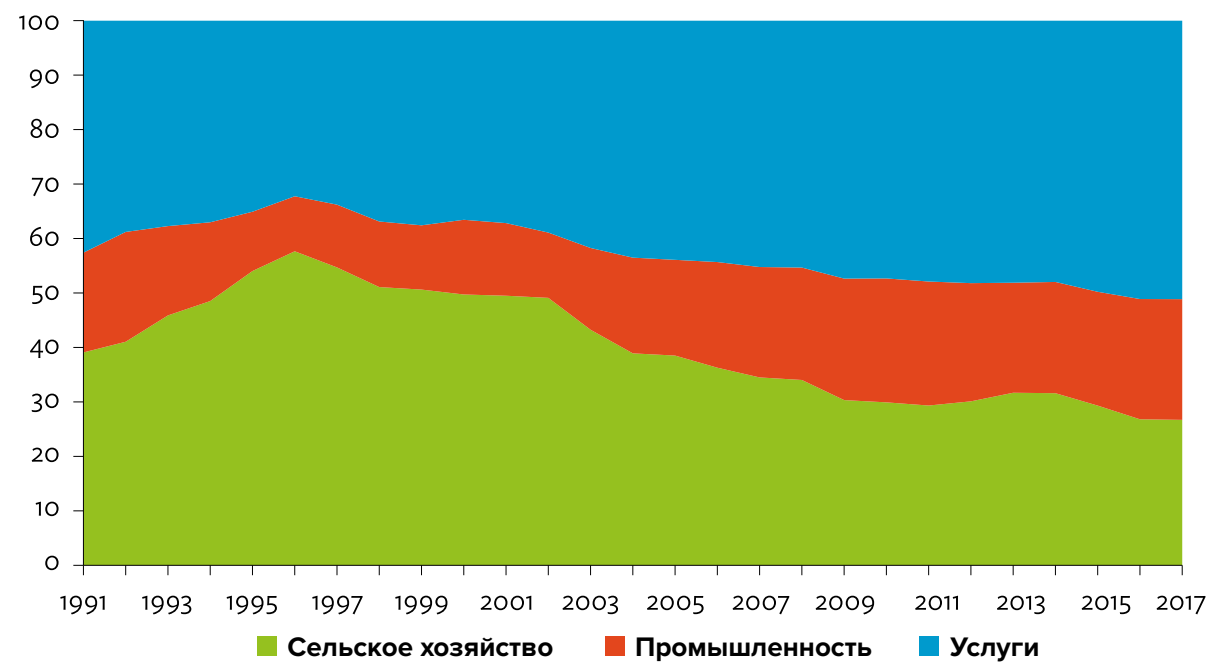

Источник: Всемирный Банк.

https://datacatalog.worldbank.org/dataset/world-development-indicators (по состоянию на 5 декабря 2018).

\section{Рисунок 4.4 Доля сектора услуг и торговли соседних стран в общем объеме ВВП страны (\% к ВВП)}

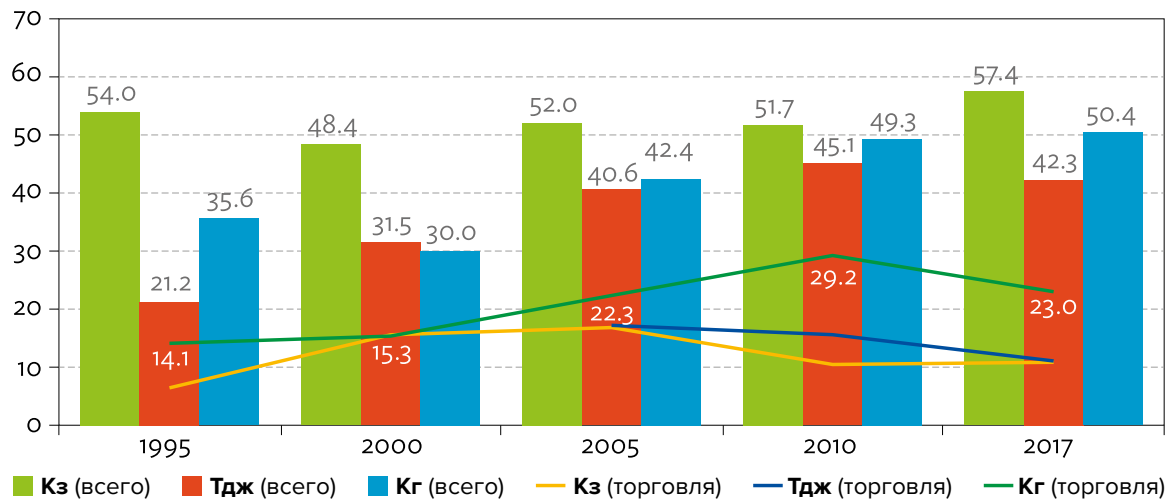

ВВП - Внутренний валовой продукт.

Примечание: Рынок услуг - это сумма экспорта и импорта.

Кз - Казахстан, Кг - Кыргызстан, Тдж - Таджикистан.

Источник: Всемирный банк. WDI. (по состоянию на 5 декабря 2018).

\section{3. Укрепление сектора услуг}

Экономический рост и развитие обычно идут параллельно структурным изменениям в производстве и уровне занятости. С возрастанием уровня индустриализации, падает уровень производства, а также доля и уровень занятости в сельском хозяйстве. В странах Восточной и Юго-Восточной Азии, доля выхода продукции 
обрабатывающей промышленности возросла после внедрения экспортно-ориентированной торговой политики (Пак, Ноланд, 2013). С течением времени доля продукции обрабатывающей промышленности достигла своего пика и начала снижаться. Это произошло в результате восстановления равновесия экономики благодаря росту доходов. Следующая стадия структурной трансформации происходит тогда, когда возрастает внутренняя потребность в сервисном компоненте. С экспортно-ориентированной политикой открытой торговли, рост доли обрабатывающей промышленности и сектора услуг опережает рост доли сельского хозяйства. Однако, эта схема не работает в Кыргызской Республике и в других странах Центральной Азии, так как существует недостаточность «экономии за счёт масштаба» и сравнительного преимущества.

Во многих Центрально-Азиатских странах транспортные затраты обычно высоки и не только из-за того, что страна «замкнута» (нет выхода к морю) и состояние дорог плохое, но и из-за задержек при пересечении границ, многочисленных разрешительных документов и процедур, различных соглашений на грузовые перевозки. Центрально-Азиатские страны, включая Кыргызстан, не обладают сравнительными преимуществами при производстве товаров. Как было уже сказано выше, кыргызстанская экономика полагается на сектор услуг. Такая схема перехода от сельского хозяйства напрямую к сектору услуг возникает из-за нерентабельных затрат в перерабатывающем секторе. Для достижения устойчивого роста экономики, для Кыргызской Республики крайне важно развивать сферу услуг; преодолеть препятствия на пути увеличения масштабов торговли и развития страны в целом.

Укрепление роста производства и производительности в секторе услуг требует развития здорового частного сектора, который, в свою очередь, «подтолкнет» рост промышленности и экономики в целом, сделает их более инклюзивными. Тем не менее, частный сектор в Кыргызской Республике не достаточно развит. Уверенно развивающийся частный сектор требует расширения доступа к кредитам, улучшения инфраструктуры, повышения квалификации работников и улучшения бизнес-среды (АБР, 2013, Пак и Ноланд, 2013).

Наряду с растущим дефицитом квалифицированных кадров, недостаточное наличие финансирования и его высокая стоимость ограничивает возможности предпринимателей диверсифицировать и повышать ценность выпускаемой продукции и предлагаемых услуг (АБР, 2013). Связь между увеличением количества кредитов и экономическим ростом остается слабой $(М В \Phi, 2016)$. Для повышения конкурентоспособности производства товаров и предоставляемых услуг необходимы: улучшенная государственная инфраструктура, более надежное и бесперебойное снабжение электроэнергией, а также эффективная координация промышленного развития (Экономическая и социальная комиссия для Азии и Тихого океана - ЭСКАТО ООН, 2016, ЕБРР и Всемирный банк, 2013).

Продолжающиеся политические реформы, направленные на улучшение инвестиционного климата и бизнес-среды в стране и уменьшение затрат на ведение бизнеса крайне важны для развития частного сектора. Исследования показывают, что для регистрации бизнес предприятий требуется выполнение многочисленных и громоздких требований, это касается процедуры лицензирования и выдачи разрешений, налоговых платежей и урегулирования неплатежеспособности. Сложность выполнения этих требований серьезно ограничивает возможность выхода предприятия на рынок и ухода с рынка (ЮНКТАД, 2013; МВФ, 2016). Существующая система способствует тому, что значительная доля занятости и производства 
в стране приходится на неформальный сектор. ${ }^{1}$ Понимание того, почему многие работники и предприниматели процветают и остаются в неформальном секторе, может помочь выявить важнейшие препятствия на пути развития частного сектора и, соответственно, помочь разработать пути и способы их устранения.

Страна должна определить конкретные отрасли, которые имеют потенциал не только расти самостоятельно и привлекать больше инвестиций, но и, возможно, обеспечить рост производства и занятости в других отраслях. Например, оказание финансовых услуг и туризм относятся к числу отраслей (подсекторов), которые могут иметь прочные взаимные связи с другими отраслями, и инициировать развитие частного сектора. Иными словами, развитие финансового сектора и рост туризма, потенциально, может оказать волновой эффект на развитие остальных секторов и отраслей всей экономики: большее количество туристов может помочь сформировать спрос на производимые товары и предлагаемые виды развлечений. Диверсификация экспорта товаров и услуг также важна для поддержания роста и минимизации волатильности (Макинтайр и др., 2018).

\section{Финансовые услуги}

Из-за сильной ориентации на внешнеэкономическую деятельность после обретения независимости, быстрое развитие отрасли банковских и финансовых услуг в период с 2000 до середины 2012 года было сосредоточено на местных финансовых услугах, в частности, на институтах микрофинансирования (ADB, 2013). В 2016 году показатели сектора были умеренными относительно роста активов, капитализации, качества и диверсификации кредитного портфеля, кредитных рисков и стабильности. Однако, помимо того, что финансирование сосредоточено на нескольких секторах, оно, в основном, является краткосрочным, а стоимость финансирования остается достаточно высокой. По сравнению с другими странами, индекс финансового развития страны находится на одном уровне с Таджикистаном, но отстает от Узбекистана и Казахстана (Рисунок. 4.5). ${ }^{2}$

Активы финансового подсектора страны составляли 195,2 миллиарда сомов (около 2,8 миллиарда долларов США), что эквивалентно 42,6\% ВВП 2016 года (НБКР, 2017). ${ }^{3}$ На банковскую систему в 2016 году приходилась большая часть активов финансового подсектора - 91,2\% от всего объема активов (НБКР, 2017). По состоянию на 2017 год банковская система включала 25 коммерческих банков, имевших 319 филиалов, работающих по всей республике (НБКР, 2018). Зарубежные собственники владеют более $47 \%$ капитала, в основном, это банки Казахстана и Российской Федерации, и международные финансовые институты (НБКР, 2018). Соотношение депозитов к ВВП составляет всего 18\%, и депозиты - это, в основном, срочные вклады. Только 26\% населения страны имеют банковские счета, что свидетельствует о малой доступности финансовых услуг (МВФ, 2016).

Размер неформальной экономики, по расчетам, составляет 24\%-40\% ВВП (МВФ 2016). «Неформальная» рыночная деятельность имеет место, в основном, в подсекторах торговля, гостиничного бизнеса, транспортных услуг, а так же в секторе сельского хозяйства.

2 Финансовое развитие определяется как сумма трех составляющих: глубины (ликвидность рынка), доступа (возможность индивида или компании иметь доступ к финансовым услугам) и эффективности (возможность институтов предлагать финансовые услуги по невысоким ставкам и уровень активности рынков капитала) (Свириженко, 2016)

3 Это выше, чем его относительный уровень в 2009 году (40\% от объема ВВП) или до того, как он упал до 32\% в 2011 году из-за цепной реакции глобального финансового кризиса и вывода валютных депозитов, связанных с политическими событиями 2010 года (АБР, 2013). 
Рисунок 4.5. Индекс финансового развития стран-компараторов, 2016 (\%)

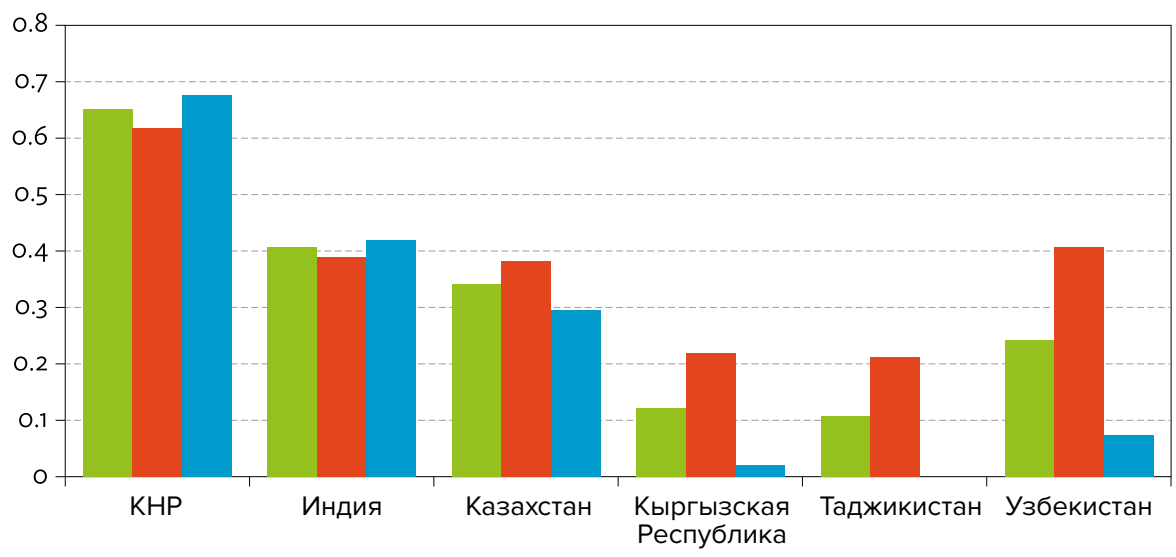

Финансовое развитие Финансовые институты Финансовый рынок

КНР- Китайская Народная Республика; Компаратор - страна, с которой проводится сопоставление.

Источник: Свириженко, 2016

На долю небанковских финансовых учреждений, включая микро-финансовые организации, приходится лишь 7\% активов финансового сектора, в то же время на долю прочих финансовых организаций - оставшиеся 1,8\%. Количество микро-финансовых организации быстро увеличивалось, в 2006 году их было 147, а в 2012 году - уже 320 (ADB, 2013, НБКР, 2018). В связи с введением новых правил регулирования и лицензирования в 2012 году, количество микро-финансовых организаций неуклонно сокращалось и, по состоянию на 2016 год, в Кыргызской Республике, по данным Национального банка, их осталось всего 162 (НБКР, 2018).

Хотя количество частных кредитов неуклонно растет с 2012 года, финансовый подсектор остается недостаточно развитым и подверженным влиянию снижения обменного курса (МВФ, 2016). В 2016 году стоимость кредитного портфеля составила около 22,8\% ВВП (НБКР, 2018). На частный сектор (через банковские кредиты) приходится 89,5\% от общего объема кредитов или 20,4\% ВВП. В целом кредитный портфель является высококонцентрированным в районах со значительными объемами хозяйственной деятельности - г. Бишкек, Жалал-Абад, Ош и Чуйская область, в тоже время в отдаленных районах доступ к кредитам затруднен (НБКР, 2018; МВФ, 2016). Наибольшая доля в общем кредитном портфеле приходится на торговлю - 28,6\% (в основном банковские займы), на сельское хозяйство - 21,6\% (в основном кредиты небанковских финансовых институтов). В совокупности более половины кредитного портфеля приходится на торговлю и сельское хозяйство.

Снижение стоимости обслуживания кредита и расширение зоны охвата имеют решающее значение для развития частного сектора и повышения его конкурентоспособности. Наличие большего количества финансовых продуктов и инструментов, а также доступных средне- или долгосрочных инвестиций могут помочь стимулировать более активную межбанковскую деятельность и привлечь частные инвестиции, включая финансирование из внутренних источников. Это также может привести к увеличению рабочих мест за счет создания новых пред- 
приятий и расширения существующих. Все вышеуказанное требует более целенаправленной оценки того, (1) что делает финансирование дорогостоящим и недоступным в определенных уголках страны, особенно для вновь открывающихся компаний, малых и средних предприятий; и (2) как справляться с ограничениями, соблюдая строгое финансовое регулирование.

\section{Перевозка грузов и транзит}

Таким же образом, эффективная работа транспорта и логистика имеют решающее значение для обеспечения устойчивого и инклюзивного роста экономики, особенно с учетом созданных глобальных цепочек добавленной стоимости (ГЦДС), что позволяет расширять глобальные производственные сети, а это, в свою очередь, приводит к усилению «географической фрагментации» производства. Многонациональные корпорации коренным образом изменили характер производства. Многие товары разрабатываются в одной стране, производятся в другой, а финальная сборка осуществляется в третьей.

Традиционно рост экспорта отражает сравнительное преимущество экономики. Если торговля носит преимущественно межотраслевой характер, то рост экспорта дает сравнительное преимущество. Появление ГЦДС способствует быстрому росту внутриотраслевых торговых потоков (Джонсон, 2014). В частности, поскольку товар идет по этим цепочкам, он проходит много раз через границы в ходе производственного процесса. В результате валовой объем экспорта превышает сумму внутренней стоимости, добавленной в экспорт. Страны, интегрированные в ГЦДС, с большей вероятностью получат выгоды от торговли. В рамках производственных процессов ГЦДС, торговые барьеры обходятся горазда дороже, чем ранее, поскольку они сдерживают индустриализацию. Например, Амити и Конингс (2007) показывают, что Индонезия способствовала увеличению производства через либерализацию торговли. Через открытый рынок компаниям получают доступ к более дешевым ресурсам, но лучшего качества, что и способствует росту производительности на уровне компании.

Однако, политики открытой торговли недостаточно для интеграции в глобальные цепочки добавленной стоимости. Для преодоления географических ограничений важно, чтобы Кыргызская Республика упростила правила транзита и пограничного контроля, а также построила эффективную транспортную инфраструктуру для обеспечения доступа к рынкам. Для многонациональных предприятий, участников ГЦдС, требуются эффективные транспортные системы для быстрой и дешевой транспортировки ресурсов и готовой продукции, как внутри регионов, так и между ними. В силу того, что Кыргызская Республика не имеет выхода к морю, ее транспортная система должна соединяться с транспортными системами стран, которые имеют морские порты. В настоящее время лучшим портом-хабом является порт Бендер-Аббас в Иране. Когда заработает экономический коридор Китай - Пакистан, у Кыргызской Республики будет связь с портом Гвадар (Пакистан) через Кашгар (северо-запад Китайской Народной Республики).

Нынешнее состояние транспортной инфраструктуры Кыргызской Республики хуже, чем в соседних странах. По данным Всемирного банка на 2018 год Кыргызская Республика занимает 108-е место среди 160 стран-участниц по эф- 
фективности логистики. ${ }^{4}$ На рисунках 4.6 и 4.7 представлены значения индексов эффективности логистики Кыргызской Республики и некоторых азиатских стран. Индекс Кыргызской Республики выше, чем у Таджикистана, но ниже, чем у двух крупных стран Центральной Азии - Казахстана и Узбекистана. Кыргызской Республике необходимо повышать эффективность логистики, чтобы полностью раскрыть свой потенциал.

\section{Рисунок 4.6. Общий индекс эффективности логистики (кол-во баллов)}

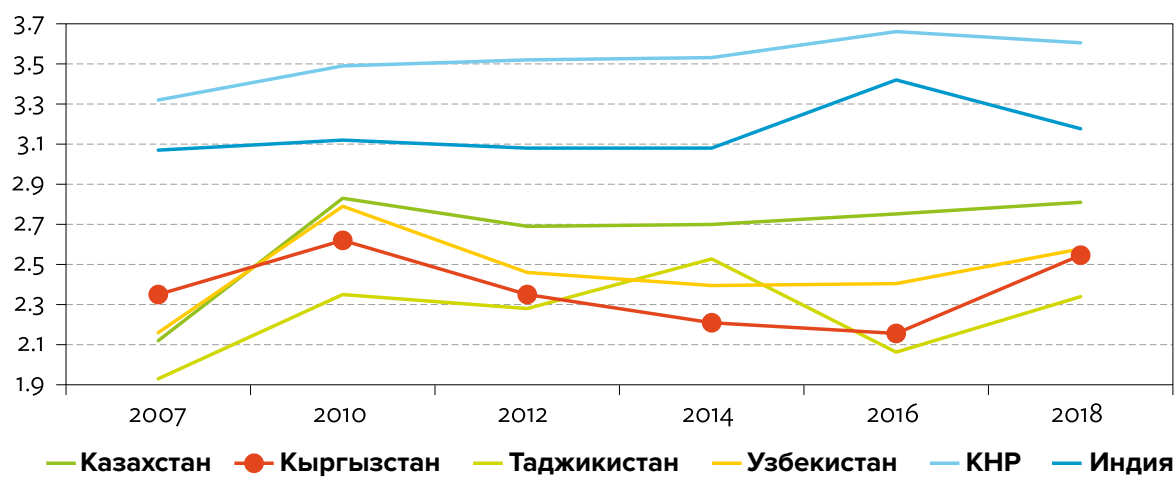

Примечание: 1 - низкий, 5 - высокий.

Источник: Всемирный банк. Индекс эффективности логистики. https://lpi.worldbank.org (по состоянию на 15 сентября 2018).

\section{Рисунок 4.7. Индекс эффективности логистики в секторе торговли и транспортных перевозок (количество баллов)}

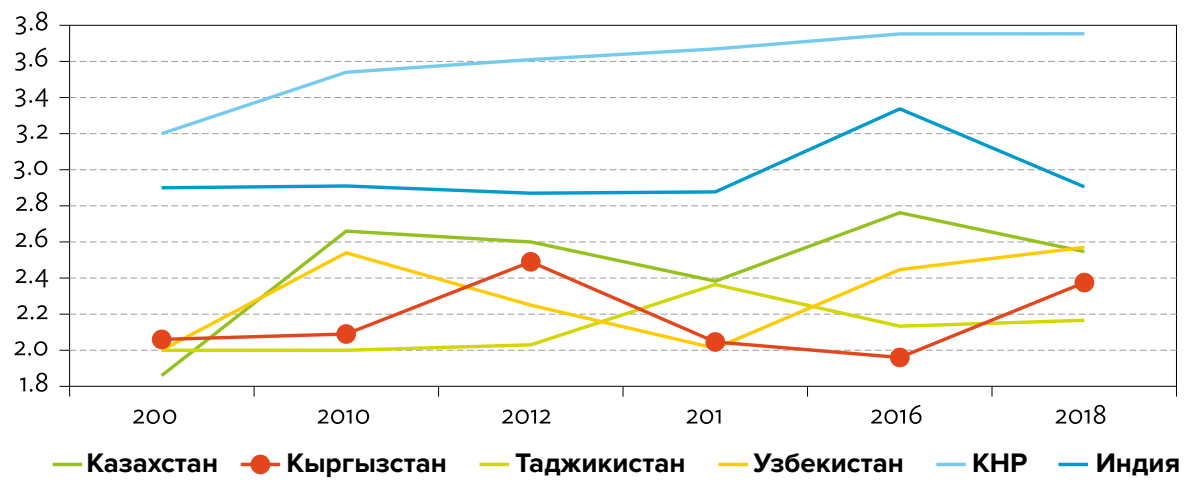

Примечание: 1 - низкий, 5 - высокий.

Источник: Всемирный банк. Индекс эффективности логистики.

https://lpi.worldbank.org (по состоянию на 15 сентября 2018).

4 Индекс эффективности логистики - это международный сравнительный индекс, созданный Всемирным банком для оказания помощи участвующим странам в выявлении проблем и возможностей в области торговой логистики. Это средневзвешенное значение шести ключевых аспектов, связанных с торговой логистикой: (1) эффективность работы органов пограничного контроля, включая таможню, (2) качество инфраструктуры, (3) простота организации поставок по конкуренткой цене, (4) компетентность и качество оказываемых логистических услуг, (5) возможность отслеживать движение грузов, и (6) своевременность доставки в пункты назначения. 


\section{4 Туристический потенциал Кыргызской Республики}

Природные, культурные, исторические достопримечательности и термальные источники Кыргызской Республики всегда привлекали туристов. Основными туристическими объектами являются Иссык-Куль (в переводе с кыргызского - теплое озеро), ледник Иныльчек, древний Шелковый путь. Эти и другие объекты, имеющие историческую и культурную ценность, делают туризм перспективной отраслью, которая может стимулировать будущий рост сектора услуг в Кыргызской Республике и рост валютных поступлений. В период с 2006 по 2018 годы валовая добавленная стоимость сектора росла на $8,2 \%$ в год. На рисунке 4.8 показано, что доля сектора в ВВП в период с 2011 по 2018 годы составила 4,7\%, что немногим выше доли сектора в ВВП за период 2006 -2010 годов (3,9\%). На рисунке 4.8 и 4.9 видно, что доход сектора увеличился благодаря увеличению количества гостей, начиная с 2011 года. Прибывающие из соседнего Казахстана составляют наибольшую долю всех гостей, далее следуют туристы из Российской Федерации и Узбекистана.

\section{Рисунок 4.8 Добавленная стоимость туристического сектора}

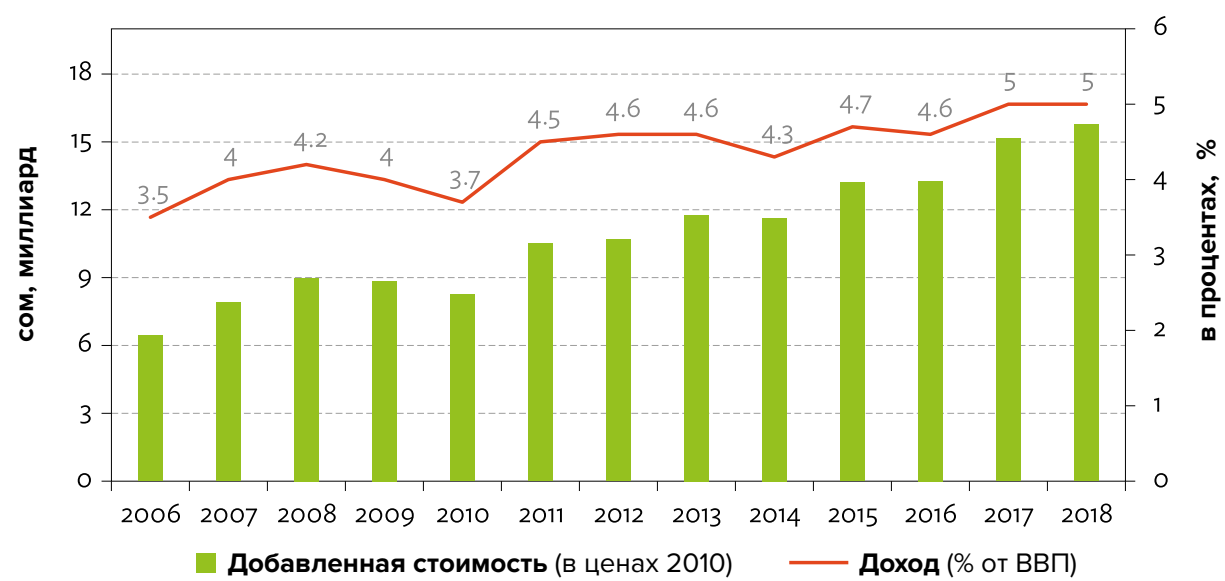

Источник: Национальный статистический комитет Кыргызской Республики. http://www.stat.kg (по состоянию на 29 мая 2019)

Одной из стратегий увеличения количества туристов и ежегодных доходов от туристического сектора является расширение рынка и увеличение количества приезжающих из других стран Азии и Европы, а также Северной Америки. Это также поможет стабилизировать получение доходов от туризма и укрепить устойчивость отрасли к неблагоприятным воздействиям от колебания спроса. Помимо устранения барьеров на въезд (например, визовые требования) и усовершенствования физической инфраструктуры, транспортного сообщения и информационно-коммуникационных технологий (ИКТ), следует лучше понять структуру и механизм работы цепочки добавленной стоимости в секторе туризма.

В целом, индустрия туризма имеет устоявшиеся связи с питающими отраслями в системе межотраслевых связей, однако в Кыргызской Республике ситуация иная. Для максимизации добавленной стоимости туризма в экономике страны 
очень важно увеличить местный контент предлагаемых туристических продуктов и услуг. Анализ цепочки добавленной стоимости сектора может помочь выявить возможности увеличения стоимости и углубления связей с другими секторами. Чтобы углубить туристический интерес к Кыргызской Республике, важно найти «узкие» места внутри цепочки и разработать стратегии диверсификации предложений.

Рис 4.9 Количество прибывших туристов

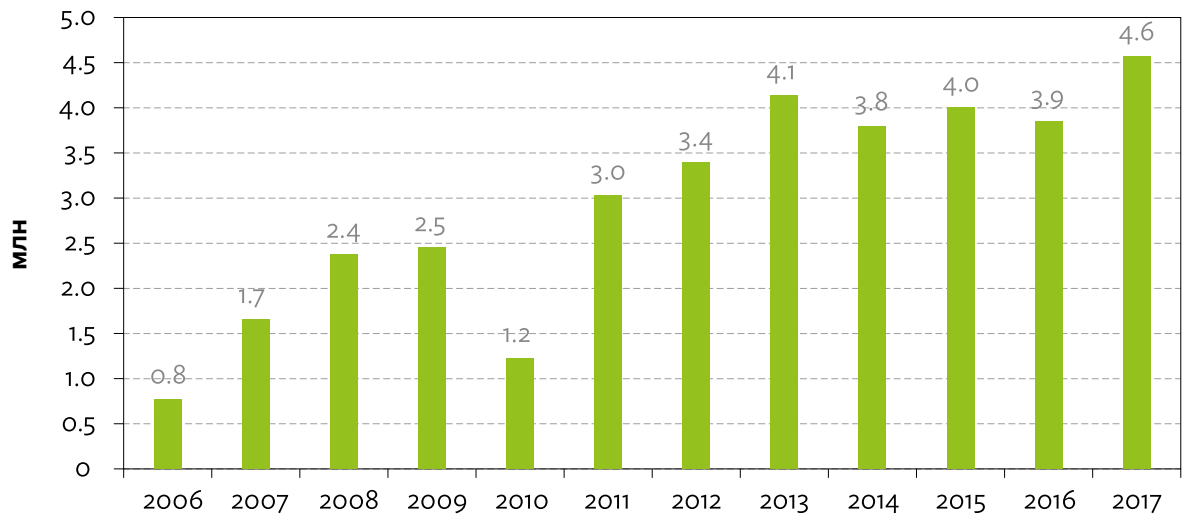

Источник: Всемирный банк, Индикаторы мирового развития, https://datacatalog.worldbank.org/dataset/world-development-indicators (по состоянию на 29 мая 2019 года)

Более крупная туристическая отрасль требует большего количества работников, способных и желающих работать в этом секторе. Например, требуются туроператоры и гиды, владеющие несколькими языками, способные эффективно координировать деятельность и предоставляемые услуги, предлагать большее количество мероприятий для различных групп туристов. Различные целевые рынки могут также потребовать различных стратегий продвижения и медиа-платформ, и, следовательно, квалифицированных кадров. Кроме того, следует устранить любые факторы, ограничивающие и ухудшающие возможности малых местных предприятий вносить свой вклад и получать выгоду в рамках цепочки добавленной стоимости. Важно также смягчить любое негативное воздействие туризма на культурную и экологическую составляющую жизни местных сообществ.

\section{Прямое, косвенное и индуцированное воздействие туризма}

Сектор путешествий и туризма - важный источник дохода во многих странах. Кроме прямого воздействия, туризм оказывает и косвенное, и индуцированное воздействие. Всемирный совет по туризму и путешествиям (ВСТП, 2017) предлагает рассмотреть общий процесс воздействие следующим образом (Рисунок 4.10). Прямое воздействие включает товары и услуги, которые приобретают туристы, включая проживание в отеле, питание, услуги туристических агентств, авиа и другие транспортные услуги, а также услуги бюро развлечений.

Компонент косвенного воздействия туризма на ВВП и занятость включает следующее:

- капитальные инвестиции, направленные на организацию новых мест для размещения гостей, ресторанов и мест отдыха, а также оборудование для пассажирского транспорта; 
- государственные расходы на продвижение туризма, информационные услуги, оказываемые туристам, административные и прочие государственные услуги; и

- эффект цепочки поставок, то есть приобретение местных товаров и услуг различными туристическими компаниями, которые влияют на их конечный туристический продукт.

\section{Рисунок 4.10. Компоненты вклада туристического сектора: прямой, косвенный и индуцированный.}

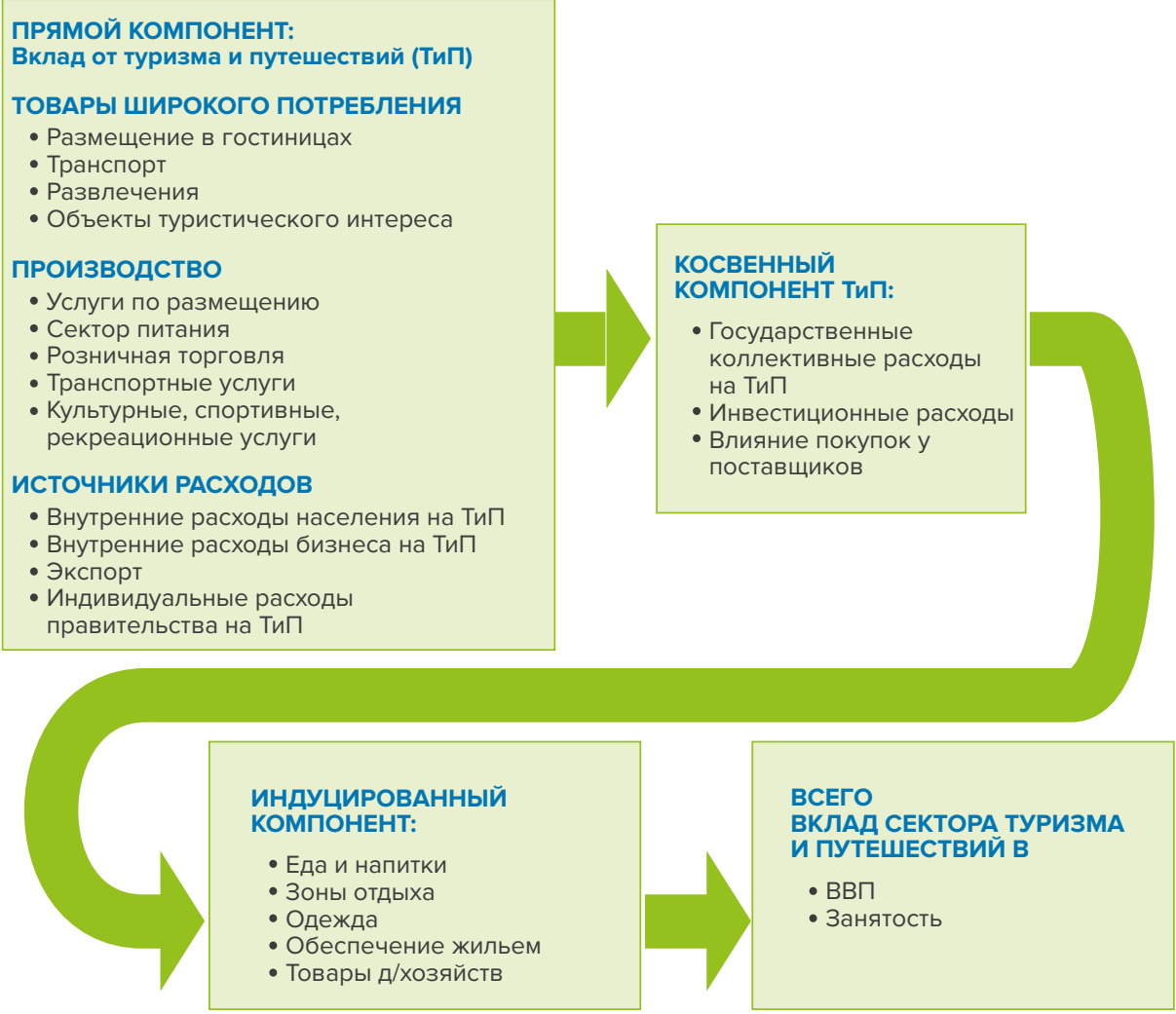

ТиП - туризм и путешествия

Источник: Составлено на основе данных ВСПТ,

http://www.wttc.com/datagateway (Данные на 3 декабря 2017 г.)

Вклад индуцированного компонента в ВВП и занятость осуществляется посредством расходов, которые несут те, кто напрямую или косвенно заняты в секторе путешествий и туризма.

Рисунок 4.11 показывает вклад всех компонентов сектора: прямого, косвенного и индуцированного в ВВП за период с 2011 по 2017 годы. В 2017 году вклад туристического сектора в ВВП исчислялся 19,1 миллиарда сомов (по ценам 2016 года), что эквивалентно 277 миллионам долларов США. Рисунок 4.11 и таблица 4.3 показывают, что прямой вклад компонента сектора путешествий и туризма 
составляет одну треть общего экономического вклада, то непрямой компонент составляет почти половину. Значимый экономический вклад сектора в ВВП и уровень занятости предполагает, что увеличивающиеся капитальные инвестиции и реализация правительственной политики, которая поможет развитию внутренней цепочки поставок, важны и окажут влияние на экономический рост в целом.

Рисунок 4.11. Подробная разбивка затрат по сектору туризма и путешествий, 2011-2017 годы. (сом, миллиард; по ценам 2016 года)

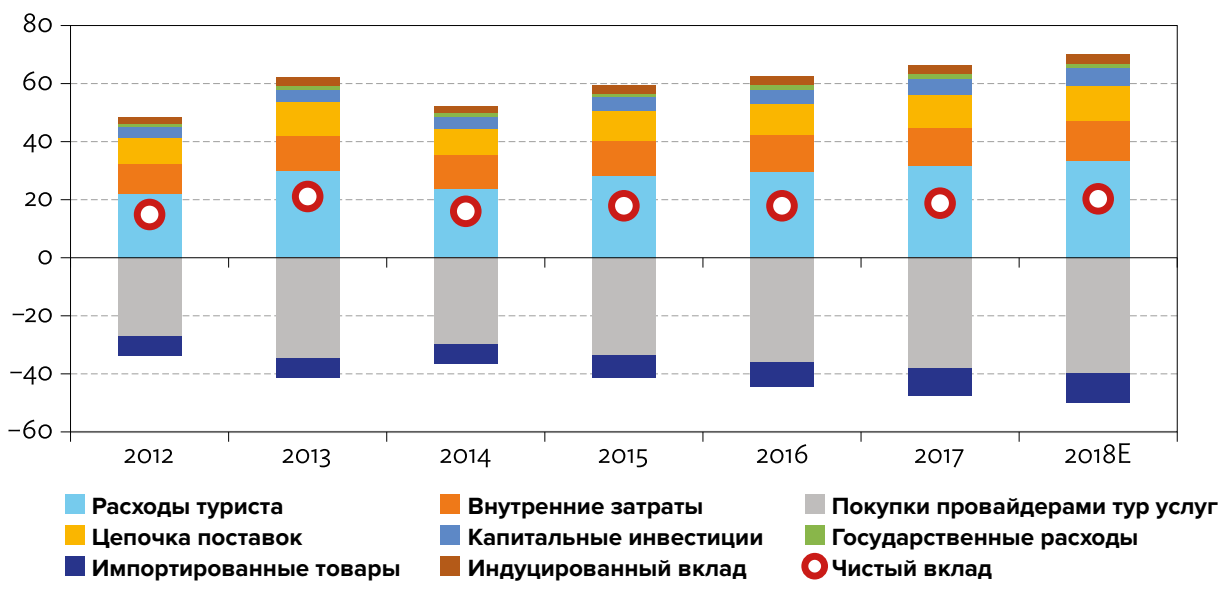

p (2018р) - расчетные данные.

Примечание: Прямой компонент равен общему объему внутренних расходов на туризм в стране за вычетом закупок на производство продуктов и услуг, включая импорт. Косвенный компонент равен сумме 4х составляющих: внутренней сети поставок, капиталовложений, государственных расходов, импортируемых товаров.

Источник: ВСТП https://www.wttc.org/datagateway (по состоянию на 23 ноября 2018).

Туризм в Кыргызской Республике развивается, но более медленными темпами, чем в соседних странах (Таблица 4.4). В 2017 году Кыргызскую Республику посетило 4,6 миллионов туристов, что ниже, чем в Казахстане (7,7 миллиона), который является главным конкурентом на Шелковом Пути. В категории «солнце, песок и море» Кыргызстан явно проигрывает Турции, которая в последнее время стала главным конкурентом в сфере туризма из Российской Федерации. По многим другим туристическим показателям Кыргызстан проигрывает своим соседям. Тем не менее, принимая факт того, что сектор работает плохо, в ходе дискуссии можно определить области, в которых Кыргызстан, при правильной мотивации, сможет проявить свой потенциал.

Таблица 4.3. Доля вкладов всех компонентов в общий экономический вклад сектора туризма (\%)

\begin{tabular}{llllllll} 
& 2012 & 2013 & 2014 & 2015 & 2016 & 2017 & $2018 p$ \\
\hline Прямой & 34,5 & 34 & 32,4 & 31,2 & 30,8 & 30,1 & 31,7 \\
\hline Косвенный & 20,3 & 20,5 & 21,2 & 21,1 & 21 & 21,7 & 20,2 \\
\hline Индуцированный & 19,0 & 18,8 & 18,6 & 19,0 & 19,6 & 20,9 & 19,9 \\
\hline
\end{tabular}

р- расчетные данные

Источник: ВСТП. https://www.wttc.org/datagateway (по состоянию на 23 ноября 2018). 
Таблица 4.4. Сравнительные показатели работы сектора путешествий и туризма в странах региона, 2018

\begin{tabular}{|c|c|c|c|c|}
\hline Страны & $\begin{array}{c}\text { Иностранные } \\
\text { туристы }\end{array}$ & $\begin{array}{l}\text { Расходы туризма } \\
\text { на экспорт услуг }\end{array}$ & $\begin{array}{c}\text { Доля туризма в } \\
\text { ВВП }\end{array}$ & $\begin{array}{c}\text { Доля туризма в } \\
\text { уровне занято- } \\
\text { сти населения }\end{array}$ \\
\hline & млн & $\%$ & $\%$ & $\%$ \\
\hline Казахстан & 7,7 & 3,0 & 5,7 & 5,7 \\
\hline Кыргызстан & 4,6 & 17,8 & 3,9 & 3,7 \\
\hline Россия & 24,4 & 3,5 & 4,8 & 4,6 \\
\hline Турция & 37,6 & 16,4 & 12,1 & 7,7 \\
\hline Узбекистан & 2,7 & 3,2 & 3,4 & 3,0 \\
\hline
\end{tabular}

Примечание: данные по количеству иностранных туристов даны за 2017 год.

Источник: Всемирный банк, ИМР- данные по международным прибытиям (по состоянию на 29 мая 2019); остальные данные от Всемирного совета по туризму и путешествиям (по состоянию на 29 мая 2019).

\section{Специализированный (нишевый) туризм в Кыргызской Республике и его потенциал}

Концепция «нишевого туризма» возникла в последние годы в качестве альтернативы так называемому «массовому туризму» (Робинсон и Новелли, 2005). «Ниша на рынке - определенная часть со своими требованиями, потребителями и продуктами." ${ }^{5}$ Ниша может означать и определенный сегмент с определенными, конкретными продуктам, предназначенными для удовлетворения потребностей определенного сегмента рынка. Рисунок 4.12 предлагает примеры нишевого туризма.

ВТО и ВСПТ (Всемирный Совет путешествий и туризма) считает, что нишевый туризм более выгоден для принимающей стороны, чем массовый (Холл и Лью, 1998). Что именно может сделать нишевый туризм для экономики Кыргызстана, учитывая, что туризм играет важную роль в росте ВВП? Как показано в таблице 4.3, примерно половина вклада сектора туризма и путешествий в ВВП приходится на индуцированный компонент. Если бы Кыргызская Республика могла успешно привлекать нишевых туристов в новые пункты назначения, то дополнительные «оставленные» в стране деньги туристов шли бы на пользу экономики, как и другие благоприятные последствия.

Кыргызская Республика обладает огромным потенциалом для развития нишевого туризма. Тем не менее, многочисленные исследования показали, что требуются крупные инвестиции, направленные на то, чтобы превратить Кыргызскую Республику в действительно привлекательное место для туристов со всего мира. Озеро Иссык-Куль имеет потенциал для роста туризма. Это второе по величине в мире горное озеро, длина которого составляет 182 километра и ширина - 6о километров, площадь зеркала воды - 6236 квадратных километров. ${ }^{6}$ Около 118 рек и ручейков впадают в озеро. Питание в основном от таяния снега, но озеро подпитывается еще и источниками, в том числе многочисленными горячими источ-

5 Словарь Коллинз. https://www.collinsdictionary.com/dictionary/english/niche (по состоянию на 29 августа 2018).

6 Международный Комитет охраны озер. Озеро Иссык Куль. http://wldb.ilec.or.jp/Details/Lake/ASI-55 (по состоянию на 22 января 2018). 
никами. В советские времена озеро было популярным курортом. Вдоль северного побережья располагались санатории, пансионаты и дома отдыха. Многие из них были сосредоточены в и вокруг города Чолпон-Ата.7 После распада Советского Союза, поток туристов сократился, город столкнулся с большими трудностями. В конце 1990-х у города началась вторая жизнь. Теперь многое в городе отремонтировано, создаются гостиничные комплексы, строятся мини-гостиницы типа типа «ночлег и завтрак» для отдыха и укрепления здоровья туристов.

\section{Рисунок 4.12. Сегменты альтернативного туризма}

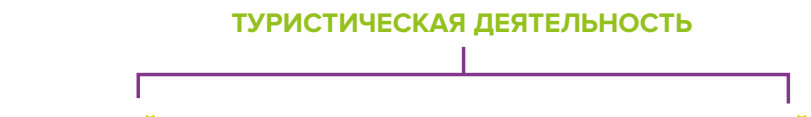

МАССОВЫЙ ТУРИЗМ

обычный туризм, большое количество туристов в определенных местах туризм по интересам, например, изучение культуры, туризм, основанный на определенной деятельности для небольшой группы туристов вдали от туристических мест

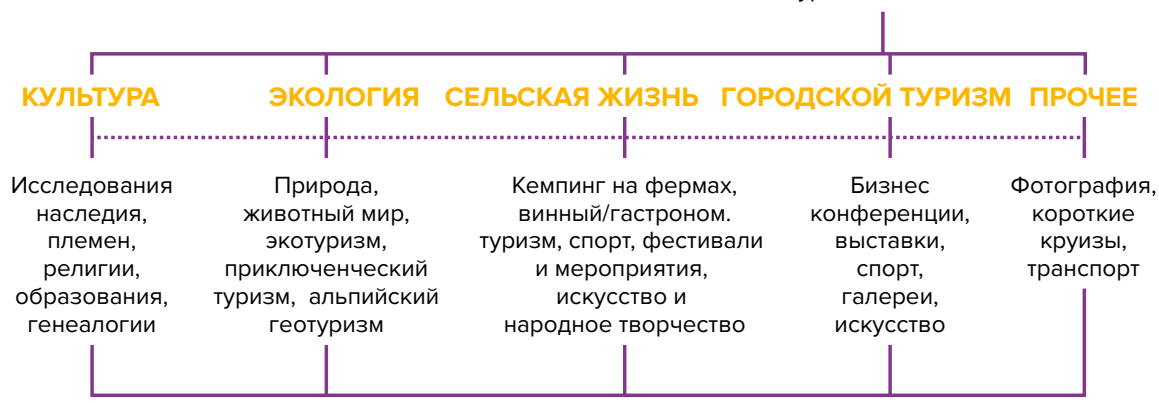

Развитие альтернативного туризма

Источник: Новелли (2005).

Многочисленные исследования и опросы туристов показывают, что качество проживания на курортах Иссык-Куля намного ниже базовых международных стандартов (Жениш, 2017, Делойт и др., 2014, SIAR, 2012).). К выявленным недостаткам можно отнести следующее: отсутствие или плохой доступ к Интернету, недостаток бассейнов и соответствующего оборудования, плохое качество питания и предоставляемых услуг, мебель низкого качества, туалеты, не соответствующие гигиеническим стандартам, частые отключения электричества и горячей воды, плохо обученный персонал и менеджеры. Далее, детские нянечки, развлечения для детей, вечерние развлекательные мероприятия, набор экскурсий - либо предоставляются в очень ограниченном количестве, либо не предоставляются вообще. Как отмечается в работе Жениша (2017), размещение и питание - одна из основных проблем. Еще один важный вопрос, который не включен в цепочку создания стоимости кыргызстанского туризма, - загрязнение окружающей среды, особенно общими и пищевыми отходами. На пляжах не проводится регулярный сбор мусора; продукты питания, продукты жизнедеятельности человека и скота сбрасываются в воды озера, иногда вблизи туристических объектов.

\footnotetext{
7 Санатории - бывшие медицинские учреждения, предназначенные для людей с хроническими, как правило, заболеваниями органов дыхания. До открытия антибиотиков таким образом лечился туберкулез в конце 19 и начале 20 веков.
} 


\section{Факторы, препятствующие развитию туризма}

Национальная стратегия устойчивого развития (НСУР) на период с 2013 по 2017 годы намечает пути развития туристического подсектора. Разработаны и другие политические документы. ${ }^{8}$ Следует отметить, что существуют хорошие перспективы роста туристического сектора, особенно сегмента «нишевый туризм», в случае, если будут продуманы основные инициативы и приняты меры по решению проблемных вопросов. Среди факторов, препятствующих развитию туризма, можно назвать следующие:

- сезонность,

- ограниченный рыночный потенциал,

- недостаток квалифицированных кадров,

- недостаток знаний для качественного управления туристическими учреждениями,

- низкое качество работы провайдеров услуг,

- недостаток качественной инфраструктуры,

- недостаточное использование технологий в продвижении туризма,

- деградация окружающей среды,

- несправедливое распределение поступлений от туризма,

- политическая нестабильность.

Для Кыргызской Республики «сезонность» туризма является серьезной проблемой, так как зимний сезон длится ориентировочно 5-6 месяцев (с октября по март). Таким образом, туристический сезон в Кыргызстане короткий; большинство туристов посещают республику в период с июня по сентябрь. В частности, озеро Иссык-Куль, как курортное направление, привлекает туристов, в основном, в период с июля по август. Сезонность создает ряд проблем и трудностей для туристической отрасли Кыргызстана. Первая из них - это сложности в привлечении и сохранении квалифицированных сотрудников, которые предпочитают круглогодичную занятость. В результате в туристический сектор нанимаются неквалифицированные работники. Следовательно, становится невозможным достичь высокого качества услуг, предоставляемых туристам. Другая проблема - трудности привлечения инвесторов в связи с сезонностью и тем фактом, что большинство мест отдыха туристов требуют модернизации и обновления, а это, в свою очередь, требует инвестиций.

Это приводит к следующей проблеме - ограниченной ёмкости рынка. Туристический сектор в Кыргызстане зависит, в первую очередь, от туристов из Казахстана, Российской Федерации, Украины и Таджикистана, а также более удаленных стран - Турции и КНР. В основном, туристы приезжают отдохнуть на Иссык-Куле. С учетом удалённости и высокого уровня затрат, пляжный туризм в Кыргызстане не может конкурировать с другими местами отдыха, предлагающими «солнце, море, песок». Существует огромный потенциал у горного, лыжного и приключенческого туризма. Зимний туризм может привлечь западных туристов, но в том случае, если инфраструктура и предлагаемые услуги будут соответствовать международным стандартам.

8 (1) Программа правительства Кыргызской Республики по развитию экспорта Кыргызской Республики на 2013- 2017 годы; (2) Стратегия развития туризма до 2015 года, предложенная в 2012 году Министерством культуры, информации и туризма. 
Одной из серьезных проблем, озвученных представителями нишевого туризма, - недостаток квалифицированных кадров, особенно квалифицированного обслуживающего персонала. В Кыргызской Республике обучение туристическому бизнесу ведется в различных образовательных учреждениях на уровне колледжей и университетов. Основной проблемой образовательных учреждений - недостаток квалифицированных лекторов и практиков, которые вели бы соответствующие курсы. Число лекторов, обладающих необходимыми навыками и знаниями в туристическом бизнесе, в последнее время растет, но пока не удовлетворяет полностью спрос. Одно из объяснений, почему трудно привлечь к образовательному процессу квалифицированных преподавателей и практиков - это низкий уровень заработной платы и в колледжах, и в университетах. Недостаток навыков проявляется и в розничной торговле, и в индустрии питания, и в гостиничном бизнесе.

В стране очевиден недостаток стандартов качества и сертификационных стандартов. Например, в Иордании Европейский банк реконструкции и развития (ЕБРР) организовал первую в стране компанию «Навыки в секторе гостиничного бизнеса и туризма», которая занимается развитием и продвижением определенных навыков в целях улучшения сектора туризма и гостиничного бизнеса (Згейб, 2018). Этот пример может быть использован и в Кыргызстане. Цель в том, чтобы помочь туроператорам и гидам, представителям гостиничного и ресторанного бизнеса инвестировать в развитие человеческих ресурсов/ персонала своих компаний, чтобы потенциальные работники приобрели навыки, требуемые в той или иной области. Такая компания (1) помогает разрабатывать программы обучения и тренингов при сотрудничестве с профессиональными училищами и другими образовательными институтами и (2) помогает вводить квалификационные и сертификационные стандарты.

Во времена Советского Союза, на Иссык-Куле ежегодно отдыхали около 800 тысяч человек из всех союзных республик. С того времени на Иссык- Куле осталось около ста центров здоровья или санаториев. Они принадлежали профсоюзам и другим организациям. Большинство из них приватизированы. Эти учреждения следует переоборудовать, чтобы они соответствовали международным стандартам. За последние 10 лет в Иссык-Кульской области и вокруг Иссык-Куля построено много пансионатов и гостиниц; строительство продолжается. Однако, как отмечалось выше, стандарты обслуживания, нехватка профессиональных кадров и отсутствие знаний и навыков управления профессиональным туристическим бизнесом и природными ресурсами, а также вопросы несправедливого распределения поступлений от туристического бизнеса являются основными проблемами, требующими более глубокого понимания на национальном уровне.

Туристические компании рассматривают недостаток гостиниц и инфраструктуры в целом как фактор, ограничивающий их развитие и рост (Жениш 2017). В республике недостаточно развито международное воздушное сообщение. Ситуация усугубляется задержками или отменами рейсов, правилами обращения с багажом; это создает негативный имидж страны. Несмотря на увеличившиеся инвестиции в восстановление дорог, ведущих к крупным туристическим центрам в Кыргызской Республике, например, на озеро Иссык-Куль, они по-прежнему находятся в плохом состоянии. В некоторых местах скопления или проживания туристов нет дорожных знаков или указателей на английском языке. Нет указателей на английском языке для туалетов, аптек, пунктов первой помощи; туристам, особенно путешествующим индивидуально, это доставляет большие неудобства. Наблюдаются постоянные сбои с электричеством, водоснабжением; власти не об- 
ращают внимание на плохую работу канализации, стоки сливаются. В некоторых местах на Иссык-Куле береговая линия забросана мусором, пляжи содержатся в антисанитарных условиях.

Еще один фактор - недостаток маркетинга красоты кыргызской природы в целях развития туризма. Необходимы эффективные стратегии управления брендами для размещения туристических продуктов Кыргызстана за рубежом. Департамент туризма начал проводить рекламные акции и презентации на зарубежных рынках, но охват ограничился территорией Центральной Азии, КНР и Индии. Цифровая платформа Таза-Коом является основным средством продвижения продукта для многих компаний и агентств, но необходимы стратегии продвижения туристических достопримечательностей и привлечения целевых групп и рынков, подобно тем, что используются в Восточной и Юго - Восточной Азии.

\section{5. Краткое изложение главы и рекомендации}

Сектор услуг обладает большим потенциалом и может выступить в качестве движущей силы устойчивого и инклюзивного экономического роста; рост сектора обеспечит создание новых рабочих мест в Кыргызской Республике. Целью диагностирования состояния сектора является нахождение возможностей «разблокировать» потенциал и обеспечить рост сектора. В этой главе освещены проблемы, которые необходимо решить в целях содействия росту сектора услуг в Кыргызской Республике. Раскрытие потенциала сектора услуг страны требует большего внимания к таким вопросам, как повышение качества и расширение рынка услуг.

Обеспечение эффективной деятельности частного сектора является ключевым фактором содействия росту сектора услуг и создания новых рабочих мест. Для развития частного сектора в стране требуется продуманная политика, направленная на модернизацию государственной инфраструктуры, развитие человеческого капитала, обеспечение доступа к финансированию и предоставление доступных кредитов и улучшение бизнес-среды. Также требуются дополнительные инвестиции для улучшение физической инфраструктуры и развития человеческого потенциала. Для улучшения конкурентоспособности предоставляемых услуг необходимо обеспечить бесперебойную работу провайдеров услуг, в частности, более надежного и простого доступа к электроснабжению, уменьшить затраты на ведение бизнеса за счет упрощения процедур регистрации. Устранение барьеров на пути развития частного сектора будет способствовать развитию сектора услуг, а также других секторов экономики.

Содействие росту финансового сектора положительно отразится на развитии частного сектора. Более доступные и дешевые в обслуживании кредиты позволят вновь открывающимся и уже существующим предприятиям улучшить их конкурентоспособность, расширить ассортимент товаров и увеличить их ценность, а также стоимость и ценность предоставляемых услуг. Строгое обеспечение финансового регулирования и соблюдения установленных правил также может способствовать снижению стоимости капитала за счет привлечения большего объема частных инвестиций.

Развитие транспортной системы страны и улучшение логистики важны для «разблокирования» сектора услуг и роста экономического потенциала. Потребуются упрощенные и прозрачные процедуры прохождения пограничного 
контроля, это позволит уменьшить количество задержек и транзакционных издержек. Требуются дополнительные ресурсы для повышения качества дорог и обновления транспортной инфраструктуры в целом и портов в частности с целью расширения сети сообщения (регионального и международного). Менее затратная транспортировка ресурсов, продуктов потребления и услуг повлечет за собой увеличение спроса на торговлю товарами и услугами.

Развитие туристической отрасли страны является перспективным источником роста сектора услуг и в целом экономического роста. Для этого необходимо обратить внимание на подготовку и повышение квалификации работников сферы туризма, на развитие транспортной и информационно-коммуникационной инфраструктуры, создание благоприятной среды для бизнеса. Иссык-Куль, одна из главных достопримечательностей Кыргызской Республики, предоставляет множество потенциальных возможностей для развития туризма и роста сектора услуг. Проведение туристических мероприятий и продвижение достопримечательностей Кыргызстана на новые рынки позволит привлечь больше туристов, особенно в зимний сезон, когда спрос низок, при сохранении традиционного летнего рынка.

Более конкретно, необходимо разработать стратегию для решения следующих задач. Во-первых, следует привлекать туристов, длительное пребывание которых повлечет за собой большие объёмы потраченных и оставленных в республике денежных средств. Из-за ограниченных возможностей многих туристических мест следует избегать массового туризма. Во-вторых, следует поощрять прямые и обратные связи. Например, элитные отели и рестораны высокого класса могут работать с сертифицированными фермерскими хозяйствами, выращивающими органическую продукцию. И, наконец, необходимо инвестировать в инфраструктуру мест пребывания туристов. 


\section{Библиография}

Азиатский банк развития (АБР). 2010. Ключевые индикаторы для стран Азии и Тихоокеанского региона. Манила,

Азиатский банк развития (АБР). 2013. Оценка частного сектора: Кыргызская Республика. Манила.

Азиатский банк развития (АБР). 2017.Ключевые индикаторы для стран Азии и Океании. Манила.

Азиатский банк развития. Статистические базы данных (по состоянию на 28 февраля 2018 года). Манила

Амити, М., Кенингс, Дж. 2007. Либерализация торговли, промежуточный товар и производительность: свидетельства из Индонезии. Американское экономическое обозрение. №97(5); С. 1611-1638.

Всемирный банк. Индекс логистики. https://lpi.worldbank.org

Всемирный банк. Индикаторы мирового развития.

https://datacatalog.worldbank.org/dataset/world-development-indicators (по состоянию на 18 декабря 2017, 15 сентября 2018 и 29 мая 2019)

Всемирный Совет по туризму и путешествиям. Экономическое воздействие туризма: Кыргызстан, 2017. Лондон: СВТП. https://www.wttc.org/-/media/ files/reports/economic-impact-research/countries-2017/kyrgyzstan2017.pdf

Всемирный Совет по туризму и путешествиям. База данных. https://www.wttc.org/datagateway (по состоянию на 18 декабря 2018)

Делойт Консалтинг, Департамент туризма Кыргызской Республики (Делойт и др.). 2014. Развитие туризма в Кыргызской Республике. Реформа, Проект ЮСАИД. https://pdf.usaid.gov/pdf_docs/paook45p.pdf (по состоянию на 15 января 2008).

Джонсон, Р. 2014. Пять фактов о добавленной стоимости экспорта и выводы для макроэкономических и торговых исследований. Экономические перспективы. №28(2). С.119 - 142.

Европейский банк реконструкции и развития (ЕБРР), Всемирный Банк. 2013. Бизнес среда и анализ работы предприятий. Профиль страны- Кыргызской Республики. https://ebrd-beeps.com/reports/beeps-v/kyrgyz-republic (по состоянию на 12 февраля 2018)

Жениш, Н. 2017. Туристический сектор Кыргызстана: тенденции и вызовы. Рабочий документ № 42. Бишкек: УЦА, Институт государственного управления и политики. http://www.ucentralasia.org/Content/Downloads/UCAIPPA-WP42_Eng.pdf (по состоянию на 12 февраля 2018).

Згхейб, Н. 2018. Европейский банк развития и реконструкции помогает развивать сектор туризма и гостиничный сектор в Иордании. https://www.ebrd. $\mathrm{com} / \mathrm{cs} /$ Satellite $\mathrm{c}=$ Content\&cid $=1395273822033 \& \mathrm{~d}=$ Mobile\&pagename $=\mathrm{EBR}$ D\%2FContent\%2FContentLayout\# 20ZvfeJFexegv8Cv.o1 (по состоянию на 7 мая 2018).

Колинз. Английский словарь - 2018. Ниша. https://www.collinsdictionary.com/ dictionary/english/niche (по состоянию на 29 августа 2018). 
Конференция ООН по торговле и развитию (ЮНКТАД). 2013. Обзор политики сектора услуг Кыргызстана. Женева: Организация Объединённых Наций.

Макинтайр, М., Ксин, Ли, Вонг, К. и др. 2018. Экономические выгоды диверсификации экспорта в малых странах. МВФ Рабочий документ №18/86. Вашингтон: МВФ.

Международный Комитет по охране озер. База данных по озерам. Озеро Иссык-Куль. http://wldb.ilec.or.jp/Details/Lake/ASI-55 (по состоянию на 22 января 2018)

Международный Валютный Фонд (МВФ). 2016. Отчет по стране № 16/55. Вашингтон, ОК.

Национальный банк Кыргызской Республики (НБКР). 2017. Отчет о стабильности финансового сектора Кыргызской Республики, июнь 2017. http://www. nbkr.kg/DOC/13032018/oо0оооооо049512.pdf (по состоянию на 12 февраля 2018)

Национальный банк Кыргызской Республики (НБКР). 2018. Тенденции развития банковской системы. http://www.nbkr.kg/printver.jsp?item=80\&lang=ENG (по состоянию на 12 февраля 2018).

Национальный Совет по устойчивому развитию Кыргызской Республики.2013. Национальная Стратегия Устойчивого Развития Кыргызской Республики на 2013-2017 годы.

Национальный статистический комитет Кыргызской Республики: http://stat.kg/ en (по состоянию на 3 декабря 2017 и 3 марта 2018)

Новелли, М. 2005. Нишевый туризм: вопросы современности, тенденции и примеры. Оксфорд: Elsevier.

Пак, Д., Ноланд, М. и др. 2013. Развитие сектора услуг как движущей силы развития стран Азии. Манила: АБР.

Робинсон, М., Новелли, М. 2005. Нишевый туризм: введение. Вопросы современности, тенденции и практические примеры. Оксфорд: Батервос Хейнеман.

Свиридженка, К. 2016. Внедряя новый обобщенный индекс финансового развития. МВФ, Рабочий документ № 16/5. Вашингтон ОК.

SIAR. 2012. Исследование туристической индустрии Кыргызской Республики. Бишкек. SIAR, http://siar-consult.com/wp-content/uploads/Issledivanieturisticheskoi-otrasli-24.12.12.pdf (по состоянию на 18 января 2018года).

Холл, М, Лью, А. 1998. География устойчивого туризма: уроки и перспективы. Харлоу: Addison Wesley Longman Ltd.

Экономическая и социальная комиссия Организации Объединенных Наций для Азии и Тихого Океана (ЭСКАТО ООН). Развитие сектора услуг для экономической диверсификации и интеграции Северной и Центральной Азии. ЭСКАТО ООН- 2016, № 34 .

ЮСАИД. Развитие. Проект Реформа ЮСАИД. https://pdf.usaid.gov/pdf_docs/ paook45p.pdf (по состоянию на 15 января 2008). 


\title{
Глава 5
}

\section{Цифровая трансформация}

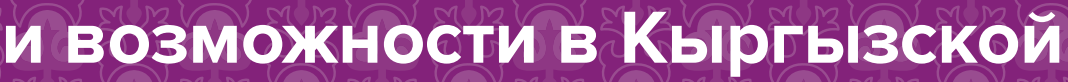 Pecnyonuke}

\author{
Соек Юн и Майкл Мингес
}

\section{1. Введение}

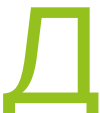

остижения в области информационно-коммуникационных технологий (ИКТ) создают огромные возможности для улучшения предоставляемых услуг и увеличения экономических возможностей в Кыргызской Республике. Цифровые технологии повышают прозрачность, уменьшают уровень коррупции и увеличивают эффективность за счет минимизации контактов между гражданами, бизнесом и правительством при предоставлении государственных услуг. В Кыргызской Республике ИКТ могут устранить барьеры, возникающие из-за географической удаленности и высоких транспортных издержек («Internet Society», 2017 г.). Стратегическое расположение страны на основных перекрестках между Азией и Европой может стать стимулом для серьезного развития ИКТ страны, поскольку транспортные коридоры потребуют широкого спектра телекоммуникационных и интернет-услуг для поддержания повседневной деятельности. Прямые мероприятия в форме ИКТ, такие как единое таможенное окно, которое может оптимизировать обработку документов, необходимых для содействия трансграничной торговле, и дистанционное картографирование, которое может использоваться для мониторинга перевозимых товаров, могут ускорить, упростить и облегчить перевозки и торговлю. Учитывая план страны по развитию таких секторов, как гидроэнергетика, туризм и другие услуги, ей потребуется более сложная передача и обработка информации, чтобы помочь резко повысить потенциал этих секторов.

В 2011 и 2013 годах доля ИКТ в общем валовом внутреннем продукте (ВВП) оценивалась соответственно в 4,4\% и 5,0\%, этот показатель был самым высоким среди стран Центральной Азии (АБР, 2018 г.). В 2016 году доход от телекоммуникационного сектора составил около 367 миллионов долларов США, или 5,6\% от ВВП (НСК, 2017 г.). Хотя вклад является относительно высоким, доходы от ИКТ падают, поскольку цены снижаются из-за конкурирующих внутренних рынков. На долю мобильной связи приходится $81 \%$ от общего объема доходов телекоммуникационной отрасли, хотя ее доля также падает, что говорит о медленном, но растущем росте спроса на услуги проводной широкополосной связи. Добавленная стоимость сектора ИКТ, включающего издательские, радиовещательные, теле- 
коммуникационные, компьютерные и информационные услуги, выросла примерно на 9,5\% в 2016 году, что составило около 1,9\% от ВВП страны, и 0,2 процентных пункта к уровню общего роста ВВП в 3,8\% (НБКР, 2017 г.). Занятость в секторе ИКТ в 2016 году составила около 30 ооо человек, что на 3,1\% меньше, чем в предыдущем году. Тем не менее, сектор еще не является важным источником внутреннего дохода, поскольку процент занятости в секторе ИКТ составляет только около 1,2\% от общей занятости страны (НСК, 2015 г.).

Кыргызская Республика прилагает значительные усилия для развития ИКТ, создавая соответствующую законодательную базу, реализуя программы и развивая человеческий потенциал в области ИКТ. Проекты информатизации ${ }^{1}$ осуществлялись в различных секторах экономики, как государственным, так и частным секторами. Созданы интернет-страницы государственных и неправительственных организаций, расширяющие доступ к информации и способствующие прозрачности. Однако из-за сложностей с внедрением ИКТ правительство осознало необходимость отойти от односторонней политики (в основном сосредоточенной на развитии коммуникационных и информационных технологий) и работать над созданием общенациональной стратегии интеграции страны в мировое информационное общество. Признана важной необходимость связать информационное пространство Кыргызской Республики с мировым пространством посредством развития информационных ресурсов, баз данных, знаний и информационных инфраструктур, которые могут использоваться как государством, так и широкой общественностью на единой основе. Однако для того, чтобы Кыргызская Республика двигалась в таких направлениях, требуется разработка информационных законов, технологических средств и организационная и внешняя поддержка как внутри страны, так и за ее пределами (ЕЭК ООН, 2002 г.).

Краткосрочные и долгосрочные (до 2040 года) национальные стратегии развития страны признают важность ИКТ, что делает их развитие одним из главных приоритетов. Это воплощено в Национальной программе цифровой трансформации на 2019-2023 годы, целью которой является трансформация страны в цифровую экономику, подчеркивая политическую решимость на высоком уровне проводить модернизацию и реформирование государственного сектора. ${ }^{2}$ Программа содержит всеобъемлющие цели по цифровизации экономики и деятельности государственного сектора через широкое использование цифровых технологий, тем самым оптимизируя взаимодействие граждан, бизнеса и правительства; искореняя коррупцию; повышая инвестиционную привлекательность и улучшая инфраструктуру для развития.

\section{2. «Электронная готовность» Кыргызской Республики: обзор}

В данном разделе анализируется нормативно-правовая среда ИКТ, а также наличие, качество и существующий спрос на инфраструктуру и услуги ИКТ в Кыргызской Республике (ее «электронная готовность»). Понимание электронной готовности страны крайне важно для оценки ее способности успешно осваивать цифровые проекты и программы.

\footnotetext{
Информатизация - внедрение информационных технологий или компьютеризация.

2 Таза Коом. http://tazakoom.kg
} 


\section{Политические, правовые и рыночные аспекты}

Государственный комитет информационных технологий и связи (ГКИТС) Кыргызской Республики является основным государственным органом, отвечающим за регулирование, политику и надзор в сфере ИКТ в Кыргызской Республике. ГКИТС был образован в июле 2016 года с целью объединения Государственного агентства связи (ГКА) и Центра электронного государственного управления, а также чтобы гармонизировать сквозные функции ИТК других ведомств. Таким образом, создание ГКИТС было вызвано желанием правительства провести централизацию всей ключевой деятельности ИКТ, избежать дублирования ролей ведомств и разрабатывать более сфокусированные программы в стране. Государственное агентство связи продолжает осуществлять регулирование в области электронной и почтовой связи, включая использование радиочастотного спектра и ресурса нумерации. ГКИТС реализует государственную политику и осуществляет межотраслевую координацию в области информатизации, электронного правительства, электронной и почтовой связи, включая радио - и телевизионное вещание. Но, поскольку Государственный комитет по иерархии считается ниже уровня министерств, он продолжает сталкиваться с проблемами в руководстве направлением политики в сфере ИКТ и получении признания со стороны министерств более высокого уровня.

С 2002 года Кыргызская Республика включила развитие ИКТ в свою национальную политику и стратегии (Таблица 5.1). Однако в первоначальной стратегии развития в 2002 году не были установлены качественные показатели результатов, сроки и индикаторы для измерения ее достижений. В последующей Стратегии развития страны на 2009-2011 гг. это было исправлено, и строительство национальной сети передачи данных было названо одним из приоритетов. До настоящего времени в стране еще не полностью сформирован документ с подробными планами ИКТ и направлениями стратегии. Пока только Национальная стратегия устойчивого развития Кыргызской Республики на 2013-2017 годы является основным документом национального планирования, в котором изложены целевые показатели страны в области ИКТ с акцентом на трех направлениях: (1) электронное правительство, (2) переход к цифровому вещанию и (3) всеобщий доступ в интернет.

\section{Таблица 5.1. Политика и стратегии в области информационных и коммуникационных технологий в Кыргызской Республике}

\begin{tabular}{|c|c|c|}
\hline Год & Политика и стратегия & Приоритетные сферы ИКТ \\
\hline 2002 & $\begin{array}{l}\text { Комплексная основа разви- } \\
\text { тия Кыргызской Республики }\end{array}$ & $\begin{array}{l}\text { Управление через ИКТ, образование в области ИКТ, экономика } \\
\text { ИКТ (например, развитие электронной торговли) }\end{array}$ \\
\hline $\begin{array}{l}2009- \\
2011\end{array}$ & Стратегия развития страны & $\begin{array}{l}\text { Строительство национальной сети передачи данных, интеграция } \\
\text { строительства национальной сети, интеграция национальной } \\
\text { сети в Интернет, телефонные услуги, переход с аналоговой на } \\
\text { цифровую сеть, прокладка волоконно-оптических линий и т. д. }\end{array}$ \\
\hline $\begin{array}{l}2013- \\
2017\end{array}$ & $\begin{array}{l}\text { Национальная стратегия } \\
\text { устойчивого развития } \\
\text { Кыргызской Республики }\end{array}$ & $\begin{array}{l}\text { Внедрение современных технологий в государственной тамо- } \\
\text { женной службе, образовании и банковском деле }\end{array}$ \\
\hline 2017 & Инициатива «Таза-Коом» & $\begin{array}{l}\text { Улучшение жизни людей с помощью технологий, цифровой } \\
\text { инфраструктуры и развития данных }\end{array}$ \\
\hline $\begin{array}{l}2019- \\
2023\end{array}$ & $\begin{array}{l}\text { Национальная программа } \\
\text { цифровой трансформации } \\
\text { «Цифровой Кыргызстан» }\end{array}$ & $\begin{array}{l}\text { Внедрить цифровые технологии в государственном управлении } \\
\text { и сфере услуг; создать центры компетенций и инновационные } \\
\text { кластеры }\end{array}$ \\
\hline
\end{tabular}

ИКТ = информационно-коммуникационные технологии.

Источник: МСЭ (2017 г.); Бакенов (2019). 
ОАО «Кыргызтелеком», 90\% которого принадлежит государству, является самым старым оператором телекоммуникаций в стране. «Кыргызтелеком» предлагает линии фиксированной телефонной связи, доступ в интернет и интернет-телевидение. Хотя он и является основным поставщиком стационарных телефонных линий, он сталкивается с конкуренцией, особенно в сегментах розничных и оптовых услуг. Несмотря на наличие соответствующей лицензии, «Кыргызтелеком» не активен на рынке мобильной сотовой связи, где конкурируют три частные компании. В отличие от многих других развивающихся стран, где действующие операторы часто тормозят либерализацию сектора, в Кыргызской Республике дело обстоит по-другому.

\section{Доступ к информационно-коммуникационным технологиям}

Телекоммуникационные технологии. Охват фиксированной телефонной связью в Кыргызской Республике остается одним из самых низких в регионе, после Таджикистана (Рисунок 5.1). В 2017 году было 362288 стационарных телефонных линий, то есть 6,2 на 100 человек. Это свидетельствует о сложности развертывания стационарной инфраструктуры в горных сельских районах. Только 27,0\% домохозяйств имели стационарные телефонные линии; в сельской местности этот показатель составлял 3,6\% (НСК и ЮНИСЕФ, 2016 г.). Кроме того, растет популярность мобильной связи, а это приводит к уменьшению количества стационарных телефонных линий. За 2014-2017 годы количество абонентов фиксированной телефонной связи сократилось на 14\%, или на 80896 абонентов. Наличие электричества не является препятствием для распространения и использования ИКТ в Кыргызской Республике, поскольку почти во все дома в сельской местности проведено электричество, а у 98,9\% населения есть телевизоры.

\section{Рисунок 5.1: Телекоммуникационные абоненты: Содружество Независимых Государств и мир}

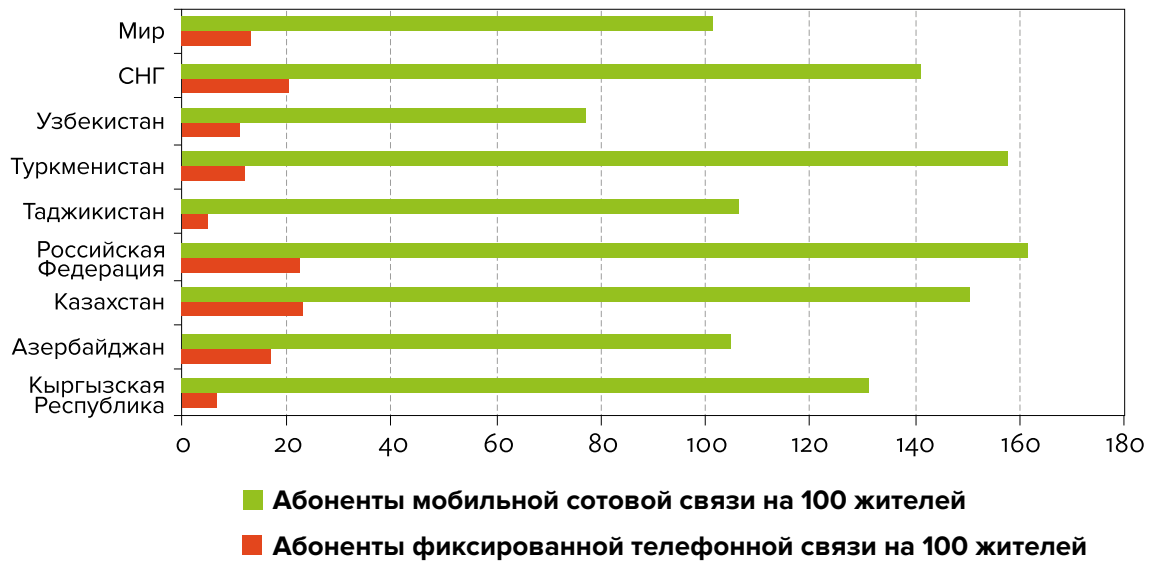

СНГ = Содружество Независимых Государств.

Источник: МСЭ. База данных статистики ИКТ.

https://www.itu.int/en/ITU-D/Statistics/Pages/stat/default.aspx (на 12 октября 2018 г.).

В Кыргызской Республике, как и во многих других развивающихся странах, популярность мобильной связи за последнее десятилетие значительно возросла, а обладание мобильным телефоном стало практически повсеместным. Число або- 
нентов мобильной сотовой связи в стране составляет 131,4 на 100 жителей, что выше, чем, например, в Азербайджане, Таджикистане, Узбекистане и в среднем по миру. Конкурентный рынок мобильной связи с тремя основными операторами стимулировал рост за счет расширения охвата и снижения цен. ${ }^{3}$ Покрытие сетью третьего поколения (3G) достигает около 60\% населения. По данным Международного союза электросвязи (МСЭ) корзина мобильных голосовых вызовов и смс-сообщений составила 4,1\% от доходов на душу населения в 2017 году (МСЭ, 2017 г.).

Уже несколько лет количество абонентов мобильной связи превышает численность населения в целом. По состоянию на 31 декабря 2017 года насчитывалось 7,3 миллиона абонентов мобильной связи, что составляет $116 \%$ от числа всего населения страны. В 2014 году 98\% домохозяйств имели мобильный телефон без статистически значимой разницы между городской и сельской местностью (НСК и ЮНИСЕФ, 2016 г.), а 95\% населения в возрасте 15 лет и старше имели мобильные телефоны (Всемирный банк, 2014 г.).

Все три оператора мобильной связи предлагают новейшие технологии мобильной широкополосной связи, хотя охват не такой высокий, как в случае узкополосной мобильной связи. Мобильная связь $3 \mathrm{G}$, которая была запущена в 2011 году, охватила только три-пятых населения, а мобильная связь четвертого поколения (4G) Long-Term Evolution (LTE), развернутая в 2014 году, охватила лишь около трети населения. Широкополосная мобильная связь достаточно широко доступна в городских районах, но остается ограниченной во многих сельских районах. Доступ к фиксированной широкополосной связи обычно ограничен городскими районами, всего 4,1 абонента на 100 человек, в то время как мобильной широкополосной связью пользуется более 30\% населения. Мобильная широкополосная связь с ежемесячным пакетом в 500 Мб данных обходится в 1\% дохода, что значительно дешевле фиксированного широкополосного пакета $(8,4 \%)$. («Terabit Consulting», 2014 г.).

Доступ в интернет. Несмотря на высокий уровень грамотности и значительное число лиц, имеющих среднее образование, по данным опроса, проведенного в 2017 году, только 38\% взрослого населения пользовались интернетом (Международный республиканский институт (МРИ), 2017 г.). Тем не менее, с 2011 по 2017 годы произошел впечатляющий рост на 20 процентных пунктов (Рисунок 5.2). Хотя большинство людей в стране имеют мобильные телефоны, только $29 \%$ домохозяйств - 44\% в городских районах и всего 19\% в сельской местности - имеют доступ к компьютерам и планшетам (НСК и ЮНИСЕФ, 2016 г.). Таким образом, доступ к интернету осуществляется преимущественно через мобильные телефоны. Опрос 2014 года показал, что 69\% интернет-пользователей или чуть более четверти взрослого населения (26\%) имеют доступ к интернету через свои телефоны (МРИ, 2017 г.). Доступ к интернету в сельской местности ограничен по причине ограниченного охвата мобильной широкополосной связью и отсутствия смартфонов и компьютеров.

Местная компания «Alfa Telecom» (торговая марка «Megacom», https://www.megacom.kg) является крупнейшим оператором для абонентов мобильной связи. «Sky Mobile» под торговой маркой «Beeline» (https://beeline.kg) является вторым по величине оператором, наполовину принадлежащим региональному оператору «Veon». Местная компания «Nur Telecom» под маркой «O!» (https://o.kg) является третьим оператором мобильной связи в стране. 


\section{Рисунок 5.2: Уровень пользования интернетом среди взрослых (2011-2017 гг.) и среди молодых женщин (2014 г.), Кыргызская Республика (\%)}

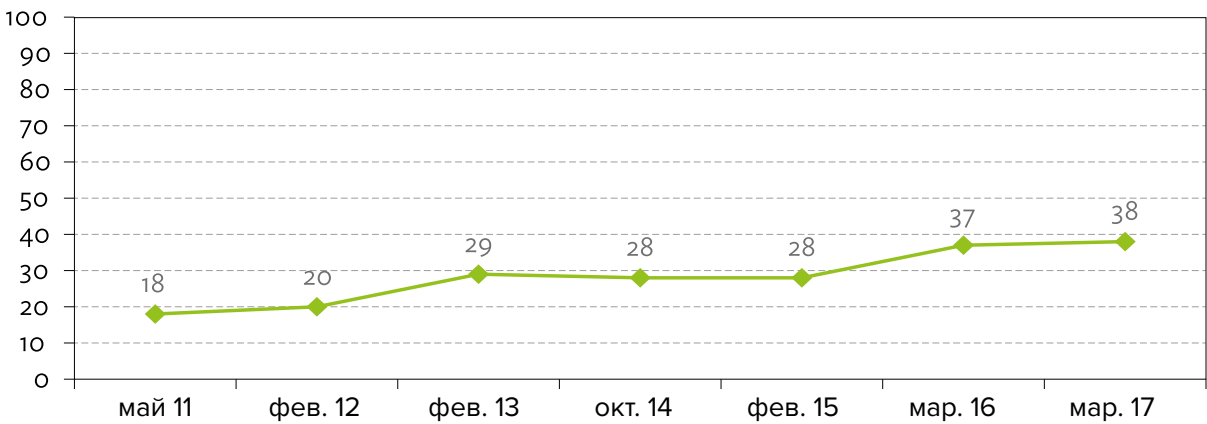

Источник: Center for Insights in Survey Research. 2017. Опрос жителей Кыргызстана. Презентация. https://www.iri.org/sites/default/files/wysiwyg/kyrgyzstan_february-march_2017_-_public.pdf (16 октября 2018г.).

\section{Магистральная инфраструктура и связанность}

Национальная и международная связанность является большой проблемой в Кыргызской Республике. Горный рельеф местности затрудняет прокладку волоконно-оптических магистралей эффективным с точки зрения затрат способом, и страна вынуждена полагаться на соседние страны (некоторые из которых также не имеют выхода к морю) для доступа к подводным волоконно-оптическим кабелям. Обширная магистральная связь и трансграничные соединения важны для того, чтобы Кыргызская Республика стала региональным хабом цифрового Шелкового пути.

В 2000 году была проложена волоконно-оптическая линия связи до границы с Кыргызской Республикой, соединяющая Бишкек с системой Трансазиатско-европейской волоконно-оптической линии связи, пролегающей от Франкфурта до Шанхая (ЭСКАТО, 2014 г.). До 2009 года не было заметного развития отечественных волоконно-оптических линий связи, поэтому страна сильно зависела от транзита через радиорелейные IP-технологии - передачи трафика (голоса, видео и данных) между распределенными узлами и централизованной точкой по радиоканалу («Terabit Consulting», 2014 г.). С 2009 года оптоволоконные линии связи были проложены до границ с Китайской Народной Республикой (КНР), Таджикистана и Узбекистана, а также проложено кольцо, соединяющее Бишкек, Нарын, Ош и Джалал-Абад (Рисунок 5.3). ${ }^{4}$ ОАО «Кыргызтелеком» владеет большей частью национальной волоконно-оптической сети, но «Мегаком» 5 также развернул сеть ВОЛП на основных маршрутах, включая национальное кольцо, а ELCAT $^{6}$ имеет оптоволоконные линии связи на некоторых основных маршрутах.

4 Интерактивная карта МСЭ. http://www.itu.int/itu-d/tnd-map-public (август 2017).

5 «Megacom»- первый и крупнейший мобильный оператор связи в Кыргызской Республике, предоставляющий услуги сотовой связи в стандартах GSM (2G) в диапазонах частот 900 и 1800 МГц, WCDMA/UMTS (3G) в диапазонах частот 2100 и 900 МГц и LTE (4G) в диапазонах частот 800, 1800 и 2100 МГц. «MegaCom» обеспечивает мобильной связью до 99\% населенной территории страны и обслуживает более 3 миллионов абонентов.(Megacom. https://megacom.kg/pages/o-kompanii).

6 ELCAT. http://www.elcat.kg/en/about/history/about-us. 


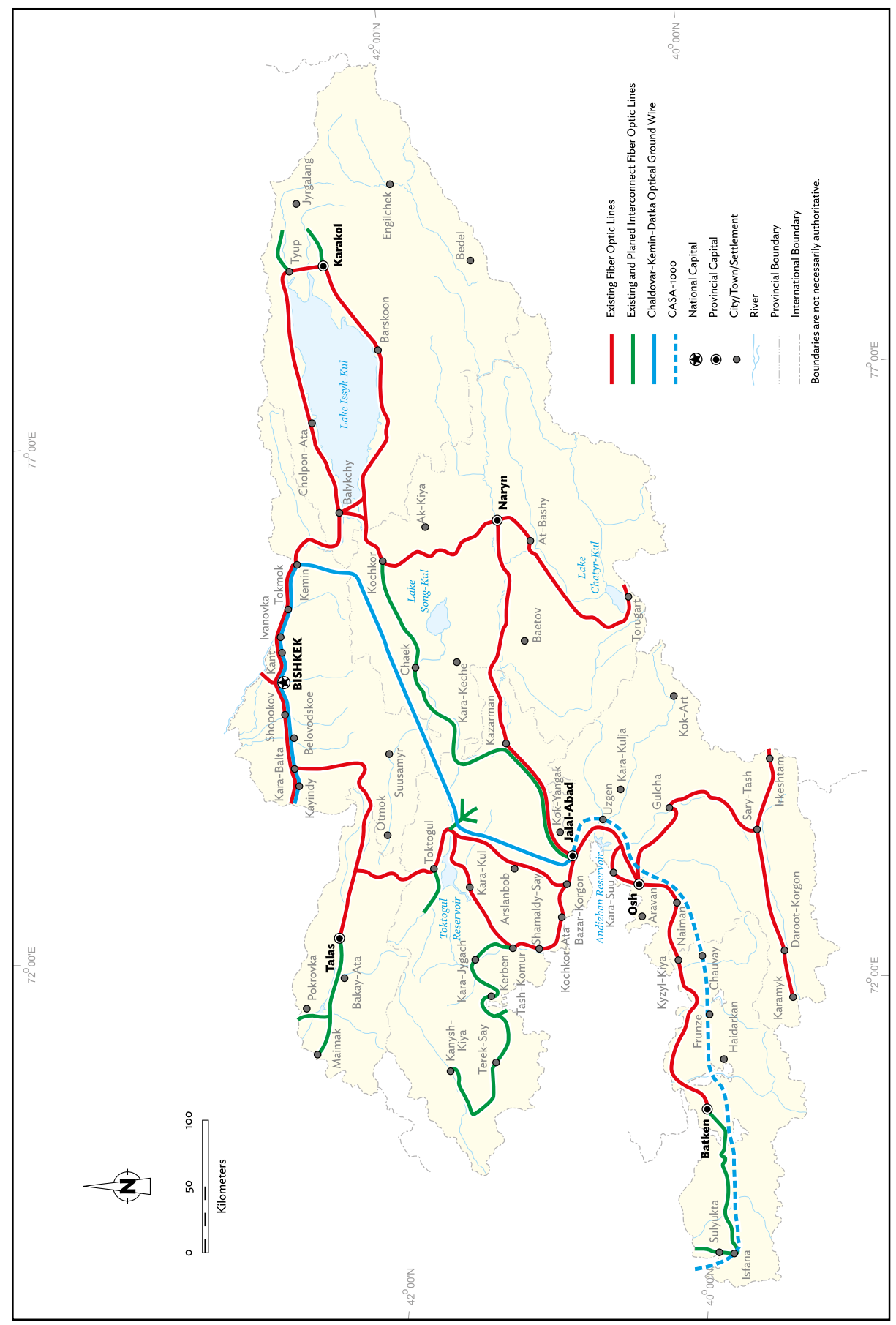


Несмотря на то, что Кыргызская Республика в настоящее время связана волоконно-оптической сетью связи с КНР, и разработаны планы по расширению оптоволоконной сети через Таджикистан, Афганистан и Пакистан, чтобы подключиться к подводным волоконно-оптическим кабелям Пакистана, на данный момент основной транзит осуществляется через Казахстан и далее в Российскую Федерацию. Любой оператор, получивший лицензию в Кыргызской Республике, может использовать волоконно-оптическую сеть, и полдюжины операторов занимаются передачей данных через Казахстан («Internet Society», 2015 г.).

К 2015 году по всей стране был проложен 4841 километр волоконно-оптического кабеля. Однако только $42 \%$ населения живет в пределах 10 километровой зоны волоконно-оптических магистралей (Рисунок 5.3). Проект Всемирного банка «Цифровая Центральная Азия и Южная Азия» («Digital CASA»)7 направлен на расширение волоконно-оптической магистральной инфраструктуры путем оказания поддержки правительству в обеспечении пропускной способности, что приведет к значительному увеличению спроса. Есть надежда, что это создаст стимулы для операторов инвестировать в расширение своих внутренних магистральных сетей и устанавливать новые трансграничные соединения. Проект также будет стимулировать совместное использование инфраструктуры и работу с электроэнергетическими компаниями и железными дорогами для использования их оптоволоконных активов. Ожидается, что это приведет к расширению волоконно-оптической магистрали и охвату всех районов и большинства населенных пунктов Кыргызской Республики.

В то время как оптовые цены на подключение к интернету в Кыргызской Республике относительно дешевы по сравнению с большинством других стран Центральной Азии (22 доллара США за Мбит/с в 2017 году) (Рисунок 5.4а), они высоки по сравнению с Казахстаном (12 долларов США за Мбит/с) и Российской Федерацией (2 доллара США). Пропускная способность международной интернет-связи в Кыргызской Республике неуклонно растет и достигла 130 Гигабит в секунду (Гбит/с) к 2016 году или 21,3 Кбит/с на человека. Недавний рост мощностей был обусловлен расширением использования мобильной широкополосной связи. Кыргызская Республика имеет более высокую международную пропускную способность интернета на душу населения, чем большинство ее соседей, но все же значительно меньше, чем Казахстан (Рисунок 5.4b). Целями проекта Всемирного банка «Digital CASA» являются как снижение стоимости международного трафика (до \$10/ Мбит/с за пять лет), так и увеличение международной пропускной способности Интернета (до 50 Кбит/с на человека).

\footnotetext{
Всемирный банк предоставил грант в размере 25 миллионов долларов США для проекта «Digital CASA-Кыргызская Республика», чтобы поддержать расширение доступа к более доступному интернету, привлечь частные инвестиции в сектор, улучшить возможности правительства по предоставлению цифровых государственных услуг и внести вклад в развитие интегрированной цифровой инфраструктуры и благоприятной среды в регионе (Всемирный банк. 2018. https://www.worldbank.org/en/news/loans-credits/2018/03/20/digital-casa-kyrgyz-republic-project).
} 
Рис 5.4. Международная пропускная способность интернета, оптовая стоимость и пропускная способность на душу населения: выборочные страны, 2016 г.

а. Оптовая стоимость за транзит интернета за мегабит (US\$), 2017 г.

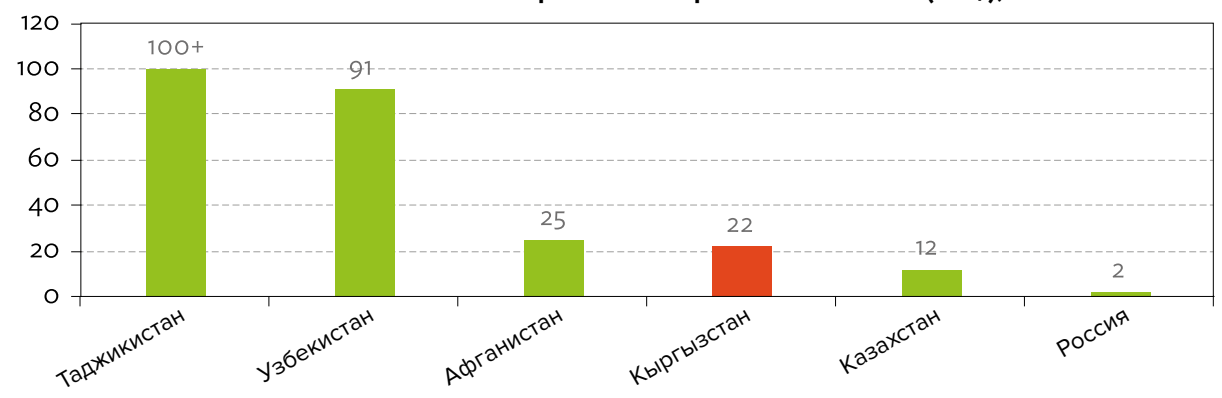

b. Международная пропускная способность интернета в ЦА, Кбит на душу населения, 2016 г.

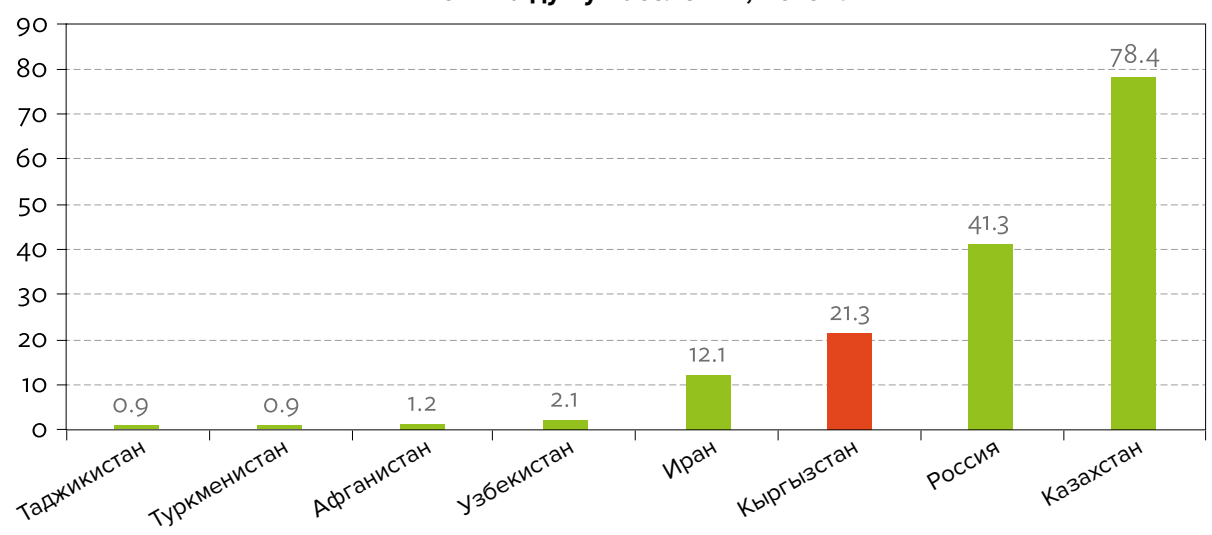

Кбит/с = килобит в секунду, Мбит/с = мегабит в секунду.

Источник: Всемирный банк (2018г.).

Точкой обмена трафиком (IXP) управляет Кыргызская ассоциация операторов связи; она располагается в центре обработки данных, или дата-центре ОАО «Кыргызтелеком». ${ }^{8}$ IXP доступен для членов ассоциации, четыре из которых обмениваются трафиком в IXP. Интернет-провайдеры и контент-провайдеры, включая международных провайдеров, которые не являются членами IXP, не могут использовать IXP. Это приводит к увеличению зависимости от более дорогостоящего международного широкополосного трафика, что влияет на развитие местного контента и государственных электронных услуг («Internet Society», 2015 г.).

Право кода домена в интернете для Кыргызской Республики (домен «.kg»)9 верхнего уровня было делегировано интернет-провайдеру ОсОО «АзияИнфо». «АзияИнфо» является официальным и единственным регистратором доменов

8 KG-IX. http://kg-ix.net/\#about.

9 «.kg»- это интернет-домен верхнего уровня для Кыргызской Республики. Регистрация обычно проводится на втором уровне, но есть и некоторые специализированные регистрации третьего уровня, такие как «gov.kg». 
второго уровня, стоимость которых составляет 2292 сома (33 доллара США), хотя другие фирмы могут предоставлять домены третьего уровня. ${ }^{10}$ По состоянию на апрель 2017 года было зарегистрировано почти 10 ооо доменов под доменом «.kg», то есть это предпоследнее место в регионе после Таджикистана. ${ }^{11}$ Кыргызское отделение интернет-общества поощряет снижение цен для развития цифровой экономики в стране.

\section{3. Достижения и препятствия на пути внедрения ИКТ в различных секторах}

Несколько организаций составляют индексы ИКТ, которые измеряют аспекты «электронной готовности» страны. Индекс развития ИКТ («ICT Development Index») Международного союза электросвязи включает ряд индикаторов в сфере инфраструктуры и образования. Кыргызская Республика заняла 110-е место в 2016 году, в основном, из-за низкого уровня проводной инфраструктуры: стационарные телефоны и фиксированная широкополосная связь (Рисунок 5.5а).

Еще одним популярным рейтингом ИКТ является Индекс сетевой готовности (NRI) Всемирного экономического форума (ВЭФ, 2016 г.). NRI состоит из десяти основных индикаторов, начиная от правового и делового климата и заканчивая доступностью, инфраструктурой и уровнем использования. Он составлен на основе «твердых» показателей и результатов опросов общественного мнения. Кыргызская Республика заняла 95-е место (из 139 стран) в 2016 году, что выше на три пункта по сравнению с предыдущим годом. В целом, результаты страны близки к группе стран с доходами ниже среднего уровня; превосходят результаты этой группы по доступности, навыкам и индивидуальному использованию, но отстают по уровню использования ИКТ бизнесом и правительством, а также по уровню экономического воздействия от использования ИКТ (Рисунок $5 \cdot 5 \mathrm{~b}$ ).

Рис 5.5: Рейтинги Кыргызской Республики в области информационно-коммуникационных технологий, 2016 г.

\section{а. Индекс развития ИКТ}

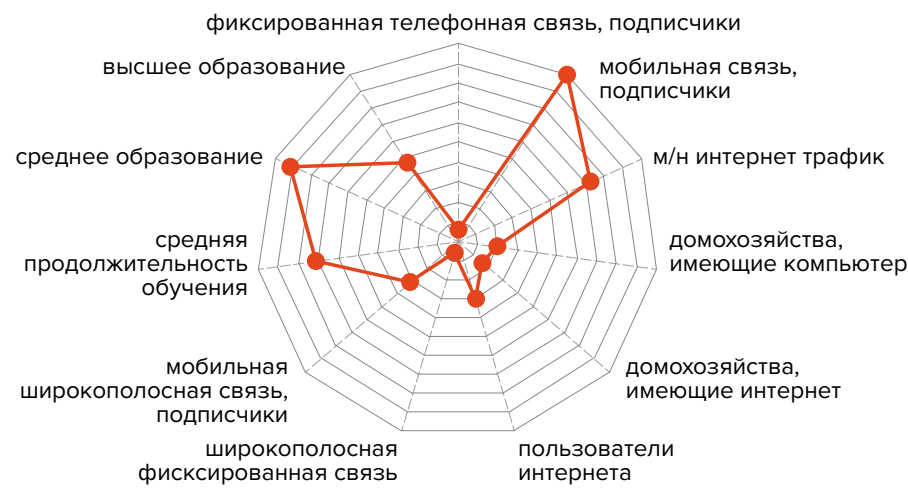

\footnotetext{
АзияИнфо. Тарифы. http://www.asiainfo.kg/rates/domain-name-registration.html

11 Инструменты доменов. WholsLookup. http://research.domaintools.com/statistics/tld-counts/ (по состоянию на сентябрь 2017 г).
} 


\section{b. Индекс сетевой готовности}

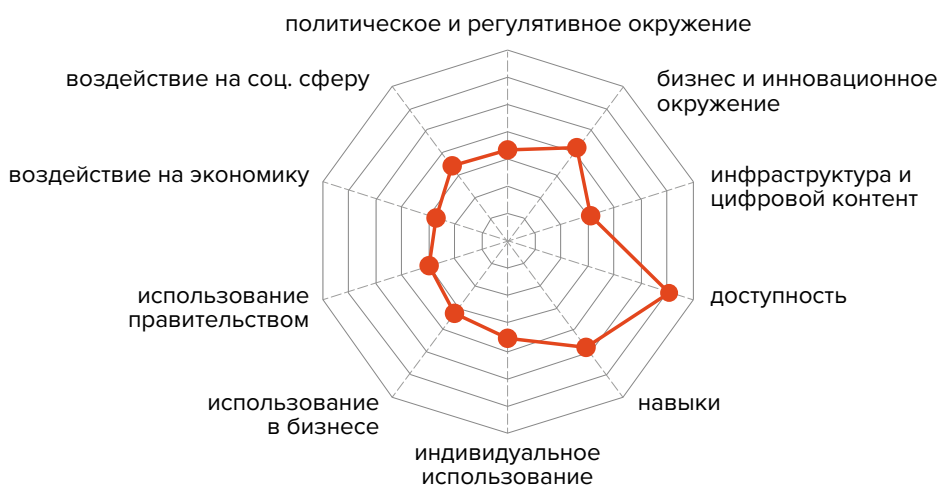

Источники: МСЭ. Индекс развития ИКТ.

https://www.itu.int/net4//TU-D/idi/2017/\#idi2017economycard-tab\&KGZ) n

ВЭФ (http://reports.weforum.org/global-information-technology-report-2016/economies/\#economy=KGZ.

\section{Ситуация с внедрением ИКТ по секторам}

Образование. Наличие ИКТ в школах остается низким. Смотрите Главу 8, раздел 8.5, в которой подробно обсуждаются технологии и навыки в области информации и коммуникаций. По данным Организации Объединенных Наций по вопросам образования, науки и культуры (ЮНЕСКО), в 2014 году подключение к интернету имели только 6\% школ, и на 57 учащихся имелся 1 компьютер, причем с большими различиями между городскими и сельскими районами (Статистический институт ЮНЕСКО, 2014 г.). Правительство признает важность ИКТ для образования, а создание «условий для развития инфраструктуры ИКТ в школах (оборудование, техническая поддержка, повышение квалификации учителей и т. д.)» является одной из 15 приоритетных областей политики в области образования в Стратегии развития образования. ${ }^{12}$ В Стратегии также отмечена необходимость использования ИКТ в таких административных областях образования, как анализ рынка труда, учебные процессы и управление образовательными учреждениями. Стратегия направлена на расширение проникновения интернета в школы до 20\% и увеличение соотношения количества компьютеров на количество учащихся до 30 (1/30) к 2020 году. Это достаточно скромные целевые показатели, отражающие ограниченные ресурсы министерства и слабое присутствие интернет связи в сельских районах. Министерство образования и науки также разрабатывает программу ИКТ для своей Стратегии развития образования на период до 2040 года.

Одним из важнейших вопросов сектора образования является вопрос качества образования. Несмотря на достаточно высокий образовательный уровень населения, существует ощущение, что качество образования ухудшилось с момента обретения независимости. Среди стран, участвующих в Международной программе по оценке образовательных достижений учащихся (Хоу, 2011 г.), Кыргызская Республика занимала последнее место по ряду предметов. В целях улучшения мониторинга качества образования Министерство образования и науки планирует создать центр качества образования. Центр будет иметь цифровую платформу для

12 Правительство Кыргызской Республики. Стратегия развития образования Кыргызской Республики на 2012-2020 годы. https://www.globalpartnership.org/content/education-developmentstrategy-kyrgyzrepublic- 2012-2020. 
осуществления мониторинга качества образования посредством проведения онлайн тестирования; а в школы с низким уровнем успеваемости будут направляться мультимедийные материалы в электронном виде, разработанные для устранения конкретных слабых мест в обучении учащихся.

Спрос на ИКТ-специалистов превышает возможности сектора высшего образования. Ресурсы для расширения профессиональной подготовки в области компьютерного программного обеспечения и смежных областях ограничены. Разрабатываются программы обучения совместно с зарубежными университетами и соответствующими ИКТ организациями. Рассматривается вопрос о целесообразности создания академии, специализирующейся на подготовке ИКТ специалистов с высшим образованием и переподготовкой.

Транспорт. Кыргызстан всецело полагается на автомобильные перевозки. Снег, лед, лавины отрицательно влияют на состояние дорог в зимнее время, а повреждение дорог от землетрясений или оползней оказывает серьезное влияние на транспортный сектор. Правительство считает, что содержание дорог является главным вызовом, и в настоящее время настоятельно призывает к внедрению комплексного управления дорожными активами. В рамках текущего проекта «Соединительной дороги между коридорами 1 и 3 программы Центральноазиатского экономического сотрудничества» (ЦАРЭС), Азиатский банк развития (АБР) планирует оказать поддержку в создании пилотной системы управления дорожными активами. Эта система предусматривает использование высоких технологий, которые будут помогать более эффективно вести мониторинг состояния дорог на региональных коридорах большой протяженности и на дорогах местного значения (АБР, 2017 г.). Что касается содержания дорог, то контроль осевых нагрузок транспортных средств является важным фактором для обеспечения устойчивости дорог. В Кыргызской Республике имеется около 23 контрольных пунктов, где осуществляться контроль веса автотранспортных средств. Однако контроль веса производится выборочно и последовательное обеспечение соблюдения весовых параметров представляет собой сложную задачу. Правительство ищет решение, каким образом с помощью ИКТ минимизировать воздействие на непрерывность движения транспортного потока в пунктах взвешивания автотранспортных средств.

Кыргызская Республика присоединилась к Евразийскому экономическому союзу (ЕАЭС) в 2015 г. Это окажет огромное влияние на транспортный сектор, включая либерализацию автомобильных грузовых перевозок и общий транспортный (автомобильный) контроль на границе ЕАЭС. Присоединение к ЕАЭС потребует стандартизации информации по транспорту и логистике, обмена информацией между соответствующими государственными органами. Региональный проект ЦАРЭС по усовершенствованию приграничных служб усовершенствовал физическую инфраструктуру двух пунктах пропуска в Кыргызской Республике и в Таджикистане; и АБР также поддержал оценку работы Национального единого окна (HEO) для внешней торговли, начиная с бизнес-процессов до технических и функциональных требований системы ИКТ. Увеличивающийся спрос на упрощение процедур торговли и логистику в регионе требует внедрения дополнительных ИКТ.

Бизнес. Уровень использования ИКТ в бизнесе несколько выше по сравнению со средними мировыми показателями. Согласно результатам обследования, проведенного Всемирным банком в Кыргызской Республике среди 270 фирм в 2013 году, около 57\% из них имели свои вебсайты, и около 86\% использовали 
электронную почту для связи с поставщиками и клиентами (Таблица 5.2). Однако существовал заметный разрыв между малыми и средними предприятиями и крупными компаниями, что подчеркивает необходимость помощи в применении ИКТ в их бизнесе.

\section{Таблица 5.2: Использование информационно-коммуникационных технологий в фирмах Кыргызской Республики, 2013 г. (\%)}

\begin{tabular}{|c|c|c|c|}
\hline Использование интернета & $\begin{array}{l}\text { Кыргызская } \\
\text { Республика }\end{array}$ & $\begin{array}{r}\text { Восточная } \\
\text { Европа и } \\
\text { Центральная } \\
\text { Азия }\end{array}$ & Все страны \\
\hline Фирмы, имеющие свои вебсайты & 56,9 & 62,2 & 44,4 \\
\hline Малые (5-19) & 54,1 & 56,2 & 36,1 \\
\hline Средние (20-99) & 53,3 & 70,9 & 56,1 \\
\hline Крупные (100+) & 72,8 & 83,8 & 74,6 \\
\hline $\begin{array}{l}\text { Фирмы, использующие электронную почту для } \\
\text { связи с клиентами и поставщиками }\end{array}$ & 85,9 & 84,7 & 71,7 \\
\hline Малые (5-19) & 82,8 & 81,5 & 65,3 \\
\hline Средние (20-99) & 83,8 & 90,1 & 82,8 \\
\hline Крупные (100+) & 98,2 & 93,8 & 92,3 \\
\hline
\end{tabular}

Источник: Всемирный банк. Обследование предприятий, Кыргызская Республика. http://www.enterprisesurveys.org/data/exploreeconomies/2013/kyrgyz-republic\#innovation-andtechnology

Кыргызская ассоциация разработчиков программного обеспечения и услуг лоббировала принятие закона в 2011 году, что привело к запуску Парка высоких технологий (Абакиров, 2017 г.). Выгода компаний, расположенных в парке, заключается в том, что они платят низкий налог на прибыль (5\%), если они экспортируют не менее 80\% своей продукции. В 2017 году в парке работало 32 компании с оборотом в 7,4 млн. долларов США; где работали 434 человека (Пиллай, 2018 г.). Ирландия, Казахстан, Япония, Российская Федерация и США являются самыми крупными экспортными рынками. Несмотря на рост Парка высоких технологий, Кыргызская Республика продолжает испытывать заметный дефицит платежного баланса в секторе компьютерных и информационных услуг (Рисунок 5.6), это говорит о недостаточном внутреннем потенциале разработки ИКТ-приложений.

В стране развивается устойчивая экосистема технологических стартапов (начинающий бизнес). Общественный фонд «KG Labs» (https://kglabs.org) coставил список и разработал карту стартапов и используемых для этого ресурсов. ${ }^{13}$ Фонд активно организует конкурсы, хакатоны, инкубационные и менторские сессии, в то время как «Ideagrad.com» реализует «инкубационные» программы.

Страна имеет хороший потенциал для развития и укрепления розничной торговли в сфере электронной коммерции. Товары и услуги становятся все более доступными для продажи онлайн, но большинство интернет-магазинов просто предлагают онлайн-каталоги своих товаров. ${ }^{14}$ В этой сфере есть возможности для

13 Общественный фонд «KG Labs». 2018. Карта технологической экосистемы Кыргызстана. https://kglabs.org/index.php/about-kyrgyzstan/startup-ecosystem-map-kyrgyzstan/

14 Министерство торговли США. Международная торговая администрация. 2017. Кыргызская Республика - электронная торговля. https://www.export.gov/article?id=Kyrgyz-Republic-Ecommerce 
цифровых стартапов. Сайты компаний для электронной коммерции «бизнес-потребителю» (B2C) в Бишкеке предлагают услуги розничной торговли, такси и доставки еды. За данные услуги обычно оплата производится наличными деньгами по доставке из-за недостаточного доверия к кредитным картам и обеспокоенности относительно конфиденциальности данных (ДиКаприо и Процак, 2016 г.). Доставка товаров также представляет собой сложную задачу, поскольку показатели логистики в Кыргызской Республике довольно слабые. Кыргызская Республика по индексу эффективности логистики (ИЭЛ) заняла в 2018 году 108 место из 160 стран - ниже Казахстана и Узбекистана (Рисунок 5.7а). Низкий рейтинг объясняется транзакционными и логистическими ограничениями. Результаты опроса в рамках «Global Findex» Всемирного банка показали, что в прошлом году только 2,9\% населения в возрасте 15 лет и старше приобретали товары через интернет (Рисунок 5.7b). ${ }^{15}$

Рис 5.6: Торговля компьютерными и информационными услугами, Кыргызская Республика (млн. долларов США)

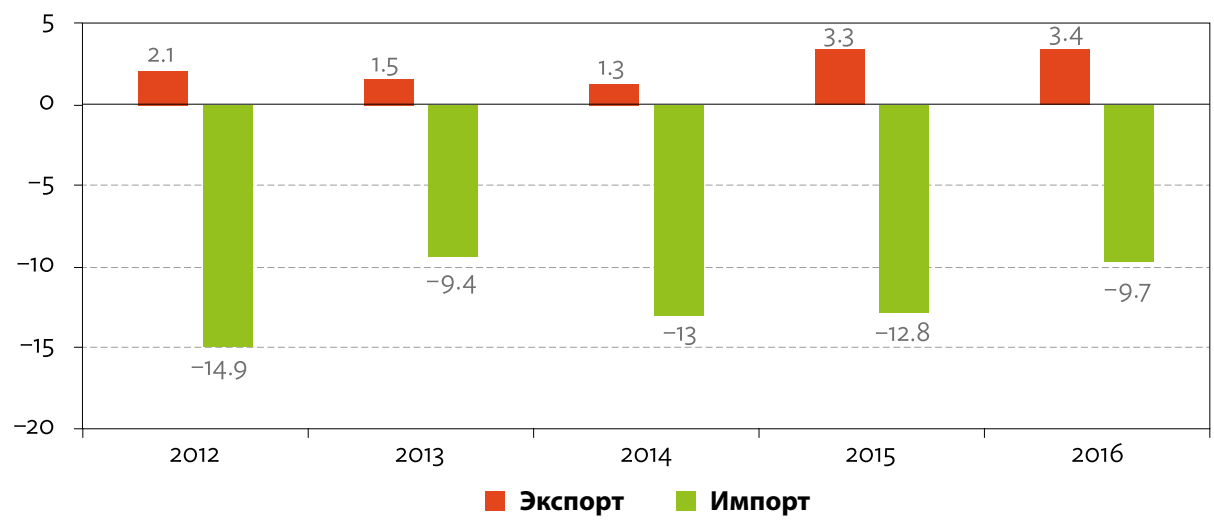

Источник: Национальный банк Кыргызской Республики.

Рис 5.7: Индекс эффективности логистики, 2018 г., и онлайновые покупки, 2017 г.

а. Оценка ИЭЛ, 2018 г.

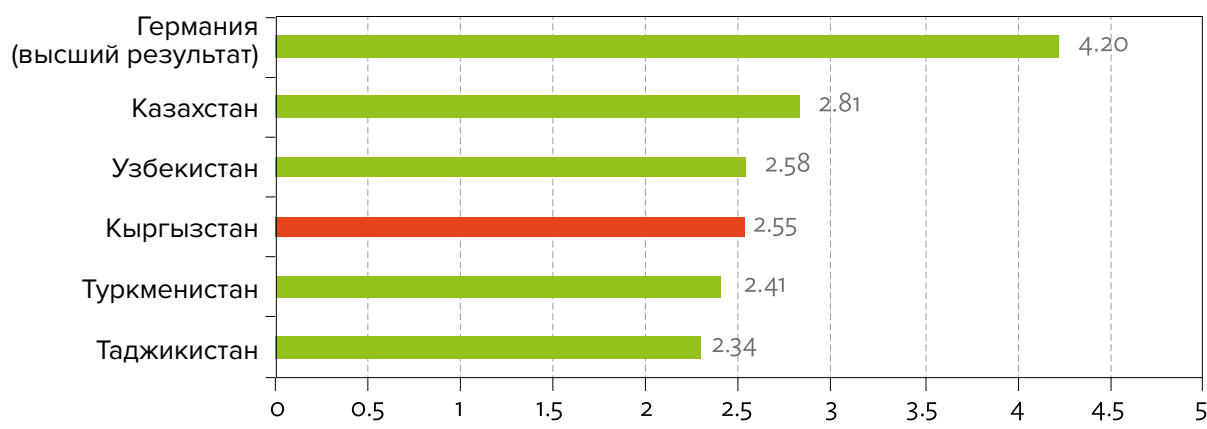

15 Всемирный банк. https://globalfindex.worldbank.org/index.php/\#data_sec_focus 
b. Покупки через интернет в 2017 году (\%, возраст 15+)

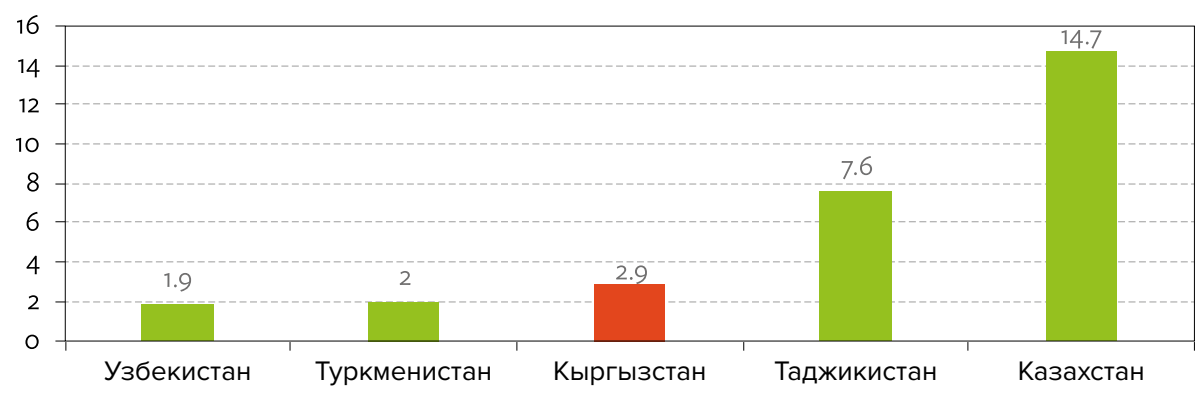

ИЭЛ = Индекс эффективности логистики.

Источники: 5.7.а., Всемирный Банк, Индекс эфффективности логистики. https://lpi.worldbank.org/ international (16.10.2018); 5.7.b., Всемирный Банк. Покупки через интернет, Global Findex.

https://globalfindex.worldbank.org/index.php/\#data_sec_focus

Сектор здравоохранения. В 2016 году в Кыргызской Республике насчитывалось 185 организаций здравоохранения, т.е. больниц и лечебно-диагностических центров. Большинство организаций здравоохранения имеют доступ в интернет. Доступ в интернет осуществляется в областных центрах через оптоволоконные линии связи, в районах - с использованием асимметричной цифровой абонентской линии (ADSL), ${ }^{16}$ а в центрах семейной медицины в селах - посредством мобильной связи. Министерство здравоохранения недавно опубликовало проект стратегии цифрового здравоохранения для получения отзывов и комментариев от заинтересованных сторон. Несколько проектов ИКТ находятся в процессе разработки или планирования. Среди них проекты соединения всех баз данных в единую систему, внедрение электронной медицинской документации (в настоящее время система электронной документации ведется в примерно десяти больницах; планируется ввести такую систему в 40 больницах), телемедицина (данная система уже внедрена в шести больницах) и создание национальной системы отслеживания и мониторинга фармацевтических препаратов. Другие проекты касаются онлайновой системы записи к врачу и портала пациентов.

Финансовый сектор. Учитывая высокий уровень проникновения мобильной связи, большое количество денежных переводов, недостаточное предложение банковских услуг в сельской местности (Херманс, 2014 г.) и относительно низкий уровень наличия банковских счетов, существует значительный потенциал для услуг «мобильные деньги». Закон «О платежной системе КР» был принят в декабре 2014 года и охватывает использование кредитных карт, а также мобильного банкинга и услуг «электронные деньги» (НБКР, 2014 г.). Несколько банков в стране предоставляют услуги «мобильный банкинг», мобильные операторы запустили услугу «мобильные деньги» (Центральноазиатский форум операторов сотовой связи, 2018 г.). Существует мобильное приложение для оплаты коммунальных услуг и других счетов. ${ }^{17}$ Мобильный банкинг важен для охвата малого бизнеса (АБР, 2016 г.).

16 Асимметричная цифровая абонентская линия (ADSL) - это технология для передачи цифровой информации с высокой пропускной способностью по существующим телефонным линиям домохозяйствам и бизнесу. ADSL обычно предлагается на скоростях передачи данных от 512 Кбит/с до 6 Мбит/с.

17 Электронный кошелек. https://www.mobilnik.kg/\#/start 
Использование кредитных/дебетовых карт растет; в 2016 году количество карт достигло уровня охвата 40\% населения в возрасте 15 лет и старше (НБКР, 2017 г.). Доступны международные кредитные карты, а на национальную дебетовую карту «Элкарт» приходится более 40\% платежных карт, находящихся в обращении. ${ }^{18}$ Одним из основных факторов увеличения количества карт в обращении является перевод государственных зарплат и пособий с наличных средств на банковские счета. Тем не менее, население по-прежнему опасается использовать платежные карты для осуществления различных транзакций, чаще всего население использует карты для снятия средств через банкоматы.

Хотя существует закон о зашифрованной подписи, узаконивший осуществление онлайновых транзакций, есть проблемы с его исполнением (Правительство Кыргызской Республики, 2004 г.). В настоящее время только биометрические удостоверения личности, выданные для президентских выборов 2017 года, соответствуют требованиям к идентификации, содержащимся в законе.

Правительство. План реализации на период 2014-2017 гг. определил развитие электронного правительства в стране. ${ }^{19}$ В Национальной стратегии устойчивого развития на 2013-2017 гг. заявлено: «Будет повышаться значение Интернета в деятельности государственных органов, будет создана современная система «электронного правительства» в целях эффективного и менее затратного администрирования, совершенствования демократии и повышения ответственности власти перед народом». ${ }^{20}$

Большинство министерств в Кыргызской Республике используют свои собственные системы оказания услуг, выделяя значительные ресурсы на их разработку, реализацию, использование и техническую поддержку. Государственные министерства в Бишкеке пользуются оптоволоконной связью, но за пределами столицы связанность неравномерная. Хотя Кыргызская Республика и продвинулась в компьютеризации государственных процессов, электронное правительство пока находится на стадии зарождения. Возможности межоперационного взаимодействия ограничены; не существует стандартов архитектуры, обмена данными и программного обеспечения; существует несколько транзакционных онлайн-сервисов с функцией приема электронных платежей, доступных для граждан и предприятий. Еще одной проблемой является необходимость пересмотра или разработки законов для внедрения онлайновых услуг.

Через Государственный портал электронных услуг предоставляется около десяти государственных услуг. ${ }^{21}$ К ним относятся процедуры получения идентификационного удостоверения личности, регистрации актов гражданского состояния, получения водительского удостоверения и др. Доступ к этим услугам для граждан, не имеющих доступ в интернет или нуждающихся в помощи, осуществляется через информационные киоски, расположенные в почтовых отделениях «Кыргыз Почтасы» в 363 айыльных аймаках. В этих киосках работают подготов-

18 «Элкарт»- это национальная платежная система (банкоматная карта) в Кыргызской Республике, предназначенная для безналичной выплаты заработной платы, пенсий и пособий государственных органов.

19 Программа Правительства Кыргызской Республики по внедрению электронного управления («электронное правительство») в государственных органах исполнительной власти и органах местного самоуправления Кыргызской Республики на 2014-2017 годы, 17 ноября 2014 года.

20 Правительство Кыргызской Республики. НСУР на 2013-2017 гг. http://www.donors.kg/en/ strategy/172-national-sustainable-development-strategy-2013-2017\#.XMjQxugzY2w стр. 18.

21 Таза Коом. https://portal.tazakoom.kg 
ленные государственные специалисты. Услуги, требующие оплаты, пока оплачиваются наличными. Дополнительно киоски будут установлены в оставшихся 90 айыльных аймаках, после обеспечения приемлемого уровня интернет-связи.

Согласно индексу ООН по уровню развития электронного правительства, ${ }^{22}$ по показателю глубины и функциональности государственных электронных услуг, Кыргызская Республика занимала между 91 и 101-м местом в 2001-2018 годах, в настоящее время она занимает 91-е место из 193 стран (Рисунок 5.8, слева). По оценке предоставляемых онлайновых услуг, страна, по сравнению со своими соседями, занимает среднюю позицию, немногим отставая от лидера Казахстана (Рисунок 5.8b). Вероятно, в последующие годы рейтинг улучшится с учетом внедрения инфраструктуры, такой как центры данных и «облачные» вычисления.

\section{Рисунок 5.8: Индекс уровня электронного правительства ООН}

а. Рейтинг по электронному правительству Кыргызской республики

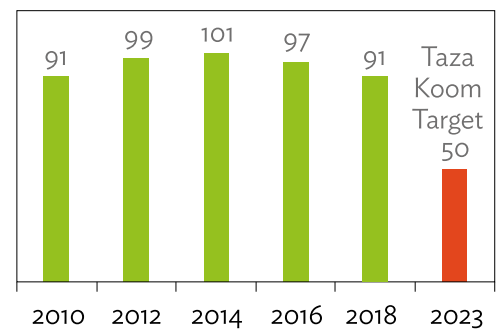

\section{b. Индекс онлайновых услуг, 2018 г.}

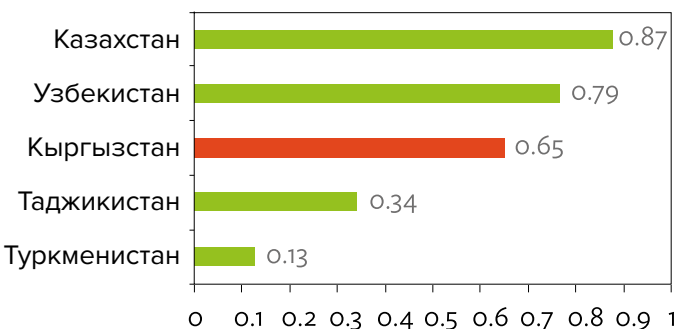

Источник: ДЭСВ ООН. База знаний электронного правительства ООН. https://publicadministration. un.org/egovkb/enus/Data/Country-Information/id/91-Kyrgyzstan (16.10.2018).

\section{4. Национальная программа цифровой трансформации}

При нынешнем правительстве Национальная программа цифровой трансформации «Цифровой Кыргызстан» на 2019-2023 годы предлагает создать условия для создания цифровой экономики путем внедрения цифровых технологий в государственное управление и услуги, создания центров компетенций и инновационных кластеров, которые будут обеспечивать новые возможности и экономический прорыв с помощью цифровых инноваций.

В 2019 году правительство объявило о своем намерении вывести страну на передний план в области цифровизации в регионе. Цифровая экономика Кыргызской Республики будет внедрена в следующих трех приоритетных сферах: (i) бизнес-процессы в финансовом и банковском секторе и повышение эффективности и конкурентоспособности отечественных компаний, (ii) разработка цифровых стратегий в сотрудничестве со странами-партнерами. включая Цифровую повестку дня Евразийского экономического союза до 2025 года и создание цифрового Великого шелкового пути посредством программы «Один пояс -один путь», (iii) снижение барьеров в развитии цифровых технологий. Посредством этих инициатив прави-

22 ДЭСВ ООН. База знаний электронного правительства ООН. https:/publicadministration.un.org/ egovkb/en-us/Data/Country-Information/id/91-Kyrgyzstan (16.10.2018) 
тельство намерено поддержать расширение рынка для частного сектора, чтобы он мог развивать новые линии продуктов и услуг, а также стимулировать формирование новых экономических кластеров в стране. Ранее в этом году Совет безопасности Кыргызской Республики утвердил концепцию цифровой трансформации «Цифровой Кыргызстан» на 2019-2023 годы и ее дорожную карту, чтобы обеспечить условия для инвестиций в новую национальную цифровую инфраструктуру.

Некоторые из инициатив и программ, определенных в концепции «Цифровой Кыргызстан на 2019-2023 годы», включают следующее:

Создание системъ Тундук (Центр электронного взаимодействия). Эта программа направлена на рационализацию информационных технологий для повышения эффективности предоставления государственных услуг и повышения их эффективности путем создания единой точки доступа ко всем информационным ресурсам государственных органов. В рамках системы Тундук министерства, государственные предприятия, муниципальные органы власти и другие организации смогут напрямую обмениваться информацией. Ожидается, что благодаря этой системе государственное управление будет улучшено и что ненужные документарные процедуры по утверждению документов будут сокращены при одновременном повышении прозрачности в государственном процессе.

Проект «Безопасный город» и дата-центры. Инициативы, начатые в рамках проекта Digital CASA, такие как обеспечение доступа в Интернет в регионах и строительство региональных центров обработки данных, будут еще более ускорены. Эта программа направлена на расширение сотрудничества между академическими и бизнес-структурами, созданными в рамках инновационных центров, что позволит предпринимателям постоянно разрабатывать инновационные решения для бизнеса и государства, а также поддерживать инновационные пилотные проекты. Будет налажено партнерство с высшими учебными заведениями в качестве принимающих площадок для обучения, тестирования и демонстрации стартапов. Посредством этого проекта правительство стремится содействовать более широкому участию граждан в процессе принятия решений на государственном и муниципальном уровнях.

Создание благоприятного делового климата для ИТ-компаний. Телекоммуникационные компании являются основной силой и вносят огромный вклад в развитие сектора. Современные технологии внедряются в персонализацию мобильных абонентов, электронной коммерции и мобильных платежей в Кыргызской Республике. Создание благоприятного делового климата, сильная отраслевая администрация и регуляторы и обновление нормативной базы для информационных технологий необходимы для привлечения инвестиций.

Региональный охват коммуникационньми технологиями. Одна из целей Цифрового Кыргызстана - обеспечить, чтобы ни один регион страны не оставался без связи. Для достижения этой цели будет проведена постепенная передача доли налога на прибыль местным бюджетам. Компании, работающие в области информационных технологий, которые открыты для субсидирования регионов, будут иметь льготы по налогу на прибыль, налогу с продаж, земельному налогу и налогу на имущество на срок от пяти до десяти лет. А предприниматели, занимающиеся импортом технологического оборудования, будут освобождены от таможенных пошлин.

Продвижение ИТ-технологий в здравоохранении. Будут созданы медицинские центры, которые могут круглосуточно обслуживать население. Эти 
центры будут предоставлять услуги онлайн-консультирования через Интернет и по телефону. Использование автоматизированной системы управления службами скорой помощи первоначально будет развернуто в Бишкеке с 2019 года, а позднее будет внедрено в других городах, таких как города Ош и Каракол, с 2020 года.

Проект «Умжая шккла». Эта программа направлена на то, чтобы охватить интернетом все школы. Будут усилены базовые процессы, такие как электронная запись в учебные заведения, цифровизация рабочего процесса учителей и учебного процесса учащихся. Все другие общественно значимые учреждения также получат выгоду от этой программы.

Устранение баръеров на пути развития бизнеса. С помощью информационных технологий правительство стремится устранить препятствия на пути развития бизнеса. Переход к электронному предоставлению лицензий и разрешений государственными учреждениями будет ускорен. Процедуры в отношении бизнеса, такие как регистрация, закрытие бизнеса, налоговая отчетность и платежи, будут усовершенствованы и станут более удобными для всех компаний. Отделы Единых окон будут созданы в различных ведомствах. Создание электронных архивов всех правительственных учреждений стало обязательным для повышения прозрачности.

Несколько агентств по развитию выразили заинтересованность в оказании помощи в усилиях правительства по созданию цифровой экономики. Самый крупный проект на сегодняшний день - это проект Всемирного банка «Digital CASA» на 25 млн. долларов США (Вставка 5.1). Министерство международного развития Великобритании (DFID) планирует разработать стратегию «Умный город» (Кабар, 2017a). Европейский банк реконструкции и развития (ЕБРР) поддерживает проекты, связанные с бизнес лицензиями, регистрационными и нотариальными электронными услугами (Кабар, 2017b). Японское агентство международного сотрудничества (JICA) выразило заинтересованность в сотрудничестве по вопросам развития человеческого потенциала (JICA, 2018 г.). Программа развития Организации Объединенных Наций (ПРООН) оказывает помощь в создании «инновационной лаборатории» (ПРООН, 2018 г.).

Дополнительная поддержка Национальной программе цифровой трансформации включает создание «жесткой» и «мягкой» цифровой инфраструктуры, включая инфраструктуру ИКТ, национальную идентичность; создание в стране базы геопространственных данных; и конкретные отраслевые и тематические программы цифрового развития. Национальная инфраструктура пространственных данных в Государственной регистрационной службе сможет объединять различные наборы данных, включая недостающие данные, и внедрять новые функциональные возможности. Географическая информационная система является важной основой для электронного правительства с такими приложениями, как управление активами (например, земля, лесное хозяйство, водоснабжение, строительство, дороги); оценка недвижимости; и содействие инвестициям частного сектора.

Закон «Об электронной подписи» узаконивает совершение онлайновых транзакций, но его реализации препятствуют проблемы, связанные с вопросом идентификации пользователей. Это относится к требованию общей идентификационной базы данных, к которой могут быть привязаны различные приложения. База идентификационных данных, наряду с национальной системой пространственных данных, представляет собой фундаментальные блоки для эффективного развития услуг электронного правительства. 


\section{Вставка 5.1: Проект «Цифровая Центральная и Южная Азия - Кыргызская Республика»}

Проект «Цифровая Центральная и Южная Азия - Кыргызская Республика» («Digital CASA») утвержден в марте 2018 года. Общей целью проекта является улучшение доступа к интернету и снижение его стоимости, привлечение частных инвестиций в ИКТ и повышение потенциала правительства в сфере предоставления электронных государственных услуг. Проект «Digital CASA - Кыргызская Республика» включает четыре основных компонента. Компонент «Региональная инфраструктура цифровой связанности» (42\% от суммы финансирования) нацелен на содействие развитию более доступных по цене высококачественных услуг доступа в Интернет для граждан, бизнеса и государства посредством стимулирования развития частной сетевой инфраструктуры и предоставления услуг на региональном и национальном уровне. Заранее закупив рабочие частоты, правительство надеется создать широкий спрос, который будет стимулом для частного сектора расширять требуемую инфраструктуру. Второй компонент - «Создание благоприятных условий для цифровой экономики» (17\% от суммы финансирования) нацелен на совершенствование нормативно-правовой базы, касающейся цифровой экономики, по всему региону, в том числе в рамках Евразийского экономического союза, и разработка политики и стратегий цифрового развития, цифровое лидерство и стратегические коммуникации. Третий компонент - «Управление проектом» - поддерживает деятельность и мониторинг результатов проекта. Исполнительным агентством проекта является Государственный комитет информационных технологий и связи Кыргызской Республики.

Источники: Всемирный Банк (2018 г.), 24.kg (2017а).

Отслеживание фармацевтических препаратов - одно из приоритетных направлений деятельности Министерства здравоохранения по мониторингу цен и сокращению масштабов злоупотреблений. Министерство здравоохранения хотело бы разработать систему фармацевтического мониторинга для отслеживания потока лекарств от границы вдоль всей цепочки поставок. Эта система будет связывать аптеки, практикующих врачей и страховые компании.

Министерство образования и науки обсудило важность мониторинга качества образования в стране. В целях улучшения мониторинга Министерство планирует создать центр качества образования. Центр будет иметь цифровую платформу, связывающую все школы, для контроля качества образования посредством онлайнового тестирования; в школы с недостаточным уровнем качества будут направляться электронные мультимедийные материалы, нацеленные на решение конкретных проблем.

\section{5. Выводы и рекомендации в области политики}

Несмотря на то, что Кыргызская Республика сталкивается со значительными сложностями в области развития, которые усугубляются отсутствием выхода к морю, страна имеет огромные возможности, который могут раскрыться благодаря применению цифровых технологий. Кыргызская Республика является второй наиболее готовой к цифровой трансформации страной в Центральной Азии. И несмотря на отсутствие прямого выхода к морю, ее географическое расположение между КНР и Европой открывает для нее потенциал стать цифровым хабом, расположенным на Шелковом пути. Признавая эти возможности, правительство 
запустило в 2017 году инициативу «Таза Коом» с целью преобразования Кыргызской Республики в страну, основанную на цифровой экономике, за чуть более чем два десятилетия. При нынешнем правительстве эти прошлые инициативы были пересмотрены и приняты в обновленной Национальной концепции цифровой трансформации «Цифровой Кыргызстан» 2019-2023. Новая программа направлена на создание условий, которые (1) через цифровые технологии приведут к революции в предоставлении государственных услуг, сократив коррупцию, повысив прозрачность и облегчив жизнь гражданам и бизнесу, и (2) создавать центры компетенций, инновационные кластеры, продвигать новые возможности, которые могут способствовать стремлению поднять уровень доходов на душу населения и способствовать экономическим прорывам.

Успех новой программы цифровой трансформации будет зависеть от того, насколько эффективно Кыргызская Республика сможет мобилизовать человеческие и финансовые ресурсы для такой амбициозной инициативы. Также будет крайне важно следовать курсу и обеспечить, чтобы институциональные механизмы для реализации программы могли ориентироваться в сложной политической обстановке в стране. Институциональные механизмы для новой программы должны иметь достаточно возможностей, полномочий и прав для осуществления надзора за реализацией такой стратегической инициативы высокого уровня по всей стране и для мониторинга и координации деятельности на разных уровнях государственного управления.

Для успешного выполнения новой программы крайне важно сформулировать стратегию реализации, предусматривающую последовательность действий. На определенном этапе стране необходимо будет перейти к общему протоколу и системам структуры электронного правительства. Этот шаг повлечет за собой значительные усилия по преобразованию существующих систем и, следовательно, должна быть определена последовательность. Расчет затрат по реализации всей инициативы или определение отдельных проектов должны быть четко обозначенными, чтобы частный сектор и другие партнеры по развитию могли определить проекты или сферы, в которых инвестиции или поддержка в области развития наиболее необходимы. 


\section{Библиография}

24.KG. 2017b. В Кыргызстане недостаточная законодательная база для электронного правительства. 3 июля 2017 г. https://24.kg/english/56496_Kyrgyzstan_ lacks_legal_base_for_egovernment_/

24.KG. 2017а. «Центр обработки данных для «Таза Коом» будет стоить 100 миллионов долларов». 11 24.KG декабря 2017 г. https://24.kg/english/70614_ Data_processing_center_for_Taza_Koom_to_cost_100_million/

Center for Insights in Survey Research. 2017. Общественное мнение: резиденты Кыргызстана. Презентация PowerPoint https://www.iri.org/sites/default/ files/wysiwyg/kyrgyzstan_february-march_2017_-_public.pdf (16 октября 2018 г.).

KG-iX. Точка обмена трафиком KP. http://kg-ix.net

NSS. 2017. https://o.kg

Terabit Consulting. 2014. Кыргызстан, Таджикистан, Туркменистан и Узбекистан: телекоммуникации и интернет-рынки и международная инфраструктура. http://www.terabitconsulting.com/downloads/ kyrgyzstan-tajikistanturkmenistan-uzbekistan-telecommunications-and-internet-marketsandinfrastructure.pdf

Абакиров, А. 2017. Кыргызский Парк высоких технологий: ИТ-инновации и креативность обеспечивают топливо для экономики Кыргызстана без нефти и газа. https://medium.com/@azisabakirov/kyrgyz-high-tech-park-2e99fded44ff.

Азиатский банк развития (АБР). 2017. Кыргызская Республика: Бизнес-план операций по стране (2018-2020 гг.). https://www.adb.org/documents/kyrgyzrepublic-country-operationsbusiness-plan-2018-2020

Азиатский банк развития (АБР). 2014. Кыргызская Республика: Региональный проект по усовершенствованию приграничных служб. Отчет о соответствии. Проект № 46124 Кредит 2995/Грант 0340-KGZ. Манила.

Азиатский банк развития (АБР). 2014. Продвижение информационных и коммуникационных технологий в операциях АБР. https://www.adb.org/sites/ default/files/publication/42673/promoting-ict-adb-operations.pdf

Азиатский банк развития (АБР). 2016. В Кыргызской Республике доступ к финансам способствует развитию малого бизнеса. Результат проекта | Tематическое исследование. 19 декабря. https://www.adb.org/results/bankingsolutions-throw-financial-lifeline-small-businesses-kyrgyzrepublic

АзияИнфо. Тарифы. http://www.asiainfo.kg/rates/domain-name-registration.html

Билайн https://beeline.kg

Всемирный банк. 2014. Данные о финансовой инклюзии / Global Findex. Кыргызская Республика. http://datatopics.worldbank.org/financialinclusion/country/ kyrgyzrepublic

Всемирный банк. 2016. Доклад Мировое развитие 2016: Цифровые дивиденды. Буклет. Всемирный банк, Вашингтон, ОК. 
Всемирный банк. 2018a=dc. Проект «Digital CASA-Кыргызская Республика». https://www.worldbank.org/en/news/loans-credits/2018/o3/20/digital-casakyrgyzrepublic-project

Всемирный банк. 2018kr. Проект «Кыргызская Республика - цифровая Центральная Азия и Южная Азия» (Digital CASA), Вашингтон, ОК. Группа Всемирного банка. http://documents.worldbank.org/curated/ en/233891521770539859/Kyrgyz-Republic-Digital-Central-Asiaand-SouthAsia-Project

Всемирный банк. Глобальная база данных Findex. https://globalfindex.worldbank. org/index.php/ \#data_sec_focus

Всемирный банк. Индекс эффективности логистики. https://lpi.worldbank.org/ international (16.10.2018)

Всемирный банк. Обследование предприятий, Кыргызская Республика. http://www.enterprisesurveys.org/ data/exploreeconomies/2013/ kyrgyzrepublic\#innovation-andtechnology

Всемирный экономический форум (ВЭФ). 2016. Глобальный отчет по информационным технологиям за 2016 год. Кыргызская Республика.

http://reports.weforum.org/global-informationtechnology-report-2016/ economies/\#economy=KGZ)

Гутеррес А. 2017. Выступление Генерального Секретаря ООН на Конференции «Таза Коом» по государственным услугам. 11 июня 2017 г. https://www. un.org/sg/en/content/sg/statement/2017-06-11/secretary-general's-remarks"taza-koom"-conference-public-service

ДиКаприо А. и Процак Дж. 2016. Краткое обзор электронной коммерции в Центральной Азии. Блог АБР. 18 января. https://blogs.adb.org/blog/snapshotecommerce-central-asia

Европейская экономическая комиссия ООН (ЕЭК ООН). 2002. На пути к экономике, основанной на знаниях: Кыргызстан. Отчет об оценке готовности страны. Женева: Организация Объединенных Наций. https://www.unece. org/fileadmin/DAM/ie/enterp/documents/coverpagkyrgyz.pdf

Инструменты доменов. WhoIsLookup. http://research.domaintools.com/statistics/ tld-counts/ (по состоянию на сентябрь 2017г).

Интернет-общество. 2017. Интернет, пересекающий границы: расширение интернет возможностей в развивающихся странах, не имеющих выхода к морю. Резюме для руководства. 20 июня 2018. https://www.internetsociety. org/resources/doc/2017/lldcreport

Интернет-общество. Оценка кыргызской интернет среды. https://www.internetsociety.org/sites/default/files/ Kyrgyzstan_Study.pdf

Кабар. 2017а. Британские эксперты помогают в реализации проекта «Умный город» в Бишкеке. 5 сентября 2017 г. http://kabar.kg/eng/news/british-expertstoassist-in-implementing-smart-city-project-in-bishkek/

Кабар. 2017b. ЕБРР поддержит «Таза Коом». 13 июля 2017. http://kabar.kg/eng/news/ebrd-to-support-taza-koom-project/ 
Кабар. 2017с. Национальная программа «Таза Коом» («Чистое общество») получит 1 миллиард сом в 2018 году. 30 ноября 2017 г.. http://kabar.kg/eng/ news/national-programtaza-koom-pure-society-gets-1-billion-soms-in-2018/

Мегаком https://www.megacom.kg

Международный республиканский институт (МРИ). 2017. Изучение общественного мнения: резиденты Кыргызстана. http://www.iri.org/sites/default/files/ wysiwyg/kyrgyzstan_february-march_2017_-_public.pdf

Международный союз электросвязи (МСЭ). 2017. Отчет «Измерение информационного общества», том 2: Профили стран. https://www.itu.int/en/ITU-D/ Statistics/Pages/publications/mis2017.aspx

Международный союз электросвязи (МСЭ). База данных статистики ИКТ, https://www.itu.int/en/ITU-D/Statistics/Pages/stat/default.aspx. (по состоянию на 12 октября 2018 г.)

Международный союз электросвязи (МСЭ). Индекс развития ИКТ за 2017 год. Кыргызстан. https://www.itu.int/net4/ITU-D/idi/2017/\#idi2017economycardtab\&KGZ

Международный союз электросвязи (МСЭ). Интерактивная карта передачи данных. http://www.itu.int/itu-d/tnd-mappublic/ (по состоянию на август 2017 г.).

Министерство торговли Соединенных Штатов Америки. 2017. Кыргызская Республика - электронная торговля. https://www.export.gov/article?id=KyrgyzRepublic-Ecommerce

Национальный Банк Кыргызской Республики (НБКР). 2014. Закон о платежной системе Кыргызской Республики. http://www.nbkr.kg/index1. jsp?item $=2725$ \&lang $=$ eng

Национальный Банк Кыргызской Республики (НБКР). 2017. Отчет о стабильности финансового сектора Кыргызской Республики. http://www.nbkr.kg/ DOC/13032018/000000000049512.pdf

Национальный статистический комитет (НСК) Кыргызской Республики и ЮНИСЕФ. 2016. Кластерное обследование по множественным показателям Кыргызстана. 2014. https://www.unicef.org/kyrgyzstan/reports/kyrgyzstanmultiple-indicator-cluster-survey

Национальный статистический комитет (НСК) Кыргызской Республики. 2015. Трудоустройство населения по видам экономической деятельности. http://stat.kg/en/statistics/zanyatost/ (по состоянию на 28 сентября 2018 г.)

Национальный статистический комитет (НСК) Кыргызской Республики. 2017. Краткий статистический справочник за 2014-2016 годы. http://stat.kg/en/ publications/kratkij-statisticheskij-spravochnik-kyrgyzstan/

Общественный фонд «KG Labs». 2018. Карта технологической экосистемы Кыргызстана. http://kglabs.org/index.php/about-kyrgyzstan/startup-ecosystemmapkyrgyzstan/

Организация Объединенных Наций, Департамент по экономическим и социальным вопросам (ДЭСВ ООН). Электронное правительство ООН. https://unstats.un.org/unsd/classifications/ https://unstats. un.org/unsd/ publication/SeriesM/seriesm_4rev4e.pdf 
Организация Объединенных Наций, Департамент по экономическим и социальным вопросам (ДЭСВ ООН). База знаний электронного правительства OOH. https://publicadministration.un.org/egovkb/en-us/Data/CountryInformation/id/91-Kyrgyzstan (по состоянию на 16 октября 2018 г.).

Пиллай Дж. 2018. Динамичный сектор услуг. Азиатский банк развития - презентация диагностики страны, Бишкек, 16 апреля.

Правительство Кыргызской Республики. 2004. Закон об электронной подписи от 17.07.2004. Бишкек

Правительство Кыргызской Республики. 2014. Программа Правительства Кыргызской Республики по внедрению электронного управления («электронное правительство») в государственных органах исполнительной власти и органах местного самоуправления Кыргызской Республики на 2014-2017 годы. Бишкек. 17 ноября 2014 г.

Правительство Кыргызской Республики. Без даты. Государственный комитет информационных технологий и связи Кыргызской Республики представляет на общественное обсуждение проект НПА. http://www.gov.kg/?p=112862\&lang=ru

Правительство Кыргызской Республики. Без даты. Стратегия развития образования в Кыргызской Республике на 2012-2020 годы. https://www.globalpartnership.org/content/educationdevelopment-strategykyrgyz-republic-2012-2020

Программа развития Организации Объединенных Нацций (ПРООН). 2018. Инновационная лаборатория «Таза Коом». Запрос предложений. 30 марта. http://procurement-notices.undp.org/view_file.cfm?doc_id=137230

Таза Коом. http://tazakoom.kg/site/index

Таза Коом. https://portal.tazakoom.kg

Таза Коом. Без даты. Стратегия устойчивого развития Кыргызской Республики на период с 2018 по 2040 гг. «Таза Коом - Жаны доор». http://tazakoom.kg/site/concept/22.

Херманс М. 2014. Кыргызская Республика мобильный банкинг приведет финансы в сельские районы. Блог АБР. 27 ноября. https://blogs.adb.org/blog/ kyrgyz-republic-banking-mobile-phones-bring-finance-ruralareas

Хоу, Динйон. 2011. Реформа образования в Кыргызской Республике - уроки МПООД (PISA). Справочный документ по уровню знаний в Европе и Центральной Азии. 40. https://openknowledge.worldbank.org/ handle/10986/10100

Центральноазиатский форум операторов сотовой связи. 2018. Нур останавливает услугу Электронный мобильный кошелек. 13 марта 2018 г.

https://www.3gca.org/nur-to-stop-e-walletservice-from-mobile-phones/

Экономическая и социальная комиссия ООН для Азии и Тихого океана (ЭСКАTO). 2014. Углубленное исследование широкополосной инфраструктуры в Северной и Центральной Азии. http://www.unescap.org/sites/default/files/ Broadband\%20Infrastructure\%20in\%20North\%20and\%20Central\%20Asia\%20 FINAL\%20_English_o.pdf 
Электронный мобильный кошелек. https://www.mobilnik.kg/\#/start

ЭлКат. http://www.elcat.kg/en/about/history/about-us

ЮНЕСКО. Институт статистики ЮНЕСКО (ИСЮ). 2014. ИКТ в образовании в Азии. http://uis.unesco.org/ sites/default/files/documents/informationcommunicationtechnologies-education-asia-ict-integration-e-readiness-schools2014-en_o.pdf

Юнкер, Ж.К. 2017. Выступление Президента Европейкой Комиссии о проекте «Таза Коом». 12 июня 2017 г. https://eeas.europa.eu/delegations/ kyrgyzrepublic/27964/node/27964_sr

Японское агентство международного сотрудничества (JICA). 2018. Встреча с Премьер Министром КР. Темы и события, 19 января.

https://www.jica.go.jp/kyrgyz/english/office/topics/180119_en.html 


\title{
Traba 6
}

\section{Транспорти логистика Аля обеспечения роста торговли И ИНКЛЮЗИВНОСТИ}

\author{
Ричард Помфрет и Айгуль Бердигулова
}

\section{1. Введение и историческая справка}

азвитие транспортной системы в современном виде началось, когда Кыргызская Республика еще входила в состав Советского Союза. Советский Союз представлял собой самодостаточную закрытую экономику, управление которой велось в соответствии с геополитическими соображениями и географическими характеристиками, ${ }^{1}$ которые сыграли решающую роль в создании транспортной системы территории, ныне являющейся Кыргызской Республикой. После советско-китайского раскола в 1960 году, граница с Китайской Народной Республикой (КНР) в общем была закрыта до 1992 года, и горная Киргизия (название Кыргызской Республики до обретения независимости) являлась конечным пунктом основных железнодорожных и автодорожных сообщений Советского Союза. Высокие горные хребты естественным образом разделяют республику на север и юг, и открытые границы между советскими республиками сделали экономически и технически целесообразным строительство обходного маршрута соединяющего север и юг страны. Транспортные маршруты строились для обеспечения жизнедеятельности экономических кластеров Советского Союза в целом.

С обретением независимости в декабре 1991 года, Кыргызская Республика унаследовала транспортную систему, обеспечивающую хорошие транспортные сообщения на дальние расстояния, но местный транспорт был недостаточно развит. Северная часть Кыргызской Республики была лучше связана с Алматы и Джамбулом (ныне Тараз), чем с городом Ош; тогда как Ош был лучше связан с Узбекистаном, чем с северной частью Кыргызской Республики. Самый удобный маршрут между двумя крупнейшими городами Бишкек и Ош пролегал по территории Казахстана, Узбекистана, Таджикистана, и затем снова через Узбекистан, чтобы в конечном итоге въехать на территорию Кыргызской Республики недалеко от города Ош. Однако появление новых независимых государств и национальных границ обозначило необходимость в создании национальной дорожной системы

Кыргызстан и Таджикистан разделяют третье и четвертое места в списке стран, не имеющих выхода к морю, по высоте расположения над уровнем моря, после Бутана и Непала (Лиссоволик И. и др., 2017). 
и повышенную потребность в модернизации дороги Бишкек-Ош. В 1990-е годы практически не было авиарейсов в страны, находящиеся за пределами Содружества независимых государств (СНГ), хотя внутренние рейсы и полеты в пределах СНГ продолжали осуществляться на унаследованных советских самолетах. ${ }^{2}$ В 1993 году Кыргызская Республика стала членом Международной организации гражданской авиации, а в 1994 году был открыт первый рейс за пределы СНГ (Бишкек-Стамбул). В зимний период 2017-2018 гг. международные направления авиаперевозчиков Кыргызстана были ограничены несколькими городами Российской Федерации и Турции, Урумчи (КНР), Дели (Индия), Алматы (Казахстан) и Душанбе (Таджикистан). Железнодорожное сообщение из Бишкека к магистрали Алматы-Ташкент сохранилось, но внутренняя железнодорожная сеть отсутствовала. Круглогодичный фрахт водным транспортом осуществлялся на озере Иссык-Куль (что в переводе с кыргызского означает «теплое озеро»), с 200 километрами (км) водного пути [МСАП 2013 г.], однако к 2017 году использование водного транспорта прекратилось. Природный газ поставлялся трубопроводом в несколько районов Баткенской, Ошской, Джалал-Абадской, Таласской и Чуйской областей. Доминирующим видом транспорта оставался автомобильный (Рисунок 6.1).

\section{Рисунок 6.1 Доля видов транспорта в увеличении объемов грузовых и пассажирских перевозок}

а. Вклад в увеличение грузовых перевозок (\%)

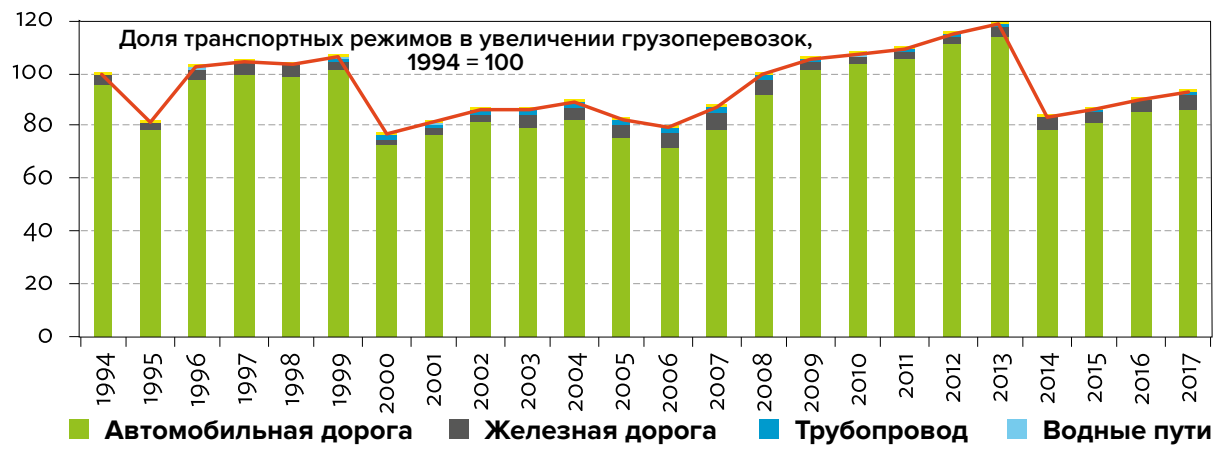

\section{b. Вклад в увеличение пассажирских перевозок (\%)}

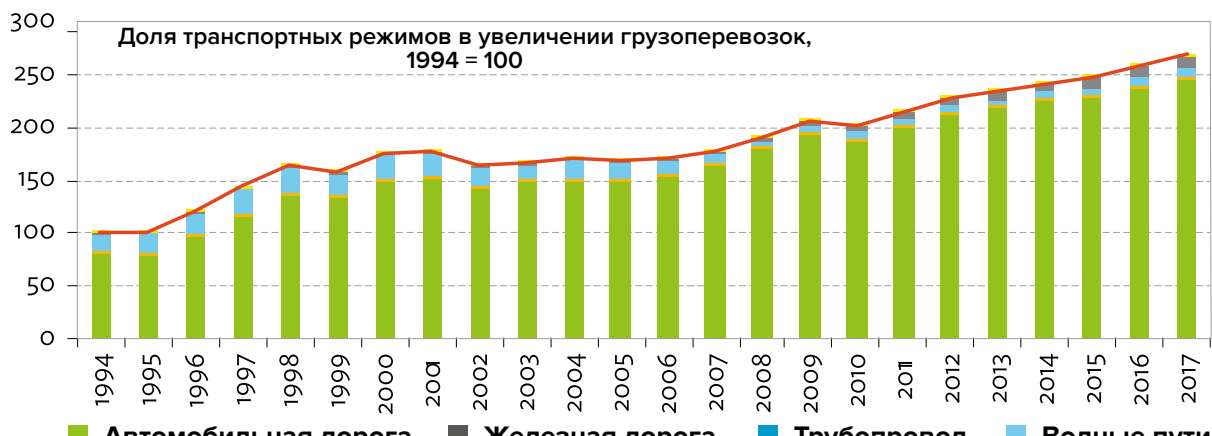

2 В советское время Ташкент был международным аэропортом, а рейсы Алматы-Урумчи начали осуществляться в 1989-1990 годах 
Источник: Оценочные расчеты авторов на основе данных Национального статистического комитета. HCK. Транспорт и коммуникации http://stat.kg/en/statistics/transport-i-svyaz/ (по состоянию на 24 февраля 2018 г.).

Главной особенностью кыргызской экономики в 2000-х годах являлась роль базаров «Дордой» и «Кара-Суу»в качестве хабов для реэкспорта товаров, преимущественно китайского производства, покупателям из стран Центральной Азии. Транспортировка товаров из КНР осуществлялась автомобильным или железнодорожным транспортом через Казахстан, а покупатели перевозили грузы автомобильным транспортом далее в другие бывшие советские республики. Положительным внешним эффектом этих торговых связей стало развитие экспорта швейных изделий и фасоли. Кроме того, с начала 2000-х годов до 2014 года, с вовлечением военных сил Соединенных Штатов в урегулирование ситуации в Афганистане, в качестве катализатора, стал функционировать Международный аэропорт «Манас» (и Транзитный центр).

В течение 2010-х годов постоянно осуществлялась модернизация дорожной сети Кыргызстана, но после 2014 года эта сеть стала сокращаться. Правительство понимало необходимость диверсификации экономики и стремилось развивать внешние транспортные связи в качестве необходимого условия для диверсификации экспорта. В это десятилетие были также предприняты шаги по модернизации аэропортов страны и созданию новых железнодорожных сообщений, а также разработке новых инициатив в области торговли энергоресурсами - импорт газа по трубопроводу или экспорт гидроэлектроэнергии по линиям электропередачи (см. Главу 7).

Несмотря на то, что в отдельные годы отмечались двузначные темпы роста, роль транспортного сектора в экономике оставалась ограниченной, составив всего о,3 процентных пункта в 2017 году. Для сравнения, в 1996 году вклад транспортного сектора в рост валового внутреннего продукта составил 0,4 процентных пункта. В транспортной отрасли задействовано около 6\%-7\% от общей численности экономически активного населения. В период независимости фактором, обеспечивающим рост сектора, в основном являлись городские пассажирские перевозки, в то время как грузоперевозки превышали уровень 1994 года лишь в отдельные годы. ${ }^{3}$ Отчасти причина в том, что в первые годы независимости почти все пассажирские перевозки были приватизированы, а приватизация в грузовом секторе шла менее активными темпами (доля грузовых перевозок автомобильным транспортом, осуществляемая индивидуальными предпринимателями, выросла с 8,8\% в 1995 году до 61,9\% в 2010 году). К 2015 году транспортный сектор состоял в основном из малых предприятий или индивидуальных предпринимателей, более половины которых имеют среднее образование. Распространение личного транспорта, а также увеличение услуг такси привело к быстрым темпам роста регистрации транспортных средств, количество которых увеличилось с 285000 в 2002 году до 1146780 в 2017 году. В 2015 году 85\% пассажирских перевозок, осуществляемых предприятиями, приходилось на поездки в черте городов. Преобладание малого бизнеса, испытывающего дефицит квалифицированной рабочей силы, ограничивает потенциал развития сектора грузовых перевозок.

Несмотря на преобладание автомобильного транспорта, эффективность железнодорожного транспорта в перевозке грузов и воздушного транспорта в перевозке пассажиров достаточно заметна. В 2017 году, 29,8 млн. тонн грузов было

3 После распада СССР макроэкономическая стабильность была достигнута в 1994 году, поэтому он был выбран в качестве базового года. 
перевезено автомобильным транспортом, а 1.9 млн. тонн (6,1\% от общего грузооборота) по железной дороге. При этом грузооборот по железной дороге составил 973,3 млн. тонно-километров (35,5\% от общего грузооборота), а автомобильным - 1,5259 млрд. тонно-километров. В 2017 году 650 млн. пассажиров путешествовали автобусами и 1,5 млн. воздушным транспортом. Пассажирооборот воздушным транспортом составил 2,626 млрд. пассажиро-километров (21,4\% от общего пассажирооборота, а пассажирооборот автобусов составил 8,931 млрд. пассажиро-километров (Рисунок 6.2). С 2002 по 2016 годы грузооборот почти удвоился - с 1,660 млрд. тонно-километров до 2,643 млрд. тонно-километров, а пассажирооборот увеличился на 125\% с 5,466 млрд. пассажиро-километров до 12,290 млрд. пассажиро-километров. 4

\section{Рисунок 6.2: Грузооборот и пассажирооборот по видам транспорта}

а. Грузооборот по видам транспорта (\% от общего грузооборота)

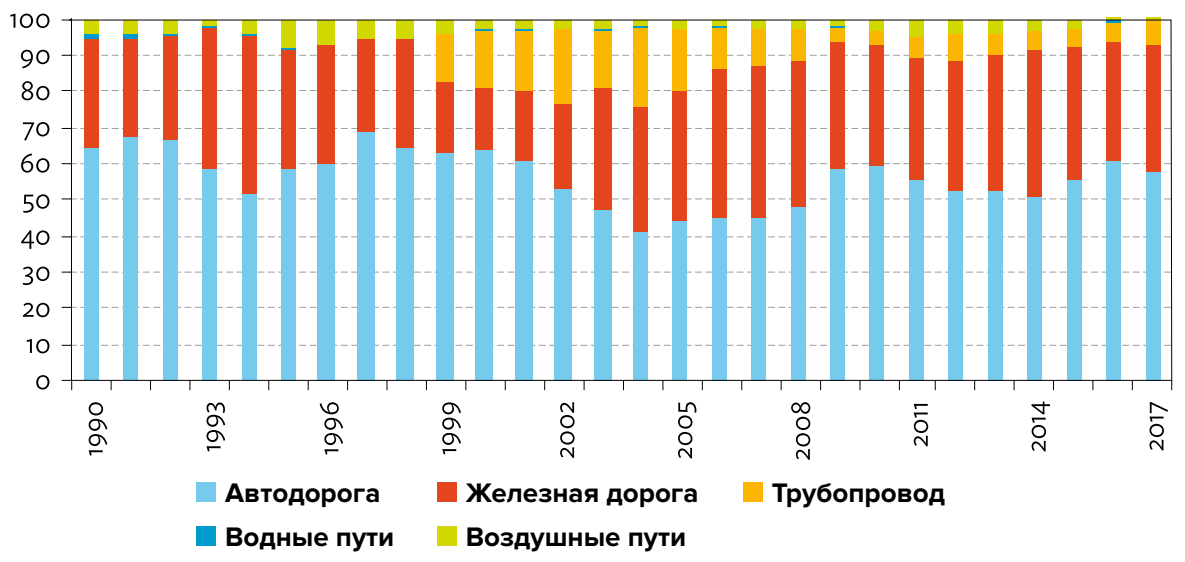

b. Пассажирооборот по видам транспорта (\% от общего пассажиропотока)

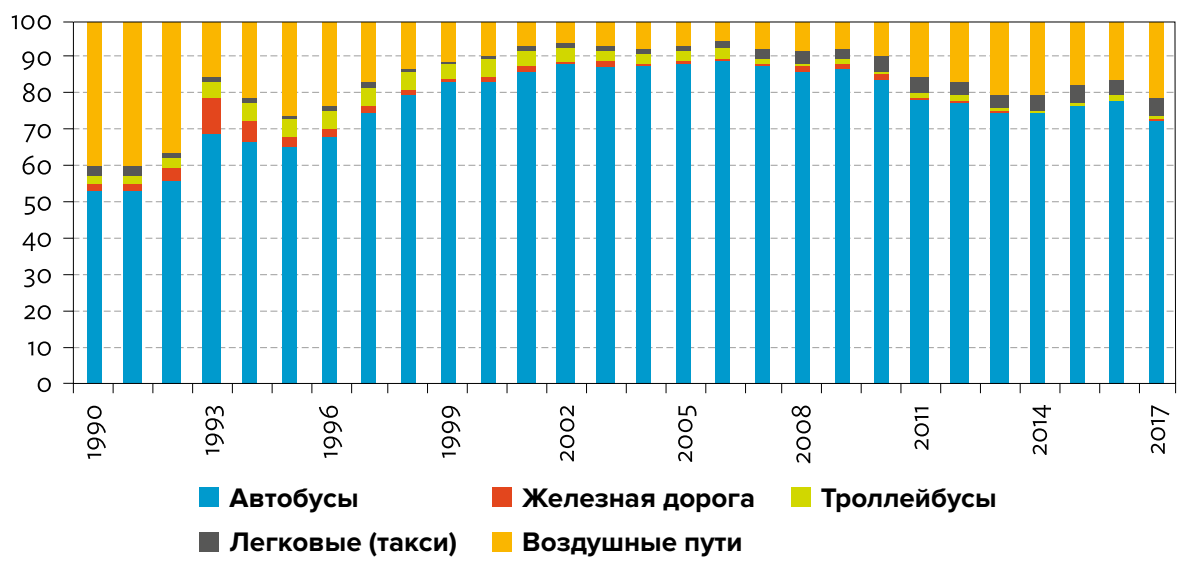

Источник: Оценочные расчеты авторов на основе данных Национального статистического комитета. НСК. Транспорт и коммуникации http://stat.kg/en/statistics/transport-i-svyaz/ (по состоянию на 24 фревраля 2018 г.).

4 Данные Национального статистического комитета Кыргызской Республики. 


\section{2 Внутренние и международные сообщения}

В этом разделе представлена информация о ныне действующих автомобильных, железнодорожных и воздушных сообщениях. Почти все внутренние пассажирские перевозки и преобладающая часть грузовых перевозок осуществляются автомобильным транспортом. Железнодорожная сеть страны разделена пополам: северный регион соединяется с Туркестано-Сибирской магистралью, ведущей до Алматы и в Российскую Федерацию, а некоторые города юга страны соединяются с Узбекистаном подъездными ветками. Железнодорожные и воздушные пути важны для международных сообщений, железнодорожные - для торговли товарами, а воздушные - для пассажирских поездок и туризма.

\section{Автомобильные дороги}

В стране около 34 ооо км автомобильных дорог. ${ }^{5}$ На Министерство транспорта и дорог возложена ответственность за содержание 4163 км дорог международного значения, 5678 км дорог национального значения и 8969 км дорог областного значения. Остальные второстепенные сельские и городские дороги (15 190 км) обслуживаются местными органами власти или сельскохозяйственными либо промышленными предприятиями (Правительство Кыргызской Республики, 2015 г.). Из общей протяженности дорог международного и национального значения «33\% находятся в плохом состоянии и требуют реабилитации и реконструкции», включая главную автомагистраль Бишкек-Ош, которая в силу климатических условий требует постоянного проведения работ по содержанию и техническому обслуживанию (АБР, 2013 г.). Национальным статистическим комитетом отмечается высокий уровень дорожно-транспортных происшествий: 4248 аварий было зарегистрировано в 2009 году и 7066 в 2015 году, что привело к 1 о6о смертельным исходам. ${ }^{6}$

Оценка сектора, проведенная Азиатским банком развития (АБР) в 2013 году, показала, что, хотя партнеры по развитию инвестировали около 1 млрд. долл. США, начиная с 1994 года, «общее состояние дорожной сети существенно не улучшилось» (АБР, 2013 г.). Весьма суровый вывод, учитывая то, что собственные оценки АБР первоначальной реабилитации дороги Бишкек-Ош, для которой АБР предоставил финансирование в размере 140 млн. долл. США, указывали на то, что время в пути сократилось с 20 часов до 9 часов, а количество транспортных средств, использующих дорогу, увеличилось с 800 в день до реабилитации до 8500 в день после нее. Однако, поскольку обновление дороги было завершено в начале 2000-х годов, состояние отдельных участков ухудшилось, особенно тех, которые расположены в высокогорье. Кроме того, движение по данному транспортному коридору часто блокируется лавинами и оползнями из-за отсутствия защитных галерей (жесткие снегозащитные сооружения над дорогами, которые подвергаются угрозе схода лавин и камнепадов).

В среднесрочных национальных стратегиях на 2009-2013 годы и на 20132017 годы правительство четко определило приоритетность обеспечения доступа

5 Общая протяженность дорог общего пользования с твердым покрытием составляет 7228 км, в том числе 11 км с цементобетонным, 4969 км с асфральтобетонным покрытием и 2248 км с покрытием из черного гравия. Дороги с гравийным покрытием - 9061 км, грунтовые дороги 1621 км. Министерство транспорта и дорог Кыргызской Республики. http://mtd.gov.kg/dorogi-2 (по состоянию на 24 февраля 2018 г.)

6 Данные Национального статистического комитета Кыргызской Республики. 
к региональным рынкам и развитие транзитного потенциала в качестве одного из основных приоритетов. Для достижения этой цели правительство определило шесть ключевых коридоров, которые нуждаются в реабилитации, и необходимость строительства железной дороги:

1. Ош - Сары-Таш - Иркештам, соединяет пункт пересечения границы КНР с городом Ош, расположенным недалеко от узбекской границы;

2. Суусамыр - Талас - Тараз, связывает северо-западную часть Таласской области с автомагистралью Бишкек - Ош и автомагистралями в южном Казахстане;

3. Бишкек - Нарын - Торугарт, соединяет второй пункт пересечения границы КНР со столицей;

4. Сары-Таш - Карамык, дорога, ведущая в Душанбе;

5. Ош - Баткен - Исфана, связывает Баткенскую область и ведет в Худжанд в Таджикистане;

6. Каракол - Тюп - Кеген, дорога, ведущая в Казахстан; и

7. Железная дорога КНР - Кыргызская Республика - Узбекистан (Раздел 6.4 настоящей главы)

Автомобильная дорога вокруг Иссык-Куля, представляющая собой больше кольцевую дорогу, нежели транспортный коридор, но имеющая решающее значение для привлечения посетителей к главной туристической достопримечательности страны, была включена в список после принятия Национальной стратегии устойчивого развития на 2013-2017 гг. Однако, финансирование дорожного строительства должно быть привязано к ресурсам, предназначенным для содержания дорог и повышения их безопасности.

Дорога от перевала Торугарт, на границе с КНР, через Ат-Баши и Нарын до Бишкека теперь представляет собой модернизированную автомагистраль (№ 3 в списке выше). Проект финансировался АБР, КНР, Исламским банком развития и Арабской координационной группой. Строительство второй дороги «Север-Юг» от Джалал-Абада до Балыкчи началось в 2014 году; были построены протяженные участки дороги, хотя строительство туннелей через самый сложный ландшафт еще предстоит завершить. ${ }^{7}$ Общая картина такова, что состояние национальной сети дорог существенно улучшилось, хотя некоторые проекты остаются незавершенными. Правительство, судя по всему, уделяет приоритетное внимание автодорогам Бишкек-Ош и Бишкек-Торугарт (БНТ), создав для них отдельные департаменты по управлению дорожными коридорами и выделяя достаточные бюджетные средства на их содержание (около 7000 долл. США на км для Бишкек-Ош и 5 ооо долл. США на км для БНТ). ${ }^{8}$

Группа реализации инвестиционных проектов. Альтернативная дорога Север-Юг. http://piumotc.kg/ru/p1861900/ (по состоянию на 24 февраля 2018 г.)

8 Ремонт и содержание дорог общего пользования осуществляют 57 дорожно-эксплуатационных предприятий (ДЭП). Существует шесть ДЭП, три управления, которые управляют международными автодорогами (Бишкек - Нарын - Торугарт, Ош - Сарыташ - Иркештам и Ош - Баткен - Исфана) и Государственная дирекция автомобильной дороги Бишкек - Ош. Общее управление девятью дорожными отделами осуществляется Главным управлением автомобильных дорог Министерства транспорта и автодорог Кыргызской Республики. http://mtd.gov.kg/dorogi-2/ (по состоянию на 24 февраля 2018 г.) 
Дан старт институциональной реформе, включающей в себя выделение из Министерства транспорта и дорог функции по обслуживанию дорог. Подразделения министерства по содержанию дорог могут по-прежнему являться государственными предприятиями, но они будут конкурировать с другими частными или иностранными компаниями в тендерах. Городские, пригородные и сельские дороги здесь не рассматриваются потому, что они подпадают под юрисдикцию местных органов власти, а не министерства, но такие проблемы, как заторы на дорогах и содержание дорог в Бишкеке, а также плохое качество дорожного полотна «последней мили» местных дорог имеют экономические последствия.

Другая институциональная реформа, предусмотренная в Стратегии развития дорожного сектора до 2025 года - это внедрение механизма государственно-частного партнерства. Первый пилотный проект предусматривает трансформацию участка на перевале Кубакы автодороги Бишкек - Нарын - Торугарт в платную дорогу. Новый участок сократит длину маршрута на 41 км. Частный партнер установит измерительную станцию, которая будет рассчитывать стоимость в зависимости от общего веса и габаритов транспортного средства. Собранная плата за проезд будет идти на покрытие расходов по содержанию дороги и инвестиции частного партнера в измерительное оборудование. Подготовлено технико-экономическое обоснование по проекту государственно-частного партнерства: объездная дорога вокруг Узгена, а ТЭО для прямой дороги Алматы - Иссык-Куль еще не начиналось.

\section{Железные дороги}

Протяженность железнодорожных путей в Кыргызской Республике составляет 424,6 км, которые проходят по двум несвязанным линиям (Рисунок 6.3). ${ }^{9}$ Северная линия (323,4 км) проходит от Казахстана до Бишкека и от Бишкека до Балыкчи - города на берегу озера Иссык-Куль. Линия Бишкек - Балыкчи проходит по живописному ландшафту, но занимает долгие 4,5 часа и функционирует только в летний период. Намного менее протяженные южные линии (101,2 км) соединяют Ош, Кара-Суу, Джалал-Абад и Кызыл-Кию с железнодорожной сетью Узбекистана и используются только для грузовых перевозок. ${ }^{10}$

Единственным оператором железных дорог является государственная компания «Кыргыз темир жолу», осуществляющая пассажирские и грузовые перевозки. Железнодорожный транспорт играет небольшую роль для Кыргызской Республики, практически не имея внутреннего железнодорожного сообщения, кроме пассажирского поезда Бишкек - Балыкчы. За годы независимости пассажирские перевозки по железной дороге сократились в 4,6 раза по причине неспособности противостоять ценовой конкуренции со стороны автоперевозчиков, ${ }^{11}$ в то время как доля грузовых перевозок выросла в три раза с 1990 года и достигла в 2017 году уровня 6,1\% (Рисунок 6.4а). Железная дорога, как правило, используется для перевозки насыпных международных грузов (Рисунок 6.4б).

9 Кыргызские железные дороги. Общая информация. http://www.kjd.kg/ru/about/strategiya-razvitiyazeleznyh-dorog/

10 Железнодорожная линия между Джалал-Абадом и Ошем через Кара-Суу проходит через территорию Узбекистана.

1123 марта 2018 года был запущен пассажирский поезд Ташкент-Бишкек-Балыкчи, который может придать импульс развитию пассажирских перевозок по железной дороге. 


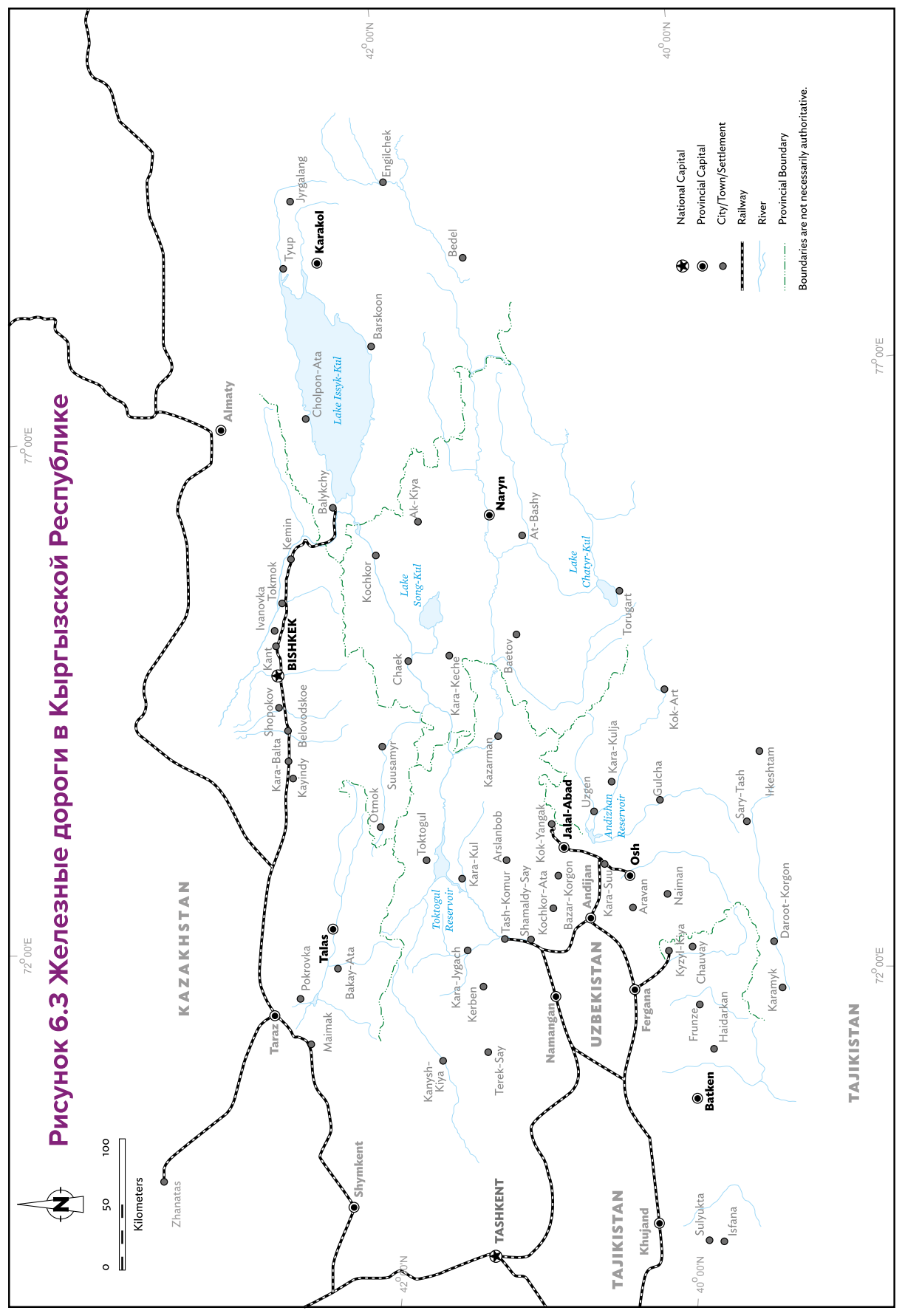




\section{Рисунок 6.4: Доля железнодорожных перевозок в общем объеме перевозок, 1990-2017 гг., и товарная структура железнодорожных грузовых перевозок, 2012-13 гг.}

а. Доля железнодорожных перевозок (\% от общего объема перевозок)

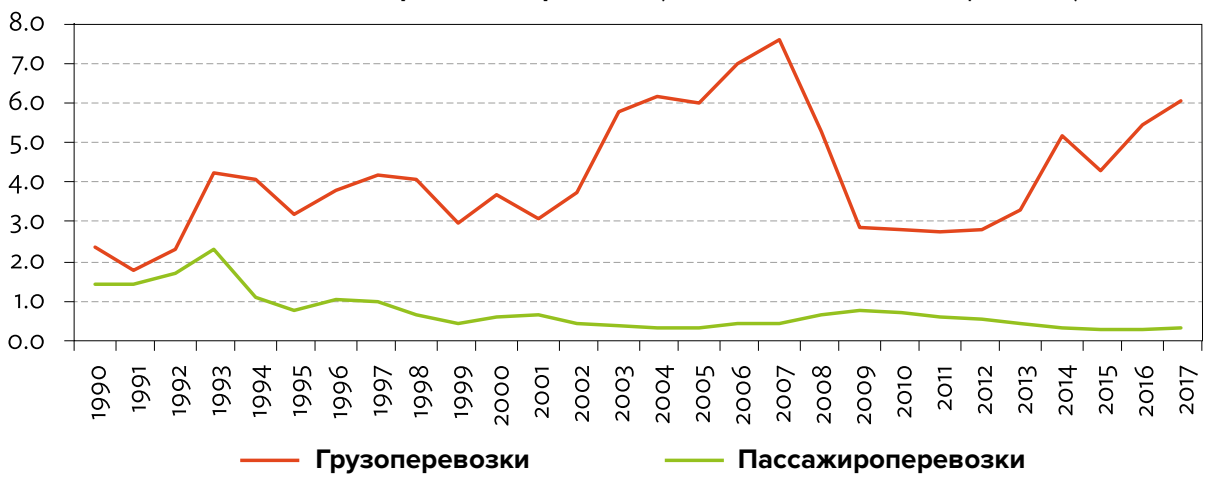

b. Железнодорожные перевозки по видам товаров

(\% от общего объема железнодорожных перевозок за 2012-2013 гг.)

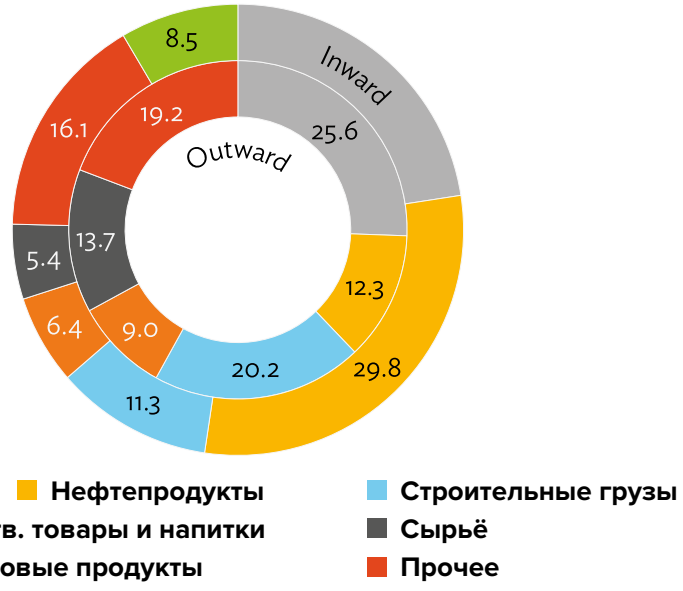

Источник: Расчеты авторов на основе данных «Кыргыз темир жолу». http://www.kjd.kg/(по состоянию на март 2018 г.)

Разрозненные и тупиковые железные дороги не содействуют торговле внутри республики и ограничивают развитие международной торговли. Дальнейшее развитие железнодорожного сектора ограничено недостатком инвестиций, необходимых для модернизации основных фондов и подвижного состава, отсутствием исследований и разработок, нехваткой квалифицированной рабочей силы, а также плохим финансовым положением «Кыргыз темир жолу». Стратегия развития железнодорожного сектора на 2014-2020 годы в основном направлена на обновление и модернизацию активов, унаследованных от Советского Союза. ${ }^{12}$ Стратегия излагает планы перехода от дизельного топлива к электричеству и ставит в качестве приоритета подготовку технико-экономического обоснования для

12 Правительство Кыргызской Республики (2014г.) 
строительства железнодорожной дороги «Север-Юг». Планы по созданию нового маршрута, связывающего КНР с Узбекистаном через юг Кыргызской Республики, рассматриваются в разделе 6.4 .

\section{Воздушный транспорт}

После распада Советского Союза была создана национальная авиакомпания «Кыргызстан аба жолдору», которая была единственной компанией, предоставляющей весь спектр авиаперевозок. С 1997 по 2001 год она была реорганизована в три независимые компании. В результате, национальный авиаперевозчик «Кыргызстан аба жолдору» и международный аэропорт «Манас» были организованы в форме акционерных компаний, а поставщик услуг аэронавигационного обслуживания «Кыргызавианавигация» является государственным предприятием. ${ }^{13}$ АО «Международный аэропорт «Манас» управляет 11 аэропортами (Рисунок 6.5).

Из 86 аэропортов, аэродромов и посадочных полос, когда-либо построенных на территории нынешней Кыргызской Республики, сейчас только 29 имеют действующие взлетно-посадочные полосы. Одиннадцать имеют регулярные коммерческие рейсы (Таблица 6.1), хотя многие услуги были прекращены после распада Советского Союза. Даже основные воздушные ворота страны, международный аэропорт «Манас», был бесхозным в течение десятилетия после обретения независимости, когда большинство иностранных гостей страны прибывали по автомобильной дороге из аэропорта г. Алматы. Только аэропорты «Манас», «Ош» и «Иссык-Куль» имеют международные коды Международной ассоциации воздушного транспорта (IATA).

В 1970-е годы главный аэропорт страны, Международный аэропорт «Манас», заменил старый аэропорт, находившийся в черте города Бишкек. Первый самолет приземлился в аэропорту «Манас» в октябре 1974 года с Председателем Совета министров СССР А. Косыгиным на борту, а первый регулярный рейс из Москвы (Домодедово) прибыл в мае 1975 года. После обретения независимости аэропорту не уделялось должного внимания, пока не начались ремонтные работы в 1996-1998 годы при финансовой поддержке Японии.

После 11 сентября 2001 года Соединенные Штаты и их партнеры по коалиции обратились к правительству Кыргызстана рассмотреть возможность размещения в аэропорту военной базы для проведения операций в Афганистане. Стоянка была освобождена от заброшенных самолетов и на их месте были построены большие временные ангары для размещения истребителей. Была построена новая стоянка для самолетов, чтобы освободить место для более крупных заправочных и транспортных самолетов, крупного грузового склада и нескольких объектов для технического обслуживания воздушных судов, а также организовано освещение с целью создания более благоприятных условий для посадки в ночное время. Напротив пассажирского терминала во временных объектах было размещено более 2000 военнослужащих, и правительство Кыргызской Республики расширило пассажирский терминал, чтобы разместить рестораны, сувенирные магазины и

13 Постепенная модернизация аэронавигационного оборудования и постоянное профессиональное развитие сотрудников «Кыргызаэронавигации» позволяют обеспечить необходимый уровень аэронавигационного обслуживания. В 2016 году национальная компания оказала услуги более чем 40000 самолетам, в том числе 11 000-12 000 самолетов запросившим транзитную поддержку. «Кыргызаэронавигация» обслуживает 15 национальных авиаперевозчиков и более 50 международных авиакомпаний («Кыргызаэронавигация». http://www.kan.kg по состоянию на 3 марта 2018 года). 
парикмахерские. В 2007 году в терминале аэропорта был проведен капитальный ремонт и перепланировка за счет внешней помощи. В 2012 году аэропорт обслужил 1 миллион пассажиров.

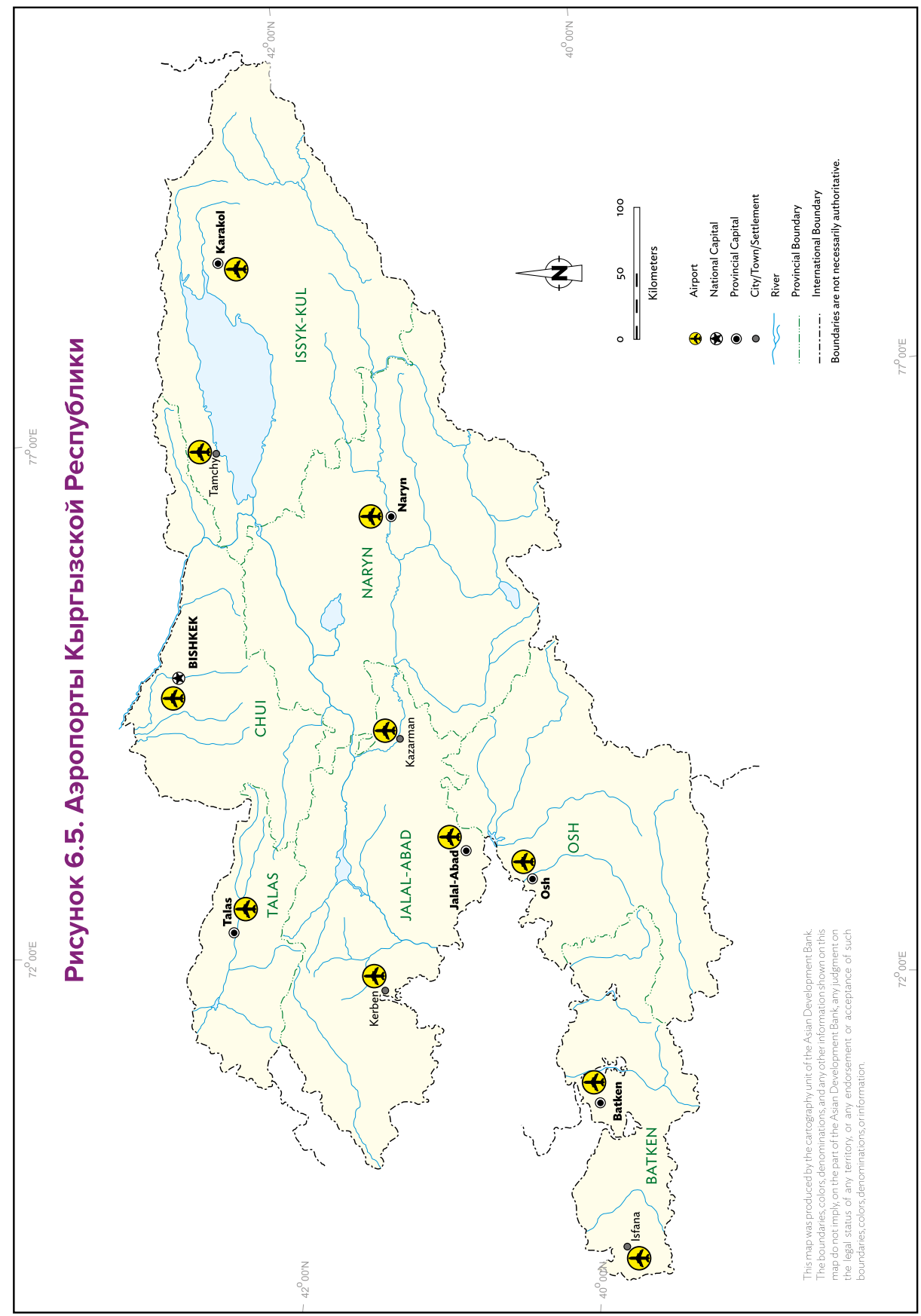




\section{Таблица 6.1: Аэропорты с регулярными коммерческими рейсами}

\begin{tabular}{|c|c|c|c|c|}
\hline Город & Область & Код ICAO & Код IATA & Наименование аэропорта \\
\hline Бишкек & Чуй & UCFM & FRU (БИШ) & Международный аэропорт «Манас» \\
\hline Ош & Ош & UCFO & OSS (ОШШ) & Международный аэропорт «Ош» \\
\hline Джалал-Абад & Джалал-Абад & UAFJ & (ДЖБ) & Аэропорт г. Джалал-Абад \\
\hline Казарман & Джалал-Абад & UAFZ & (K3M) & Аэропорт г. Казарман \\
\hline Кербен & Джалал-Абад & UAFE & (KPФ) & Аэропорт г. Караван \\
\hline Баткен & Баткен & UAFB & (БАТ) & Международный аэропорт г. Баткен \\
\hline Иссрана & Баткен & UAFI & (ИФА) & Аэропорт г. Исфана \\
\hline Нарын & Нарын & UAFN & $(\mathrm{HЫH})$ & Аэропорт г. Нарын \\
\hline Талас & Талас & UAFT & (ТЛС) & Аэропорт г. Талас \\
\hline Тамчи & Иссык-Куль & UCFL & $(\mathrm{IKU})$ & Международный аэропорт «Иссык-Куль» \\
\hline Каракол & Иссык-Куль & UCFP & (КПЖ) & Международный аэропорт г. Каракол \\
\hline
\end{tabular}

ICAO = Международная организация гражданской авиации , IATA = Международная ассоциация воздушного транспорта,

Примечание: Коды IATA на руссом языке приведены в скобках. Коды IATA для Бишкека и Оша приведены на английском и русском языках; для всех других аэропортов, коды ІАТА приведены только на русском языке.

Источник: Составлено авторами на основе данных ICAO, IATA, и АО Международный аэропорт «Манас».

Авиабаза «Манас» была переименована в «Транзитный центр» в «Манасе» в 2009 году. Он был закрыт и передан властям Кыргызстана в 2014 году. Одновременно были модернизированы его эксплуатационные мощности при поддержке Японии. ${ }^{14}$ Второй терминал был построен для обслуживания VIP лиц, Международный аэропорт «Манас» считается прибыльным, но для масштабов столичного аэропорта маршрутная сеть ограничена. Регулярно осуществляются полеты по 24 международным пассажирским направлениям (среди них всего 3 мировых хаба: Дубай, Стамбул и Москва), по 6 местным направлениям и по 5 международным грузовым направлениям. В 2017 году количество рейсов увеличилось в 1,7 раза по сравнению с 2010 годом. Число пассажиров достигло 3,5 млн. человек в 2017 году, увеличившись в 3,2 раза по сравнению с уровнем 2012 года.

Международный аэропорт «Ош» является еще одним крупным пассажирским аэропортом. В 2012 году аэропорт обслужил о,8 млн. пассажиров, а в 2016 году эта цифра выросла до 1,2 млн., несмотря на то, что инфраструктура аэропорта продолжала оставаться прежней. В марте 2018 года была проведена реконструкция зала прибытия. Семь авиакомпаний обслуживают внутренние маршруты (несколько рейсов в день в Бишкек), а также осуществляют рейсы в российские города и в Урумчи. Пассажиры, отбывающие в Российскую Федерацию, в основном являются трудовыми мигрантами, в том числе из северного Таджикистана и из узбекской части Ферганской долины. В 2017 году аэропорт Ош обслужил 10269 рейсов, почти половина которых приходилась на международные перевозки.

14 Японское правительство предоставило радиолокационное оборудование VOR/DME в 2014 году. VOR/DME=OBЧ-всенаправленный диапазон (VOR) и дистанционное измерительное оборудование (DME). 
Другие аэропорты начинали деятельность в качестве посадочных полос, построенных в 1930-х, 1940-х и 1950-х годах для обслуживания местных населенных пунктов, проектов гидроэнергетики и горнодобывающей отрасли. Взлетно-посадочные полосы и терминалы были построены в 1970-х годах, и была создана сеть внутренних воздушных сообщений. Многие из услуг были прекращены в 1990-х годах. Это аэропорты регионального значения класса $3 \mathrm{C},{ }^{15}$ чьи взлетно-посадочные полосы имеют весовой предел в 22 тонны, не обладающие оборудованием для посадки самолетов по приборами, и соответственно эксплуатируемые только в дневное время. В 2000-х годах правительство начало восстанавливать некоторые из аэропортов, включая предоставление «международного» статуса и установку иммиграционных и таможенных постов в трех аэропортах.

Аэропорт «Тамчи» начал работать в 1975 году в качестве запасного для близлежащего аэропорта Чолпон-Ата. Действующая в настоящее время взлетно-посадочная полоса и терминал были построены в 2003 году, когда данный аэропорт заменил аэропорт Чолпон-Ата, который до 2003 года имел регулярное сообщение с городами Бишкек, Ош и Джалал-Абад. В том же году правительство Кыргызской Республики переименовало аэропорт «Тамчи» в Международный аэропорт «Иссык-Куль». В 2015-2016 годах были завершены первые два этапа реконструкции аэропорта. Регулярные рейсы осуществляются в летний период в Ош, Алматы (Казахстан), Новосибирск (Российская Федерация), и Ташкент (Узбекистан).

Международный аэропорт «Каракол» начал свою деятельность в 1940-х годах, а нынешняя взлетно-посадочная полоса и терминал были построены в 1978 году. В ноябре 2011 года правительство Кыргызской Республики присвоило аэропорту «международный статус». Первый международный рейс - полет, осуществленный компанией SCAT Air из Алматы 2 декабря 2011 года, также стал первым регулярным рейсом аэропорта с 1991 года. Планируется начать полеты в города Бишкек, Джалал-Абад, Ош в Кыргызской Республике, а также в Омск и Новосибирск в Российской Федерации, и продвигать аэропорт в качестве воздушных ворот в горнолыжный регион Кыргызской Республики. Однако в настоящее время его использование сведено к минимуму.

Международный аэропорт «Баткен» начал свою деятельность в 1958 году в качестве посадочной полосы. Текущая взлетно-посадочная полоса и терминал были построены в 1984 году. Аэропорт «Баткен» получил международный статус 19 апреля 2014 года. Планируется установить таможенные и пограничные пункты пропуска, а взлетно-посадочную полосу удлинить на 400 метров. Внутренние рейсы выполняются в Джалал-Абад, Исфану и Ош.

Аэропорты Джалал-Абад, Исфана, Казарман и Кербен осуществляют внутренние коммерческие рейсы, но не имеют оборудования для осуществления международных рейсов. Кызыл-Кия, Тамга и другие аэропорты, как правило, используются в качестве запасных аэропортов (выделенных для специального использования) в соответствующих регионах.

Что касается воздушных перевозок, по состоянию на март 2018 года пять пассажирских перевозчиков и одна грузовая авиакомпания имели действующие

15 Для каждого аэродрома, используемого оператором в качестве пункта назначения или приемлемой альтернативы, существует регулятивное требование к проведению оценки рисков. На основе этой оценки присваивается категория аэродрома по классификации А, B, или С (самый высокий уровень риска). Категория С считается категорий аэродромов, имеющих проблемы с подходом, посадкой и/или взлетом. 
сертификаты авиаперевозчика, выданные Агентством гражданской авиации при Министерстве транспорта и дорог Кыргызской Республики. Большинство зарегистрировавшихся в стране авиакомпаний с момента обретения независимости просуществовали недолго. Кыргызские авиалинии имеют широкую географию полетов в российские города, как правило, обслуживая рынок трудовых мигрантов. Самый популярный внутренний маршрут - Ош-Бишкек, а использование направлений в остальные девять аэропортов незначительное.

«Долгожителем» среди кыргызских авиаперевозчиков является авиакомпания «Air Kyrgyzstan» основанная в сентябре 2001 года сначала как «Алтын Эйр» и переименованная в «Air Kyrgyzstan» в июле 2006 года, став преемником национальной авиакомпании «Кыргызстан аба жолдору». «Air Kyrgyzstan» базируется в Бишкеке и принадлежит «Al Sayegh Airlines» из города Шарджа, Объединенные Арабские Эмираты. Зимой 2017-2018 гг. авиакомпания «Air Kyrgyzstan» осуществляла регулярные пассажирские рейсы в Ош, а также в Белгород, Краснодар, Красноярск, Сургут, Челябинск и Москву в Российской Федерации.

Еще одна авиакомпания с относительно продолжительным периодом существования, это «Avia Traffic», основанная в 2003 году гражданами Кыргызской Республики и начавшая осуществлять чартерные и регулярные внутренние рейсы. Начиная с 2008 года, она расширила свою деятельность на международные рейсы. Зимой 2017-2018 гг. география полетов охватывала 4 города в Кыргызской Республике, 11 городов в Российской Федерации, Алматы в Казахстане, Душанбе в Таджикистане и Стамбул в Турции. ${ }^{16}$

Авиакомпания «Air Manas» была создана в 2006 году в качестве чартерной компании. В 2012 году турецкий инвестор «Pegasus Airline» выкупил 49\% акций компании «Air Manas», внедрил новые технологии и управлял ею в качестве бюджетной авиакомпании под названием «Pegasus Asia». Стремительное развитие позволило «Air Manas» вернуться к собственному названию бренда в 2015 году. Компания осуществляет внутренние (Бишкек и Ош) и международные рейсы (Дели, Москва, Ташкент и Урумчи). 1 марта 2018 года «Air Manas» стала первой кыргызской авиакомпанией, получившей Сертификат аудита операционной безопасности (IOSA) Международной ассоциации воздушного транспорта (IATA), удостоверяющий, что нормы безопасности компании соответствуют строгим международным стандартам. ${ }^{17}$

Авиакомпания «Tez Jet» была основана в 2013 году и обслуживает рейсы в Бишкек, Баткен, Джалал-Абад, Исфану и Ош. ${ }^{18}$ Несколько других авиакомпаний представляют собой небольшие чартерные компании, а все другие компании сложно отследить. Из-за соображений безопасности все кыргызские авиалинии входят в список авиаперевозчиков, запрещенных в Европейском Союзе. ${ }^{19}$

Международные авиакомпании, пользующиеся услугами Международного аэропорта «Манас», осуществляют пассажирские перевозки в КНР («China Southern»), Казахстан («Air Astana»), Дубай («FlyDubai» и «mirates»), Российскую Федерацию («Аэрофлот», «S7», «Сибирские» и «Уральские авиалинии»),

\footnotetext{
Компания «Avia Traffic». https://www.aero.kg/o-nas (по состоянию на 3 марта 2018 г.)

17 Компания «Air Manas». https://airmanas.com/en/about-airmanas.html (по состоянию на 3 марта 2018 г.)

18 «Tez Jet». http://tezjet.kg/about.html (по состоянию на 3 марта 2018 г.)

19 Первая версия списка была опубликована в 2006 году на основе Положения Европейской комиссии N $\mathrm{N}^{\circ}$ 474/2006 от 22 марта того же года. Действующая версия списка была опубликована 30 ноября 2017 года.
} 
Таджикистан («Tajik Air»), Турцию («Pegasus»), Турцию и Монголию («Turkish Airlines»), и Узбекистан («Uzbekistan Airways»). Грузовые перевозки осуществляются компаниями «MNG Airlines» (в Алматы), «RUS Aviation» (в Шарджу), «Silk Way» (в Баку и Урумчи) и «Uzbekistan Airways» (в Навои). «Turkish Airlines Cargo» обеспечивает грузоперевозки до пунктов назначения согласно своей обширной сети маршрутов, хотя непассажирские рейсы часто осуществляются через субподрядчиков. ${ }^{20}$

Правительство либерализовало воздушное пространство Кыргызстана, предоставив «пятую степень свободы», то есть право перевозить пассажиров рейсом, исходящем из своей страны, а также из стран, в которых осуществляются остановки в ходе перелёта до конечного пункта назначения.

\section{Физическая и нематериальная инфраструктура}

Унаследованная транспортная инфраструктура Кыргызской Республики прошла десятилетие деградации в 1990-х годах, когда обедневшее новое государство столкнулось с серьезными проблемами после окончания эпохи централизованного планирования, распада Советского Союза и гиперинфляции. После 2000-х годов ситуация постепенно стала улучшаться по мере строительства новых или реконструкции старых дорог и восстановления инфраструктуры аэропортов.

Общая проблема для стран Центральной Азии вытекала из того, что некогда интегрированный регион было разделен национальными границами и ограничительными мерами, сдерживающими международную торговлю. Проблема подтвердила наблюдение о том, что преимущества, которые получают страны от обновленной физической инфраструктуры (автомобильные дороги, железные дороги, аэропорты и т. д.) могут быть ограничены, если они не сопровождаются улучшениями в нематериальной инфраструктуре. Роль Кыргызской Республики в качестве реэкспортного хаба обеспечивалась вступлением республики во Всемирную торговую организацию и низкими тарифами, но стоимость ведения бизнеса и расходы на международную торговлю оставались высокими во всех странах Центральной Азии, в том числе и в Кыргызской Республике.

Основными автомобильными коридорами, которыми пользуются национальные перевозчики для международных грузовых перевозок, являются:

- Бишкек - Джалал-Абад - Ош;

- Бишкек - Нарын - Торугарт - Каши (КНР);

- Ош -- Сары-Таш - Иркештам - Каши (КНР);

- Ош - Кок-Талаа - Пульгон (Узбекистан) - Баткен - Исфана;

- Бишкек - Тараз (Казахстан) - Шымкент (Казахстан) - Ташкент (Узбекистан):

- Ош - Джалал-Абад - Андижан (Узбекистан);

- Бишкек - Алматы (Казахстан) - Караганда (Казахстан) - Астана (Казахстан) - Петропавловск (Российская Федерация); и

- Бишкек - Шымкент (Казахстан) - Кызыл-Орда (Казахстан) - Актюбинск (Казахстан) - Российская Федерация.

20 Турецкая компания, осуществляющая грузовые перевозки (переименована в авиакомпанию «MyCargo» после продажи 49\% акций китайской компании “HNA Group”, а самолет был взят в аренду у компании «LCI Freighters One Limited» (Ирландия). 
Недавняя ратификация КНР Конвенции о международных дорожных перевозках Организации объединенных наций (МДП ООН) несет в себе большой потенциал для увеличения объемов международной торговли вдоль маршрута Ташкент (Узбекистан) - Андижан (Узбекистан) - Ош (Кыргызская Республика) Иркештам (Кыргызская Республика) - Каши (КНР). МДП ООН уже действует в Кыргызской Республике и Узбекистане (MCAT, 2017 г.).

Согласно Индексу эффективности логистики, рассчитываемому Всемирным банком (Рисунок 6.6), Кыргызская Республика входит в число стран с наихудшими показателями эффективности логистики. В 2018 году в глобальном рейтинге Индекса эффективности логистики страна заняла 108-е место из 166 стран (с общим показателем Индекса эффективности логистики на уровне 2,55). Самыми неэффективными областями являются международные перевозки и качество торговой и транспортной инфраструктуры. Республика Беларусь, занявшая 120-е место, также не имеет выхода к морю, разделяет советское наследие и является членом Евразийского экономического союза (ЕАЭС). Более того, Беларусь имеет более низкие торговые издержки по сравнению с Кыргызской Республикой (Рисунок 6.6а). ${ }^{21}$

\section{3 Торговые издержки Кыргызской Республики по сравнению с Центральной Азией}

Известно, что торговые издержки в Центральной Азии высоки, и Кыргызская Республика не является исключением, о чем свидетельствуют задержки на сухопутных границах Кыргызской Республики. В то же время, трудно оценить расходы, связанные с международной торговлей (расходы на своевременную торговлю). Формальные барьеры, в том числе пошлины на импорт, как правило, низкие. Более того, кыргызская торговля имеет смешанный характер, где золото предположительно имеет низкие адвалорные торговые издержки благодаря его высокому соотношению стоимости к весу, в то время как сельскохозяйственная и промышленная продукция, как правило, перевозится партиями, поэтому сложно сравнивать связанные с ними торговые издержки. Вдобавок ко всему, значительные объемы торговли осуществляются неформально и не регистрируются.

Самые популярные измерения торговых издержек приводятся в базе данных «Ведение бизнеса» Всемирного банка. В Отчете «Ведение бизнеса за 2015 год», Кыргызская Республика заняла 102-е место из 190 стран за общий показатель Индекса легкости ведения бизнеса и вошла в число семи самых худших мест в мире для ведения международной торговли (Таблица 6.2). В Отчете «Ведение бизнеса за 2019 год», Кыргызская Республика передвинулась на значительно более высокую позицию по Индексу легкости ведения бизнеса (с 102-го на 70-е место), и по легкости ведения международной торговли (с 183-го на 70-е место).

21 Беларусь расположена ближе к международным маршрутам, чем Кыргызская Республика и опередила ее по критериям таможенного оформления и инфраструктуры. Это частично отражено в заметной разнице издержек на ведение международной торговли. В среднем, издержки на торговлю с соседними странами Беларуси были в 1,5 раза ниже, чем у Кыргызской Республики (ЭСКАТО-Всемирный банк. База данных по торговле. http://www.unescap.org/resources/escapworld-bank-trade-cost-database, по состоянию на 10 марта 2018 г.). 


\section{Рисунок 6.6: Торговые издержки и эффективность логистики}

а. Издержки на ведение международной торговли Кыргызской Республики по сравнению с соседними торговыми партнерами, в среднем за 2011-2015 гг.

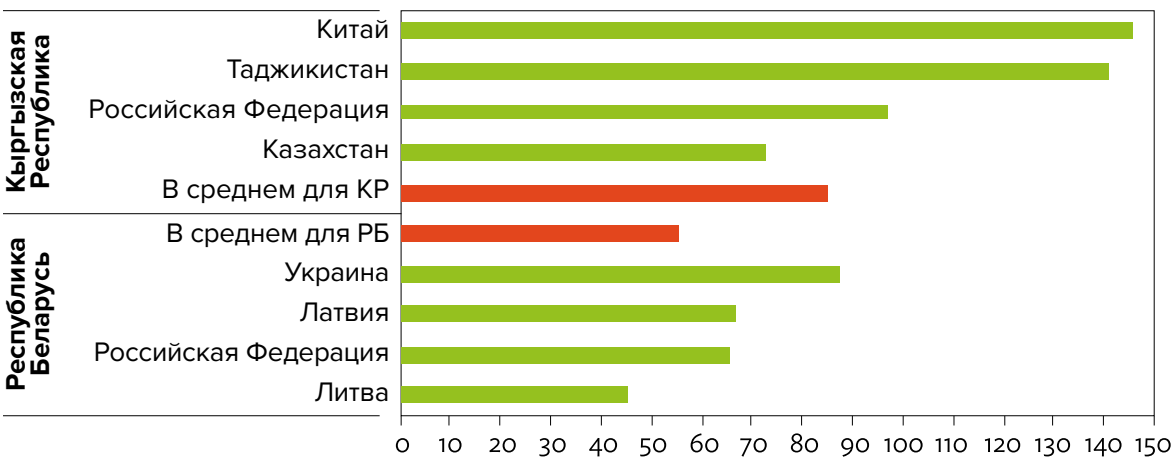

\section{b. Индекс эффективности логистики, 2018 год}

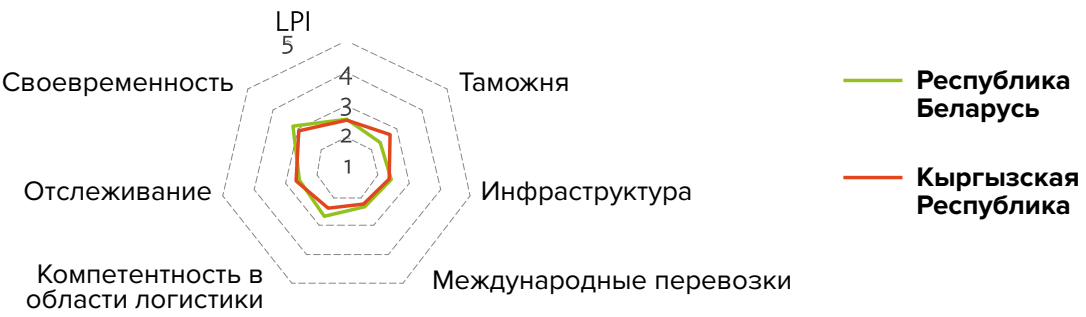

Примечание: Узбекистан не включён в базу данных

Источник: ЭСКАТО - Всемирный банк. База данных по торговым расходам http://www.unescap.org/ resources/escap-world-banktrade-cost-database (по состоянию на 10 марта 2018 г.).

Таблица 6.2: Легкость ведения бизнеса, июнь 2014-2019 гг.

\begin{tabular}{|c|c|c|c|c|c|c|c|c|c|c|c|c|}
\hline & \multicolumn{6}{|c|}{$\begin{array}{c}\text { Общий индекс легкости ведения } \\
\text { бизнеса }{ }^{\text {a, b }}\end{array}$} & \multicolumn{6}{|c|}{$\begin{array}{c}\text { Легкость ведения международной } \\
\text { торговли }\end{array}$} \\
\hline & 2014 & 2015 & 2016 & 2017 & 2018 & 2019 & 2014 & 2015 & 2016 & 2017 & 2018 & 2019 \\
\hline Казахстан & 50 & 77 & 41 & 35 & 36 & 28 & 186 & 185 & 122 & 119 & 123 & 102 \\
\hline $\begin{array}{l}\text { Кыргызская } \\
\text { Республика }\end{array}$ & 68 & 102 & 67 & 75 & 77 & 70 & 182 & 183 & 83 & 79 & 84 & 70 \\
\hline Таджикистан & 143 & 166 & 132 & 128 & 123 & 126 & 188 & 188 & 132 & 144 & 149 & 148 \\
\hline Узбекистан & 146 & 141 & 87 & 87 & 74 & 76 & 189 & 189 & 159 & 165 & 168 & 165 \\
\hline
\end{tabular}

а Общий рейтинг на основе невзвешенного среднего количества баллов по 10 направлениям;

ь 189 стран в 2014 и 2015 годы, и 190 стран в 2016-2017 гг. Туркменистан не включен в базу данных. Источник: Всемирный банк. www.doingbusiness.org (по состоянию на 7 февраля 2019 г.).

Картина 2015 и 2016 годов вводит в заблуждение. Ситуация не была такой плохой, как показывают рейтинги 2015 года. Методология «Ведение бизнеса» основана на опросах информированных лиц в столицах государств о стоимости перевозки одного контейнера в денежном и временно́м выражении из коммерческого центра страны, что может являться более подходящим методом для таких стран, как Сингапур, но менее подходящим для стран Центральной Азии, где доля 
перевозок контейнерами мала и существует большая разница между тем, что может слышать наблюдатель в столице, и тем, что происходит на самом деле. Резкое значительное улучшение, отмеченное в издержках на ведение торговли с 2015 по 2016 гг. неубедительно. Хотя относительная позиция стран Центральной Азии в 2015 и 2016 годах правдоподобна и соответствует результатам случайных наблюдений, цифры «Ведения бизнеса» незначительную часть магнитуды издержек на ведение международной торговли в Центральной Азии. ${ }^{22}$

Программа «Измерение и мониторинг эффективности коридоров» (ИМЭК), осуществляемая грузоперевозчиками под эгидой секретариата Центрально-азиатского регионального экономического сотрудничества (ЦАРЭС) вырабатывает самые надежные измерения торговых издержек в Центральной Азии и некоторых соседних странах. ${ }^{23}$ Программа ИМЭК функционирует с 2010 года и проводит 2000-300о наблюдений в год, например выборка 2016 года состояла из 2756 поездок, 70\% автомобильным и 26\% железнодорожным транспортом. Для каждой поездки, респондент на грузовике или поезде, держащем путь по основным коридорам, ведет измерение понесенных расходов и затраченного времени. Индикаторы ИМЭК для расходов и скорости обеспечивают детальную информацию о трудностях осуществления торговли сухопутным транспортом в регионе Центральной Азии.

Общая картина, которая складывается из данных ИМЭК, свидетельствует о достаточно продолжительных задержках и нетривиальных сборах на границе, с большим диапазоном варьирования. Данные в Таблице 6.3 говорят о снижении издержек на границе, в то время как Таблицы 6.4 и 6.5 указывают на большой диапазон варьирования издержек, даже на пунктах въезда одной и той же соседней страны. Большое количество наблюдений позволяет иллюстрировать неопределённость и изменчивость размера издержек и времени, и средние величины указывают на то, как торговые издержки зависят от изменений политики, как например, создание Евразийского таможенного союза, а позднее ЕАЭС. Тем не менее, большой диапазон варьирования говорит о том, что процесс сокращения торговых издержек осуществляется фрагментарно, и водители грузовиков подъезжающих к пункту пересечения границы (ППГ) сталкиваются со значительной неопределенностью относительного того, сколько времени и сколько денег потребуется, чтобы пересечь границу.

Кыргызская Республика вступила в ЕАЭС в августе 2015 года, после чего таможенный контроль был упразднен на границе с Казахстаном. На ППГ был отменен фитосанитарный контроль в ноябре 2015 года, а остался только пограничный и ветеринарный контроль. Эти изменения отражены в данных по Чалдовару в Таблице 6.3, в которой показаны увеличившиеся задержки в 2013 году, когда к Таможенному союзу присоединился Казахстан, а Кыргызская Республика еще не была членом, и обратный ход того увеличения после вступления Кыргызской Республики в ЕАЭС. Однако, кыргызские участники ВЭД все еще сталкиваются с издержками

22 Индикаторы «Ведения бизнеса» находятся под растущим пристальным вниманием и, особенно подвергаются критике компоненты международной торговли за предоставление конкретных показателей времени и стоимости. Исследователи продолжают пользоваться обследованиями «Ведение бизнеса» по той причине, что показатели охватывают широкий перечень стран и индикаторы считаются стандартизованными. Однако, данные «Ведения бизнеса» зачастую собираются от представителей консультационных и юридических компаний, которые, как правило, не участвуют в торговле и ссылаются на нормативные правовые акты из книг, а не реализацию на практике.

23 Для ознакомления с программой ИМЭК, см. АБР (2014г.). В 2016 году, кыргызский партнер Ассоциация международных автомобильных перевозчиков Кыргызской Республики (AIRTO) провела мониторинг 116 поездок, в число поездок через пункты пропуска на границе Кыргызской Республики, охваченным мониторингом, также включало грузовики из других стран. 
за пределами границ, чтобы обеспечить предварительное оформление на границе, и операторы сообщают о частых остановках на проверочных пунктах в Казахстане для подтверждения транзитного статуса их груза (ИМЭК, 2018 г., стр. 21).

\section{Таблица 6.3: Среднее время прохождения выборочных пунктов пересечения границы, 2011-2016 гг. (часы)}

\begin{tabular}{llcccccc} 
Пункт пропуска & Направление & 2011 & 2012 & 2013 & 2014 & 2015 & 2016 \\
\hline Чалдовар & прибытие & 5.1 & 4.9 & 6.6 & 6.5 & 6.5 & 5.2 \\
\hline Иркештам & прибытие & 12.0 & 9.9 & 7.2 & 6.1 & 5.2 & 5.7 \\
\hline Карамык & выбытие & 7.9 & 3.2 & 2.2 & - & 4.8 & 3.7 \\
\hline
\end{tabular}

- = данные отсутствуют

Источник: ИМЭК (2016 г.), стр.42; ИМЭК (2018 г.), стр.44-5.

Таблица 6.4: Затрачиваемое время (часы) и издержки (долл. США) в выборочных пунктах пересечения границы, 2015 г.

\begin{tabular}{|c|c|c|c|c|c|c|}
\hline \multirow[b]{2}{*}{ Пункт пропуска } & \multirow[b]{2}{*}{ Направление } & \multirow[b]{2}{*}{ Наблюдения } & \multicolumn{2}{|c|}{ Время (часы) } & \multicolumn{2}{|c|}{ Издержки (долл. США) } \\
\hline & & & $\begin{array}{l}\text { Среднее } \\
\text { значение }\end{array}$ & Медиана & $\begin{array}{l}\text { Среднее } \\
\text { значение }\end{array}$ & Медиана \\
\hline Чалдовар & прибытие & 13 & 6,5 & 6,4 & 120 & 120 \\
\hline Ак-Тилек & прибытие & 152 & 0,3 & 0,3 & 20 & 17 \\
\hline Иркештам & прибытие & 132 & 5,2 & 5,2 & 138 & 110 \\
\hline Торугарт & прибытие & 61 & 2,3 & 2,5 & 34 & 37 \\
\hline Карамык & выбытие & 6 & 4,8 & 4,8 & 113 & 113 \\
\hline Торугарт & выбытие & 9 & 0,4 & 0,2 & 31 & 32 \\
\hline Ак-Тилек & выбытие & 60 & 0,3 & 0,3 & 20 & 19 \\
\hline
\end{tabular}

Таблица 6.5: Затрачиваемое время (часы) и издержки (долл. США) в выборочных пунктах пересечения границы в 2016 году

\begin{tabular}{|c|c|c|c|c|c|c|}
\hline \multirow[b]{2}{*}{ Пункт пропуска } & \multirow[b]{2}{*}{ Направление } & \multirow[b]{2}{*}{ Наблюдения } & \multicolumn{2}{|c|}{ Время (часы) } & \multicolumn{2}{|c|}{ Издержки (долл. США) } \\
\hline & & & $\begin{array}{l}\text { Среднее } \\
\text { значение }\end{array}$ & Медиана & $\begin{array}{l}\text { Среднее } \\
\text { значение }\end{array}$ & Медиана \\
\hline Чалдовар & прибытие & 10 & 5,2 & 5,2 & 75 & 78 \\
\hline Ак-Тилек & прибытие & 79 & 0,2 & 0,3 & 12 & 13 \\
\hline Иркештам & прибытие & 157 & 5,7 & 5,6 & 343 & 170 \\
\hline Торугарт & прибытие & 49 & 1,9 & 2,1 & 37 & 37 \\
\hline Карамык & прибытие & 6 & 0,6 & 0,7 & 31 & 31 \\
\hline Карамык & выбытие & 62 & 3,7 & 4,4 & 75 & 95 \\
\hline Торугарт & выбытие & 1 & 0,2 & 0,2 & 18 & 18 \\
\hline Ак-Тилек & выбытие & 23 & 0,2 & 0,3 & 14 & 13 \\
\hline
\end{tabular}

Источник: ИМЭК (2018 г.), стр.44-5 
Удивительной характеристикой данных ИМЭК для кыргызско-казахских ППГ является большая разница между Чалдоваром и Ак-Тилеком. Ак-Тилек является основным пунктом пересечения границы для грузоперевозок по автодороге Алматы-Бишкек, заменив ППГ Ак-Жол, который ввиду перегруженности теперь используется для пассажирских перевозок. В то время как в 2015 году, Чалдовар был одним из самых медленных ППГ в Центральной Азии, и издержки были в средних пределах, ППГ Ак-Тилек (также въездной из Казахстана) был одним из самых быстрых и менее затратных. (Таблица 6.4); крупными издержками в ППГ Чалдовар были расходы на таможенную очистку (43 долл. США), пограничный контроль (33 долл. США), фитосанитарные сборы (20 долл. США), и весогабаритный контроль (20 долл. США), все они были незначительными расходами в Ак-Тилеке. Расходы в Чалдоваре были ниже в 2016 году (Таблица 6.5), но все же включали среднюю оплату в размере 44 долл. США за таможенную очистку и 32 долл. США за пограничный контроль.

Аналогичным образом, для грузовиков, въезжающих из КНР, существует большая разница во времени и издержках между ППГ Иркештам и ППГ Торугарт. ${ }^{24}$ В 2015 году основные виды издержек в Иркештаме были схожи с издержками в Чалдоваре, за исключением визовых сборов (таможенная очистка - 61 долл. США; безопасность границ - 20 долл. США; весогабаритный контроль - 24 долл. США ; а также визовый/иммиграционный сбор - 22 долл. США), в то время как в Торугарте средний визовый сбор составил 16 долл. США а другие сборы были ниже, чем в Иркештаме. В 2016 году, задержки в Иркештаме были чуть продолжительнее и финансовые расходы были выше уровня предыдущего года: таможенная очистка - 137 долл. США; безопасность границ - 16 долл. США; весогабаритный контроль - 93 долл. США; а также визовый/иммиграционный сбор - 23 долл. США. В Торугарте средний размер визовых сборов по-прежнему равнялся 16 долл. США, а другие сборы были незначительными.

Разница, возможно, заключается в том, что преобладающая часть автотранспортных средств, проходящих через Торугарт, направляется в пункты назначения в Кыргызской Республике, а 90\% грузов на Иркештаме следуют транзитом в другие страны. Ситуация обстоит хуже, чем показано в Таблице 6.5, ввиду длинных очередей на границе КНР. Более того, хотя таможенный контроль и осуществляется в Иркештаме, водители грузовиков, которым предстоит оплатить сбор, должны произвести остановку на таможне Кара-Суу, где груз может подвергнуться повторной оценке для подтверждения приемлемости задекларированной стоимости.

Отчет ИМЭК за 2016 год содержит вставку по ППГ Иркештам, где описывается посещение в апреле 2016 года, когда командой была насчитана очередь из 50 грузовиков. ППГ открыт с 9:00 до 20:0о зимой и с 8:00 до 18:0о летом; он закрывается с 12:00 до 14:00 на обед. Кыргызские законы требуют электронного декларирования товаров в таможню за 2 часа до прибытия в ППГ, что позволяет произвести очистку в ППГ в течение 30 минут при условии отсутствия каких-либо ошибок. Однако, электронный обмен данными между таможенными брокерами и партнерами из КНР неэффективен, и по оценкам, 70\% деклараций не соблюдают двухчасовое требование, в результате чего данные должны вводиться вручную в ППГ.

24 Могут возникнуть сомнения относительно выборки, в зависимости от того, когда осуществлялась 61 поездка через Торугарт в 2015 году. Отчет ИМЭК (2016 г., стр. 37) указывает на то, что время ожидания в Иркештаме в первые 7 месяцев 2015 года составляло 4-8 часов на грузовик но в последние 5 месяцев оно составляло 16-22 часа. Кыргызская Республика вступила в ЕАЭС в августе 2015 года. Присутствует также обеспокоенность относительно того, что размер выборки в Торугарте был небольшим. 
К сожалению, отчеты ИМЭК содержат очень ограниченную информацию о кыргызско-таджикских ППГ и никакой информации о кыргызско-узбекских ППГ. Карамык расположен на одном из самых прямых маршрутов из Карши в Душанбе, однако Кыргызская Республика объявила его двусторонним ППГ исключительно для кыргызских и таджикских пользователей, что препятствует транзитной торговле по данному маршруту. Кыргызско-узбекская граница часто бывает закрыта ввиду плохих отношений между правительствами двух стран, и имеет множество неформальных пунктов перехода.

Общая картина крайне неоднозначна. На бумаге, ситуация на кыргызских границах может быть очень благоприятной, с лишь небольшими задержками и относительно низкими издержками при пересечении важных ППГ, расположенных к примеру на автодороге Бишкек-Алматы, или ППГ Торугарт между Каши и Нарыном и Бишкеком. Однако, есть также главные «черные пятна», где задержки и сборы высоки и непредсказуемы. Отчеты ИМЭК выделяют Иркештам в качестве одного из наихудших ППГ в Центральной Азии. Пересечение границы между Кыргызской Республикой и Таджикистаном или Узбекистаном остается непредсказуемым, и особенно на незагруженных ППГ существуют истории спонтанного сбора экологических налогов и других неофициальных платежей. Ситуация может улучшиться в случае с Казахстаном в силу общего членства в ЕАЭС, с Узбекистаном - после смены президента, и с КНР - из соображений перспективных совместных инфраструктурных проектов. Однако, основной проблемой остаются внутренние правила, и, что еще более важно, их реализация.

\section{4 Евразийский сухопутный мост посредством улучшенной железнодорожной системы}

Одним из самых интересных направлений развития транспорта в Центральной Азии в 21-м веке является создание регулярных железнодорожных грузовых перевозок между КНР и Европой. Первые попытки представляли собой маршрутные контейнерные поезда, доставляющих комплектующие детали для сборочных заводов европейских автопроизводителей, с использованием российской Транссибирской железной дороги в конце 2000-х годов. ${ }^{25}$ В 2011 году, вслед за реализацией политики КНР «Идем на запад» и открытия крупных заводов по сборке электроники в г.Чончин такими компаниями как «Foxconn» (для продуктов «Apple»), «НР» и «Acer», был создан маршрут через Казахстан-Российскую Федерацию-Беларусь-Польшу в г.Дуйсбург в Германии. Компании по производству электроники изначально планировали осуществлять экспорт по реке Янцзы, но с увеличением речных перевозок, шлюзы стали перегружены. Железнодорожный транспорт оказался намного быстрее и надежнее, чем речной и морской, компенсируя более высокую стоимость в расчете на один контейнер.

Начиная с 2011 года, были опробованы новые маршруты и объем перевозок увеличился. Новостная служба КНР сообщила в декабре 2017 года о том, что грузовые поезда совершили в общей сложности 6235 поездок по 57 маршрутам, с момента запуска сообщения КНР-Европа в 2011 году, связывающего 35 городов

Аналогичным образом, автомобильный завод «Daewoo» в Андижане (Узбекистан, вблизи границы с Кыргызстаном) закупал комплектующие из Республики Корея на фрагментарных маршрутах поставок через города Ляньюньган и Ташкент. Такой механизм продолжал действовать и после того, как завод был трансформирован в «GM Uzbekistan». 
КНР с 34 европейскими городами в 12 странах с 2011 по 2017 годы. («China Daily», 2017 г.). По словам Чжао Джуна, руководителя департамента грузоперевозок Китайской железнодорожной корпорации, между городами на двух континентах было совершено свыше 3270 поездок в 2017 году, и в 2018 году ожидается увеличение количества таких поездок до 4000.

«Сухопутный мост» выстроен вдоль существовавшего ранее маршрута. Он потребовал от лидирующих компаний «Deutsche Bundesbahn» и Китайской железнодорожной корпорации предварительной координации между национальными железными дорогами, но взаимовыгодные результаты воодушевили промежуточные железнодорожные компании. Казахская железнодорожная компания заработала свыше миллиарда долларов США в виде транзитных пошлин в 2015 году (ИМЭК, 2016 г., стр. 43). Эффективность «сухопутного моста» усилена за счет непрерывного повышения качества услуг, предлагаемых грузоперевозчиками и компаниям, таким как «DHL», «FedEx» и «UPS», например, совмещение заказов ля перевозки в одном контейнере, организация связующих транспортных услуг, обеспечение холодильными контейнерами, обеспечение беспроблемного транзита для товаров, находящихся под санкцией Европейского союза или Российской Федерации и т.д.

Концепция «сухопутного моста» была интегрирована в программу КНР «Один пояс - один путь», объявленную в сентябре 2013 года, и сейчас известную под названием Инициатива «Пояс-путь» (ИПП). ИПП стала краеугольным камнем политики КНР, обеспечивая высокий уровень признания (например, на Международном форуме «Один пояс - один путь» в Пекине, проходившем в мае 2017 года) и обещая значительные инвестиции в инфраструктуру через Азиатский банк инфраструктурных инвестиций (об открытии которого было объявлено в октябре 2013 года, а официальное открытие состоялось в январе 2016 года) и Фонд «Шелковый путь» (созданный в 2014 году). Значительная часть ИПП - это заинтересованность КНР в альтернативных дорогах помимо существующих сухопутных мостов через Казахстан и Российскую Федерацию. На картах ИПП КНР обычно изображена железнодорожная линия, которая проходит к югу, нежели чем к северу от Каспийского моря.

Особенно важным для Кыргызской Республики среди предложений КНР по усилению и диверсификации железнодорожных веток «сухопутного моста» является железнодорожная ветка Каши-Ош-Андижан, которая предоставит недостающую линию потенциальной основной железной дороги КНР-Иран-Европейский Союз. Строительство 1446 км Южно-Синьцзянской железной дороги КНР от Турфана до Каши было завершено в декабре 1999 года, и в начале 200о-х годов КНР предложила продлить железную дорогу добавив линию Каши-Андижан, соединяющую магистраль с сетью железных дорог Узбекистана. ${ }^{26}$ Железная дорога КНР - Кыргызская Республика - Узбекистан будет располагаться и проходить через туннель от дальнего западного железнодорожного вокзала КНР в Каши до приграничного кыргызско-узбекского города и торгового узла в Кара-Суу, в 20 км к северу от Оша, и затем соединяться с железной дорогой Ферганской долины, связывающей крупные города региона и завод «GM Uzbekistan» в Андижане. Тем не менее, проект бездействовал в период между 2005 и 2010 годами.

26 Это было поддержано Узбекистаном, например, на третьем совещании группы экспертов ЕЭК ООН-ЭСКАТО по развитию евроазиатских транспортных связей, которое состоялось в Стамбуле 27-29 июня 2005 года. (UNECE-ESCAP. 2005. https://www.unece.org/fileadmin/DAM/trans/main/ eatl/docs/3rd_EGM_Doc3_e.pdf) 
В июне 2016 года открыли железную дорогу Ангрен-Пап. 19-километровый туннель «Камчик» устраняет необходимость для узбекских поездов следовать транзитом через Таджикистан в Ферганскую долину из Ташкента и обеспечивает всепогодную альтернативу автодороге, пролегающей через перевал Ангрен на уровне 2267 м. Первый поезд из Ангрена в Пап прошел через туннель за 16 минут. ${ }^{27}$ Благодаря улучшению прямого сообщения с Ташкентом и основными магистральными линиями Центральной Азии, ветка Ангрен-Пап повышает привлекательность железной дороги от Каши до Ферганской долины. Железнодорожная сеть КНР - Кыргызская Республика - Узбекистан может быть интегрирована в ИПП КНР через соединения с портами в Пакистане, Иране и Турции. ${ }^{28}$

\section{5 Торговые инициативы и экспортный потенциал}

Насколько важны улучшенные железнодорожные, автомобильные и воздушные сообщения для кыргызского экспорта? Ответ зависит от наличия соответствующей нематериальной и физической инфраструктуры, а также внутренней политики (легкость ведения бизнеса и пр.). Специфика будет зависеть от характера продаваемых товаров, но если страна хочет диверсифицировать свою экономику от зависимости от золота и денежных переводов, то необходимо снижать торговые издержки, чтобы воспользоваться преимуществами существующей и новой инфраструктуры.

В частности, чтобы Кыргызская Республика расширила свой экспорт фруктов и овощей, должны быть снижены торговые издержки с точки зрения денежного выражения, времени и неопределенности. Необходимо обеспечить договоренность с соседними и транзитными странами о создании «зеленых» коридоров, по которым предварительно одобренные участники ВЭД могли бы осуществлять перевозки без препятствий или помех. В более общих чертах, потребуется отношение на основе оценки риска, а не контроля в ППГ. Новая президентская власть в Узбекистане и увеличение сотрудничества со странами ЕАЭС способствовали открытию окна возможностей для таких перемен. Если Кыргызская Республика сможет развивать производственные мощности, выполняя задачи в рамках глобальных цепочек создания добавленной стоимости, то те же требования будут применимы и к снижению затрат; вынужденное удерживание товарно-материальных запасов для того, чтобы справиться с потенциальными задержками - это анафема для цепочек добавленной стоимости.

\section{6 Заключительные замечания и последствия}

\section{дЛя ПОЛИТИКИ}

Литература о взаимосвязи между улучшением транспорта и экономическим развитием указывает на сильный положительный эффект не только в силу прямой

27 Железнодорожная линия, построенная «China Railway Tunnel Group» включает также 25 мостов и 6 путепроводов.

28 Каши является северным конечным пунктом Каракорумского шоссе, которое КНР модернизировала для создания жизнеспособного автомобильного маршрута к океанскому порту Гвадар. У КНР есть долгосрочные планы относительно железной дороги, параллельной шоссе. В 2017 году осуществлен пробный пробег грузового поезда Даха-Стамбул по маршруту, пролегающему через Иран в Турцию и Босфорский туннель в Европу. 
связи между транспортными расходами и уровнем торговли, но также и потому, что расширение рынка стимулирует инновации и другие улучшения производительности. Кыргызская Республика сталкивается с двойной проблемой недостаточных связей и рыночной интеграции как внутри страны, так и за ее пределами.

Внутри страны с начала века произошли значительные улучшения в автодорожной сети, хотя техническое содержание автодорог и безопасность дорожного движения все еще являются проблемой. Не произошло никаких изменений во внутренней железнодорожной сети, которая продолжает оставаться крайне незначительной, несмотря на амбициозные планы 1990-х годов в отношении веток «Север-Юг».

Международные автомобильные сообщения также улучшились, о чем свидетельствует появление экспорта молочной и другой сельскохозяйственной продукции, а также одежды, как правило, осуществляемого автомобильным транспортом в Российскую Федерацию, Турцию, Восточную Европу и КНР. Железнодорожные сообщения, унаследованные от Советского Союза, продолжают оставаться неэффективными. Тем не менее, расширение Евразийской железнодорожной сети, вслед за успешными услугами «сухопутного моста» между КНР и Европой, а также приверженность КНР к ИПП могут предоставить Кыргызской Республике важное окно возможностей.

Улучшение автомобильного, железнодорожного и воздушного сообщений внутри страны и с зарубежьем потребует финансирования, что, очевидно, представляется трудным для небольшой бедной страны со сложным ландшафтом. В то же время, еще более важной необходимостью, чем новые инвестиции, является необходимость совершенствования нематериальной инфраструктуры, связанной с транспортом. 


\section{Библиография}

«Air Manas». Домашняя страница. https://airmanas.com/en/about-airmanas.html (по состоянию на март 2018 г.)

24.kg. https://24.kg/archive/en/bigtiraj/174417-news24.html (посещался в марте 2018).

China Daily (Xinhua). 2017. Более 6200 поездок на поезде между Китаем и Европой за 6 лет. 26 декабря. http://www.chinadaily.com.cn/a/201712/26/ WS5a41fcf5a310o8cf 16da38a5.html

АБР. 2014. Измерение и мониторинг эффективности коридоров Центральноазиатского регионального экономического сотрудничества: Взгляд на дальнюю перспективу. Манила.

Авиакомпания «Tez Jet». Домашняя страница. http://tezjet.kg/about.html

Азиатский банк развития (АБР). 2013. Страновая стратегия партнерства: Кыргызская Республика, 2013-2017 гг. Оценка сектора (Резюме): Транспорт. Манила.

Бишкек. http://mtd.gov.kg

Всемирный банк. Ведение бизнеса. www.doingbusiness.org

Всемирный банк. Набор данных для индекса эффективности логистики. https://lpi.worldbank.org (по состоянию на 10 марта 2018 г.).

Газпром Кыргызстан. 2018. Бишкек. http://kyrgyzstan.gazprom.ru/about/project/ genshema

Группа реализации инвестиционных проектов. Альтернативная дорога «Север-Юг». http://

Департамент дорожного хозяйства при Министерстве транспорта и коммуникаций КР. http:// mtd.gov.kg/dorogi-2 (accessed 24 February 2018).

Европейская экономическая комиссия ООН (ЕЭК ООН)- Экономическая и социальная комиссия ООН для Азии и Тихого океана (ЭСКАТО). 2005 г. Документ 3. Сводка ответов, полученных по предлагаемым маршрутам. Третье совещание группы экспертов по развитию Евроазиатских транспортных связей, Стамбул, 27-29 июня 2005 года. https://www.unece.org/fileadmin/ DAM/trans/main/eatl/docs/3rd_EGM_Doc3_e.pdf

Компания «Air Manas». Главная страница. https://www.aero.kg/o-nas

Кыргыз темир жолу. http://www.kjd.kg

Кыргызаэронавигация. Бишкек. http://www.kan.kg

Кыргызские железные дороги. 2018. http://www.kjd.kg

Кыргызские железные дороги. Общая информация. http://www.kjd.kg/ru/about/ strategiya- razvitiya-zeleznyh-dorog/

Лиссоволик, Я., А. Кузнецов, А. Бердигулова и Н. Чернов. 2017г. Специальный отчет. Экономическая география стран Евразии. Макро-обзор ЕБР. Евразийский банк развития. Январь. стр. 47-51. eabr.org/upload/ iblock/292/special_report_2.pdf 
Межгосударственный авиационный комитет. 2017. Предварительный отчет о Boeing 747-412F TC MCL. https://reports.aviation-safety.net/2017/20170116O_B744_TC-MCL.pdf

Международная ассоциация воздушного транспорта (IATA). Домашняя страница. https://www.iata.org/ Pages/default.aspx (по состоянию на март 2018 г.).

Международная организация гражданской авиации (ICAO). разные годы. Базы данных и исследования. https://www.icao.int/sustainability/Pages/Tools.aspx (по состоянию на март 2018 г.).

Международный союз автомобильного транспорта (МСАТ). 2013. Свод правил MCAT. Автодорожный транспорт Кыргызстана 2012-2013 гг. Бишкек. https://www.iru.org/sites/default/ files/2016-02/ru-road-transportkyrgyzstan-12-13.pdf

Министерство транспорта и дорог Кыргызской Республики (МТД). 2018 г.

MCAT. 2017. Узбекистан, Кыргызстан и Китай активизируют новый сухопутный торговый путь. https://www.iru.org/resources/newsroom/uzbekistankyrgyzstan-and-china-activate-new-overland-trade-route. IRU Newsroom. 30 октярбя.

Национальный статистический комитет (НСК) Кыргызской Республики. 2018. Бишкек. http:// stat.kg

НСК. Транспорт и коммуникации. http://stat.kg/en/statistics/transport-i- svyaz/

Открытое акционерное общество Международный аэропорт «Манас» (MAM). История. Бишкек. http://www.airport.kg/about/history (по состоянию на 24 февраля 2018 г.).

Правительство Кыргызской Республики. 2013. Национальная стратегия устойчивого развития Кыргызской Республики на 2013-2017 годы. Бишкек.

Правительство Кыргызской Республики. 2014. Бишкек. Стратегия развития железных дорог на 2014-2020 годы. Бишкек.

Правительство Кыргызской Республики. 2015. Стратегия развития дорожного сектора до 2025 года. Бишкек.

Программа Измерения и мониторинга эффективности коридоров (ИМЭК). 2016. Годовой отчет Программы Изменения и мониторинга эффективности коридоров. Секретариат ЦАРЭС. https://www.carecprogram.org/?publication =carec-corridor-performance-measurement-andmonitoring-annual-report-2015

Программа ИМЭК. 2018. Годовой отчет Программы Изменения и мониторинга эффективности коридоров. Секретариат ЦАРЭС. https://www.carecprogram. org/ ?publication=carec-corridor-performance-measurement-andmonitoringannual-report-2016

Экономическая и социальная комиссия ООН для Азии и Тихого океана (ЭСКАTO) - Всемирный банк. База данных по торговым издержкам. http://www. unescap.org/resources/escap-world-bank-trade-cost-database (по состоянию на 10 марта 2018 г.). 


\title{
Fraba 7
}

\section{Реформирование}

\section{cekтора энергетики}

\section{Кьіргызской Республики}

\author{
Нил Мак-Каллох, Ки-Юн Нами Лотис Цюйяо
}

ектор энергетики в Кыргызской Республике имеет чрезвычайно важное значение для всей экономики в целом. Не только надежное снабжение электроэнергией жизненно необходимо для производственного сектора, но подсектор также несет нагрузку по выработке тепловой энергии и горячего водоснабжения, необходимых для отопления в холодные кыргызские зимы. В настоящей главе начинается обзор сектора энергетики в целом. В последующем разделе приводится описание текущего состояния, структуры и показателей сектора электроэнергетики. Далее приводится описание текущей методологии установления тарифов для развития сектора энергетики, потребления и состояния государственного бюджета. Затем мы приводим краткий обзор опыта других стран по реформированию систем субсидирования сектора энергетики. В заключительном разделе приведен перечень возможностей для продвижения в решении спорных вопросов по реформе субсидирования сектора.

\section{1. Структура сектора энергетики в Кыргызской Республике ${ }^{1}$}

\section{Энергоресурсы, резервы, спрос и предложение}

Кыргызская Республика обладает огромными гидроэнергетическими ресурсами, объем которых по оценкам составляет 142,5 тераватт-часов (ТВт-ч), 42\% этого объема пригодны для промышленной разработки. Существует громадный потенциал для дальнейшего освоения гидроресурсов, так как в последние годы осваивалось лишь 20\%-25\% ресурсов годных для промышленной разработки. Страна обладает значительными объемами угля с разведанными запасами, приблизительно, 27,5 млрд. тонн и около 971 млн. тонн подтвержденных извлекаемых запасов (Таблица 7.1). При нынешних темпах производства, запасов угля хватит на 2110 лет. Республика также обладает небольшими запасами нефти и газа, но как правило импортирует эти виды энергии из Казахстана и Российской Федерации. Возобнов-

Этот раздел в значительной степени опирается на документ АБР (2017 г.). 
ляемые источники энергии Кыргызской Республики представлены солнечной, ветровой, геотермальной энергией и энергией, получаемой из биомассы. Продолжительность солнечного сияния варьируется от 2100 до 2900 часов, а нормальная энергетическая экспозиция прямого солнечного излучения составляет от 1600 до 2 ооо киловатт/часов на квадратный метр (кВт/ч на кв.м) в год в Нарынской и Иссык-Кульской областях, и 1600 кВт/ч на кв.м в год в самом густонаселенном районе страны - городе Бишкек и его окрестностях. ${ }^{2}$ Продолжительность активных ветров в горных районах составляет от 5000 до 7 ооо часов в год, при удельной энергоемкости 2000 кВт/ч на кв.м., хотя отдаленность таких перспективных участков усложняет развитие систем генерирования ветровой энергии. Запасы геотермальной энергии, по оценкам, составляют 613 млрд. гигаджоулей в год и сосредоточены на севере республики. Энергия биомассы животного и растительного происхождения, а также других органических материалов оценивается в размере 1,61 млрд. кубометров горючего метана в год (Министерство промышленности и энергетики, 2013 г.).

Таблица 7.1: Энергетические ресурсы и запасы (2016 год, если не указано иное)

\begin{tabular}{|c|c|c|}
\hline & $\begin{array}{c}\text { Единица } \\
\text { измерения }\end{array}$ & $\begin{array}{c}\text { Последние } \\
\text { данные }\end{array}$ \\
\hline \multicolumn{3}{|l|}{ Peсурсы } \\
\hline Гидроэлектроэнергия, общие теоретические запасы & ГВт-4 & 142500 \\
\hline $\begin{array}{l}\text { Гидроэлектроэнергия, запасы годные для } \\
\text { промышленной разработки }\end{array}$ & ГВТ-ч & 55200 \\
\hline Уголь & млн. Т & 27528 \\
\hline Сырая нефть, ГКа & млн. барр. & 73 \\
\hline Природный газ & млн. куб .м & 20000 \\
\hline \multicolumn{3}{|l|}{ Запасы } \\
\hline Уголь & млн. Т & 971 \\
\hline Неочищенная нефть, ГКс & млн. барр. & 41 \\
\hline Природный газ & млн. куб. м & 500 \\
\hline Производство & 0.8 & 88.6 \\
\hline Гидроэлектроэнергия & ГВТ-4 & 11095 \\
\hline Уголь ${ }^{f}$ & Млн. Т & 0,46 \\
\hline Сырая нефть & млн. барр. & 1,02 \\
\hline Природный газ & млн. куб. м & 0,00003 \\
\hline
\end{tabular}

ГВт-ч = гигаватт-часов; млн. барр. = миллион баррелей; млн.куб.м = миллион кубических метров; млн. т = миллион тонн; ГК = газоконденсат.

Примечания:

а Ресурсы природной сырой нести, ГК.

ь Ресурсы обычного природного газа.

с Разведанные запасы природной сырой нефти, ГК

d Разведанные запасы обычного природного газа.

e 2015 г.

f 2014 г.

Источник: Enerdata. База данных Enerdata. http;//www.enerdata.net (по состоянию на 7 марта 2018 г.) и Оценка Института водных проблем и гидроэнергетики Национальной академии наук Кыргызской Республики.

2 Всемирный банк. Глобальный атлас солнечной энергии. ESMAP, SOLARGIS.http:IIglobalsolaratlas.info 
В 2015 году общий объем производства энергии в Кыргызстане составил 1798 тысяч тонн нефтяного эквивалента (к.т.н.э.) - 53\% за счет гидроэлектроэнергии и $39 \%$ за счет угля (Рисунок 7.1). Однако, на внутреннее производство пришлось только 45\% от 3981 к.т.н.э. общего объема производства первичной энергии в 2015 г. (Рисунок 7.2). Объем импортируемой электроэнергии в размере 2800 к.т.н.э. состоит из угля, нефти, природного газа и электроэнергии, которая дополняет местное производство. Страна также экспортирует около 227 к.т.н.э. в виде нефти, угля и электроэнергии.

\section{Рисунок 7.1: Производство энергии, 2015 г.}

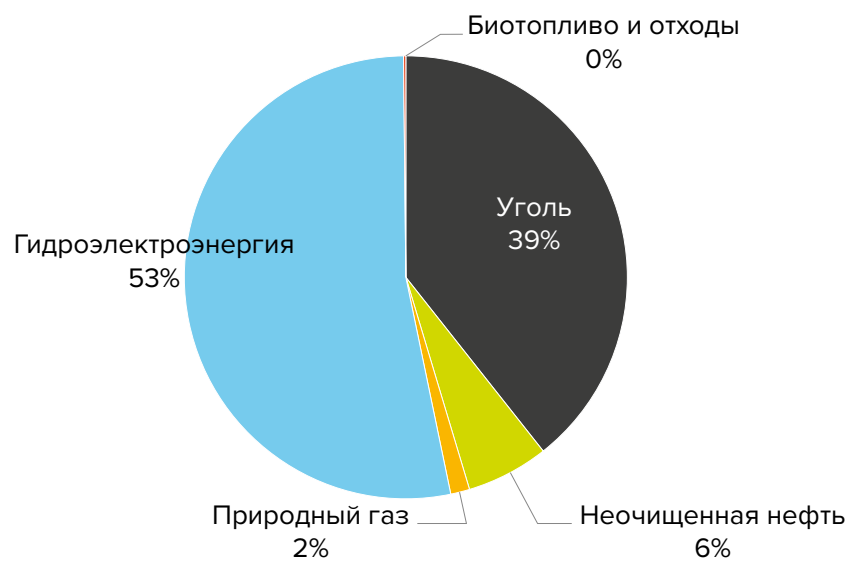

Источник: Международное энергетическое агентство (МЭА). Кыргызская Республика: Баланс на 2015 год. http://www.iea.org/statistics/statisticssearch/report/?country=Kyrgyzstan\&product=balances (от 23 марта 2018г.).

В общем объеме энергоснабжения около 41\% составили нефть и нефтепродукты, которые, как правило, импортировались. Местное производство сырой нефти составляет лишь 108 к.т.н.э., или около 6\% от общего производства энергии. Уголь и гидроэлектроэнергия имеют почти равные доли в общем объеме предложения первичной энергии, составляя 28\% (1 128 к.т.н.э.) и 24\% (955 к.т.н.э.), соответственно. В то время, как Кыргызская Республика выработала около 708 к.т.н.э. угля, она также импортировала почти такой же объем (680 к.т.н.э.).

\section{Рисунок 7.2: Общий объем предложения первичной энергии, 2015 г.}

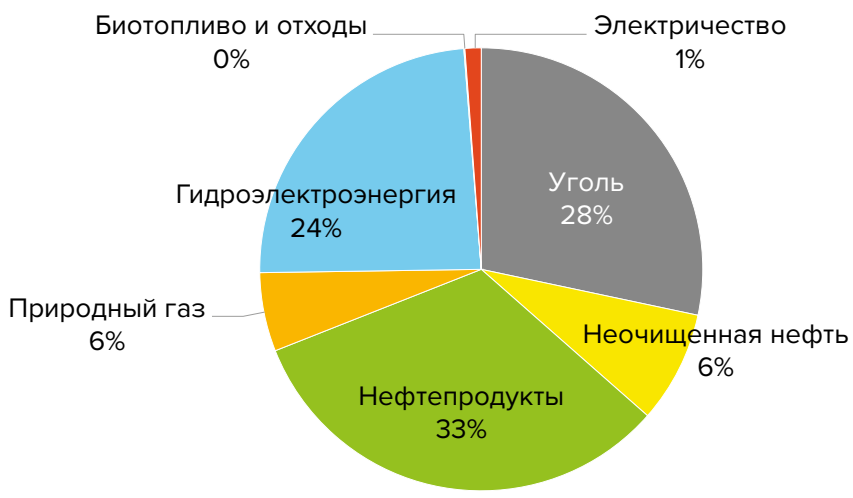


Источник: МЭА. Кыргызская Республика: Баланс на 2015 г. http://www.iea.org/statistics/ statisticssearch/report/?country=Kyrgyzstan\&product=balances (по состоянию на 23 марта 2018 г.).

В объеме конечного потребления энергии, почти половина приходится на нефтепродукты (1 564 к.т.н.э.), около четверти на электричество (910 к.т.н.э.) и приблизительно 14\% на уголь. Бытовой сектор является самым крупным потребителем энергии - 37\% от общего объема (1 255 к.т.н.э.); транспорт на втором месте (925 к.т.н.э.), а промышленность на третьем (730 к.т.н.э.) (Рисунок 7.3).

\section{Рисунок 7.3: Конечное потребление энергии по типу и по видам использования, 2015 г. (\%)}

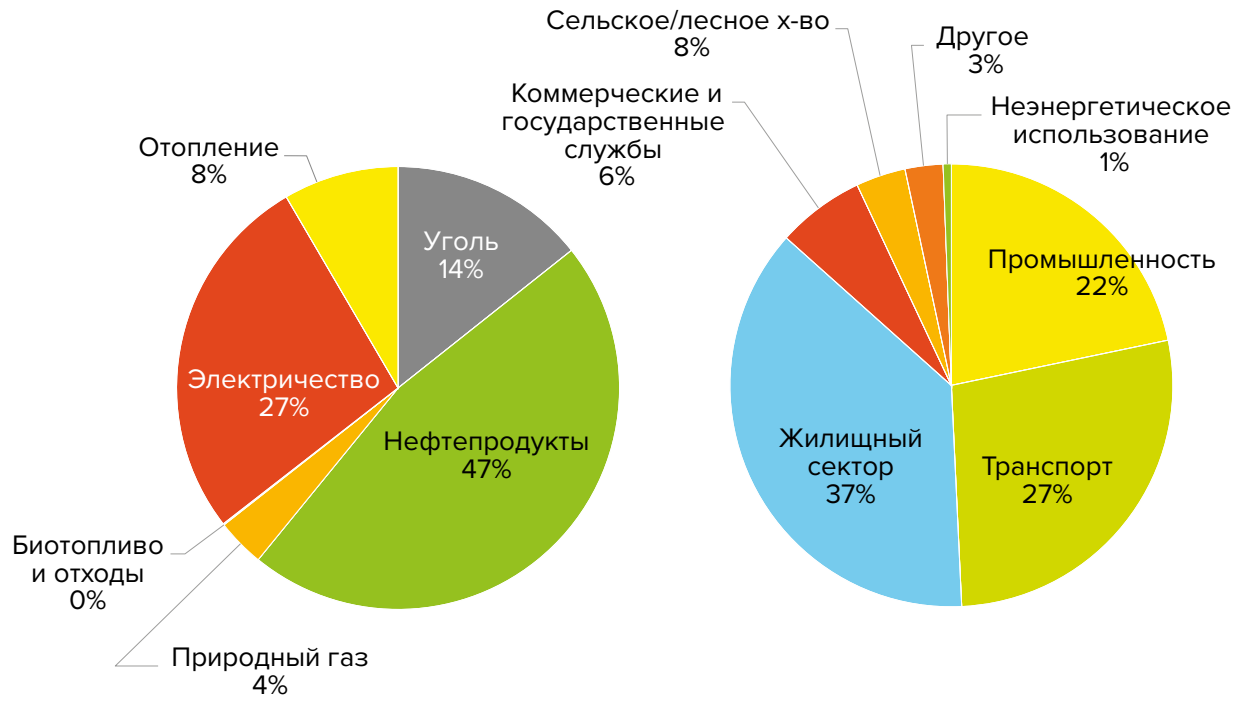

Источник: МЭА. Кыргызская Республика: Баланс на 2015 г. http://www.iea.org/statistics/ statisticssearch/report/?country=Kyrgyzstan\&product=balances (от 23 марта 2018г.).

Сектор энергетики Кыргызской Республики в преобладающей степени зависит от гидроэлектроэнергии. В 2015 году 85\% от общего объема выработки электричества приходилось на гидроэлектроэнергию (по сравнению со средним мировым показателем 16\%); 3 068,5 мегаватт (МВТ) из 3920 МВТ общей номинальной мощности в стране приходились на гидроэлектроэнергию. ${ }^{3}$ Остальной объем производства энергии относится к двум тепловым электростанциям (ТЭЦ): Бишкекской ТЭЦ и Ошской ТЭЦ. Преобладающая часть выработки гидроэлектроэнергии приходится на Нарынский каскад с пятью крупными электростанциями с установленной мощностью 2870 МВТ, однако объем неосвоенного технически реализуемого гидроэнергетического потенциала оценивается в пределах 18 ооо МВТ. Почти 100\% населения подключены к электрическим сетям.

Еще одним важным компонентом энергосистемы является наличие энергии для центрального отопления, горячего водоснабжения и источника энергии для приготовления пищи. Присутствует существенная разница между энергоресурсами, доступными в городских населенных пунктах, в частности, в столицегороде Бишкек и остальных регионах страны. Более половины населения города

3 Международное энергетическое агентство (МЭА, 2017); Данные предоставлены автору ОАО «Электрические станции». 
Бишкек (и почти четверть в других городских населенных пунктах) получают центральное отопление от теплоэлектростанций (ТЭЦ) городов Бишкек и Ош. Более того, почти три четверти населения столицы имеют доступ к газоснабжению по трубопроводу, тогда как жители горных и сельских районов его почти не имеют (Гассман, 2017 г.). В результате, основной источник отопления для $64 \%$ населения, проживающего в сельских и горных районах - это их собственная печь, как правило, отапливаемая углем. Одним из факторов, влияющих на сезонное увеличение потребления электричества, является интенсивное использование электричества домашними хозяйствами для целей отопления. Более одной пятой городского населения, проживающего за пределами Бишкека, используют электричество в качестве основного источника отопления. В ходе обследования, проводившегося в 2016 году, 49 процентов респондентов ответили, что используют электричество в качестве одного из источников отопления. (M-Vector, 2017 г.).

Кыргызская Республика импортирует нефть из Казахстана и Российской Федерации, и газ через российское предприятие «Газпром» с большой долей государственной собственности, по той причине, что ее собственных запасов нефти и природного газа недостаточно для удовлетворения объемов внутреннего потребления. В 2014 году «Газпром» взял на себя управление распределительным предприятием «КыргызГаз», прежде принадлежавшем государству, а также ответственность за импорт, транспортировку, распределение и реализацию газа.

Кроме того, Кыргызская Республика начинает импортировать уголь осенью, чтобы обеспечить запасы угля до начала отопительного периода с ноября по март, и продолжает импортировать уголь до зимы из-за ограниченных мощностей местных поставщиков угля. Несмотря на то, что страна обладает огромными запасами угля, ее местное производство угля остается ограниченным из-за неразвитых производственных и транспортных мощностей, и технологических и производственных ограничений. Выработка гидроэлектроэнергии самая высокая в зимнии месяцы. ТЭЦ вырабатывают не только тепло в зимние месяцы, но также вырабатывает электричество, когда выработка других существующих гидроэлектростанций недостаточна для удовлетворения спроса.

В 2015 году объем неудовлетворенного зимнего потребления электричества составил 581 ГВт-ч, и страна была вынуждена компенсировать его за счет импорта. При том, что в прошлом Кыргызская Республика являлась чистым экспортером электричества в соседние страны, она стала чистым импортером в 2014 году, и, несмотря на запланированные инвестиции, прогнозируется, что республике придется импортировать электроэнергию в зимний период еще в течение некоторого времени (МВФ, 2017 г.). Необходимость импорта электроэнергии в зимний период значительно зависит от погодных условий, так как объемы потоков воды с гор в зимнее время зависят от температуры воздуха. Следовательно, недостаток зимнего предложения (Рисунок 7.4) и высокий уровень зависимости страны от гидроэнергетики представляет собой ее стратегическую уязвимость по той причине, что на уровне принятия политических решений из года в год не представляется возможным оценивать объемы необходимого импорта значительно более дорогостоящей электроэнергии из других стран. Это также создает трудности в управлении водными ресурсами, потому что страна должна запасаться водой в летний период с целью минимизации уязвимости в зимний - однако это может вызывать недовольство стран, расположенных ниже по течению и желающих использовать воду для полива. 
Рисунок 7.4: Недостаток зимнего предложения

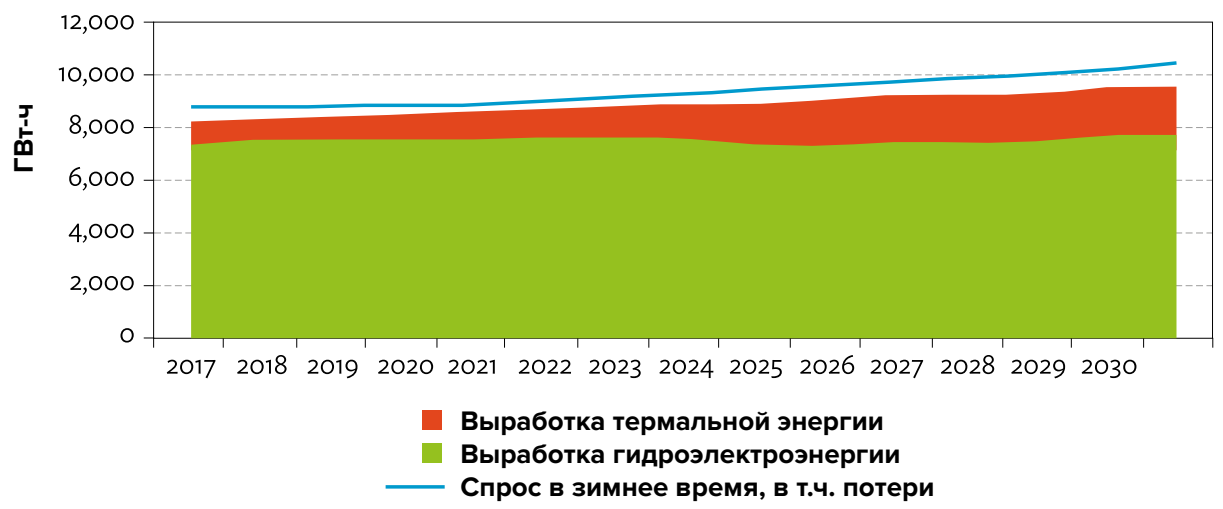

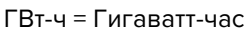

Источник: Гасснер, К. В., Розенталь, Н. и Ханкинсон, Д. Дж. (2017 г.).

\section{Правовая, институциональная и регуляторная структура сектора электроэнергии}

В 2001 году вертикально-интегрированное государственное предприятие «Кыргызэнерго» было разделено на генерирующее предприятие, передающее предприятие, четыре распределительные компании и компанию по производству и сбыту тепловой энергии. Однако, 93\% этого сектора продолжает оставаться в государственной собственности. В последние годы были предприняты многочисленные шаги по реструктуризации отрасли. В 2013-2014 годах при поддержке партнеров по развитию был реализован План действий по реформированию энергосектора. ${ }^{4}$ Все это поддержало работу над законом об электроэнергетике, в который были внесены изменения и дополнения в конце 2014 года, а также разработку и утверждение Среднесрочной тарифной политики на 2014-2017 годы ${ }^{5}$ и создание регулятора (Государственное агентство по регулированию топливно-энергетического комплекса), уполномоченного устанавливать тарифы и осуществлять лицензирование. $^{6}$ В 2015 году был создан Кыргызский энергетический расчетный центр, на который была возложена ответственность за прозрачное распределение доходов между предприятиями сектора. Министерство энергетики и промышленности было упразднено в 2015 году, а его функция в качестве исполнительного агентства по Проекту передана Министерству экономики. В июле 2016 года была проведена еще одна реорганизация правительства, в рамках которой был создан Государственный комитет промышленности, энергетики и недропользованию (ГКПЭН), которому было поручено принять на себя функции Министерства экономики.

4 Правительство Кыргызской Республики. 2013. Постановление № 299. План действий по ресормированию энергосектора на 2013-2014 гг. Бишкек.

5 С 1 августа 2015 года приказом Госагентства от 31 июля 2015 года № 142 и с апреля 2015 года приказом Госагентства от 15 декабря 2014 года № 46 установлены действующие тарифы на электрическую и тепловую энергию в соответствии с постановлением Правительства Кыргызской Республики «Об утверждении Среднесрочной тарифной политики Кыргызской Республики на электрическую и тепловую энергию на 2014-2017 годы» от 20 ноября 2014 года № 660.

6 В настоящее время, Распоряжением Правительства Кыргызской Республики от 27 декабря 2018 года № 459-р тарифы на электрическую и тепловую энергию установлены на уровне тарифов, действовавших в 2017 году, и сохранятся до принятия новой тарифной политики на следующий среднесрочный период. 
Госагентство разрабатывает проект Среднесрочной тарифной политики на электрическую энергию на 2019-2023 годы, в рамках которого прорабатывается вопрос поэтапного приведения тарифов для бытовых абонентов к стоимости и выделения энергоемких потребителей («майнингферм» и «дата-центров») в отдельную группу потребителей электроэнергии и установление для них отдельных тарифов на электроэнергию.

На Рисунке 7.5 представлена структура отрасли. Основных участников и взаимоотношения между ними можно охарактеризовать следующим образом:

- Национальный энергохолдинг - орган управления, созданный постановлением Правительства Кыргызской Республики от 6 января 2016 года № 4 в целях реформирования управления энергетической отраслью.

- Государственное агентство по регулированию топливно-энергетического комплекса - орган исполнительной власти, уполномоченный Правительством Кыргызской Республики осуществлять государственное регулирование деятельности субъектов топливно-энергетического комплекса посредством лицензирования и установления тарифов на электрическую, тепловую энергию и природный газ.

- Государственный комитет промышленности, энергетики и недропользования - это уполномоченный государственный орган, уполномоченный Правительством Кыргызской Республики осуществлять функции по выработке и реализации государственной политики в области энергетики.

- Государственная инспекция по экологической и технической безопасности - орган исполнительной власти, уполномоченный Правительством Кыргызской Республики осуществлять функции в сфере обеспечения технической безопасности, надежности и бесперебойности выработки, передачи, распределения и потребления электрической, тепловой энергии и природного газа, а также за эффективностью их использования.

- ОАО «Кыргызский энергетический расчетный центр» (КЭРЦ) выполняет функции сбора и предоставления точных, прозрачных и своевременных данных измерений, данных о потоке энергии и информации о мониторинге финансовых расчетов в рамках двусторонних соглашений между энергетическими компаниями. КЭРЦ уже работает, но в настоящее время работы выполняются вручную, поскольку в настоящее время разрабатывается аппаратное и программное обеспечение для системы управления данными измерений, основного инструмента сбора и обработки данных КЭРЦ. Функции по распределению доходов между компаниями электроэнергетического сектора не были переданы КЭРЦ и по-прежнему выполняются Государственным агентством по регулированию топливно-энергетического комплекса.

- Фонд управления государственным имуществом обеспечивает эффективное использование, управление и приватизацию государственного имущества. 


\section{Рисунок 7.5: Институциональная структура кыргызского сектора электроэнергии}

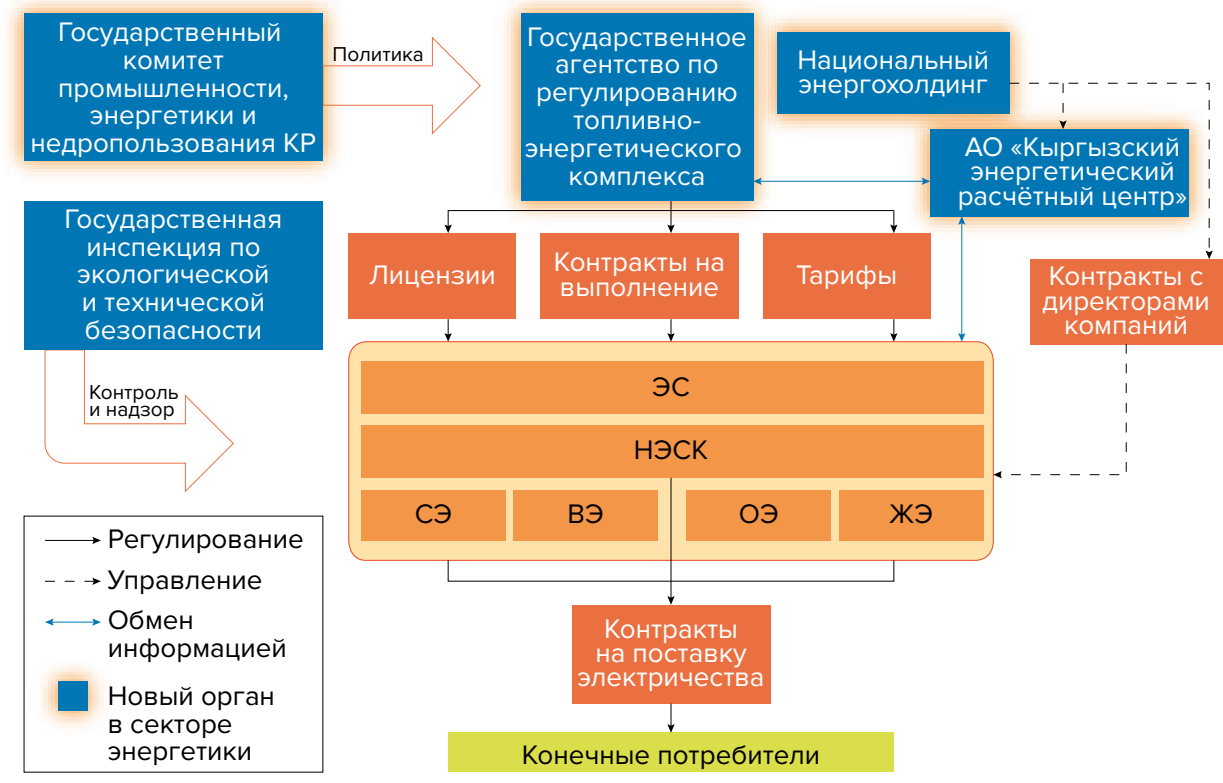

ЭС = ОАО «Электрические станции», ДЭ = «Джалалабадэлектро», НЭСК = Национальная электрическая сеть Кыргызстана, ОЭ = «Ошэлектро», СЭ = «Северэлектро», ВЭ = «Востокэлектро». Источник: (Всемирный банк, 2017а)

\section{Технические показатели сектора электроэнергии}

В Таблице 7.2 приведены генерирующие активы Кыргызской Республики. Система электроэнергии страны небольшая и находится в сильной зависимости от небольшого числа предприятий по выработке гидроэлектроэнергии, а в зимний период еще и от двух ТЭЦ. Это делает страну крайне уязвимой и зависимой как от уровня воды в Токтогульском водохранилище, так и от аварий или отключений на основных предприятиях.

\section{Таблица 7.2: Генерирующие мощности в секторе электроэнергии Кыргызстана}

\begin{tabular}{|c|c|c|}
\hline Генерирующее предприятие & $\begin{array}{c}\text { Мощности } \\
\text { (МВт) }\end{array}$ & $\begin{array}{c}\text { Объем выработки } \\
\text { (млн. КВТ-4) }\end{array}$ \\
\hline \multicolumn{3}{|l|}{ Гэс } \\
\hline \multicolumn{3}{|l|}{ Нарынский каскад } \\
\hline Токтогульская ГЭС & 1,200 & 4,400 \\
\hline Курпсайская ГЭС & 800 & 2,630 \\
\hline Ташкумырская ГЭС & 450 & 1,555 \\
\hline Шамалдысайская ГЭС & 240 & 902 \\
\hline Учкурганская ГэС & 180 & 820 \\
\hline
\end{tabular}




\begin{tabular}{|c|c|c|}
\hline Генерирующее предприятие & $\begin{array}{l}\text { Мощности } \\
\text { (МВт) }\end{array}$ & $\begin{array}{c}\text { Объем выработки } \\
\text { (млн. КВт-4) }\end{array}$ \\
\hline ГЭС Камбарата-2 & 120 & 500 \\
\hline Атбашинская ГЭС & 40 & 160 \\
\hline Всего по АО Электрические станции & 3,030 & 10,967 \\
\hline ОАО Чакан ГЭС & 35 & 234 \\
\hline \multirow{2}{*}{ Общий объем гидроэлектроэнергии } & 3,065 & 11,201 \\
\hline & $78 \%$ & $92 \%$ \\
\hline \multicolumn{3}{|l|}{ тЭц } \\
\hline ТЭЦ Бишкек & 812 & 1,000 \\
\hline ТЭЦ Ош & 50 & 0 \\
\hline \multirow{2}{*}{ Общий объем тепловой энергии } & 716 & 1,000 \\
\hline & $22 \%$ & $8 \%$ \\
\hline Bcero & 3,927 & $12,201^{\mathrm{a}}$ \\
\hline
\end{tabular}

ТЭЦ = теплоэлектростанция, ГЭС = гидроэлектростанция, АО = акционерная компания, МВт = мегаватт.

Установленная мощность ТЭЦ Бишкек отражает недавно проведенную реконструкцию; данных по объемам генерирования пока нет (источник: ОАО «Электрические станции»).

а Основано на мощностях до реконструкции в объеме 3781 МВТ.

Источник: ОАО «Электрические станции»

Источники: Всемирный банк (2017а:Таблица 1.1); см. также документы Правительства Кыргызской Республики (2017 г.), которые включают слегка отличающиеся цифры по Чакан ГЭС: 9 малых ГЭС, включая 8 ГЭС Аламединского каскада (29,7 МВТ) и Быстровскую ГЭС (8,7 МВТ); а также частные малые ГЭС: Тегирменскую ГЭС (3 МВТ), Иссык-Атинскую ГЭС (1,6 МВТ); Ак-Суйскую ГЭС (0,5 МВТ) и Кыргыз-Атинскую ГЭС (0,25 МВТ). Данные по Бишкекской ТЭЦ предоставлены Государственным комитетом промышленности, энергетики и недропользования Кыргызской Республики (источник: ОАО «Электрические станции»).

Подобные отключения случались и прежде. Высокая зависимость страны от гидроэнергетики привела к крупному энергетическому кризису в 2007-2009 годы, когда уровень воды в Токтогульском водохранилище упал ниже критического уровня, что в результате привело к веерным отключениям по всей стране. Аналогично, недостаточное инвестирование в резервные мощности привело к тому, что в результате остановки одной гидротурбины мощностью 300 МВТ в декабре 2012 года имели место обширные снижения нагрузки зимой 2011-2012 гг. и 2012-2013 гг. (Курманбек, 2016 г.). Еще одна авария на Токтогульской ГЭС зимой 2015 года привела к ограничениям потребления (хотя они и были устранены на следующий день), затем имела место кратковременная авария в декабре 2016 года.

Фактически, преобладающее большинство электроэнергетических активов Кыргызстана продолжают работать в течение многих лет после окончания экономически целесообразного срока службы и, в результате, растет их уязвимость к частому возникновению проблем, связанных с надежностью. На Рисунке 7.6 показаны сроки службы генерирующих активов страны. Как показано на рисунке, отдельные объекты генерирующих мощностей республики используются в течение чрезвычайно длительного срока. 
Рисунок 7.6: Срок службы генерирующих активов в Кыргызской Республике

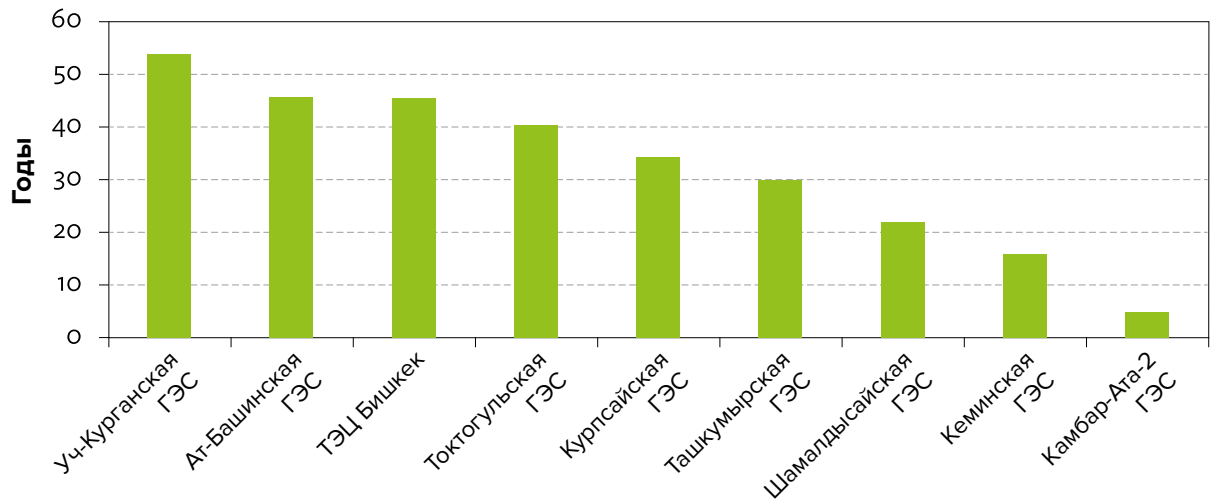

ТЭЦ = теплоэлектростанция, ГЭС = гидроэлектростанция.

Источник: Всемирный банк (2017а).

Передающие и распределительные активы также устарели и остановки в их работе происходят довольно часто. В результате, отмечаются высокие объемы технических и нетехнических потерь. Различные источники приводят разные объемы потерь. В 2016 году потери составили 12-13\% на распределение и еще 7\% процентов на передачу электроэнергии. Последние официальные данные приведены на Рисунке 7.7, согласно которым потери на этапе выработки составили 0,3\%; потери на этапе передачи - 5,7\%; и потери на этапе распределения - 13,9\%, а суммарные потери в итоге составляют 19,9\% по всей системе.

Рисунок 7.7: Потери на этапах генерирования, передачи и распределения электроэнергии, 2012-2016 гг.

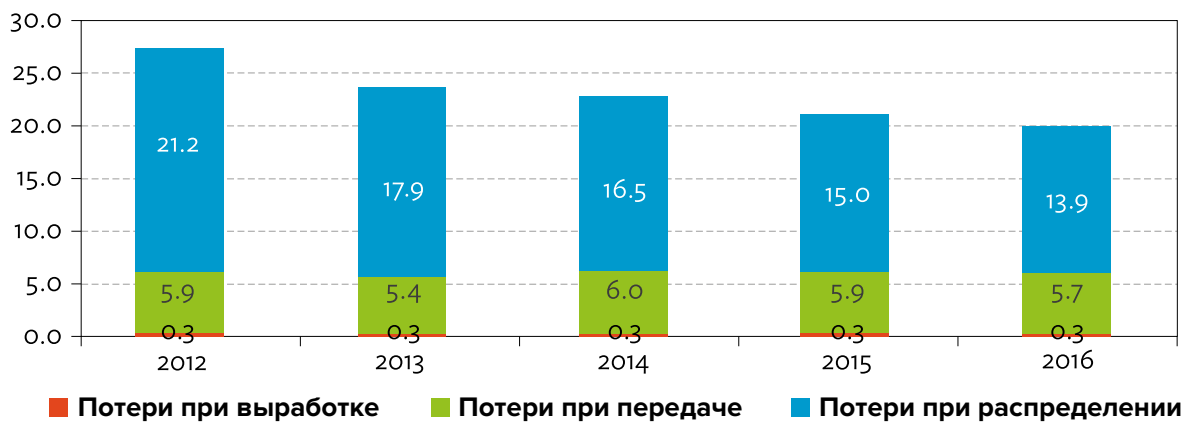

Источник: Расчеты автора и технические данные, полученные автором от энергокомпаний.

Результатом всех этих проблемных вопросов стало то, что сектор работал с довольно низкими показателями, особенно в зимнее время. Например, в 2012 году распределительная компания, снабжающая Бишкек, сообщала о том, что 85\% ее о,4-киловольтных линий и оборудования требуют незамедлительного ремонта. Распределительные компании сообщали о том, что среднее количество отключений в период с 2009 по 2012 годы составило 43 отключений в день в связи с низким уровнем воды в Токтогульском водохранилище и авариями в системе (Всемирный банк, 2014 г.). В 2013 году 73\% производственных предприятий 
испытывали отключения электричества (что заставило 39\% фирм приобрести в собственность или совместное пользование генераторы - эти цифры превышают средний показатель для Восточной и Центральной Азии почти в два раза), что составило около 4\% от величины реализуемых объемов (Сыдыкова, 2015 г.).7 Однако, реконструкция и другие мероприятия, осуществленные за последние пять лет, улучшили показатели. По самым последним данным, количество отключений в день в зимние месяцы 2015 года составило 16, и 15 за тот же период в 2016 году. ${ }^{8}$ Несмотря на прогресс, достигнутый в последние годы, Кыргызская Республика все еще имеет низкие показатели относительно международных стандартов. Индекс «Ведение бизнеса» Всемирного банка за 2018 год включает показатель «Подключение к системе энергоснабжения», в который заложен индекс надежности электроснабжения и прозрачности тарифов, оценивающий эти факторы по шкале от о до 8 (8 - означает полную надежность обеспечения электроэнергией и прозрачность тарифа). Кыргызская Республика получила о, притом, что средний показатель для Восточной и Центральной Азии равен 5,2. Общий рейтинг по получению электроэнергии составил 164-е место среди 187 стран. ${ }^{9}$

На качестве также сказались регулярные колебания напряжения и частоты тока. Более половины респондентов обследования, проводившегося в 2013 году, указывали на проблемы с напряжением, а 18,9\% респондентов сообщили о повреждениях электрических приборов, вызванных качеством электричества. (Абдырасулова и др., 2013 г.). Многие фирмы не только используют собственные генераторы, но также меняют часы работы на ночное время, чтобы воспользоваться более высоким напряжением (АБР, 2014 г.); 40\% фирм отметили готовность платить на 25\%-100\% больше за более качественное энергоснабжение. Обслуживание потребителей - качество выставления счетов и тарификации, а также оказание помощи потребителям также оставляют желать лучшего. И даже доступ к новой электроэнергии требует значительных финансовых и временных затрат. Хотя доступ составляет почти 100\%, процесс подключения к сети занимает 125 дней, а стоимость составляет $858 \%$ дохода на душу населения (Всемирный банк, 2018 г.).

В следующем разделе более подробно рассмотрены действующие в настоящее время механизмы установления тарифов (и следовательно определения субсидий).

\section{2. Механизм установления тарифов и субсидий}

\section{ОБЗОР}

Детальная методология установления тарифов (и следовательно определения уровня субсидий) производится Государственным агентством по регулированию

Всемирный банк. Опрос предприятий, http://www.enterprisesurveys.org/

8 Регулятор также сообщает, что средний индекс частоты прерываний в работе системы упал до 2,1 в 2017 году, хотя эквивалент индекса продолжительности отключений все еще оставался на уровне более 600 минут (инфоормация с сайта с ограниченным доступом: http://regulatortek.kg/ ru/content/pokazateli-saifi-saidi-i-caidi-oao-severelektro-za-1-kvartal-2017-goda).

9 Индекс включает в себя продолжительность и частоту отключений электроэнергии, механизмы их мониторинга и сокращения, а также прозрачность и доступность тарифов - см. Всемирный банк (2018г.) 
топливно-энергетического комплекса и состоит из трех этапов (Рисунок 7.8). ${ }^{10}$ Сначала расходы агрегируются в общую сумму, затем, части этой общей суммы делятся и относятся к каждому классу потребителей; и наконец, разрабатываются тарифы для покрытия части расходов, отнесенных к каждому классу потребителей.

\section{Рисунок 7.8: Этапы методологии установления тарифов}

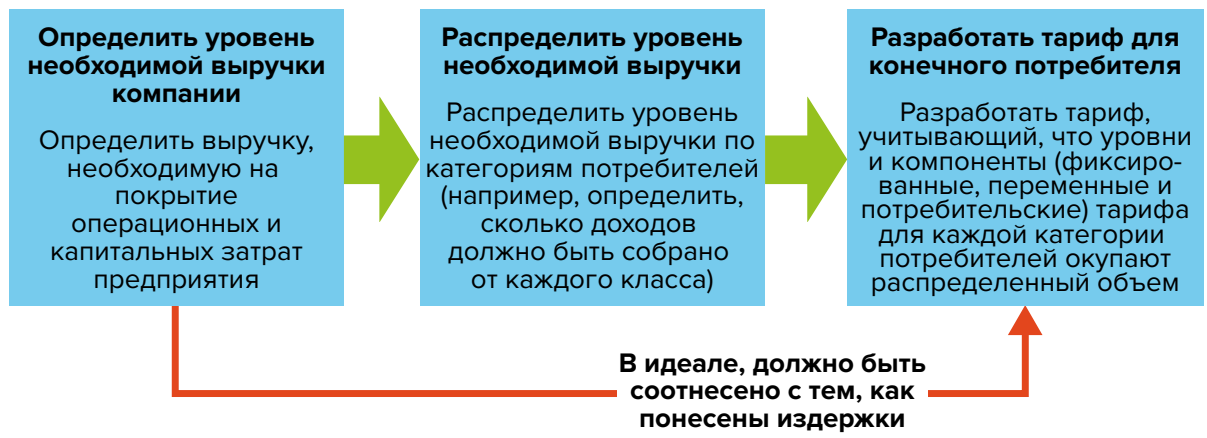

Источник: Всемирный банк (без даты) на основе информации от Государственного агентства по регулированию топливно-энергетического комплекса.

Определение требуемого объема выручки. Первый этап методологии заключается в оценивании требуемого дохода для каждой из компаний. Это зависит от «основных затрат» (фактических потребностях в денежных средствах) каждой из компаний сектора. Традиционное применение данного подхода подверглось сильной критике (USAID, 2011 г.) по той причине, что он не включал:

- доходность балансовой стоимости основного капитала.

- доходность оборотного капитала (поправка материально-производственные запасы и задолженность - разрешенные дни для счетов к получению).

- разрешенные разумные затраты, связанные с неуплатой по счетам за электричество и потерями.

Доходность от основных фондов и рабочего капитала была исключена из основных затрат, потому что большинство активов в Кыргызской Республике уже в значительной степени изношены. Следовательно, применение метода нормы доходности привело бы к значениям, которые оказались бы крайне низкими по сравнению с потребностью в средствах на текущий ремонт, техническое обслуживание и замену активов. Также, в традиционный подход не включались потери энергии (по той причине, что в нем требуемый доход делится на сумму выставленных счетов за минусом оцениваемых потерь), но этот подход не давал компаниям никакого стимула к сокращению потерь. Это происходит потому, что уровень потерь разнится от компании к компании, а также из-за разницы в эффективности сборов платежей. ${ }^{11}$

10 Индекс включает в себя продолжительность и частоту отключений электроэнергии, механизмь их мониторинга и сокращения, а также прозрачность и доступность тарифов - см. Всемирный банк (2018г.).

11 При этом эффективность сборов в последние годы улучшилась. Например, в 2010 году, по данным «Северэлектро», сборы составили 90\% от бытовых потребителей; в 2017 году общий показатель эффективности сборов составил 99,5\%. 
Новая тарифная методология рассчитана на усовершенствование традиционного подхода посредством добавления некоторых новых элементов в формулу расчета необходимого объема выручки, а именно:

$$
\mathrm{RR}=\mathrm{DS}+\mathrm{RA}+\mathrm{CR}+\mathrm{PC}+\mathrm{AC}-\mathrm{ELA}-\mathrm{OR}
$$

Где:

$R R$ - это требование к доходности;

$D S$ - долговые обязательства по обслуживанию;

$R A$ - счет резервных средств на ремонт и техническое обслуживание;

$C R$ - заложенные в бюджет расходы на капитальный ремонт и техническое обслуживание;

PC - производственные расходы;

$A C$ - административные расходы;

$E L A$ - корректировка для учета избыточных потерь электроэнергии;

$O R$ - сумма всех прочих доходов.

Обратите внимание на включение счета резервных средств на ремонт и на техническое обслуживание и бюджета на капитальный ремонт. Предполагается, что эти средства компенсируют отсутствие расчета коэффициента окупаемости активов. Более того, корректировка на потери электроэнергии (ELA) позволяет регулятору обозначить уровень потерь, который допустим, чтоб компания достигала наилучших показателей, от которых получит выгоду, тогда как за менее высокие показатели компания облагается штрафами.

Требование к распределению прибыли. Для определения тарифов для различных категорий потребителей, агрегированное требование к доходности должно быть распределено по различным категориям потребителей. Для достижения этого, каждый элемент себестоимости (обслуживание долга, капитальный ремонт, резервы, материальные издержки и др.) распределяются между различными категориями потребителей с применением либо пропорции потребителей (для фиксированных расходов), либо пропорции потребления (КВт/ч - для переменных издержек). ${ }^{12}$

Определение тарифа для конечного потребителя. Общие требуемые доходы, распределяемые на каждую категорию потребителей, затем делятся на «детерминанты расчетов», т.е. общее количество КВт/ч, с целью обеспечения для каждой категории потребителей тарифа, покрывающего издержки.

В то время как этот тариф отражает издержки, окончательный размер тарифа для конечного потребителя определяется правительством и зависит от ряда принципов, в том числе:

- действующая политика энергосектора;

- простота (т.е. предпочтительно не устанавливать много разных уровней);

- постепенность (ограничение ежегодного повышения ниже 25\%) и

- справедливость (в отношении фирм, через окупаемость издержек).

12 В теории, для некоторых категорий расходов также применяются спрос или мощности, однако отсутствие достоверных данных по спросу/потреблению означает, что такое пока не делается. 
Часто происходит так, что окончательный уровень тарифа для конечного потребителя, определяемый правительством, будет ниже, чем тариф покрывающий издержки для некоторых категорий потребителей, что приводит к дефициту. Вместо того, чтобы просто допускать возникновение дефицита на любом участке системы, где он накапливается, методология основана на распределении дефицита по каждому участнику рынка пропорционально необходимой выручке, с целью справедливого распределения бремени, по меньшей мере, в теории. Тарифы, выплачиваемые распределительными компаниями передающим компаниям, и тарифы, выплачиваемые передающими компаниями генерирующим компаниям, затем корректируются для обеспечения того, чтобы каждая из компаний получила свой необходимый объем выручки за минусом распределенного на нее дефицита.

\section{Финансовые показатели подсектора}

Наиглавнейшей причиной тому, что кыргызский сектор энергетики не способен предоставить услуги высокого качества, являются его финансовые показатели. Подсектор в целом характеризуется большими потерями, как правило, по той причине, что несмотря на методологию, описанную выше, тарифы на электроэнергию и отопление установлены намного ниже себестоимости. В Таблице 7.3 показаны текущие фактические тарифы на электроэнергию и отопление для бытовых и небытовых потребителей. Разрывы между фактическими тарифами и покрытием издержек крайне большие. В результате, по оценкам Международного валютного фонда, доналоговая субсидия ${ }^{13}$ на электроэнергию, центральное отопление и горячее водоснабжение составляет около 3\% валового внутреннего продукта (ВВП).

Последствие таких низких тарифов относительно себестоимости, заключается в том, что электрические и теплоэлектрические предприятия терпят большие операционные убытки, финансируемые государством. Финансовые потери компаний, вырабатывающих тепло и электричество, достигли 5,9 млрд. сом (85,4 млн. долл. США), 7,2 млрд. сом (104,2 млн. долл. США) и 3,2 млрд. сом (46,3 млн. долл. США) в 2014, 2015 и 2016 годах, соответственно. ${ }^{14}$ Чтобы фирмы сектора продолжали функционировать, правительство должно оказывать им поддержку. Однако, преобладающая доля этой поддержки не приходит через бюджет. Прямые бюджетные трансферты в 2016 году составили 1.5 млрд. сом (21,7 млн. долл. США) или 0,3\% ВВП, и в основном были переданы государственной компании по производству тепла («Кыргызжилкоммунсоюз») на покрытие ее потерь в процессе подачи тепла бытовым потребителям, и электрическим компаниям на компенсацию предоставления субсидированных тарифов потребителям в районе Токтогульского водохранилища. Напротив, большая доля помощи приходит в форме льготных кредитов Государственного фонда экономического развития, либо через бюджетные кредиты по нулевой процентной ставке, либо субсидиарные кредиты, выдаваемые за счет финансовых средств международных доноров по льготным ставкам. В конце 2016 года сумма невыплаченного долга, накопившегося у энергокомпаний за последние 25 лет, составила 82 млрд. сом (1,2 млрд. долл. США), или около 18\% ВВП, гарантированного в конечном итоге деньгами налогоплательщиков $(\mathrm{MB} \Phi, 2017)$.

13 Потребительские доналоговые субсидии на электроэнергию определяются как разрыв между ценой, фактически оплачиваемой потребителями, и стоимостью поставки энергии.

14 Обменный курс, использованный в этом разделе, равен 69,1136 сома за один доллар США. 


\section{Таблица 7.3: Фактические тарифы и тарифы, покрывающие себестоимость, на электричество и отопление}

\begin{tabular}{|c|c|c|c|}
\hline & Фактич. & Окупаемость расх. & Разрыв (\%) \\
\hline \multicolumn{4}{|c|}{ Бытовые потребители } \\
\hline Электричество - ниже порога (сом/квт-ч) & 0,77 & 1,97 & $156 \%$ \\
\hline Электричество - выше порога (сом/квт-ч) & 2,16 & 1,97 & $-9 \%$ \\
\hline Отопление - ТЭЦ (сом/гкал) & 1,135 & 3,405 & $200 \%$ \\
\hline Отопление - только бойлер (сом/гкал) & 1,135 & 6,881 & $506 \%$ \\
\hline Горячее водоснабжение (сом/гкал) & 982 & 3,405 & $247 \%$ \\
\hline \multicolumn{4}{|c|}{ Небытовые потребители } \\
\hline Электричество (сом/квт-ч) & 2,24 & 1,55 & $-31 \%$ \\
\hline Электричество - насосные станции (сом/квт-ч) & 0,78 & 1,55 & $99 \%$ \\
\hline Отопление - ТЭЦ (сом/гкал) & 1,695 & 2,681 & $58 \%$ \\
\hline
\end{tabular}

ТЭЦ = тепловая электростанция, ГКал = гигакалория, кВт/ч = киловат/час.

Источник: МВФ (2017 г.).

Задолженности и продолжающиеся потери сектора, в результате тарифов ниже себестоимости, делают инвестирование в сектор непривлекательным. Фундаментальная причина такой изношенности генерирующих, передающих и распределительных активов заключается в том, что не представляется возможным и не было возможным на протяжении многих лет для фирм, отвечающих за эти активы, привлечь значительные инвестиции. Как следствие, единственным источником крупных инвестиций остается государственный бюджет - который крайне ограничен, или международные партнеры по развитию.

Отмечается, что в большинстве соседних стран действуют иные принципы установления тарифов (Таблица 7.4). Тарифы в Кыргызстане, и особенно для бытовых потребителей, значительно ниже аналогичных тарифов, установленных в сравнимых странах.

\section{Таблица 7.4. Тарифы за электроэнергию в некоторых странах}

\begin{tabular}{lcc} 
Страна & $\begin{array}{c}\text { Бытовое } \\
\text { потребление }\end{array}$ & $\begin{array}{c}\text { Небытовое } \\
\text { потребление }\end{array}$ \\
\hline $\begin{array}{l}\text { Армения } \\
\text { Азербайджан }\end{array}$ & 5,57 & 7,47 \\
\hline Грузия & 5,67 & 5,72 \\
\hline Россия & 4,9 & 4,98 \\
\hline Украина & 1,51 & 7,78 \\
\hline Кыргызская Республика & 1,48 & 5,70 \\
\hline
\end{tabular}

Источник: Гасснер, Розенталь и Ханкинсон (2017г.).

\section{Среднесрочная тарифная политика на 2014-2017 годы}

Хотя тарифная реформа не является единственным механизмом решения проблем сектора, понятно, что без реформирования методов установления тарифов, достичь какого-либо прогресса будет очень сложно. В последние несколько лет 
наблюдается значительное продвижение в тарифной реформе. Государственное агентство по регулированию топливно-энергетического комплекса приняло новые методы установления тарифов на электроэнергию, отопление и горячее водоснабжение. С 2015 года действует двухуровневый тариф для бытовых потребителей, более низкий тариф применяется к тем, кто потребляет менее 700 КВт/ч, а тариф для тех, кто потребляет больше данного уровня - намного выше. В Среднесрочной тарифной политике (СТП) на 2014-2017 годы закреплен принцип окупаемости издержек в секторе в среднесрочном периоде.

Однако, как показано в Таблице 7.5 , политика не была реализована в полной мере, и повышение тарифа для бытовых потребителей, потребляющих ниже установленного порогового значения, неоднократно откладывалось. Первоначальное намерение заключалось в том, чтобы тариф для данной категории потребителей достиг уровня окупаемости издержек до 1 апреля 2017 года, со значительными повышениями каждый апрель-месяц. Однако, каждое изменение СТП откладывало срок, к которому эти повышения должны были произойти. Повышение с 2014 по 2015 годы было ниже первоначально запланированного; повышение до 0,932 сом/ КВт/ч, запланированное на 2016 год, было затем отложено на год и пересмотрено в сторону уменьшения; затем в июне 2017 года оно опять было отложено. Так как категория бытовых потребителей является самым крупным и создающим потери компонентом тарифного плана, эти переносы оказали серьезное воздействие на способность сектора достичь уровня окупаемости затрат. Аналогично, тарифы на центральное отопление также следовали СТП в 2014 и 2015 годах, но повышения, запланированные на 2016 и 2017 годы не были реализованы.

\section{Таблица 7.5: Пересмотры Среднесрочной тарифной политики на 2014-2017 гг. для отдельных групп потребителей}

\begin{tabular}{|c|c|c|c|c|c|c|}
\hline \multicolumn{7}{|c|}{ Дата } \\
\hline Постановление № & Период & 2014 & 01.07 .14 & 01.04 .15 & 01.04 .16 & 01.04 .17 \\
\hline \multicolumn{7}{|c|}{ Потребители с объемом потребления ниже 700 кВт/ч./месяц } \\
\hline \multirow{2}{*}{660} & 20.11.14 & 70.0 & 70.0 & 84.0 & 100.8 & 121.0 \\
\hline & & & 01.07 .14 & 01.08 .15 & 01.08 .16 & 01.08 .17 \\
\hline 527 & 24.07 .15 & 70.0 & 70.0 & 77.0 & 93.2 & 121.0 \\
\hline 421 & 01.08 .16 & 70.0 & 70.0 & 77.0 & 77.0 & 84.7 \\
\hline \multirow[t]{2}{*}{396} & 22.06 .17 & 70.0 & 70.0 & 77.0 & 77.0 & 77.0 \\
\hline & \multicolumn{6}{|c|}{ Тарифы предприятий, подающих горячую воду ${ }^{\mathrm{b}}$} \\
\hline \multirow[t]{2}{*}{660} & 20.11.14 & 70.0 & 72.8 & 77.9 & 83.3 & 89.2 \\
\hline & & & 01.07 .14 & 01.08 .15 & 01.08 .16 & 01.08 .17 \\
\hline 527 & 24.07 .15 & 70.0 & 72.8 & 77.9 & 83.3 & 89.2 \\
\hline 421 & 01.08 .16 & 70.0 & 72.8 & 77.9 & 77.9 & 84.7 \\
\hline 396 & 22.06 .17 & 70.0 & 72.8 & 77.9 & 77.9 & 77.9 \\
\hline
\end{tabular}

кВТ/ч = киловатт/час, СТП = Среднесрочная тарифная политика.

Все величины даны в сомах за Квт/ч.

а СТП на 2014-2017 годы и соответствующие постановления.

b Исключая высокогорные и отдаленные местности на период с 1 октября по 1 мая.

с Данные по Постановлению №660 применимы к потребителям с 1-фазной подачей: эта категория была изменена в 2015 году. 
Источники: Составлено на основе постановлений Правительства Кыргызской Республики №396 (2017 г.), N421 (2016 г.), N527 (2015 г.) и Nº 660 (2014 г.).

Намного более высокие тарифы для других категорий потребителей (например, бытовые потребители с объемом потребления свыше 700 Квт, сельскохозяйственные потребители и промышленные предприятия) в целом, были внедрены и действуют, создавая большой разрыв между тарифами, оплачиваемыми большинством населения - бытовыми потребителями, за электричество и отопление, и тарифами, которые платят крупные потребители.

\section{Прибыльность и задолженность энергокомпаний}

Большой разрыв между тарифом возмещения издержек и тарифами, фактически применяемыми к большинству категорий потребителей, продолжает приводить к большим потерям для энергокомпаний. В Таблице 7.6 приводятся расходы и доходы энергокомпаний, наряду с их убытками в 2016 году; на Рисунке 7.9 показаны долгосрочные обязательства двух крупнейших фирм за период 2012-2016 годы. Все энергокомпании терпят убытки - обычно от 1 до 6 процентов от своего дохода. Передающая компания - «Национальная электрическая сеть Кыргызстана», является особенно бедной, получая доход, который на 28 процентов ниже расходов (17\% на основе официальных цифр). Эти убытки накапливаются в течение длительного времени, «съедая» капитал компаний и увеличивая их долгосрочные обязательства. Резкое увеличение этих обязательств отражает, по большей части, заимствование для целей обновления генерирующих, передающих и распределительных активов. Тем не менее, продолжающиеся убытки ухудшают капитальную базу фирм, требуя промежуточных капитальных вливаний от правительства и подтверждая тот факт, что единственным источником долгосрочного финансирования является либо государственное заимствование, либо фонды партнеров по развитию. Составляя около 1,5 млрд. сом в год (около 22 млн. долл. США), общие убытки системы электроэнергии значительны, и без основательной тарифной реформы могут расти и дальше.

Таблица 7.6: Расходы, доходы и убытки энергокомпаний, 2016 г.

\begin{tabular}{lcccccc}
\hline & ЭС & HэСК & Cэ & BЭ & Оэ & Дэ \\
Общие расходы & $9,096,301$ & $4,002,870$ & $7,182,102$ & $1,691,146$ & $2,511,866$ & $1,641,019$ \\
\hline Фактическая выручка & $8,993,854$ & $3,116,058$ & $6,942,013$ & $1,664,111$ & $2,359,500$ & $1,582,208$ \\
\hline Прибыль (Убыток) & $-102,446$ & $-886,812$ & $-240,089$ & $-27,035$ & $-152,366$ & $-58,810$ \\
\hline Процент от выручки & $-1 \%$ & $-28 \%$ & $-3 \%$ & $-2 \%$ & $-6 \%$ & $-4 \%$ \\
\hline
\end{tabular}

ЭС = Электрические станции, ДжЭ = Джалал-АбадЭлектро, НЭСК = Национальная электрическая сеть Кыргызстана, ОЭ = ОшЭлектро, СВ = СеверЭлектро, ВЭ = ВостокЭлектро.

Все денежные величины даны в сомах

а Убытки НЭСК указаны в размере -541315 на счетах, однако это не разница между расходами и выручкой, как показано выше. Цифры по убыткам меняются из года в год; в 2015 году общий убыток для всех компаний в секторе составил 7,2 млрд. сом., в основном, в результате очень большого убытка в размере 6,5 млрд. сом у ЭС.

Источник: Прибыли и убытки энергокомпаний, рассчитанные на основе данных, предоставленные автору Национальной энергетической холдинговой компанией. 


\section{Рисунок 7.9: Долгосрочные обязательства ЭС и НЭСК, 2012-2016 гг.}

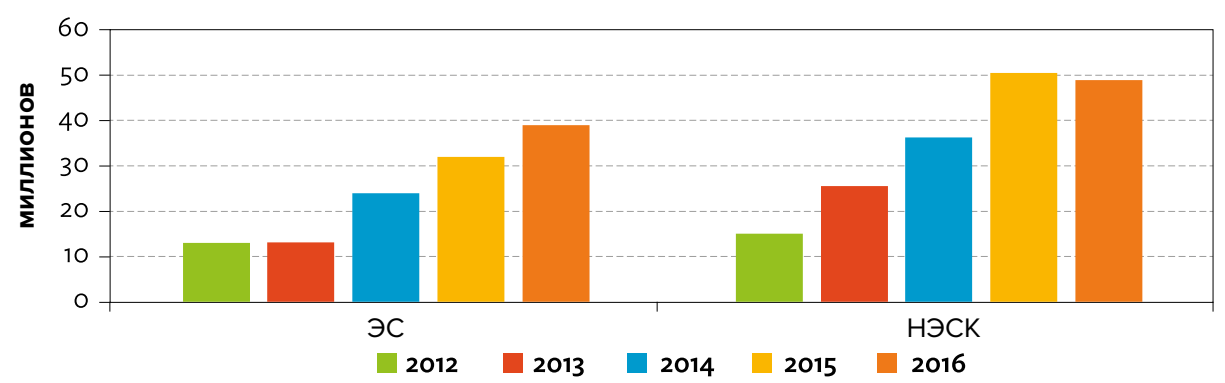

ЭС = Электрические станции, НЭСК = Национальная электрическая сеть Кыргызстана Источники: Балансовые отчеты энергокомпаний, предоставленные автору Национальной энергетической холдинговой компанией.

\section{3. Воздействие действующих тарифов}

\section{Развитие сектора энергетики}

Одно из последствий действующих уровней тарифов заключается в том, что Кыргызская Республика пока не способна привлекать частные инвестиции в сектор энергетики. ${ }^{15}$ Вливание капитала в энергокомпании как правило ориентировалось на покрытие текущих потерь и стремление обеспечивать ремонт и техническое обслуживание имеющегося оборудования, с относительно небольшими суммами, имеющимися для существенных капитальных вложений. В результате, большинство крупных инвестиционных проектов финансировалось за счет средств партнеров по развитию. В Таблице 7.7 представлен перечень основных реализуемых в настоящее время проектов, финансируемых при их поддержке. Сюда входит несколько проектов по реабилитации, в частности крупных гидроэлектростанций на Токтогульской гидроэлектростанции (ГЭС), а также запуск второго гидроагрегата на Камбаратинской ГЭС-2 и реконструкция Атбашинской ГЭС. Кроме того, инвестиции осуществляются в электрические сети городов Бишкек и Ош и улучшение энергоснабжения Аркинского массива; также значительный объем инвестиций направлен на Энергетический проект Центральная Азия - Южная Азия, известный как «CASA-1000». Эта крупная международная инициатива ставит цель соединить страны с потенциальным излишком производства гидроэлектроэнергии, а именно Кыргызскую Республику и Таджикистан, со странами, испытывающими дефицит электроэнергии, в том числе Афганистан и Пакистан. В Кыргызской Республике это потребует строительства линии переменного тока в 500 КВ от Датки до подстанции Сугда (477 км в Таджикистане).

В дополнение к инвестициям в генерирующие и передающие мощности, партнеры по развитию оказывают поддержку в инвестировании в четыре распределительные компании, с целью реабилитации существующих электрических сетей и повышения эффективности и подотчетности.

15 Безусловно, низкие тарифы не являются единственной причиной низкого объема инвестиций - важным фактором также является общий инвестиционный климат. Более того, экспортная цена электроэнергии намного выше (например для CASA-1000 - «Энергетический проект Центральная Азия - Южная Азия») и тарифы на возобновляемые энергоресурсы тоже выше. Тем не менее, низкие тарифы препятствуют инвестированию в производство электроэнергии для бытового потребления. 


\section{Таблица 7.7: Текущие проекты, финансируемые партнерами по развитию}

\begin{tabular}{|c|c|c|c|c|}
\hline$\Pi / \Pi$ & Название проекта & $\begin{array}{c}\text { Партнер } \\
\text { по развитию }\end{array}$ & $\begin{array}{l}\text { Сумма фринансирования } \\
\text { (млн. долл. США, если не } \\
\text { указано иное) }\end{array}$ & $\begin{array}{c}\text { Период } \\
\text { реализации } \\
\text { проекта }\end{array}$ \\
\hline \multicolumn{5}{|c|}{ ОАО «Электрические станции» } \\
\hline 1 & $\begin{array}{l}\text { Запуск второго агрегата на } \\
\text { Камбаратинской ГЭС-2 }\end{array}$ & $\begin{array}{c}\text { Евразийский банк } \\
\text { развития }\end{array}$ & 110 & $\begin{array}{l}\text { Пока не } \\
\text { начат }\end{array}$ \\
\hline 2 & Реабилитация сектора энергетики & АБР & 55,0 (Грант = 40 и Кредит = 15) & 2013-2019 \\
\hline \multirow[t]{2}{*}{3} & $\begin{array}{l}\text { Реабилитация Токтогульской ГЭС. } \\
\text { Фаза } 2\end{array}$ & АБР & 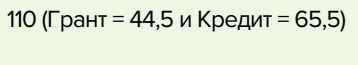 & 2015-2021 \\
\hline & & $\begin{array}{c}\text { Евразийский банк } \\
\text { развития }\end{array}$ & 100 (Кредит) & \\
\hline \multirow[t]{2}{*}{4} & $\begin{array}{l}\text { Реабилитация Токтогульской ГЭС. } \\
\text { Фаза } 3\end{array}$ & АБР & 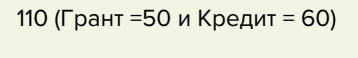 & $2016-2024$ \\
\hline & & $\begin{array}{c}\text { Евразийский банк } \\
\text { развития }\end{array}$ & 40 (Кредит) & \\
\hline 5 & Реконструкция Атбашинской ГЭС & $\begin{array}{l}\text { Швейцарская } \\
\text { конфедерация }\end{array}$ & $\begin{array}{c}\text { 19,82 швейц. фрранков } \\
\text { (Грант) }\end{array}$ & $2014-2021$ \\
\hline \multicolumn{5}{|c|}{ OAO «HЭСК» } \\
\hline 6 & $\begin{array}{l}\text { Улучшение энергоснабжения в } \\
\text { городах Бишкек и Ош }\end{array}$ & $\begin{array}{c}\text { Исламский банк } \\
\text { развития }\end{array}$ & 23,08 (Кредит) & 2013-2016 \\
\hline 7 & Улучшение сектора энергетики & АБР & 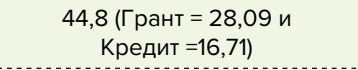 & 2013-2017 \\
\hline 8 & $\begin{array}{l}\text { Улучшение энергоснабжения } \\
\text { Аркинского массива Лейлекского } \\
\text { района Баткенской области }\end{array}$ & $\begin{array}{c}\text { Исламский банк } \\
\text { развития }\end{array}$ & 16,25 (Кредит) & 2014-2017 \\
\hline \multirow[t]{5}{*}{9} & CASA-1000 & Всемирный банк & 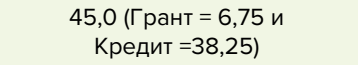 & $2016-2021$ \\
\hline & & $\begin{array}{l}\text { Европейский инве- } \\
\text { стиционный банк }\end{array}$ & 70 Евро (Кредит) & \\
\hline & & $\begin{array}{l}\text { Исламский банк } \\
\text { развития }\end{array}$ & 50 (Кредит) & \\
\hline & & $\begin{array}{c}\text { Трастовый фонд } \\
\text { США }\end{array}$ & 7,5 (Грант) & \\
\hline & \multicolumn{4}{|c|}{ ОАО «Северэлектро» } \\
\hline 10 & $\begin{array}{l}\text { Улучшение локальных электриче- } \\
\text { ских сетей города Бишкек }\end{array}$ & \multirow[t]{2}{*}{$\begin{array}{l}\text { Германский банк } \\
\text { развития KfW }\end{array}$} & \multirow[t]{2}{*}{$\begin{array}{c}\text { 33,6 Евро }(Г \text { рант }=2 \\
\text { и Кредит }=31,6)\end{array}$} & \multirow[t]{2}{*}{$2011-2017$} \\
\hline 11 & $\begin{array}{l}\text { Повышение эффективности элек- } \\
\text { трораспределительных сетей }\end{array}$ & & & \\
\hline 12 & $\begin{array}{l}\text { Проект по улучшению подотчёт- } \\
\text { ности и повышению надёжности } \\
\text { электроснабжения в Кыргызской } \\
\text { Республике }\end{array}$ & Всемирный банк & 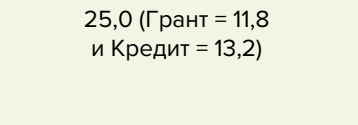 & 2014-2018 \\
\hline \multicolumn{5}{|c|}{ ОАО «Ошэлектро» } \\
\hline 13 & Реабилитация ОАО «Ошэлектро» & ЕБРР & 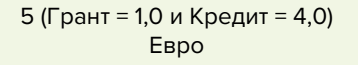 & $2017-2020$ \\
\hline \multicolumn{5}{|c|}{ ОАО «Востокэлектро» } \\
\hline 14 & $\begin{array}{l}\text { Реабилитация ОАО «Восток- } \\
\text { электро» }\end{array}$ & ЕБРР & 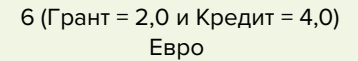 & $2018-2023$ \\
\hline
\end{tabular}




\begin{tabular}{|c|c|c|c|c|}
\hline П/п & Название проекта & $\begin{array}{c}\text { Партнер } \\
\text { по развитию }\end{array}$ & $\begin{array}{c}\text { Сумма финансирования } \\
\text { (млн. долл. США, если не } \\
\text { указано иное) }\end{array}$ & $\begin{array}{c}\text { Период } \\
\text { реализации } \\
\text { проекта }\end{array}$ \\
\hline \multicolumn{5}{|c|}{ ОАО «Бишкектеплосеть» } \\
\hline 15 & Улучшение энергоснабжения & Всемирный банк & 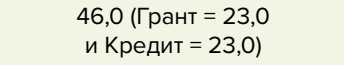 & 2018-2023 \\
\hline 16 & $\begin{array}{l}\text { Реконструкция и строительство } \\
\text { насосных станций }\end{array}$ & ЕБРР & 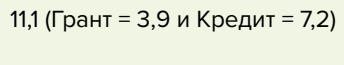 & $2018-2021$ \\
\hline 17 & $\begin{array}{l}\text { Линия электропередачи Датка- } \\
\text { Кемин }\end{array}$ & ЭКСИМ Банк Китая & 389 (Кредит) & 2011-2015 \\
\hline 18 & Линия электропередачи Датка-Юг & ЭКСИМ Банк Китая & & \\
\hline 19 & Реабилитация ТЭЦ Бишкек & ЭКСИМ Банк Китая & 386 (Кредит) & $2013-2018$ \\
\hline
\end{tabular}

АБР = Азиатский банк развития, CASA-1000 = Энергетический проект Центральная Азия - Южная Азия, ЕБРР = Европейский банк реконструкции и развития, ЕХIM = экспорт-импорт, ГЭС = гидроэлектростанция, ОАО = открытое акционерное общество.

Источник: Основано на информации и данных, предоставленных автору руководителем отдела подготовки и реализации проектов Государственного комитета промышленности, энергетике и горнодобывающей промышленности

В идеале, такие государственные инициативы должны сопровождаться значительными частными инвестициями в энергосектор. К сожалению, ныне действующая политика и регулятивный климат не стимулируют частные инвестиции. На октябрь 2018 года функционирует лишь небольшое число частных малых независимых производителей электроэнергии (Тегирментинская ГЭС (3 МВт), Иссык-Атинская ГӘС (1,6 МВт), Калининская ГЭС (1,4 МВт), Аксуйская ГЭС (o,5 МВт) и Кыргыз-Атинская ГЭС (0,25 МВт)).

В принципе, существующие положения позволяют новым малым ГЭС получать тариф на период 8 лет, после чего он должен обновляться ежегодно. По закону, распределительные компании должны оплачивать этот тариф. Однако, в целях минимизации своих собственных потерь, распределительные компании не желают оплачивать этот тариф. После окончания 8-летнего периода, переговоры по ежегодному обновлению создают ощутимую неопределенность для частных инвесторов, что и делает инвестиции в этот сектор непривлекательными. Частный сектор также жалуется на проблемы с отводом земли - процесс этот длительный и затратный; и на неэффективное управление. Многие из этих проблем возникают из-за существующей тарифной политики. Низкие тарифы приводят к убыткам энергокомпаний, что отбивает у них желание покупать электроэнергию по коммерческим тарифам. Поэтому, для большинства частных инвесторов, вложение в сектор без гарантии того, что тариф обеспечит разумный возврат инвестиций, не оправдано. Ироничен тот факт, что в итоге, недостаток электроэнергии, при очевидном гидроэнергетическом потенциале страны, приходится компенсировать за счет импорта казахской электроэнергии, производимой с использованием ископаемого топлива по ценам, превышающим ту, которую пришлось бы платить частным малым ГЭС.

\section{Потребление}

Потребление электроэнергии в Кыргызской Республике в последние годы растет ускоренными темпами (Рисунок 7.10). Длительное сокращение потребления отражало период экономического спада в течение 10 лет после распада Советского 
Союза в 1991 году. Однако, начиная с 2010 года, уровень потребления на душу населения растет.

Рисунок 7.10: Потребление электроэнергии на душу населения, 1990-2015 гг. (кВт/ч)

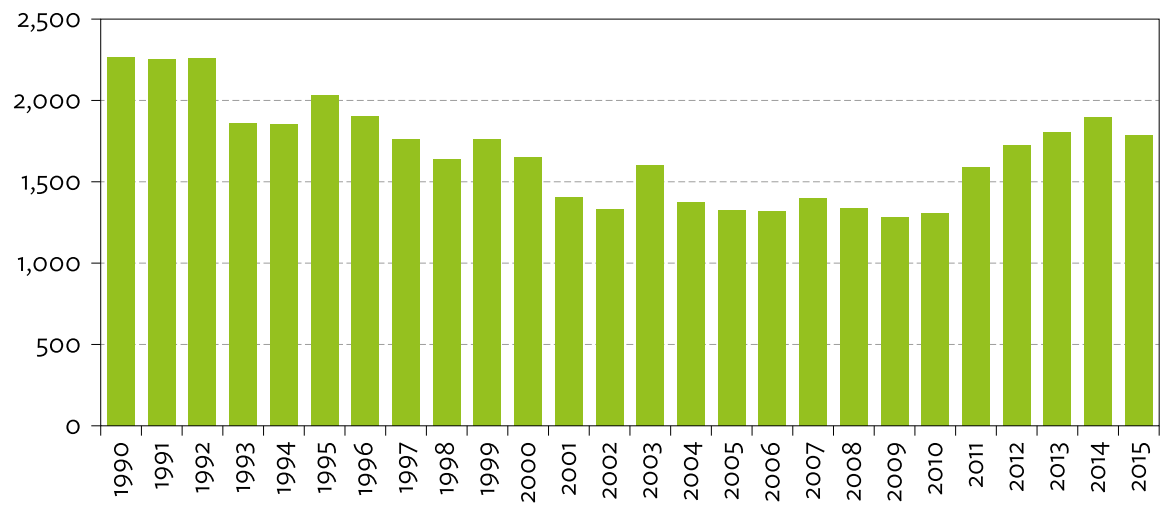

$\mathrm{KBT} / 4=$ киловатт/час.

Источник: Enerdata. База данных Enerdata (по состоянию на 8 марта 2018 г.).

Увеличение потребления вызвано быстрым расширением бытового потребления, в то время как промышленное потребление продолжает сокращаться. Это обусловлено относительно высоким уровнем тарифов для промышленных пользователей, спадом в промышленном производстве и низким тарифом для бытового потребления для объемов ниже 700 кВт/ч в месяц (кВТ/ч/мес.). Средние уровни потребления для домохозяйств составили 409 кВт/ч/мес. в 2016 году, что значительно превышает аналогичные показатели в странах с аналогичными климатическими условиями, в том числе в Казахстане - 218 кВт/ч/мес. или в России - 208 кВт/ч/мес.) (МВФ, 2017 г). Из-за субсидий, расходы на электроэнергию составляют относительно небольшой процент от общей суммы расходов домохозяйств. В среднем, в масштабах республики, расходы на электроэнергию, центральное отопление и горячее водоснабжение составили $3,4 \%$ от общих расходов домохозяйств в 2015 году, включая 2,5\% на электроэнергию (МВФ, 2017 г.). В то же время, наличие дешевой электроэнергии для бытового потребления, стимулирует использование электроэнергии для отопительных целей, тем самым усугубляя и без того высокую сезонность в цикле потребления (Рисунок 7.11). Это создает дополнительную нагрузку на электрическую систему в зимние месяцы, когда гидроэнергетические ресурсы доступны в минимальном объеме - тем самым еще более увеличивая издержки сектора.

Низкие тарифы на бытовое потребление также привели к тому, что Кыргызская Республика имеет самый высокий уровень энергоемкости ВВП (киловатт-часов на один доллар ВВП) в Центральноазиатском регионе (Рисунок 7.12), что в два раза превышает показатель некоторых соседних стран. По большей части, это является отражением изношенности и энергетической неэффективности сооружений и приборов. Программа Европейского банка реконструкции и развития и Европейского Союза предлагает меры по стимулированию фирм и индивидуальных предпринимателей с целью повышения энергоэффективности. Это уже приводит к экономии 125000 МВт-часов ежегодно (эквивалент потребления электроэнергии 6 ооо домохозяйствами), а также сокращению ежегодного выброса $\mathrm{CO}_{2}$ на 
38 ооо тонн. Однако, эта программа небольшая, и, следовательно, охват ее ограничен. В то время как существует потенциал для значительного улучшения, который в свою очередь, облегчит нагрузку на энергосистему, энергоэффективность пока еще не является приоритетом для правительства.

Рисунок 7.11: Среднемесячное потребление электроэнергии, 2015 г. (кВт/ч в месяц)

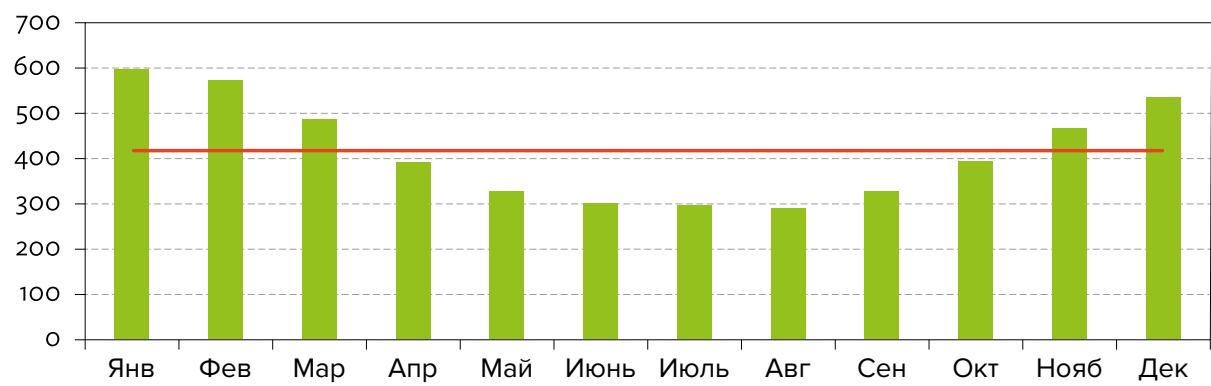

Среднемесячное потребление, кВт.ч

Готовое среднемесячное потребление

$\mathrm{kBт} / 4=$ киловатт/час.

Источник: Всемирный банк (2017b).

Рисунок 7.12: Энергоемкость валового внутреннего продукта (кВт/ч на тыс. долл. США в ППС 2015 г.)

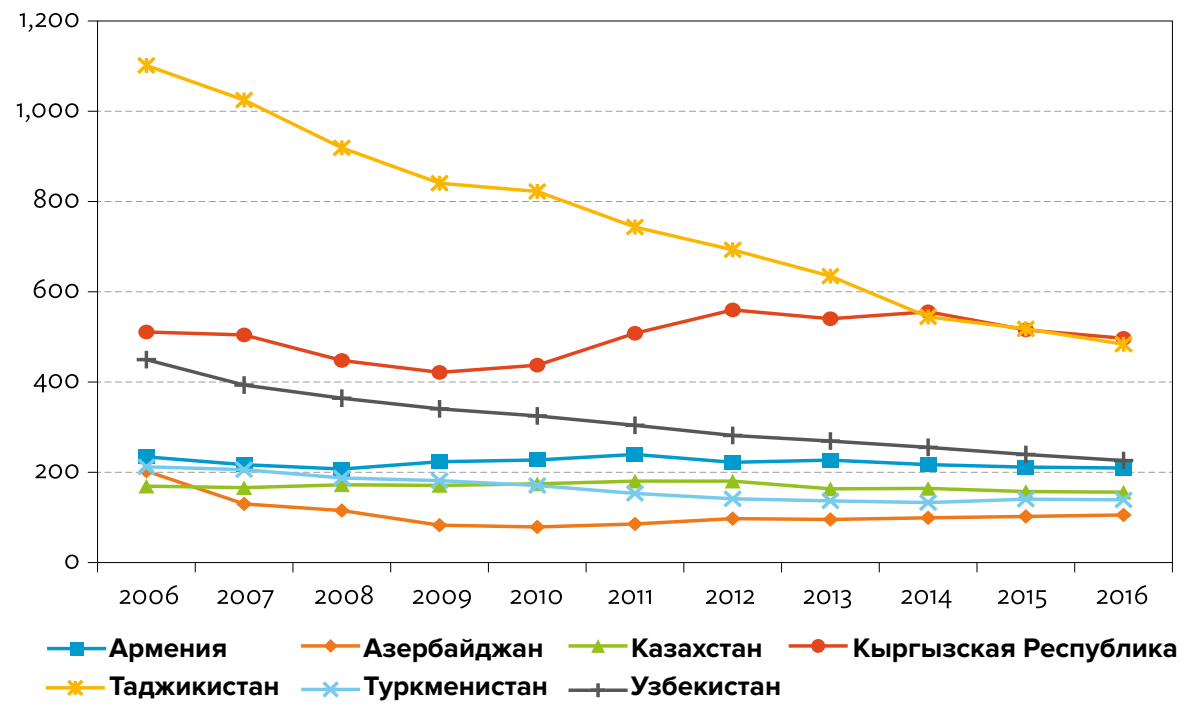

ВВП = валовой внутренний продукт, кВт/ч = киловатт/час, ППС = паритет покупательной способности.

Источник: Enerdata. База данных Enerdata.http://www.enerdata.net (по состоянию на 8 марта 2018 г).

Более того, скрытые субсидии, предоставляемые посредством низких тарифов на электроэнергию, центральное отопление и горячее водоснабжение действуют регрессивно. На Рисунке 7.13 показано распределение энергосубсидий по децилям уровней доходов, с разбивкой на городских/сельских потребителей и по 
типу энергии. Поскольку бытовые потребители, проживающие в городских населенных пунктах, в основном в Бишкеке и Оше, являются крупнейшими потребителями как электроэнергии, так и центрального отопления (в еще более значительных масштабах), основной объем субсидий приходится на эту группу. Полные 20 процентов от всей субсидии предоставляются верхнему децилю населения, в то время как самые бедные 10 процентов населения получают лишь 5 процентов от энергосубсидий. Низкие тарифы поэтому представляют собой очень неэффективный способ защиты бедных.

\section{Рисунок 7.13: Распределение энергосубсидий по децилям уровней доходов}

а. По городским/сельским (\%)

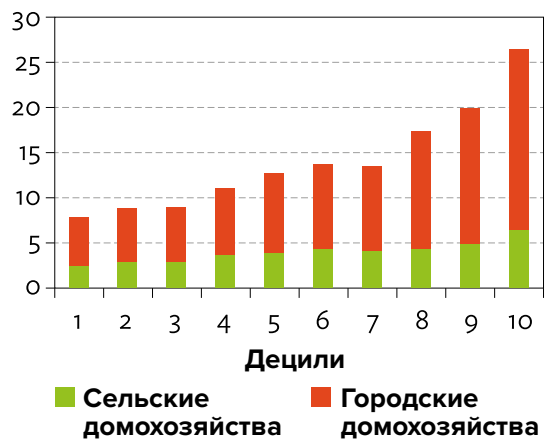

b. По видам энергии (\%)

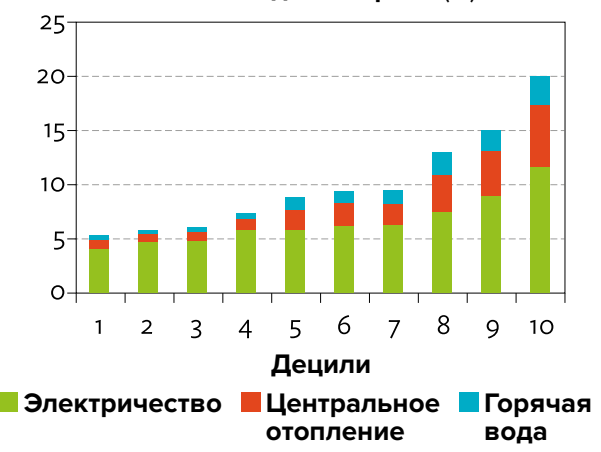

Источник: МВФ (2017 г.) на основе Интегрированного обследования домашних хозяйств КР (IHSN, 2017 г.).

\section{Состояние государственного бюджета}

Существующий механизм определения тарифов имеет важные последствия для состояния бюджета правительства. По оценкам Международного валютного фонда, сумма субсидий на электроэнергию, отопление и горячее водоснабжение составила около $3 \%$ ВВП - намного больше, чем в большинстве стран региона (МВФ, 2017 г.). Эта оценка не включает косвенные эффекты, связанные с субсидиями (т.е. прочие расходы, которые могли бы быть выше, если бы не было субсидий).

Непогашенный долг, накопленный энергокомпаниями за последние 25 лет, составил 82 млрд. сомов (около 18\% ВВП) на конец 2016 года (МВФ, 2017 г.). Если бы льготные кредиты энергокомпаний были включены в государственные счета, фискальный дефицит был бы выше на 0,4-0,2 процентных пункта ВВП.

Субсидии также представляют собой важные альтернативные издержки для правительства. В Таблице 7.8 показан объем социального страхования и основные формы социальной помощи в Кыргызской Республике. Социальное страхование составляет около 9\% ВВП и представлено главным образом пенсиями, управляющий орган - Социальный фонд. Социальная помощь находится в ведении Министерства труда и социального развития и включает три основные программы: ежемесячное пособие для малообеспеченных семей; ежемесячные социальные льготы для детей, инвалидов и пожилых людей; а также единое денежное пособие по перечню, в который входят 25 категорий получателей. Предполагалось, 
что третья программа будет финансироваться за счет повышения тарифов в 2010 году, но выдача пособия продолжилась несмотря на то, что повышение тарифа было отменено после событий апреля 2010 года.

Таблица 7.8: Социальное страхование и социальная помощь в Кыргызской Республике, 2016 г.

\begin{tabular}{|ccc}
\hline & Млн. сом & $\%$ к ВВП \\
\hline Социальное страхование & 42,366 & $9.2 \%$ \\
\hline Социальная помощь & 7,136 & $1.5 \%$ \\
\hline ЕЛМС & 2,966 & $0.6 \%$ \\
\hline Ежемесячные социальные льготы & 2,430 & $0.5 \%$ \\
\hline Денежное пособие & 1,161 & $0.3 \%$ \\
\hline Энергосубсидии & 13,815 & $3.0 \%$ \\
\hline
\end{tabular}

ВВП = валовой внутренний продукт, ЕЛМС = ежемесячные льготы для малообеспеченных семей. Источник: МВФ, 2017

Как показано в Таблице 7.8, даже при том, что вся величина энергосубсидий не отражена в бюджете, они превышают сумму всего бюджета социальной помощи. Хотя присутствуют проблемы и недостатки как в охвате, так и в распределении социальной помощи, она все равно считается более прогрессивной, чем энергосубсидии. Следовательно, переход от энергосубсидий к социальной помощи, вероятно будет иметь непосредственную пользу для самых бедных слоев общества.

\section{4 Международный опыт в реформировании энергосубсидий}

В настоящем разделе приводится краткий обзор литературы по реформам сектора энергетики, энергосубсидий и тарифов в развивающихся странах, а также представлены три кратких практических примера стран, которые реализовали значительные реформы в области тарифов на электроэнергию и решении вызовов, с которыми им пришлось столкнуться.

\section{Обзор литературы}

Проблема реформирования системы энергосубсидий и тарифов имеет очень длительную историю во многих странах. Большой объем литературы фокусирует внимание на более широкой теме реформирования сектора энергетики. Например, Гратвик и Эберхард (2008 г.) и Эберхард и другие (2016 г.) описывают проблемы в реформировании сектора энергетики в Центральной и Западной Африке; Дубаш и Раджан (2001 г.) и Тонгия (2003 г.) описывают реформу сектора энергетики в Индии; Виктор и Хеллер (2008 г.) описывают политику реформ в пяти крупных развивающихся экономиках; Скотт и Сет (2013 г.) предоставили обзор литературы по реформированию распределительных энергокомпаний в развивающихся странах; а Коджима, Бэйкон и Тримбл (2014 г.) сделали обзор литературы по реформе субсидий в энергосекторе. 
На основе обзора этого большого объема литературы сделано несколько основных выводов - уроков на будущее. Один - это необходимость реформ сектора энергетики, чтобы отражать контекст, в котором они реализуются. До начала 2000-х годов подход, применявшийся в странах Организации экономического сотрудничества и развития (ОЭСР), сводился к «стандартному» или «традиционному» подходу к реструктуризации сектора в развивающихся странах. Стандартные шаги в этом процессе включали корпоратизацию, коммерциализацию, законодательство, регулирование, реструктуризацию, приватизацию и конкуренцию (Гратвик и Эберхард 2008 г., Джоскоу, 2006 г.; Литтлчайлд, 2006 г.; Хант, 2002 г.). К сожалению, применение «стандартной модели» реформирования в развивающихся странах дало довольно скромные результаты, по той причине, что столкнулось с политическими барьерами (Бесант-Джонс, 2006 г., Чойновски, 2004 г.), и в результате появился целый ряд гибридных структур (Эберхард и др. 2016 г.) Они возникли, в частности, в результате политической борьбы между разными действующими игроками, появившимися в каждой стране (коммунальные предприятия, независимые производители энергии, регуляторы, министерства финансов, министерства энергетики и политические лидеры), а также между внутренними и международными игроками, например, независимыми энергопроизводителями и партнерами по развитию.

За последнее десятилетие партнеры по развитию предпринимали попытки применить более индивидуальный подход к поддержке стран, проводящих у себя реформу энергетического сектора, при этом Всемирный банк сегодня аргументирует, что «один размер не подходит для всех» и выступает за контекстно-зависимые подходы к проведению подобных реформ (Безант-Джонс, 2006 г.). Например, в отношении финансовой устойчивости, последние исследования предполагают, что в данном случае необходим более всеохватывающий взгляд. Тримбл и др. (2016 г.) показали, что предприятия в странах Африки, расположенные к югу от Сахары, часто оказываются нежизнеспособными из-за высоких издержек. Эти издержки высоки в силу разных причин, включая структурные причины (географическое положение страны и обеспеченность природными ресурсами); высокие технические потери из-за устаревшего или технически плохо обслуживаемого оборудования; а также большие коммерческие потери и хищениям как следствие неплатежей большинством пользователей и слабые системы учета и сбора оплаты. Следовательно, сокращение затрат в некоторых странах может обеспечить более политически приемлемый маршрут для обеспечения возмещения затрат в некоторых странах.

Аналогично, подходы к компенсационным программам должны быть адаптированы к условиям конкретной страны. Как следствие, проводились многочисленные эксперименты с разными компенсационными механизмами, например, создание национальной базы данных бедных слоев населения в Индонезии (Битон, Лонтох и Вай-Пой, 2017 г.) или биометрической идентификации в Индии (Хари, 2016 г.).

В процессе реализации реформы энергетического сектора, правительства также принимали целый ряд дополнительных видов политики. Например, страны, испытывающие недостаток энергии, часто поддерживали внедрение энергоээфективности или измерительных приборов, чтобы минимизировать спрос. Аналогично, некоторые пакеты реформ напрямую включали подержание связей и ведение диалога с гражданским обществом, так как различное понимание этого сектора среди населения иногда серьезно затрудняло диалог в отношении реформ 
(См. Вуд, 2005 г.). Одной из причин недостаточного доверия является распространенное мнение о коррупции, существующей в секторе. Как результат, правительства, стремящиеся реформировать этот сектор, время от времени пытаются вовлечь гражданское общество в выявление проблем коррупции в этом секторе (Абдырасулова и др., 2013 г.).

В странах, где присутствует большой разрыв между текущими доходами сектора и его издержками, усилия по улучшению финансовой устойчивости могут высвободить значительные ресурсы для других целей. Таким образом, некоторые реформы успешно использовали эти ресурсы на производство товаров и услуг за пределами энергосектора, что получило высокую оценку общества. Так например, в Индонезии, отмена субсидий на бензин и (частично) на дизельное топливо высвободило дополнительные 15,6 млрд. долл. США, которые были перенаправлены, по крайне мере частично, на популярные виды услуг - здравоохранение, образование и развитие инфраструктуры (Прадиптио и др., 2016). Индонезия провела главную реформу в отношении субсидий на свое ископаемое топливо, отменив субсидии на бензин (за исключением издержек на распределение за пределами территории центральных островов: Ява, Бали и Мадура).

В целом, главный вывод, вытекающий из изученной литературы: контекст страны имеет значение и программы реформирования должны быть разработаны с учетом такой специфики. В следующем разделе приводится ряд конкретных примеров того, какие разные подходы использовали три страны к вопросу реформирования сектора энергетики.

\section{Практические примеры стран}

Армения. Саргсян и др., (2006 г.) описывают проблемы в секторе энергетики Армении, которые во многим схожи с теми, которые имеются в Кыргызской Республике. Например, распад Советского союза оставил Армению с энергетической системой, которая зависела от топлива, импортируемого из очень отдаленного источника, в то время как конфликт в регионе (с Азербайджаном и Турцией) привел к прекращению поставок нефти и газа. Землетрясение заставило Армению закрыть атомную электростанцию.

В результате, энергокризис, начавшийся в начале 1990-х годов, заставил Армению внедрить радикальные реформы. Субсидии в 1995 году были огромными, около 11\% ВВП, огромными были и коммерческие потери. Как следствие, правительством было принято решение приватизировать сектор, разделив генерирование, передачу и распределение; продав некоторые активы гидроэнергетики и создав независимого регулятора. Прежде всего были сокращены коммерческие потери, в основном, за счет переноса имеющихся приборов учета в общественные места (что намного усложнило фальсификации) и установки новых приборов учета с защитой от фальсификации и систем получения данных. В 2001 году правительство предприняло попытку приватизации сектора; эта инициатива не получила поддержки со стороны политической оппозиции внутри страны, и вместо этого, в 2002 году, правительство назначило «Midland Resources Holding» управляющим подрядчиком для распределительной системы. Это изменение резко улучшило показатели, увеличив сборы почти до 100\% и сократив потери до лишь 4\%. Более высокие цены позволили привлечь инвестиции в энергетическую эффективность, и правительство перешло от выплат в сектор существенных субсидий к получению прибыли от сектора. 

стран:

Саргсян и др., (2006 г.: 17) обобщили опыт Армении в 12 уроков для других

- Самый первый и самый важный урок: политическая воля имеет первостепенную важность.

- Естественное следствие первого урока: личности имеют значение.

- Не допускать контроля процесса со стороны заинтересованных сторон.

- Создать условия для «чемпионов» посредством поддержания с ними контактов по сути вопросов на раннем этапе.

- Первоначальная неудача может быть лучше, чем совсем не пытаться чтото сделать.

- Более частые и содержательные коммуникации между участниками тендера и собственником.

- В плане фактической реализации реформ, важен интегрированный, межсекторальный подход.

- Комплексный подход также означает принятие во внимание социального воздействия реформы, как элемента, отдельного от реформы энергосектора.

- Имеет смысл для правительства осуществить максимально возможный объем улучшений в секторе до приватизации.

- Важно, чтобы партнеры по развитию обеспечивали правильное сочетание структурных изменений и инвестиционного финансирования.

- При найме частного оператора, имеет смысл меньше фокусироваться на уровне инвестиций, которые оператор готов вложить, а больше фокусироваться на качестве услуг или других результатах.

- Правительства и партнеры по развитию должны учитывать необходимость адаптации стандартных тендерных требований и процедур к новому типу стратегического инвестора.

Саргсян и др., (2006 г.) аргументируют три фактора, которые были существенно важны для достижения успеха. Во-первых, тот факт, что правительство серьезно стремилось продолжать реализацию реформы, даже когда первоначальные попытки потерпели неудачу. Во-вторых, был предпринят широкий межсекторальный подход, который включал в себя хорошие коммуникации и социальную защиту для уязвимых слоев населения. В-третьих, то, что к решению проблем был применен адаптивный подход, рассматривающий их по мере возникновения, вместо того, чтобы иметь заранее подготовленный четкий план.

Доминиканская Республика. Инчаусте и Виктор (2017 г.) предоставили исчерпывающий отчет о проведении реформ в Доминиканской Республике с конца 1990-х годов. В 1998-1999 годах правительство разукрупнило сектор энергетики, создав при этом две генерирующие и три распределительные компании. Тем не менее, сектор продолжал работать плохо, с широко распространенными нелегальными подключениями, неуплатой счетов и тарифами, которые не отражали фактические издержки. В 2005 году правительство вновь предприняло попытку реформировать сектор (Правительство Доминиканской Республики, 2005 г.) путем повышения тарифов и сокращения потерь и привязав поставку энергии к оплате. Кроме того, правительство сделало попытку позволить ценам колебаться в соответствии с международными ценами на нефть и обменным кур- 
сом. (Правительство Доминиканской Республики, 2007 г.). К сожалению, в 2008 году резкое повышение цен на нефть привело к резкому увеличению субсидий до 2,75\% ВВП. Более того, распределение субсидий было регрессивным в абсолютном выражении, при этом верхний дециль получал субсидии в пять раз превышающие субсидии для беднейшего дециля. При этом, реформа бы ударила по бедным, потому что субсидии по-прежнему составляли значительную долю их доходов (МВФ, 2010 г.).

Коррупционный скандал в Доминиканской корпорации государственных электрических компаний (CDEEE) подтолкнул правительство, избранное в 2008 году, приступить к более скоординированным реформам. Программа субсидий была отменена и новая программа денежных трансфертов, называемая «Bonoluz», была разработана для того, чтобы компенсировать отмену субсидий бедным домохозяйствам. Программа «Bonoluz» покрывала стоимость первых 100 кВт/ч потребленной электроэнергии в месяц для бедных. Программа базировалась на административной системе существующей программы субсидий для потребителей газа, и использовала такие же критерии правомочности. Кроме того, правительство снизило порог, после которого домашние хозяйства не могли больше получать субсидии с 700 кВт/ч/в месяц до 300 кВт/ч/в месяц, и увеличило тарифы (Ваглиасинди, 2012 г.).

Мексика. Хузар и Китт (2016 г.) представили описание реформ в энергетической отрасли, предпринятых Мексикой в 2002 году. Эти реформы были начаты в качестве комплексного пакета реформ, направленных на серьезное сокращение размера субсидий с их отменой для потребителей, потребляющих свыше 140 кВт/ч в месяц. Реформы также предполагали сделать субсидии менее регрессивными, на тот момент три наименее обеспеченные категории потребителей получали $16 \%$ субсидий, в то время, как три наиболее обеспеченные категории получали 40\% (Комивес и др., 2009 г.).

Однако этот план столкнулся со значительной оппозицией. Люди в более жарких в регионах и фермеры, которые использовали электрические насосы для орошения, были против сокращения субсидий, как и Центральный банк, из-за опасений, что реформа спровоцирует инфляцию. С другой стороны, отдельные коммерческие предприятия и местные органы власти поддерживали реформы по той причине, что у них были бы более низкие тарифы, по сравнению с предшествующими (Хернандез, 2007 г.; SHCP, 2007 г.; SIA, 2002 г.). Этот план также не был поддержан в Конгрессе, который внес в него изменения, существенно снизив первоначальную экономию от реформы. Например, в 2003 году была принята Инициатива Переса де Альва («Iniciativa Pérez de Alva») направленная на предоставление льгот потребителям в северных штатах, которые не могли оплачивать счета; аналогичным образом, Инициатива «Любберта II» («Iniciativa Luebbert II») изменила классифицкацию потребителей в жарких зонах на группы с более низкими тарифами.

Более того, в то время, когда структура тарифов стала немного более прогрессивной, главным образом благодаря высоким тарифам для домашних хозяйств с высоким уровнем потребления энергии, тарифная система также стала намного более сложной со множеством тарифов, обусловленных климатом и переклассификацией хозяйств на различные категории. Все эти изменения означали, что систематические и структурные реформы были отброшены в угоду более маргинальных реформ в структуре тарифов. Мексика также воспользовалась 
своими программами социальной защиты для компенсации роста цен бедным хозяйствам. В 2007 году была введена в действие программа, называемая «Возможности энергетики» - «Oportunidades Energéticas», созданная на базе главной программы денежных трансфертов. Программа «Oportunidades» (сегодня она называется «Prospera»), включает элемент денежных трансфертов для покрытия расходов на энергию для бедных хозяйств в сельских районах. Однако эта программа была реализована в дополнение к электрическим субсидиям, а не в качестве механизма с целью их сокращения.

\section{5 Возможные дальнейшие шаги для сектора энергетики кыргызской республики}

\section{Планы по реформированию сектора}

Правительство Кыргызской Республики разработало комплексный национальный план развития, который включает сектор энергетики. План детально изложен в Документе «Единство, доверие, созидание» (Правительство Кыргызской Республики, 2018 г.), который описывает планы правительства в широком разнообразии сфер. В частности, правительство обозначило, что развитие сектора энергетики будет фокусироваться на трех основных сферах деятельности с целью достижения следующих целей:

(1) генерирование электроэнергии:

- обеспечение запасов энергии в размере 10\%;

- повышение установленной мощности существующих станций с 2025 до 4500 МВт;

- достижение уровня выработки электроэнергии до 16-17 млрд. кВт/ч.

(2) передача электроэнергии:

- обеспечение энергетической независимости от смежных энергосистем;

- достижение выработки электроэнергии на существующих и перспективных станциях;

- обеспечение необходимой мощности электрических сетей на 110500 кВ;

- продвижение предложений по проектам межгосударственных электрических линий (например, «CASA-1000»).

(3) распределение электроэнергии:

- обеспечение высокого качества услуг для потребителей;

- создание возможности технологического подсоединения для каждого клиента и полное устранение барьеров для подключения к электрическим сетям;

- обеспечение надежного и бесперебойного энергоснабжения («Smart Grid»). 
Эти цели могут быть достигнуты за счет реализации следующих четырех инициатив:

(1) запуск (строительство или модернизация) 15 ГЭС, 11 из которых - малые ГЭС, с целью обеспечения надежных и устойчивых поставок электроэнергии населению страны, обеспечения энергетической безопасности Кыргызской Республики и повышения энергетического потенциала для развития промышленности страны;

(2) разработка новой Среднесрочной тарифной политики на период с 2018 по 2023 годы;

(3) реализация проекта «CASA-10о0».

(4) реализация проекта «Smart Grid».

Цель запуска новых ГЭС заключается в увеличении генерирующих мощностей до 6503 МВТ к 2023 году. Это предполагает, что страна способна привлечь крупные инвестиции, в том числе для строительных проектов на Каракечинской ТЭС, Камбаратинской ГЭС-1, (общей мощностью 1860 МВТ) и Казарманском каскаде (1 160 МВт).

Достижение этого уровня инвестиций потребует разработки новой Среднесрочной тарифной политики на 2018-2023 годы. Согласно политике правительства, «уровень тарифов будет адекватно отражать потребительские возможности населения и уровень окупаемости энергосектора» (Правительство Кыргызской Республики, 2017 г.). Кроме того, предполагается, что тарифы будут (1) гибкими, зависеть от времени и периода потребления, а также от нужд различных категорий потребителей, и (2) будут обновляться на регулярной основе. Государственное агентство по регулированию топливно-энергетического комплекса разрабатывает эту политику, однако правительство пока не выпустило новую политику.

Для повышения экспортного потенциала сектора энергетики, правительство реализует проект «CASA-1000», который позволит экспортировать электроэнергию в Афганистан и Пакистан. На практике, строительство ЛЭП на 500 кВ протяженностью 477 км от подстанции Датка до подстанции Сугд (Таджикистан) начнется в 2018 году. Проект «CASA-1000» должен дать возможность энергокомпаниям получать чистый доход до 80 млн. долл. США ежегодно.

И наконец, реализация проекта «Smart Grid» будет состоять из четырех компонентов. Во-первых, реализация системы SCADA, ${ }^{16}$ которая обеспечит операторов возможностями осуществления контроля над технологическими процессами в режиме реального времени (например, обмен данными с приборами учета, логический контроль сети, сигнализация и управление аварийными ситуациями, а также мониторинг реализации проекта «CASA-1000»). Во-вторых, будет реализована полностью функционирующая автоматическая система коммерческого учета потребления электроэнергии (АСКУЭ). Это позволит удаленно считывать показания измерительных приборов, осуществлять мониторинг государственных электрических предприятий, рассчитывать параметры электрической сети, выстраивать графики нагрузок, рассчитывать балансы и много другое. В-третьих, планируется биллинговая система (система выставления счетов), которая позволит осуществлять единое управление рядом процессов, в том числе: информацией о подписчиках, центром обслуживания потребителей; сбором показаний измери16 SCADA: диспетчерское управление и сбор данных. 
тельных приборов и платежами. Она будет связана с системой АСКУЭ, обеспечивая автоматизацию потоков электроэнергии с привязкой к платежам. В-четвертых, планируется внедрение системы управления общеорганиазационными ресурсами в соответствующих энергокомпаниях.

\section{Важнейшие элементы реформирования сектора электроэнергии}

Пятилетняя стратегия правительства «Единство, доверие, созидание» дает отличную дорожную карту технических изменений, необходимых для достижения эффективного функционирования сектора энергетики в Кыргызской Республике. Однако, достижение этих инвестиций потребует уделить особое внимание пяти областям, некоторые из которых не получают достаточного внимания.

Долгосрочная финансовая устойчивость. Необходимая первоочередная и самая фундаментальная реформа - эффективная реализация новой тарифной политики. Основная причина низких финансовых показателей сектора в последние годы кроется в политике реализации электроэнергии по ценам, которые гораздо ниже себестоимости. Это способствует неэффективности энергетики, препятствует привлечению инвестиций в сектор и отнимает ресурсы у других социальных целей и целей развития. Существование независимого регулятора и рациональной методологии определения тарифов означает, что разработка новой СТП, которая постепенно переходит к самоокупаемости тарифов в принципе не является сложной. Намного сложнее придерживаться ее графика, принимая во внимание неизбежное политическое давление, которое возникает при существенном повышении тарифов. Опыт многих стран показывает, что несмотря на техническую независимость регулятора, на практике такие решения - это политический выбор. Поэтому ключом к долгосрочной финансовой устойчивости сектора является не вступление новой СТП в силу, а эффективная политическая стратегия по ее выполнению. Три вопроса, рассматриваемые в последующих разделах, являлись компонентами стратегий, применявшихся в других странах для получения согласия со стороны общества на реализацию изменений в тарифах.

Улучшение качества услуг. Граждане обычно не желают платить более высокий тариф, если не уверены в том, что получат что-то взамен. Провайдеры, следовательно, находятся в замкнутом круге проблем - неспособны предоставить услугу высокого качества из-за низких объемов выручки, которые в свою очередь обусловлены низкими тарифами. Если бы тарифы повысились, более высокий уровень качества был бы возможен, но повышение тарифа не будет принято пока улучшение качества услуг не будет очевидным.

Важным элементом решения этой проблемы является роль партнеров по развитию. Правительство уже инвестирует внушительные суммы в сектор при поддержке партнеров по развитию с целью существенного улучшения качества услуг, предоставляемых потребителям. Дальнейшие инвестиции такого характера могут продемонстрировать четкие улучшения надежности и качества поставок в течение относительно короткого периода времени. Это может дать возможность правительству продемонстрировать «добросовестность» в отношении потребителей, что усиливает восприятие закономерности повышения тарифов.

Защита малообеспеченных слоев, но также и среднего класса. У правительства уже имеется целый ряд программ, конкретно направленных на малообеспеченные домохозяйства, детей, престарелых и инвалидов. Улучшение охвата и качества этих программ может гарантировать, что повышение тарифов 
не будет иметь значительного отрицательного воздействия на самые бедные домохозяйства. Фактически, привязывание повышения тарифов к вливаниям средств в такие программы может продемонстрировать, что субсидии не изымаются, а «трансформируются» в более эффективные методы помощи бедным. Опыт других стран показывает, что уровень бедности может фактически снизиться в результате реформирования субсидий, по той причине, что у бедных домохозяйств появляются дополнительные ресурсы.

В то же время, одной из центральных дилемм реформирования субсидий является то, что как раз из-за регрессивного характера субсидий, группами, получающими сильнейший удар реформы субсидий в абсолютном выражении являются жители городов, которые по сравнению со своими сельскими согражданами, живут относительно лучше. Политическое противостояние относительно реформы в Мексике, как было описано выше, иллюстрирует данную проблему. Такие группы обычно более образованны и более активны в отстаивании своих позиций, чем сельское население, делая отмену льгот для таких групп политически сложным. В результате, успешные программы реформ зачастую подразумевают конкретные меры помощи таким группам (например, субсидирование повышения энергоэффективности для минимизации общих счетов). Еще один подход для предоставления ресурсов на популярные социальные программы, несущие выгоду для всего населения, как например улучшение всеобщего охвата, через программу реформы здравоохранения «Ден Соолук». Такие социальные программы имеют тенденцию оказания широкой поддержки и обычно более прогрессивны, чем энергосубсидии. Следовательно, хотя они не так эффективны в защите бедных, как адресные программы, они зачастую более приемлемы в политическом плане, так как они приносят выгоды более широким слоям населения, в том числе тем, кто больше всего теряет в результате реформ.

Борьба с коррупцией. Сектор электроэнергии во многих странах подвержен коррупционным проявлениям. Присуждение крупных контрактов на проекты по выработке и передаче создают возможности для коррупционных закупок, а существование субсидий создает широкое разнообразие непрозрачных финансовых потоков, которые также могут быть подвержены коррупции. Коррупция также усложняет осуществление тарифной реформы, и не без оснований, граждане не желают платить больше, если часть дополнительных сборов вероятно окажется в карманах коррупционеров. Однако, возможности для борьбы с коррупцией могут также создать возможность для проведения реформ, как показывает пример Доминиканской Республики. Другой пример: реформы субсидий в Нигерии в 2012 году были безуспешны как раз потому, что преобладало мнение, что правительство на тот момент было коррумпированным и поэтому повышение цен не было оправданным; последующее избрание в 2015 году Президента с сильной репутацией борца с коррупцией означало, что реформы, инициированные в последующем году, были восприняты с меньшим сопротивлением. Следовательно, усиленные и видимые меры по борьбе с коррупцией зачастую сопровождают успешную реформу субсидий.

Основная инициатива в области политики в этом плане заключается в требовании и поощрении прозрачности путем вовлечения гражданского общества в борьбу с коррупцией в секторе. Кыргызская Республика имеет успешный опыт осуществления таких инициатив. С 2005 по 2010 годы Инициатива прозрачности топливно-энергетического комплекса открыла сектор вниманию общественности и значительно улучшила подотчётность и прозрачность сектора. (Абдырасулова 
и др., 2013 г.). Однако, после завершения этой инициативы, введенные ею меры не были институционализированы. Аналогичная инициатива демонстрации заинтересованности правительства в борьбе с коррупцией могла бы помочь в выстраивании легитимности реформ и обеспечении их устойчивости.

Кризис и настойчивость. Как показали примеры конкретных стран выше, реформы субсидий зачастую инициируются в ответ на фискальный кризис, который делает режим субсидий непозволительным по стоимости. Кризис обеспечивает движущую мотивацию для реформы, хотя он может также сделать процесс реформ еще более болезненным по той причине, что они реализуются в период широкого экономического стресса. Однако, глубокий кризис может также представлять собой возможность испытания новых подходов, которые прежде были бы политически невозможны. Например, армянский кризис сделал возможной приватизацию, что в конечном итоге привело к отмене субсидий и эффективному функционированию сектора. Однако, приватизация, сама по себе, не является панацеей и попытки других стран решить проблемы приватизацией потерпели неудачу (например, Индия, Нигерия и Пакистан). Основным фактором успеха Армении была настойчивость относительно задачи реформ, и непрерывная адаптация с целью нахождения решения, подходящего для политического контекста страны.

Коммуникационная стратегия. В заключение, возможно одним и самым важным компонентом успешных программ реформ в международном плане была эффективная коммуникационная стратегия, одобренная и открыто поддерживаемая на самом высоком уровне правительства. Такие противоречивые реформы, как изменение тарифов, требующие доверия населения для обеспечения успеха, обычно более успешны, когда правительство открыто информирует граждан о причинах реформ и выгодах, которые она принесет (Хусар и Китт, 2016 г.). Проведение консультаций с гражданами и повсеместных дебатов помогает обеспечить широкое понимание имеющихся вариантов. Принятие во внимание мнений граждан о том, кто должен быть защищен и как, а также их предпочтений относительно расходования сэкономленных в результате средств, может помочь обеспечить легитимность и политическую защиту реформ. Зачастую такие реформы требуют времени и поэтому разработка эффективной постоянной коммуникационной стратегии - это ключ к формированию коалиций поддержки, необходимой для успеха. 


\section{Библиография}

Абдырасулова Н., Кравцов Н. и Сулайманова Д. 2013. Анализ систем распределения и потребления электроэнергии в Кыргызстане. Бишкек. http://www.unison.kg/sites/default/files/2013_analiz_edit_eng_o.pdf

Агентство международного развития США (ЮСАИД). 2011. Обзор стоимости электроэнергии. Проект. https://www.scribd.com/document/248468478/ Cost-of-Electricity-Review-in-Kyrgyzstan

Азиатский банк развития (АБР). 2017. Оценка сектора энергетики Кыргызской Республики. Манила.

Безант-Джонс Дж. 2006. Реформирование энергетических рынков в развивающихся странах: что мы узнали? Документ для обсуждений Совета по энергетике и горному делу, документ № 19. Вашингтон, О. К.: Всемирный банк.

Битон С., Лонтох Л. и Вай-Пой М. 2017. Индонезия: Реформы ценообразования, социальная помощь и значение восприятия, в: Политическая экономия реформы энергосубсидий, стр. 133-207. Вашингтон, О. К.: Всемирный банк.

Ваглиасинди М. 2012. Структура и эффективность рынка электроэнергии. Рабочий документ исследования политики 6123. Вашингтон, О. К.: Всемирный банк. https: // openknowledge. worldbank.org/handle/10986/11933

Всемирный банк. 2014. Документ политики энергосектора Кыргызской Республики. Апрель. https://openknowledge.worldbank.org/handle/10986/18652

Всемирный банк. 2017а. Анализ сектора энергетики Кыргызской Республики. https://openknowledge.worldbank.org/handle/10986/29045

Всемирный банк. 2017b. Влияние тарифов на электроэнергию на кыргызские домохозяйства, представлено на встрече партнеров по развитию, Бишкек, декабрь.

Всемирный банк. 2018. Ведение бизнеса за 2018 год: Проведение реформ для создания рабочих мест. Вашингтон, О. К.: Всемирный банк. http://www.doingbusiness.org/en/reports/global-reports/doing-business-2018

Всемирный банк. (без даты). Методология тарифов в секторе энергетики. Вашингтон, О. К.. Всемирный банк. Обследования предприятий. http://www.enterprisesurveys.org

Виктор Д. и Хеллер Т. 2008. Политическая экономия реформы энергосектора: Опыт пяти крупных развивающихся стран, Energy Journal. https://doi.org/10.1017/CBO9781107415324.004.

Вуд Д. 2005. Преодоление разрыва в управлении: гражданское общество, демократизация и реформа электроэнергетики, представлено на «Новых рубежах социальной политики», Аруша, Танзания, 12-15 декабря 2005 г.

Гассман Ф. 2014. Выключение света: воздействие повышения тарифов на электроэнергию на домохозяйства в Кыргызской Республике. Журнал сравнительной экономики. Elsevier. 42 (3), с. 755-69

Гасснер К. В., Розенталь Н. и Ханкинсон Д. Дж. 2017. Анализ энергетического сектора Кыргызской Республики. Вашингтон, О. К.: Всемирный банк. 
http://documents.worldbank.org/curated/en/ 370411513356783137/Analysisof-the-Kyrgyz-Republics-Energy-Sector

Гратвик К. Н. и Эберхард А. 2008. Разбор стандартных моделей для реформы энергосектора и возникновение гибридных энергетических рынков, Политика энергосектора, 36(10): pp. 3948-396o. http://dx.doi.org/10.1016/ j.enpol.2008.07.021.

Дубаш Н. К. и Раджан С. Ц. оо1. Политика энергосектора: процесс реформы энергосектора в Индии. Экономический и политический еженедельник, 36(35), стр. 3367-3390. https://do.org/10.2307/4411059.

Инчаусте Г. и Виктор Д. 2017. Политическая экономия реформы энергетических субсидий. Вашингтон, О.К.: Всемирный банк. https://doi.org/10.1596/ 978-1-4648-1007-7.

Йосков П. 2006. Конкурентные рынки электроэнергии и инвестиции в новые генерирующие мощности. Рабочий документ AEI-Brookings Joint Center № o6-14. https://dx.doi.org/10.2139/ssrn.902005

Кожима М., Бейкон Р. и Тримбл С. 2014. Политическая экономия субсидий в энергосекторе : Обзор на основе стран Африки к югу от Сахары. Вашингтон, О. К.: Всемирный банк. http://documents.worldbank.org/ curated/en/860371467990087260/Political-economy-of-power-sectorsubsidiesa-review-with-reference-to-Sub-Saharan-Africa

Комивес К., Джонсон Т., Халперн Дж., Абурто Дж. и Скотт Дж. 2009. Субсидии на бытовую электроэнергию в Мексике: изучение вариантов реформирования и усиления воздействия на бедных. Рабочий документ № 160. Вашингтон, O. К.: Всемирный банк. https://openknowledge.worldbank.org/handle/ 10986/5959

Курманбек А. 2016. Политика оптимизации тарифов на энергию в Кыргызской Республике. Центрально-Европейский университет. Будапешт, Венгрия. https://doi.org/10.1146/annurev.energy. 30.050504.144321.

Литтлчайлд С. 2006. Предисловие: Рынок против регулирования. Сишанси и Пфаффенбергер (ред.). Реформа рынка электроэнергии: международная перспектива. Оксфорд: Elsevier.

Международное энергетическое агентство (МЭА). 2017. Международные энергетические балансы. 2017. Париж.

Международное энергетическое агентство (МЭА). 2017. Кыргызская Республика: балансы за 2015 год. http://www.iea.org/statistics/statisticssearch/report/ ?country=Kyrgyzstan\&product=balances (по состоянию на 23 марта 2018 г.).

Международная сеть обследования домашних хозяйств (IHSN). 2017. Кыргызская Республика - Интегрированное обследование кыргызских домохозяйств в 2015 году - Модуль миграции. http://catalog.ihsn.org/index.php/ catalog/6718/study-description

Международный валютный фонд (МВФ). 2010. Доминиканская Республика: отчет персонала для консультаций 2009 года по Статье IV и запрос на резервное соглашение; Дополнение к отчету персонала и заявлению персонала; Публичное информационное сообщение и пресс-релиз об обсуждении в Совете. Страновой отчет 10/135. Вашингтон, О. К.: МВФ. 
Международный валютный фонд (МВФ). 2017а. Субсидии в Кыргызской Республике. Обзор энергосубсидий и социальной защиты. Отчет по технической помощиМарт 2017. Вашингтон, О. К.

Правительство Доминиканской Республики. 2005. Доминиканская Республика: Письмо о намерениях, Меморандум по экономической и финансовой политике и Технический меморандум о взаимопонимании. Санто-Доминго, 14 января. http://www.imf.org/external/np/loi/2005/dom/011405.pdf.

Правительство Доминиканской Республики. 2007. Доминиканская Республика: Письмо о намерениях, Меморандум по экономической и финансовой политике и Технический меморандум о взаимопонимании. Санто-Доминго, 31 января. http://www.imf.org/external/np/loi/2007/dom/013107.pdf.

Правительство Кыргызской Республики. 2013. План действий по реформированию энергосектора на 2013-2014 годы. Постановление №299. Бишкек.

Правительство Кыргызской Республики. 2017. Об организационных мерах в связи с утверждением новой структуры Правительства Кыргызской Республики. Постановление №768. Бишкек.

Правительство Кыргызской Республики. 2016. О Государственном комитете промышленности, энергетики и недропользования Кыргызской Республики. Постановление №373. Бишкек.

Правительство Кыргызской Республики. 2017. 40 шагов к новой эпохе на период 2018-2023 гг. Бишкек.

Правительство Кыргызской Республики. 2018. Программа развития Кыргызской Республики на период 2018-2022 гг. «Единство, доверие, созидание». Бишкек.

Правительство Кыргызской Республики. Постановления №396 (2017 г.), №421 (2016 г.), №527 (2015 г.) и № 660 (2014 г.)

Министерство энергетики и промышленности (МЭиП) Кыргызской Республики. 2013. Развитие возобновляемых источников энергии. Презентация PowerPoint.

Прадиптио Р., Сусамто А., Виротомо А., Адисасмита А. и Битон С. 2016. Финансирование развития с субсидиями на ископаемое топливо: перераспределение субсидий на бензин и дизельное топливо в Индонезии, 2015. Виннипег: Международный институт устойчивого развития.

Саргсян Г., Балабанян А. и Ханкинсон Д. 2006. От кризиса до стабильности в энергосекторе Армении: Полученные уроки в ходе реформирования сектора энергетики Армении, Всемирный банк, Рабочий документ. Вашингтон, O. К.: Всемирный банк. http://siteresources.worldbank.org/INTARMENIA/ Resources/ Armenia-Energy-Crisis-to-Stability.pdf

Скотт А. и Сет П. 2013. Политическая экономия распределения электроэнергии в развивающихся странах. Обзор литературы. https://www.odi.org/sites/ odi.org.uk/files/odi-assets/publications-opinion-files/8332.pdf.

Сыдыкова М. 2015. Диагностика ограничений роста в Центральной Азии: Пример Кыргызской Республики. Документ представлен на 55-м Конгрессе Европейской региональной научной ассоциации: «Мировой ренессанс: 
изменение роли людей и мест», 25-29 августа 2015 г., Лиссабон, Португалия. Louvain La Neuve: Европейская региональная научная ассоциация (ERSA). http://www.econstor.eu/handle/ 10419/124845.

Тонгия Р. 2003. Политическая экономия энергетики в Индии. Рабочий документ № 4, Стэнфорд: Центр экологической науки и политики, Стэндфордский институт международных исследований. стр. 19-20.

Тримбл С., Коджима М., Перез Арройо И. и Мохаммадзаде Ф. 2016. Финансовая устойчивость секторов электроэнергии в странах Африки к югу от Сахары. Квазифискальный дефицит и скрытые издержки. Рабочий документ по исследованию политики 7788. Вашингтон, О. К.: Всемирный банк. https://openknowledge.worldbank.org/handle/10986/24869.

Хант С. 2002. Как заставить конкуренцию работать в области электричества. Нью-Йорк: Wiley

Хари В. 2016. Цены на топливо и реформы субсидий в Азии после падения цен на нефть в 2014 году: сравнительное исследование стратегий. Сингапур. Vanda Insights. https://vandainsights.com/wp-content/uploads/2017/o7/SPGlobal_ Fuel_Pricing_Reforms_2016-11-09.pdf

Хусар Дж. и Китт Ф. 2016. Серии по странам-партнерам - реформа субсидий на ископаемые источники энергии в Мексике и Индонезии в 2016 году. Париж: МЭА. https://www.iea.org/publications/freepublications/ publication/ PartnerCountrySeriesFossi l_Fuel_Subsidy_Reform_Mexico_Indonesia_2016_ WEB.pdf

Чойновски П.2004. Реструктуризация и регулятивная реформа в энергетическом секторе: обзор опыта и проблемы. Манила: Азиатский банк развития.

Эберхард А., Гратвик К., Морелла Е. и Антманн П. 2016. Независимые энергетичские проекты в странах Африки к югу от Сахары: Уроки из пяти основных стран, направления в развитии. Энергетика и горнодобывающая отрасль. doi:10.1596/978-1-4648-0800-5.

Enerdata. База данных Enerdata. http://www.enerdata.net (по состоянию на март 2018 г.)

Эрнандез Ч. 2007. La Reforma Cautiva: Inversión, Trabajo y Empresa en el Sector Eléctrico Mexicano (Реформа: инвестиции, труд и предпринимательство в мексиканском секторе электроэнергетики). г. Мехико: Centro de Investigacion para el Desarrollo (CIDAC). стр. 50-6o.

M-Vector. 2017. Исследование общественной осведомленности о реформах энергосектора в Кыргызской Республике. Анализ энергетического сектора Кыргызской Республики. Вашингтон, О. К.: Всемирный банк. https://openknowledge.worldbank.org/handle/10986/29045

Secretaría de Hacienda y Crédito Público (Министерство финансов Мексики). 2007. Acuerdo que autoriza el ajuste, modificación y reestructuración a las tarifas para suministro y venta de energía eléctrica y reduce el subsidio a las tarifas domésticas (Соглашение, разрешающее регулирование, изменение и реструктуризацию сборов за поставку и продажу электроэнергии и сокращение внутренних субсидий и сокращение внутренних субсидий) www.cfe.gob.mx/casa/ Conocetutarifa/Paginas/Acuerdos-que-autorizan-o-modificantarifas.aspx 
Servicio de Investigación y Análisis de la Cámara de Diputados (SIA-Служба исследований и анализа). 2002. Tarifas eléctricas: Impacto en los hogares mexicanos por el incremento de las tarifas eléctricas residenciales. Análisis por deciles de ingresos [[Тарифы на электроэнергию: влияние на мексиканские домохозяйства из-за повышения тарифов на электроэнергию для населения. Анализ по децилям доходов]. Мехико: SIA. www.diputados.gob.mx/ sedia/sia/se/SIA-DEC-30-2002.pdf. 


\title{
Глава 8
}

\section{Развитие}

\section{человечеckoro notehuhana АЛЯ ИНКЛЮзивHOFO рOста}

\author{
Дамир Эсеналиев и Киоши Танагучи
}

\section{1. Введение}

() данной главе представлены последние достижения в области развития человеческого потенциала в Кыргызской Республике; рассматриваются данные рынка труда, миграции, образования, навыков и определенные демографические факторы. В основу данной главы легли последние статистические данные, аналитические и программные документы, и научные статьи.

Кыргызская Республика является страной с уровнем дохода чуть ниже среднего; численность населения, по данным на 2018 год, самая низкая среди Центрально-Азиатских стран и составляет более 6 миллионов человек. Согласно докладу ПРООН о человеческом развитии за 2016 год, страна занимает 120-е место среди 188 стран по уровню человеческого развития, то есть входит в группу стран со средним рейтингом (ПРООН, 2016). Сравнение показателей по развитию человеческого потенциала по странам Центрально- Азиатского региона выявило, что показатели Кыргызской Республики вполне сопоставимы с показателями соседних стран (Таблица 8.1). В стране более высокая продолжительность жизни; республика занимает второе место по продолжительности школьного обучения, но проигрывает соседям по уровню участия на рынке труда и по уровню использования Интернета.

Среди последних, важных для развития страны, событий было присоединение к Евразийскому экономическому союзу (ЕАЭС) в середине 2015 года. Хотя и ожидалось, что членство в ЕАЭС принесет немедленные экономические выгоды, первые два года членства были отмечены проведением сложных согласований, которые совпали с периодом экономического спада в Российской Федерации и более низким темпом экономического роста Казахстана, двух ключевых членов ЕАЭС. В то время как некоторые из внутренних секторов экономики (например, молочная промышленность) столкнулись с высокой конкуренцией с другими странами - членами ЕАЭС, другие сектора выиграли от правил свободной торговли и послабления регулирования. Одним из главных положительных последствий вступления в Евразийский экономический союз стал облегченный процесс миграции в страны ЕАЭС, в основном, в Российскую Федерацию. Создание прак- 
тически единого рынка труда имеет как положительные, так и отрицательные последствия для рынка труда Кыргызстана.

\section{Таблица 8.1: Отдельные показатели по человеческому развитию, 2015}

\begin{tabular}{|c|c|c|c|c|c|c|}
\hline Показатель & Армения & Казахстан & $\begin{array}{c}\text { Кыргыз- } \\
\text { стан }\end{array}$ & $\begin{array}{l}\text { Российская } \\
\text { Федерация }\end{array}$ & $\begin{array}{l}\text { Таджики- } \\
\text { стан }\end{array}$ & $\begin{array}{c}\text { Узбеки- } \\
\text { стан }\end{array}$ \\
\hline Население (млн) & 3,0 & 17,6 & 5,9 & 143,5 & 8,5 & 29,9 \\
\hline $\begin{array}{l}\text { Ожидаемая продолжительность } \\
\text { жизни при рождении (годы) }\end{array}$ & 74,9 & 69,6 & 70,8 & 70,3 & 69,6 & 69,4 \\
\hline ИЧР (уровень) & 84 & 56 & 120 & 49 & 129 & 105 \\
\hline ИЧР (ценность) & 0,74 & 0,79 & 0,66 & 0,80 & 0,63 & 0,70 \\
\hline $\begin{array}{l}\text { Продолжительность школьного } \\
\text { обучения }\end{array}$ & 12,7 & 15,0 & 13,0 & 15,0 & 11,3 & 12,2 \\
\hline $\begin{array}{l}\text { Кол-во занятых, относительно } \\
\text { всего населения, \% }\end{array}$ & 53 & 67 & 58 & 60 & 61 & 56 \\
\hline Индекс гендерного развития & 0,99 & 1,01 & 0,97 & 1,02 & 0,93 & 0,95 \\
\hline $\begin{array}{l}\text { Пользователи интернета, } \\
\text { \% населения }\end{array}$ & 58 & 73 & 30 & 73 & 19 & 43 \\
\hline
\end{tabular}

ИчР *- Индекс человеческого развития.

Источник: ПРООН (2016)

В этой главе, разделах 2 и 3, рассматриваются текущие изменения на рынке труда Кыргызской Республики; рассматриваются вопросы как занятости, так и безработицы, вопросы участия молодежи и женщин на рынке труда. В разделе 4, посвященном трудовой миграции, приводятся последние данные об уровне денежных переводов и дается анализ тенденций в области трудовой миграции. В разделах 5 и 6 анализируется ситуация, сложившаяся в области образования; проводится сопоставление получаемых навыков и необходимых навыков для трудоустройства. В разделе 7 рассматриваются демографические вопросы и вопросы здравоохранения. В последнем, завершающем разделе, предлагаются ключевые идеи, выводы и рекомендации.

\section{2. Занятость}

В Кыргызской Республике наблюдается избыток рабочей силы, поскольку темпы экономического роста и создания рабочих мест отстают от темпов роста населения. Большая часть населения трудоустраивается, в основном, в секторе услуг и сельском хозяйстве, в меньшей степени - в промышленности. За десятилетие до 2016 года, в экономике Кыргызской Республики происходило перемещение рабочей силы из низко производительного сектора сельского хозяйства в сферу услуг и в трудовую миграцию за границу (следуя модели Льюиса). Результаты анализа ниже показывают, что увеличилось количество краткосрочных оплачиваемых работ и уменьшилось количество официальных рабочих мест. Большую нишу занимает так называемая само занятость, в основном, в сельских районах. В данном разделе суммируются последние изменения в вопросах трудоустройства в республике; приводятся результаты последних исследований, основные положения статистических отчетов, результаты исследования рынка рабочей силы, а также 
некоторые данные на уровне индивида и/или домохозяйства (Вставка 2). В основном используются данные «Интегрированного обследования домохозяйств Кыргызской Республики» (ИОДХ) и исследования «Жизнь в Кыргызстане» (ЖвК). ${ }^{1}$ В первом разделе представлены данные о последних изменениях на рынке труда и в политике рынка труда. Последующие три раздела рассматривают вопросы, связанные с трудоустройством в целом, а затем с занятостью по найму и другим видам занятости.

\section{Результаты анализа рынка труда}

Все больше людей трудоустраиваются в различных секторах экономики, но не всем удается найти работу (Таблица 8.2). Ежегодный прирост населения трудоспособного возраста в Кыргызстане в период с 1995 по 2016 год составлял 2,8\%, в то время как рост рабочей силы составлял только 1,8\% в указанный период. По данным 2016 года, численность экономически активного населения была на $38 \%$ выше по сравнению с 1991 годом. Тем не менее, уровень участия на рынке труда, включая работающих за рубежом, снизился с $76 \%$ в середине 1990-х годов до 62\% в 2015 году и, в основном, это объяснялось сокращением участия женщин на рынке труда.

\section{Таблица 8.2: Показатели рынка труда, 1991-2015}

\begin{tabular}{|c|c|c|c|c|c|c|}
\hline Показатели & 1991 & 1995 & 2000 & 2005 & 2010 & 2015 \\
\hline Всего трудоустроено, кол-во & 1754 & 1642 & 1768 & 2077 & 2244 & 2352 \\
\hline Уровень роста занятости населения, \% & - & $-6,4$ & 7,7 & 17,5 & 8,0 & 4,8 \\
\hline Уровень участия, \% от кол-ва взрослого населения & - & 76,0 & 71,2 & 64,8 & 64,2 & 62,4 \\
\hline Уровень безработицы, \% & $0,3^{\text {a) }}$ & 5,7 & 7,5 & 8,1 & 8,4 & 7,6 \\
\hline
\end{tabular}

- = данные отсутствуют.

а Данные относятся к 1992 году;

Замечание: показатель занятости и уровня участия включают работников, занятых за рубежом.

Источник: Национальный статистический комитет Кыргызской Республики, 2016

Уровень безработицы, по данным исследований рынка рабочей силы, в последние годы составляет около 7-8\%. Самый высокий уровень безработицы наблюдается среди молодежи и в городских районах. Официальная статистика показывает значение безработицы в 2-3\% от общего количества экономически активного населения. Этот показатель исчисляется на основании количества претендентов на пособия по безработице; эта цифра показывает количество людей, потерявших работу и в прошлом занимавших официальные рабочие места.

Доля неактивного населения растет. Основными причинами этого феномена являются (1) недостаток производительных рабочих мест, (2) трудовая миграция (через увеличение уровня приемлемой заработной платы - то есть минимального уровня оплаты труда, который побуждает работника согласиться на предложенную работу и перераспределения внутрисемейных ролей в семьях мигрантов), (3) недостаточность дошкольных учреждений для родителей, имеющих маленьких детей, а также (4) укрепление социальных норм, которые делают упор

Комплексное обследование домохозяйств Кыргызской Республики: 
на уменьшение значимости работающих женщин и увеличение значимости роли женщин в домашнем хозяйстве.

Политика рынка труда за последнее время практически не изменилась. Хотя политика в области занятости и миграции занимает важное место в политической повестке дня, возможности правительства Кыргызстана по активной реализации своих решений - ограничены. Бюджеты на пособия по безработице или активную трудовую политику, например, проведение переподготовки, очень малы. Минимальная заработная плата на протяжении многих лет была настолько низкой, что стала использоваться только для установления базового уровня социальных выплат.

\section{Занятость}

Структура занятости в Кыргызской Республике претерпела существенные изменения. В то время как в постсоветской экономике занятость распределялась более или менее равномерно по всем секторам экономики: сельское хозяйство, промышленность, сфера услуг; то последние доступные цифры показывают, что каждый второй трудоустроен в сфере услуг, около 29\% - в сельском хозяйстве и около 21\% - в промышленности и строительстве (Рисунок 8.1). Таким образом, самым большим недавним изменением стало перемещение рабочей силы из сельского хозяйства в сферу услуг. Если на начало 2000-х годов в сельском хозяйстве было занято около 53\% от всех работающих, то впоследствии это количество неуклонно снижалось и в 2015 году достигло значения менее 30\%.

\section{Вставка 8.1: Источники данных по рынку рабочей силы в Кыргызской Республике}

Основным источником данных по рынку труда являются результаты Интегрированного обследования домохозяйств Кыргызской Республики (ИОДХ), включающее обследование рабочей силы (ОРС). В рамках ИОДХ обследуются около пяти (5) тысяч домохозяйств. Впервые Национальный статистический комитет (НСК) провел ИОДХ в 2003 году и с тех пор данные собираются ежегодно. ОРС проводится ежеквартально и данные публикуются статистическим комитетом ежегодно (например, НСК 2017). ИОДХ - важный источник данных по уровню бедности, продовольственной безопасности, здравоохранения и доступа к услугам. Цикл проведения ОРС (сбор, обработка и публикации данных) представляется не достаточно быстрым для разработки политики, поскольку на публикацию данных по рынку рабочей силы и уровню бедности уходит несколько месяцев.

Еще одним источником данных по вопросу рынка труда является исследование Жизнь в Кыргызстане (ЖвК). Жизнь в Кыргызстане является панельным исследованием (многократно повторяющимся исследованием одной и той же совокупности через определенное время по одной и той же программе и методике) более восьми (8) тысяч респондентов и трех (3) тысяч домохозяйств; исследование начали проводить с 2010 года (Брюк и др., 2014). С того времени исследование ЖвК проводилось четыре (4) раза, в 2011, 2012, 2013 и 2016 годах. Данные собираются раз в год, в октябре ноябре. Информация о рынке труда собирается при проведении ЖвК, но следует учесть, что информация, получаемая в рамках ИОДХ - более детальна. Основной плюс исследования ЖвК в том, что это панельное исследование и данные носят как субъективный, так и объективный характер. 
Официальные данные по уровню безработицы, получаемые из Министерства труда и социальной защиты, исчисляются на основании количества претендентов на пособия по безработице.

Статистика по рынку труда в Кыргызстане не вполне согласуется с данными по трудовой миграции. С учетом того, что количество работающих за рубежом варьируется в пределах от 0,5 до миллиона человек, количество экономически активных жителей в стране должно быть меньше, чем отражено в данных НСК. НСК включает работающих за рубежом в общее количество экономически активных жителей. Например, в 2015 году количество экономически активных жителей исчислялось 2,5 миллионами, из которых 0,29 миллиона - это работающие за рубежом. Если количество работающих за рубежом вычесть из вышеназванной цифры, то доля работающих (участвующих на рынке труда) среди трудоспособного населения будет 67\%, а не 70\%, как указано в статистике, и уровень безработицы будет 8,4\%, что выше указанных 7,6\%. И даже эти цифры не полные, так как не учитывают «постоянных» мигрантов и тех, кто уехал за рубеж с семьями и, соответственно, они не попали в число респондентов при проведении исследований.

Источник: Эсеналиев, Крёгер и Штайнер (2011), НСК (2017), Брюк и др. (2014), данные ЖвК, предоставленные авторами.

\section{Рисунок 8.1: Кол-во занятых в основных секторах, 1991-2015}

(тыс.работающих)

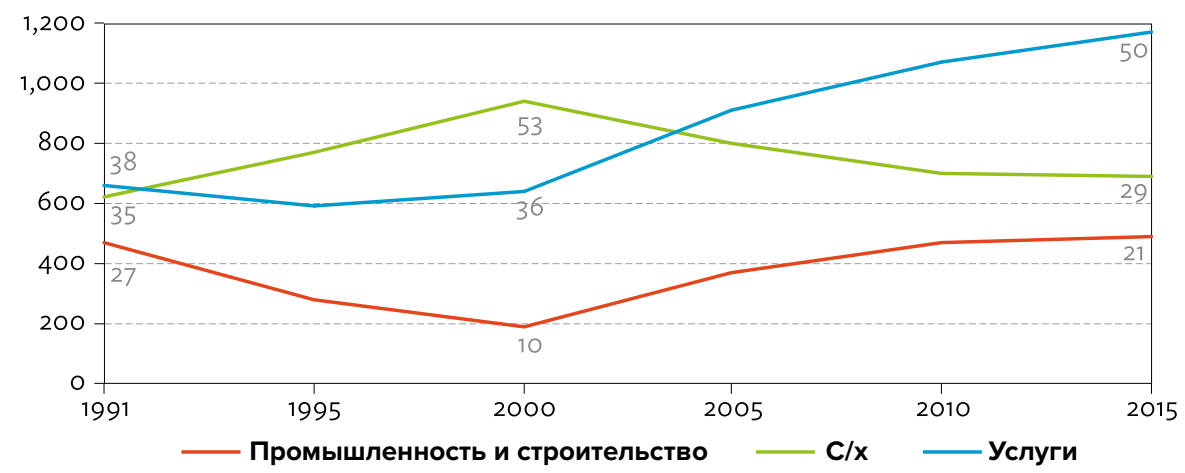

Источник: НСК, 2017

Различия в уровне производительности в разных секторах экономики могут привести к структурным сдвигам на рынке труда Кыргызстана. На рисунке 8.2 показано, что «вклад» в ВВП каждого работника, занятого в промышленности, выше, чем в любом другом секторе, а самый низкий «вклад» - в сельском хозяйстве (Рисунок 8.2). Эти факты могут объяснить недавний отток рабочей силы из сектора сельского хозяйства в сектор услуг Промышленный сектор является относительно капиталоёмким и, по-видимому, большую роль в этом играет вклад горнодобывающих предприятий, среди которых предприятия по добычи золота - ключевые. В течение периода с 1993 по 2015 гг. сельское хозяйство отставало от всех секторов, и рост производительности труда был не столь быстрым, как в трех других секторах. Сектор строительства, по количеству работающих, выглядит достаточно крупным. Данные в середине 2000-х годов указывают на снижение уровня производительности труда в этом секторе, чем в сельском хозяйстве, хотя это может быть следствием статистической классификации сектора. 
Рисунок 8.2: Номинальное значение ВВП на работника, по секторам, 1993-2015, (тыс. сом)

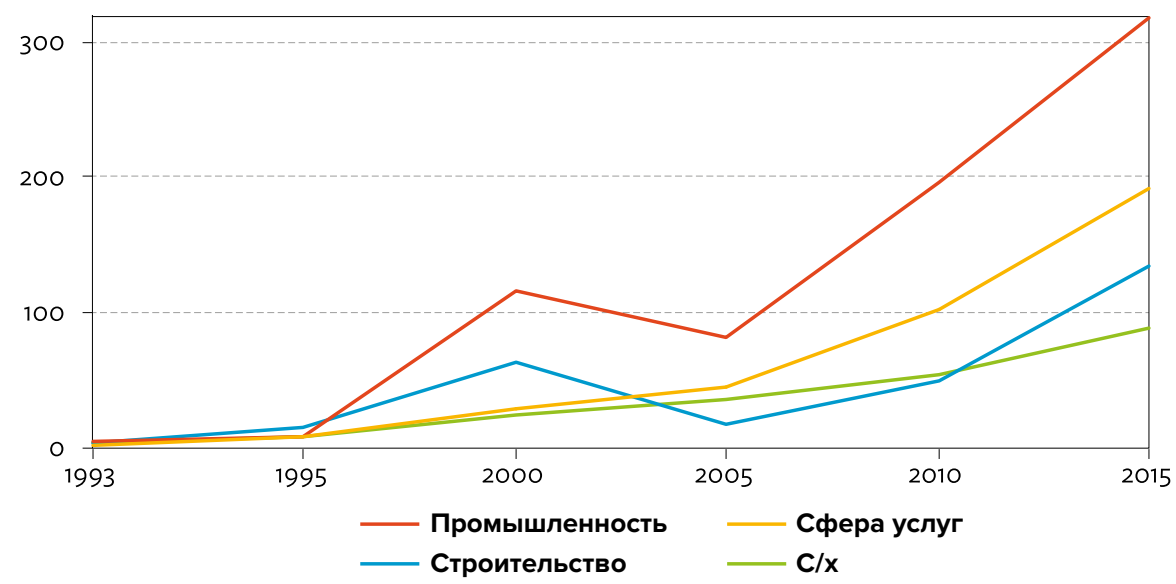

Источник: НСК, 2017с

Значимое изменение на рынке труда, с точки зрения спроса, состоит в том, что все больше физических лиц выступают работодателями, создавая рабочие места. В то время, как компании и фермерские хозяйства обеспечивают работой в различных секторах экономики каждому третьему из числа трудоспособных людей, вторая по значимости группа, создающая рабочие места и обеспечивающая занятость - это физические лица нанимающие других физических лиц. Факт появления такой группы работодателей (как правило в сфере малого бизнеса) заслуживает большего внимания. Можно сказать, что работники, ушедшие из сектора сельского хозяйства, либо стали наниматься на краткосрочную оплачиваемую работу в других секторах, либо стали работать на себя. (Рисунок 8.3).

Между северным и южным регионами нет принципиальной разницы в уровне занятости, то есть количество работающих приблизительно одинаково. Но поскольку трудовые мигранты - это, в основном, жители южных регионов: Баткен, Жалал-Абад, Ош, то доля работающих в северном регионе выше.

\section{Рисунок 8.3: Место основной работы, 2005-2015}

(\% от общего количества занятых)

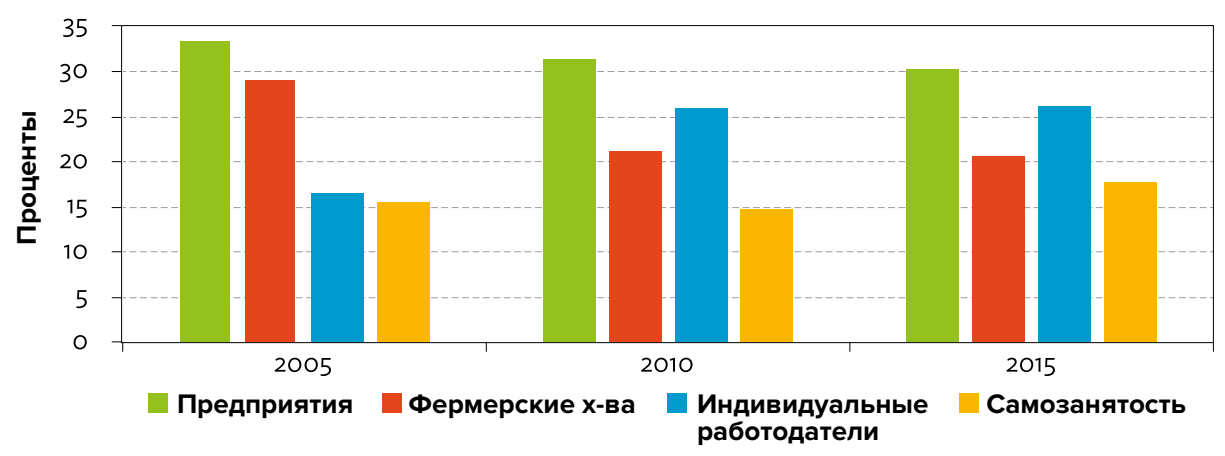

Источник: HCK, 2017с 


\section{Наемные работники}

Доля наемных работников в Кыргызской экономике растет. В 2015 году таковая доля составляла около 55\% по сравнению с 49\% в 2005 году. Три пятых от числа работающих в 2015 году являлись наемными работниками и были трудоустроены на предприятиях, две пятых - наняты индивидуальными лицами. Категория «наемные работники, нанятые индивидуальными лицами» вводит в заблуждение, поскольку сюда же относятся «помогающие по домохозяйству», которые составляют около половины этого числа.

Контрактный характер трудоустройства наемных работников подвергся значительным изменениям. Доля работников, имеющих постоянные контракты, снизилась с $62 \%$ в 2005 году до $46 \%$ в 2015 году, что означает снижение в общем качества рабочих мест (Вставка 8.2). Эта тенденция совпадает с направлением глобального развития (МОТ, 2015), другая тенденция - увеличение количества контрактов, заключаемых на фиксированный срок, не распространилась в Кыргызстане. Это указывает на то, что официальные рабочие места заменяются на неофициальные. Вызывающим настороженность фактором являются так называемые «устные» контракты, количество которых постоянно увеличивается. Эти контракты ставят работников в невыгодное положение (Рисунок 8.4).

\section{Рисунок 8.4: Типы трудового договора для наёмных работников (\% от общего количества работающих)}

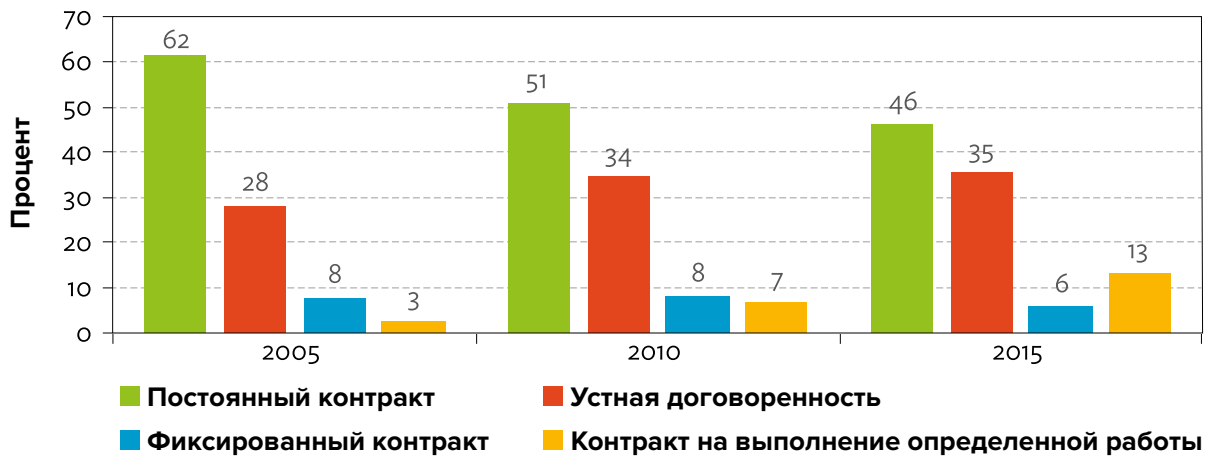

Источник: НСК, 2017с.

\section{Вставка 8.2: Качество работы в Кыргызской Республике}

Измерение «хорошей» работы изменилось с точки зрения рассмотрения не только размера получаемого дохода и длительности рабочего времени, но и дополнительно учета субъективных характеристик рабочих мест, таких как автономия, стабильность и формальность. Считается, что эти комплексные подходы помогают не только охарактеризовать важные аспекты работы, но и обогатить анализ качества рабочих мест. Например, «удовлетворенность жизнью» хорошо объясняется комплексной моделью «хорошая работа», описанной в работе Эсеналиева и Фергюсона (2017). В этой работе проверяется обоснованность концепции многомерности понимания качества работы; разработан индекс качества работы, состоящий из 6 (шести) компонентов. Индекс разработан на основе данных, полученных в результате проведения исследования Жизнь в Кыргызстане в 2013 году. В этой работе выявлено, что мужчины 
имеют лучшие рабочие места, нежели женщины на рынке труда Кыргызстана, хотя между регионами больших различий не существует. Статья способствует углублению наших знаний о важности измерения качества работы в определенном, специфическом контексте, и важности постановки политических целей, которые были бы направлены на увеличение количества рабочих мест и создание более качественных рабочих мест в развивающихся странах.

Источник: Эсеналиев и Фергюсон (2017).

Появление работы, выполняемой по устной договоренности, и рабочих мест, основанных на устном соглашении, ведет к тому, что характерные черты «хорошей» работы, как то: оплачиваемый ежегодный отпуск, отпуск по временной нетрудоспособности, отпуск по беременности и рождению ребенка - в таких контрактах не учитываются. Не ведется учет отработанного времени, нет записей в трудовой книжке, не производятся социальные и налоговые вычеты. Все это снижает социальную защищенность работников и их семей в целом.

\section{Работники не по найму}

Работники, занятые не по найму, в основном, представлены само занятыми. Эта группа включает в себя работодателей, самозанятых, неоплачиваемых членов домохозяйств, семейные фирмы и членов кооперативов. Из пяти работников не по найму, трое - работают на себя, один - является членом домохозяйства, еще один - либо представляет семейную фирму, либо является членом кооператива. В целом, доля работников не по найму сокращается, хотя абсолютное количество этих работников стабильно составляет около 1 миллиона человек.

Самозанятость - это, в основном, доминирующая деятельность мужчин в сельских районах. Около трех четвертей самозанятых составляют мужчины; такая же доля проживают в сельских районах. На данный момент в процессе самозанятости наступила стагнация, поскольку количество людей, занятых в бизнесе, не увеличивается. Предпринимательство - не является идеальным вариантов начала рабочей карьеры. Уровень конкуренции среди малых и средних предприятий высок; предприятия в некоторых секторах объединяются, тем самым ужесточая конкуренцию. Например, если раньше в секторе розничной торговли рынки и небольшие магазины были основными точками покупок населения, то сейчас значение супермаркетов быстро растет в городах.

В сельских районах по-прежнему сохраняется проблема неполной занятости, поскольку работа в сельскохозяйственном секторе носит сезонный характер. В зимние месяцы (декабрь-февраль) работы практически не ведутся. Среднее число отработанных в течение года часов работником, занятого в сельскохозяйственном производстве, увеличилось с примерно 30 часов в неделю в 2005 году до почти 33 часов в неделю в 2015 году (Рисунок 8.5). На рисунке показано, что количество рабочего времени увеличилось на четыре (4) часа в неделю в первом календарном квартале, а в четвертом квартале - на семь (7) часов/неделю. Возможно, это результат оттока работников из сельского хозяйства и увеличения количества наёмных работников (получающих зарплату) на рынке труда в сельской местности. Среднее количество рабочего времени в городских районах остается стабильным, приблизительно 41 - 42 часа в неделю, наблюдается лишь малое увеличение в период с 2005 по 2015 годы. 
Рисунок 8.5: Среднее кол-во отработанных часов в сельской местности, 2005-2015 (часов/неделю на человека)

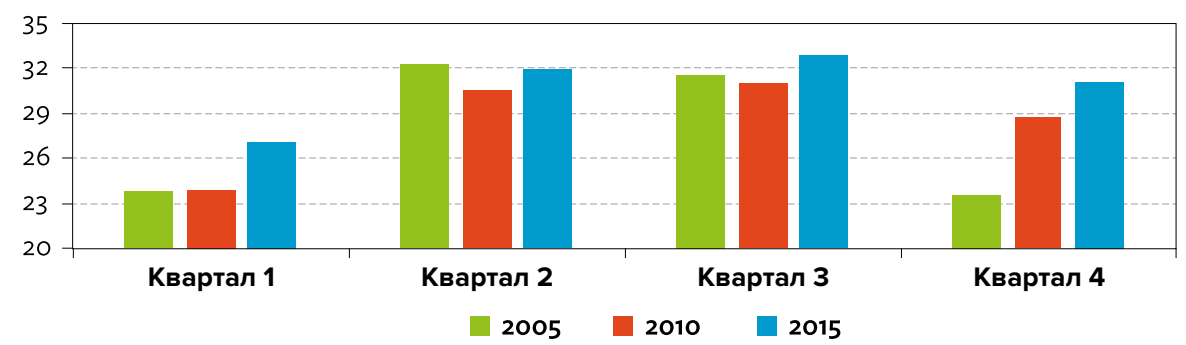

Замечание: Кварталы 1-4 соответствуют календарным кварталам.

Источник: расчеты авторов на основании ИОДХ за 2005, 2010 и 2015 годы

\section{Неофициальная занятость}

Неофициальная занятость определяется в Кыргызской Республике юридически. Неформальная работа - это занятость без государственной регистрации (НСК 2016). При государственной регистрации считается, что сохраняются преимущества «хорошей» работы, такие как ежегодный оплачиваемый отпуск, отпуск по уходу за ребенком, медицинское и социальное страхование. Существует еще ряд аспектов, касающихся неформальной экономики и неформальной (неофициальной) занятости. В частности, не учитываются фирмы, где работает пять (5) или менее работников. Некоторые зарегистрированные компании могут применять «неформальные» принципы, например, часть заработной платы не проводить по бухгалтерским документам (Леман и Зайцева, 2013).

Неофициальная занятость составляет две трети от уровня общей занятости (Рисунок 8.6). Работа без соответствующей официальной регистрации отражает преобладание неформальной экономической деятельности, главным образом, в сельском хозяйстве (39\%), а так же в торговле (20\%) и строительстве (15\%). Неофициальная занятость практикуется как в сельских, так и в городских регионах; ее уровень выше, чем уровень официальной занятости. Но на сельские районы приходится две трети неофициальной занятости. Что касается регионов, то в северном регионе существуют как официальная, так и неофициальная занятость, а в южных, в основном, неофициальная.

\section{Рисунок 8.6: Уровень неофициальной занятости, 2005 и 2015} (\% от общего количества занятых)

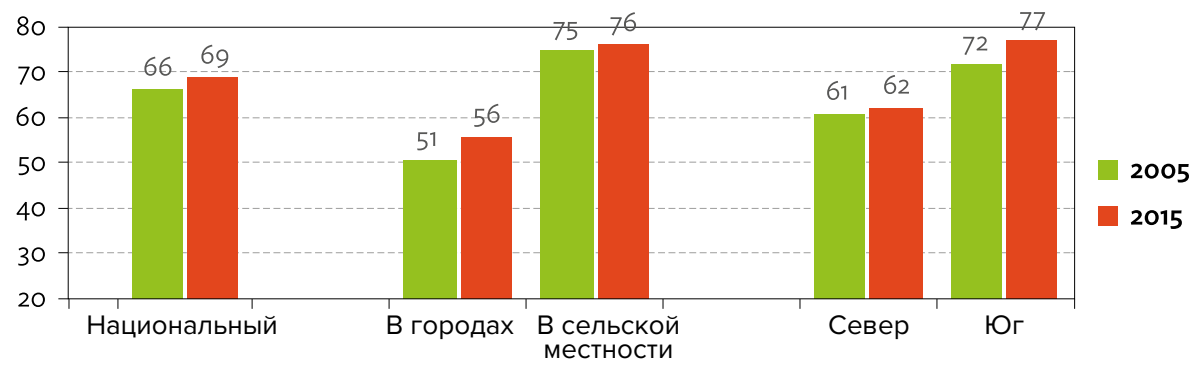

Замечания: Международные трудовые мигранты исключены из расчетов

Источник: расчеты автора на основании результатов ИОДХ 2005, 2010, 2015 
Неофициальная занятость уменышает затраты на рабочую силу. В целом, неофициальная занятость уменьшает права работника, создает трудности с удержанием квалифицированных кадров, ограничивает возможности роста и технологического развития предприятия. Но в некоторой степени неофициальная занятость выгодна производителям и потребителям. Как было определено Могилевским (2018), неофициальная занятость придает гибкость производству, уменьшает транзакционные затраты, налоговые отчисления и уменьшает цены для потребителя.

Как видно из таблицы 8.3, существуют значительные различия в характеристиках работы официального и неформального секторов. Работники, занятые в неформальном секторе, как правило, моложе, менее образованны и зарабатывают в два раза меньше, чем работники официального сектора. Но что более важно, работа в неформальном секторе не дает никаких трудовых льгот, таких как трудовой отпуск, медицинское страхование или пенсионное обеспечение. Неудивительно, что отсутствие этих льгот приводит к увеличению экономической уязвимости.

Стимулов для перехода в официальный сектор не существует. С учетом глобальных тенденций, когда все большее количество работников имеют краткосрочные контракты на выполнение определенной работы, число занятых в неформальном секторе в Кыргызстане не уменьшится, а возможно, со временем и увеличится. Исследование Национального института стратегических исследований (2014) указывает на то, что работодатели нанимают работников неофициально, дабы уйти от уплаты подоходного налога и социальных отчислений, а также избежать официальных правил найма и увольнения работников и предоставления трудовых льгот, таких, как ежегодный отпуск или отпуск по болезни (НИСИ 2014). В целом не существует стимула для перехода в официальный сектор, поскольку и неформальные субъекты, и официальные компании пытаются сократить издержки ведения бизнеса, уплачивая минимальный уровень налогов и социальных отчислений, и заключая контракты на свободной договорной основе. Штрафные санкции за подобные нарушения законодательства невысоки. Хотя неформальная занятость и имеет негативные последствия как для государства, так и для работников, но существование крупного неформального сектора, как представляется, делает рынок труда более гибким и сохраняет уровень безработицы на умеренном уровне. При большем регулировании уровень безработицы, вероятно, был бы намного выше.

Таблица 8.3: Характеристики официальной и неформальной работы, 2015

\begin{tabular}{|c|c|c|c|}
\hline & Вся работа & $\begin{array}{c}\text { Форм } \\
\text { работа }\end{array}$ & $\begin{array}{c}\text { Неформ } \\
\text { работа }\end{array}$ \\
\hline \multicolumn{4}{|l|}{ Характеристика работника } \\
\hline Возраст (года) & 37,1 & 40,2 & 35,7 \\
\hline Женщины & 0,40 & 0,51 & 0,35 \\
\hline Сельская местность & 0,65 & 0,50 & 0,71 \\
\hline Юг & 0,48 & 0,35 & 0,54 \\
\hline Кол-во лет в школе & 11,1 & 12,5 & 10,5 \\
\hline \multicolumn{4}{|l|}{ Условия работы } \\
\hline Кол-во часов, отработанных за предыдущую неделю & 36 & 39 & 34 \\
\hline Заработок за предыдущий месяц, сом & 6302 & 8119 & 5530 \\
\hline
\end{tabular}




\begin{tabular}{|c|c|c|c|}
\hline & Вся работа & $\begin{array}{c}\text { Форм } \\
\text { работа }\end{array}$ & $\begin{array}{l}\text { Неформ } \\
\text { работа }\end{array}$ \\
\hline Контракт с открытой датой или постоянный контракт & 0,29 & 0,87 & 0,04 \\
\hline Оплачиваемый отпуск по болезни & 0,24 & 0,79 & 0,01 \\
\hline Оплачиваемый отпуск & 0,24 & 0,78 & 0,01 \\
\hline $\begin{array}{l}\text { Сохранение рабочего места во время отпуска по } \\
\text { уходу за ребенком }\end{array}$ & 0,08 & 0,24 & 0,01 \\
\hline Пенсионные отчисления со стороны работодателя & 0,24 & 0,78 & 0,02 \\
\hline Уведомление об окончании работы/увольнении & 0,17 & 0,52 & 0,02 \\
\hline \multicolumn{4}{|l|}{ Характеристики домохозяйств } \\
\hline Размер д/х, кол-во членов $д / x$ & 4,5 & 4,2 & 4,6 \\
\hline Уровень потребления в д/х на человека, сом/месяц & 3871 & 4189 & 3736 \\
\hline Уровень дохода в д/х на человека, сом/месяц & 4812 & 5661 & 4452 \\
\hline Уровень бедности, \% & 24,3 & 19,2 & 26,5 \\
\hline Собственная земля, га & 0,75 & 0,52 & 0,84 \\
\hline Наличие авто в д/х & 0,26 & 0,25 & 0,27 \\
\hline
\end{tabular}

Замечание: 1) Неформальная/неофициальная работа- выполняемая работа без государственной регистрации. 2) Взвешенные расчетные цифры

Источник: ИОДХ и ЖвК, 2015

Крупные компании, работающие официально, несмотря на рост производительности и достаточно легкий доступ к государственному и банковскому финансированию, не создают больше рабочих мест. Это один из выводов исследования, проведенного Всемирным банком в 2015 году. В то же время наиболее динамичными являются малые компании, в которых работает менее 10 человек, но переход малого предприятия в разряд среднего влечет за собой большие затраты на социальное обеспечение и другие выплаты, а также следование более жесткому регулированию. Это одна из причин, почему государственные компании выглядят неэффективными по сравнению с частными фирмами, которые могут выбрать наиболее лояльный налоговый режим и получать прибыль, в то время как государственные компании, как ожидается, будут следовать всем официальным правилам. Рынки услуг и товаров достаточно конкурентные, поскольку вход на рынок не влечет огромных затрат для компании, а экономика - недостаточно развита, что делает продажи непредсказуемыми. В основном, малые и средние предприятия привязывают размер заработной платы и длительность контракта к циклам выпуска продукции, что заставляет работников нести риски наряду с работодателями.

Членство в ЕАЭС по-разному влияет на различные сектора экономики. Хотя и предполагалось, что торговый сектор пострадает в наибольшей степени, пока, как представляется, этого не произошло. Наоборот, импорт товаров из Китайской Народной Республики (КНР) увеличился в 2016 году и достиг 1,47 миллиарда долларов, то есть на 40\% по сравнению с предыдущим годом, и оставался стабильным в течение 9 месяцев 2017 года (НБКР 2018). Некоторые отечественные отрасли, в частности, молочная промышленность, столкнулась с конкуренцией со стороны других стран-членов союза, но устойчивость местной валюты сделала импорт рентабельным. Тем не менее, некоторые секторы выиграли из-за вступления страны в ЕАЭС и организации общего рынка за счет сокращения постоянных затрат и препятствий, связанных с бюрократическими процедурами. Исследование, проведенное Шрёдер 
и Шрёдер в 2017 году, указывает на некоторые случаи, когда выполнение импортно-экспортных операций со странами-членами ЕАЭС стало намного проще.

\section{3. Безработица и неактивность}

В данном разделе рассматриваются тенденции относительно безработицы, неактивности и уровня участия молодежи и женщин на рынках труда. Уровень безработицы в Кыргызстане умеренно высок и практически не менялся за последнее десятилетие. Одной из особенностей рынка труда в стране является снижение количества работающих женщин. В данном разделе анализируются данные, полученные в ходе исследований ИОДХ и ЖвК, а также исследований по гендерным вопросам Фонда ООН в области народонаселения.

\section{Безработица}

Безработица относительно высока, но, как представляется, не зависит от макроэкономических циклов. Уровень безработицы в последние годы составляет 7-8\% и, похоже, не является важным политическим показателем для проведения мониторинга. Как уже было отмечено, Национальный статистический комитет публикует данные по этому вопросу со значительной временной задержкой - 6-9 месяцев после окончания сбора данных. Правительство собирает данные о безработице, основываясь на количестве претендентов на пособия по безработице; уровень «официальной» безработицы составляет около 2-3\%.

Политика Министерства труда и социального развития в области безработицы включает как активные, так и пассивные компоненты, такие, как переподготовка кадров, общественные работы и предоставление пособий по безработице, которые правительство начало выплачивать в 1991 году. Пособия рассматривались как мера социальной защиты в свете увеличивающегося уровня безработицы в связи с закрытием предприятий. Ресурсы, предоставляемые Министерству труда и социального развития, весьма ограничены. Например, бюджет, выделенный на разработку политики по рынку труда, в 2017 году составил 87 миллионов сом, что составляет около 1,3 миллиона долларов США (\$) или около 12 долларов на одного заявителя. (Министерство финансов, 2016). Базовое пособие по безработице составляет 250 сом в месяц (приблизительно $3,6 \$$ ), что крайне мало. Компенсация по безработице доступна для работников, которые потеряли работу десять или более недель назад и которые во время работы делали отчисления в фонд компенсации по безработице, по крайней мере, в течение 12 месяцев за последние три года. На практике это означает, что право на получение пособия по безработице имеют только работники официального сектора, хотя консультации и возможные варианты трудоустройства предлагаются всем безработным. Безработным предлагаются программы по переподготовке; тем, кто согласен и отобран для прохождения переподготовки, выдается небольшая субсидия. Финансирование проведения инспектирования охраны труда было сведено к минимуму; трудовой кодекс не соблюдается, что приводит к снижению качества и безопасности труда.

\section{Занятость молодежи}

Среди молодежи высокий уровень безработицы. Уровень участия на рынке труда в Кыргызской Республике молодых людей в возрасте с 15 до 29 лет снизился. 
Уровень участия на рынке наиболее уязвимой молодежной группы (20-29 лет) снизился с 73\% в 2005 году до 67\% в 2015 году (Рисунок 8.7). Снижение можно объяснить количеством неработающих женщин. Большая часть молодых людей заняты в неформальном секторе; уровень безработицы среди этой молодежной группы самый высокий.

Рисунок 8.7: Участие молодежи на рынке труда, 2005-2015

(\%, возрастная группа 20-29 лет)

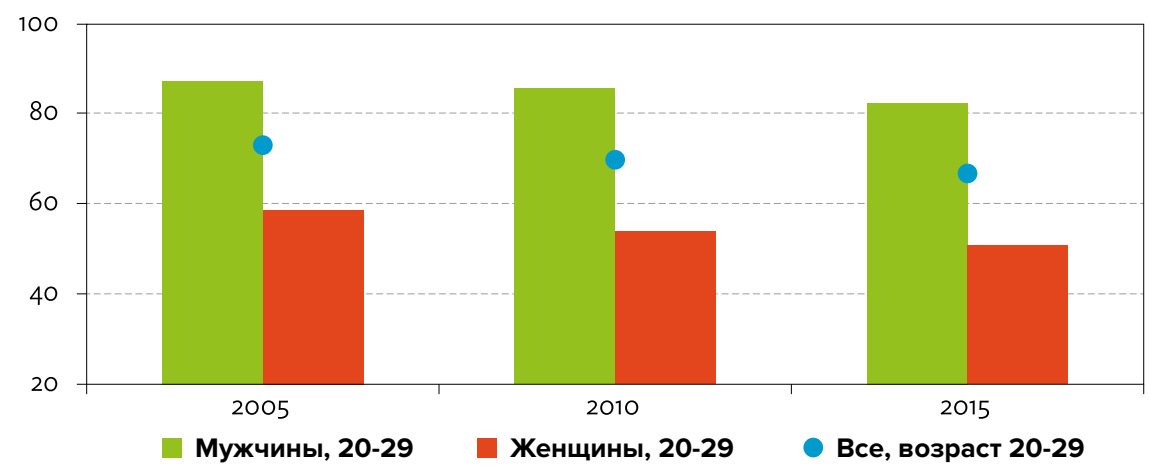

Источник: НСК, 2017c; HСK, 2015b.

\section{Участие женщин на рынке труда}

Участие женщин на рынке труда становится менее активным (Таблица 8.4). Эта тенденция касается, в основном, возрастной группы от 20 до 35 лет. Причинами могут быть рождение детей, недостаток рабочих мест, миграция (Саумик, 2018), а также проявление культурных аспектов, которые нивелируют роль женщины в участии на рынке труда.

Таблица 8.4: Участие женщин на рынке труда, 2015

\begin{tabular}{|c|c|c|c|c|c|}
\hline \multirow[t]{2}{*}{ Показатель } & \multirow[t]{2}{*}{ Bcero } & \multirow[t]{2}{*}{ Мужчины } & \multirow[t]{2}{*}{ Женщины } & \multicolumn{2}{|c|}{$\begin{array}{c}\text { Возрастная группа, } \\
\text { женщины }\end{array}$} \\
\hline & & & & $20-29$ & 30-39 \\
\hline Экономически активные, ‘000 & 2544 & 1501 & 1043 & 288 & 269 \\
\hline трудоустроенные, '000 & 2352 & 1403 & 949 & 249 & 247 \\
\hline безработные, '000 & 192 & 98 & 94 & 40 & 22 \\
\hline Неактивные, '000 & 1534 & 487 & 1047 & 280 & 140 \\
\hline Уровень участия, \% & 62,4 & 75,5 & 49,9 & 50,7 & 65,7 \\
\hline Уровень безработицы, \% & 7,6 & 6,5 & 9,0 & 13,8 & 8,1 \\
\hline Безработные с высшим образованием, \% & 18,2 & 15,5 & 21,0 & 35,8 & 12,3 \\
\hline Неактивные с высшим образованием, \% & 10,2 & 8,1 & 11,1 & 12,7 & 22,0 \\
\hline
\end{tabular}

Источник: НСК, 2016; расчет автора на основании ИОДХ и ЖвК, 2015.

Существует некоторый перекос в гендерных отношениях в пользу мужчин (Вставка 8.3). Хотя в Кыргызской Республике и продвигается гендерное равенство (Всемирный экономический форум, 2017), одной из причин более низкого уровня 
участия женщин в экономической и политической жизни, по сравнению с мужчинами, являются традиционные отношения, которые благоприятствуют мужчинам, но не женщинам (Рисунок 8.8). Большинство респондентов, принимавших участие в исследовании Жизнь в Кыргызстане, согласны с ведущей ролью мужчины - кормильца, и второстепенной ролью женщины. Респонденты-женщины в меньшей степени согласны с ведущей ролью мужчин, хотя ответы и мужчин, и женщин разнятся не в большой степени. Не очевидно, меняются ли гендерные отношения и что является движущей силой изменений, но в целом, вероятно, главной причиной все же является отсутствие хороших рабочих мест.

\section{Рисунок 8.8: Отношение к работе и образованию по полу}

(\% ответов «Согласен» и «Абсолютно согласен»)

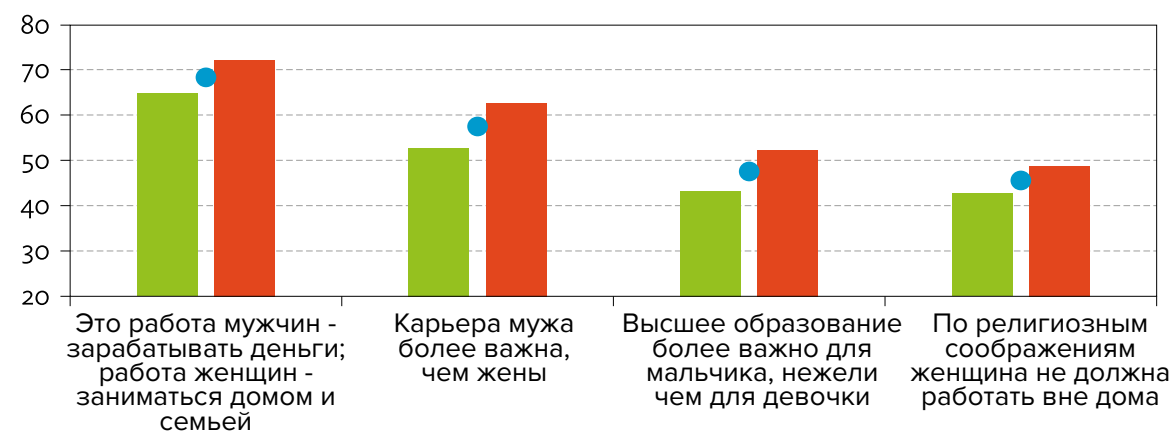

\section{Женщины Мужчины В среднем}

Замечание: Кол-во респондентов: 7917 индивидуальных респондентов, из них 4314 -женщины. Источник: Расчеты авторов на основании исследования «Жизнь в Кыргызстане» за 2016 год.

\section{Вставка 8.3: Гендерные отношения и их восприятие}

В докладе ЮНФПА (2016 г.) представлены результаты исследования положения женщин в экономической и политической жизни и в вопросах миграции. Опрос проводился среди 6000 домохозяйств по всем регионам Кыргызстана; респондентами выступили все взрослые члены домохозяйств. В результате было получено более 16 тысяч индивидуальных ответов. В докладе анализируются гендерные аспекты формирования домохозяйств, ведения внутри семейных переговоров, а так же вопросы, касающиеся рынка труда, миграции, социальных норм. В большинстве случаев, между мужчинами и женщинами принципиальной разницы в оценке экономических и социальных вопросов выявлено не было. Женщины чувствуют себя более ответственными, если супруг уезжает на заработки. Уровень религиозности не возрастает по возвращению из миграции, если только миграция не была в арабские страны и/или Турцию. В докладе отмечается, что гендерные нормы и ожидания в отношении присутствия в «обществе» в значительной степени благоприятствуют мужчинам. Это благоприятствование считается одной из причин сокращения участия женщин на рынках труда.

Источник: ЮНФПА и др., 2016

\section{4. Работающие за рубежом}

Трудовая миграция является важным явлением в Кыргызской Республике. Миграция снижает напряженность на внутреннем рынке труда; денежные перево- 
ды трудовых мигрантов являются важным пополнением для экономики страны и источником благосостояния жителей. Благодаря вступлению Кыргызской Республики в Евразийский экономический союз, миграция, по всей видимости, становится все более жизнеспособным вариантом трудоустройства по причине уменьшения фиксированных расходов и доступности более высокооплачиваемых рабочих мест в Российской Федераций, основной стране назначения для трудовых мигрантов. Хотя экономическая трудовая миграция приносит пользу, она сопряжена с социальными издержками и может привести к росту внутренних цен и заработной платы, и к возникновению своего рода «Голландской болезни». В настоящем разделе кратко излагаются последние события и тенденции в области трудовой миграции и денежных переводов, и анализируются социальные последствия миграции.

\section{Существующие тенденции трудовой миграции}

Количество трудовых мигрантов из Кыргызской Республики является значительным и, вероятно, будет расти в будущем. Число кыргызских мигрантов установить трудно (Вставка 8.4). Различные источники приводят разные цифры, от 300 до 700 тысяч человек. По данным Государственной миграционной службы за 2018 год число официально зарегистрированных трудовых мигрантов из Кыргызской Республики в Российскую Федерацию составило более 600 тысяч, а учитывая, что число жителей Кыргызстана, получивших российское гражданство за последние 15 лет, составляет 180 тысяч человек, доля трудовых мигрантов в Российскую Федерацию существенна в абсолютном и относительном выражении к общей численности рабочей силы. Среди трудовых мигрантов из Кыргызстана есть и женщины, и мужчины, в отличие от миграции из Таджикистана, где доминируют мужчины. По данным ИОДХ и ЖвК, 25-30\% кыргызских мигрантов - женщины. (ИОДХ, 2016; ЖвК, 2013 и 2016). ${ }^{2}$

\section{Вставка 8.4: Какова численность мигрантов из Кыргызстана?}

Установление численности трудовых мигрантов из Кыргызской Республики является запутанной задачей. Политики приводят расчетную цифру в один миллион и даже более, а по результатам исследований домохозяйств, эта цифра значительно скромнее, в пределах 300 тысяч человек. Одним из аспектов этого спорного вопроса является определение - кто такой мигрант. Во-первых, это определение подходит к тем, кто выехал из страны с целью получения гражданства другой страны, во-вторых, мигрант - это сезонный рабочий. Обычно под словом мигрант понимают человека, выехавшего в другую страну на определенное время для работы, не потерявшего связь со своей родной страной и посылающего денежные переводы свои родным. Тем не менее, существует и другое понимание мигранта. Те, кто получил российское гражданство, возможно постепенно сокращают общение с родственниками, и посылают относительно меньше денег. Такого типа мигранты сплачиваются в диаспору и, со временем, наиболее успешные сами становятся работодателями для новой волны мигрантов (Кашнитский и Дементьева 2017). Другая категория мигрантов включает тех, кто уехал в эмиграцию всей семьей. Эти две категории не учитываются в исследовании домохозяйств, но они играют свою роль в статистике денежных переводов.

Источник: Тьем, 2014; Шмидт и Сагынбекова, 2008; Сагынбекова, 2017; Правительство КР, 2012; Государственная миграционная служба, 2018; Кашнитский и Дементьева, 2017.

2 ИОДХ доступна в $h$ ttp://catalog.ihsn.org/index.php/catalog/6718/study-description ЖвК 2013 доступен в http://lifeinkyrgyztsan.org/?page_id=51

ЖвК 2016 - доступен непосредственно авторам. 
Вступление в Евразийский экономический союз (ЕАЭС) смягчило негативное влияние регионального религиозного фактора. На уровень миграции из Центральной Азии и сумм денежных переводов в регион серьезно повлияло падение цен на нефть в конце 2014 года. Кроме того, экономические санкции, введенные западными государствами против Российской Федерации в связи с событиями в Крыму и Восточной Украине, а так же девальвация рубля в начале 2015 года негативно сказались на доступности рабочих мест в Российской Федерации. Тем не менее, геополитическая ситуация также оказала неожиданный положительный эффект - количество мигрантов из Украины сократилось к 2017 году, так как с июня 2017 года между странами ЕС и Украиной установлен безвизовый режим (Русская служба ВВС 2018).

Членство Кыргызской Республики в ЕАЭС с 2015 года является благоприятным фактором для миграции. Кыргызские трудовые мигранты стали обладать большими правами и уменьшилось количество ограничений на их трудоустройство в странах ЕАЭС, хотя доказательств, подтверждающих это утверждение, нет. Членство в ЕАЭС снизило затраты, раннее необходимые для начала работы в Российской Федерации, уменьшилось количество бюрократических препон. Уменьшение препятствий означает более свободный вход на рынок, следовательно, миграция стала более жизнеспособным вариантом трудоустройства, нежели когда-либо ранее. Как указано в исследовании Сагынбековой (2017), последствия от вступления в ЕАЭС следующие: (1) повысилось качество работы и рабочих мест: мигранты переходят с низкооплачиваемой нелегальной работы на более высокооплачиваемую и требующую определенных навыков, (2) суммы денежных переводов, гипотетически, могут расти из за сокращения фиксированных затрат, раннее необходимых для начала работы.

Из-за разницы в экономическом развитии Кыргызской Республики и Российской Федерации уровень трудовой миграции, похоже, останется высоким. С учетом того, что экономика Кыргызстана не может создать необходимое количество рабочих мест для большого количества появляющейся рабочей силы (избыточное предложение рабочей силы), ситуация «смягчается» за счет трудовой миграции. Низкий уровень рождаемости в Российской Федерации и высокий уровень рождаемости в Кыргызской Республике и соседних Центрально-Азиатских странах, а также разница в экономическом развитии двух стран (Рисунок 8.9) создает, в долгосрочной перспективе, обоюдовыгодную ситуацию и благоприятные условия для трудовой миграции. Дополнительно, членство республики в ЕАЭС привело к созданию лучших условий для работы кыргызских трудовых мигрантов. Приведенные на рисунке цифры показывают средний уровень заработной платы по стране, не зависимо от сектора. В основном, цифры - официальные и не отражают уровень зарплаты в неофициальном секторе. По данным за 2015 год, уровень неофициальной занятости в Российской Федерации составил 20\% от общего количества работающих, а в Кыргызстане эта цифра была гораздо выше $69 \%$.

Миграция затронула каждую пятую семью в южных регионах. Внешняя трудовая миграция зародилась на юге страны и практически не затронула северные регионы. В южных областях страны на 2015 год число домохозяйств в которых, по меньшей мере, существует один трудовой мигрант, составляло 8\% от всего количества домохозяйств в Оше и 29\% - в Баткенской области (Таблица 8.5). 


\section{Рисунок 8.9. Сравнение размеров заработной платы в Кыргызской Республике и Российской Федерации, 2013-2017}

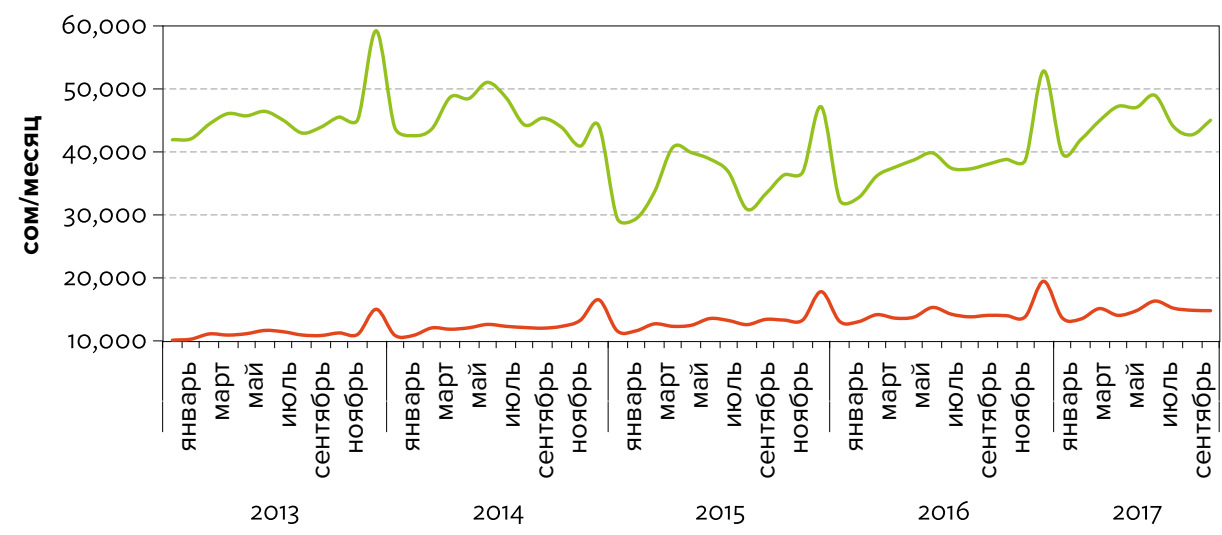

— Кыргызская Республика Российская Федерация

Замечания: сумма заработной платы в России, выплачиваемая в рублях, была конвертирована в сомы. В качестве обменного курса использовалось среднемесячное значение Национального банка Кыргызской Республики (НБКР).

Источники: 1) Национальный статистический комитет Кыргызской Республики, 2018 (размер заработной платы взят с сайта www.stat.kg/ru/statistics/trud-i-zarabotnaya-plata / по состоянию на 29 марта, 2018); 2) Бюллетень Национального Банка Кыргызской Республики 2017 (www.nbkr.kg/index1. jsp?item=137\&lang=ENG (по состоянию на декабрь 2017); 3) Федеральная служба государственной статистики Российской Федерации, 2018 (www.gks.ru/wps/wcm/connect/rosstat_main/rosstat/ru/ statistics/wages/ (по состоянию на март 29, 2018).

Миграция создает дефицит квалифицированной рабочей силы на рынке страны. Безусловно, миграция привлекает как не квалифицированных, так и квалифицированных работников, а это создает трудности для местных компаний, которые планировали инвестировать в технологии, соответственно, им нужны квалицированные работники. Исследование, проведенное Всемирным банком в 2014 году показало, что 2/3 компаний испытывают трудности из-за невысокого уровня образования и недостатка навыков у своих работников. Это классифицировалось в 2013 году как четвертая по степени важности и серьезности проблема ведения бизнеса.

Миграция, как представляется, не является самым лучшим выбором начала занятости. Скорее, миграция является последним средством преодоления трудностей (ЮНФПА, 2016). Большая часть мигрантов работает в неформальном секторе в зарубежных странах, соответственно, они не имеют гарантированных рабочих мест и подвергаются различным рискам. «Черный список» правительства Российской Федерации - серьезная проблема, так как мигранты, подчиняясь официальным правилам миграции и проживания, депортируются и вносятся в «черный список», следовательно, не могут вернуться в Российскую Федерацию. «Черный список»- один из вопросов миграционной политики. На конец 2017 года в него были внесены 78 тысяч фамилий (Государственная миграционная служба, 2018). 


\section{Таблица 8.5: Домохозяйства мигрантов, получающих денежные переводы по регионам, 2010-2015 (\% от общего количества домохозяйств)}

\begin{tabular}{|c|c|c|c|c|}
\hline & \multicolumn{2}{|c|}{2010} & \multicolumn{2}{|c|}{2015} \\
\hline & Миграция & $\begin{array}{l}\text { Денежные } \\
\text { переводы }\end{array}$ & Миграция & $\begin{array}{l}\text { Денежные } \\
\text { переводы }\end{array}$ \\
\hline Республика & 10,9 & 9,6 & 9,1 & 6,6 \\
\hline Города & 5,6 & 7,7 & 4,7 & 5,0 \\
\hline Сельская местность & 14,6 & 10,9 & 12,1 & 7,8 \\
\hline Север & 1,3 & 5,4 & 1,0 & 3,5 \\
\hline Юг & 22,0 & 14,4 & 18,0 & 10,1 \\
\hline Иссык-Кульская обл & 7,6 & 6,5 & 9,0 & 13,8 \\
\hline Жалал-Абадская & 18,2 & 15,5 & 21,0 & 35,8 \\
\hline Нарынская & 0,4 & 0,6 & 0,1 & 1,0 \\
\hline Баткенская & 19,7 & 11,1 & 28,8 & 7,1 \\
\hline Ошская & 25,5 & 19,9 & 17,1 & 15,0 \\
\hline Таласская & 4,1 & 5,9 & 1,9 & 4,5 \\
\hline Чуйская & 1,3 & 10,6 & 2,3 & 6,3 \\
\hline Бишкек & 0,9 & 2,1 & 0,2 & 1,8 \\
\hline Ош (город) & $\ldots$ & $\ldots$ & 8,4 & 8,9 \\
\hline
\end{tabular}

Замечания: Взвешенные расчеты. Статус мигранта применим для возрастной группы от 18 до 70 лет. Источник: Расчеты автора на основании ИОДХ 2005, 2010, 2015; НСК (различные года)

Кыргызская Республика является одной из стран мира, получающих больше всего денежных переводов. Приток денежных переводов от трудовых мигрантов в 2017 году составил около 2,5 миллиарда долларов США, что составляет 31\% ВВП страны (Всемирный банк, 2018). Большая часть денежных переводов, около 90\%, приходят из Российской Федерации. С середины 2000-х годов денежные переводы являются крупнейшим источником иностранной валюты; сумма переводов из Российской Федерации значительно превышает объем прямых иностранных инвестиций (ПИИ) или полученных средств на развитие (ОПР) (Глава 2). Считается, что денежные переводы оказывают существенное макро- и микроэкономическое воздействие. На макроуровне денежные переводы стимулируют совокупный спрос, влияют как на денежно-кредитную политику, так и на обменный курс и, вероятно, оказывают влияние на рынок труда путем повышения приемлемой заработной платы. Считается, что наиболее важные последствия переводов имеют место на микроуровне, поскольку денежные переводы непосредственно влияют на экономическое благосостояние домохозяйств, получающих эти денежные переводы.

Денежные переводы важны для преодоления бедности. Денежные переводы влияют на доход и объемы потребления членов домохозяйств, куда поступают эти денежные средства. Как было отмечено статистическим комитетом (НСК 2017), без денежных переводов уровень бедности в 2016 году был бы выше на семь процентных пунктов (32\% по сравнению с 25\% фактическими). Денежные переводы крайне важны для жителей южных регионов, в особенности для Ошской, Жалал-Абадской и Баткенской областей. 
Данные на микроуровне как по миграции, так и по денежным переводам показывают весьма скромную картину, по сравнению с данными макро уровня (Таблица 8.5). На национальном уровне, только 9-11\% всех домохозяйств подтвердили наличие мигрантов в своем домохозяйстве. Хотя на юге домохозяйств, участвующих в трудовой миграции, было гораздо больше - 18\% (данные на 2015 год). В Баткенской области этот показатель наиболее высокий - 29\%, далее в Ошской и Жалал-Абадской областях - по 17\%.

Доля домохозяйств, получающих денежные переводы, ниже. Эта доля составила всего 10\% в 2010 году и 6,6\% в 2015 году. На самом деле, есть много семей, которые не сообщают о наличии мигрантов от домохозяйства, но получают денежные переводы. ${ }^{3}$ Денежные переводы не обязательно отражают географическое распределение миграции и проживания мигрантов. Например, в Оше и Ошской области количество получающих переводы более или менее совпадает с указанным количеством мигрантов, а в Баткенской и Жалал-Абадской областях - нет. Доля домохозяйств, получающих переводы, ниже доли домохозяйств, где есть мигранты. Еще одно интересное наблюдение - денежные переводы поступают и в северные регионы, в частности, в Чуйскую область, и в близлежащие от Бишкека районы. Это отражает внутренние миграционные потоки и указывает на «получателей» результатов внутренней миграции, так как именно этот регион считается наиболее развитым в экономическом отношении.

\section{Социальные аспекты миграции}

Миграция, безусловно, имеет не только макроэкономические и социальные последствия, но и более широкие последствия на уровне отдельных домохозяйств и общин (Абазов 1999; ВТО, 2009; Шмидт и Сагынбекова, 2008). Во-первых, мигранты, находясь за рубежом, приобретают навыки, у них меняются отношение и взгляды (Брюк и др., 2018; Хилл и Хаски, 2015). Во-вторых, оставшиеся дома члены домохозяйств должны пересмотреть выполняемые роли внутри домохозяйства и принимаемые решения (Давалос и др., 2017; Исабаева, 2011; Исмаилбекова, 2014; Недолужко и Андерсон, 2007, Рубинов, 2014, Саумик, 2018). В-третьих, мигранты, посылающие денежные средства в родные места, тоже меняются и по социальным нормам, и денежным взаимоотношениям (Атаманов и ван дер Берг 2012; Винокуров 2013; Чакраборты, Миркасимов и Штейнер 2015; Шох, Штайман и Тиеме 2010) и по отношению к денежным переводам, которые используются на местные нужды развития (Ронер 2007; Ривес 2012).

Социальные издержки миграции связаны с оставшимися в родных местах членами семьи и вопросом будущего пенсионного обеспечения. Миграция изменяет распределение рабочей силы внутри домохозяйств и меняет роли в принятии решений, так как в большинстве случаев мигрируют наиболее экономически дееспособные члены семей (Андерсен и Крюгер 2013). В результате во многих домашних хозяйствах остаются женщины и дети. В случаях, когда оба супруга уезжают, дети остаются с бабушкой и дедушкой и другими близкими членами семьи (Международная федерация за права человека, FIDH, 2016). Это создает психологические и другие проблемы. Например, дети мигрантов, как правило, хуже успе-

\footnotetext{
Дополнительная информация, полученная при проведении ИОДХ, о заработной плате, получаемой за рубежом, как представляется, свидетельствует о возможном включение заработной платы в понятие миграции и денежных переводов. Неясно, каким образом переводятся эти средства в Кыргызстан. Но эти цифры показывают долю домашних хозяйств, которые, потенциально, получают денежные переводы. Эта цифра составляет приблизительно 18-21\% от всех домохозяйств. В южных регионах доля еще выше и составляет 34-38\% от всех домохозяйств.
} 
вают в школе и имеют больше психологических проблем, нежели дети, живущие в семьях с родителями.

Большинство мигрантов намерены вернуться в страну в пенсионном возрасте (Тиеле 2014). В связи с этим возникает вопрос о пенсиях, поскольку они не делали отчислений в действующий пенсионный фонд, то как смогут получить пособие по старости и оплачивать расходы на проживание и здравоохранение? В некоторых странах, например, на Филиппинах, практикуется регистрация в пенсионных структурах перед выездом на заработки. Возможно, Кыргызская Республика последует этому примеру.

\section{5. Навыки, необходимые для повышения}

\section{потенциала роста}

\section{Навыки}

В данном разделе обобщаются последние данные по требуемым на рынке труда навыкам. Большая часть занятости сегодня приходится, в основном, на сферу услуг, и на малые предприятия. Доля женщин, занятых в этих секторах, превышает долю мужчин. Изменения, происходившие в отдельных секторах, повлекли за собой изменения навыков, необходимых для выполнения новых видов работ. С 2008 года спрос на навыки «работать руками» снизился, а спрос на когнитивные навыки и навыки «новой экономики» увеличился (Аджвал и др., 2014). У работников, которые не готовы к этим изменениям, меньше шансов на трудоустройство, но выше вероятность, что они будут выполнять разовую, низкооплачиваемую работу (Вставка 8.5).

\section{Вставка 8.5: Исследование 2013 года по развитию профессиональных навыков}

На рынке труда в Кыргызстане, как и в некоторых странах Европы и Центральной Азии ощущается разрыв между умениями, приобретёнными и требуемыми; этот разрыв со временем углубляется (Аджвад и др. 2014). В рамках исследования, которое проводилось в Кыргызстане в 2013 году Всемирным банком, проводилась оценка когнитивных и не когнитивных навыков работников. В исследовании приняло участие более 1500 домохозяйств. В результат проведенного исследования можно утверждать, что человек с хорошими навыками и умениями, вероятнее всего, быстро найдет работу и работу более качественную.

Вместе с тем, как представляется, система и условия формирования и преподавания профессиональных навыков не отличаются последовательностью и качеством. Например, только один из четырех детей в возрасте 3-5 лет посещает дошкольное учреждение, а это важный этап в жизни человека, когда формируются как когнитивные, так и некогнитивные навыки. Несмотря на высокие показатели зачисления и завершения обучения в средних и высших учебных заведениях, различия в полученной квалификации велики - выпускник университета может иметь навыки ниже требований среднего уровня. В отчете предлагается ряд шагов по совершенствованию процесса формирования навыков, в том числе расширение доступа к дошкольным учреждениям, обогащение школьных программ обучением некогнитивным навыкам, а также приведение перечня преподаваемых навыков в соответствие с требованиями работодателей.

Источник: Аджвад и др., 2014 
Навыки «новой экономики» включают технические навыки, приобретаемые при получении профессионального образования или на рабочем месте, а также некогнитивные навыки, такие как открытость, экстравертность и умение принимать решения. Аджвад и соавторы (2014) считают, что работники с этими некогнитивными навыками с большей вероятностью получат хорошую работу в официальном секторе, чем другие работники. Основная проблема в формировании навыков, как представляется, связана с несоответствием получаемых навыков и отсутствием спроса на эти навыки со стороны работодателей. Половина экономики - это частный сектор и малые предприятия, которые не инвестируют в развитие навыков или технологий

\section{Информационно-коммуникационные технологии и навыки}

Информационно-коммуникационные технологии (ИКТ) являются катализатором и источником роста экономики и занятости (АБР, 2014; Всемирный банк, 2016). Мобильные телефоны, интернет и компьютеры уже стали частью бизнеса и используются многими работниками в Кыргызской Республике, хотя, в основном, в городских районах и в официальном секторе экономики. Как показывает результаты анализ, приведенные ниже, проникновение ИКТ в стране было довольно ограниченным.

По показателям относительно уровня разработки и использования ИКТ, Кыргызстан располагается к конце списка. Индекс сетевой готовности (ИСГ), составленный для всех стран в 2016 году на Всемирном экономическом форуме (ВЭФ, 2016), отражает готовность страны к цифровой трансформации. В соответствии с этим индексом в 2016 году Кыргызская Республика заняла 95-е место (из 139 стран). Для сравнения, соседний Казахстан занимает 39-е место, а Таджикистан - 114-е. Как описано в главе 5, Кыргызстан получил низкий рейтинг по многим показателям, в частности, воздействие на социальную сферу и экономику, политический и нормативно-правовой климат, инфраструктура. В целом, развитие ИКТ в Кыргызской Республике происходило органично, соответствует глобальным и региональным трендам; на него не влияли экономические решения или частный бизнес.

Информационно коммуникационные технологии не очень широко применяются в стране, хотя в некоторых подсекторах происходит динамичный рост использования ИКТ. В отчете Фонда Сороса (2012) отмечаются последние достижения в использовании ИКТ, определяются перспективы для страны. Например, 100\% населения пользуется сотовыми телефонам, хотя уровень использования компьютеров и интернета - гораздо ниже. По данным Всемирной статистики на конец 2017 года - интернетом пользуется около 41\% населения (2018). Использование ИКТ и программного обеспечения в бизнесе ограничено, неформальный сектор, не имея мотивации, не инвестирует в развитие и не инициирует широкое использование ИКТ. Медиа, работающие с международными компаниями, используют компьютеры и интернет достаточно широко.

Внедрение и использование ИКТ началось с минимума, и на данный момент используется все шире. Существует материальная и не материальная выгода быть «в цифровом поле» (Всемирный банк 2016). Использование компьютеров, приложений, мобильных телефонов ведет в увеличению продуктивности, экономии средств и времени. Хотя в Кыргызстане многие инициативы продвигаются повсеместно, широкое использование ИКТ наблюдается в больших городах. 
Бишкек в этом отношении лидирует: здесь расположены 53\% всех компаний, использующих компьютеры, 68\% компаний, имеющих вебсайты; 84\% результатов использования ИКТ аккумулировано в столице, а такие области как Нарынская и Таласская - считаются самыми отстающими. Если руководствоваться источниками данных на микро-уровне, степень использования компьютеров остается низким. Например, исследование Жизнь в Кыргызстане показывает, что только 15-19\% жителей страны в возрасте от 15 до 64 лет используют компьютер в образовательных и рабочих целях (Таблица 8.6, Рисунок 8.10). Подростки, в возрасте с 15 до 19 лет, используют компьютеры чаще других возрастных групп (35\%). Рисунок 8.10 показывает, что не существует разницы в использовании компьютеров между мужчинами и женщинами. Уровень пользования компьютерами не установлен точно, значение варьируется в зависимости от источника. В главе 5 указывается, что 29\% домохозяйств используют компьютеры, в ИОДХ - цифра меньше. Подобным образом, различаются оценки относительно использования интернета: от 15-19\% по данным ИОДХ до 38\% населения; эта цифра дана в главе 5 .

Интернет приобретает все большее значение как средство коммуникации, бизнеса и образования, хотя доступ к нему неравномерен. Интернет, в основном, используется в северных регионах и городских районах страны, а качество мобильного интернета в отдаленных регионах либо очень слабое, либо доступа к мобильному интернету нет. Подключение к интернету идет через Российскую Федерацию и Казахстан, прямого подключения к основным каналам нет. Проект Digital CASA (Цифровая Центральная м Южная Азия) направлен на решение проблем высокоскоростного доступа в Интернет и создание инфраструктуры в регионах (Всемирный банк, 2018). У большинства населения нет стимула инвестировать в ИКТ или в получение навыков, связанных с использованием интернета. Частично проблема состоит в отсутствии интернет-контента в кыргызском интернет-пространстве.

Многие технологические компании предоставляют услуги в области ИКТ и интернет-продуктов, включая, например, разработку и обслуживание вебсайтов, приложений и технологий. Уровень занятости в сфере ИКТ за последние 5 лет увеличился, по данным НСК на 2016 год в данной сфере работало около 20000 человек (НСК, 2017), а количество компаний, использующих ИКТ, выросло на 30\%.

Образовательный потенциал для поддержки сектора ИКТ, хотя и растет, но все же ограничен. В Кыргызской Республике только три ВУЗа имеют эффективные ИТ-школы, а ежегодное количество выпускников университетов невелико. Образовательные учреждения прилагают определенные усилия для создания систем дистанционного обучения, но нет доказательств его эффективности. Существуют частные компании, которые проводят тренинги и обучение на рабочем месте. Большинство технологий поступают из русскоязычных стран (DR Analytica, 2016). Существует мало вариантов внешкольного образования для молодежи (например, обучение программированию, робототехнике), но и эти обучающие центры располагаются только в Бишкеке.

Использование ИКТ на уровне домашних хозяйств и на индивидуальном уровне, в основном, ограничено городскими районами. Мобильная связь стала универсальным способом общения; технологии ИКТ присутствуют и используются в повседневной жизни людей. Использование электронной коммерции растет, но со стороны предложения; трудно судить о распространении электронной коммерции, учитывая, что она практикуется только в крупных городах. Количество платежных карт растет, но все еще находится на низком уровне: по итогам 2016 
года использовалось около 1,6 миллиона платежных карт, то есть их использует только четверть населения страны. Тем не менее, это число в четыре раза больше, чем в 2012 году. Другой пример - электронные банковские услуги, предлагаемые большинством банков страны. Платежные терминалы широко используются для оплаты коммунальных и других услуг. Уровень использования фиксированной телефонной связи не растет; количество подписчиков стабильно остается на уровне в 1 миллион абонентов.

\section{Таблица 8.6: Использование информационных-коммуникационных технологий; наличие соответствующего оборудования \\ (\% от общего количества, если не обозначено иначе)}

\begin{tabular}{|c|c|c|c|c|c|}
\hline & 2010 & 2011 & 2012 & 2013 & 2016 \\
\hline \multicolumn{6}{|l|}{ Доля домохозяйств, где есть } \\
\hline Сотовые телефоны & 89 & 92 & 95 & 93 & 96 \\
\hline Компьютеры & 9 & 10 & 13 & 13 & 15 \\
\hline Выход в Интернет & 4 & 6 & 7 & 6 & 6 \\
\hline \multicolumn{6}{|l|}{ Жители в возрасте с 15 до 64, кто } \\
\hline Используют компьютер для работы или учебы & 14,9 & 18,5 & 19,0 & $\ldots$ & 15,5 \\
\hline Пользование компьютером, час/неделю & 7,2 & 6,7 & 6,5 & $\ldots$ & 10,8 \\
\hline
\end{tabular}

Источник: Исследование Жизнь в Кыргызстане, 2010-2012, 2016.

\section{Рисунок 8.10: Использование компьютеров разными возрастными группами}

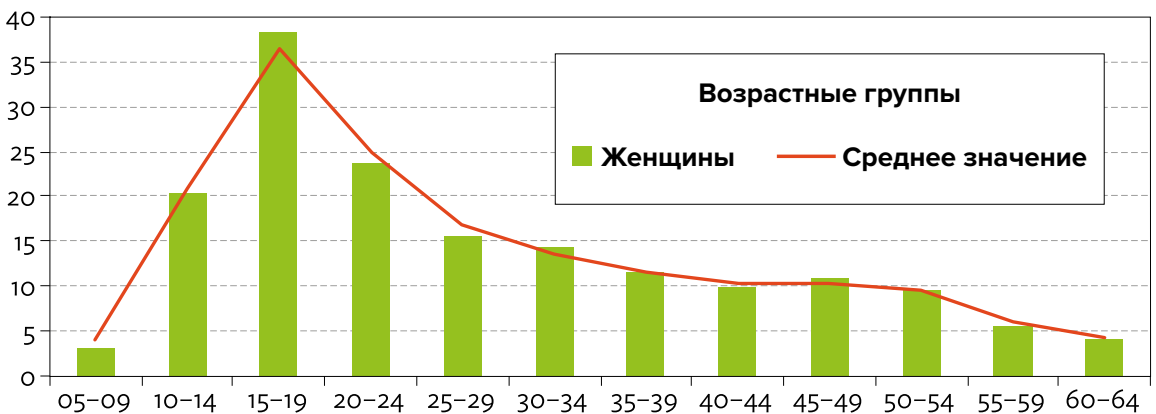

Источник: Исследование Жизнь в Кыргызстане, 2010-2012, 2016

Политические решения относительно ИКТ принимаются не системно и не носят всеобъемлющего характера. Правительство продвигает ИКТ, но усилия были сосредоточены на нескольких государственных учреждениях, например, на налоговой службе (АБР, 2014а), существует недостаток финансовой поддержки. Предпринятые в последнее время усилия государства по созданию электронного правительства, онлайн-сервисов - Национальная программа цифровой трансформации - и созданию сети общественных услуг будет крайне благоприятно сказываться на росте бизнеса и чувстве удовлетворенности граждан услугами, оказываемыми государственными структурами. Но на выполнение этой программы может повлиять нестабильная политическая обстановка. Парк высоких технологий - одна из инициатив в рамках государственно - частного партнерства (Аба- 
киров, 2017), - пример расширения использования ИКТ компаниями благодаря предоставленным им налоговым льготам.

\section{6. Образование}

\section{Последние достижения в секторе образования}

Правительство Кыргызской Республики пытается создать современную систему образования. За разработку и выполнение политики в области образования отвечает Министерство образования и науки. Были внедрены достаточно широко некоторые экспериментальные подходы. Выполняется много проектов, связанных со школами, например, введение школьных парламентов. А так же Программа ЮНИСЭФ «Школа без насилия»(ЮНИСЭФ, 2015), Программа «Жить Бок о Бок» (Аладышева и др., 2017); Программа ЮСАИД «Читаем вместе» (ЮСАИД, 2017). Проведено много реформ в секторе образования (Правительство Кыргызской Республики, 2012), включая постепенное внедрение Информационной системы управления образованием, которая является инструментом управления, коммуникации, и обмена данными.

Правительство Кыргызстана сохраняет высокую долю государственных расходов на образование, однако, государственные расходы на образование, в основном, покрывают заработную плату учителей, в то время как другие важные компоненты обучения, такие как учебники, школьная инфраструктура, подготовка и переподготовка учителей, остаются недофинансированными. Эти факторы, наряду с нехваткой учителей по основополагающим предметам, в частности, естественным наукам и иностранным языкам, считаются основными причинами ухудшения качества образования.

Сектор образования занимает самую большую долю в фонде заработной платы государственного сектора. Согласно данным за 2011 год, доля заработной платы, направленный в сектор образования составил 5\% от ВВП, далее следует сектор здравоохранения на уровне 2,1\% от ВВП (Всемирный Банк, 2014). Одной из причин является реформа системы оплаты труда учителей (2011 и 2015 годы), в ходе которой, в целом, фонд оплаты труда работников образования увеличился на две трети (2/3). Эта реформа отменила систему заработной платы на основе категорий и ввела новую систему, основанную на фактически отработанных часах с фиксированной оплатой за час преподавания. Как представляется, эта реформа в значительной степени отвечает интересам учителей сельских школ и учителей начальных классов. Молодые учителя и учителя со льготами, в соответствии со старой системой оплаты, похоже, мало выиграли; стало больше учителей, минимальная рабочая нагрузка была уменьшена (Институт Булан, 2018; Жениш, 2015).

Наиболее серьезным неблагоприятным изменением, произошедшим в период переходной экономики, стало резкое сокращение дошкольных учреждений. В Советское время дошкольные учреждения размещались в каждом населенном пункте, закреплялись за крупными предприятиями, но система, не в малой степени благодаря процессу приватизации и нехватки финансирования дошкольной системы у местных органов власти, резко ухудшилась. Недавние оценки указывают на то, что только около 13-17\% детей дошкольного возраста посещают дошкольные учреждения. По всей Центральной Азии меньше детей посещают 
дошкольные учреждения только в Таджикистане. (Всемирный банк, 2013). Если в 1990 году на одного ребенка, зачисленного в первый класс, приходилось два ребенка, посещающих детский садик, то эта пропорция снизилась до 1:0,4 ребенка в середине 1990х, а в 2015 году - изменилась и стала 1: 1,3 (Рисунок 8.11).

Рисунок 8.11: Количество детей в дошкольных учреждениях и принятых в 1-й класс начальной школы

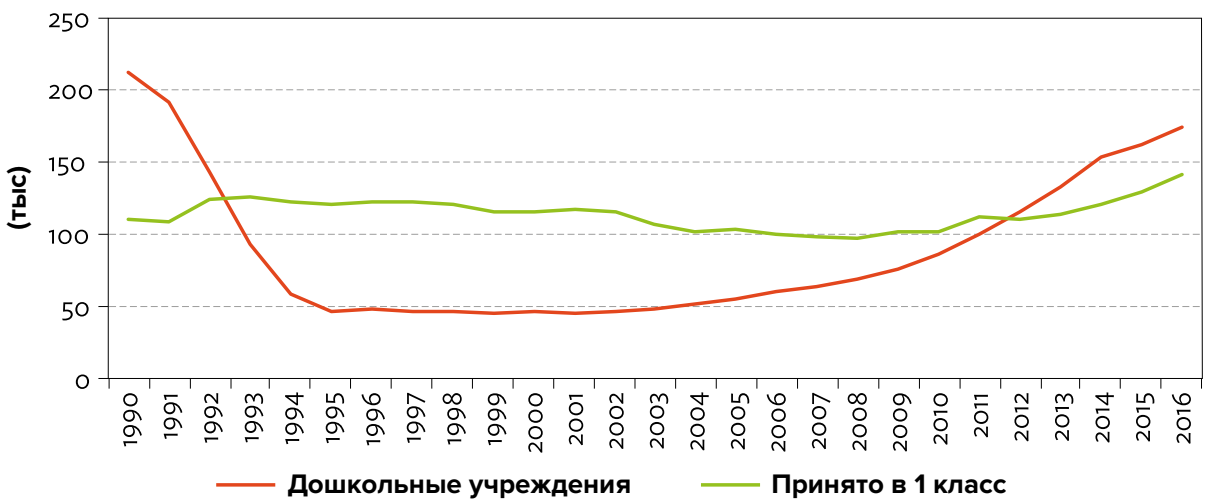

Источник: НСК, 2018

Структура системы образования Кыргызской Республики в значительной степени остается неизменной с момента обретения независимости. Школьная система основана на схеме: 4-5-2 (4 года - 5 лет - 2 года). Дети в возрасте от 6 до 7 лет начинают обучение в начальной школе, где проводят с 1-го по 4-й классы. Следующий уровень - базовое образование - продолжается до 9 класса. Незаконченное среднее является минимальным уровнем обязательного школьного образования. После 9-го класса учащиеся имеют выбор: либо продолжить обучение в старшей школе еще в течение двух лет, а далее поступить в университет или другой ВУЗ, либо уйти из школы в сферу профессионального обучения, по окончании которого также можно поступить в университет или другой ВУЗ. Режим обучения по-прежнему основан на схеме «учитель - в центре», почти на всех уровнях, включая высшее образование. Необходимо позволять студентам определять, что нужно им, на основе практического обучения.

Доступ к образованию, в целом, обеспечен. Благодаря обязательному школьному образованию до 9 класса и наличию многих возможностей для продолжения образования, система, в значительной степени, открыта для любой социальной группы. Тем не менее, следует обратить внимание на образование детей-инвалидов (Мизуноя и др., 2016). Кыргызстану еще предстоит улучшить охват включение детей-инвалидов в обычные образовательные учреждения и создания соответствующих условий. После обретения независимости правительство продолжало поощрять гендерное равенство в сфере образования; возможности получения высшего образования расширились, причем как для мужчин, так и для женщин. В Кыргызстане больше женщин, нежели мужчин, получают высшее образование.

Качество среднего образования, как представляется, ухудшается. Об этом говорят данные национального тестирования навыков и знаний учащихся. Во-первых, участие страны в Международной программе по оценке образовательных достижений учащихся (МПООД), показало, что 14-летние учащиеся из Кыргызской 
Республики оказались менее всего подготовленными и заняли последнее место (ОЭСР и Всемирный Банк, 2010). Другим источником данных является Национальная выборочная оценка учащихся 4 и 8 классов, проведенная в 2007, 2009, 2014 и 2017 годах. Результаты показывают, что более 60\% учащихся 4 класса не обладают базовым уровнем понимания прочитанного (ЦООиМО, 2018). Хотя со временем ситуация несколько улучшилась, масштабы проблемы растут. Подобный тест проводился и среди учащихся 8-х классов в 2017 году, который показал, что около $65 \%$ учащихся не обладают базовыми знаниями по математике, а $52 \%$ не имеют базового понимания прочитанного. Однако, эти результаты несколько лучше, чем результаты оценки, проведенной в 2007 году, когда $84 \%$ не имели базовых знаний по математике, а 73\% учащихся не имели базового понимания прочитанного.

Учитель и процесс обучения являются самыми важными составляющими хорошего образования. Проблема в том, что преподавание не только оплачивается плохо, но и не финансовые льготы, которые существовали в советское время и были достаточно существенны, практически отсутствуют. Для примера, в 2010 году ежемесячная зарплата учителя составляла около \$75 по сравнению с зарплатой государственного служащего около \$144 в месяц (Институт Булан, 2018; Тилешалиев, 2013). В 2011 году была проведена реформа системы оплаты труда учителя, в 2015 оплата повысилась еще раз, но повышение оказалось неравномерным и сделало уязвимыми некоторые категории учителей, в частности, молодых учителей. Удержание учителей в школах - проблема; из 100 студентов ВУЗов, прошедших обучение по педагогическим специальностям, только 17 приходят работать в школы. Из них около 20\% уходят из профессии в течение первого года работы (Телешалиев, 2013). В результате, на данный момент, около 20\% учителей являются молодыми учителями, а каждый седьмой учитель - пенсионер, но продолжающий работать. Кроме того, по профессии учителя работают, в основном, женщины; доля преподавателей - мужчин составляет лишь 10-30\%.

Число учащихся, которые остались в школах для обучения в 10 и 11 классах, сократилось с пикового значения в 80\% в начале 2000-х годов до 56\% в 2015 году. Это, отчасти, объясняется двумя причинами. Во-первых, введение в 2002 году Национального тестирования затруднило процесс поступления в высшие учебные заведения из-за минимального количества баллов, которые необходимо набрать для зачисления. Во-вторых, отсутствие перспектив трудоустройства для выпускников университетов заставляет молодых людей поступать в профессионально-технические училища, число учащихся в которых растет. Этот рост также объясняется повышением спроса на квалифицированных работников со стороны компаний оперирующих в сфере услуг.

Около 3\% школ являются частными (НСК, 2015), в которых обучаются около $2 \%$ всех учеников. Частные средние школы различаются по своему охвату и качеству образования. Существуют хорошие примеры, в частности, лицей, финансируемый Турцией, школы, которые финансируются из внутренних или международных источников. Национальное тестирование 2017 года показало, что студенты из частных школ демонстрируют более высокие академические достижения (ЦООиМО, 2018). Хотя сравнения не могут быть объективными, поскольку прием в частные школы осуществляется на основе уже высокой успеваемости кандидата. В стране работает около ста (100) религиозных школ, хотя условия с точки зрения учебных помещений в этих учреждениях разная (Институт Булан, 2017).

Привлекательность высшего образования снижается. Либерализация и дерегулирование системы высшего образования в постсоветское время привели к 
буму возникновения университетов: число университетов и других ВУЗов увеличилось в четыре раза за десятилетие. В Кыргызстане в 2010 году было 33 государственных и 23 частных университета - по сравнению с только девятью в советское время. Резко повысился спрос на высшее образование. В середине 200о-х годов число студентов, принимаемых в ВУЗы, достигло своего пика; в ВУЗы ежегодно принимаются 50-6о тысяч студентов (Рисунок 8.12). Таким образом, набор в высшие учебные заведения определенной возрастной группы увеличился с 10\% в начале 1990-х годов до примерно 48\% в середине 2000-х годов (ОЭСР, Всемирный банк, 2010). Тем не менее, существует мнение, что только несколько университетов дают хорошее образование и имеют соответствующую инфраструктурную базу. Диплом университета помогает трудоустройству, хотя доля безработных, имеющих высшее образование, велика, около 18\%, по данным на 2015 год, но эта цифра еще выше в Оше и Бишкеке, она составляет $31 \%$ и 40\% соответственно (НСК, 2018). Начиная с 2012 года, количество абитуриентов стабилизировалось на цифре 30 тысяч. Снижение цифры объясняется еще и сокращением приема студентов на заочные отделения.

\section{Рисунок 8.12: Поступление в учебные учреждения после окончания средней школы ('000)}

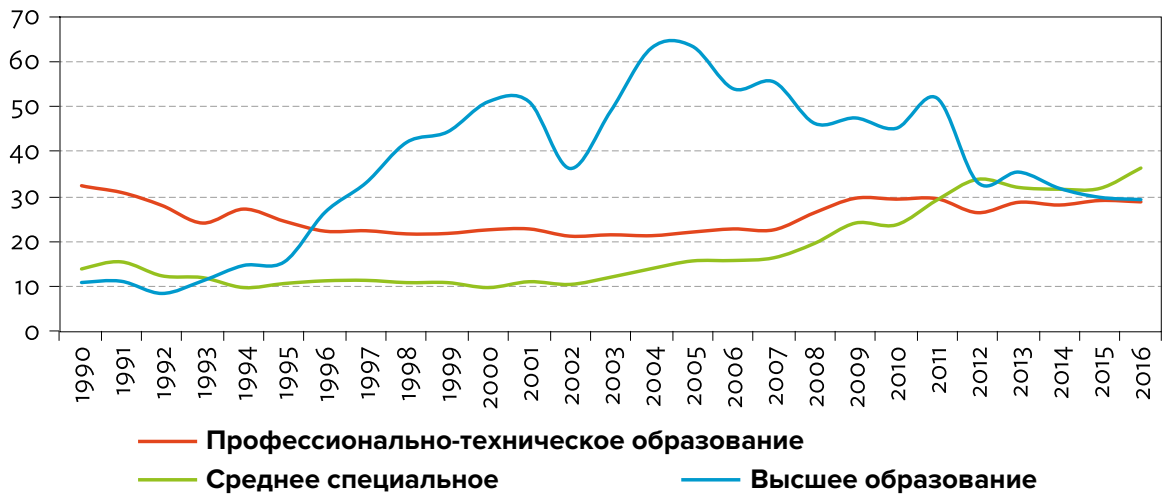

Замечание: Резкое падение количества студентов в ВУЗ в 2003 году объясняется школьной реформой 1989 года, когда систему 10-летнего образования заменили на новую, 11-летнюю.

Источник: НСК 2016.

Качество высшего образования зависит от многочисленных заочных и дистанционных программ. Практически в каждом ВУЗе есть так называемые заочные и дистанционные программы, которые позволяют получать образование, не находясь в ВУЗе. Данная модель создана во времена социализма и практикуется многими, кто хочет повысить свои шансы на получение лучшей работы или соответствовать требованиям определенной должности. Такие студенты посещают учебные заведения два раза в год, чтобы прослушать лекции и сдать экзамены. Во многих случаях качество преподавания ставится под сомнение, поскольку в большинстве случаев тесты и экзамены легко сдаются посредством неформальных механизмов, например, взяток.

Ключевой задачей политики является инвестирование в качественное профессиональное образование. Высшее образование выглядит не слишком обещающим из-за несоответствующего уровня образованности выпускников средних 
школ. Экономика должна ориентироваться на оснащение работников навыками, востребованными нынешними и будущими работодателями $(А Б Р, 2016)$. Профессиональные учреждения предпочитают предлагать специальности, не требующие учебной или серьезной материальной базы, в частности - лабораторий. Например, многие гуманитарные и социальные науки предлагаются чаще всего, в то время как технические или инженерные профессии довольно редко. Возможно, правительство возьмет на себя роль эффективного регулятора, катализатора, а не просто поставщика услуг, и будет оказывать поддержку частным образовательным учреждениям и системе профессионально - технического образования, где студенты будут получать навыки и проходить подготовку в соответствии с требованиями рынка труда (Могилевский, 2018). Это поможет приобрести гибкость всему сектору и воплощать в жизнь инновационные решения, такие как совместное использование ресурсов, государственно - частное партнерство и непрерывное образование.

\section{7. Демография и здравоохранение}

\section{Умеренный прирост населения}

Прирост населения в год в Кыргызской Республике за период 2011 - 2017 годы составлял 1,6\% в год , что сопоставимо с показателями стран Центральной Азии, но выше по сравнению со среднемировыми показателями в 1,2\% (ЮНФПА, 2018). По состоянию на 2018 год численность населения, по оценкам, составила 6,2 миллиона человек, при этом около трети населения проживало в городах (НCК, 2017). Средний возраст населения страны составляет 27 лет, но поскольку в стране уже более 4\% населения составляет население старше 65 лет, то в целом население считается умеренно пожилым. Население, по прогнозам, вырастет к 2030 году до 7 миллионов, а к 2050 году до 8 миллионов (Департамент по экономическим и социальным вопросам ООН (ДЭСВ), 2018). Ожидается, что рост населения будет сопровождаться увеличением жителей в городских регионах и увеличением продолжительности жизни, что изменит как региональную, так и возрастную структуру населения (Рисунок 8.13).

Рисунок 8.13: Динамика роста населения, 1980-2050 (млн. человек)

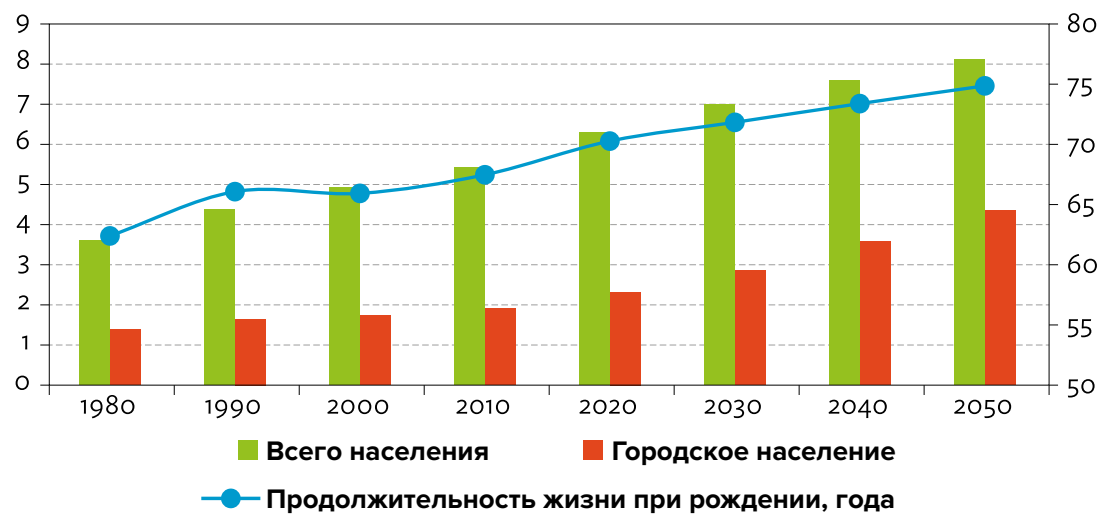

Источник: ДЭСВ, 2018. 


\section{Ожидается рост городского населения.}

За последние два десятилетия, до 2017 года, городское население оставалось на уровне $34 \%$ от населения республики. Это цифра считается небольшой, учитывая активную внутреннюю миграцию сельского населения в городские районы (Хэтчер и Тьеме 2016; Сатыбалдиева и др., 2014). Одна из причин этого может быть связана с системой регистрации, известной как «прописка», которую нелегко получить и которая ограничивает передвижение по стране. Соответственно, фактические темпы урбанизации могут быть выше, поскольку многие приезжие предпочитают не регистрироваться в районах назначения, особенно в Бишкеке и его окрестностях. Предстоящая перепись населения, запланированная на 2020 год (ЕЭК ООН, 2018), может выявить более правдивую картину с количеством городского населения.

\section{Продолжительность жизни увеличится и изменит структуру населения.}

За последние два десятилетия продолжительность жизни в Кыргызской Республике слегка увеличилась (Таблица 8.7). Наблюдаемое увеличение продолжительности жизни касается, в основном, женщин. Продолжительность жизни мужчин остается без изменения. Вероятно, это связано с заболеваниями (сердечными и онкологическими) и рисками, которым мужчины себя подвергают. Смертность среди взрослых мужчин в два раза выше, чем у женщин.

Таблица 8.7: Показатели системы здравоохранения, 1980-2015

\begin{tabular}{|c|c|c|c|c|c|c|}
\hline & 1980 & 1990 & 2000 & 2005 & 2010 & 2015 \\
\hline Продолжительность жизни, женщины, года & 67 & 73 & 72 & 72 & 74 & 75 \\
\hline Продолжительность жизни, мужчины, года & 59 & 64 & 65 & 64 & 65 & 67 \\
\hline Уровень смертности, женщины, на 1000 человек & 154 & 134 & 150 & 144 & 124 & 109 \\
\hline Уровень смертности, мужчины, на 1000 человек & 301 & 266 & 298 & 301 & 274 & 249 \\
\hline Показатель фертильности, кол-во родов на женщину & 4,4 & 3,6 & 2,4 & 2,5 & 3,1 & 3,2 \\
\hline Уровень детской смертности, на 1000 рожденных & 77 & 54 & 42 & 34 & 26 & 20 \\
\hline
\end{tabular}

Источник: Всемирный банк. Индикаторы. http://datacatalog.worldbank.org//dataset/worlddevelopment-indicators (по состоянию на февраль 2018).

\section{Снизился уровень детской смертности, коэффициент фертильности стабилизировался}

Коэффициент фертильности достаточно высок, произошел рост коэффициента с 2,4 родов/женщину в 2000 до 3,2 в 2015 году. В среднесрочной перспективе коэффициент рождаемости несколько снизится. Ситуация с детской смертностью за последние 15 лет улучшилась. 


\section{8. Заключительные замечания и практические выводы}

В настоящем разделе излагаются некоторые варианты политики для Кыргызской Республики в сфере человеческих ресурсов. В целом, в стране есть понимание, что необходимо сделать для повышения квалификации работников, улучшения их навыков, для создания рабочих мест и улучшения качества жизни. Однако, возникают затруднения в реализации «понимания», частично из-за недостатка ресурсов, частично из-за недостаточно высокого потенциала государственного управленческого аппарата. В качестве примера можно привести недавнюю попытку внедрить новую систему социальных пособий, ставшую неудачной из-за отсутствия запланированных ресурсов (Мировая продовольственная программа, 2018). Кыргызские государственные учреждения, возможно, могли бы сосредоточиться на вопросах усиления политики в точках соприкосновения с населением, например, в агентствах, выдающих документы, лицензии, сертификаты и меньше на институтах, осуществляющих инспекции, и на регулятивных органах. Очевидно, что некоторые направления политики должны быть приоритетными с точки зрения финансирования. К примеру, инвестиции в профессиональное и техническое образование молодых людей с тем, что бы они могли приобрести навыки, позволяющие им расширить свои возможности в плане заработка.

\section{Занятость}

Выравнивание «правил игры» для малых и средних предприятий. У большинства фирм и компаний нет стимулов для соблюдения трудового законодательства. Поскольку некоторые бизнес игроки выполняют регулятивные документы, соответственно, остальные вынуждены следовать их примеру, чтобы бы выдержать конкуренцию на тех же рынках. Предлагаемые возможности, которые согласуются с описанными Могилевским в своей работе (Могилевский, 2018) вариантами, следующие: уравнять налогообложение для малых и крупных компаний, снизить налоги на заработную плату и уменьшить регулятивное и коррупционное давление на крупные фирмы; поддерживать малые официальные предприятия.

\section{Использовать факторы, вынуждающие компании перейти в официальный сектор.}

Следует поддержать компании в процессе перехода в официальный сектор. Например, система государственных закупок может стать стимулом для перехода к более официальной деятельности для компаний, подающих заявки на участие в тендерах на осуществление государственных закупок. У государства большой спрос на товары и услуги и выполнение государственных закупок - один из механизмов стимулирования. Еще один пример связан с вступлением Кыргызской Республики в ЕАЭС. Этот шаг рассматривается как стимул для многих компаний внедрить производственные стандарты и практики, чтобы иметь возможность экспортировать свою продукцию и услуги.

Стимулировать мигрантов и работающих в неформальном секторе граждан обеспечить защиту своих социальных прав. Трудоустройство в республике становится менее безопасным с точки зрения получение каких-либо льгот; все большее количество работников имеют краткосрочные контракты на 
выполнение определенной работы. Важно обеспечить механизмы нынешней и будущей социальной защиты. Очень немногие домохозяйства и индивидуальные предприниматели пользуются услугами страхования и пенсионного обеспечения. Представляется крайне важным укрепление системы страхования и негосударственного пенсионного обеспечения в сочетании с более активной работой по информированию об этом жителей.

\section{Образование}

Инвестировать дополнительные средства в качественное обучение. Следует усилить мотивацию, усовершенствовать навыки самого учителя. Несмотря на большие расходы на образование, следует обратить серьезное внимание на плохие результаты тестирований, проводимых на национальном уровне. Как отмечается в исследовании ОЭСР (Организация экономического сотрудничества и развития, 2018), в странах, где учащиеся демонстрируют лучшие академические достижения, существует ряд отличительных особенностей, в частности, профессиональные и карьерные возможности для учителей, культура сотрудничества, система наставничества, оценка эффективности и ряд социальных льгот для учителей. Следовательно, инвестируя ресурсы в подготовку и переподготовку учителей, внедряя систему мониторинга качества преподавания в привязке к результативности, можно улучшить качество преподавания и результаты обучения.

Продвигать и стимулировать изучение русского и английского языков. Русский язык остается важным средством получения информации и знаний. Вероятно, нынешний уровень инвестиций в сохранение русского языка должен быть увеличен, чтобы все больше и больше детей владели русским языком, наряду с другими местными языками. Учитывая очень низкий процент населения, знающего английский язык, маловероятно, что он станет основным средством обучения и получения информации в будущем. Однако, необходимо поддерживать усилия по улучшению знания английского языка, что бы усилить конкурентоспособность студентов на глобальном уровне.

Включить в школьную программу «жизненные навыки». Типичная школа в стране уделяет внимание, в основном, приобретению академических знаний и навыков, а необходимые жизненные навыки остаются в стороне, хотя они играют важную роль в дальнейшей жизни учащихся. Например, умение общаться, проводить презентацию, управлять своим временем и денежными средствами, умение выстраивать отношения, ведение здорового образа жизни - все эти вопросы не являются частью школьной программы. Представляется целесообразным уделить большее внимание этому вопросу.

Расширить спектр ИТ навыков, получаемых в рамках школьной программы. Следует внедрить образовательные стандарты по овладению навыками ИКТ. В школьную программу обучения необходимо включить предметы компьютерной грамотности и программирования. Базовые знания: умение печатать на компьютере, использовать офисные приложения и поисковые системы в интернете помогут школьникам в будущем, как для дальнейшего обучения, так и для работы.

\section{Навыки}

Вкладывать больше государственных средств в профессиональное обучение и переподготовку. Бюджеты для выполнения активной и пассивной 
политики в области занятости остаются весьма низкими. Для реализации человеческого потенциала и создания высокооплачиваемых рабочих мест необходимы больше средств.

Оказывать поддержку в разработке отраслевых квалификационных стандартов. С учетом того, что государство не может самолично продвигать секторальные стандарты и утверждать перечень требуемых навыков и квалификаций, следует распространять и институализировать секторальные инициативы по разработке квалификационных стандартов. Некоторые отраслевые ассоциации, например, текстильной и пищевой промышленности, разрабатывают набор квалификационных стандартов и требований к будущим работникам; аттестация будет проводиться независимым органом. Это позволит работникам, не получившим официальное образование, но прошедшим подготовку на рабочем месте, подтвердить свою квалификацию и получить доступ к рабочим местам более высокого уровня. Правительством Кыргызской Республики уже внедрены на законодательном уровне основы для разработки таких стандартов, такие как Национальная система квалификации и Национальные рамки квалификации.

Активизировать систему непрерывного обучения. Система непрерывного обучения существовала ранее, но в настоящее время практически отсутствует. Продвижение такой системы позволит удовлетворить потребности в обучении работников, нуждающихся в повышении или изменении квалификации.

\section{Миграция}

Продолжать помогать мигрантам получать навыки и информацию, необходимую для легального трудоустройства в Российской Федерации и Казахстане. Как показывают данные, собранные на микро-уровне, большинство мигрантов по-прежнему работают на нелегальных работах, несмотря на то, что условия работы как в Российской Федерации, так и в Казахстане улучшились с момента присоединения Кыргызской Республики к Евразийскому экономическому союзу. Обладание навыками и информацией позволит трудовым мигрантам получить лучшую работу; это скажется положительно на повышении уровня благосостояния, как на уровне домашних хозяйств, так и на макроэкономическом уровне.

Снижать транзакционные издержки для мигрантов из Кыргызской Республики. Эта работа, проводимая государственными учреждениями и Международной организацией по миграции, включает в себя предоставление информации и оказание мер по правовой защите. Как представляется, требуется дополнительная работа по обеспечению мигрантов информацией о предъявляемых к ним требованиям в странах, где предполагается трудоустройство. Необходимо оказание постоянной правовой и иной поддержки, а так же регулирование деятельности посредников, нанимающих работников, для обеспечения наиболее благоприятных условий для мигрантов.

Помочь в обеспечении мигрантов определенными социальными льготами, включая пенсию. Один из вопросов, включенных в политическую повестку дня, это вопрос - какую пенсионную поддержку, в случае возвращения в страну по достижению пенсионного возраста, могут получить мигранты. Обязательный компонент пенсии слишком мал для покрытия расходов на проживание. Было бы желательно предпринять определенные усилия по вовлечению мигрантов в частные пенсионные фонды. 
Помочь решить вопрос «черного списка» для мигрантов. Проблема «черного списка» стала предметом общественного обсуждения после того, как правительство Российской Федерации запретило возвращаться на ее территорию определенным мигрантам, нарушившим миграционное и трудовое законодательство. Тех, чья провинность была невелика, при содействии правительства Кыргызской Республики, исключили из списка и разрешили продолжить работу. Этот список включает несколько тысяч имен. Тем не менее, необходимо продолжать усилия, чтобы помочь максимальному количеству мигрантов работать за границей.

\section{Здравоохранение}

Пропагандировать здоровый образ жизни. Здоровый образ жизни поддерживает только некоторая часть населения, проживающая, в основном, в Бишкеке. Они занимаются спортом и придерживаются системы здорового питания.

Проводить обучение рациональному питанию. Сердечно-сосудистые заболевания вызываются рядом причин, включая избыточный вес. В стране царит стиль питания, где преобладают жиры и углеводы. Включение овощей и фруктов в систему питания благотворно скажется на здоровье и поможет пропагандировать здоровый образ жизни.

Предотвращать опасное/рискованное поведения. Третьей причиной, уносящей многие жизни, является опасное/ рискованное поведение, в частности дорожно-транспортные происшествия и персональная агрессия. Некоторые виды рискованного поведения могут быть пресечены при помощи технологических средств, например, обеспечением соблюдения правил дорожного движения, фиксирование нарушений при помощи камер. В школьную программу следует включить перечень предметов, нацеленных на уменьшение рискованного поведения и прививающие ученикам «жизненные» навыки. 


\section{Библиография}

Абазов, Р. Экономическая миграция в постсоветской Центральной Азии: на примере Кыргызстана. Посткоммунистические страны. / Р. Абазов. [Электронный ресурс]. - Режим доступа: doi:10.1080/14631379996002

Абакиров, А. Парк высоких технологий Кыргызстана: в отсутствие нефти и газа ставка сделана на ИТ-креатив [Электронный ресурс] / А. Абакиров // Медиум. - 2017. - Режим доступа: https://medium.com/@azisabakirov/ kyrgyz-high-tech-park-2e99fded44ff

АБР. Реализуя систему налогообложения в Кыргызской Республике. - Манила: Азиатский банк развития, 2014. [Электронный ресурс]. - Режим доступа: https://www.adb.org/sites/default/files/publication/151365/taxadministration-systemkyrgyz-republic.pdf

Аджвад, М., Лаат, Д., Хат, С., и др. Развитие профессиональных умений для расширения возможностей трудоустройства в Кыргызской Республике / М. Аджвад, Д. Лаат, С. Хат. - Вашингтон: Всемирный банк, 2014.

Аладышева, А., Асылбек кызы, Брюк, Т. Оценка воздействия программ укрепления мира в Кыргызстане и образовательной программы «Жить Бок о Бок”. Заключительный отчет. [Электронный ресурс] / А. Аладашева, Асылбек кызы, Т. Брюк // Режим доступа: https://www.3ieimpact.org/media/filer public/2017/o8/22/gfr-pw213-kyrgyzstan-peace-building-web.pdf

Аналитика (DR Analytica) (Информационно цифровой портал). Кыргызстан: Обзор сектора ИТК за 2016. - Оттава: DR Analytica, 2016

Андерсон,К., Крегер, А. Денежные переводы и способности детей: новые факты из Кыргызстана, 2005-2008 [Электронный ресурс] / Андерсон, К. Крегер, А. Крегер // Анализ и изучение CASE Metwork. - 2013. - Режим доступа: doi:10.1017/CBO9781107415324.004

Асиан, К. Трудовая миграция и ее потенциальные последствия для Центральной Азии / К. Асиан // Центрально-Азиатский аналитик. - 2008. - C.13-15

Атаманов, А., Марит ван ден Берг. Международная трудовая миграция и деятельность на местном уровне в Кыргызской Республике: определяющие факторы и компромиссы [Электронный ресурс] / А. Атаманов, Берг Марит ван ден // Центрально-Азиатский обзор (Central Asian Survey). - 2012. - Т. 31 (2). - С. 119-136. - Режим доступа: doi:10.1080/02634937.2012.671992

БиБиСи. За длинным злотым. Как украинцы спасают экономику Польши. - ВВС - 2018. [Электронный ресурс] - Режим доступа: https://www.bbc.com/ russian/features-43475502

Брюк, Т., Эсеналиев, Д., Крёгер, А. и др. Обследование домохозяйств: данные для исследования по благосостоянию и поведению в Центральной Азии [Электронный ресурс] / Т. Брюк, Д. Эсеналиев, А. Крёгер и др. // Сравнительная экономика. - 2014. - № 42(3). - С. 819-835. - Режим доступа: doi:10.1016/ j.jce.2013.02.003

Брюк, Т, Махе, К., Науде, В. Возвратная миграция и самозанятость: данные из Кыргызстана [Электронный ресурс] / Т. Брюк, К. Махе, В. Науде. - Бонн: IZA Institute, 2018. - №11332. - Режим доступа: http://ftp.iza.org/dp11332.pdf. 
Булан Институт. Религиозное образование в Кыргызстане: медресе нуждаются в срочной реформе. - Бишкек, 2017 [Электронный ресурс]. - Режим доступа: http://bulaninstitute.org/wp-content/uploads/2017/o9/Report-on-REUs-inEnglish.pdf

Бюллетень НБКР. [Электронный ресурс]. - Режим доступа: http://www.nbkr.kg/ index1.jsp?item=137\&lang=ENG (по состоянию на декабрь 2017)

Винокуров, Е. Искусство выживания: Трудовая миграция в Кыргызской Республике, Человеческий капитал и социальные связи [Электронный ресурс] / Е. Винокуров // Экономика Центральной Азии. - Вашингтон: Университет Джорджа Вашингтона, 2013. - док 7. - Режим доступа: http://centralasiaprogram.org/archives/7546

Всемирный банк. Системный подход для получения лучших результатов в образовании: Страновой доклад о развитии детей в раннем возрасте: Кыргызская Республика. (SABER). - Вашингтон: ВБ, 2013

ВЭФ. Глобальные информационные технологии: Отчет, 2016. ВЭФ. [Электронный ресурс]. - Режим доступа: http://www3.weforum.org/docs/GITR2016/ WEF_GITR_Full_Report.pdf

Глобальный гендерный разрыв: Отчет, 2017 [Электронный ресурс]. - Режим доступа: https://www.weforum.org/reports/the-global-gender-gap-report-2017

Государственная миграционная служба. Миграционная статистика. ГМС - 2018. [Электронный ресурс]. - Режим доступа: http://ssm.gov.kg/полезная-информация/статистика/ (доступно с 31 мая 2018)

Давалос, Й., Карымшаков, К., Сулайманова, Б., и др. Денежные переводы и предложение рабочей силы - молодежи: данные из Кыргызстана [Электронный ресурс] / Й. Давалос, К. Карысшаков, Б. Сулайманова и др. // Азиатская и Тихоокеанская миграция. - 2017. - № 26 (3). - С.352-380. - Режим доступа: doi:10.1177/0117196817729190

Демографический ежегодник Кыргызской Республики 2011-2016. - Бишкек: НCK, 2017

Департамент по экономическим и социальным вопросам ООН. Пересмотренные перспективы населения мира, 2017: основные выводы и таблицы. Нью Йорк: 2017

Доклад о мировом развитии 2016 «Цифровые дивиденды». - Вашингтон ОК: ВБ, 2016

Европейская экономическая комиссия (ЕЭК) ООН. 2020 Раунд Переписи Населения. ЕЭК ООН - 2018 [Электронный ресурс]. - Режим доступа: https:// statswiki.unece.org/display/censuses/2020+Population+Census+Round

Жениш, Н. Воздействие повышения заработной платы на предложение рабочей силы в Кыргызской Республике: на примере учителей и среднего медицинского персонала. Рабочий документ № 33 [Электронный ресурс] / Н. Жениш. - Бишкек: УЦА, 2015. Режим доступа: http://www.ucentralasia.org/ Content/Downloads/UCA-IPPA-WP3-LabourSupply-Eng.pdf

Жизнь в Кыргызстане. Исследования. [Электронный ресурс]. - Режим доступа: https://lifeinkyrgyzstan.org/?page_id=51 
Индексы мирового развития: сайт [Электронный ресурс]. - Режим доступа: http://datacatalog.worldbank.org//dataset/world-development-indicators (по состоянию на февраль 2018)

Информационно-коммуникационные технологии в Кыргызской Республике. Бишкек: НСК, 2017

Информационные и коммуникационные технологии для женщин-предпринимателей. - Манила: АБР, 2014. [Электронный ресурс]. - Режим доступа: https://www.adb.org/sites/default/files/publication/42869/ict-womenentrepreneurs.pdf

Исабаева, Э. Уйти, чтобы позволить другим остаться: Денежные переводы и экономика новой морали миграции на юге Кыргызстана [Электронный ресурс] / Э. Исабаева // Центрально Азиатские исследования 2011. - № 30 (3-4). - С. 541-554. - Режим доступа: doi:10.1080/02634937.2011.607917

Исмаилбекова, А. Миграция и наследование по мужской линии: роль женщин в Кыргызстане [Электронный ресурс] / А. Исмаилбекова //Центрально Азиатские исследования. - 2014. - № 33 (3). - С. 375-389. - Режим доступа: doi:10.1080/02634937.2014.961305

Кашницкий, Д., Деминцева, Е. Кыргызская клиника в Москве: Медицинские центры для мигрантов из Центральной Азии [Электронный ресурс] / Д. Кашницкий, Е. Деминцева // Медицинская антропология. - 2017. № 12. - С.1-11. - Режим доступа: doi:10.1080/01459740.2017.1417280

ИОДХ. Разные года. [Электронный ресурс]. - Режим доступа: http://catalog.ihsn. org/index.php/catalog/6718/study-description

Кыргызская Республика - Цифровая Центральная и Южная Азия. Проект. Вашингтон D.C: Всемирный банк, 2018

Кыргызская Республика: Второй проект АБР «Профессиональное образование и развитие навыков». - Манила: АБР, 2016 [Электронный ресурс]. - Режим доступа: https://www.adb.org/publications/kgz-2nd-voc-educ-and-skillsdevelopment-project-brief

Кыргызская Республика: Занятость и безработица в 2015. - Бишкек: НСК, 2016

Кыргызская Республика: Занятость и безработица в 2016. - Бишкек: НСК, 2017.

Лехман, Х., Зайцева, А. Неформальная занятость в России: определения, охват, детерминанты и сегментация рынка труда / Х. Лейман, А. Зайцева. Париж: ОЭСР, 2013

Международная федерация за права человека. Женщины и дети из Кыргызстана, вовлеченные в миграцию // Повышенная уязвимость. - Париж: FIDH, 2016

Миграция и развитие. Кратко. - Вашингтон ОК: Всемирный банк, 2018

Мизуноя, С., Митра, С, Ямосаки, И. В направлении инклюзивного образования: Влияние инвалидности на посещаемость школы в развивающихся странах. Рабочий документ. № 2016-03 / С. Мизуноя, С. Митра, И. Ямосаки. Флоренция: ЮНИСЭФ, 2016 
Министерство Финансов Кыргызской Республики. Закон О республиканском бюджете Кыргызской Республики на 2017 год и прогнозе на 2018-2019 годы. - Бишкек: Жогорку Кенеш, 2016

Мировая занятость и социальные перспективы: Тенденции 2015. - Женева: MOT, 2015

Мировая статистика по использованию интернета. Статистика использования интернета в Азии и статистика населения в 2018 [Электронный ресурс]. Режим доступа: https://www.internetworldstats.com/stats3.htm\#asia (ПО состоянию на с 17 мая 2018)

Могилевский, Р. Варианты политики рынка труда для технологического развития Центральной Азии. Университет Центральной Азии. Рабочий документ. № 2016-03 / Р. Могилевский. - Бишкек: УЦА, 2016

МОТ. Трудовая миграция и продуктивное использование человеческих ресурсов: Кыргызская Республика. - Бишкек: МОT, 2009

Национальный статистический комитет. Кыргызская Республика: Занятость и безработица в 2014. - Бишкек: НСК, 2015

НБКР. Платёжный баланс Кыргызской Республики за 9 месяцев 2017 года. Бишкек: 2018

Недолюжко, Л., Андерссон, Г. Миграция и Родительство: данные из Кыргызстана [Электронный ресурс] / Л. Недолюжко, Г. Андерссон // Демографические исследования. - 2007. - №17. - С. 741-774. - Режим доступа: doi:10.4054/ DemRes.2007.17.25

Обзор государственных расходов Кыргызской Республики: Заработная плата. Вашингтон ОК: Всемирный банк, 2014

Образование и культура//Официальная статистика НСК. - Бишкек: НСК, 2018. Режим доступа: http://www.stat.kg/en/statistics/obrazovanie/

Организация экономического сотрудничества и развития (ОЭСР). Эффективная политика учителя. ОЭСР, 2018 [Электронный ресурс]. - Режим доступа: doi:10.1787/9789264301603-en

ОЭСР, Всемирный Банк. Обзор национальной политики в области образования. ОЭСР, 2010 [Электронный ресурс]. - Режим доступа: doi:10.1787/9789264088757-en

Пересмотренные перспективы населения мира, 2018: основные выводы и таблицы. - Нью Йорк: 2018

Переход к лучшей работе в Кыргызской Республике: диагностика работы. Вашингтон, ОК: Всемирный банк, 2015

Правительство Кыргызской Республики. Стратегия развития образования в Кыргызской Республике на 2012-2020 годы. - Бишкек: 2012

ПРООН. Отчет о человеческом развитии 2016: Человеческое развитие для всех и каждого. - Нью Йорк: 2016 
Ривз, М. Черная работа, зеленые деньги: денежные переводы, ритуалы и домашняя экономика в Южном Кыргызстане / М. Ривз //Славянский обзор. - 2012. - № 71 (o1). - C 108-34. - Режим доступа: doi:10.5612/ slavicreview.71.1.0108

Рохнер, И. Национальная и международная трудовая миграция: Баткен, Кыргызстан [Электронный ресурс] / И. Рохнер. - Берн: NCCR North-South, 2007. - Режим доступа: https://www.zora.uzh.ch/id/eprint/77187/1/2007_ RohnerI-2007_Kopie_.pdf

Рубинов, И. Объединения мигрантов: строительство постсоциалистических домохозяйств Кыргызстана с помощью денежных переводов [Электронный ресурс] / И. Рубинов // Антропологический квартал. - 2014. - №87 (1). С. 183-215. - Режим доступа: doi:10.1353/anq.2014.0006

Сагынбекова, Л. Международная трудовая миграция в контексте ЕАЭС: проблемы кыргызских мигрантов в России. УЦА. Рабочий документ 39. Бишкек: УЦА, 2017 [Электронный ресурс] / Л. Сагунбекова. - Режим доступа: http://dx.doi.org/10.2139/ssrn.3023259

Сатыбалдиева, Э., Фрайер П., Насретдинов, Э. Движение к пропасти? Миграция в Кыргызкой Республике [Электронный ресурс] / Э. Сатыбалдиева, П. Фрайер, Э. Насретдин // События в Центральной Азии. - 2014. № 1 (2). - С 171-98. - Режим доступа: doi:10.1163/22142290-00102002

Саумик, П. Эффект эмиграции на предложение домашней рабочей силы: Факты из Центральной Азии и Южного Кавказа. Рабочий документ №822 / П. Саумик - Мандалуонг: АБР, 2018

Социальный статус школьных учителей в Кыргызской Республике. - Бишкек, 2018. [Электронный ресурс]. - Режим доступа: http://bulaninstitute.org/ wp-content/uploads/2017/o9/Reporton-REUs-in-English.pdf

Стандарты жизни населения Кыргызской Республики, 2012-2016. - Бишкек: НСК, 2017 - дайте мне учить // Европейское образование. - 2013. - №45 (2). - C 51-74. - Режим доступа: doi:10.2753/EUE1056-4934450203

Тилешалиев, Н. Оставьте меня в покое - дайте мне учить [Электронный ресурс] / Н. Тилешалиев // Европейское образование. - 2013. - №45 (2). - С 51-74. - Режим доступа: doi:10.2753/EUE1056-4934450203.

Тиеме, С. Возвратная Миграция: возвращение домой? Закономерности и особенности возвратной миграции в Кыргызстане [Электронный ресурс] / С. Тиеме // Международная миграция. - 2014. - № 52(5). - С. 127-43. Режим доступа: doi:10.1111/j.1468-2435.2011.00724.x

Уровень бедности в Кыргызской Республике в 2016. - Бишкек: НСК, 2017.

Фонд Сорос-Кыргызстан. Анализ потребностей регионов Кыргызстана в Информационно-коммуникативных технологиях и перспективы развития. - Бишкек, 2012

Хетчер, Г., Тиеме, С. Институциональная трансформация: Внутренняя миграция, прописка, и пост социалистические изменения в Бишкеке, Кыргызстан [Электронный ресурс] / Г. Хетчер, С. Тиеме //SAGE Городские исследования. - 2016. - Т. 53(10). - С. 2175-291. - Режим доступа: doi:10.1177/0042098015587252 
Хилл, Д., Хаски, Е. Ставки на выборах, Трудовая миграция, явка избирателей: Выборы Президента в Кыргызстане в 2011 году //Демократизация: Журнал постсоветская демократизация. - 2015. - № 23 (1). - С. 3-30

ЦООМО. Национальная оценка 2017. - Бишкек: 2018

Чакраборту, Т., Миркасымов, Б., Штайнер, С. 2015. Трансферное поведение в сообществах мигрантов [Электронный ресурс] / Т. Чакраборту, Б. Миркасымов, С. Шнайдер // Сравнительная Экономика. IZA Institute. - 2015. № 43 (3). - С. 690-705. - Режим доступа: doi:10.1016/j.jce.2014.09.004.

Шмидт, М., Сагынбекова, Л. Миграция: прошлое и современность [Электронный ресурс] / М. Шмидт, Л. Сагынбекова // Центрально-азиатские исследования. - 2008. - № 27(2). - 11-27. - Режим доступа: https://doi. org/10.1080/02634930802355030

Шмидт, М., Сагынбекова Л. 2008. Миграция в прошлом и настоящем: изменяющиеся паттерны в Кыргызстане [Электронный ресурс] / М. Шмидт, Л. Сагынбекова // Центрально-Азиатский журнал исследований. Режим доступа: doi:10.1080/02634930802355030

Шох, Н., Штайнман Б., Тиеме С. Миграция и животноводство: Конкурирующие или дополняющие стратегии обеспечения жизнедеятельности. Данные из Кыргызстана// Форум природных ресурсов.- 2010. - № 34 (3). - С. 211221. - Режим доступа: doi:10.1111/j.1477-8947.2010.01306.x

Шрёдер, Ф., Шрёдер Э. Предпринимательство в Кыргызстане: адаптация к меняющейся экономической среде. - Бишкек: 2017

Эсеналиев, Д., Крёгер, А., Штайнер, С. Комплексное обследование домохозяйств в Кыргызской Республике / Д. Эсеналиев, А. Крёгер, С. Штайнер // A Primer. - Берлин: DIW Berlin. - 2011. - № 62.

Эсеналиев, Д., Фергюсон, Н. Влияние качества работы на благосостояние: свидетельства само-занятых и наемных работников. Дискуссионный документ / Д. Эсеналиев, Н. Фергюсон. - Бишкек: УЦА, Институт государственного управления и политики (ИГУП), 2017. - Т. 41

ЮНИСЭФ. Кыргызстан: Оценка программы «Школа без насилия». - Бишкек: 2015 [Электронный ресурс]. - Режим доступа: https://www.unicef.org/ evaldatabase/index_90165.html

ЮНФПА, МОМ, Женщины ООН, НСК. Гендерное восприятие в обществе. Бишкек: ЮНФПА, 2016

ЮНФПА. Панельный мониторинг населения мира. - 2018: [Электронный pecypc]. - Режим доступа: https://www.unfpa.org/data/world-populationdashboard

ЮСАИД. Читаем вместе: Информационный обзор: сайт [Электронный ресурс]. - Режим доступа: https://www.usaid.gov/kyrgyz-republic/fact-sheets/qualityreading-project-reading-together (по состоянию на 13 июня 2018 